Report prepared jointly by the U.S. Geological Survey and Environment Canada.

Cooperating agencies: U.S. Army Corps of Engineers and the U.S. Fish and Wildlife Service.

\title{
Data from the 2011 International Piping Plover Census
}

\section{Data Series 922}





\section{Data from the 2011 International Piping Plover Census}

By Elise Elliott-Smith, Mark Bidwell, Amanda E. Holland, and Susan M. Haig

Report prepared jointly by the U.S. Geological Survey and Environment Canada.

Cooperating agencies: U.S. Army Corps of Engineers and the U.S. Fish and Wildlife Service.

Data Series 922 


\title{
U.S. Department of the Interior SALLY JEWELL, Secretary
}

\section{U.S. Geological Survey \\ Suzette M. Kimball, Acting Director}

\author{
U.S. Geological Survey, Reston, Virginia: 2015
}

For more information on the USGS - the Federal source for science about the Earth, its natural and living resources, natural hazards, and the environment—visit http://www.usgs.gov or call 1-888-ASK-USGS.

For an overview of USGS information products, including maps, imagery, and publications, visit http://www.usgs.gov/pubprod/.

Any use of trade, firm, or product names is for descriptive purposes only and does not imply endorsement by the U.S. Government.

Although this information product, for the most part, is in the public domain, it also may contain copyrighted materials as noted in the text. Permission to reproduce copyrighted items must be secured from the copyright owner.

Suggested citation:

Elliott-Smith, E., Bidwell, M., Holland, A.E., and Haig, S.M., 2015, Data from the 2011 International Piping Plover Census: U.S. Geological Survey Data Series 922, 296 p., http://dx.doi.org/10.3133/ds922.

ISSN 2327-638X (online) 


\section{Contents}

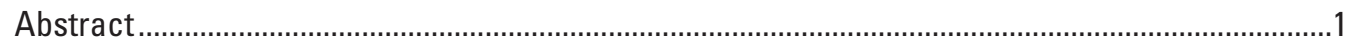

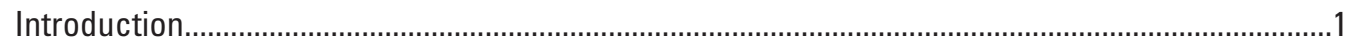

Methods

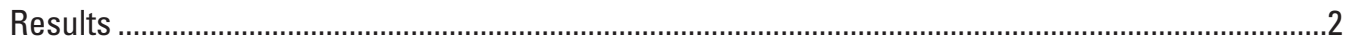

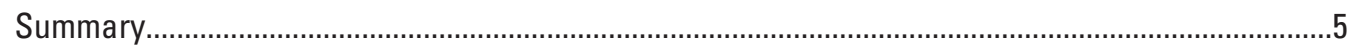

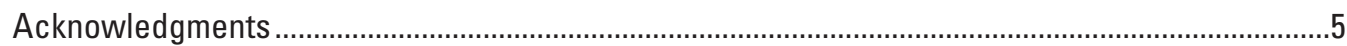

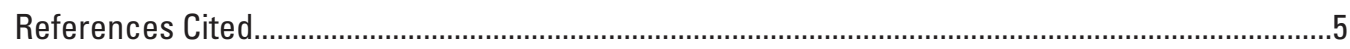

Appendix 1. State/Provincial Summaries ......................................................................................

\section{Tables}

Table 1. Distribution and abundance of wintering Piping Plovers, 2011 .....................................2

Table 2. Census effort and coverage for the 2011 International Piping Plover breeding census

\section{Conversion Factors}

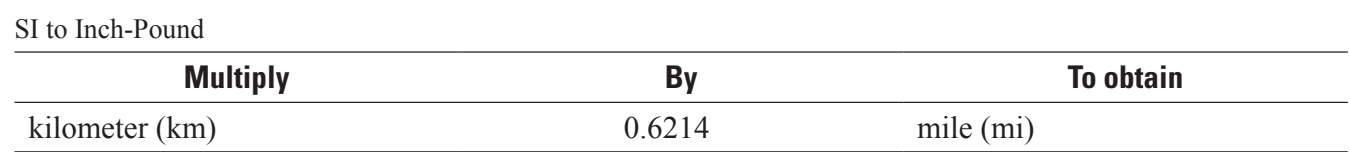





\title{
Data from the 2011 International Piping Plover Census
}

\author{
By Elise Elliott-Smith ${ }^{1}$, Mark Bidwell ${ }^{2}$, Amanda E. Holland ${ }^{3}$, and Susan M. Haig'
}

\section{Abstract}

This report provides results from the 2011 International Census of Piping Plovers (Charadrius melodus). Distribution and abundance data for wintering and breeding Piping Plovers are summarized in tabular format. An appendix provides census data for every site surveyed in every state, province, and island. The 2011 winter census resulted in the observation of 3,973 Piping Plovers. Expanded coverage outside of the United States led to the discovery of more than 1,000 Piping Plovers wintering in the Bahamas. The breeding census detected 2,771 birds in Atlantic Canada and the Plains, Prairies, and Great Lakes regions of the United States and Canada. Combining the census count with the U.S. Atlantic "window census" provides a total minimum estimate of 5,723 breeding birds for the species.

\section{Introduction}

The Piping Plover (Charadrius melodus) is one of the most imperiled shorebirds in the United States and Canada (Brown and others, 2001; Elliott-Smith and Haig, 2004) and is federally listed in both countries. Every 5 years since 1991, the U.S. Geological Survey (USGS) coordinates an International Piping Plover Census to provide a comprehensive view of abundance and distribution that assists in evaluating the effectiveness of recovery efforts. In 2011, for the fifth time in 20 years, a comprehensive inventory of Piping Plovers was conducted across their winter and breeding range in the United States, Canada, France (islands near Canada), Mexico, and the Caribbean.

\section{Methods}

The 2011 International Piping Plover Census was conducted using similar and compatible methods to those used during 1991, 1996, 2001, and 2006 (Haig and Plissner,

\footnotetext{
${ }^{1}$ U.S. Geological Survey.

${ }^{2}$ Canadian Wildlife Service, Environment Canada.

${ }^{3}$ University of Georgia.
}

1993; Plissner and Haig, 2000; Haig and others, 2005). The census was led by a census coordinator (Elise ElliottSmith, U.S. Geological Survey). Individual surveys were organized with the assistance of state, provincial, island, and regional coordinators.

The winter census was conducted prior to the breeding census in order to count only those birds capable of being present in the subsequent breeding census. January 24 through February 6, 2011 was designated as the time period for the winter census. The breeding census was conducted from June 4 through June 17. We attempted to conduct the census during a short time interval to minimize recounting of birds resulting from their movement between sites. Specific dates were selected based on similarity to previous census dates. An additional factor when in coastal areas was selection of winter census dates that would coincide with a period of daytime high tides, particularly on the Texas coast. Some data collected outside the designated winter census time interval were accepted to document use in regions where Piping Plovers are rare. Likewise, we accepted some data outside the breeding census window. Flooding of interior breeding sites and access roads required that some surveys be conducted after the census window, when water levels receded.

Generally, the census was conducted by covering all habitat at each site with a single pass in a single day and recording the total number of adult plovers seen. Pairs were noted and enumerated for the breeding census whenever two birds were seen together. Most surveys were conducted on foot and guidance was given to surveyors to increase the likelihood of Piping Plover detection. Participants were advised to conduct surveys when weather was favorable because visibility and detectability may be limited during high winds, rain, and fog. At tidally influenced sites, surveyors generally were advised to survey at high tide when birds are concentrated and habitat is easier to cover. A subset of breeding sites were surveyed twice to allow for estimates of detection probability by studies using data reported herein.

Types of data collected during the 2011 International Piping Plover Census were similar to data collected in prior census years. Information recorded included the number of birds, location, weather, tidal stage, approximate length of shoreline covered, presence or absence of leg-bands and any band combinations, and surveyor information. Additionally, this year we collected data on potential disturbance to birds or habitat and the vulnerability of winter sites to sea-level rise. 
This inventory is referred to as a "census" because of the breadth of habitat that is covered across the species range, which is as complete as possible. However, we recognize that it is impossible to count every plover because of imperfect coverage and imperfect detection during surveys. Although double-counting plovers is possible, the constrained census window is intended to minimize this source of uncertainty. As indicated in the individual areas summaries presented in appendix I, incomplete coverage and imperfect detection are likely more common. As a result, the census totals reported herein most likely represent minimum population estimates. As in prior years, we attempted to cover as much known and potential Piping Plover habitat as possible throughout the species winter and breeding range. Surveying winter habitat outside the United States is a particular challenge and, although coverage improved in 2011, it was still incomplete. Given 2006 results, which suggested the Bahamas could be an important wintering area, we expanded our surveys in this island group. Breeding census counts are always higher than winter counts, likely because of improved coverage and detection. However, identifying all suitable breeding habitat in the interior is difficult during extreme wet and dry years. Extensive flooding and use of non-traditional breeding habitat (for example, gravel roads adjacent to sites) in 2011 made it impossible to obtain a thorough count of birds in the Plains and Prairie region; thus, counts in this report are likely underestimates of true population size. In future surveys, more work needs to be done to improve coverage and account for imperfect detection so that counts from breeding surveys can be used to estimate population size more reliably.

Unlike prior years, none of the U.S. Atlantic States participated in the 2011 census. The U.S. Atlantic breeding population is estimated annually from a "window census" conducted near the timeframe of the census. This survey differs from the census in that the focus is estimating pairs rather than making a count of individuals, and although some data reflect a single count, multiple visits are made to some sites. Thus, we present pair counts from the 2011 "window census" (A. Hecht, U.S. Fish and Wildlife Service, written commun., 2012) and double the total pair count to obtain a total adult count for the region. Because detection probability is not accounted for, when combining U.S. Atlantic States window data with our results, this provides a likely minimum estimate for the Atlantic Coast population and for the entire species.

\section{Results}

A total of 3,973 Piping Plovers were seen during the 2011 winter census (table 1). The Bahamas was identified as an important wintering area, ranking second only to Texas in number of Piping Plovers. Preliminary genetic analyses by Dr. Susan Haig and observations of banded birds (during the census and as reported by C. Gratto-Trevor, oral comm.,

Table 1. Distribution and abundance of wintering Piping Plovers, 2011.

[Sites surveyed, kilometers surveyed, and Participants: Numbers reported serve as minimum estimates. Not all censusers included this information. na, not applicable]

\begin{tabular}{lrrrrrl}
\hline \multicolumn{1}{c}{ State/Country } & $\begin{array}{c}\text { Number } \\
\text { of Piping } \\
\text { Plovers }\end{array}$ & $\begin{array}{c}\text { Percentage } \\
\text { of all birds } \\
\text { censused }\end{array}$ & $\begin{array}{c}\text { Sites } \\
\text { surveyed }\end{array}$ & $\begin{array}{c}\text { Kilometers } \\
\text { surveyed }\end{array}$ & Participants & Coordinator \\
\hline Virginia & 1 & $<0.1$ & 22 & 177 & 20 & R. Boettcher \\
North Carolina & 43 & 1.1 & 36 & 405 & 41 & S. Schweitzer \\
South Carolina & 86 & 2.2 & 36 & 144 & 50 & M. Bimbi, F. Sanders \\
Georgia & 63 & 1.6 & 17 & 136 & 50 & B. Winn, T. Keyes \\
Florida & 306 & 7.7 & 201 & 1,299 & 291 & P. Kelly, B. Brooks \\
$\quad$ Atlantic ${ }^{1}$ & 83 & 2.1 & 91 & 630 & na & M. Knight \\
$\quad$ Gulf & 223 & 5.6 & 110 & 669 & na & \\
Alabama & 38 & 1.0 & 6 & 12 & 3 & R. Clay \\
Mississippi & 88 & 2.2 & 18 & 146 & 21 & N. Winstead \\
Louisiana & 86 & 2.2 & 16 & 119 & 11 & M. Seymour \\
Texas & 2,145 & 54.0 & 88 & 1,600 & 68 & D. Anderson, R. Cobb, L. Gallo, M. Zdravkovic \\
Mexico & 30 & 0.8 & 5 & 175 & 2 & A. Banda, G. Garcia \\
Bahamas & 1,066 & 26.8 & 203 & 678 & 29 & P. Moore, E. Elliott-Smith \\
Cuba & 19 & 0.5 & 10 & 45 & 3 & P. Rodriguez \\
Puerto Rico & 2 & $<0.1$ & 6 & 13 & 4 & A. Pérez \\
$\quad$ & 3,973 & 100 & 664 & 4,949 & 593 & \\
\hline
\end{tabular}

${ }^{1}$ Regional subtotals within Florida. 
2013) indicate that Piping Plovers wintering in the Bahamas may be primarily from the Atlantic Coast breeding population. The Bahamas count $(1,066)$ was 32 percent of the Atlantic breeding count $(3,362)$. This number likely does not represent the exact percentage of Atlantic birds wintering in the Bahamas, but it does suggest the relative importance of the Bahamas to the breeding population. Likewise, the Texas coast is very important to Prairie Canada breeders (Gratto-Trevor and others, 2012), but further research is needed to fully understand population connectivity and the importance of specific wintering sites.
In total, 2,771 Piping Plovers were counted during the breeding census in the Plains/Prairies, Atlantic Canada, and Great Lakes (table 2). As in prior years, the breeding census was conducted in the interior United States and Canada, the Great Lakes region, and Atlantic Canada. The U.S. Atlantic region did not officially participate, but their "window census" resulted in the detection of 1,476 pairs. Doubling the U.S. Atlantic pair count and combining with the census count results in an overall species count of at least 5,723 Piping Plovers during the breeding season.

Table 2. Census effort and coverage for the 2011 International Piping Plover breeding census.

[Sites surveyed, Kilometers surveyed, and Participants: Numbers reported serve as minimum estimates. Not all censusers included this information. na, not applicable; nr, information was not reported]

\begin{tabular}{|c|c|c|c|c|c|c|c|c|}
\hline State/Province & Adults & $\begin{array}{l}\text { Census } \\
\text { (percent) }\end{array}$ & $\begin{array}{l}\text { Region } \\
\text { (percent) }\end{array}$ & $\begin{array}{c}\text { Breeding } \\
\text { pairs }\end{array}$ & $\begin{array}{c}\text { Sites } \\
\text { surveyed }\end{array}$ & $\begin{array}{c}\text { Linear } \\
\text { kilometers } \\
\text { surveyed }\end{array}$ & $\begin{array}{l}\text { Partici- } \\
\text { pants }\end{array}$ & Coordinator \\
\hline Northern Great Plains/Prairies & 2,249 & 39.3 & na & 706 & 772 & 3,853 & 340 & \\
\hline Prairie Canada & 1,012 & 17.7 & 45.0 & 288 & 385 & 2,750 & 180 & \\
\hline Alberta & 244 & 4.3 & 10.8 & 91 & 70 & 252 & 31 & D. Prescott \\
\hline Saskatchewan & 764 & 13.3 & 34.0 & 195 & 278 & 2,473 & 131 & M. Ranalli, J. Rumancik \\
\hline Manitoba & 2 & 0.0 & 0.1 & 1 & 33 & 15 & 16 & K. Porteous \\
\hline Ontario (Lake of the Woods) & 2 & 0.0 & 0.1 & 1 & 4 & 10 & 2 & L. Heyens, B. Campbell \\
\hline U.S. Northern Great Plains & 1,237 & 21.6 & 55.0 & 418 & 387 & 1,103 & 160 & \\
\hline Minnesota & 2 & 0.0 & 0.1 & 1 & 4 & 6 & 2 & K. Haws \\
\hline Montana & 91 & 1.6 & 4.0 & 35 & 59 & 32 & 17 & K. Brennan, F. Prellwitz \\
\hline Montana (Missouri River) ${ }^{1}$ & 2 & na & na & 1 & 3 & $<1$ & na & \\
\hline North Dakota & 623 & 10.9 & 27.7 & 255 & 178 & 295 & 43 & K. Brennan \\
\hline North Dakota (Missouri River) $^{1}$ & 31 & na & na & 18 & 25 & 2 & na & \\
\hline South Dakota & 151 & 2.6 & 6.7 & 21 & 45 & 113 & 16 & N. Gates \\
\hline South Dakota (Missouri River) ${ }^{1}$ & 151 & na & na & 20 & 20 & 112 & na & \\
\hline Nebraska & 350 & 6.1 & 15.6 & 97 & 86 & 632 & 44 & J. Jorgenson \\
\hline Nebraska (Missouri River) & 2 & na & na & 1 & 1 & $<1$ & na & \\
\hline Missouri River (MT, ND, SD, NE) ${ }^{1}$ & 186 & 3.3 & 8.3 & 40 & 49 & 114 & 36 & G. Pavelka, G. Borman \\
\hline Iowa $^{2}$ & na & na & na & na & 0 & 0 & 0 & D. Howell \\
\hline Kansas $^{2}$ & na & na & na & na & 0 & 0 & 0 & D. Mulhern \\
\hline Colorado & 20 & 0.3 & 0.9 & 9 & 15 & 25 & 2 & D. Nelson, P. Plage \\
\hline Great Lakes & 112 & 2.0 & na & 43 & 130 & 550 & 96 & \\
\hline Canada (Ontario) & 14 & 0.2 & 12.5 & 6 & 58 & 207 & 50 & S. Mackenzie \\
\hline United States & 98 & 1.7 & 87.5 & 37 & 72 & 343 & 46 & \\
\hline Michigan & 90 & 1.6 & 80.4 & 33 & 56 & 283 & 32 & V. Cavalieri \\
\hline Wisconsin & 8 & 0.1 & 7.1 & 4 & 8 & 35 & 8 & V Cavalieri \\
\hline $\mathrm{MN} / \mathrm{IL} / \mathrm{IN} / \mathrm{OH} / \mathrm{PA} / \mathrm{NY}$ & 0 & 0.0 & 0.0 & 0 & 8 & 25 & 6 & V. Cavelieri, K. Haws \\
\hline Atlantic & 3,362 & 40.8 & na & 1,576 & 859 & 1,947 & 319 & \\
\hline St. Pierre and Miquelon (France) & 4 & 0.1 & 0.1 & 1 & 4 & 19 & 4 & R. Etcheberry \\
\hline Atlantic Canada & 406 & 7.1 & 12.1 & 165 & 387 & 1,093 & 158 & \\
\hline Newfoundland & 51 & 0.9 & 1.5 & 22 & 100 & 126 & 29 & K. Baker \\
\hline Quebec & 66 & 1.2 & 2.0 & 22 & 17 & 131 & 31 & F. Shaffer \\
\hline Prince Edward Island & 67 & 1.2 & 2.0 & 28 & 82 & 189 & 18 & J. Rock \\
\hline New Brunswick & 130 & 2.3 & 3.9 & 54 & 61 & 263 & 41 & J. Rock \\
\hline Nova Scotia & 92 & 1.6 & 2.7 & 39 & 127 & 384 & 39 & S. Abbott, K. Potter \\
\hline
\end{tabular}


Table 2. Census effort and coverage for the 2011 International Piping Plover Breeding Census._-Continued

[Sites surveyed, Kilometers surveyed, and Participants: Numbers reported serve as minimum estimates. Not all censusers included this information. na, not applicable; nr, information was not reported]

\begin{tabular}{|c|c|c|c|c|c|c|c|c|}
\hline State/Province & Adults & $\begin{array}{c}\text { Census } \\
\text { (percent) }\end{array}$ & $\begin{array}{c}\text { Region } \\
\text { (percent) }\end{array}$ & $\begin{array}{c}\text { Breeding } \\
\text { pairs }\end{array}$ & $\begin{array}{c}\text { Sites } \\
\text { surveyed }\end{array}$ & $\begin{array}{c}\text { Linear } \\
\text { kilometers } \\
\text { surveyed }\end{array}$ & $\begin{array}{c}\text { Partici- } \\
\text { pants }\end{array}$ & Coordinator \\
\hline U.S. Atlantic ${ }^{3}$ & 2,952 & 51.6 & 87.8 & 1,476 & $\mathrm{nr}$ & $\mathrm{nr}$ & $\mathrm{nr}$ & \\
\hline Maine $^{3}$ & $\mathrm{nr}$ & na & na & 33 & $\mathrm{nr}$ & $\mathrm{nr}$ & $\mathrm{nr}$ & L. Zitske \\
\hline New Hampshire ${ }^{3}$ & $\mathrm{nr}$ & na & na & 4 & $\mathrm{nr}$ & $\mathrm{nr}$ & $\mathrm{nr}$ & B.Clifford \\
\hline Massachusetts $^{3}$ & $\mathrm{nr}$ & na & na & 630 & $\mathrm{nr}$ & $\mathrm{nr}$ & $\mathrm{nr}$ & S. Melvin \\
\hline Rhode Island ${ }^{3}$ & $\mathrm{nr}$ & na & na & 86 & $\mathrm{nr}$ & $\mathrm{nr}$ & $\mathrm{nr}$ & E. King, C. Wiitala \\
\hline Connecticut $^{3}$ & $\mathrm{nr}$ & na & na & 26 & $\mathrm{nr}$ & $\mathrm{nr}$ & $\mathrm{nr}$ & J. Victoria \\
\hline New York ${ }^{3}$ & $\mathrm{nr}$ & na & na & 318 & $\mathrm{nr}$ & $\mathrm{nr}$ & $\mathrm{nr}$ & F. Hamilton \\
\hline New Jersey ${ }^{3}$ & $\mathrm{nr}$ & na & na & 97 & $\mathrm{nr}$ & $\mathrm{nr}$ & $\mathrm{nr}$ & T. Pover \\
\hline Delaware $^{3}$ & $\mathrm{nr}$ & na & na & 8 & $\mathrm{nr}$ & $\mathrm{nr}$ & $\mathrm{nr}$ & M. Bailey \\
\hline Maryland $^{3}$ & $\mathrm{nr}$ & na & na & 36 & $\mathrm{nr}$ & $\mathrm{nr}$ & $\mathrm{nr}$ & T. Pearl \\
\hline Virginia $^{3}$ & $\mathrm{nr}$ & na & na & 179 & $\mathrm{nr}$ & $\mathrm{nr}$ & $\mathrm{nr}$ & R. Boettcher \\
\hline North Carolina ${ }^{3}$ & $\mathrm{nr}$ & na & na & 59 & $\mathrm{nr}$ & $\mathrm{nr}$ & $\mathrm{nr}$ & S. Schweitzer \\
\hline \multicolumn{9}{|l|}{ Totals } \\
\hline U.S. & 4,287 & 74.9 & na & 1,931 & 459 & 1,446 & 206 & \\
\hline Canada & 1,432 & 25.0 & na & 459 & 830 & 4,050 & 388 & \\
\hline France & 4 & 0.1 & na & 1 & 4 & 19 & 4 & \\
\hline Grand total & 5,723 & na & na & 2,391 & 1,932 & 5,515 & 598 & \\
\hline
\end{tabular}

${ }^{1}$ Regional subtotals within a given State. Missouri River results by State are included in State results.

${ }^{2}$ Iowa and Kansas did not participate in the 2011 Census due to high water levels and lack of habitat. One nest and a few adults were observed in Iowa later in the season after water receded.

${ }^{3}$ The U.S. Atlantic did not participate in the 2011 Census. U.S. Atlantic breeding pair estimates were obtained from the 2011 Atlantic Window Census, which focuses on estimating breeding pairs. The total for U.S. Atlantic adults presented here was obtained by doubling the estimated number of pairs, and thus does not include any unpaired adults present at the time of the survey.

Overall winter numbers were similar to 2006, but our data from Louisiana is incomplete because of the Deepwater Horizon oil spill. This spill occurred in spring and summer of 2010, affecting the entire northern Gulf of Mexico coastline and in particular the Louisiana Mississippi River Delta (Mendelssohn and others, 2012). Through the Natural Resource Damage Assessment (NRDA) process, some Piping Plover habitat was closed to the public but subject to special studies to determine oil spill impacts. Data collected as part of the NRDA process include counts of Piping Plovers, but these data have not yet been released. At some time, we should be able to fill in the data gaps, which could add 200 or more Piping Plovers to the winter count (based on prior census results). Coverage was fairly comprehensive elsewhere in the United States. Although the survey effort in the Bahamas represents an increase over previous efforts, some habitat remains to be surveyed. Other gaps in coverage include parts of Mexico, Cuba, and elsewhere in the northern Caribbean.

The 2011 breeding census count was substantially lower than the last census in 2006 when the overall count was $8,092(5,723$ in 2011) with more than 4,500 birds seen in the northern Great Plains and Prairie region (2,249 in 2011;
Elliott-Smith and others, 2009). This apparent decrease could be real, or it could be an artifact of extreme flooding in the Prairie and Plains region during 2011, which rendered much traditional habitat unsuitable. Some birds were observed using non-traditional habitat, such as flooded agricultural fields and gravel roads adjacent to traditional sites. It remains unknown what proportion of plovers use such sites, or other areas, during extreme wet and dry years.

During the winter census, potential disturbance to birds included people (46 percent of sites), off-leash dogs (23 percent), fishing (14 percent), vehicles (14 percent) and other activities ( 9 percent). Habitat disturbance included vehicle ruts (14 percent), invasive species (10 percent), hardened shoreline (10 percent), dredged material ( 7 percent), oil (3 percent), geotubes ( 1 percent), and other habitat disturbances ( 9 percent). Many winter sites may be vulnerable to sea-level rise, given that 71 percent of sites were rated "flat or gently sloping" and 29 percent have habitat only at low or mid tides.

During the breeding census, we collected disturbance data pertaining only to habitat. This included vehicle ruts (12 percent of sites), cattle tramping ( 7 percent), housing 
development ( 5 percent), invasive species ( 2 percent), industry ( 2 percent), and dredged material ( 1 percent). Most disturbances fell into the "other" category (19 percent), with comments suggesting impacts from human recreation, dogs, ATVs, garbage, encroaching vegetation, erosion, etc., all of which were exacerbated in some instances by flood conditions.

\section{Summary}

This report presents the results of 2011 International Piping Plover Census. The winter census, conducted from January 24 to February 6, detected 3,973 Piping Plovers. The breeding census, conducted from June 4 to 17 , detected 5,723 Piping Plovers including those counted during the U.S. Atlantic "window census."

\section{Acknowledgments}

Appreciation is extended to all those who supported the census. The U.S. Army Corps of Engineers, U.S. Geological Survey, Forest and Rangeland Ecosystem Science Center, Environment Canada, and the U.S. Fish and Wildlife Service provided financial support. Multiple partners provided support for coordination and implementation of on-the-ground surveys in individual States and Provinces and in particular we would like to thank the Canadian Wildlife Service for assistance in Canada and on the winter grounds. The International Piping Plover Coordination Group was instrumental in the planning and implementation of the census. The coordination group assisted in recruitment and assignment of State and Provincial coordinators and helped ensure that completed data sheets were submitted. Additionally, the census would not have been possible without on-the-ground coordination of State, Provincial, regional, and island coordinators. These included Federal, State, and non-governmental personnel who recruited surveyors, distributed census materials, and collated data. Thousands of people actually conducted the surveys. The volume of data that went into this report was extraordinary and several students assisted with entering data and developing tabular summaries, including Megan McClelland, Karla Garcia, and Reilly Newman.

\section{References Cited}

Brown, S., Hickey, C., Harrington, B., and Gill, R., eds., 2001, The U.S. Shorebird Conservation Plan, (2nd ed.): Manomet, Mass., Manomet Center for Conservation Sciences.

Elliott-Smith, E., and Haig, S.M., 2004, Piping Plover (Charadrius melodus), in Poole, A., ed., The Birds of North America online: Ithaca, New York, Cornell Lab of Ornithology, doi:10.2173/bna.2, http://bna.birds.cornell.edu/ bna/species/002.

Eliott-Smith, E., Haig, S.M., and Powers, B.M., 2009, Data from the 2006 International Piping Plover Census: U.S. Geological Survey Data Series 426, 332 p.

Gratto-Trevor, C., Amirault-Langlaise, D., Cuthbert, F., Fraser, J., Maddock, S., Roche, E., and Shaffer, F., 2012, Connectivity in Piping Plovers-Do breeding populations have distinct winter distributions?: Journal of Wildlife Management, v. 76, p. 348-355.

Haig, S.M., Ferland, C.L., Cuthbert, F.J., Dingledine, J., Goossen, J.P., Hecht, A., and McPhillips, N., 2005, A complete species census and evidence for regional declines in Piping Plovers: Journal of Wildlife Management, v. 69, p. $160-173$.

Haig, S.M., and Plissner, J.H., 1993, Distribution and abundance of Piping Plovers - Results and implications of the 1991 International Census: Condor, v. 95, p. 145-156.

Mendelssohn, I.A., Anderson, G.L., Baltz, D.M., Caffey, R.H., Carman, K.R., Fleeger, J.W., Joye, S.B., Lin, Q., Maltby, E., Overton, E.B., and Rozas, L.P., 2012, Oil impacts on coastal wetlands - Implications for the Mississippi River Delta ecosystem after the Deepwater Horizon oil spill: BioScience, v. 62, no. 6, p. 562-574.

Plissner, J.H., and Haig, S.M., 2000, Status of a broadlydistributed endangered species - Results and implications of the Second International Piping Plover Census: Canadian Journal of Zoology, v. 78, p. 1-12. 
Data from the 2011 International Piping Plover Census

This page left intentionally blank 


\section{Appendix 1 \\ State/Provincial Summaries}

Following are detailed accounts of the 2011 International Piping Plover Census for each state, province, island or island group. Accounts include a narrative prepared by the state, provincial, island, regional, or census coordinator assessing the success of the census in their area. At the bottom of each narrative is a small table with Piping Plover numbers for each census year. Each narrative is followed by a map of sites surveyed and a detailed table which includes information on each and every site surveyed during the census. Winter Census results are presented first, followed by results from each population censused on the breeding grounds. Furthermore, presentation of results generally starts with the northeast most state/province and ends in the southwest.

We conducted a detectability study during the 2011 Breeding Census and this information is also included in the state/provincial accounts. For provinces and states that participated in the detectability study there is a table at the end of the narrative with the name of each site included in the detectability study and a tally of how many birds were counted during the first and second surveys. It should be noted that for states/provinces that participated in the detectability study, the "high count" for each site is included in the detailed site tables following each map. 


\section{Key to 2011 Database Variables}

Results tabulated in this report represent data collected during the 2011 census. Listed below are explanations for the variables presented.

\section{Universal Variables:}

Map \# - Reference for associated map

Km - Kilometers surveyed

Site Description - Habitat description where surveying occurred (see "Other Variables")

Disturbance Concerns - Description of potential disturbance concerns where birds were observed (see "other Variables"). We note "none" for no disturbance; if questions were skipped we note "n.r." (none reported).

Prior Years Censused \& Years Seen - If previously surveyed, years surveyed are noted. Bold and underlined years indicate plovers were seen at the site during that Census year. Years with no emphasis indicate that no plovers were observed at that site during that Census year.

Owner - Site ownership (see "Site Ownership Variables"). If left blank we note "n.r." (none reported).

PIPL - Piping Plover

SNPL - Snowy Plover

WIPL - Wilson's Plover

\section{Other Variables:}

\begin{tabular}{||ll|}
\hline \hline \multicolumn{2}{|l|}{ Winter Habitat Variables } \\
\hline \hline Water Body: & \\
I & Ocean \\
II. & Protected Bay, Harbor, Cove, \\
III. & Lagoon \\
IV. & Gulf of Mexico \\
V. & Ocean Inlet \\
\hline Shoreline: & Other \\
A. & Mainland \\
B. & Barrier Island \\
C. & Spoil Island \\
D. & Bar \\
E. & Other Island \\
F. & Washover Area \\
G. & Other \\
\hline
\end{tabular}

\begin{tabular}{|c|c|}
\hline \multicolumn{2}{|c|}{ Breeding Habitat Variables } \\
\hline \multicolumn{2}{|c|}{ Water Body: } \\
\hline I & Ocean \\
\hline II. & $\begin{array}{l}\text { Protected Bay, Harbor, Cove, } \\
\text { Lagoon, Sound }\end{array}$ \\
\hline III. & River \\
\hline IV. & Alkali Lake/Pond \\
\hline V. & Natural Freshwater Lake \\
\hline VI. & Reservoir \\
\hline VII. & Industrial Pond \\
\hline VIII. & Sandpit \\
\hline IX. & Other \\
\hline \multicolumn{2}{|c|}{ Shoreline: } \\
\hline A. & Mainland (of coast, lake, river) \\
\hline B. & Barrier Beach \\
\hline C. & Barrier Island \\
\hline D. & Protected Shore \\
\hline E. & Natural Bar/Island \\
\hline F. & Man Made Bar/Island \\
\hline G. & Dry Lakebed \\
\hline H. & Agricultural Field \\
\hline I. & Other \\
\hline \multicolumn{2}{|c|}{ Disturbance /Concern Variables } \\
\hline A. & $\begin{array}{l}\text { Agricultural Activities (incl. } \\
\text { cattle trampling, etc.) }\end{array}$ \\
\hline D. & Dogs \\
\hline G. & Flat or Gently Sloping \\
\hline H. & Human activity \\
\hline I. & Invasive Species \\
\hline L. & Habitat Only at Low/Mid Tides \\
\hline N. & Industry \\
\hline V. & Vehicles/Vehicle Ruts \\
\hline W. & High Water/Flooding \\
\hline P. & Pollutants/Oil \\
\hline \multirow[t]{2}{*}{ S. } & Shoreline \\
\hline & Stabilization/Dredging/Geotubes \\
\hline B. & Airboats \\
\hline F. & Fishing \\
\hline U. & Urbanization/Housing and \\
\hline & Development \\
\hline O. & Other \\
\hline \multicolumn{2}{|c|}{ Ownership: } \\
\hline f. & Federal \\
\hline$s(p)$ & State/Provincial \\
\hline $\mathrm{m}$. & Municipal \\
\hline p. & Private \\
\hline c. & County \\
\hline unk. & Unknown \\
\hline
\end{tabular}




\section{The 2011 International Piping Plover Winter Census in Virginia}

Ruth Boettcher

VA Dept. of Game and Inland Fisheries

11116 Bayside Rd.

Machipongo, VA 23405

757-709-0766

ruth.boettcher@dgif.virginia.gov

The 2011 Census was only the second time Virginia participated in the International Winter Census because the state is not generally considered to be part of the species' winter range. During the 2011 Census, 20 observers surveyed a total of 22 sites, all of which encompass the same locations covered during annual breeding surveys. As during the 2006 Census, this year's effort yielded only one Piping Plover, once again confirming that Virginia beaches are not used extensively by Piping Plovers in the winter. Similar to the 2006 Census, the single observation occurred on one of Virginia's northern barrier islands; however, not as far north as the 2006 sighting.

\section{Comparison of Census Numbers}

\begin{tabular}{|l|c|c|c|c|c|}
\hline Species & 1991 & 1996 & 2001 & 2006 & 2011 \\
\hline $\begin{array}{l}\text { Piping } \\
\text { Plover }\end{array}$ & - & - & - & 1 & 1 \\
\hline $\begin{array}{l}\text { Snowy } \\
\text { Plover }\end{array}$ & - & - & - & n.a. & n.a. \\
\hline $\begin{array}{l}\text { Wilson's } \\
\text { Plover }\end{array}$ & - & - & - & 0 & 0 \\
\hline
\end{tabular}




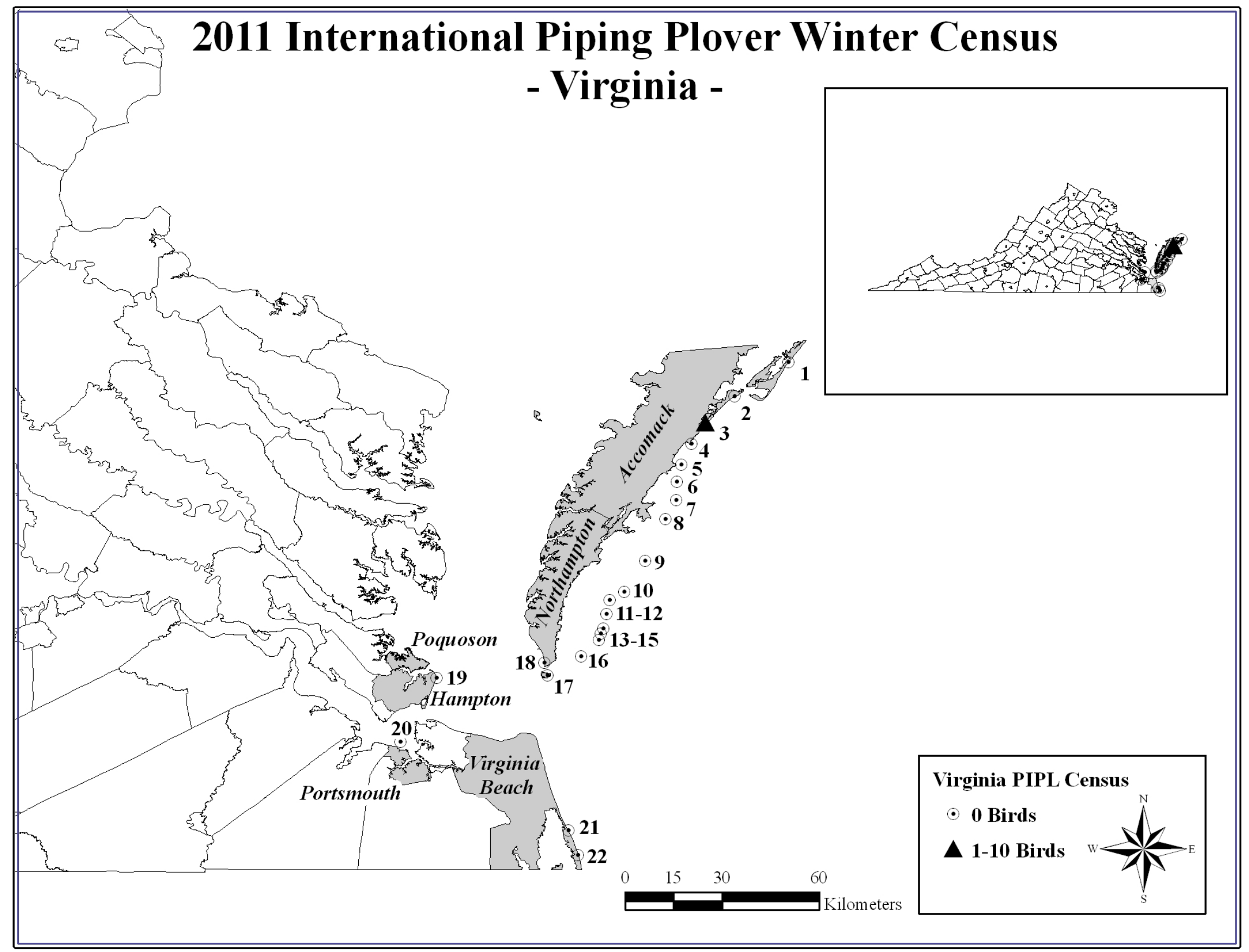


The 2011 International Piping Plover Winter Census in Virginia

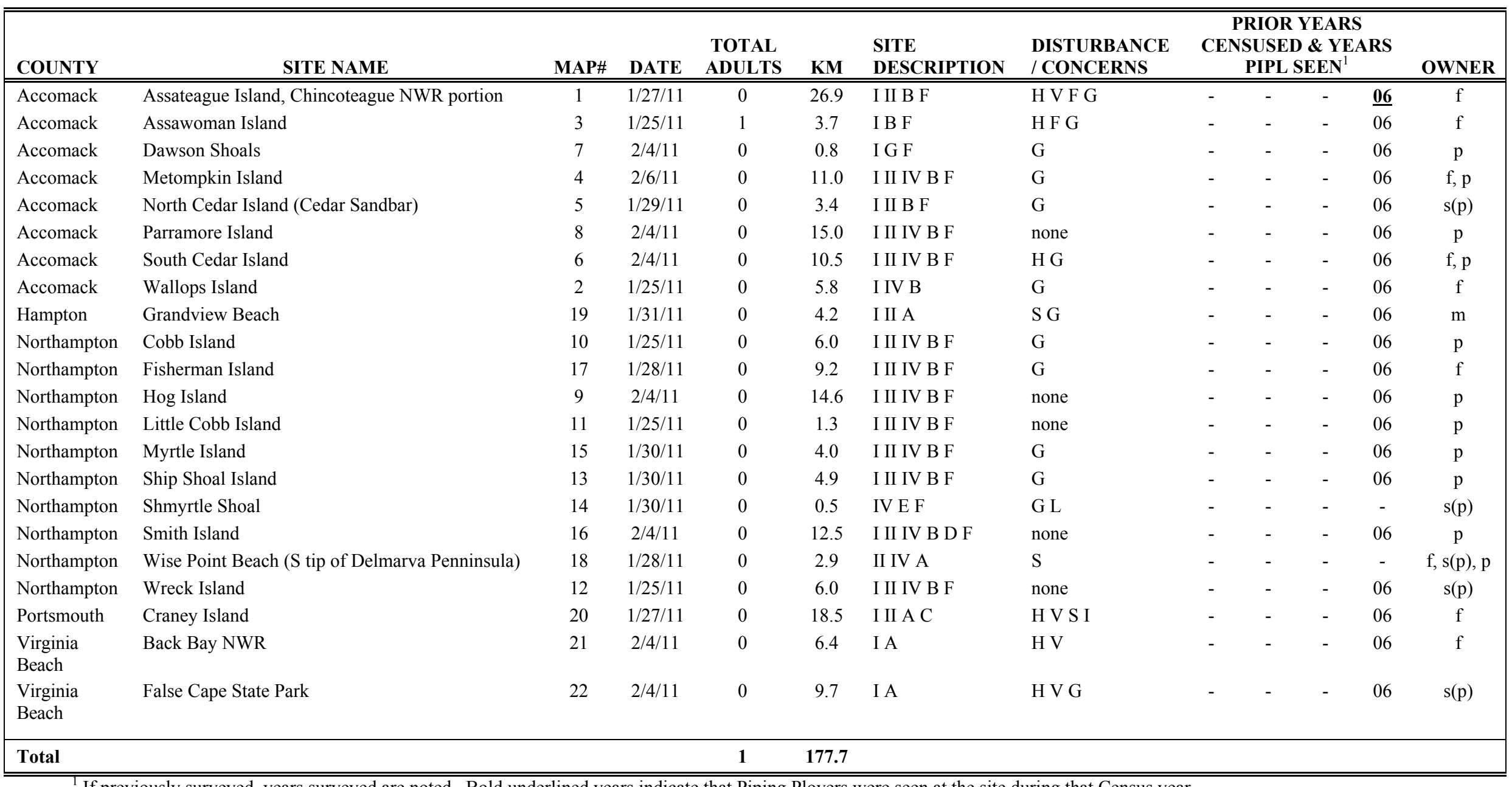

If previously surveyed, years surveyed are noted. Bold underlined years indicate that Piping Plovers were seen at the site during that Census year. 


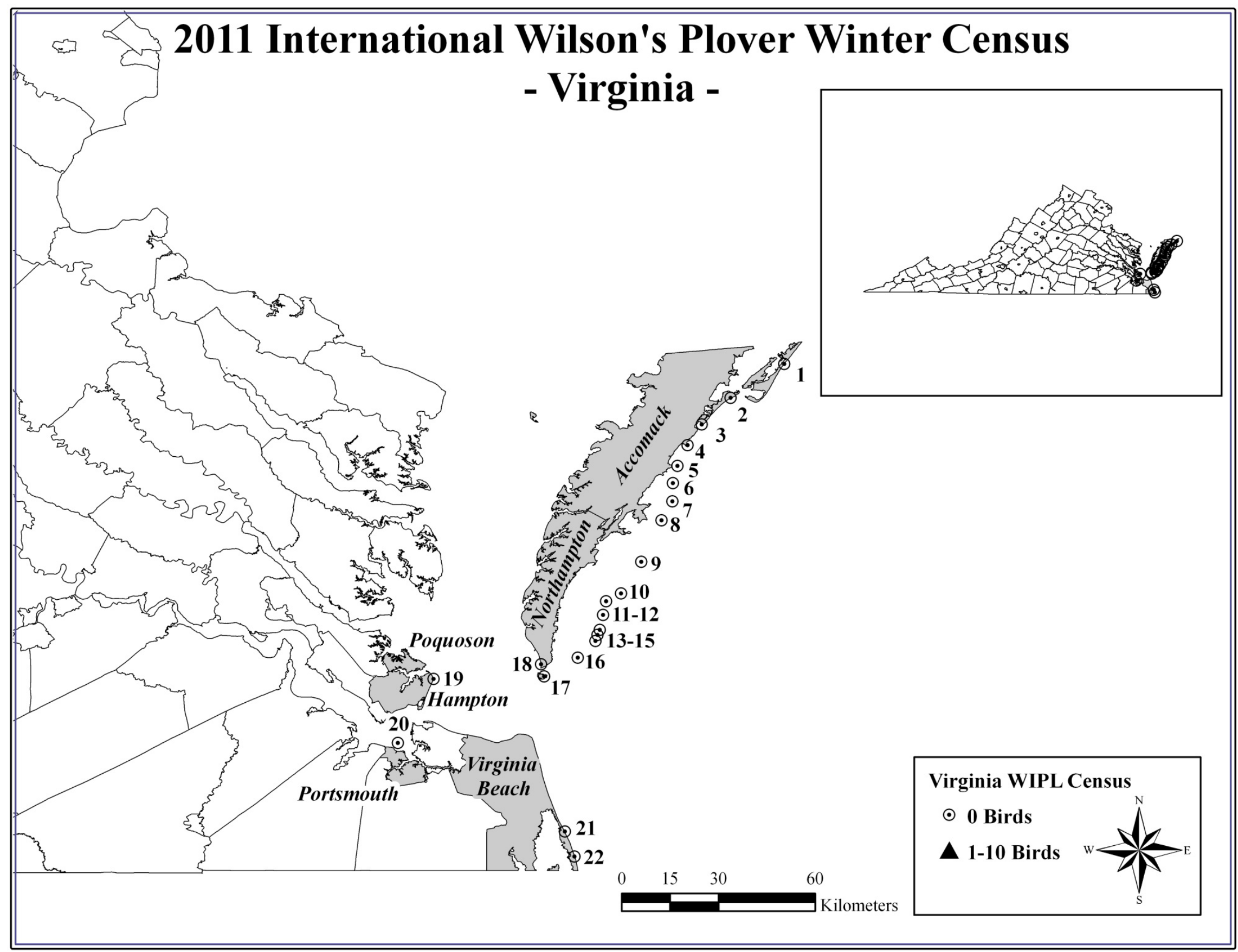


The 2011 International Wilson's Plover Winter Census in Virginia

\begin{tabular}{|c|c|c|c|c|c|c|c|c|c|c|c|c|}
\hline \multirow{2}{*}{$\begin{array}{l}\text { COUNTY } \\
\text { Accomack }\end{array}$} & SITE NAME & \multirow{2}{*}{ MAP\# } & \multirow{2}{*}{$\begin{array}{l}\text { DATE } \\
1 / 27 / 11\end{array}$} & \multirow{2}{*}{$\begin{array}{c}\text { TOTAL } \\
\text { ADULTS } \\
0\end{array}$} & \multirow{2}{*}{$\begin{array}{l}\text { KM } \\
26.9\end{array}$} & \multirow{2}{*}{$\begin{array}{l}\text { SITE } \\
\text { DESCRIPTION } \\
\text { I II B F }\end{array}$} & \multirow{2}{*}{$\begin{array}{l}\text { DISTURBANCE } \\
\text { / CONCERNS } \\
\mathrm{H} \mathrm{V} \mathrm{F} \mathrm{G}\end{array}$} & \multicolumn{4}{|c|}{$\begin{array}{c}\text { PRIOR YEARS } \\
\text { CENSUSED \& YEARS } \\
\text { WIPL SEEN }^{1} \\
\end{array}$} & \multirow{2}{*}{$\frac{\text { OWNER }}{\mathrm{f}}$} \\
\hline & Assateague Island, Chincoteague NWR portion & & & & & & & - & - & - & 06 & \\
\hline Accomack & Assawoman Island & 3 & $1 / 25 / 11$ & 0 & 3.7 & I B F & H F G & - & - & - & 06 & $\mathrm{f}$ \\
\hline Accomack & Dawson Shoals & 7 & $2 / 4 / 11$ & 0 & 0.8 & I G F & G & - & - & - & 06 & $\mathrm{p}$ \\
\hline Accomack & Metompkin Island & 4 & $2 / 6 / 11$ & 0 & 11.0 & I II IV B F & G & - & - & - & 06 & $\mathrm{f}, \mathrm{p}$ \\
\hline Accomack & North Cedar Island (Cedar Sandbar) & 5 & $1 / 29 / 11$ & 0 & 3.4 & I II B F & G & - & - & - & 06 & $\mathrm{~s}(\mathrm{p})$ \\
\hline Accomack & Parramore Island & 8 & $2 / 4 / 11$ & 0 & 15.0 & I II IV B F & none & - & - & - & 06 & $\mathrm{p}$ \\
\hline Accomack & South Cedar Island & 6 & $2 / 4 / 11$ & 0 & 10.5 & I II IV B F & H G & - & - & - & 06 & $\mathrm{f}, \mathrm{p}$ \\
\hline Accomack & Wallops Island & 2 & $1 / 25 / 11$ & 0 & 5.8 & I IV B & G & - & - & - & 06 & $\mathrm{f}$ \\
\hline Hampton & Grandview Beach & 19 & $1 / 31 / 11$ & 0 & 4.2 & I II A & S G & - & - & - & 06 & $\mathrm{~m}$ \\
\hline Northampton & Cobb Island & 10 & $1 / 25 / 11$ & 0 & 6.0 & I II IV B F & G & - & - & - & 06 & $\mathrm{p}$ \\
\hline Northampton & Fisherman Island & 17 & $1 / 28 / 11$ & 0 & 9.2 & I II IV B F & G & - & - & - & 06 & $\mathrm{f}$ \\
\hline Northampton & Hog Island & 9 & $2 / 4 / 11$ & 0 & 14.6 & I II IV B F & none & - & - & - & 06 & $\mathrm{p}$ \\
\hline Northampton & Little Cobb Island & 11 & $1 / 25 / 11$ & 0 & 1.3 & I II IV B F & none & - & - & - & 06 & $\mathrm{p}$ \\
\hline Northampton & Myrtle Island & 15 & $1 / 30 / 11$ & 0 & 4.0 & I II IV B F & G & - & - & - & 06 & $\mathrm{p}$ \\
\hline Northampton & Ship Shoal Island & 13 & $1 / 30 / 11$ & 0 & 4.9 & I II IV B F & G & - & - & - & 06 & $\mathrm{p}$ \\
\hline Northampton & Shmyrtle Shoal & 14 & $1 / 30 / 11$ & 0 & 0.5 & IV E F & G L & - & - & - & - & $\mathrm{s}(\mathrm{p})$ \\
\hline Northampton & Smith Island & 16 & $2 / 4 / 11$ & 0 & 12.5 & I II IV B D F & none & - & - & - & 06 & $\mathrm{p}$ \\
\hline Northampton & Wise Point Beach (S tip of Delmarva Penninsula) & 18 & $1 / 28 / 11$ & 0 & 2.9 & II IV A & $\mathrm{S}$ & - & - & - & - & $f, s(p), p$ \\
\hline Northampton & Wreck Island & 12 & $1 / 25 / 11$ & 0 & 6.0 & I II IV B F & none & - & - & - & 06 & $\mathrm{~s}(\mathrm{p})$ \\
\hline Portsmouth & Craney Island & 20 & $1 / 27 / 11$ & 0 & 18.5 & I II A C & H V S I & - & - & - & 06 & $\mathrm{f}$ \\
\hline $\begin{array}{l}\text { Virginia } \\
\text { Beach }\end{array}$ & Back Bay NWR & 21 & $2 / 4 / 11$ & 0 & 6.4 & I A & H V & - & - & - & 06 & $\mathrm{f}$ \\
\hline $\begin{array}{l}\text { Virginia } \\
\text { Beach }\end{array}$ & False Cape State Park & 22 & $2 / 4 / 11$ & 0 & 9.7 & I A & H V G & - & - & - & 06 & $\mathrm{~s}(\mathrm{p})$ \\
\hline Total & & & & $\mathbf{0}$ & 177.7 & & & & & & & \\
\hline
\end{tabular}

If previously surveyed, years surveyed are noted. Bold underlined years indicate that Wilson's Plovers were seen at the site during that Census year. 


\section{The 2011 International Piping Plover Winter Census in North Carolina}

Sara H. Schweitzer

NC Wildlife Resources Commission

Wildlife Diversity Biologist

Coastal Waterbirds

106 Ferret Run Ln, New Bern, NC 28562

252-639-8534

sara.schweitzer@ncwildlife.org

The 2011 International Piping Plover Census in North Carolina was largely complete with most known sites and suitable habitats surveyed. Thirty people covered almost all suitable habitats and slightly more habitat than in 2006. This year's count of 43 birds is lower than the number of Piping Plovers counted in 1996, 2001, and 2006, but higher than the 1991 count. We censused a greater length of shoreline (over $400 \mathrm{~km}$ ) this year and had more participants.

We had several days with high winds, rain, and snow during the census window; however, we censused all but two sites within the time frame. Winter storms and snow reduce the number of plovers in North Carolina and these weather events may have brought about the lower number of plovers in 2011. We tried to avoid counting during high winds and rain, but a couple of sites were surveyed during these conditions so it is possible that birds were not detected at these sites. Browns Island, a small barrier island just north of Onslow Beach, was not surveyed during the census window because the Marine Corps Base would not grant access to the restricted area.
Approximately $6 \mathrm{~km}$ along the east end of Cedar Island were not censused because they were inaccessible by foot and waterfowl hunters were hunting in the area. We consider the east end of Cedar Island suitable habitat although we do not have many records of Piping Plovers using it. Piping Plovers may use narrow sand and mudflats behind barrier islands or other inaccessible areas within the sounds. Many kilometers of narrow, developed, ocean-facing beach were not surveyed because we rarely see Piping Plovers in these areas and do not consider them to be suitable habitat. Human activities and stronger wind and wave impacts in these areas likely render them unsuitable for Piping Plovers. We did not survey all natural and dredge-material islands near Ocracoke Inlet, including North Rock, Shell Castle, Beacon, and Casey Islands.

During the census for Piping Plovers, we also recorded all Wilson's and Snowy Plovers detected. Only two Wilson's Plovers were detected, and both of them were on the east end of Ocean Isle Beach. No Snowy Plovers were detected. The North Carolina coast is not a common wintering area for either of these plover species.

Comparison of Census Numbers

\begin{tabular}{|l|c|c|c|c|c|}
\hline Species & 1991 & 1996 & 2001 & 2006 & 2011 \\
\hline $\begin{array}{l}\text { Piping } \\
\text { Plover }\end{array}$ & 21 & 50 & 87 & 84 & 43 \\
\hline $\begin{array}{l}\text { Snowy } \\
\text { Plover }\end{array}$ & - & - & - & n.a. & n.a. \\
\hline $\begin{array}{l}\text { Wilson's } \\
\text { Plover }\end{array}$ & - & - & - & 1 & 2 \\
\hline
\end{tabular}




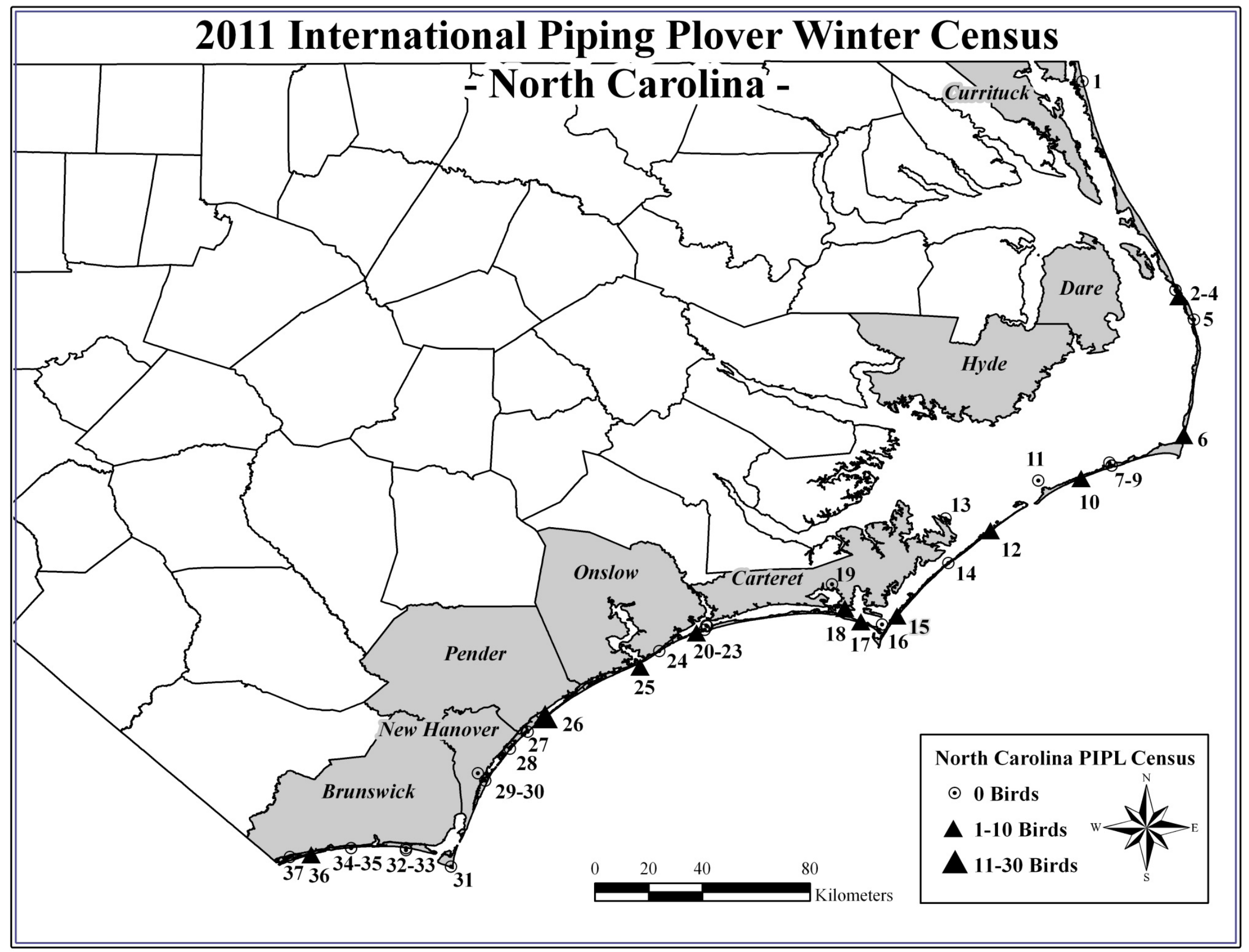


The 2011 International Piping Plover Winter Census in North Carolina

\begin{tabular}{|c|c|c|c|c|c|c|c|c|c|c|c|c|}
\hline \multirow{2}{*}{$\frac{\text { COUNTY }}{\text { Brunswick }}$} & \multirow{2}{*}{$\begin{array}{c}\text { SITE NAME } \\
\text { Bald Head Island to S. End of Ft. Fisher }\end{array}$} & \multirow{2}{*}{ MAP\# } & \multirow{2}{*}{$\begin{array}{c}\text { DATE } \\
2 / 3 / 11\end{array}$} & \multirow{2}{*}{$\begin{array}{c}\text { TOTAL } \\
\text { ADULTS } \\
0\end{array}$} & \multirow{2}{*}{$\frac{\mathbf{K M}}{27.3}$} & \multirow{2}{*}{$\begin{array}{l}\text { SITE } \\
\text { DESCRIPTION } \\
\text { I II IV B }\end{array}$} & \multirow{2}{*}{$\begin{array}{l}\text { DISTURBANCE } \\
\text { / CONCERNS } \\
\mathrm{V} \mathrm{S} \mathrm{G}\end{array}$} & \multicolumn{4}{|c|}{$\begin{array}{c}\text { PRIOR YEARS } \\
\text { CENSUSED \& YEARS } \\
\text { PIPL SEEN }^{1} \\
\end{array}$} & \multirow{2}{*}{$\frac{\text { OWNER }}{=\mathrm{s}(\mathrm{p}), \mathrm{m}}$} \\
\hline & & & & & & & & 91 & 96 & $\underline{01}$ & $\underline{06}$ & \\
\hline Brunswick & Fort Caswell; E end Oak Island & 32 & $2 / 3 / 11$ & 0 & 3.5 & I IV B & $\mathrm{H}$ & 91 & 96 & 01 & 06 & $\mathrm{~m}$ \\
\hline Brunswick & Holden Beach; E end (Lockwood Folly's Inlet) & 34 & $2 / 3 / 11$ & 0 & 4.0 & I IV B & H D V O G & 91 & 96 & 01 & 06 & $\mathrm{~m}, \mathrm{p}$ \\
\hline Brunswick & Holden Beach; W end (Shallotte Inlet) & 35 & $2 / 3 / 11$ & 0 & 4.8 & I IV B & $\mathrm{H} \mathrm{G}$ & $\underline{91}$ & 96 & 01 & 06 & $\mathrm{~m}, \mathrm{p}$ \\
\hline Brunswick & Long Beach; W end Oak Island & 33 & $2 / 3 / 11$ & 0 & 3.2 & I IV B D & H D & 91 & 96 & 01 & 06 & $\mathrm{~m}$ \\
\hline Brunswick & Ocean Isle Beach East and West Ends & 36 & $2 / 3 / 11$ & 1 & 8.8 & I IV B & $\mathrm{H}$ & 91 & 96 & 01 & $\underline{06}$ & $\mathrm{~s}(\mathrm{p})$ \\
\hline Brunswick & Sunset Beach and Bird Island & 37 & $2 / 6 / 11$ & 0 & 6.4 & I IV B & H D G & 91 & $\underline{96}$ & 01 & 06 & $\mathrm{~s}(\mathrm{p})$ \\
\hline Carteret & $\begin{array}{l}\text { Cape Lookout NS; Morgan Island \& Sandbag } \\
\text { Island }\end{array}$ & 16 & $2 / 1 / 11$ & 0 & 4.0 & $\mathrm{~V} \mathrm{C}$ & none & 91 & 96 & 01 & 06 & $\mathrm{f}$ \\
\hline Carteret & Cape Lookout NS - North Core Banks & 12 & $1 / 28 / 11$ & 6 & 37.0 & I IV B & G & $\underline{91}$ & $\underline{96}$ & 01 & $\underline{06}$ & $\mathrm{f}$ \\
\hline Carteret & Cape Lookout NS - Shackleford Banks & 17 & $1 / 24 / 11$ & 7 & 14.5 & I II IV B & $\mathrm{O}$ & 91 & $\underline{96}$ & 01 & $\underline{06}$ & $\mathrm{f}$ \\
\hline Carteret & Cape Lookout NS - South Core Banks & 15 & $1 / 24 / 11$ & 2 & 37.0 & I II IV B & G & $\underline{91}$ & $\underline{96}$ & $\underline{01}$ & $\underline{06}$ & $\mathrm{f}$ \\
\hline Carteret & Cedar Island & 13 & $1 / 24 / 11$ & 0 & 4.0 & V E & H V A G & 91 & 96 & 01 & 06 & $\mathrm{f}$ \\
\hline Carteret & Dump Island and New Dump Island & 14 & $2 / 1 / 11$ & 0 & 3.5 & $\mathrm{~V} \mathrm{C}$ & none & - & - & - & - & $\mathrm{s}(\mathrm{p})$ \\
\hline Carteret & Ft. Macon SP & 19 & $1 / 24 / 11$ & 0 & 1.6 & I IV B & $\mathrm{G}$ & 91 & $\underline{96}$ & 01 & 06 & $\mathrm{~s}(\mathrm{p})$ \\
\hline Carteret & $\begin{array}{l}\text { Rachel Carson Estuarine Research Reserve } \\
\text { (Bird Shoal) }\end{array}$ & 18 & $1 / 24 / 11$ & 3 & 2.6 & IV C E & none & 91 & $\underline{96}$ & 01 & $\underline{06}$ & $\mathrm{~s}(\mathrm{p})$ \\
\hline Carteret/Onslow & Bogue Inlet Shoals & 20 & $2 / 3 / 11$ & 0 & 2.0 & IV D G & $\mathrm{G}$ & 91 & 96 & 01 & 06 & $\mathrm{~s}(\mathrm{p})$ \\
\hline Currituck & Currituck National Wildlife Refuge & 1 & $1 / 24 / 11$ & 0 & 17.7 & I G & H V G L & 91 & 96 & 01 & 06 & $\mathrm{f}$ \\
\hline Dare & Cape Hatteras NS; Rodanthe to Buxton & 2 & $1 / 26 / 11$ & 0 & 37.0 & I B & V G L & - & - & - & 06 & $\mathrm{f}$ \\
\hline Dare & Cape Hatteras NS; Bodie Island & 3 & $1 / 27 / 11$ & 0 & 9.1 & I IV V B F & H D V F G & $\underline{91}$ & 96 & 01 & 06 & $\mathrm{f}$ \\
\hline Dare & Cape Hatteras NS; Cape Point to Hatteras Inlet & 7 & $1 / 27 / 11$ & 0 & 27.4 & I IV V B & H V D G L & $\underline{91}$ & 96 & 01 & 06 & $\mathrm{f}$ \\
\hline Dare & Clam Shoal & 6 & $1 / 27 / 11$ & 3 & 8.0 & V G & H G L & - & $\underline{96}$ & 01 & $\underline{06}$ & $\mathrm{~s}(\mathrm{p})$ \\
\hline Dare & Oregon Inlet and multiple islands & 4 & $1 / 28 / 11$ & 1 & 11.0 & $\mathrm{~V} \mathrm{C}$ & $\mathrm{U}$ & - & - & 01 & $\underline{06}$ & $s(p)$ \\
\hline Dare & Pea Island National Wildlife Refuge & 5 & $1 / 27 / 11$ & 0 & 19.3 & IV V B & $\mathrm{OG}$ & 91 & 96 & $\underline{01}$ & $\underline{06}$ & $\mathrm{f}$ \\
\hline Dare/Hyde & $\begin{array}{l}\text { DOT Island, Ferry Channel Island, and Cora } \\
\text { June Island }\end{array}$ & 8 & $1 / 27 / 11$ & 0 & 13.0 & $\mathrm{~V} \mathrm{C}$ & none & 91 & 96 & 01 & 06 & $\mathrm{~s}(\mathrm{p})$ \\
\hline Hyde & Cape Hatteras NS; Ocracoke Island & 10 & $1 / 28 / 11$ & 6 & 27.4 & I IV V B & H V G & 91 & 96 & 01 & 06 & $\mathrm{f}$ \\
\hline Hyde & Ocracoke Inlet; Big Foot Island & 11 & $1 / 27 / 11$ & 0 & 3.2 & $\mathrm{VC}$ & $\mathrm{G}$ & - & - & - & - & $\mathrm{s}(\mathrm{p})$ \\
\hline New Hanover & Carolina Beach State Park & 30 & $2 / 6 / 11$ & 0 & 8.0 & I IV B & H D V F & 91 & 96 & 01 & 06 & $\mathrm{~s}(\mathrm{p})$ \\
\hline New Hanover & Figure Eight Island and Wrightsville Beach & 28 & $2 / 3 / 11$ & 0 & 4.8 & I II IV B & $\mathrm{G}$ & - & $\underline{96}$ & 01 & 06 & $\mathrm{~m}, \mathrm{p}$ \\
\hline New Hanover & Masonboro Inlet ${ }^{4}$ & 29 & $2 / 9 / 11$ & 0 & 11.8 & I II IV B D & $\mathrm{H} \mathrm{G}$ & 91 & 96 & 01 & $\underline{06}$ & $\mathrm{~s}(\mathrm{p})$ \\
\hline Onslow & Bogue Inlet Islands, Dudley Island ${ }^{4}$ & 21 & $2 / 23 / 11$ & 0 & 1.6 & IV G & G & 91 & 96 & 01 & 06 & unk \\
\hline
\end{tabular}


The 2011 International Piping Plover Winter Census in North Carolina (Continued)

\begin{tabular}{|c|c|c|c|c|c|c|c|c|c|c|c|c|}
\hline \multirow{2}{*}{$\begin{array}{l}\text { COUNTY } \\
\text { Onslow }\end{array}$} & \multirow{2}{*}{$\begin{array}{r}\text { SITE NAME } \\
\text { East Bear Island }\end{array}$} & \multirow{2}{*}{ MAP\# } & \multirow{2}{*}{$\frac{\text { DATE }}{2 / 3 / 11}$} & \multirow{2}{*}{$\begin{array}{c}\text { TOTAL } \\
\text { ADULTS } \\
2\end{array}$} & \multirow{2}{*}{$\frac{\mathbf{K M}}{3.2}$} & \multirow{2}{*}{$\begin{array}{l}\text { SITE } \\
\text { DESCRIPTION } \\
\text { I IV B }\end{array}$} & \multirow{2}{*}{$\begin{array}{l}\text { DISTURBANCE } \\
\text { CONCERNS } \\
\mathrm{G}\end{array}$} & \multicolumn{4}{|c|}{$\begin{array}{c}\text { PRIOR YEARS } \\
\text { CENSUSED \& YEARS } \\
\text { PIPL SEEN }^{1} \\
\end{array}$} & \multirow{2}{*}{$\frac{\text { OWNER }}{}$} \\
\hline & & & & & & & & 91 & 96 & 01 & 06 & \\
\hline Onslow & N Topsail Beach; New River Inlet & 25 & $2 / 6 / 11$ & 1 & 0.8 & IV B F & H V S G & 91 & 96 & 01 & 06 & $\mathrm{~m}$ \\
\hline Onslow & $\begin{array}{l}\text { Onslow Beach, Camp Lejeune (U.S. Marine } \\
\text { Corps Base) }\end{array}$ & 24 & $2 / 4 / 11$ & 0 & 12.9 & I IV B F & V G & - & - & 01 & 06 & $\mathrm{f}$ \\
\hline Onslow & West Bear Island & 22 & $2 / 4 / 11$ & 0 & 7.2 & I IV B & G & 91 & 96 & 01 & 06 & $s(p)$ \\
\hline Pender & Hutaff Island and Rich Inlet Shoals ${ }^{4}$ & 27 & $2 / 7 / 11$ & 0 & 6.6 & I IV B D & $\mathrm{H} \mathrm{G}$ & $91^{2}$ & 96 & $\underline{01}$ & $\underline{06}$ & $s(p), p$ \\
\hline Pender & Lea Island; S Topsail Beach and Inlet & 26 & $2 / 3 / 11$ & 11 & 11.1 & I IV B D & V S G & $91^{3}$ & 96 & $\underline{01}$ & $\underline{06}$ & $\mathrm{~m}, \mathrm{p}$ \\
\hline Total & & & & 43 & 405.3 & & & & & & & \\
\hline
\end{tabular}

If previously surveyed, years surveyed are noted. Bold underlined years indicate that Piping Plovers were seen at the site during that Census year.

${ }^{2}$ Only a portion of this site was surveyed in 1991 but this included Figure Eight Island and PIPL were seen there in 1991.

${ }^{3} \mathrm{~S}$ Topsail Beach was covered in 1991 and this was where PIPL were seen in 2011.

${ }^{4}$ Please note that this survey was conducted outside the Census window. 


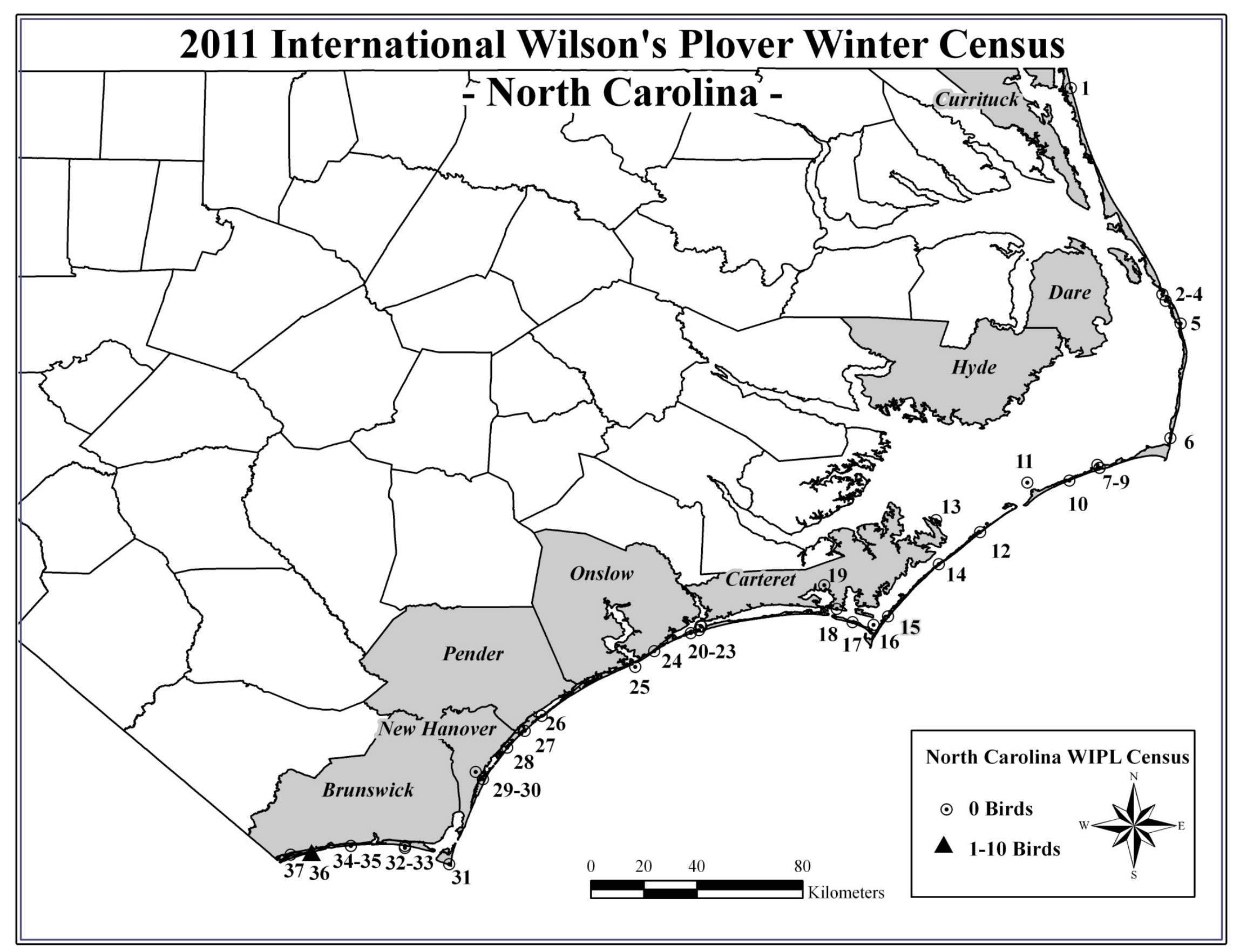


The 2011 International Wilson's Plover Winter Census in North Carolina

\begin{tabular}{|c|c|c|c|c|c|c|c|c|c|c|c|c|}
\hline \multirow{2}{*}{$\begin{array}{l}\text { COUNTY } \\
\text { Brunswick }\end{array}$} & \multirow{2}{*}{$\frac{\text { SITE NAME }}{\text { Bald Head Island to S. End of Ft. Fis }}$} & \multirow{2}{*}{ MAP\# } & \multirow{2}{*}{$\begin{array}{c}\text { DATE } \\
2 / 3 / 11\end{array}$} & \multirow{2}{*}{$\begin{array}{c}\text { TOTAL } \\
\text { ADULTS } \\
0\end{array}$} & \multirow{2}{*}{$\frac{\mathbf{K M}}{27.3}$} & \multirow{2}{*}{$\begin{array}{l}\text { SITE } \\
\text { DESCRIPTION } \\
\text { I II IV B }\end{array}$} & \multirow{2}{*}{$\begin{array}{l}\text { DISTURBANCE } \\
\text { / CONCERNS } \\
\text { V S G }\end{array}$} & \multicolumn{4}{|c|}{$\begin{array}{c}\text { PRIOR YEARS } \\
\text { CENSUSED \& YEARS } \\
\text { WIPL SEEN }^{1} \\
\end{array}$} & \multirow{2}{*}{$\begin{array}{c}\text { OWNER } \\
\mathrm{s}(\mathrm{p}), \mathrm{m}\end{array}$} \\
\hline & & & & & & & & - & - & - & 06 & \\
\hline Brunswick & Fort Caswell; E end Oak Island & 32 & $2 / 3 / 11$ & 0 & 3.5 & I IV B & $\mathrm{H}$ & - & - & - & 06 & $\mathrm{~m}$ \\
\hline Brunswick & Holden Beach; E end (Lockwood Folly's Inlet) & 34 & $2 / 3 / 11$ & 0 & 4.0 & I IV B & H D V O G & - & - & - & 06 & $\mathrm{~m}, \mathrm{p}$ \\
\hline Brunswick & Holden Beach; W end (Shallotte Inlet) & 35 & $2 / 3 / 11$ & 0 & 4.8 & I IV B & H G & - & - & - & 06 & $\mathrm{~m}, \mathrm{p}$ \\
\hline Brunswick & Long Beach; W end Oak Island & 33 & $2 / 3 / 11$ & 0 & 3.2 & I IV B D & H D & - & - & - & 06 & $\mathrm{~m}$ \\
\hline Brunswick & Ocean Isle Beach East and West Ends & 36 & $2 / 3 / 11$ & 2 & 8.8 & I IV B & $\mathrm{H}$ & - & - & - & 06 & $\mathrm{~s}(\mathrm{p})$ \\
\hline Brunswick & Sunset Beach and Bird Island & 37 & $2 / 6 / 11$ & 0 & 6.4 & I IV B & H D G & - & - & - & 06 & $\mathrm{~s}(\mathrm{p})$ \\
\hline Carteret & $\begin{array}{l}\text { Cape Lookout NS; Morgan Island \& Sandbag } \\
\text { Island }\end{array}$ & 16 & $2 / 1 / 11$ & 0 & 4.0 & $\mathrm{~V} \mathrm{C}$ & none & - & - & - & 06 & $\mathrm{f}$ \\
\hline Carteret & Cape Lookout NS - North Core Banks & 12 & $1 / 28 / 11$ & 0 & 37.0 & I IV B & $\mathrm{G}$ & - & - & - & 06 & $\mathrm{f}$ \\
\hline Carteret & Cape Lookout NS - Shackleford Banks & 17 & $1 / 24 / 11$ & 0 & 14.5 & I II IV B & $\mathrm{O}$ & - & - & - & 06 & $\mathrm{f}$ \\
\hline Carteret & Cape Lookout NS - South Core Banks & 15 & $1 / 24 / 11$ & 0 & 37.0 & I II IV B & $\mathrm{G}$ & - & - & - & 06 & $\mathrm{f}$ \\
\hline Carteret & Cedar Island & 13 & $1 / 24 / 11$ & 0 & 4.0 & V E & H V A G & - & - & - & 06 & $\mathrm{f}$ \\
\hline Carteret & Dump Island and New Dump Island & 14 & $2 / 1 / 11$ & 0 & 3.5 & $\mathrm{~V} \mathrm{C}$ & none & - & - & - & - & $\mathrm{s}(\mathrm{p})$ \\
\hline Carteret & Ft. Macon SP & 19 & $1 / 24 / 11$ & 0 & 1.6 & I IV B & $\mathrm{G}$ & - & - & - & 06 & $\mathrm{~s}(\mathrm{p})$ \\
\hline Carteret & $\begin{array}{l}\text { Rachel Carson Estuarine Research Reserve } \\
\text { (Bird Shoal) }\end{array}$ & 18 & $1 / 24 / 11$ & 0 & 2.6 & IV C E & none & - & - & - & $\underline{06}$ & $\mathrm{~s}(\mathrm{p})$ \\
\hline Carteret/Onslow & Bogue Inlet Shoals & 20 & $2 / 3 / 11$ & 0 & 2.0 & IV D G & $\mathrm{G}$ & - & - & - & 06 & $\mathrm{~s}(\mathrm{p})$ \\
\hline Currituck & Currituck National Wildlife Refuge & 1 & $1 / 24 / 11$ & 0 & 17.7 & I G & H V G L & - & - & - & 06 & $\mathrm{f}$ \\
\hline Dare & Cape Hatteras NS; Rodanthe to Buxton & 2 & $1 / 26 / 11$ & 0 & 37.0 & I B & V G L & - & - & - & 06 & $\mathrm{f}$ \\
\hline Dare & Cape Hatteras NS; Bodie Island & 3 & $1 / 27 / 11$ & 0 & 9.1 & I IV V B F & H D V F G & - & - & - & 06 & $\mathrm{f}$ \\
\hline Dare & Cape Hatteras NS; Cape Point to Hatteras Inlet & 7 & $1 / 27 / 11$ & 0 & 27.4 & I IV V B & H V D G L & - & - & - & 06 & $\mathrm{f}$ \\
\hline Dare & Clam Shoal & 6 & $1 / 27 / 11$ & 0 & 8.0 & V G & H G L & - & - & - & 06 & $\mathrm{~s}(\mathrm{p})$ \\
\hline Dare & Oregon Inlet and multiple islands & 4 & $1 / 28 / 11$ & 0 & 11.0 & $\mathrm{~V} \mathrm{C}$ & $\mathrm{U}$ & - & - & - & 06 & $\mathrm{~s}(\mathrm{p})$ \\
\hline Dare & Pea Island National Wildlife Refuge & 5 & $1 / 27 / 11$ & 0 & 19.3 & IV V B & $\mathrm{OG}$ & - & - & - & 06 & $\mathrm{f}$ \\
\hline Dare/Hyde & $\begin{array}{l}\text { DOT Island, Ferry Channel Island, and Cora } \\
\text { June Island }\end{array}$ & 8 & $1 / 27 / 11$ & 0 & 13.0 & $\mathrm{~V} \mathrm{C}$ & none & - & - & - & 06 & $s(p)$ \\
\hline Hyde & Cape Hatteras NS; Ocracoke Island & 10 & $1 / 28 / 11$ & 0 & 27.4 & I IV V B & H V G & - & - & - & 06 & $\mathrm{f}$ \\
\hline Hyde & Ocracoke Inlet; Big Foot Island & 11 & $1 / 27 / 11$ & 0 & 3.2 & $\mathrm{VC}$ & $\mathrm{G}$ & - & - & - & - & $\mathrm{s}(\mathrm{p})$ \\
\hline New Hanover & Carolina Beach State Park & 30 & $2 / 6 / 11$ & 0 & 8.0 & I IV B & H D V F & - & - & - & 06 & $\mathrm{~s}(\mathrm{p})$ \\
\hline New Hanover & Figure Eight Island and Wrightsville Beach & 28 & $2 / 3 / 11$ & 0 & 4.8 & I II IV B & $\mathrm{G}$ & - & - & - & 06 & $\mathrm{~m}, \mathrm{p}$ \\
\hline New Hanover & Masonboro Inlet $^{2}$ & 29 & $2 / 9 / 11$ & 0 & 11.8 & I II IV B D & $\mathrm{H} \mathrm{G}$ & - & - & - & 06 & $\mathrm{~s}(\mathrm{p})$ \\
\hline Onslow & Bogue Inlet Islands, Dudley Island ${ }^{2}$ & 21 & $2 / 23 / 11$ & 0 & 1.6 & IV G & $\mathrm{G}$ & - & - & - & 06 & unk \\
\hline
\end{tabular}


The 2011 International Wilson's Plover Winter Census in North Carolina (Continued)

\begin{tabular}{|c|c|c|c|c|c|c|c|c|c|c|c|}
\hline \multirow{2}{*}{ COUNTY } & \multirow{2}{*}{$\begin{array}{l}\text { SITE NAME } \\
\text { East Bear Island }\end{array}$} & \multirow{2}{*}{ MAP\# } & \multirow{2}{*}{$\begin{array}{c}\text { DATE } \\
2 / 3 / 11\end{array}$} & \multirow{2}{*}{$\begin{array}{c}\text { TOTAL } \\
\text { ADULTS } \\
0\end{array}$} & \multirow{2}{*}{$\frac{\mathbf{K M}}{3.2}$} & \multirow{2}{*}{$\begin{array}{l}\text { SITE } \\
\text { DESCRIPTION } \\
\text { I IV B }\end{array}$} & \multirow{2}{*}{$\begin{array}{l}\text { DISTURBANCE } \\
\text { / CONCERNS } \\
\mathrm{G}\end{array}$} & \multicolumn{3}{|c|}{$\begin{array}{c}\text { PRIOR YEARS } \\
\text { CENSUSED \& YEARS } \\
\text { WIPL SEEN }^{1} \\
\end{array}$} & \multirow{2}{*}{$\frac{\text { OWNER }}{}$} \\
\hline & & & & & & & & - & - & 06 & \\
\hline Onslow & N Topsail Beach; New River Inlet & 25 & $2 / 6 / 11$ & 0 & 0.8 & IV B F & H V S G & - & - & 06 & $\mathrm{~m}$ \\
\hline Onslow & $\begin{array}{l}\text { Onslow Beach, Camp Lejeune (U.S. Marine } \\
\text { Corps Base) }\end{array}$ & 24 & $2 / 4 / 11$ & 0 & 12.9 & I IV B F & V G & - & - & 06 & $\mathrm{f}$ \\
\hline Onslow & West Bear Island & 22 & $2 / 4 / 11$ & 0 & 7.2 & I IV B & G & - & - & 06 & $\mathrm{~s}(\mathrm{p})$ \\
\hline Pender & Hutaff Island and Rich Inlet Shoals ${ }^{2}$ & 27 & $2 / 7 / 11$ & 0 & 6.6 & I IV B D & $\mathrm{H} \mathrm{G}$ & - & - & 06 & $\mathrm{~s}(\mathrm{p}), \mathrm{p}$ \\
\hline Pender & Lea Island; S Topsail Beach and Inlet & 26 & $2 / 3 / 11$ & 0 & 11.1 & I IV B D & V S G & - & - & 06 & $\mathrm{~m}, \mathrm{p}$ \\
\hline Total & & & & 2 & 405.3 & & & & & & \\
\hline
\end{tabular}




\section{The 2011 International Piping Plover Winter Census in South Carolina}

Melissa Bimbi

U.S. Fish \& Wildlife Service

176 Croghan Spur Road, Suite 200

Charleston, SC 29407

843-727-4707 ext. 217

melissa_bimbi@fws.gov

Felicia Sanders

SC Department of Natural Resources

P.O. Box 37

McClellanville, SC 29458

843-520-0961

sandersf@dnr.sc.gov

Thirty-six sites were surveyed during the 2011 International Census in South Carolina. We intended to survey all 42 sites surveyed during the 2006 Census, but the weather, boat-only access, and limited surveyors in the southern part of the state prevented complete coverage. Total shoreline surveyed was also down from $2006(256.6 \mathrm{~km}$ in 2006 compared to 144.4 in 2011). Of the few sites missed in 2011, only one site had any Piping Plovers in 2006. Bay Point had one Piping Plover in 2006 and five Piping Plovers were seen there during an unofficial survey in very early March 2011. Little Capers Island also likely had plovers but was missed. Of the 37 sites surveyed during the 2011 Census, Piping Plovers were observed at 18.
In total, 86 Piping Plovers were counted during the 2011 Census between 24 January and 6 February. The top 3 sites for Piping Plovers during the 2011 Census were Hilton Head Island $(\mathrm{N}=12)$, Deveaux Bank $(\mathrm{N}=$ $11)$, and Harbor Island $(\mathrm{N}=10)$. Both the 2001 Census and the 1996 Census detected 78 birds, and the 2006 Census detected 100 birds. The 2011 Census count was likely low due to inclement weather which reduced coverage and likely impaired detectability. Several surveyors thought they detected fewer birds than would have been counted at their sites under more favorable conditions. Furthermore, intensive survey work completed in South Carolina (S. Maddock unpublished data) suggest that the International Piping Plover Winter Census results are likely an underestimate of our winter population.

Summarized by M. Bimbi

Comparison of Census Numbers

\begin{tabular}{|l|c|c|c|c|c|}
\hline Species & 1991 & 1996 & 2001 & 2006 & 2011 \\
\hline $\begin{array}{l}\text { Piping } \\
\text { Plover }\end{array}$ & 51 & 78 & 78 & 100 & 86 \\
\hline $\begin{array}{l}\text { Snowy } \\
\text { Plover }\end{array}$ & n.a. & n.a. & n.a. & n.a. & 1 \\
\hline $\begin{array}{l}\text { Wilson's } \\
\text { Plover }\end{array}$ & n.r. & n.r. & n.r. & 30 & 7 \\
\hline
\end{tabular}




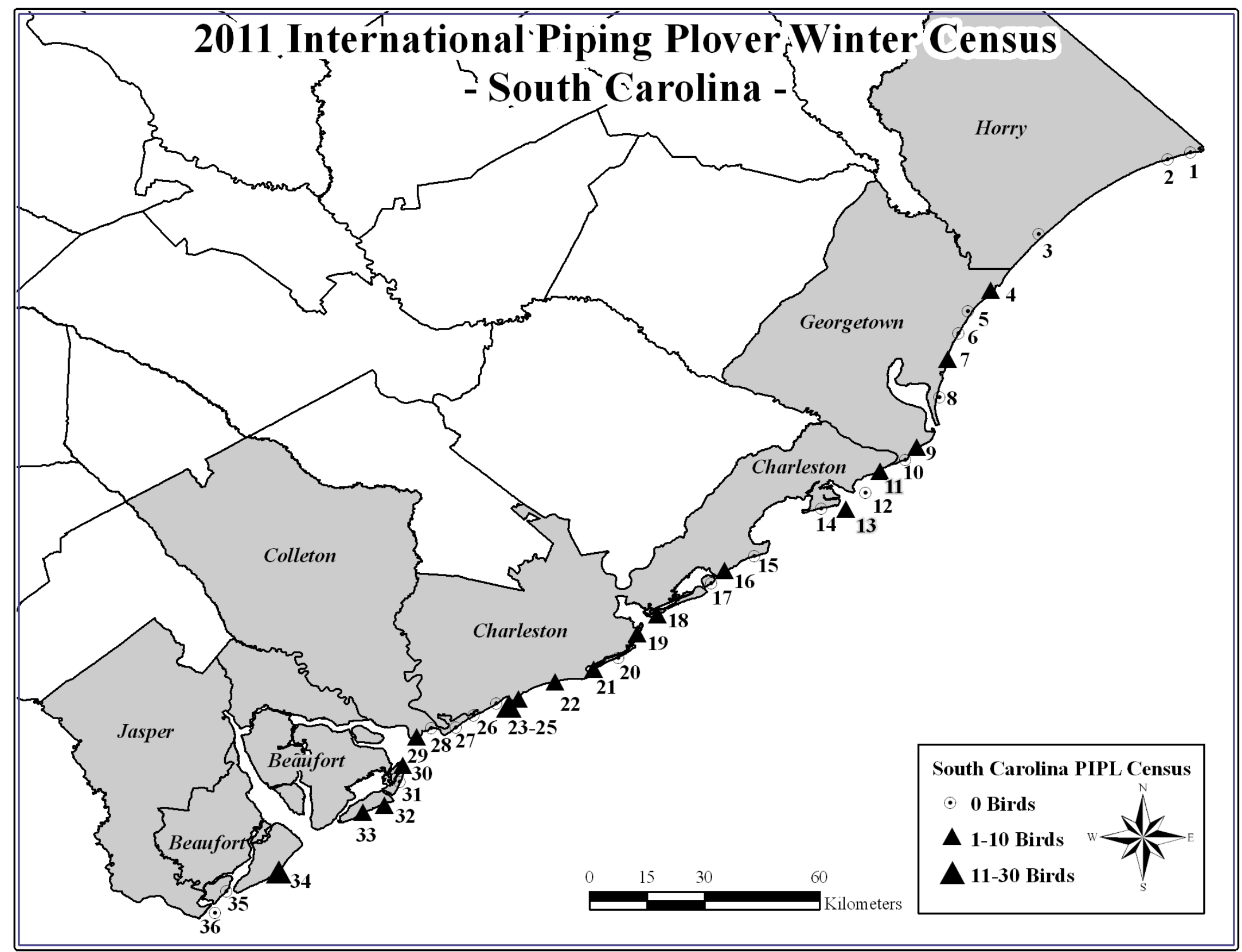


The 2011 International Piping Plover Winter Census in South Carolina

\begin{tabular}{|c|c|c|c|c|c|c|c|c|c|c|c|c|}
\hline \multirow{2}{*}{$\begin{array}{l}\text { COUNTY } \\
\text { Beaufort }\end{array}$} & \multirow{2}{*}{$\begin{array}{c}\text { SITE NAME } \\
\text { Daufuskie Island }\end{array}$} & \multirow{2}{*}{ 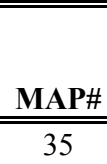 } & \multirow{2}{*}{$\frac{\text { DATE }}{1 / 26 / 11}$} & \multirow{2}{*}{$\begin{array}{c}\text { TOTAL } \\
\text { ADULTS } \\
0\end{array}$} & \multirow{2}{*}{$\frac{\mathbf{K M}}{1.6}$} & \multirow{2}{*}{$\begin{array}{l}\text { SITE } \\
\text { DESCRIPTION } \\
\text { I IV E }\end{array}$} & \multirow{2}{*}{$\begin{array}{l}\text { DISTURBANCE } \\
\text { / CONCERNS } \\
\mathrm{G}\end{array}$} & \multicolumn{4}{|c|}{$\begin{array}{c}\text { PRIOR YEARS } \\
\text { CENSUSED \& YEARS }^{\text {PIPL SEEN }}{ }^{1} \\
\text { PIPL }^{-}\end{array}$} & \multirow{2}{*}{$\frac{\text { OWNER }}{\mathrm{p}}$} \\
\hline & & & & & & & & - & - & 01 & 06 & \\
\hline Beaufort & Fripp Island & 32 & $1 / 24 / 11$ & 4 & 1.6 & I II B & S G & 91 & $\underline{96}$ & 01 & $\underline{06}$ & $\mathrm{p}$ \\
\hline Beaufort & Harbor Island & 30 & $1 / 24 / 11$ & 10 & 1.6 & I E & $\mathrm{G}$ & $\underline{91}$ & $\underline{96}$ & $\underline{01}$ & $\underline{06}$ & $\mathrm{p}$ \\
\hline Beaufort & Hilton Head Island & 34 & $2 / 3 / 11$ & 12 & 4.8 & I B & S G & $\underline{91}$ & $\underline{96}$ & $\overline{01}$ & $\overline{06}$ & $\mathrm{p}$ \\
\hline Beaufort & Hunting Island & 31 & $1 / 24 / 11$ & 0 & 1.6 & I IV E & S G & - & 96 & $\underline{01}$ & 06 & $\mathrm{~s}(\mathrm{p})$ \\
\hline Beaufort & Pritchards Island & 33 & $1 / 29 / 11$ & 3 & 0.4 & I IV B & $\mathrm{G}$ & 91 & $\underline{96}$ & - & 06 & $\mathrm{~s}(\mathrm{p})$ \\
\hline Charleston & Bird Key Stono & 21 & $1 / 24 / 11$ & 4 & 0.8 & IV B & G L & 91 & - & $\underline{01}$ & $\underline{06}$ & $\mathrm{~s}(\mathrm{p})$ \\
\hline Charleston & Botany Bay Island and Plantation & 25 & $1 / 27 / 11$ & 0 & 6.0 & I IV A & $\mathrm{G}$ & 91 & 96 & - & $\overline{06}$ & $\mathrm{~s}(\mathrm{p}), \mathrm{p}$ \\
\hline Charleston & Bull Island (Cape Romain NWR) & 15 & $1 / 28 / 11$ & 0 & 0.5 & I B & $\mathrm{G}$ & 91 & $\underline{96}$ & 01 & 06 & $\mathrm{f}$ \\
\hline Charleston & Cape Island & 12 & $1 / 27 / 11$ & 0 & 2.0 & I IV B & n.r. & $\underline{91}$ & $\underline{96}$ & 01 & $\underline{06}$ & $\mathrm{f}$ \\
\hline Charleston & Capers Island & 16 & $1 / 28 / 11$ & 1 & 3.0 & IV B & $\mathrm{G}$ & $\overline{91}$ & $\overline{96}$ & 01 & $\overline{06}$ & $s(p)$ \\
\hline Charleston & Deveaux Bank & 24 & $2 / 3 / 11$ & 11 & 4.8 & I II IV D E & $\mathrm{G}$ & $\underline{91}$ & $\underline{96}$ & $\underline{01}$ & $\underline{06}$ & $\mathrm{~s}(\mathrm{p})$ \\
\hline Charleston & Dewees Island & 17 & $1 / 28 / 11$ & 0 & 4.3 & I IV B & $\mathrm{G}$ & - & - & $\underline{01}$ & $\underline{06}$ & $\mathrm{p}$ \\
\hline Charleston & Edingsville & 26 & $1 / 30 / 11$ & 0 & 1.0 & I A & H G & 91 & 96 & - & 06 & $\mathrm{p}$ \\
\hline Charleston & Edisto Beach State Park & 27 & $2 / 3 / 11$ & 0 & 3.2 & I IV B & H S G & - & 96 & - & 06 & $\mathrm{~s}(\mathrm{p}), \mathrm{p}$ \\
\hline Charleston & Folly Beach & 20 & $1 / 30 / 11$ & 0 & 4.0 & I IV B & H D S G L & - & - & - & $\underline{06}$ & $\mathrm{p}, \mathrm{c}$ \\
\hline Charleston & Kiawah Island & 22 & $1 / 24 / 11$ & 8 & 17.7 & I II IV B & $\mathrm{G}$ & - & $\underline{96}$ & $\underline{01}$ & $\underline{06}$ & $\mathrm{p}$ \\
\hline Charleston & Lighthouse Island & 13 & $1 / 27 / 11$ & 7 & 4.0 & I IV B & n.r. & 91 & - & - & $\underline{06}$ & $\mathrm{f}$ \\
\hline Charleston & Morris Island & 19 & $1 / 30 / 11$ & 2 & 1.6 & I IV D E & H D G L & - & - & - & $\overline{06}$ & $\mathrm{~m}, \mathrm{p}$ \\
\hline Charleston & Murphy Island & 11 & $2 / 1 / 11$ & 5 & 0.8 & I B D & G & - & - & 01 & $\underline{06}$ & $\mathrm{~s}(\mathrm{p})$ \\
\hline Charleston & Raccoon Key $^{2}$ & 14 & $1 / 23 / 11$ & 0 & 7.0 & I IV B & $\mathrm{G}$ & 91 & - & $\underline{01}$ & 06 & $\mathrm{f}$ \\
\hline Charleston & Seabrook Island & 23 & $1 / 24 / 11$ & 1 & 5.6 & I IV B & H D S G L & - & - & $\underline{01}$ & 06 & $\mathrm{p}$ \\
\hline Charleston & Sullivan's Island & 18 & $2 / 4 / 11$ & 2 & 9.0 & I IV B & H D G & 91 & 96 & - & $\underline{06}$ & $\mathrm{p}$ \\
\hline Colleton & Otter Island & 29 & $1 / 24 / 11$ & 4 & 6.4 & I E & G & - & 96 & $\underline{01}$ & - & $\mathrm{s}(\mathrm{p})$ \\
\hline Colleton & Pine Island & 28 & $1 / 24 / 11$ & 0 & 3.2 & I E & $\mathrm{G}$ & - & - & 01 & - & $\mathrm{s}(\mathrm{p})$ \\
\hline Georgetown & Cedar Island & 10 & $1 / 27 / 11$ & 0 & 3.1 & I B & none & - & - & - & $\underline{06}$ & $\mathrm{~s}(\mathrm{p})$ \\
\hline Georgetown & Debidue Beach ${ }^{2}$ & 7 & 2/9/11 & 6 & 6.3 & IV B & $\mathrm{G}$ & - & - & 01 & 06 & $\mathrm{p}$ \\
\hline Georgetown & Huntington Beach & 4 & $2 / 6 / 11$ & 1 & 4.8 & I IV B D & H D G & - & - & $\underline{01}$ & $\underline{06}$ & $\mathrm{~s}(\mathrm{p})$ \\
\hline Georgetown & Litchfield Beach & 5 & $1 / 24 / 11$ & 0 & 6.3 & I B & $\mathrm{G}$ & 91 & - & 01 & 06 & $\mathrm{~m}, \mathrm{p}$ \\
\hline Georgetown & North Island & 8 & $1 / 25 / 11$ & 2 & 0.1 & I B & $\mathrm{G}$ & $\underline{91}$ & $\underline{96}$ & $\underline{01}$ & $\underline{06}$ & $\mathrm{~s}(\mathrm{p})$ \\
\hline Georgetown & Pawleys Island & 6 & $1 / 24 / 11$ & 0 & 6.0 & I IV B & G & - & - & 01 & 06 & $\mathrm{~m}, \mathrm{p}$ \\
\hline Georgetown & South Island, Sand Island & 9 & $2 / 6 / 11$ & 3 & 9.8 & I B & $\mathrm{G}$ & 91 & 96 & 01 & 06 & $\mathrm{~s}(\mathrm{p})$ \\
\hline
\end{tabular}


The 2011 International Piping Plover Winter Census in South Carolina (Continued)

\begin{tabular}{|c|c|c|c|c|c|c|c|c|c|c|c|}
\hline \multirow{2}{*}{$\begin{array}{l}\text { COUNTY } \\
\text { Horry }\end{array}$} & \multirow[t]{2}{*}{ SITE NAME } & \multirow{2}{*}{ MAP\# } & \multirow{2}{*}{$\begin{array}{c}\text { DATE } \\
2 / 10 / 11\end{array}$} & \multirow{2}{*}{$\begin{array}{c}\text { TOTAL } \\
\text { ADULTS } \\
0\end{array}$} & \multirow{2}{*}{$\frac{\mathbf{K M}}{24.0}$} & \multirow{2}{*}{$\begin{array}{l}\text { SITE } \\
\text { DESCRIPTION } \\
\text { I A B }\end{array}$} & \multirow{2}{*}{$\begin{array}{l}\text { DISTURBANCE } \\
\text { / CONCERNS } \\
\mathrm{H} \mathrm{D} \mathrm{G}\end{array}$} & \multicolumn{3}{|c|}{$\begin{array}{c}\text { PRIOR YEARS } \\
\text { CENSUSED \& YEARS } \\
\text { PIPL SEEN }^{1} \\
\end{array}$} & \multirow{2}{*}{$\begin{array}{c}\text { OWNER } \\
\mathrm{m}, \mathrm{p}\end{array}$} \\
\hline & & & & & & & & $\begin{array}{ll}- & -\end{array}$ & 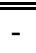 & 06 & \\
\hline Horry & Myrtle Beach State Park & 3 & $2 / 6 / 11$ & 0 & 1.6 & I B & $\mathrm{G}$ & - & - & 06 & $\mathrm{~s}(\mathrm{p})$ \\
\hline Horry & Waites Island ${ }^{2}$ & 1 & $2 / 10 / 11$ & 0 & 4.0 & I B & G & - & - & $\underline{06}$ & $\mathrm{p}$ \\
\hline Jasper & Tomkins Island & 36 & $1 / 28 / 11$ & 0 & 1.6 & IV C & $\mathrm{H}$ & - & - & 06 & f \\
\hline Total & & & & 86 & 144.4 & & & & & & \\
\hline
\end{tabular}

${ }^{1}$ If previously surveyed, years surveyed are noted. Bold underlined years indicate that Piping Plovers were seen at the site during that Census year.

${ }^{2}$ Please note that this survey was conducted outside the Census window. 


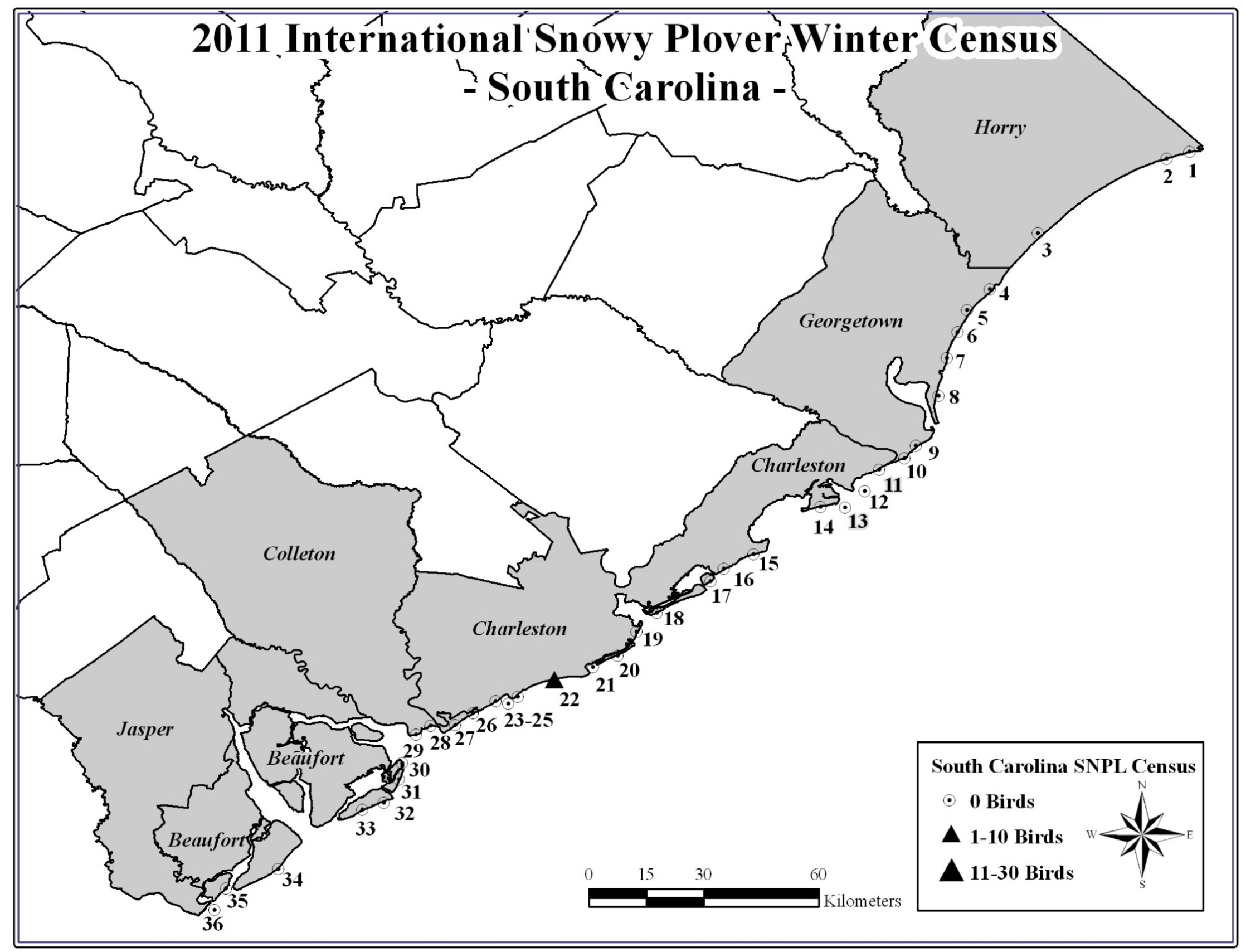


The 2011 International Snowy Plover Winter Census in South Carolina

\begin{tabular}{|c|c|c|c|c|c|c|c|c|c|c|c|c|}
\hline \multirow{2}{*}{ 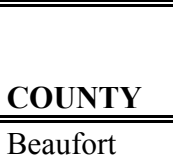 } & \multirow{2}{*}{$\begin{array}{c}\text { SITE NAME } \\
\text { Daufuskie Island }\end{array}$} & \multirow{2}{*}{ 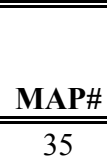 } & \multirow{2}{*}{$\frac{\text { DATE }}{1 / 26 / 11}$} & \multirow{2}{*}{$\begin{array}{c}\text { TOTAL } \\
\text { ADULTS } \\
0\end{array}$} & \multirow{2}{*}{$\frac{\mathbf{K M}}{1.6}$} & \multirow{2}{*}{$\begin{array}{l}\text { SITE } \\
\text { DESCRIPTION } \\
\text { I IV E }\end{array}$} & \multirow{2}{*}{$\begin{array}{l}\text { DISTURBANCE } \\
\text { / CONCERNS } \\
\mathrm{G}\end{array}$} & \multicolumn{4}{|c|}{$\begin{array}{c}\text { PRIOR YEARS } \\
\text { CENSUSED \& YEARS } \\
\text { SNPL SEEN }^{1} \\
\end{array}$} & \multirow{2}{*}{$\frac{\text { OWNER }}{\mathrm{p}}$} \\
\hline & & & & & & & & - & 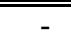 & 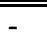 & - & \\
\hline Beaufort & Fripp Island & 32 & $1 / 24 / 11$ & 0 & 1.6 & I II B & S G & - & - & - & - & $\mathrm{p}$ \\
\hline Beaufort & Harbor Island & 30 & $1 / 24 / 11$ & 0 & 1.6 & I E & $\mathrm{G}$ & - & - & - & - & $\mathrm{p}$ \\
\hline Beaufort & Hilton Head Island & 34 & $2 / 3 / 11$ & 0 & 4.8 & I B & $\mathrm{S} \mathrm{G}$ & - & - & - & - & $\mathrm{p}$ \\
\hline Beaufort & Hunting Island & 31 & $1 / 24 / 11$ & 0 & 1.6 & I IV E & $\mathrm{S} \mathrm{G}$ & - & - & - & - & $\mathrm{s}(\mathrm{p})$ \\
\hline Beaufort & Pritchards Island & 33 & $1 / 29 / 11$ & 0 & 0.4 & I IV B & $\mathrm{G}$ & - & - & - & - & $\mathrm{s}(\mathrm{p})$ \\
\hline Charleston & Bird Key Stono & 21 & $1 / 24 / 11$ & 0 & 0.8 & IV B & G L & - & - & - & - & $\mathrm{s}(\mathrm{p})$ \\
\hline Charleston & Botany Bay Island and Plantation & 25 & $1 / 27 / 11$ & 0 & 6.0 & I IV A & $\mathrm{G}$ & - & - & - & - & $s(p), p$ \\
\hline Charleston & Bull Island (Cape Romain NWR) & 15 & $1 / 28 / 11$ & 0 & 0.5 & I B & $\mathrm{G}$ & - & - & - & - & $\mathrm{f}$ \\
\hline Charleston & Cape Island & 12 & $1 / 27 / 11$ & 0 & 2.0 & I IV B & n.r. & - & - & - & - & $\mathrm{f}$ \\
\hline Charleston & Capers Island & 16 & $1 / 28 / 11$ & 0 & 3.0 & IV B & $\mathrm{G}$ & - & - & - & - & $s(p)$ \\
\hline Charleston & Deveaux Bank & 24 & $2 / 3 / 11$ & 0 & 4.8 & I II IV D E & $\mathrm{G}$ & - & - & - & - & $\mathrm{s}(\mathrm{p})$ \\
\hline Charleston & Dewees Island & 17 & $1 / 28 / 11$ & 0 & 4.3 & I IV B & $\mathrm{G}$ & - & - & - & - & $\mathrm{p}$ \\
\hline Charleston & Edingsville & 26 & $1 / 30 / 11$ & 0 & 1.0 & I A & H G & - & - & - & - & $\mathrm{p}$ \\
\hline Charleston & Edisto Beach State Park & 27 & $2 / 3 / 11$ & 0 & 3.2 & I IV B & H S G & - & - & - & - & $s(p), p$ \\
\hline Charleston & Folly Beach & 20 & $1 / 30 / 11$ & 0 & 4.0 & I IV B & H D S G L & - & - & - & - & $\mathrm{p}, \mathrm{c}$ \\
\hline Charleston & Kiawah Island & 22 & $1 / 24 / 11$ & 1 & 17.7 & I II IV B & $\mathrm{G}$ & - & - & - & - & $\mathrm{p}$ \\
\hline Charleston & Lighthouse Island & 13 & $1 / 27 / 11$ & 0 & 4.0 & I IV B & n.r. & - & - & - & - & $\mathrm{f}$ \\
\hline Charleston & Morris Island & 19 & $1 / 30 / 11$ & 0 & 1.6 & I IV D E & H D G L & - & - & - & - & $\mathrm{m}, \mathrm{p}$ \\
\hline Charleston & Murphy Island & 11 & $2 / 1 / 11$ & 0 & 0.8 & I B D & G & - & - & - & - & $\mathrm{s}(\mathrm{p})$ \\
\hline Charleston & Raccoon Key $^{2}$ & 14 & $1 / 23 / 11$ & 0 & 7.0 & I IV B & $\mathrm{G}$ & - & - & - & - & $\mathrm{f}$ \\
\hline Charleston & Seabrook Island & 23 & $1 / 24 / 11$ & 0 & 5.6 & I IV B & H D S G L & - & - & - & - & $\mathrm{p}$ \\
\hline Charleston & Sullivan's Island & 18 & $2 / 4 / 11$ & 0 & 9.0 & I IV B & H D G & - & - & - & - & $\mathrm{p}$ \\
\hline Colleton & Otter Island & 29 & $1 / 24 / 11$ & 0 & 6.4 & I E & $\mathrm{G}$ & - & - & - & - & $\mathrm{s}(\mathrm{p})$ \\
\hline Colleton & Pine Island & 28 & $1 / 24 / 11$ & 0 & 3.2 & I E & $\mathrm{G}$ & - & - & - & - & $\mathrm{s}(\mathrm{p})$ \\
\hline Georgetown & Cedar Island & 10 & $1 / 27 / 11$ & 0 & 3.1 & I B & none & - & - & - & - & $\mathrm{s}(\mathrm{p})$ \\
\hline Georgetown & Debidue Beach ${ }^{2}$ & 7 & 2/9/11 & 0 & 6.3 & IV B & $\mathrm{G}$ & - & - & - & - & $\mathrm{p}$ \\
\hline Georgetown & Huntington Beach & 4 & $2 / 6 / 11$ & 0 & 4.8 & I IV B D & H D G & - & - & - & - & $\mathrm{s}(\mathrm{p})$ \\
\hline Georgetown & Litchfield Beach & 5 & $1 / 24 / 11$ & 0 & 6.3 & I B & $\mathrm{G}$ & - & - & - & - & $\mathrm{m}, \mathrm{p}$ \\
\hline Georgetown & North Island & 8 & $1 / 25 / 11$ & 0 & 0.1 & I B & $\mathrm{G}$ & - & - & - & - & $\mathrm{s}(\mathrm{p})$ \\
\hline Georgetown & Pawleys Island & 6 & $1 / 24 / 11$ & 0 & 6.0 & I IV B & $\mathrm{G}$ & - & - & - & - & $\mathrm{m}, \mathrm{p}$ \\
\hline Georgetown & South Island, Sand Island & 9 & $2 / 6 / 11$ & 0 & 9.8 & I B & $\mathrm{G}$ & - & - & - & - & $s(p)$ \\
\hline
\end{tabular}


The 2011 International Snowy Plover Winter Census in South Carolina

(Continued)

\begin{tabular}{|c|c|c|c|c|c|c|c|c|c|c|c|}
\hline COUNTY & SITE NAME & \multirow{2}{*}{ MAP\# } & \multirow{2}{*}{$\frac{\text { DATE }}{2 / 10 / 11}$} & \multirow{2}{*}{$\begin{array}{c}\text { TOTAL } \\
\text { ADULTS } \\
0\end{array}$} & \multirow{2}{*}{$\frac{\mathbf{K M}}{4.0}$} & \multirow{2}{*}{$\begin{array}{l}\text { SITE } \\
\text { DESCRIPTION } \\
\text { I A B }\end{array}$} & \multirow{2}{*}{$\begin{array}{l}\text { DISTURBANCE } \\
\text { / CONCERNS } \\
\mathrm{H} \mathrm{D} \mathrm{G}\end{array}$} & \multicolumn{3}{|c|}{$\begin{array}{c}\text { PRIOR YEARS } \\
\text { CENSUSED \& YEARS } \\
\text { SNPL SEEN }^{1} \\
\end{array}$} & \multirow{2}{*}{$\frac{\text { OWNER }}{\mathrm{m}, \mathrm{p}}$} \\
\hline Horry & "Cherry Grove ${ }^{2}$ & & & & & & & - & - & - & \\
\hline Horry & Myrtle Beach State Park & 3 & $2 / 6 / 11$ & 0 & 1.6 & I B & G & - & - & - & $\mathrm{s}(\mathrm{p})$ \\
\hline Horry & Waites Island $^{2}$ & 1 & $2 / 10 / 11$ & 0 & 4.0 & I B & $\mathrm{G}$ & - & - & - & $\mathrm{p}$ \\
\hline Jasper & Tomkins Island & 36 & $1 / 28 / 11$ & 0 & 1.6 & IV C & $\mathrm{H}$ & - & - & - & $\mathrm{f}$ \\
\hline Total & & & & 1 & 144.4 & & & & & & \\
\hline
\end{tabular}

${ }^{1}$ If previously surveyed, years surveyed are noted. Bold underlined years indicate that Snowy Plovers were seen at the site during that Census year.

${ }^{2}$ Please note that this survey was conducted outside the Census window. 


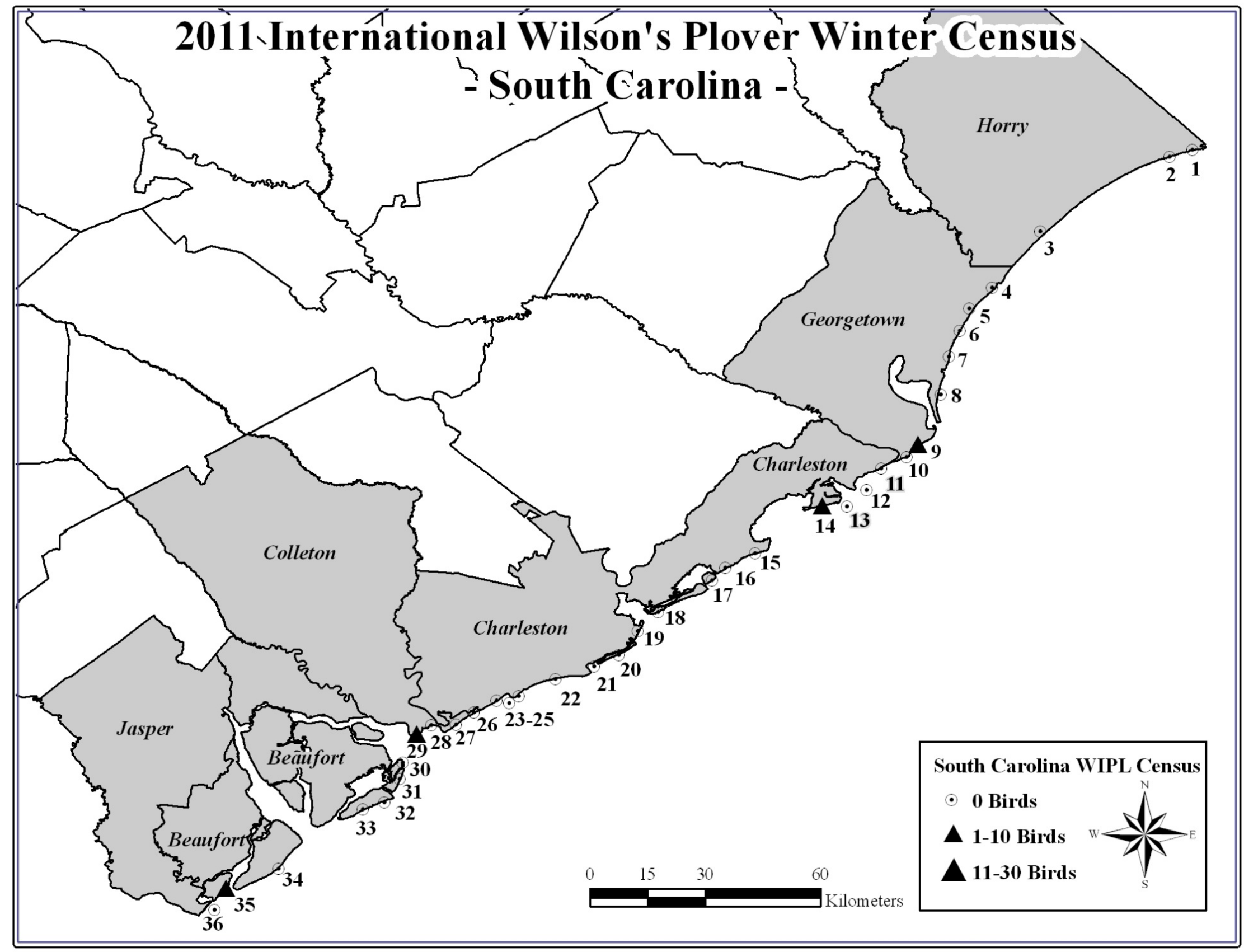


The 2011 International Wilson's Plover Winter Census in South Carolina

\begin{tabular}{|c|c|c|c|c|c|c|c|c|c|c|c|c|}
\hline \multirow{2}{*}{ 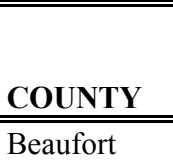 } & \multirow{2}{*}{$\begin{array}{c}\text { SITE NAME } \\
\text { Daufuskie Island }\end{array}$} & \multirow{2}{*}{ 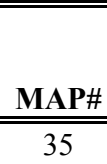 } & \multirow{2}{*}{$\frac{\text { DATE }}{1 / 26 / 11}$} & \multirow{2}{*}{$\begin{array}{c}\text { TOTAL } \\
\text { ADULTS } \\
1\end{array}$} & \multirow{2}{*}{$\frac{\mathbf{K M}}{1.6}$} & \multirow{2}{*}{$\begin{array}{l}\text { SITE } \\
\text { DESCRIPTION } \\
\text { I IV E }\end{array}$} & \multirow{2}{*}{$\begin{array}{l}\text { DISTURBANCE } \\
\text { / CONCERNS } \\
\mathrm{G}\end{array}$} & \multicolumn{4}{|c|}{$\begin{array}{c}\text { PRIOR YEARS } \\
\text { CENSUSED \& YEARS } \\
\text { WIPL SEEN }^{1} \\
\end{array}$} & \multirow{2}{*}{$\frac{\text { OWNER }}{\mathrm{p}}$} \\
\hline & & & & & & & & - & 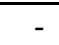 & 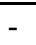 & 06 & \\
\hline Beaufort & Fripp Island & 32 & $1 / 24 / 11$ & 0 & 1.6 & I II B & S G & - & - & - & $\underline{06}$ & $\mathrm{p}$ \\
\hline Beaufort & Harbor Island & 30 & $1 / 24 / 11$ & 0 & 1.6 & I E & $\mathrm{G}$ & - & - & - & $\underline{06}$ & $\mathrm{p}$ \\
\hline Beaufort & Hilton Head Island & 34 & $2 / 3 / 11$ & 0 & 4.8 & I B & S G & - & - & - & $\overrightarrow{06}$ & $\mathrm{p}$ \\
\hline Beaufort & Hunting Island & 31 & $1 / 24 / 11$ & 0 & 1.6 & I IV E & S G & - & - & - & 06 & $\mathrm{~s}(\mathrm{p})$ \\
\hline Beaufort & Pritchards Island & 33 & $1 / 29 / 11$ & 0 & 0.4 & I IV B & $\mathrm{G}$ & - & - & - & 06 & $\mathrm{~s}(\mathrm{p})$ \\
\hline Charleston & Bird Key Stono & 21 & $1 / 24 / 11$ & 0 & 0.8 & IV B & G L & - & - & - & 06 & $\mathrm{~s}(\mathrm{p})$ \\
\hline Charleston & Botany Bay Island and Plantation & 25 & $1 / 27 / 11$ & 0 & 6.0 & I IV A & $\mathrm{G}$ & - & - & - & 06 & $s(p), p$ \\
\hline Charleston & Bull Island (Cape Romain NWR) & 15 & $1 / 28 / 11$ & 0 & 0.5 & I B & $\mathrm{G}$ & - & - & - & $\underline{06}$ & $\mathrm{f}$ \\
\hline Charleston & Cape Island & 12 & $1 / 27 / 11$ & 0 & 2.0 & I IV B & n.r. & - & - & - & 06 & $\mathrm{f}$ \\
\hline Charleston & Capers Island & 16 & $1 / 28 / 11$ & 0 & 3.0 & IV B & $\mathrm{G}$ & - & - & - & 06 & $s(p)$ \\
\hline Charleston & Deveaux Bank & 24 & $2 / 3 / 11$ & 0 & 4.8 & I II IV D E & G & - & - & - & $\underline{06}$ & $\mathrm{~s}(\mathrm{p})$ \\
\hline Charleston & Dewees Island & 17 & $1 / 28 / 11$ & 0 & 4.3 & I IV B & $\mathrm{G}$ & - & - & - & $\underline{06}$ & $\mathrm{p}$ \\
\hline Charleston & Edingsville & 26 & $1 / 30 / 11$ & 0 & 1.0 & I A & H G & - & - & - & 06 & $\mathrm{p}$ \\
\hline Charleston & Edisto Beach State Park & 27 & $2 / 3 / 11$ & 0 & 3.2 & I IV B & H S G & - & - & - & 06 & $s(p), p$ \\
\hline Charleston & Folly Beach & 20 & $1 / 30 / 11$ & 0 & 4.0 & I IV B & H D S G L & - & - & - & 06 & $\mathrm{p}, \mathrm{c}$ \\
\hline Charleston & Kiawah Island & 22 & $1 / 24 / 11$ & 0 & 17.7 & I II IV B & $\mathrm{G}$ & - & - & - & 06 & $\mathrm{p}$ \\
\hline Charleston & Lighthouse Island & 13 & $1 / 27 / 11$ & 0 & 4.0 & I IV B & n.r. & - & - & - & $\underline{06}$ & $\mathrm{f}$ \\
\hline Charleston & Morris Island & 19 & $1 / 30 / 11$ & 0 & 1.6 & I IV D E & H D G L & - & - & - & $\underline{06}$ & $\mathrm{~m}, \mathrm{p}$ \\
\hline Charleston & Murphy Island & 11 & $2 / 1 / 11$ & 0 & 0.8 & I B D & G & - & - & - & 06 & $\mathrm{~s}(\mathrm{p})$ \\
\hline Charleston & Raccoon Key $^{2}$ & 14 & $1 / 23 / 11$ & 3 & 7.0 & I IV B & $\mathrm{G}$ & - & - & - & 06 & $\mathrm{f}$ \\
\hline Charleston & Seabrook Island & 23 & $1 / 24 / 11$ & 0 & 5.6 & I IV B & H D S G L & - & - & - & 06 & $\mathrm{p}$ \\
\hline Charleston & Sullivan's Island & 18 & $2 / 4 / 11$ & 0 & 9.0 & I IV B & H D G & - & - & - & 06 & $\mathrm{p}$ \\
\hline Colleton & Otter Island & 29 & $1 / 24 / 11$ & 1 & 6.4 & I E & G & - & - & - & - & $\mathrm{s}(\mathrm{p})$ \\
\hline Colleton & Pine Island & 28 & $1 / 24 / 11$ & 0 & 3.2 & I E & $\mathrm{G}$ & - & - & - & - & $\mathrm{s}(\mathrm{p})$ \\
\hline Georgetown & Cedar Island & 10 & $1 / 27 / 11$ & 0 & 3.1 & I B & none & - & - & - & 06 & $\mathrm{~s}(\mathrm{p})$ \\
\hline Georgetown & Debidue Beach ${ }^{2}$ & 7 & 2/9/11 & 0 & 6.3 & IV B & $\mathrm{G}$ & - & - & - & 06 & $\mathrm{p}$ \\
\hline Georgetown & Huntington Beach & 4 & $2 / 6 / 11$ & 0 & 4.8 & I IV B D & H D G & - & - & - & 06 & $\mathrm{~s}(\mathrm{p})$ \\
\hline Georgetown & Litchfield Beach & 5 & $1 / 24 / 11$ & 0 & 6.3 & I B & $\mathrm{G}$ & - & - & - & 06 & $\mathrm{~m}, \mathrm{p}$ \\
\hline Georgetown & North Island & 8 & $1 / 25 / 11$ & 0 & 0.1 & I B & $\mathrm{G}$ & - & - & - & 06 & $\mathrm{~s}(\mathrm{p})$ \\
\hline Georgetown & Pawleys Island & 6 & $1 / 24 / 11$ & 0 & 6.0 & I IV B & G & - & - & - & 06 & $\mathrm{~m}, \mathrm{p}$ \\
\hline Georgetown & South Island, Sand Island & 9 & $2 / 6 / 11$ & 2 & 9.8 & I B & $\mathrm{G}$ & - & - & - & 06 & $\mathrm{~s}(\mathrm{p})$ \\
\hline
\end{tabular}


The 2011 International Wilson's Plover Winter Census in South Carolina (Continued)

\begin{tabular}{|c|c|c|c|c|c|c|c|c|c|c|c|}
\hline \multirow{2}{*}{$\begin{array}{l}\text { COUNTY } \\
\text { Horry }\end{array}$} & \multirow[t]{2}{*}{ SITE NAME } & \multirow{2}{*}{ MAP\# } & \multirow{2}{*}{$\begin{array}{c}\text { DATE } \\
2 / 10 / 11\end{array}$} & \multirow{2}{*}{$\begin{array}{c}\text { TOTAL } \\
\text { ADULTS } \\
0\end{array}$} & \multirow{2}{*}{$\frac{\mathbf{K M}}{4.0}$} & \multirow{2}{*}{$\begin{array}{l}\text { SITE } \\
\text { DESCRIPTION } \\
\text { I A B }\end{array}$} & \multirow{2}{*}{$\begin{array}{l}\text { DISTURBANCE } \\
\text { / CONCERNS } \\
\mathrm{H} \mathrm{D} \mathrm{G}\end{array}$} & \multicolumn{3}{|c|}{$\begin{array}{c}\text { PRIOR YEARS } \\
\text { CENSUSED \& YEARS } \\
\text { WIPL SEEN }^{1} \\
\end{array}$} & \multirow{2}{*}{$\frac{\text { OWNER }}{\mathrm{m}, \mathrm{p}}$} \\
\hline & & & & & & & & - & - & 06 & \\
\hline Horry & Myrtle Beach State Park & 3 & $2 / 6 / 11$ & 0 & 1.6 & I B & $\mathrm{G}$ & - & - & 06 & $\mathrm{~s}(\mathrm{p})$ \\
\hline Horry & Waites Island $^{2}$ & 1 & $2 / 10 / 11$ & 0 & 4.0 & I B & G & - & - & 06 & $\mathrm{p}$ \\
\hline Jasper & Tomkins Island & 36 & $1 / 28 / 11$ & 0 & 1.6 & IV C & $\mathrm{H}$ & - & - & 06 & $\mathrm{f}$ \\
\hline Total & & & & 7 & 144.4 & & & & & & \\
\hline
\end{tabular}




\section{The 2011 International Piping Plover Winter Census in Georgia}

Brad Winn (current contact information ${ }^{1}$ ) Manomet Center for Conservation Siences P.O. Box 35

Manomet, MA 02345

508-224-6521

bwinn@manomet.org

Tim Keyes

Wildlife Biologist

Georgia Department of Natural Resources

Wildlife Resources Division

One Conservation Way

Brunswick, GA 31520

912-262-3191

tim.keyes@gadnr.org

The 2011 Piping Plover Survey in Georgia went off smoothly. We were able to visit all sites on January 24th except for Wolf Island and Queens Island, which due to rough seas had to be visited on January 27th. In total, we visited 17 sites and counted 63 Piping Plovers.
Although coverage was similar to 2006, Piping Plover numbers were much lower in 2011. Observation conditions were not likely to blame with partly cloudy skies, temperatures in the 50's, and winds 10-15 knots from the northeast. Several of our more accessible sites (Tybee Island, St Simons and Jekyll Islands) noted potential disturbance by walkers and un-leashed dogs, but these were the minority of sites. One factor which may have affected Piping Plover numbers in Georgia during the 20102011 winter was a two-week extreme cold spell in December.

\section{Comparison of Census Numbers}

\begin{tabular}{|l|c|c|c|c|c|}
\hline Species & 1991 & 1996 & 2001 & 2006 & 2011 \\
\hline $\begin{array}{l}\text { Piping } \\
\text { Plover }\end{array}$ & 37 & 124 & 111 & 212 & 63 \\
\hline $\begin{array}{l}\text { Snowy } \\
\text { Plover }\end{array}$ & n.a. & n.a. & n.a. & n.a. & n.a. \\
\hline $\begin{array}{l}\text { Wilson's } \\
\text { Plover }\end{array}$ & n.r. & n.r. & n.r. & 2 & 31 \\
\hline
\end{tabular}

${ }^{1}$ at time of Census Brad Winn was a project manager for Georgia Department of Natural Resources.

Assessment written by Tim Keyes and edited by Elise Elliott-Smith 


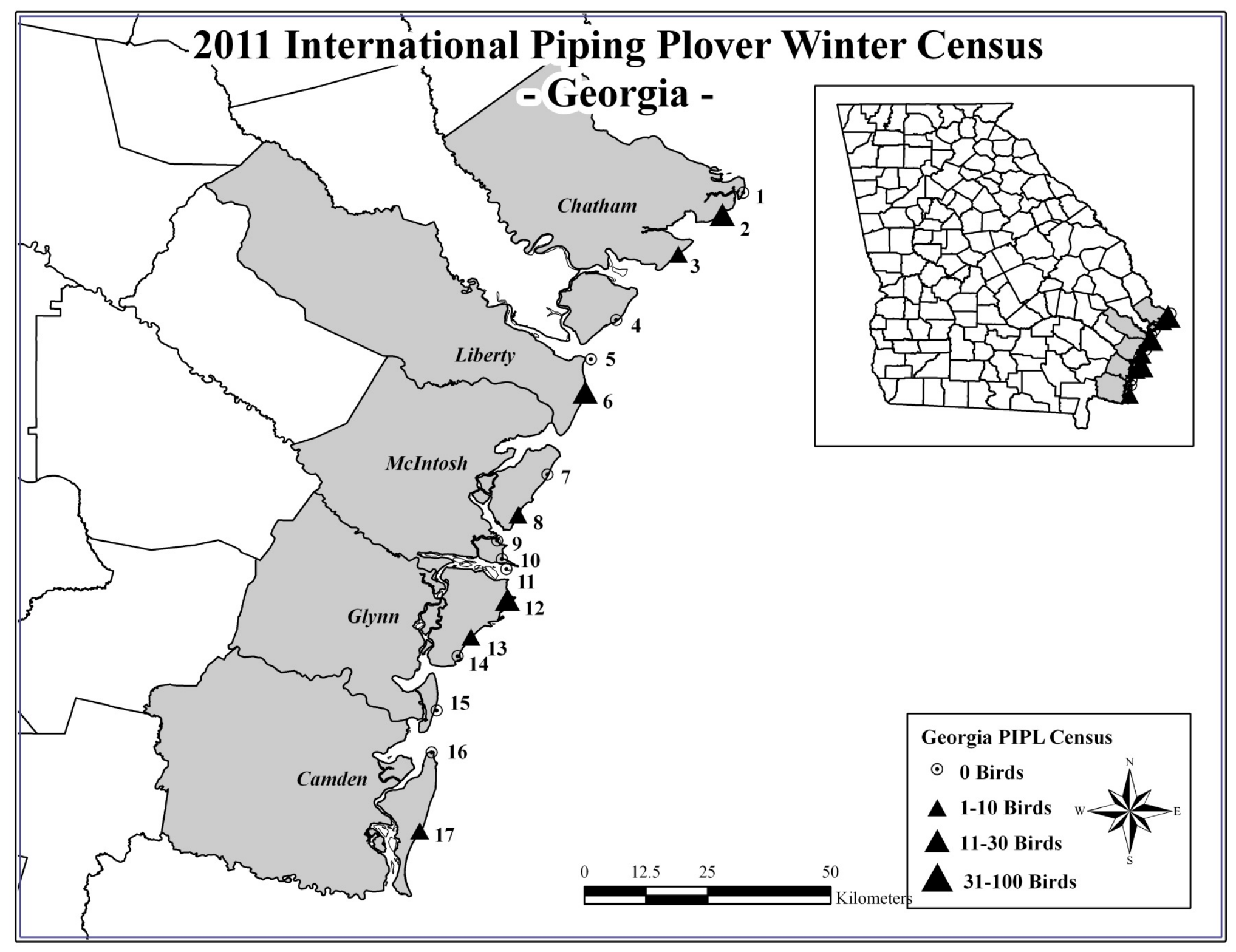


The 2011 International Piping Plover Winter Census in Georgia

\begin{tabular}{|c|c|c|c|c|c|c|c|c|c|c|c|c|}
\hline \multirow{2}{*}{$\begin{array}{l}\text { COUNTY } \\
\text { Camden }\end{array}$} & \multirow{2}{*}{$\begin{array}{c}\text { SITE NAME } \\
\text { Cumberland Island National Seashore }\end{array}$} & \multirow{2}{*}{ MAP\# } & \multirow{2}{*}{$\begin{array}{c}\text { DATE } \\
1 / 24 / 11\end{array}$} & \multirow{2}{*}{$\begin{array}{c}\text { TOTAL } \\
\text { ADULTS } \\
5\end{array}$} & \multirow{2}{*}{ KM } & \multirow{2}{*}{$\begin{array}{l}\text { SITE } \\
\text { DESCRIPTION } \\
\text { I B }\end{array}$} & \multirow{2}{*}{$\begin{array}{l}\text { DISTURBANCE } \\
\text { / CONCERNS } \\
\mathrm{G}\end{array}$} & \multicolumn{4}{|c|}{$\begin{array}{c}\text { PRIOR YEARS } \\
\text { CENSUSED \& YEARS } \\
\text { PIPL SEEN }^{1} \\
\end{array}$} & \multirow{2}{*}{$\frac{\text { OWNER }}{\mathrm{f}}$} \\
\hline & & & & & & & & $\underline{91}$ & $\underline{96}$ & $\underline{01}$ & $\underline{06}$ & \\
\hline Camden & Little Cumberland Island & 16 & $1 / 24 / 11$ & 0 & 6.8 & I IV B & H D G & 91 & $\underline{96}$ & 01 & - & $\mathrm{p}$ \\
\hline Chatham & Little Tybee Island & 2 & $1 / 24 / 11$ & 15 & n.r. & I B & $\mathrm{G}$ & $\underline{91}$ & $\underline{96}$ & $\underline{01}$ & $\underline{06}$ & $\mathrm{~s}(\mathrm{p})$ \\
\hline Chatham & Ossabaw Island & 4 & $1 / 24 / 11$ & 0 & 18.1 & I IV B & $\mathrm{G}$ & $\underline{91}$ & $\underline{96}$ & $\underline{01}$ & $\underline{06}$ & $\mathrm{~s}(\mathrm{p})$ \\
\hline Chatham & Tybee Island & 1 & $1 / 24 / 11$ & 0 & 6.4 & I II B & H S G & 91 & 96 & 01 & - & $\mathrm{p}$ \\
\hline Chatham & Wassaw NWR & 3 & $1 / 24 / 11$ & 2 & 10.5 & I IV B & $\mathrm{G}$ & 91 & 96 & $\underline{01}$ & $\underline{06}$ & $\mathrm{f}$ \\
\hline Glynn & Jekyll Island & 15 & $1 / 24 / 11$ & 0 & 9.4 & I B & H D G & $\underline{91}$ & 96 & $\underline{01}$ & $\underline{06}$ & $\mathrm{~s}(\mathrm{p})$ \\
\hline Glynn & Little Egg Island sandbar & 11 & $1 / 24 / 11$ & 0 & 2.8 & I D & $\mathrm{G}$ & - & $\underline{96}$ & $\underline{01}$ & $\underline{06}$ & $\mathrm{~s}(\mathrm{p})$ \\
\hline Glynn & Little St. Simons Island & 12 & $1 / 24 / 11$ & 20 & 11.3 & I B & $\mathrm{G}$ & $\underline{91}$ & $\underline{96}$ & $\underline{01}$ & $\underline{06}$ & $\mathrm{p}$ \\
\hline Glynn & Sea Island & 13 & $1 / 24 / 11$ & 1 & 5.6 & I B & H S G & $\overline{91}$ & $\overline{96}$ & $\overline{01}$ & $\overline{06}$ & $\mathrm{p}$ \\
\hline Glynn & St. Simons Island & 14 & $1 / 24 / 11$ & 0 & 2.5 & I B & H D G & - & - & 01 & - & $\mathrm{s}(\mathrm{p})$ \\
\hline Liberty & St. Catherine's Island & 6 & $1 / 24 / 11$ & 18 & 13.3 & I II IV B & G & $\underline{91}$ & $\underline{96}$ & $\underline{01}$ & $\underline{06}$ & $\mathrm{p}$ \\
\hline Liberty & St. Catherine's Island sandbar & 5 & $1 / 24 / 11$ & 0 & 3.2 & I D & $\mathrm{G}$ & - & 96 & $\underline{01}$ & $\underline{06}$ & $\mathrm{~s}(\mathrm{p})$ \\
\hline McIntosh & Blackbeard Island NWR & 7 & $1 / 24 / 11$ & 0 & 11.3 & I B & G & 91 & 96 & 01 & $\underline{06}$ & $\mathrm{f}$ \\
\hline McIntosh & North Wolf NWR and Queens & 9 & $1 / 27 / 11$ & 0 & 3.2 & I IV B & none & - & $\underline{96}$ & 01 & - & $\mathrm{f}, \mathrm{p}$ \\
\hline McIntosh & Sapelo Island & 8 & $1 / 24 / 11$ & 2 & 10.0 & I IV B & H G L & 91 & $\underline{96}$ & $\underline{01}$ & $\underline{06}$ & $\mathrm{~s}(\mathrm{p})$ \\
\hline McIntosh & Wolf Island NWR & 10 & $1 / 24 / 11$ & 0 & 4.0 & I B & none & - & 96 & $\underline{01}$ & $\underline{06}$ & $\mathrm{f}$ \\
\hline Total & & & & 63 & 135.5 & & & & & & & \\
\hline
\end{tabular}

${ }^{1}$ If previously surveyed, years surveyed are noted. Bold underlined years indicate that Piping Plovers were seen at the site during that Census year. 


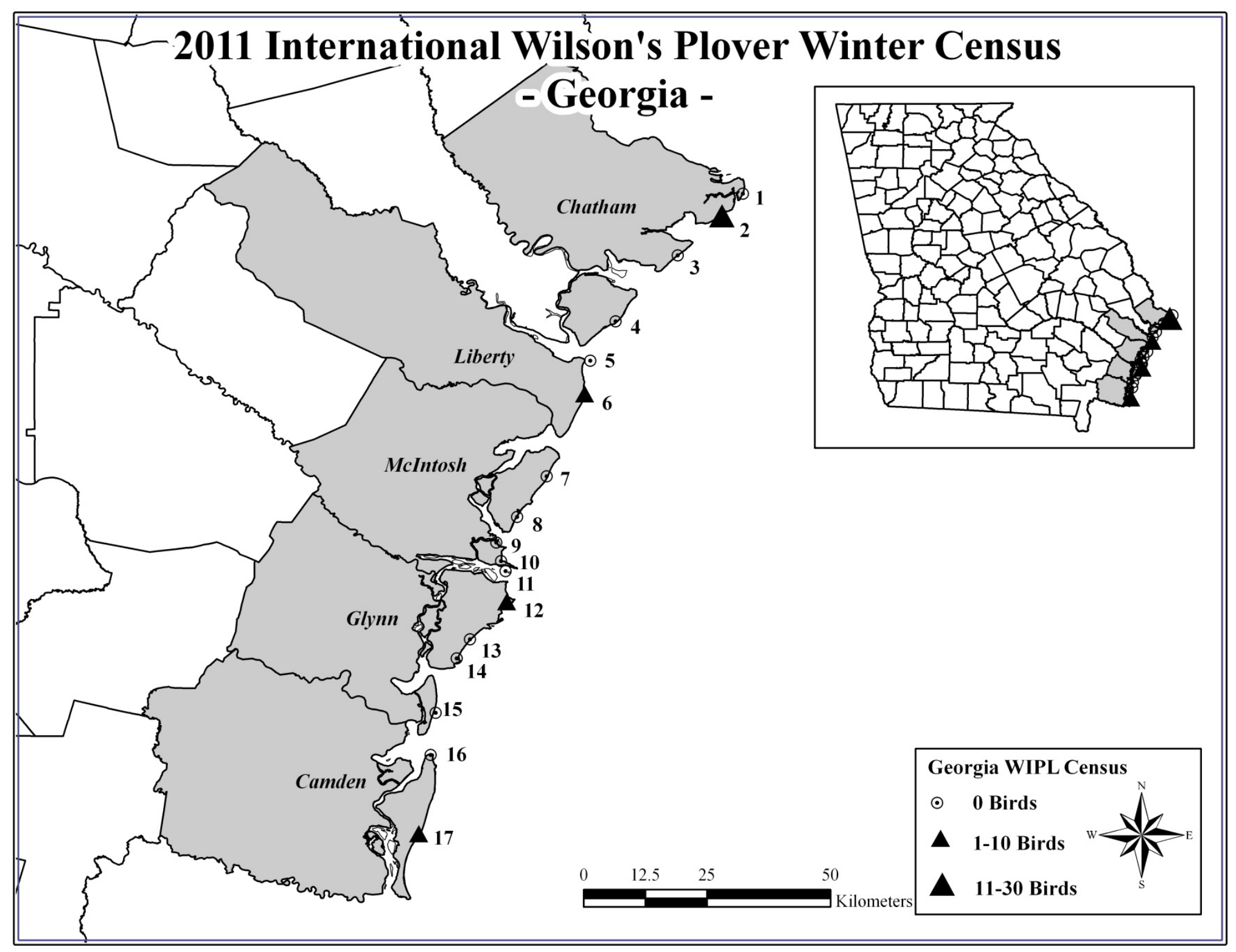


The 2011 International Wilson's Plover Winter Census in Georgia

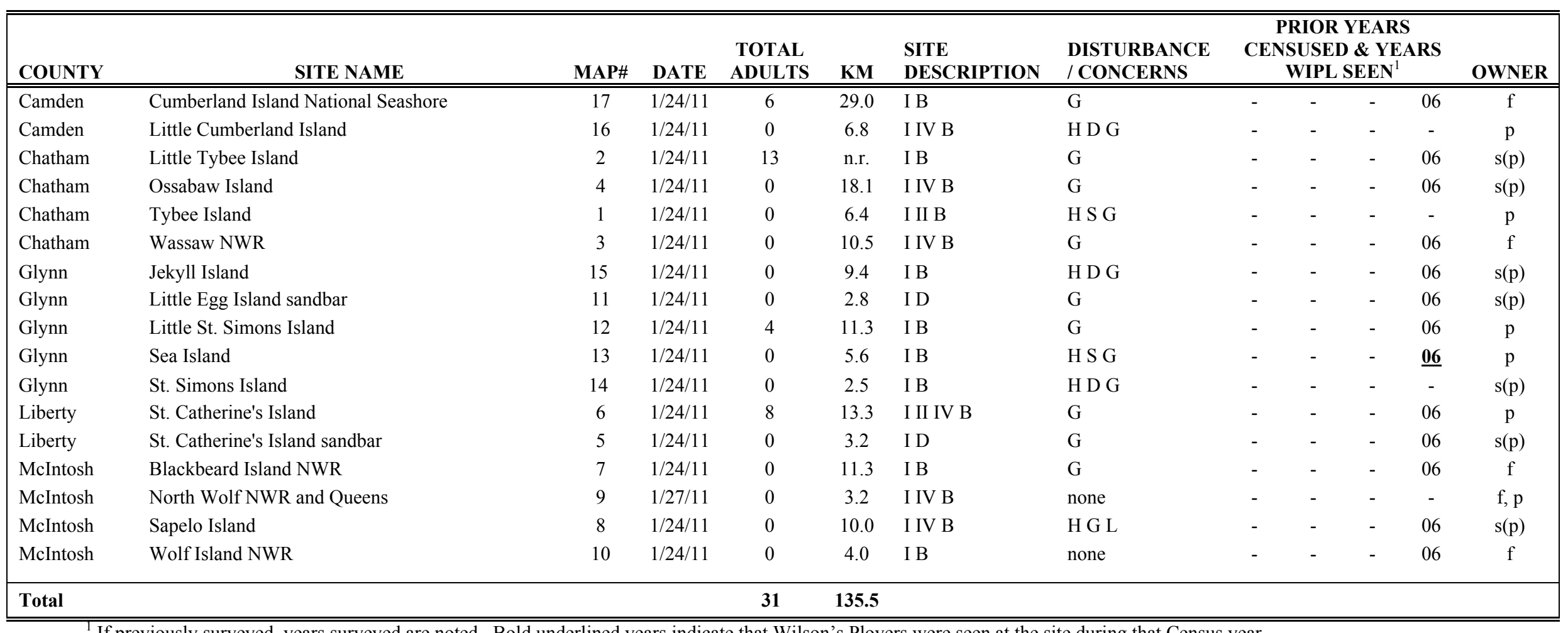

If previously surveyed, years surveyed are noted. Bold underlined years indicate that Wilson's Plovers were seen at the site during that Census year. 


\section{The 2011 International Piping Plover Winter Census in Florida}

The 2011 Census was coordinated by three individuals from the U. S. Fish and Wildlife Service, who split the Florida coast into three Census regions. The first region, northwest Florida, spans the beaches from the Alabama border to the east end of Jefferson County. The second region, north Florida, includes Gulf coast counties southeast of the panhandle region to the south end of Manatee County and from the Georgia border to south end of Brevard County. The third region, southern Florida, includes all the remaining counties in Florida south to Key West National Wildlife Refuge. The total number of Piping Plovers estimated during the 2011 Census of Florida was 306, with 223 reported on the Gulf of Mexico coast and 83 on the Atlantic Coast. Additionally, 495 Snowy Plovers and 305 Wilson's Plovers were sighted on Florida beaches during the 2011 Census. The Florida Piping Plover total was lower than any prior Census, yet the 2011 Snowy Plover total is the highest Census count. Surveyors covered a total of $1298 \mathrm{~km}$ (807 miles).

\section{Comparison of Census Numbers}

\begin{tabular}{|l|c|c|c|c|c|}
\hline Species & 1991 & 1996 & 2001 & 2006 & 2011 \\
\hline $\begin{array}{l}\text { Piping } \\
\text { Plover }\end{array}$ & 551 & 375 & 416 & $454^{*}$ & 306 \\
\hline $\begin{array}{l}\text { Snowy } \\
\text { Plover }\end{array}$ & n.r. & n.r. & 311 & 312 & 495 \\
\hline $\begin{array}{l}\text { Wilson's } \\
\text { Plover }\end{array}$ & n.r. & n.r. & n.r. & 394 & 292 \\
\hline
\end{tabular}

*Datasheets from two sites were lost; surveyors estimated that they saw 40 Piping Plovers and this number is included in the 2006 total. We have no data on Wilson's or Snowy Plovers for either site.

\section{Northwest Florida (panhandle)}

Patty Kelly

U.S. Fish \& Wildlife Service

Panama City Ecological Services Office

1601 Balboa Avenue

Panama City, FL 32405

850-769-0552

patricia_kelly@fws.gov

In the nine coastal counties located in northwest Florida along the Gulf of Mexico (Gulf), 36 Federal and State biologists and avid birders in the private sector (some associated with local Audubon Chapters) surveyed along approximately 363 km (226 miles) of shoreline (Gulf of Mexico beaches and bayside shorelines). Surveyors focused on mainland, peninsular, and island beaches. Surveys were conducted on Gulf beach fronts, bayside habitats, coastal dune inlets, and barrier island inlets.

Surveys conducted between January 24 and February 6, 2011, documented a total of 83 Piping Plovers in 5 out of 9 counties. Three hundred and thirteen (313) Snowy Plovers were documented in 7 of 9 counties. Results from different survey days on Dog Island and John S. Phipps Preserve, lands in close proximity in Franklin County, are possibly documenting all or some of the same 17 Snowy Plovers, thereby inflating the total numbers. Bay and Gulf Counties reported two Wilson's Plover each.

Surveys occurred during all tidal ranges, with most between low to mid-tide levels. Temperatures ranged between 38 and 68 degrees Fahrenheit with wind speeds less than 1 and up to 15 miles per hour. Most skies were overcast or cloudy with a few sunny days. In the 2006 Census, grave attempts were made for a comprehensive survey effort which succeeded in covering $592 \mathrm{~km}$ (368 miles). The 2011 Census covered only 61 percent of habitat compared to the 2006 Census. Optimal areas with 
historic use by Piping Plovers were the primary focus and most were covered to our knowledge. Inaccessible (shallow) bayside and marsh flats within all the northwest Florida bays and bayous remain the unknown locations that need surveys. These areas are difficult to survey due to shallow waters as well as limited accessibility from land.

\section{North Florida}

\section{Billy Brooks}

U.S. Fish and Wildlife Service

7915 Baymeadows Way, Suite 200

Jacksonville, FL 32256

904-731-3136

billy_brooks@fws.gov

One hundred and fifty-six participants including Federal, State, and County agencies, Audubon Chapters, and other volunteers conducted surveys on 71 survey routes covering approximately $383 \mathrm{~km}$ (238 miles) of coastal beaches, inlets and waterways between (1/28/2011 and 2/6/2011). One hundred and nine Piping Plovers, 67 Snowy Plovers, and 168 Wilson's Plovers were observed in North Peninsula Florida.

Thirty-one routes were surveyed between in 7 counties on the northern Gulf Coast of peninsula Florida from Taylor south through Manatee County covering $129 \mathrm{~km}$ (80 miles) of coastline. Eightyfour Piping Plovers were recorded during these surveys at eight locations: Cedar Key, North Anclote Bar, Anclote Key, Three Rooker Bar, Honeymoon Island, Caladesi Island, Madeira Beach and Shell Key. These Gulf Coast surveys were conducted between (1/28/2011 and 2/4-6/2011) and weather does not appear to be a factor in the low number of Piping Plover observations.

On the northern Atlantic Coast of peninsula Florida, forty routes in 7 counties from Nassau south to Brevard County were surveyed covering close to $258 \mathrm{~km}$ (158 miles) of coastal beaches and inlets. An additional $48 \mathrm{~km}$ (30 miles) of the ICW and other coastal waterways primarily in Volusia were surveyed by boat. Twenty-five Piping Plovers were documented during these surveys at three locations:
Little Talbot Island, Matanzas Inlet and Ponce Inlet. Almost all of the North Atlantic Coast of Florida was surveyed simultaneously on 2/4/2011 and the weather does not appear to have been a factor in the low number of Piping Plover observations.

All sites that were surveyed in 2006 were surveyed in 2011 except for one of the Bird Islands in Nassau Sound, Duval County on the Atlantic Coast and Florida Barge Canals in Citrus County and Brasher Park/Green Key/Gulf Harbors Beach/Sand Bay Salt Springs State Park $(3.9 \mathrm{~km})$ in Pasco County on the Gulf Coast.

The Piping Plover numbers documented in North Peninsula Florida in 2011 as compared to 2006 is lower (109 birds in 2011 compared to 225 in 2006). However, the cause for the drop in numbers is unclear.

\section{South Florida}

\section{Marilyn Knight}

U.S. Fish \& Wildlife Service

South Florida Ecological Services Office $133920^{\text {th }}$ Street

Vero Beach, FL 32960

772-562-3909

marilyn_knight@fws.gov

One hundred and fifty participants including Federal, State, and County agencies, Audubon Chapters, and other volunteers surveyed 82 sites along approximately 428 $\mathrm{km}$ (266 miles) of shoreline in 11 south Florida coastal counties from Sarasota County south to Collier County on the Gulf Coast and Indian River County south to Monroe County along the Atlantic Coast. A total of 114 Piping Plovers (56 Gulf and 58 Atlantic) were censused in south Florida between January 24 and February 6, 2011. Additionally, 115 Snowy Plovers (all but one on the Gulf Coast) and 120 Wilson's Plovers (103 on the Gulf Coast and 17 on the Atlantic Coast) were observed. With 
growing concerns over the decline in numbers of Red Knots, the Florida Fish and Wildlife Conservation Commission (FWC) requested that the number of knots observed during the census also be recorded. Beaches are generally narrow in Florida, allowing the observers to visually search both lower and upper beach habitat for birds.

The total number of Piping Plovers censused in south Florida along the Gulf Coast this year (56) was comparable to numbers recorded in 1991 (67), lower than those recorded in 1996 (76) and 2006 (74), and up from 2001 (50). In 1991, Piping Plovers were located at the Charlotte Beach State Recreation Area, Marco Island, North Captiva Island, Fort Myers Beach, and Midnight Pass. In 1996, they were observed at Sand Dollar and Big Marco Pass Critical Wildlife Area, Big Marco Pass Shoals, and Fort Myers Beach. In 2001, they were only observed at Little Estero Lagoon and Marco Island/Big Marco Pass Shoals. In 2006, they were recorded along the Charlotte County Barrier Islands, Little Estero Lagoon Critical Wildlife Area, North Captiva Island, Cayo Costa Island, Marco Island/Big Marco Pass Shoals, and Keywadeen Island. This year they were recorded at Venice Beach, Marco Island, Kice Island, Cayo Costa Island, North Captiva Island, Bunche Beach, and Little Estero Lagoon Critical Wildlife Area. Concentrations of Piping Plovers along the Gulf Coast included 19 at Marco Island, 15 at Bunche Beach, and 9 at Little Estero Lagoon Critical Wildlife Area.

The total number of Piping Plovers censused in south Florida along the Atlantic Coast (58) was higher than the 1991 (46), 1996 (15), and 2006 (44) census results, and lower than the 2001 results (67). In 1991, Piping Plovers were located at St. Lucie Inlet, Carl Ross Key, Boca Grande Key, and Ohio Key. In 1996, they were recorded at St. Lucie Inlet, Boca Grande, and Ohio Key. In 2001, they were observed at St. Lucie Inlet Sailfish Point, Crandon Park, and Woman Key. In 2006, they were only recorded at Boca Grande Key and Crandon Park.
This year, they were recorded along the Indian River County beaches south of the Barber Bridge, St. Lucie Inlet sandbars, Crandon Park, Boca Grande Key, and the Sandy Keys. The observation of the Piping Plover along the Indian River County beaches is particularly noteworthy, as the species was thought to historically occur in this county, but the date of last observation is unknown. A total of 37 of the 58 Piping Plovers observed on the Atlantic Coast were located at Crandon Park and 14 on Boca Grande Key.

Census coverage in suitable habitat in south Florida was relatively comprehensive this year and covered most of the south Florida coastline, but there were some areas where surveys were not conducted that should be included in the 2016 census. Surveys were not conducted from St. Lucie Inlet State Park south to Hobe Sound National Wildlife Refuge or at Jonathan Dickinson State Park in Martin County because habitat was thought to be marginal; however, there was an unconfirmed historical report of a Piping Plover using inland habitat at Jonathan Dickinson. No one was able to survey Lower Matecumbe, Pavilion Key, or the Marquesas Keys in Monroe County or other areas in the Everglades this year due to personnel time constraints and accessibility.

Along the Gulf Coast, areas that were not censused this year that should be surveyed in 2016 include suitable habitat in the Ten Thousand Islands area and Big Marco Pass Shoals in Collier County; Skimmer Island, San Carlos Bay Flats, and Big Hickory Island in Lee County; and Lemon Bay in Charlotte County. Other areas that are not as high of a priority but could be censused in 2016 include Barefoot Beach, Clam Pass County Park, and Naples Pier in Collier County; Casperson and Manasota Beaches in Sarasota County; and Charlotte Harbor (east) in Charlotte County. Additionally, 
Little Sarasota Bay and suitable habitat within the Intercoastal Waterway in Sarasota County should be included in future censuses. Aerial photographs should be assessed to identify tidal preserve areas and un-vegetated flats that may provide suitable habitat not specifically associated with coastal beaches.

Census coverage in south Florida was comparable to 2006, but weather conditions were better this year. The results from this year's census were most likely not significantly affected by weather conditions in south Florida. Although weather conditions during the census in 2006 were suboptimal, the total number of Piping Plovers observed in 2006 was the same as this year. Whether this indicates a decline in the total number of Piping Plovers wintering in south Florida or is the result of some other factor is unknown.

Because accessibility seems to be a primary limitation in surveying several important areas of Florida, especially in the southwest corner of the state in and around the Everglades area and along numerous chains of offshore islands, it may be worth considering the feasibility of using other survey methods, such as aerial surveys. 







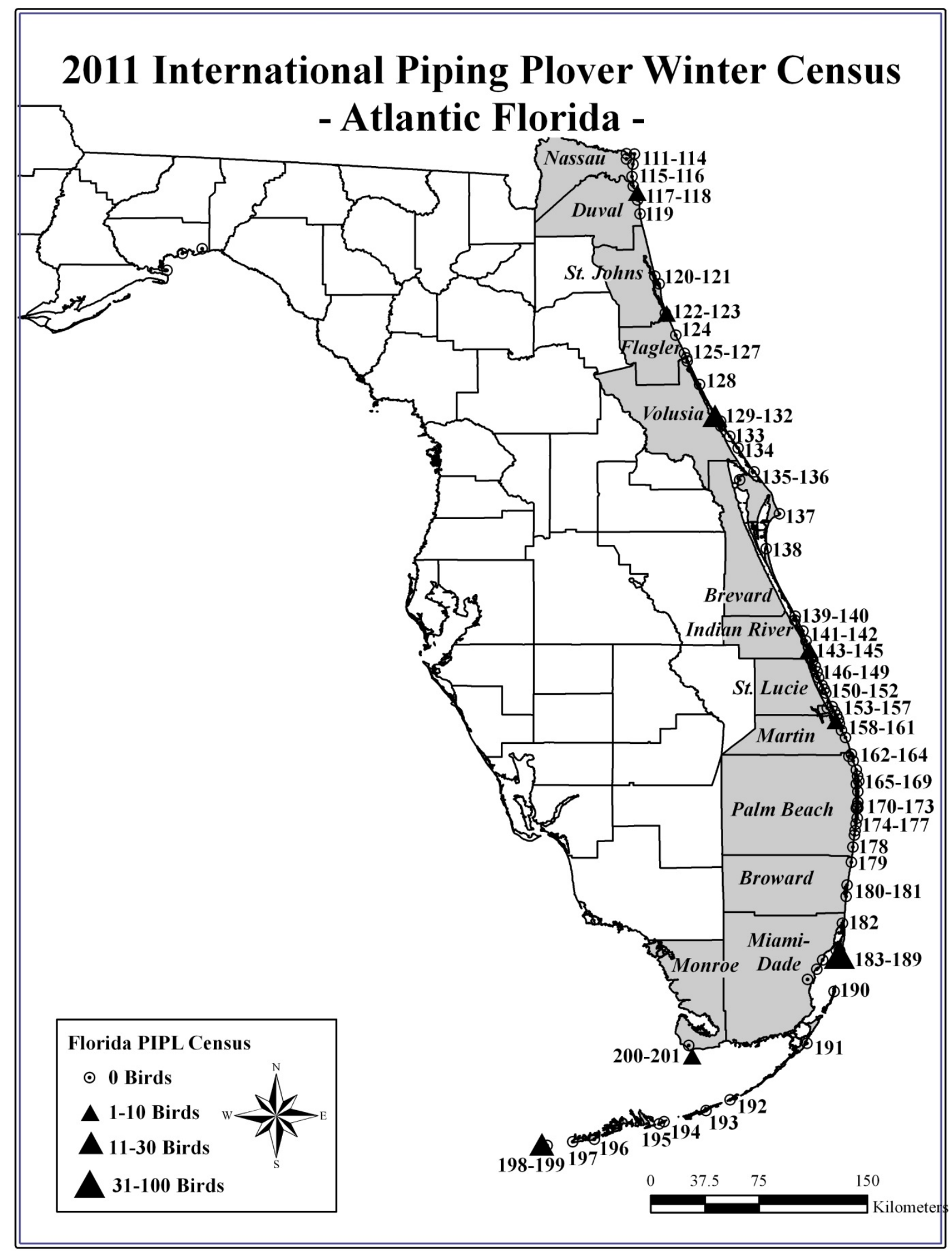


The 2011 International Piping Plover Winter Census in Florida

\begin{tabular}{|c|c|c|c|c|c|c|c|c|c|c|c|c|}
\hline \multirow{2}{*}{$\begin{array}{l}\text { COUNTY } \\
\text { Bay }\end{array}$} & \multirow[t]{2}{*}{ SITE NAME } & \multirow{2}{*}{ MAP\# } & \multirow{2}{*}{$\frac{\text { DATE }}{1 / 27 / 11}$} & \multirow{2}{*}{$\begin{array}{c}\text { TOTAL } \\
\text { ADULTS } \\
0\end{array}$} & \multirow{2}{*}{$\frac{\mathbf{K M}}{2.6}$} & \multirow{2}{*}{$\begin{array}{l}\text { SITE } \\
\text { DESCRIPTION } \\
\text { III A }\end{array}$} & \multirow{2}{*}{$\begin{array}{l}\text { DISTURBANCE } \\
\text { / CONCERNS } \\
\text { H D S G }\end{array}$} & \multicolumn{4}{|c|}{$\begin{array}{c}\text { PRIOR YEARS } \\
\text { CENSUSED \& YEARS } \\
\text { PIPL SEEN }^{1}\end{array}$} & \multirow{2}{*}{$\frac{\text { OWNER }}{p}$} \\
\hline & & & & & & & & 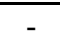 & 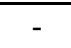 & 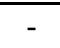 & 06 & \\
\hline Bay & Camp Helen State Park & 17 & $1 / 27 / 11$ & 0 & 0.7 & I II III IV A & H D F V O G & - & - & 01 & 06 & $\mathrm{~s}(\mathrm{p})$ \\
\hline Bay & Crooked Island East & 26 & $1 / 27 / 11$ & 0 & 9.7 & III B F & V G & $\underline{91}$ & $\underline{96}$ & 01 & $\underline{06}$ & $\mathrm{f}$ \\
\hline Bay & Crooked Island West & 24 & $1 / 27 / 11$ & 0 & 8.9 & III B F & V O G & $\underline{91}$ & 96 & 01 & 06 & $\mathrm{f}$ \\
\hline Bay & Grand Lagoon - Bay Point, Alligator Point & 20 & $1 / 24 / 11$ & 0 & 0.4 & II A D & H D G L & $\underline{91}$ & - & $\underline{01}$ & 06 & $\mathrm{~s}(\mathrm{p})$ \\
\hline Bay & Marifarms North & 18 & $1 / 28 / 11$ & 0 & 5.4 & II V G & $\mathrm{S}$ & - & - & 01 & 06 & $\mathrm{~s}(\mathrm{p}), \mathrm{p}$ \\
\hline Bay & Mexico Beach ${ }^{7}$ & 28 & $2 / 24 / 11$ & 0 & 2.6 & III A & H G & $\underline{91}$ & $\underline{96}^{2}$ & 01 & 06 & $\mathrm{~m}, \mathrm{c}$ \\
\hline Bay & Shell Island & 23 & $1 / 27 / 11$ & 9 & 15.2 & III B F & V G & 91 & $\underline{96}$ & $\underline{01}$ & 06 & $f, s(p)$ \\
\hline Bay & St. Andrew Bay - Davis Pt. to Redfish Pt. & 22 & $1 / 27 / 11$ & 0 & 1.6 & II A D & $\mathrm{L}$ & - & - & $\underline{01}$ & 06 & $\mathrm{f}$ \\
\hline Bay & St. Andrews State Recreation Area & 19 & $1 / 27 / 11$ & 0 & 3.3 & II III A & H D S V O G L & $\underline{91}$ & 96 & 01 & 06 & $\mathrm{~s}(\mathrm{p})$ \\
\hline Bay & Tyndall AFB (Buck Beach) & 25 & $1 / 27 / 11$ & 0 & 4.8 & II A & G L & - & - & - & 06 & $\mathrm{f}$ \\
\hline Bay & West Beach Drive & 21 & $2 / 1 / 11$ & 0 & 4.0 & II A & H G L & - & - & 01 & 06 & $\mathrm{~m}, \mathrm{p}$ \\
\hline Brevard & Cape Canaveral Air Force Station & 137 & $2 / 4 / 11$ & 0 & 21.0 & I B & H F G & 91 & 96 & 01 & 06 & $\mathrm{f}$ \\
\hline Brevard & Merritt Island NWR (Shiloh Impoundments) & 136 & $1 / 28 / 11$ & 0 & 10.5 & V G & $\mathrm{G}$ & - & - & - & - & $\mathrm{f}$ \\
\hline Brevard & Patrick Air Force Base & 138 & $2 / 4 / 11$ & 0 & 9.2 & I B & H D F O G & - & - & - & 06 & $\mathrm{f}$ \\
\hline Brevard & South Canaveral National Seashore & 135 & $2 / 4 / 11$ & 0 & 20.1 & I B & H G & 91 & 96 & 01 & 06 & $\mathrm{f}$ \\
\hline Broward & Broward County Northern Link to Hillsboro Inlet & 179 & $2 / 1 / 11$ & 0 & 6.8 & I B & $\mathrm{H} \mathrm{S}$ & 91 & - & - & 06 & $\mathrm{~m}, \mathrm{p}$ \\
\hline Broward & Hugh Taylor Birch State Park & 180 & $1 / 31 / 11$ & 0 & 1.6 & I II V & H D V F S I U L & - & - & - & 06 & $\mathrm{~s}(\mathrm{p}), \mathrm{m}$ \\
\hline Broward & John U. Lloyd Beach S.P. & 181 & $1 / 29 / 11$ & 0 & 4.0 & I II IV B & $\mathrm{H} \mathrm{L}$ & 91 & - & 01 & 06 & $\mathrm{~s}(\mathrm{p})$ \\
\hline Charlotte & Barrier Island (Don Pedro) & 91 & $1 / 29 / 11$ & 0 & 3.2 & III B & n.r. & 91 & - & - & 06 & $\mathrm{p}$ \\
\hline Charlotte & Barrier Island (Knight Island) & 90 & $1 / 30 / 11$ & 0 & 3.2 & II III IV V B F & F S V O & 91 & - & 01 & $\underline{06}$ & $\mathrm{~m}$ \\
\hline Charlotte & Barrier Island (Little Gasparilla Island) & 92 & $1 / 29 / 11$ & 0 & 3.2 & III B & H D G & 91 & - & - & 06 & $\mathrm{p}$ \\
\hline Charlotte & Gasparilla Island & 93 & $2 / 4 / 11$ & 0 & 4.8 & III B & H D G & 91 & - & - & 06 & $\mathrm{f}, \mathrm{p}$ \\
\hline Charlotte & Stump Pass Beach & 89 & $1 / 30 / 11$ & 0 & 2.1 & II III V B & H S G & 91 & 96 & - & - & $\mathrm{s}(\mathrm{p})$ \\
\hline Collier & Big Marco Pass Shoal & 107 & $2 / 1 / 11$ & 19 & 4.0 & III B & H D & $\underline{91}$ & $\underline{96}$ & $\underline{01}$ & $\underline{06}$ & $\mathrm{~s}(\mathrm{p})$ \\
\hline Collier & Cape Romano & 108 & $1 / 25 / 11$ & 0 & 3.4 & III B D & H D F G & - & - & - & 06 & $\mathrm{~s}(\mathrm{p}), \mathrm{p}$ \\
\hline Collier & Caxambas Island & 109 & $1 / 31 / 11$ & 0 & 0.3 & III D & H D G & - & - & - & 06 & $\mathrm{~s}(\mathrm{p})$ \\
\hline Collier & Delnor-Wiggins Pass State Park & 105 & $2 / 2 / 11$ & 0 & 0.8 & III B & $\mathrm{H} \mathrm{G}$ & - & - & - & 06 & $\mathrm{~s}(\mathrm{p})$ \\
\hline Collier & Keewaydin Island & 106 & $1 / 31 / 11$ & 0 & 12.1 & III B & H D F S O G & - & - & - & $\underline{06}$ & $\mathrm{~s}(\mathrm{p}), \mathrm{p}$ \\
\hline Collier & Kice Island & 110 & $1 / 31 / 11$ & 5 & 4.0 & III B D & H D F O G & - & - & - & - & $\mathrm{s}(\mathrm{p})$ \\
\hline Duval & Little Talbot Island State Park & 117 & $2 / 4 / 11$ & 6 & 6.5 & I IV B & H G & $\underline{91}$ & $\underline{96}$ & $\underline{01}$ & $\underline{06}$ & $\mathrm{~s}(\mathrm{p})$ \\
\hline Duval & Mayport Jetty South to County Line & 119 & $2 / 4 / 11$ & 0 & 16.0 & I B & G & 91 & 96 & 01 & 06 & $\begin{array}{c}\mathrm{f}, \mathrm{s}(\mathrm{p}) \\
\mathrm{m}, \mathrm{c}\end{array}$ \\
\hline
\end{tabular}


The 2011 International Piping Plover Winter Census in Florida

(Continued)

\begin{tabular}{|c|c|c|c|c|c|c|c|c|c|c|c|c|}
\hline \multirow{2}{*}{$\begin{array}{l}\text { COUNTY } \\
\text { Duval }\end{array}$} & \multirow{2}{*}{$\begin{array}{c}\text { SITE NAME } \\
\text { Ward's Bank (Huguenot Park) }\end{array}$} & \multirow{2}{*}{$\frac{\text { MAP\# }}{1118}$} & \multirow{2}{*}{$\frac{\text { DATE }}{2 / 4 / 11}$} & \multirow{2}{*}{$\begin{array}{c}\text { TOTAL } \\
\text { ADULTS } \\
0\end{array}$} & \multirow{2}{*}{$\frac{\text { KM }}{26.4}$} & \multirow{2}{*}{$\begin{array}{l}\text { SITE } \\
\text { DESCRIPTION } \\
\text { I II IV A }\end{array}$} & \multirow{2}{*}{$\begin{array}{l}\text { DISTURBANCE } \\
\text { / CONCERNS } \\
\mathrm{VG}\end{array}$} & \multicolumn{4}{|c|}{$\begin{array}{c}\text { PRIOR YEARS } \\
\text { CENSUSED \& YEARS }^{\text {PIPL SEEN }}{ }^{1} \\
\end{array}$} & \multirow{2}{*}{$\frac{\text { OWNER }}{\mathrm{f}_{\mathrm{f}, \mathrm{s}(\mathrm{p})}}$} \\
\hline & & & & & & & & $\underline{91}$ & $\underline{96}$ & $\underline{01}$ & $\underline{06}$ & \\
\hline Escambia & Fort Pickens Gulf Islands N.S. & 2 & $1 / 29 / 11$ & 0 & 24.1 & II III B & $\mathrm{H} V \mathrm{G}$ & $\underline{91}$ & 96 & 01 & 06 & $\mathrm{f}$ \\
\hline Escambia & Perdido Key Gulf Islands N.S. & 1 & $2 / 2 / 11$ & 0 & 26.1 & II B C & H V G & - & 96 & $\underline{01}$ & 06 & $\mathrm{f}$ \\
\hline Escambia & Santa Rosa Gulf Islands N.S. & 3 & $1 / 27 / 11$ & 19 & 25.6 & III B & H D V G & - & 96 & 01 & $\underline{06}$ & $\mathrm{f}$ \\
\hline Flagler & $\begin{array}{l}\text { Flagler Beach and ICW (Pier to Gamble Rogers } \\
\text { MSRA) }\end{array}$ & 125 & $2 / 4 / 11$ & 0 & 4.9 & I V B G & $\mathrm{H} \mathrm{G}$ & 91 & 96 & - & - & $\mathrm{m}, \mathrm{c}$ \\
\hline Flagler & Flagler Beach Pier to Marineland & 124 & $2 / 4 / 11$ & 0 & 22.3 & I B & H G & - & - & - & - & $\mathrm{m}, \mathrm{c}$ \\
\hline Flagler & Gamble Rogers Memorial SRA & 126 & $2 / 4 / 11$ & 0 & 3.4 & I II V B & H G & - & - & - & 06 & $\mathrm{~s}(\mathrm{p}), \mathrm{m}$ \\
\hline Franklin & Bald Pt. State Park & 46 & $2 / 5 / 11$ & 3 & 1.5 & II III A & $\mathrm{H} \mathrm{G}$ & - & 96 & 01 & $\underline{06}$ & $\mathrm{~s}(\mathrm{p})$ \\
\hline Franklin & Carrabelle Beach & 40 & $2 / 1 / 11$ & 1 & 2.2 & II A & H D F G & $\underline{91}$ & $\underline{96}$ & 01 & 06 & $\mathrm{c}$ \\
\hline Franklin & Dog Island & 41 & $1 / 28 / 11$ & 1 & 13.7 & III V B & H F O G & $\underline{91}$ & - & $\underline{01}$ & $\underline{06}$ & $\mathrm{~s}(\mathrm{p}), \mathrm{p}$ \\
\hline Franklin & Flagg Island (Off St. Vincent Refuge) & 38 & $2 / 5 / 11$ & 1 & 2.3 & III G & $\mathrm{HO} \mathrm{G}$ & - & - & - & - & $\mathrm{s}(\mathrm{p})$ \\
\hline Franklin & FSU Marine Lab & 43 & $2 / 1 / 11$ & 0 & 1.6 & III A & H D G & - & - & 01 & 06 & $\mathrm{p}$ \\
\hline Franklin & John S. Phipps Reserve (West end of Peninsula) & 45 & $1 / 29 / 11$ & 8 & 3.2 & II III G & $\mathrm{G}$ & $\underline{91}^{3}$ & 96 & $\underline{01}$ & $\underline{06}$ & $\mathrm{p}$ \\
\hline Franklin & Lanark Reef & 42 & $1 / 28 / 11$ & 4 & 1.6 & III V B & $\mathrm{G}$ & 91 & $\underline{96}$ & $\underline{01}$ & $\underline{06}$ & $\mathrm{~s}(\mathrm{p})$ \\
\hline Franklin & St. George Island State Park & 39 & $2 / 4 / 11$ & 17 & 18.0 & II III B & $\mathrm{H} \mathrm{V} \mathrm{O}$ & $\underline{91}$ & $\underline{96}$ & $\underline{01}$ & $\underline{06}$ & $\mathrm{~s}(\mathrm{p})$ \\
\hline Franklin & St. Vincent Island & 37 & $2 / 1 / 11$ & 8 & 19.8 & II III B D & $\mathrm{G}$ & 91 & $\underline{96}$ & 01 & 06 & $\mathrm{f}$ \\
\hline Franklin & Turkey Point to St. Teresa Beach & 44 & $2 / 1 / 11$ & 0 & 8.8 & II A & H D V F G & 91 & 96 & 01 & $\underline{06}$ & $\mathrm{p}, \mathrm{c}$ \\
\hline Gulf & Highland View (Scamp St. to Port St. Joe) & 31 & $2 / 2 / 11$ & 0 & 1.6 & II A G & S L & - & - & - & 06 & n.r. \\
\hline Gulf & Indian Pass to Cape San Blas and Stump Hole & 36 & $2 / 2 / 11$ & 5 & 11.6 & III A & H D V G & $\underline{91}$ & $\underline{96}$ & $\underline{01}$ & $\underline{06}$ & $\mathrm{~m}, \mathrm{c}$ \\
\hline Gulf & NE St. Joe Bay Shoreline & 32 & $2 / 3 / 11$ & 0 & 3.2 & II A & $\mathrm{G}$ & 91 & 96 & 01 & - & $\mathrm{s}(\mathrm{p})$ \\
\hline Gulf & Simmons Bayou & 34 & $2 / 3 / 11$ & 0 & 0.5 & II A & $\mathrm{G}$ & - & - & - & - & $\mathrm{s}(\mathrm{p})$ \\
\hline Gulf & St. Joe Beach (County Line to Pine St.) & 29 & $2 / 24 / 11$ & 0 & 4.0 & III A & H G & - & - & - & 06 & $\mathrm{~m}, \mathrm{c}$ \\
\hline Gulf & St. Joe Peninsula SP (Northern Portion) & 33 & $2 / 3 / 11$ & 4 & 17.3 & II III G & $\mathrm{H} \mathrm{V} \mathrm{O}$ & $\underline{91}$ & $\underline{96}$ & $\underline{01}$ & $\underline{06}$ & $\mathrm{~s}(\mathrm{p})$ \\
\hline Gulf & St. Joe Peninsula SP (Southern Portion) & 35 & $1 / 31 / 11$ & 0 & 9.5 & III G & H D G L & $\underline{91}$ & $\underline{96}$ & 01 & $\underline{06}$ & $\mathrm{~m}, \mathrm{c}$ \\
\hline Gulf & Windmark Beach (Pine St. to N Signal Ln Pier) & 30 & $1 / 28 / 11$ & 0 & 4.7 & II A & H G L & 91 & 96 & 01 & 06 & $\mathrm{p}$ \\
\hline Hernando & Pine Island & 53 & $1 / 28 / 11$ & 0 & 0.8 & II III B & H G & - & - & - & - & $\mathrm{c}$ \\
\hline Hillsborough & Cypress Point Park & 63 & $2 / 5 / 11$ & 0 & 1.0 & II A & $\mathrm{HO} \mathrm{G}$ & - & - & - & - & $\mathrm{s}(\mathrm{p})$ \\
\hline Hillsborough & Egmont Key NWR \& State Park & 79 & $2 / 4 / 11$ & 0 & 4.8 & II III B & $\mathrm{G}$ & 91 & 96 & 01 & 06 & $\mathrm{f}$ \\
\hline Indian River & Indian River Co. Beaches & 143 & $2 / 3 / 11$ & 1 & 10.2 & I B & H D F S O G & 91 & 96 & - & 06 & $\mathrm{~m}, \mathrm{p}$ \\
\hline Indian River & Pelican Island NWR & 140 & $2 / 1 / 11$ & 0 & 21.7 & II V B C D E G & H F S V I O G & 91 & 96 & - & - & $\mathrm{f}$ \\
\hline Indian River & Round Island Conservation Area & 144 & $2 / 2 / 11$ & 0 & 1.6 & V G & $\mathrm{H} \mathrm{D} \mathrm{O} \mathrm{G}$ & 91 & - & - & 06 & $\mathrm{f}, \mathrm{c}$ \\
\hline Indian River & Round Island Park & 145 & $2 / 3 / 11$ & 0 & 0.7 & I B & H F G & 91 & 96 & - & 06 & $\mathrm{p}, \mathrm{c}$ \\
\hline
\end{tabular}


The 2011 International Piping Plover Winter Census in Florida

(Continued)

\begin{tabular}{|c|c|c|c|c|c|c|c|c|c|c|c|c|}
\hline \multirow{2}{*}{$\begin{array}{l}\text { COUNTY } \\
\text { Indian River }\end{array}$} & SITE NAME & \multirow{2}{*}{$\begin{array}{c}\text { MAP\# } \\
139\end{array}$} & \multirow{2}{*}{$\begin{array}{c}\text { DATE } \\
2 / 1 / 11\end{array}$} & \multirow{2}{*}{$\begin{array}{c}\text { TOTAL } \\
\text { ADULTS } \\
0\end{array}$} & \multirow{2}{*}{$\begin{array}{c}\text { KM } \\
9.7\end{array}$} & \multirow{2}{*}{$\begin{array}{l}\text { SITE } \\
\text { DESCRIPTION } \\
\text { I B }\end{array}$} & \multirow{2}{*}{$\begin{array}{l}\text { DISTURBANCE } \\
\text { / CONCERNS } \\
\text { H D F O G }\end{array}$} & \multicolumn{4}{|c|}{$\begin{array}{c}\text { PRIOR YEARS } \\
\text { CENSUSED \& YEARS }^{\text {PIPL SEEN }}{ }^{1} \\
\end{array}$} & \multirow{2}{*}{$\begin{array}{c}\text { OWNER } \\
\mathrm{f}, \mathrm{s}(\mathrm{p}) \\
\mathrm{m}\end{array}$} \\
\hline & Sebastian Inlet State Park to Wabasso Beach Park & & & & & & & 91 & 96 & - & 06 & \\
\hline Indian River & Tracking Station Access to Barber Bridge & 142 & $2 / 3 / 11$ & 0 & 2.6 & I B & H D S U O & 91 & 96 & - & 06 & $\mathrm{~m}, \mathrm{p}$ \\
\hline Indian River & Tracking Station Park N to Wabasso Beach & 114 & $2 / 3 / 11$ & 0 & 10.3 & I B & H D S G & 91 & 96 & - & 06 & $\begin{array}{l}\mathrm{s}(\mathrm{p}), \mathrm{m} \\
\mathrm{p}, \mathrm{c}\end{array}$ \\
\hline Lee & Bonita Beach & 104 & $2 / 4 / 11$ & 0 & 6.9 & III & H F G & - & - & - & 06 & $\mathrm{~m}, \mathrm{p}, \mathrm{c}$ \\
\hline Lee & Bunche Beach & 99 & $1 / 29 / 11$ & 15 & 2.4 & II V A & H F G L & 91 & 96 & 01 & - & $\mathrm{f}, \mathrm{m}, \mathrm{c}$ \\
\hline Lee & Captiva Island & 97 & $2 / 1 / 11$ & 0 & 7.7 & I III A B & H F G & 91 & - & - & 06 & $\mathrm{~m}, \mathrm{c}$ \\
\hline Lee & Cayo Costa & 95 & $1 / 26 / 11$ & 4 & 11.7 & II III B G & H G & 91 & - & 01 & $\underline{06}$ & $\mathrm{~s}(\mathrm{p}), \mathrm{p}$ \\
\hline Lee & Estero Island (R1) & 100 & $1 / 28 / 11$ & 0 & 4.7 & II III B C & H D O G L & - & 96 & 01 & 06 & $\mathrm{~m}, \mathrm{p}, \mathrm{c}$ \\
\hline Lee & Estero Island (R2) & 101 & $1 / 24 / 11$ & 0 & 4.3 & II III B F & H D V F O G & $\underline{91}$ & 96 & 01 & 06 & $\mathrm{~m}, \mathrm{p}, \mathrm{c}$ \\
\hline Lee & Estero Island (R3) & 102 & $2 / 5 / 11$ & 9 & 2.4 & II III B & H G & - & $\underline{96}$ & $\underline{01}$ & $\underline{06}$ & $\begin{array}{l}\mathrm{s}(\mathrm{p}), \mathrm{m} \\
\mathrm{p}, \mathrm{c}\end{array}$ \\
\hline Lee & Gasparilla Island & 94 & $2 / 4 / 11$ & 0 & 11.3 & III B & H D G & - & - & - & 06 & $\mathrm{f}, \mathrm{s}(\mathrm{p}), \mathrm{p}$ \\
\hline Lee & Lovers Key State Park & 103 & $2 / 5 / 11$ & 0 & 4.0 & III B & $\mathrm{HO} \mathrm{G}$ & - & - & - & 06 & $\mathrm{~s}(\mathrm{p})$ \\
\hline Lee & N. Captiva Island & 96 & $1 / 27 / 11$ & 2 & 3.4 & II III B & H D V F O G L & $\underline{91}$ & $\underline{96}$ & - & $\underline{06}$ & $\mathrm{~s}(\mathrm{p})$ \\
\hline Lee & Sanibel Island & 98 & $2 / 1 / 11$ & 0 & 20.0 & I III A B D F & H D F O G & 91 & 96 & 01 & 06 & $\mathrm{~s}(\mathrm{p}), \mathrm{m}$ \\
\hline Levy & Cedar Key Area & 52 & $1 / 24 / 11$ & 5 & 12.9 & III D & F G & 91 & - & - & $\underline{06}$ & $\mathrm{~s}(\mathrm{p})$ \\
\hline Manatee & Anna Maria Island & 80 & $1 / 30 / 11$ & 0 & 10.0 & I B & n.r. & $\underline{91}$ & 96 & 01 & 06 & n.r. \\
\hline Manatee & Longboat Key (formerly "Beer Can Island") & 81 & $1 / 30 / 11$ & 0 & 7.3 & I B & n.r. & 91 & 96 & $\underline{01}$ & 06 & n.r. \\
\hline Martin & Hobe Sound NWR & 160 & $1 / 31 / 11$ & 0 & 5.6 & I B & H F S G & 91 & 96 & 01 & 06 & f \\
\hline Martin & Hutchinson Island, Alex's Beach to Stuart Beach & 154 & $1 / 31 / 11$ & 0 & 2.9 & I B & H F O G & 91 & 96 & - & 06 & $\mathrm{~s}(\mathrm{p})$ \\
\hline Martin & $\begin{array}{l}\text { Hutchinson Island, Bathtub Beach to St. Lucie } \\
\text { Inlet }\end{array}$ & 156 & $1 / 31 / 11$ & 0 & 2.7 & I IV B & H F G L & $\underline{91}$ & 96 & - & 06 & $\mathrm{p}$ \\
\hline Martin & $\begin{array}{l}\text { Hutchinson Island, St. Lucie Line S to Alex's } \\
\text { Beach }\end{array}$ & 157 & $2 / 1 / 11$ & 0 & 2.8 & I B & H F O G & 91 & 96 & - & 06 & $\mathrm{~s}(\mathrm{p})$ \\
\hline Martin & Hutchinson Island, Stuart Beach to Bathtub Beach & 155 & $1 / 31 / 11$ & 0 & 3.4 & I B & $\mathrm{HF}$ & 91 & 96 & - & 06 & $\mathrm{~s}(\mathrm{p})$ \\
\hline Martin & Jupiter Island Beaches & 161 & $1 / 31 / 11$ & 0 & 7.6 & I B & H D F V S G & 91 & 96 & - & - & $\mathrm{m}$ \\
\hline Martin & St. Lucie Inlet sandbars & 158 & $1 / 31 / 11$ & 4 & 3.2 & II D & H D O S G & - & $\underline{96}$ & $\underline{01}$ & 06 & $\mathrm{~s}(\mathrm{p})$ \\
\hline Martin & St. Lucie Inlet State Park & 159 & $1 / 31 / 11$ & 0 & 9.0 & I IV B & D V G & 91 & 96 & 01 & 06 & $\mathrm{~s}(\mathrm{p})$ \\
\hline Martin & W shore of Indian River Near Jensen Beach & 153 & $2 / 1 / 11$ & 0 & 0.4 & II A D & H G L & - & - & - & 06 & $\mathrm{~s}(\mathrm{p})$ \\
\hline Miami-Dade & Bill Baggs State Park lighthouse to Crandon Park & 185 & $1 / 27 / 11$ & 0 & 3.9 & I B & H V & - & - & 01 & 06 & $\mathrm{~s}(\mathrm{p}), \mathrm{m}$ \\
\hline Miami-Dade & Biscayne National Park & 190 & $2 / 4 / 11$ & 0 & 9.7 & I II IV B D & H F G L & - & 96 & - & 06 & $\mathrm{f}$ \\
\hline Miami-Dade & Crandon Park Beach & 186 & $1 / 27 / 11$ & 37 & 2.8 & I B D & H V G L & 91 & - & $\underline{01}$ & $\underline{06}$ & $\mathrm{c}$ \\
\hline
\end{tabular}


The 2011 International Piping Plover Winter Census in Florida

(Continued)

\begin{tabular}{|c|c|c|c|c|c|c|c|c|c|c|c|c|}
\hline \multirow{2}{*}{$\begin{array}{l}\text { COUNTY } \\
\text { Miami-Dade }\end{array}$} & \multirow{2}{*}{$\begin{array}{r}\text { SITE NAME } \\
\text { Cutler Wetlands }\end{array}$} & \multirow{2}{*}{ MAP\# } & \multirow{2}{*}{$\frac{\text { DATE }}{2 / 3 / 11}$} & \multirow{2}{*}{$\begin{array}{c}\text { TOTAL } \\
\text { ADULTS } \\
0\end{array}$} & \multirow{2}{*}{$\frac{\mathbf{K M}}{0.5}$} & \multirow{2}{*}{$\begin{array}{l}\text { SITE } \\
\text { DESCRIPTION } \\
\mathrm{VA}\end{array}$} & \multirow{2}{*}{$\begin{array}{l}\text { DISTURBANCE } \\
\text { / CONCERNS } \\
\mathrm{H} \mathrm{D} \mathrm{V}\end{array}$} & \multicolumn{4}{|c|}{$\begin{array}{c}\text { PRIOR YEARS } \\
\text { CENSUSED \& YEARS } \\
\text { PIPL SEEN }^{1} \\
\end{array}$} & \multirow{2}{*}{$\frac{\text { OWNER }}{\mathrm{p}}$} \\
\hline & & & & & & & & - & - & - & - & \\
\hline Miami-Dade & Deering Estate and Chicken Key & 188 & $2 / 2 / 11$ & 0 & 3.1 & II A C G & H D F O G L & - & - & - & 06 & $\mathrm{~s}(\mathrm{p}), \mathrm{c}$ \\
\hline Miami-Dade & Matheson Hammock & 187 & $2 / 4 / 11$ & 0 & 1.2 & II A G & H D O G L & - & - & - & 06 & $\mathrm{c}$ \\
\hline Miami-Dade & Oleta River State Park & 182 & 2/4/11 & 0 & 0.3 & II A & G & - & - & - & - & $\mathrm{s}(\mathrm{p})$ \\
\hline Miami-Dade & Rickenbacker Causeway Shoreline & 183 & $1 / 28 / 11$ & 0 & 1.7 & II E & H D F S I G & - & - & 01 & 06 & $\mathrm{c}$ \\
\hline Miami-Dade & Virginia Key Critical Wildlife Area & 184 & $1 / 28 / 11$ & 0 & 2.6 & II B & H S I & 91 & 96 & 01 & 06 & $\mathrm{~m}$ \\
\hline Monroe & Bahia Honda State Park & 195 & $1 / 24 / 11$ & 0 & 4.8 & I G & H F O G & 91 & 96 & 01 & 06 & $\mathrm{~s}(\mathrm{p})$ \\
\hline Monroe & Boca Chica Beach & 196 & $1 / 27 / 11$ & 0 & 1.3 & I E & H D V S G & - & 96 & - & 06 & $\mathrm{~s}(\mathrm{p})$ \\
\hline Monroe & Boca Grande Key & 199 & $1 / 25 / 11$ & 14 & 1.2 & V E G & H D G L & $\underline{91}$ & $\underline{96}$ & 01 & $\underline{06}$ & $\mathrm{f}$ \\
\hline Monroe & Curry Hammock State Park & 193 & $1 / 24 / 11$ & 0 & 0.4 & I G & $\mathrm{HO} \mathrm{G}$ & - & - & - & 06 & $\mathrm{~s}(\mathrm{p})$ \\
\hline Monroe & Fort Taylor Historic State Park & 197 & $2 / 1 / 11$ & 0 & 0.8 & I III E & $\mathrm{H} \mathrm{G}$ & - & - & - & 06 & $\mathrm{~s}(\mathrm{p})$ \\
\hline Monroe & $\begin{array}{l}\text { John D. Pennekamp state Park/ Carysfort Yacht } \\
\text { Club }\end{array}$ & 191 & $2 / 3 / 11$ & 0 & 1.0 & I II A & $\mathrm{H} \mathrm{G}$ & - & - & 01 & 06 & $\mathrm{~s}(\mathrm{p})$ \\
\hline Monroe & Lake Ingraham & 200 & $1 / 29 / 11$ & 0 & 1.6 & II & G L & 91 & 96 & - & - & $\mathrm{f}$ \\
\hline Monroe & Long Key State Park & 192 & $1 / 24 / 11$ & 0 & 1.6 & I G & H G L & - & 96 & - & 06 & $\mathrm{~s}(\mathrm{p})$ \\
\hline Monroe & Ohio Key & 194 & $1 / 27 / 11$ & 0 & 0.5 & I E G & H D G & 91 & $\underline{96}$ & 01 & 06 & $\mathrm{f}$ \\
\hline Monroe & Sandy Key to Carl Ross Key & 201 & $2 / 6 / 11$ & 2 & 1.5 & II E & G & $\underline{91}$ & 96 & - & - & $\mathrm{f}$ \\
\hline Monroe & Woman Key & 198 & $1 / 25 / 11$ & 0 & 1.3 & I E & H D G L & - & 96 & $\underline{01}$ & 06 & $\mathrm{f}$ \\
\hline Nassau & Amelia Island State Park & 116 & 2/4/11 & 0 & 2.8 & I IV B & G & 91 & - & 01 & 06 & $\mathrm{~s}(\mathrm{p})$ \\
\hline Nassau & Bell River Spoil Island & 113 & $2 / 6 / 11$ & 0 & 0.4 & $\mathrm{~V} \mathrm{C}$ & $\mathrm{OG}$ & - & - & - & - & $\mathrm{p}$ \\
\hline Nassau & Fort Clinch State Park & 112 & $2 / 4 / 11$ & 0 & 6.4 & I II IV B & $\mathrm{H} \mathrm{S}$ & 91 & - & 01 & 06 & $\mathrm{~s}(\mathrm{p})$ \\
\hline Nassau & Little Tiger Island & 111 & $2 / 6 / 11$ & 0 & 2.4 & V E & $\mathrm{O}$ & - & - & $\underline{01}$ & $\underline{06}$ & $\mathrm{p}$ \\
\hline Nassau & North Fernandina Beach & 114 & $4 / 4 / 11$ & 0 & 11.0 & I B & H S G & - & - & - & 06 & $\mathrm{~s}(\mathrm{p})$ \\
\hline Nassau & South Fernandina Beach & 115 & 2/4/11 & 0 & 7.4 & I B & $\mathrm{H}$ & - & - & - & - & $\mathrm{p}$ \\
\hline Okaloosa & $\begin{array}{l}\text { Eglin AFB (E restricted beach), Santa Rosa } \\
\text { Island }\end{array}$ & 6 & $1 / 27 / 11$ & 0 & 9.7 & III B & H V G & 91 & 96 & 01 & 06 & $\mathrm{f}$ \\
\hline Okaloosa & Eglin AFB (Public Beach), Okaloosa Island & 8 & $1 / 27 / 11$ & 0 & 7.4 & I IV B & H V S G & 91 & 96 & 01 & 06 & $\mathrm{f}$ \\
\hline Okaloosa & Henderson Beach State Park & 9 & $1 / 28 / 11$ & 0 & 2.2 & III A & H D V O G L & - & - & 01 & 06 & $\mathrm{~s}(\mathrm{p})$ \\
\hline Okaloosa & Okaloosa Holding Ponds & 7 & $1 / 25 / 11$ & 0 & 4.5 & V A & n.r. & - & - & - & - & n.r. \\
\hline $\begin{array}{l}\text { Okaloosa/ } \\
\text { Santa Rosa }\end{array}$ & $\begin{array}{l}\text { Eglin AFB (W restricted beach), Santa Rosa } \\
\text { Island }\end{array}$ & 4 & $1 / 27 / 11$ & 0 & 9.7 & III B & V G & 91 & 96 & 01 & 06 & $\mathrm{f}$ \\
\hline $\begin{array}{l}\text { Okaloosa/ } \\
\text { Santa Rosa }\end{array}$ & Eglin AFB (N restricted beach) & 5 & $2 / 2 / 11$ & 3 & 22.7 & II III B & G L & 91 & - & $\underline{01}$ & 06 & $\mathrm{f}$ \\
\hline Palm Beach & Boynton Inlet to Gulfstream Park & 175 & $2 / 1 / 11$ & 0 & 4.8 & I IV A & H S O G & - & - & - & 06 & $\mathrm{~m}, \mathrm{p}, \mathrm{c}$ \\
\hline
\end{tabular}




\section{The 2011 International Piping Plover Winter Census in Florida}

(Continued)

\begin{tabular}{|c|c|c|c|c|c|c|c|c|c|c|c|c|}
\hline \multirow{2}{*}{$\begin{array}{l}\text { COUNTY } \\
\text { Palm Beach }\end{array}$} & SITE NAME & \multirow{2}{*}{$\begin{array}{c}\text { MAP\# } \\
176\end{array}$} & \multirow{2}{*}{$\begin{array}{l}\text { DATE } \\
2 / 2 / 11\end{array}$} & $\begin{array}{c}\text { TOTAL } \\
\text { ADULTS }\end{array}$ & KM & $\begin{array}{l}\text { SITE } \\
\text { DESCRIPTION }\end{array}$ & $\begin{array}{l}\text { DISTURBANCE } \\
\text { / CONCERNS } \\
\end{array}$ & \multicolumn{4}{|c|}{$\begin{array}{r}\text { PRIOR YEARS } \\
\text { CENSUSED \& YEA }\end{array}$} & \multirow{2}{*}{ OWNER } \\
\hline & $\begin{array}{l}\text { Gulfstream Park to N. Delray Beach } \\
\end{array}$ & & & 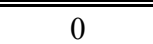 & 6.4 & 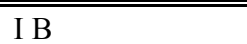 & $\overline{\mathrm{H} \mathrm{HOG}}$ & $\overline{-1}$ & 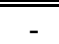 & $\overline{-1}$ & 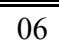 & \\
\hline Palm Beach & Highland Beach & 178 & $2 / 3 / 11$ & 0 & 13.4 & I IV B & H D V S I & - & - & - & 06 & $\mathrm{~m}, \mathrm{p}, \mathrm{c}$ \\
\hline Palm Beach & Ibis Isle Restoration Area & 171 & $2 / 3 / 11$ & 0 & 0.6 & II B & G L & - & - & - & - & $\mathrm{s}(\mathrm{p})$ \\
\hline Palm Beach & Juno Beach Park to MacArthur State Park & 165 & $2 / 3 / 11$ & 0 & 6.5 & I B & HF & - & - & - & 06 & $\mathrm{c}$ \\
\hline Palm Beach & Jupiter Beach to Juno Beach Park & 164 & $2 / 3 / 11$ & 0 & 5.8 & I IV B & H D F S & - & - & - & 06 & $\mathrm{c}$ \\
\hline Palm Beach & Jupiter Sound, Jupiter inlet, Loxahatchee River & 163 & $2 / 3 / 11$ & 0 & 7.4 & II IV V A B D & H D S U G L & 91 & - & - & 06 & $\mathrm{~s}(\mathrm{p})$ \\
\hline Palm Beach & Lantana Park to Boynton Inlet & 174 & $2 / 1 / 11$ & 0 & 4.3 & I IV F & G & - & - & - & 06 & $\mathrm{c}$ \\
\hline Palm Beach & MacArthur Beach State Park & 166 & $2 / 4 / 11$ & 0 & 2.4 & I II B & H D F G & 91 & 96 & 01 & 06 & $\mathrm{~s}(\mathrm{p})$ \\
\hline Palm Beach & $\begin{array}{l}\text { MacArthur Beach State Park to Palm Beach } \\
\text { Shores }\end{array}$ & 167 & $2 / 3 / 11$ & 0 & 4.6 & I IV B & H V F & - & - & - & 06 & $\mathrm{~m}, \mathrm{p}$ \\
\hline Palm Beach & N. Delray Beach to Atlantic Dunes Park & 177 & $2 / 5 / 11$ & 0 & 0.8 & n.r. & H D G & - & 96 & - & 06 & n.r. \\
\hline Palm Beach & Palm Beach Shores to Southern Blvd & 169 & $2 / 3 / 11$ & 0 & 11.9 & I IV B & H D S G & - & - & - & - & $\mathrm{s}(\mathrm{p}), \mathrm{m}$ \\
\hline Palm Beach & Peanut Island & 168 & $1 / 31 / 11$ & 0 & 1.6 & V B & $\mathrm{H} \mathrm{G}$ & - & - & - & - & $\mathrm{m}$ \\
\hline Palm Beach & Sloan's Curve to Lantana Beach & 172 & $2 / 3 / 11$ & 0 & 6.4 & I B & $\mathrm{HVS}$ & - & - & - & 06 & $\begin{array}{l}\mathrm{s}(\mathrm{p}), \mathrm{m}, \\
\mathrm{p}, \mathrm{c}\end{array}$ \\
\hline Palm Beach & $\begin{array}{l}\text { Snook Islands Natural Area to Lake Worth } \\
\text { Lagoon }\end{array}$ & 173 & $2 / 6 / 11$ & 0 & 2.0 & II A G & S G L & - & - & - & - & $\mathrm{m}$ \\
\hline Palm Beach & Southern Blvd to Sloan's Curve & 170 & $2 / 3 / 11$ & 0 & 3.3 & I A & $\mathrm{H} \mathrm{G}$ & - & - & - & 06 & $\mathrm{~m}, \mathrm{p}$ \\
\hline $\begin{array}{l}\text { Palm Beach/ } \\
\text { Martin }\end{array}$ & $\begin{array}{l}\text { Jupiter Island - Jupiter Inlet through Blowing } \\
\text { Rocks Preserve }\end{array}$ & 162 & $1 / 31 / 11$ & 0 & 3.2 & I IV B & H D V F & - & 96 & - & 06 & $\mathrm{c}$ \\
\hline Pasco & Anclote Key sandbar & 54 & $2 / 4 / 11$ & 4 & 2.7 & III D & $\mathrm{H} \mathrm{G}$ & - & $\underline{96}$ & $\underline{01}$ & $\underline{06}$ & $\mathrm{~s}(\mathrm{p})$ \\
\hline Pasco/Pinellas & Anclote Key State Park & 55 & $2 / 4 / 11$ & 27 & 8.0 & III B & $\mathrm{G}$ & $\underline{91}$ & $\underline{96}$ & $\underline{01}$ & $\underline{06}$ & $\mathrm{~s}(\mathrm{p})$ \\
\hline Pinellas & Belleair Causeway Bridge & 64 & $2 / 4 / 11$ & 0 & 4.8 & II A B & H F G L & - & - & $\overline{-}$ & - & n.r. \\
\hline Pinellas & Caladesi Island State Park & 59 & $2 / 4 / 11$ & 2 & 4.0 & II III B & $\mathrm{HO} \mathrm{G}$ & $\underline{91}$ & $\underline{96}$ & $\underline{01}$ & - & $\mathrm{s}(\mathrm{p})$ \\
\hline Pinellas & Clearwater Beach & 60 & $2 / 4 / 11$ & 0 & 4.4 & n.r. & n.r. & - & - & - & 06 & n.r. \\
\hline Pinellas & $\begin{array}{l}\text { Courtney Campbell Causeway, Clearwater, } \\
\text { Public Beach }\end{array}$ & 62 & $2 / 4 / 11$ & 0 & 29.0 & II V G & H D F V G & $\underline{91}^{4}$ & - & - & - & $\mathrm{m}$ \\
\hline Pinellas & Dunedin Causeway (to Honeymoon Island) & 58 & $2 / 4 / 11$ & 0 & 1.6 & II G & $\mathrm{H} \mathrm{G}$ & 91 & 96 & 01 & 06 & $\mathrm{c}$ \\
\hline Pinellas & Ft. DeSoto County Park, E beach & 77 & $2 / 4 / 11$ & 0 & 4.0 & V B & V G & $\underline{91}^{5}$ & 96 & - & 06 & $\mathrm{c}$ \\
\hline Pinellas & Ft. DeSoto County Park, NW Beach & 76 & $2 / 6 / 11$ & 0 & 4.5 & III B & n.r. & $\overline{91}$ & $\underline{96}$ & $\underline{01}$ & 06 & n.r. \\
\hline Pinellas & Ft. DeSoto County Park, South tip & 78 & $2 / 1 / 11$ & 0 & 1.1 & n.r. & n.r. & $\overline{91}$ & - & $\overline{-}$ & - & n.r. \\
\hline Pinellas & Honeymoon Island SRA & 57 & $2 / 4 / 11$ & 2 & 6.4 & III B & H S G & $\underline{91}$ & $\underline{96}$ & $\underline{01}$ & $\underline{06}$ & $\mathrm{~s}(\mathrm{p})$ \\
\hline Pinellas & Indian Rocks Beach & 65 & $2 / 5 / 11$ & 0 & 3.7 & n.r. & n.r. & $\underline{91}^{6}$ & - & $\overline{-}$ & $\overline{06}$ & n.r. \\
\hline Pinellas & Lassing Park & 71 & $1 / 26 / 11$ & 0 & 0.7 & n.r. & n.r. & - & - & - & - & n.r. \\
\hline Pinellas & Madeira Beach & 68 & $1 / 27 / 11$ & 4 & 5.1 & III A & H V F G & - & - & - & 06 & $\mathrm{~m}$ \\
\hline
\end{tabular}


The 2011 International Piping Plover Winter Census in Florida

(Continued)

\begin{tabular}{|c|c|c|c|c|c|c|c|c|c|c|c|c|}
\hline \multirow{2}{*}{$\begin{array}{l}\text { COUNTY } \\
\text { Pinellas }\end{array}$} & \multirow{2}{*}{$\begin{array}{l}\text { SITE NAME } \\
\text { Pass-a-Grille Beach }\end{array}$} & \multirow{2}{*}{ MAP\# } & \multirow{2}{*}{$\begin{array}{c}\text { DATE } \\
2 / 5 / 11\end{array}$} & \multirow{2}{*}{$\begin{array}{c}\text { TOTAL } \\
\text { ADULTS } \\
0\end{array}$} & \multirow{2}{*}{$\frac{\mathbf{K M}}{2.7}$} & \multirow{2}{*}{$\begin{array}{l}\text { SITE } \\
\text { DESCRIPTION } \\
\text { III B }\end{array}$} & \multirow{2}{*}{$\begin{array}{l}\text { DISTURBANCE } \\
\text { / CONCERNS } \\
\mathrm{H} \mathrm{G}\end{array}$} & \multicolumn{4}{|c|}{$\begin{array}{c}\text { PRIOR YEARS } \\
\text { CENSUSED \& YEARS } \\
\text { PIPL SEEN }^{1} \\
\end{array}$} & \multirow{2}{*}{$\frac{\text { OWNER }}{\mathrm{m}}$} \\
\hline & & & & & & & & 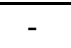 & 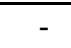 & 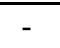 & 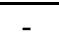 & \\
\hline Pinellas & Pinellas Point & 73 & $1 / 30 / 11$ & 0 & 1.6 & V A & O G L & - & - & - & - & $\mathrm{m}$ \\
\hline Pinellas & Redington Beach/North Redington Beach & 67 & $2 / 6 / 11$ & 0 & 4.4 & III B & $\mathrm{HO} \mathrm{G}$ & - & - & - & 06 & $\mathrm{~s}(\mathrm{p})$ \\
\hline Pinellas & Sandy Park to Bellair Beach Morgan Dr. Park & 61 & $2 / 5 / 11$ & 0 & 3.4 & n.r. & n.r. & $\underline{91}^{6}$ & - & - & 06 & n.r. \\
\hline Pinellas & Shell Key & 75 & $2 / 6 / 11$ & 11 & 2.4 & II B & H G L & - & $\underline{96}$ & $\underline{01}$ & $\underline{06}$ & $\mathrm{c}$ \\
\hline Pinellas & St. Pete Beach & 72 & $2 / 4 / 11$ & 0 & 3.4 & n. $r$. & n.r. & - & - & - & - & n.r. \\
\hline Pinellas & St. Petersburg- North shore park area & 69 & $1 / 30 / 11$ & 0 & 0.8 & n.r. & n.r. & - & - & - & 06 & n.r. \\
\hline Pinellas & Three Rooker Bar & 56 & $2 / 4 / 11$ & 29 & 3.2 & III B & G & $\underline{91}$ & $\underline{96}$ & $\underline{01}$ & $\underline{06}$ & $\mathrm{~s}(\mathrm{p})$ \\
\hline Pinellas & Treasure Island & 70 & $2 / 6 / 11$ & 0 & 6.4 & III A G & H U G & - & - & - & 06 & $\mathrm{~m}$ \\
\hline Pinellas & Walsingham Road South to Park Blvd & 66 & $2 / 4 / 11$ & 0 & 3.0 & III B & H F G & - & - & - & 06 & $\mathrm{~m}$ \\
\hline Sarasota & Caspersen Beach (Venice Beach) & 88 & $2 / 5 / 11$ & 2 & 6.1 & III A & H S & 91 & - & - & 06 & $\begin{array}{l}\mathrm{s}(\mathrm{p}), \mathrm{m} \\
\mathrm{p}, \mathrm{c}\end{array}$ \\
\hline Sarasota & Lido Beach & 83 & $1 / 29 / 11$ & 0 & 4.0 & III B & H S O G & 91 & - & - & 06 & $\mathrm{c}$ \\
\hline Sarasota & North Casey Key & 86 & $2 / 5 / 11$ & 0 & 4.8 & III B & H D S G & - & 96 & - & 06 & n.r. \\
\hline Sarasota & Siesta Key, N end to Point of Rocks & 84 & $2 / 5 / 11$ & 0 & 4.7 & III B & H D V G & - & - & - & 06 & $\mathrm{c}$ \\
\hline Sarasota & Siesta Key, Turtle Beach to Point of Rocks & 85 & $2 / 6 / 11$ & 0 & 3.1 & II III B F & H D G & - & - & - & 06 & $s(p), c$ \\
\hline Sarasota & South Casey Key & 87 & $2 / 5 / 11$ & 0 & 5.0 & III B & H D S O G & - & 96 & - & 06 & $\mathrm{p}, \mathrm{c}$ \\
\hline Sarasota & South Longboat Key & 82 & $2 / 5 / 11$ & 0 & 4.8 & III B & H S U O & - & - & - & 06 & $\mathrm{p}$ \\
\hline St. Johns & Anastasia State Recreation Area & 121 & $2 / 4 / 11$ & 0 & 7.9 & I IV B & $\mathrm{HO} \mathrm{G}$ & $\underline{91}$ & 96 & 01 & 06 & $\mathrm{~s}(\mathrm{p})$ \\
\hline St. Johns & Rattlesnake Island & 122 & $2 / 4 / 11$ & 0 & 1.0 & IV E & n.r. & - & - & - & - & n.r. \\
\hline St. Johns & St. Augustine Beach (Matanzas Inlet) & 123 & $2 / 4 / 11$ & 4 & 25.7 & I II IV V A B C D & H D V F S U G & - & 96 & - & $\underline{06}$ & $\begin{array}{c}\mathrm{f}, \mathrm{s}(\mathrm{p}) \\
\mathrm{m}, \mathrm{c}\end{array}$ \\
\hline St. Johns & Vilano Point to North Beach & 120 & $2 / 4 / 11$ & 0 & 25.7 & I B & D G & - & 96 & 01 & 06 & $\mathrm{f}, \mathrm{c}$ \\
\hline St. Lucie & Avalon State Park & 146 & $2 / 3 / 11$ & 0 & 2.4 & I B & $\mathrm{H}$ & 91 & 96 & 01 & 06 & $\mathrm{~s}(\mathrm{p})$ \\
\hline St. Lucie & Fort Pierce Inlet State Park & 148 & $2 / 3 / 11$ & 0 & 1.4 & I IV B & H F G & 91 & 96 & 01 & 06 & $\mathrm{~s}(\mathrm{p})$ \\
\hline St. Lucie & Fort Pierce Inlet State Park to Avalon State Park & 147 & $1 / 28 / 11$ & 0 & 6.4 & I B & H G & 91 & 96 & 01 & 06 & $\mathrm{p}, \mathrm{c}$ \\
\hline St. Lucie & S Hutchinson Island & 149 & $1 / 31 / 11$ & 0 & 24.5 & I B & H D F & 91 & 96 & - & 06 & $\mathrm{~m}, \mathrm{p}, \mathrm{c}$ \\
\hline St. Lucie & $\begin{array}{l}\text { South Hutchinson Island- Little Mud Creek N to } \\
\text { Frederick Douglass Park }\end{array}$ & 151 & $1 / 31 / 11$ & 0 & 3.7 & I B & H D F & 91 & 96 & - & 06 & $\mathrm{~m}, \mathrm{p}, \mathrm{c}$ \\
\hline St. Lucie & $\begin{array}{l}\text { South Hutchinson Island- Little Mud Creek S to } \\
\text { the narrows }\end{array}$ & 152 & $1 / 31 / 11$ & 0 & 6.4 & I B & H D F & 91 & 96 & - & 06 & $\mathrm{~m}, \mathrm{p}, \mathrm{c}$ \\
\hline St. Lucie & $\begin{array}{l}\text { South Hutchinson Island-Fredrick Douglass Park } \\
\text { to Inlet }\end{array}$ & 150 & $1 / 31 / 11$ & 0 & 6.4 & I B & H D F & 91 & 96 & - & 06 & $\mathrm{~m}, \mathrm{p}, \mathrm{c}$ \\
\hline Taylor & Hagen's Cove & 51 & $2 / 4 / 11$ & 0 & 0.7 & n.r. & n.r. & - & - & 01 & 06 & n.r. \\
\hline
\end{tabular}




\section{The 2011 International Piping Plover Winter Census in Florida}

(Continued)

\begin{tabular}{|c|c|c|c|c|c|c|c|c|c|c|c|c|}
\hline COUNTY & SITE NAME & MAP\# & DATE & $\begin{array}{r}\text { TOTAL } \\
\text { ADULTS } \\
\end{array}$ & $\mathbf{K M}$ & $\begin{array}{l}\text { SITE } \\
\text { DESCRIPTION } \\
\end{array}$ & $\begin{array}{l}\text { DISTURBANCE } \\
\text { / CONCERNS } \\
\end{array}$ & \multicolumn{4}{|c|}{$\begin{array}{c}\text { PRIOR YEARS } \\
\text { CENSUSED \& YEARS } \\
\text { PIPL SEEN }^{1} \\
\end{array}$} & \multirow{2}{*}{$\frac{\text { OWNER }}{\mathrm{O} \mathrm{s}(\mathrm{p})}$} \\
\hline Taylor & Hickory Mound Impoundment & 50 & $2 / 4 / 11$ & 0 & 5.0 & III V G & n.r. & - & - & - & - & \\
\hline Volusia & Disappearing Island & 129 & $2 / 4 / 11$ & 15 & 3.0 & IV V C D & H D F O G & - & - & - & $\underline{06}$ & $\mathrm{~s}(\mathrm{p})$ \\
\hline Volusia & Indian River Lagoon Park & 132 & $2 / 4 / 11$ & 0 & 13.7 & II A B C & G & - & - & - & - & $\mathrm{m}$ \\
\hline Volusia & Intercoastal Waterway (Other islands) & 130 & 2/4/11 & 0 & 19.3 & V B C D E & S I & - & - & - & - & $\mathrm{s}(\mathrm{p})$ \\
\hline Volusia & Mosquito Lagoon & 133 & $2 / 4 / 11$ & 0 & 9.3 & II B C & none & - & - & - & - & $\mathrm{f}, \mathrm{s}(\mathrm{p})$ \\
\hline Volusia & New Smyrna Beach & 131 & 2/4/11 & 0 & 15.0 & I II IV V B D F G & H D V F S I O G & $\underline{91}$ & 96 & 01 & $\underline{06}$ & $\mathrm{~s}(\mathrm{p}), \mathrm{p}, \mathrm{c}$ \\
\hline Volusia & North Canaveral National Seashore & 134 & $2 / 4 / 11$ & 0 & 18.5 & I B & $\mathrm{G}$ & 91 & 96 & 01 & 06 & $\mathrm{f}$ \\
\hline Volusia & North Peninsula SRA, Intracoastal Waterways & 127 & $2 / 4 / 11$ & 0 & 4.0 & V B G & $\mathrm{H} \mathrm{B} \mathrm{O}$ & - & - & - & - & $\mathrm{s}(\mathrm{p})$ \\
\hline Volusia & $\begin{array}{l}\text { Volusia/Flagler County Line to North Side of } \\
\text { Ponce De Leon Inlet }\end{array}$ & 128 & $2 / 4 / 11$ & 0 & 51.3 & I II IV A B C D & H V S G & - & 96 & 01 & 06 & $\begin{array}{l}\mathrm{s}(\mathrm{p}), \mathrm{m}, \\
\mathrm{p}, \mathrm{c}\end{array}$ \\
\hline Wakulla & St. Marks - Oyster Bay & 48 & $2 / 1 / 11$ & 0 & 23.3 & II A & n.r. & - & - & - & 06 & n.r. \\
\hline Wakulla & $\begin{array}{l}\text { St. Marks National Wildlife Refuge } \\
\text { Impoundments }\end{array}$ & 49 & $2 / 1 / 11$ & 0 & 7.5 & II A & n.r. & - & - & - & 06 & n.r. \\
\hline Wakulla & Mashes Is County Park & 47 & $2 / 1 / 11$ & 0 & 4.1 & II A & H D G & 91 & 96 & 01 & 06 & $\mathrm{~s}(\mathrm{p})$ \\
\hline Walton & Deer Lake State Park & 16 & $1 / 28 / 11$ & 0 & 1.0 & III V A & $\mathrm{HOG}$ & - & - & - & 06 & $\mathrm{~s}(\mathrm{p})$ \\
\hline Walton & Grayton Beach State Park-Little Redfish Lake & 15 & $1 / 28 / 11$ & 0 & 0.8 & III V A & H D V O G & 91 & - & 01 & 06 & $\mathrm{c}$ \\
\hline Walton & Grayton Beach State Park-Main Park Access & 11 & $1 / 28 / 11$ & 0 & 1.8 & III V A & H D V O G & 91 & - & 01 & 06 & $\mathrm{~s}(\mathrm{p})$ \\
\hline Walton & Grayton Beach State Park-Pine Street Access & 13 & $1 / 28 / 11$ & 0 & 0.7 & III V A & H V O G & 91 & - & 01 & 06 & $\mathrm{~s}(\mathrm{p})$ \\
\hline Walton & Topsail Hill Preserve State Park & 10 & $1 / 28 / 11$ & 0 & 6.0 & III V A & H D V O G & - & - & 01 & 06 & $\mathrm{~s}(\mathrm{p})$ \\
\hline Walton & Walton County Public Beach-Gulf Breeze & 14 & $1 / 28 / 11$ & 0 & 0.4 & III V A & H D V O G & - & - & - & 06 & $\mathrm{c}$ \\
\hline Walton & Walton County Public Beach-Town of Grayton & 12 & $1 / 28 / 11$ & 0 & 0.5 & III V A & H D V O G & - & - & - & 06 & $\mathrm{c}$ \\
\hline Total & & & & 306 & 1297.5 & & & & & & & \\
\hline
\end{tabular}

${ }^{1}$ If previously surveyed, years surveyed are noted. Bold underlined years indicate that Piping Plovers were seen at the site during that Census year.

${ }^{2}$ More area on Mexico Beach was surveyed during the 1996 Census than in 2011. In 1996, one PIPL was seen, but its specific location was not given. We do not know for certain whether the single PIPL was seen within the span of the 2011 survey route.

${ }^{3}$ In 1991, 1 PIPL was observed on Alligator Point (which included Phipps Reserve), but its specific location was not given. We do not know for certain whether the single PIPL was seen within the span of the 2011 survey route.

${ }^{4}$ No official census, but 6 PIPL were seen here on 12/22/1990.

${ }^{5}$ The 1991 datasheet and map indicate that 2 PIPL were seen here on 12/1/1990.

${ }^{6}$ In 1991, 10 PIPL were seen on "Sand Key", a route which overlaps with this 2011 site. Specific locations of the PIPL were not given. We do not know for certain whether the PIPL were seen within the span of the 2011 survey route

${ }^{7}$ Please note that this survey was conducted outside the Census window. 


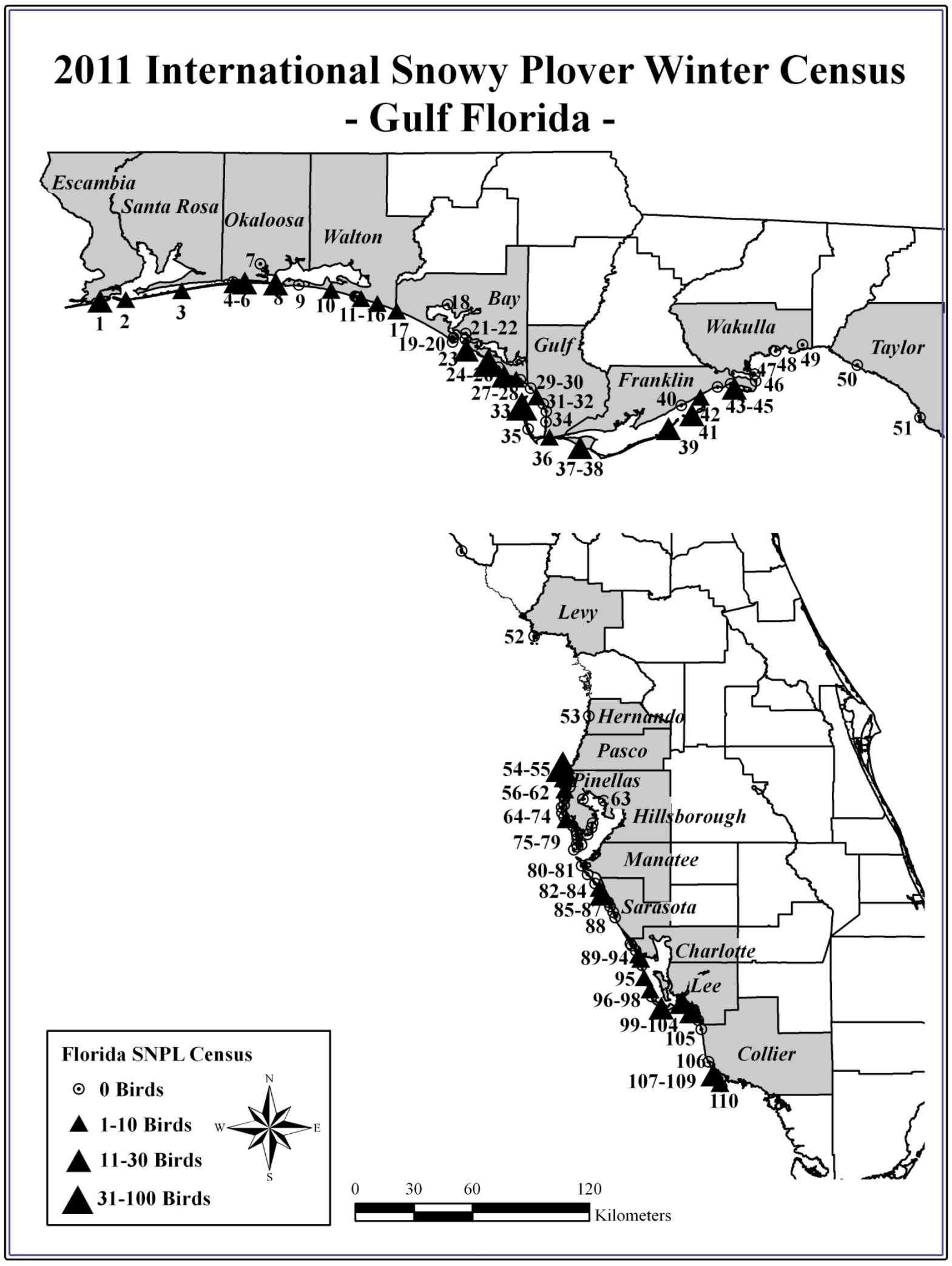




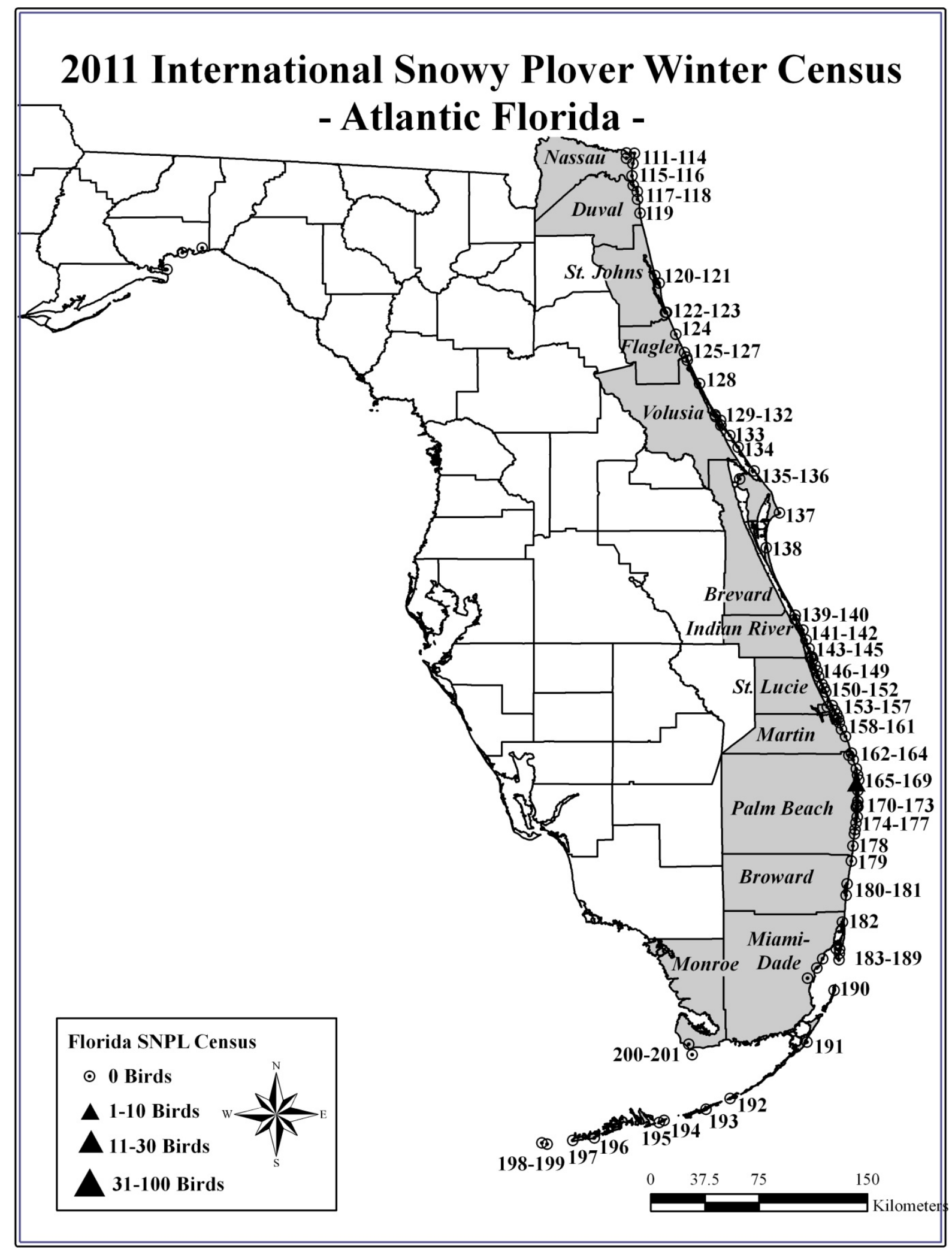


The 2011 International Snowy Plover Winter Census in Florida

\begin{tabular}{|c|c|c|c|c|c|c|c|c|c|c|c|c|}
\hline \multirow{2}{*}{$\begin{array}{l}\text { COUNTY } \\
\text { Bay }\end{array}$} & \multirow[t]{2}{*}{ SITE NAME } & \multirow{2}{*}{$\frac{\text { MAP\# }}{27}$} & \multirow{2}{*}{$\frac{\text { DATE }}{1 / 27 / 11}$} & \multirow{2}{*}{$\begin{array}{c}\text { TOTAL } \\
\text { ADULTS } \\
4\end{array}$} & \multirow{2}{*}{$\frac{\mathbf{K M}}{2.6}$} & \multirow{2}{*}{$\begin{array}{l}\text { SITE } \\
\text { DESCRIPTION } \\
\text { III A }\end{array}$} & \multirow{2}{*}{$\begin{array}{l}\text { DISTURBANCE } \\
\text { / CONCERNS } \\
\text { H D S G }\end{array}$} & \multicolumn{4}{|c|}{$\begin{array}{c}\text { PRIOR YEARS } \\
\text { CENSUSED \& YEARS } \\
\text { SNPL SEEN }^{1} \\
\end{array}$} & \multirow{2}{*}{$\frac{\text { OWNER }}{\mathrm{p}}$} \\
\hline & & & & & & & & 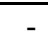 & 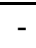 & 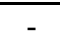 & $\underline{06}$ & \\
\hline Bay & Camp Helen State Park & 17 & $1 / 27 / 11$ & 9 & 0.7 & I II III IV A & H D F V O G & - & - & 01 & 06 & $\mathrm{~s}(\mathrm{p})$ \\
\hline Bay & Crooked Island East & 26 & $1 / 27 / 11$ & 27 & 9.7 & III B F & V G & - & - & $\underline{01}$ & $\underline{06}$ & $\mathrm{f}$ \\
\hline Bay & Crooked Island West & 24 & $1 / 27 / 11$ & 31 & 8.9 & III B F & V O G & - & - & $\underline{01}$ & $\underline{06}$ & $\mathrm{f}$ \\
\hline Bay & Grand Lagoon - Bay Point, Alligator Point & 20 & $1 / 24 / 11$ & 0 & 0.4 & II A D & H D G L & - & - & 01 & 06 & $\mathrm{~s}(\mathrm{p})$ \\
\hline Bay & Marifarms North & 18 & $1 / 28 / 11$ & 0 & 5.4 & II V G & $\mathrm{S}$ & - & - & 01 & 06 & $\mathrm{~s}(\mathrm{p}), \mathrm{p}$ \\
\hline Bay & Mexico Beach ${ }^{2}$ & 28 & $2 / 24 / 11$ & 0 & 2.6 & III A & H G & - & - & 01 & 06 & $\mathrm{~m}, \mathrm{c}$ \\
\hline Bay & Shell Island & 23 & $1 / 27 / 11$ & 23 & 15.2 & III B F & V G & - & - & $\underline{01}$ & $\underline{06}$ & $\mathrm{f}, \mathrm{s}(\mathrm{p})$ \\
\hline Bay & St. Andrew Bay - Davis Pt. to Redfish Pt. & 22 & $1 / 27 / 11$ & 0 & 1.6 & II A D & $\mathrm{L}$ & - & - & 01 & 06 & $\mathrm{f}$ \\
\hline Bay & St. Andrews State Recreation Area & 19 & $1 / 27 / 11$ & 0 & 3.3 & II III A & H D S V O G L & - & - & 01 & $\underline{06}$ & $\mathrm{~s}(\mathrm{p})$ \\
\hline Bay & Tyndall AFB (Buck Beach) & 25 & $1 / 27 / 11$ & 0 & 4.8 & II A & G L & - & - & - & 06 & $\mathrm{f}$ \\
\hline Bay & West Beach Drive & 21 & $2 / 1 / 11$ & 0 & 4.0 & II A & H G L & - & - & 01 & 06 & $\mathrm{~m}, \mathrm{p}$ \\
\hline Brevard & Cape Canaveral Air Force Station & 137 & $2 / 4 / 11$ & 0 & 21.0 & I B & H F G & - & - & 01 & 06 & $\mathrm{f}$ \\
\hline Brevard & Merritt Island NWR (Shiloh Impoundments) & 136 & $1 / 28 / 11$ & 0 & 10.5 & V G & G & - & - & - & - & $\mathrm{f}$ \\
\hline Brevard & Patrick Air Force Base & 138 & $2 / 4 / 11$ & 0 & 9.2 & I B & H D F O G & - & - & - & 06 & $\mathrm{f}$ \\
\hline Brevard & South Canaveral National Seashore & 135 & $2 / 4 / 11$ & 0 & 20.1 & I B & H G & - & - & 01 & 06 & $\mathrm{f}$ \\
\hline Broward & Broward County Northern Link to Hillsboro Inlet & 179 & $2 / 1 / 11$ & 0 & 6.8 & I B & $\mathrm{H} \mathrm{S}$ & - & - & - & 06 & $\mathrm{~m}, \mathrm{p}$ \\
\hline Broward & Hugh Taylor Birch State Park & 180 & $1 / 31 / 11$ & 0 & 1.6 & I II V & H D V F S I U L & - & - & - & 06 & $\mathrm{~s}(\mathrm{p}), \mathrm{m}$ \\
\hline Broward & John U. Lloyd Beach S.P. & 181 & $1 / 29 / 11$ & 0 & 4.0 & I II IV B & $\mathrm{H} \mathrm{L}$ & - & - & 01 & 06 & $\mathrm{~s}(\mathrm{p})$ \\
\hline Charlotte & Barrier Island (Don Pedro) & 91 & $1 / 29 / 11$ & 0 & 3.2 & III B & n.r. & - & - & - & 06 & $\mathrm{p}$ \\
\hline Charlotte & Barrier Island (Knight Island) & 90 & $1 / 30 / 11$ & 0 & 3.2 & II III IV V B F & F S V O & - & - & $\underline{01}$ & $\underline{06}$ & $\mathrm{~m}$ \\
\hline Charlotte & Barrier Island (Little Gasparilla Island) & 92 & $1 / 29 / 11$ & 5 & 3.2 & III B & H D G & - & - & - & 06 & $\mathrm{p}$ \\
\hline Charlotte & Gasparilla Island & 93 & $2 / 4 / 11$ & 7 & 4.8 & III B & H D G & - & - & - & $\underline{06}$ & $\mathrm{f}, \mathrm{p}$ \\
\hline Charlotte & Stump Pass Beach & 89 & $1 / 30 / 11$ & 0 & 2.1 & II III V B & H S G & - & - & - & - & $\mathrm{s}(\mathrm{p})$ \\
\hline Collier & Big Marco Pass Shoal & 107 & $2 / 1 / 11$ & 19 & 4.0 & III B & H D & - & - & $\underline{01}$ & $\underline{06}$ & $\mathrm{~s}(\mathrm{p})$ \\
\hline Collier & Cape Romano & 108 & $1 / 25 / 11$ & 0 & 3.4 & III B D & H D F G & - & - & - & 06 & $\mathrm{~s}(\mathrm{p}), \mathrm{p}$ \\
\hline Collier & Caxambas Island & 109 & $1 / 31 / 11$ & 0 & 0.3 & III D & H D G & - & - & - & 06 & $\mathrm{~s}(\mathrm{p})$ \\
\hline Collier & Delnor-Wiggins Pass State Park & 105 & $2 / 2 / 11$ & 0 & 0.8 & III B & $\mathrm{H} \mathrm{G}$ & - & - & - & $\underline{06}$ & $\mathrm{~s}(\mathrm{p})$ \\
\hline Collier & Keewaydin Island & 106 & $1 / 31 / 11$ & 0 & 12.1 & III B & H D F S O G & - & - & - & 06 & $\mathrm{~s}(\mathrm{p}), \mathrm{p}$ \\
\hline Collier & Kice Island & 110 & $1 / 31 / 11$ & 1 & 4.0 & III B D & H D F O G & - & - & - & - & $\mathrm{s}(\mathrm{p})$ \\
\hline Duval & Little Talbot Island State Park & 117 & $2 / 4 / 11$ & 0 & 6.5 & I IV B & H G & - & - & 01 & 06 & $\mathrm{~s}(\mathrm{p})$ \\
\hline Duval & Mayport Jetty South to County Line & 119 & $2 / 4 / 11$ & 0 & 16.0 & I B & G & - & - & 01 & 06 & $\begin{array}{c}\mathrm{f}, \mathrm{s}(\mathrm{p}) \\
\mathrm{m}, \mathrm{c}\end{array}$ \\
\hline
\end{tabular}


The 2011 International Snowy Plover Winter Census in Florida

(Continued)

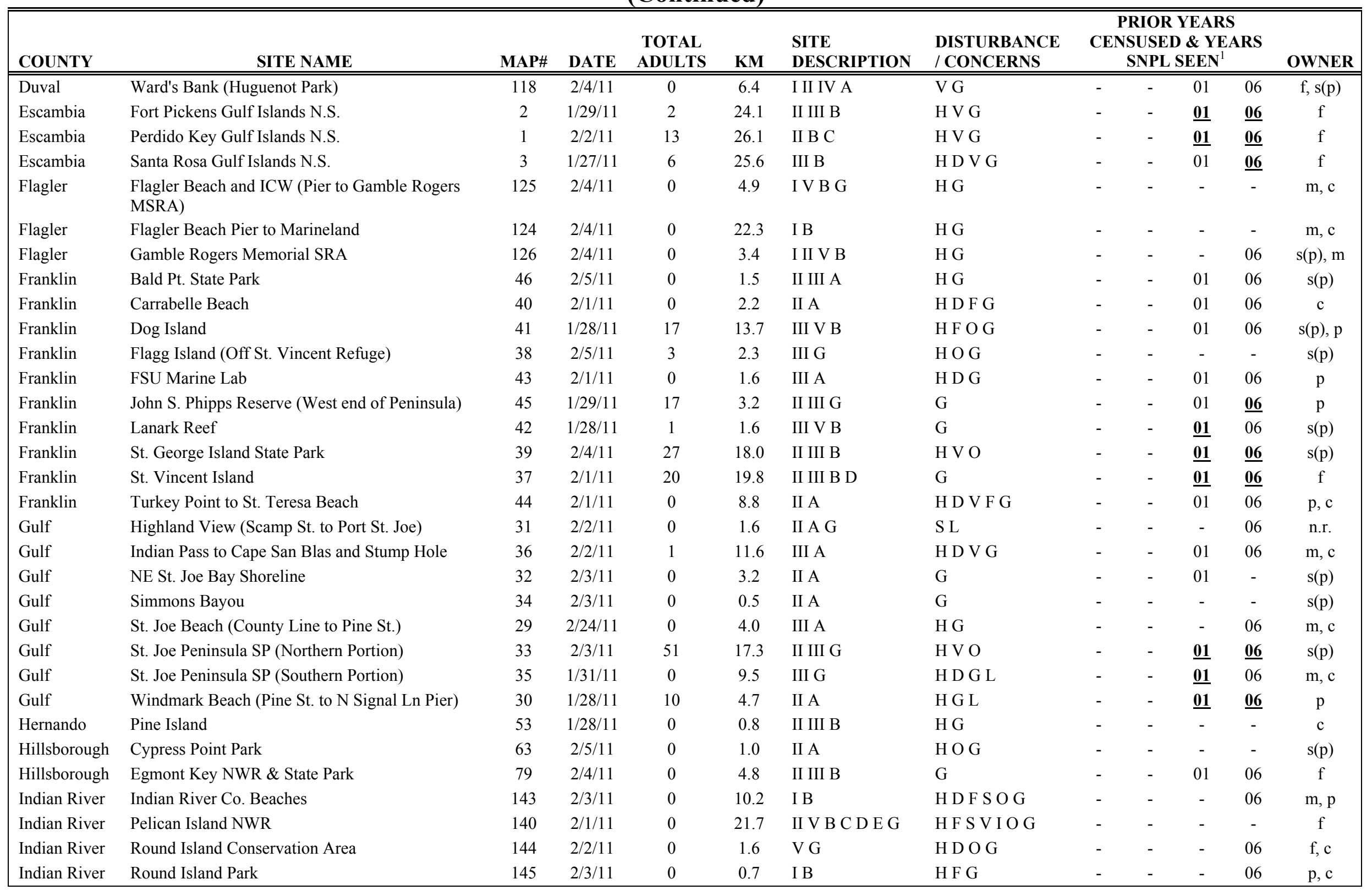


The 2011 International Snowy Plover Winter Census in Florida

(Continued)

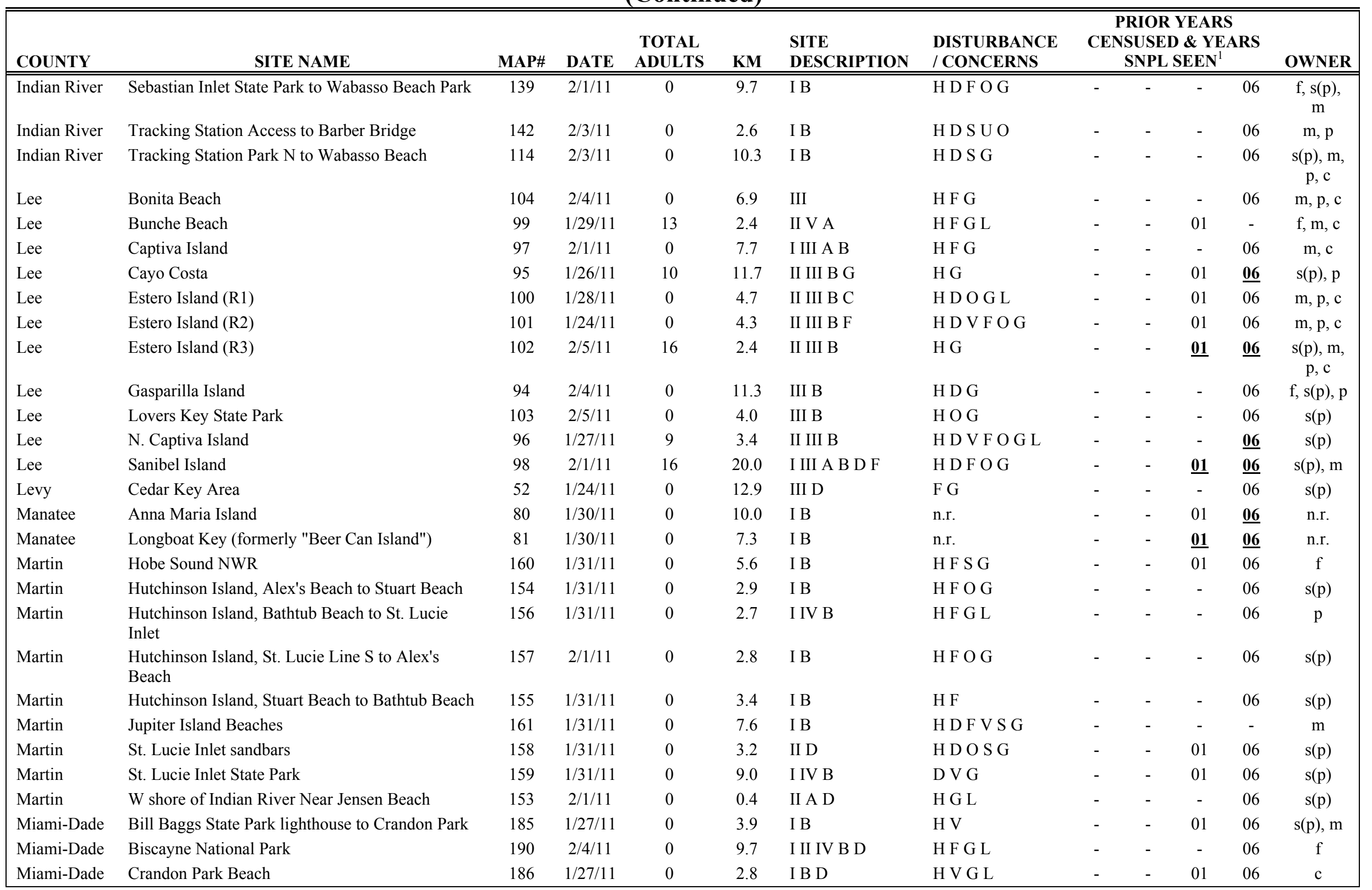


The 2011 International Snowy Plover Winter Census in Florida

(Continued)

\begin{tabular}{|c|c|c|c|c|c|c|c|c|c|c|c|c|}
\hline \multirow{2}{*}{$\begin{array}{l}\text { COUNTY } \\
\text { Miami-Dade }\end{array}$} & \multirow{2}{*}{$\begin{array}{l}\text { SITE NAME } \\
\text { Cutler Wetlands }\end{array}$} & \multirow{2}{*}{$\begin{array}{c}\text { MAP } \\
\# \\
189\end{array}$} & \multirow{2}{*}{$\begin{array}{c}\text { DATE } \\
2 / 3 / 11\end{array}$} & \multirow{2}{*}{$\begin{array}{c}\text { TOTAL } \\
\text { ADULT } \\
\text { S } \\
0\end{array}$} & \multirow{2}{*}{$\frac{\mathbf{K M}}{0.5}$} & \multirow{2}{*}{$\begin{array}{l}\text { SITE } \\
\text { DESCRIPTION } \\
\mathrm{VA}\end{array}$} & \multirow{2}{*}{$\begin{array}{l}\text { DISTURBANCE } \\
\text { / CONCERNS } \\
\mathrm{H} \mathrm{D} \mathrm{V}\end{array}$} & \multicolumn{4}{|c|}{$\begin{array}{c}\text { PRIOR YEARS } \\
\text { CENSUSED \& YEARS }^{\text {PNPL SEEN }} \\
\text { SNPL }^{1} \\
\end{array}$} & \multirow{2}{*}{$\frac{\text { OWNER }}{\mathrm{p}}$} \\
\hline & & & & & & & & - & - & - & - & \\
\hline Miami-Dade & Deering Estate and Chicken Key & 188 & $2 / 2 / 11$ & 0 & 3.1 & II A C G & H D F O G L & - & - & - & 06 & $\mathrm{~s}(\mathrm{p}), \mathrm{c}$ \\
\hline Miami-Dade & Matheson Hammock & 187 & $2 / 4 / 11$ & 0 & 1.2 & II A G & H D O G L & - & - & - & 06 & $\mathrm{c}$ \\
\hline Miami-Dade & Oleta River State Park & 182 & $2 / 4 / 11$ & 0 & 0.3 & II A & G & - & - & - & - & $\mathrm{s}(\mathrm{p})$ \\
\hline Miami-Dade & Rickenbacker Causeway Shoreline & 183 & $1 / 28 / 11$ & 0 & 1.7 & II E & H D F S I G & - & - & 01 & 06 & $\mathrm{c}$ \\
\hline Miami-Dade & Virginia Key Critical Wildlife Area & 184 & $1 / 28 / 11$ & 0 & 2.6 & II B & H S I & 91 & 96 & 01 & 06 & $\mathrm{~m}$ \\
\hline Monroe & Bahia Honda State Park & 195 & $1 / 24 / 11$ & 0 & 4.8 & I G & H F O G & - & - & 01 & 06 & $\mathrm{~s}(\mathrm{p})$ \\
\hline Monroe & Boca Chica Beach & 196 & $1 / 27 / 11$ & 0 & 1.3 & I E & H D V S G & - & - & 01 & 06 & $\mathrm{~s}(\mathrm{p})$ \\
\hline Monroe & Boca Grande Key & 199 & $1 / 25 / 11$ & 0 & 1.2 & V E G & H D G L & - & - & 01 & 06 & $\mathrm{f}$ \\
\hline Monroe & Curry Hammock State Park & 193 & $1 / 24 / 11$ & 0 & 0.4 & I G & $\mathrm{HO} \mathrm{G}$ & - & - & - & 06 & $\mathrm{~s}(\mathrm{p})$ \\
\hline Monroe & Fort Taylor Historic State Park & 197 & $2 / 1 / 11$ & 0 & 0.8 & I III E & $\mathrm{H} \mathrm{G}$ & - & - & 01 & 06 & $\mathrm{~s}(\mathrm{p})$ \\
\hline Monroe & $\begin{array}{l}\text { John D. Pennekamp state Park/ Carysfort Yacht } \\
\text { Club }\end{array}$ & 191 & $2 / 3 / 11$ & 0 & 1.0 & I II A & $\mathrm{H} \mathrm{G}$ & - & - & - & 06 & $\mathrm{~s}(\mathrm{p})$ \\
\hline Monroe & Lake Ingraham & 200 & $1 / 29 / 11$ & 0 & 1.6 & II & G L & - & - & - & 06 & $\mathrm{f}$ \\
\hline Monroe & Long Key State Park & 192 & $1 / 24 / 11$ & 0 & 1.6 & I G & H G L & - & - & 01 & 06 & $\mathrm{~s}(\mathrm{p})$ \\
\hline Monroe & Ohio Key & 194 & $1 / 27 / 11$ & 0 & 0.5 & I E G & H D G & - & - & - & - & $\mathrm{f}$ \\
\hline Monroe & Sandy Key to Carl Ross Key & 201 & $2 / 6 / 11$ & 0 & 1.5 & II E & G & - & - & - & 06 & $\mathrm{f}$ \\
\hline Monroe & Woman Key & 198 & $1 / 25 / 11$ & 0 & 1.3 & I E & H D G L & - & - & 01 & 06 & $\mathrm{f}$ \\
\hline Nassau & Amelia Island State Park & 116 & $2 / 4 / 11$ & 0 & 2.8 & I IV B & G & - & - & - & - & $\mathrm{s}(\mathrm{p})$ \\
\hline Nassau & Bell River Spoil Island & 113 & $2 / 6 / 11$ & 0 & 0.4 & $\mathrm{~V} \mathrm{C}$ & $\mathrm{OG}$ & - & - & 01 & 06 & $\mathrm{p}$ \\
\hline Nassau & Fort Clinch State Park & 112 & $2 / 4 / 11$ & 0 & 6.4 & I II IV B & $\mathrm{H} \mathrm{S}$ & - & - & - & - & $\mathrm{s}(\mathrm{p})$ \\
\hline Nassau & Little Tiger Island & 111 & $2 / 6 / 11$ & 0 & 2.4 & V E & $\mathrm{O}$ & - & - & - & - & $\mathrm{p}$ \\
\hline Nassau & North Fernandina Beach & 114 & $4 / 4 / 11$ & 0 & 11.0 & I B & H S G & - & - & 01 & 06 & $\mathrm{~s}(\mathrm{p})$ \\
\hline Nassau & South Fernandina Beach & 115 & $2 / 4 / 11$ & 0 & 7.4 & I B & $\mathrm{H}$ & - & - & 01 & 06 & $\mathrm{p}$ \\
\hline Okaloosa & $\begin{array}{l}\text { Eglin AFB (E restricted beach), Santa Rosa } \\
\text { Island }\end{array}$ & 6 & $1 / 27 / 11$ & 13 & 9.7 & III B & H V G & - & - & - & 06 & $\mathrm{f}$ \\
\hline Okaloosa & Eglin AFB (Public Beach), Okaloosa Island & 8 & $1 / 27 / 11$ & 12 & 7.4 & I IV B & H V S G & - & - & - & - & $\mathrm{f}$ \\
\hline Okaloosa & Henderson Beach State Park & 9 & $1 / 28 / 11$ & 0 & 2.2 & III A & H D V O G L & - & - & 01 & 06 & $\mathrm{~s}(\mathrm{p})$ \\
\hline Okaloosa & Okaloosa Holding Ponds & 7 & $1 / 25 / 11$ & 0 & 4.5 & V A & n.r. & - & - & $\underline{\mathbf{0 1}}$ & 06 & n.r. \\
\hline $\begin{array}{l}\text { Okaloosa/ } \\
\text { Santa Rosa }\end{array}$ & $\begin{array}{l}\text { Eglin AFB (W restricted beach), Santa Rosa } \\
\text { Island }\end{array}$ & 4 & $1 / 27 / 11$ & 7 & 9.7 & III B & V G & - & - & $\underline{01}$ & 06 & $\mathrm{f}$ \\
\hline $\begin{array}{l}\text { Okaloosa/ } \\
\text { Santa Rosa }\end{array}$ & Eglin AFB (N restricted beach) & 5 & $2 / 2 / 11$ & 0 & 22.7 & II III B & G L & - & - & - & - & $\mathrm{f}$ \\
\hline Palm Beach & Boynton Inlet to Gulfstream Park & 175 & $2 / 1 / 11$ & 0 & 4.8 & I IV A & H S O G & - & - & $\underline{01}$ & 06 & $\mathrm{~m}, \mathrm{p}, \mathrm{c}$ \\
\hline
\end{tabular}


The 2011 International Snowy Plover Winter Census in Florida

(Continued)

\begin{tabular}{|c|c|c|c|c|c|c|c|c|c|c|c|c|}
\hline \multirow{2}{*}{$\begin{array}{l}\text { COUNTY } \\
\text { Palm Beach }\end{array}$} & \multirow{2}{*}{$\begin{array}{c}\text { SITE NAME } \\
\text { Gulfstream Park to N. Delray Beach }\end{array}$} & \multirow{2}{*}{ MAP\# } & \multirow{2}{*}{$\begin{array}{c}\text { DATE } \\
2 / 2 / 11\end{array}$} & \multirow{2}{*}{$\begin{array}{c}\text { TOTAL } \\
\text { ADULTS } \\
0\end{array}$} & \multirow{2}{*}{$\frac{\mathbf{K M}}{26.4}$} & \multirow{2}{*}{$\begin{array}{l}\text { SITE } \\
\text { DESCRIPTION } \\
\text { I B }\end{array}$} & \multirow{2}{*}{$\begin{array}{l}\text { DISTURBANCE } \\
\text { / CONCERNS } \\
\text { H O G }\end{array}$} & \multicolumn{4}{|c|}{$\begin{array}{c}\text { PRIOR YEARS } \\
\text { CENSUSED \& YEARS } \\
\text { SNPL SEEN }^{1} \\
\end{array}$} & \multirow{2}{*}{$\frac{\text { OWNER }}{}$} \\
\hline & & & & & & & & - & - & 01 & $\underline{06}$ & \\
\hline Palm Beach & Highland Beach & 178 & $2 / 3 / 11$ & 0 & 13.4 & I IV B & H D V S I & - & - & - & 06 & $\mathrm{~m}, \mathrm{p}, \mathrm{c}$ \\
\hline Palm Beach & Ibis Isle Restoration Area & 171 & $2 / 3 / 11$ & 0 & 0.6 & II B & G L & - & - & - & 06 & $\mathrm{~s}(\mathrm{p})$ \\
\hline Palm Beach & Juno Beach Park to MacArthur State Park & 165 & $2 / 3 / 11$ & 0 & 6.5 & I B & $\mathrm{H} \mathrm{F}$ & - & - & - & 06 & $\mathrm{c}$ \\
\hline Palm Beach & Jupiter Beach to Juno Beach Park & 164 & $2 / 3 / 11$ & 0 & 5.8 & I IV B & H D F S & - & - & - & - & $\mathrm{c}$ \\
\hline Palm Beach & Jupiter Sound, Jupiter inlet, Loxahatchee River & 163 & $2 / 3 / 11$ & 0 & 7.4 & II IV V A B D & H D S U G L & - & - & - & 06 & $\mathrm{~s}(\mathrm{p})$ \\
\hline Palm Beach & Lantana Park to Boynton Inlet & 174 & $2 / 1 / 11$ & 0 & 4.3 & I IV F & $\mathrm{G}$ & - & - & - & 06 & $\mathrm{c}$ \\
\hline Palm Beach & MacArthur Beach State Park & 166 & $2 / 4 / 11$ & 0 & 2.4 & I II B & H D F G & - & - & 01 & 06 & $\mathrm{~s}(\mathrm{p})$ \\
\hline Palm Beach & $\begin{array}{l}\text { MacArthur Beach State Park to Palm Beach } \\
\text { Shores }\end{array}$ & 167 & $2 / 3 / 11$ & 0 & 4.6 & I IV B & $\mathrm{H} \mathrm{V} \mathrm{F}$ & - & - & - & 06 & $\mathrm{~m}, \mathrm{p}$ \\
\hline Palm Beach & N. Delray Beach to Atlantic Dunes Park & 177 & $2 / 5 / 11$ & 0 & 0.8 & n.r. & H D G & - & - & - & 06 & n.r. \\
\hline Palm Beach & Palm Beach Shores to Southern Blvd & 169 & $2 / 3 / 11$ & 0 & 11.9 & I IV B & H D S G & - & - & - & - & $\mathrm{s}(\mathrm{p}), \mathrm{m}$ \\
\hline Palm Beach & Peanut Island & 168 & $1 / 31 / 11$ & 1 & 1.6 & V B & $\mathrm{H} \mathrm{G}$ & - & - & - & - & $\mathrm{m}$ \\
\hline Palm Beach & Sloan's Curve to Lantana Beach & 172 & $2 / 3 / 11$ & 0 & 6.4 & I B & H V S & - & - & - & 06 & $\begin{array}{l}\mathrm{s}(\mathrm{p}), \mathrm{m} \\
\mathrm{p}, \mathrm{c}\end{array}$ \\
\hline Palm Beach & $\begin{array}{l}\text { Snook Islands Natural Area to Lake Worth } \\
\text { Lagoon }\end{array}$ & 173 & $2 / 6 / 11$ & 0 & 2.0 & II A G & S G L & - & - & - & - & $\mathrm{m}$ \\
\hline Palm Beach & Southern Blvd to Sloan's Curve & 170 & $2 / 3 / 11$ & 0 & 3.3 & I A & $\mathrm{H} \mathrm{G}$ & - & - & - & 06 & $\mathrm{~m}, \mathrm{p}$ \\
\hline $\begin{array}{l}\text { Palm Beach/ } \\
\text { Martin }\end{array}$ & $\begin{array}{l}\text { Jupiter Island - Jupiter Inlet through Blowing } \\
\text { Rocks Preserve }\end{array}$ & 162 & $1 / 31 / 11$ & 0 & 3.2 & I IV B & H D V F & - & - & - & 06 & $\mathrm{c}$ \\
\hline Pasco & Anclote Key sandbar & 54 & $2 / 4 / 11$ & 14 & 2.7 & III D & $\mathrm{H} \mathrm{G}$ & - & - & $\underline{01}$ & 06 & $\mathrm{~s}(\mathrm{p})$ \\
\hline Pasco/Pinellas & Anclote Key State Park & 55 & $2 / 4 / 11$ & 38 & 8.0 & III B & G & - & - & $\underline{01}$ & 06 & $\mathrm{~s}(\mathrm{p})$ \\
\hline Pinellas & Belleair Causeway Bridge & 64 & $2 / 4 / 11$ & 0 & 4.8 & II A B & H F G L & - & - & - & - & n.r. \\
\hline Pinellas & Caladesi Island State Park & 59 & $2 / 4 / 11$ & 6 & 4.0 & II III B & $\mathrm{HO} \mathrm{G}$ & - & - & $\underline{01}$ & - & $\mathrm{s}(\mathrm{p})$ \\
\hline Pinellas & Clearwater Beach & 60 & $2 / 4 / 11$ & 0 & 4.4 & n.r. & n.r. & - & - & - & 06 & n.r. \\
\hline Pinellas & $\begin{array}{l}\text { Courtney Campbell Causeway, Clearwater, } \\
\text { Public Beach }\end{array}$ & 62 & $2 / 4 / 11$ & 0 & 29.0 & II V G & H D F V G & - & - & - & - & $\mathrm{m}$ \\
\hline Pinellas & Dunedin Causeway (to Honeymoon Island) & 58 & $2 / 4 / 11$ & 0 & 1.6 & II G & H G & - & - & 01 & 06 & $\mathrm{c}$ \\
\hline Pinellas & Ft. DeSoto County Park, E beach & 77 & $2 / 4 / 11$ & 0 & 4.0 & V B & V G & - & - & - & 06 & $\mathrm{c}$ \\
\hline Pinellas & Ft. DeSoto County Park, NW Beach & 76 & $2 / 6 / 11$ & 0 & 4.5 & III B & n.r. & - & - & $\underline{01}$ & 06 & n.r. \\
\hline Pinellas & Ft. DeSoto County Park, South tip & 78 & $2 / 1 / 11$ & 0 & 1.1 & n.r. & n.r. & - & - & - & - & n.r. \\
\hline Pinellas & Honeymoon Island SRA & 57 & $2 / 4 / 11$ & 0 & 6.4 & III B & H S G & - & - & $\underline{01}$ & $\underline{06}$ & $\mathrm{~s}(\mathrm{p})$ \\
\hline Pinellas & Indian Rocks Beach & 65 & $2 / 5 / 11$ & 0 & 3.7 & n.r. & n.r. & - & - & - & 06 & n.r. \\
\hline Pinellas & Lassing Park & 71 & $1 / 26 / 11$ & 0 & 0.7 & n.r. & n.r. & - & - & - & - & n.r. \\
\hline Pinellas & Madeira Beach & 68 & $1 / 27 / 11$ & 7 & 5.1 & III A & H V F G & - & - & - & 06 & $\mathrm{~m}$ \\
\hline
\end{tabular}


The 2011 International Snowy Plover Winter Census in Florida

(Continued)

\begin{tabular}{|c|c|c|c|c|c|c|c|c|c|c|c|c|}
\hline \multirow{2}{*}{$\begin{array}{l}\text { COUNTY } \\
\text { Pinellas }\end{array}$} & \multirow{2}{*}{$\begin{array}{l}\text { SITE NAME } \\
\text { Pass-a-Grille Beach }\end{array}$} & \multirow{2}{*}{ MAP\# } & \multirow{2}{*}{$\frac{\text { DATE }}{2 / 5 / 11}$} & \multirow{2}{*}{$\begin{array}{c}\text { TOTAL } \\
\text { ADULTS } \\
0\end{array}$} & \multirow{2}{*}{$\frac{\mathbf{K M}}{2.7}$} & \multirow{2}{*}{$\begin{array}{l}\text { SITE } \\
\text { DESCRIPTION } \\
\text { III B }\end{array}$} & \multirow{2}{*}{$\begin{array}{l}\text { DISTURBANCE } \\
\text { / CONCERNS } \\
\mathrm{H} \mathrm{G}\end{array}$} & \multicolumn{4}{|c|}{$\begin{array}{c}\text { PRIOR YEARS } \\
\text { CENSUSED \& YEARS } \\
\text { SNPL SEEN }^{1} \\
\end{array}$} & \multirow{2}{*}{$\frac{\text { OWNER }}{\mathrm{m}}$} \\
\hline & & & & & & & & - & - & - & - & \\
\hline Pinellas & Pinellas Point & 73 & $1 / 30 / 11$ & 0 & 1.6 & V A & O G L & - & - & - & - & $\mathrm{m}$ \\
\hline Pinellas & Redington Beach/North Redington Beach & 67 & $2 / 6 / 11$ & 0 & 4.4 & III B & $\mathrm{HO} \mathrm{G}$ & - & - & - & 06 & $\mathrm{~s}(\mathrm{p})$ \\
\hline Pinellas & Sandy Park to Bellair Beach Morgan Dr. Park & 61 & $2 / 5 / 11$ & 0 & 3.4 & n.r. & n.r. & - & - & - & 06 & n.r. \\
\hline Pinellas & Shell Key & 75 & $2 / 6 / 11$ & 0 & 2.4 & II B & H G L & - & - & $\underline{01}$ & $\underline{06}$ & $\mathrm{c}$ \\
\hline Pinellas & St. Pete Beach & 72 & $2 / 4 / 11$ & 0 & 3.4 & n. $r$. & n.r. & - & - & - & - & n.r. \\
\hline Pinellas & St. Petersburg- North shore park area & 69 & $1 / 30 / 11$ & 0 & 0.8 & n.r. & n.r. & - & - & - & 06 & n.r. \\
\hline Pinellas & Three Rooker Bar & 56 & $2 / 4 / 11$ & 2 & 3.2 & III B & G & - & - & $\underline{01}$ & 06 & $\mathrm{~s}(\mathrm{p})$ \\
\hline Pinellas & Treasure Island & 70 & $2 / 6 / 11$ & 0 & 6.4 & III A G & H U G & - & - & - & 06 & $\mathrm{~m}$ \\
\hline Pinellas & Walsingham Road South to Park Blvd & 66 & $2 / 4 / 11$ & 0 & 3.0 & III B & H F G & - & - & - & 06 & $\mathrm{~m}$ \\
\hline Sarasota & Caspersen Beach (Venice Beach) & 88 & $2 / 5 / 11$ & 0 & 6.1 & III A & $\mathrm{H} \mathrm{S}$ & - & - & - & 06 & $\begin{array}{l}\mathrm{s}(\mathrm{p}), \mathrm{m} \\
\mathrm{p}, \mathrm{c}\end{array}$ \\
\hline Sarasota & Lido Beach & 83 & $1 / 29 / 11$ & 2 & 4.0 & III B & H S O G & - & - & - & $\underline{06}$ & $\mathrm{c}$ \\
\hline Sarasota & North Casey Key & 86 & $2 / 5 / 11$ & 0 & 4.8 & III B & H D S G & - & - & - & 06 & n.r. \\
\hline Sarasota & Siesta Key, N end to Point of Rocks & 84 & $2 / 5 / 11$ & 16 & 4.7 & III B & H D V G & - & - & - & $\underline{06}$ & $\mathrm{c}$ \\
\hline Sarasota & Siesta Key, Turtle Beach to Point of Rocks & 85 & $2 / 6 / 11$ & 0 & 3.1 & II III B F & H D G & - & - & - & 06 & $\mathrm{~s}(\mathrm{p}), \mathrm{c}$ \\
\hline Sarasota & South Casey Key & 87 & $2 / 5 / 11$ & 0 & 5.0 & III B & H D S O G & - & - & - & 06 & $\mathrm{p}, \mathrm{c}$ \\
\hline Sarasota & South Longboat Key & 82 & $2 / 5 / 11$ & 0 & 4.8 & III B & H S U O & - & - & - & 06 & $\mathrm{p}$ \\
\hline St. Johns & Anastasia State Recreation Area & 121 & $2 / 4 / 11$ & 0 & 7.9 & I IV B & $\mathrm{HO} \mathrm{G}$ & - & - & 01 & 06 & $\mathrm{~s}(\mathrm{p})$ \\
\hline St. Johns & Rattlesnake Island & 122 & $2 / 4 / 11$ & 0 & 1.0 & IV E & n.r. & - & - & - & - & n.r. \\
\hline St. Johns & St. Augustine Beach (Matanzas Inlet) & 123 & $2 / 4 / 11$ & 0 & 25.7 & I II IV V A B C D & H D V F S U G & - & - & - & 06 & $\begin{array}{l}\mathrm{f}, \mathrm{s}(\mathrm{p}) \\
\mathrm{m}, \mathrm{c}\end{array}$ \\
\hline St. Johns & Vilano Point to North Beach & 120 & $2 / 4 / 11$ & 0 & 25.7 & I B & D G & - & - & 01 & 06 & f, c \\
\hline St. Lucie & Avalon State Park & 146 & $2 / 3 / 11$ & 0 & 2.4 & I B & $\mathrm{H}$ & - & - & 01 & 06 & $\mathrm{~s}(\mathrm{p})$ \\
\hline St. Lucie & Fort Pierce Inlet State Park & 148 & $2 / 3 / 11$ & 0 & 1.4 & I IV B & H F G & - & - & 01 & 06 & $\mathrm{~s}(\mathrm{p})$ \\
\hline St. Lucie & Fort Pierce Inlet State Park to Avalon State Park & 147 & $1 / 28 / 11$ & 0 & 6.4 & I B & H G & - & - & 01 & 06 & $\mathrm{p}, \mathrm{c}$ \\
\hline St. Lucie & S Hutchinson Island & 149 & $1 / 31 / 11$ & 0 & 24.5 & I B & H D F & - & - & - & 06 & $\mathrm{~m}, \mathrm{p}, \mathrm{c}$ \\
\hline St. Lucie & $\begin{array}{l}\text { South Hutchinson Island- Little Mud Creek N to } \\
\text { Frederick Douglass Park }\end{array}$ & 151 & $1 / 31 / 11$ & 0 & 3.7 & I B & H D F & - & - & - & 06 & $\mathrm{~m}, \mathrm{p}, \mathrm{c}$ \\
\hline St. Lucie & $\begin{array}{l}\text { South Hutchinson Island- Little Mud Creek S to } \\
\text { the narrows }\end{array}$ & 152 & $1 / 31 / 11$ & 0 & 6.4 & I B & H D F & - & - & - & 06 & $\mathrm{~m}, \mathrm{p}, \mathrm{c}$ \\
\hline St. Lucie & $\begin{array}{l}\text { South Hutchinson Island-Fredrick Douglass Park } \\
\text { to Inlet }\end{array}$ & 150 & $1 / 31 / 11$ & 0 & 6.4 & I B & H D F & - & - & - & 06 & $\mathrm{~m}, \mathrm{p}, \mathrm{c}$ \\
\hline Taylor & Hagen's Cove & 51 & $2 / 4 / 11$ & 0 & 0.7 & n.r. & n.r. & - & - & 01 & 06 & n.r. \\
\hline
\end{tabular}


The 2011 International Snowy Plover Winter Census in Florida

(Continued)

\begin{tabular}{|c|c|c|c|c|c|c|c|c|c|c|c|}
\hline \multirow{2}{*}{$\begin{array}{l}\text { COUNTY } \\
\text { Taylor }\end{array}$} & \multirow{2}{*}{$\begin{array}{r}\text { SITE NAME } \\
\text { Hickory Mound Impoundment }\end{array}$} & \multirow{2}{*}{ MAP\# } & \multirow{2}{*}{$\begin{array}{c}\text { DATE } \\
2 / 4 / 11\end{array}$} & \multirow{2}{*}{$\begin{array}{c}\text { TOTAL } \\
\text { ADULTS } \\
0\end{array}$} & \multirow{2}{*}{$\frac{\mathbf{K M}}{5.0}$} & \multirow{2}{*}{$\begin{array}{l}\text { SITE } \\
\text { DESCRIPTION } \\
\text { III V G }\end{array}$} & \multirow{2}{*}{$\begin{array}{l}\text { DISTURBANCE } \\
\text { CONCERNS } \\
\text { n.r. }\end{array}$} & \multicolumn{3}{|c|}{$\begin{array}{c}\text { PRIOR YEARS } \\
\text { CENSUSED \& YEARS }^{\text {\&NPL SEEN }}{ }^{1} \\
\text { SNPL S }^{2}\end{array}$} & \multirow{2}{*}{$\begin{array}{c}\text { OWNER } \\
\mathrm{s}(\mathrm{p})\end{array}$} \\
\hline & & & & & & & & 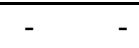 & 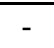 & 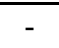 & \\
\hline Volusia & Disappearing Island & 129 & $2 / 4 / 11$ & 0 & 3.0 & IV V C D & H D F O G & - & - & 06 & $\mathrm{~s}(\mathrm{p})$ \\
\hline Volusia & Indian River Lagoon Park & 132 & $2 / 4 / 11$ & 0 & 13.7 & II A B C & G & - & - & - & $\mathrm{m}$ \\
\hline Volusia & Intercoastal Waterway (Other islands) & 130 & $2 / 4 / 11$ & 0 & 19.3 & V B C D E & S I & - & - & - & $\mathrm{s}(\mathrm{p})$ \\
\hline Volusia & Mosquito Lagoon & 133 & $2 / 4 / 11$ & 0 & 9.3 & II B C & none & - & - & - & $f, s(p)$ \\
\hline Volusia & New Smyrna Beach & 131 & $2 / 4 / 11$ & 0 & 15.0 & I II IV V B D F G & H D V F S I O G & - & 01 & 06 & $\mathrm{~s}(\mathrm{p}), \mathrm{p}, \mathrm{c}$ \\
\hline Volusia & North Canaveral National Seashore & 134 & $2 / 4 / 11$ & 0 & 18.5 & I B & G & - & 01 & 06 & $\mathrm{f}$ \\
\hline Volusia & North Peninsula SRA, Intracoastal Waterways & 127 & $2 / 4 / 11$ & 0 & 4.0 & V B G & $\mathrm{H} \mathrm{B} \mathrm{O}$ & - & - & - & $\mathrm{s}(\mathrm{p})$ \\
\hline Volusia & $\begin{array}{l}\text { Volusia/Flagler County Line to North Side of } \\
\text { Ponce De Leon Inlet }\end{array}$ & 128 & $2 / 4 / 11$ & 0 & 51.3 & I II IV A B C D & H V S G & - & 01 & 06 & $\begin{array}{l}\mathrm{s}(\mathrm{p}), \mathrm{m} \\
\mathrm{p}, \mathrm{c}\end{array}$ \\
\hline Wakulla & St. Marks - Oyster Bay & 48 & $2 / 1 / 11$ & 0 & 23.3 & II A & n.r. & - & - & 06 & n.r. \\
\hline Wakulla & $\begin{array}{l}\text { St. Marks National Wildlife Refuge } \\
\text { Impoundments }\end{array}$ & 49 & $2 / 1 / 11$ & 0 & 7.5 & II A & n.r. & - & - & 06 & n.r. \\
\hline Wakulla & Mashes Is County Park & 47 & $2 / 1 / 11$ & 0 & 4.1 & II A & H D G & - & 01 & 06 & $s(p)$ \\
\hline Walton & Deer Lake State Park & 16 & $1 / 28 / 11$ & 7 & 1.0 & III V A & $\mathrm{HO} \mathrm{G}$ & - & - & 06 & $\mathrm{~s}(\mathrm{p})$ \\
\hline Walton & Grayton Beach State Park-Little Redfish Lake & 15 & $1 / 28 / 11$ & 0 & 0.8 & III V A & H D V O G & - & 01 & 06 & $\mathrm{c}$ \\
\hline Walton & Grayton Beach State Park-Main Park Access & 11 & $1 / 28 / 11$ & 6 & 1.8 & III V A & H D V O G & - & 01 & 06 & $\mathrm{~s}(\mathrm{p})$ \\
\hline Walton & Grayton Beach State Park-Pine Street Access & 13 & $1 / 28 / 11$ & 0 & 0.7 & III V A & H V O G & - & 01 & $\underline{06}$ & $\mathrm{~s}(\mathrm{p})$ \\
\hline Walton & Topsail Hill Preserve State Park & 10 & $1 / 28 / 11$ & 6 & 6.0 & III V A & H D V O G & - & 01 & 06 & $\mathrm{~s}(\mathrm{p})$ \\
\hline Walton & Walton County Public Beach-Gulf Breeze & 14 & $1 / 28 / 11$ & 0 & 0.4 & III V A & H D V O G & - & - & 06 & $\mathrm{c}$ \\
\hline Walton & Walton County Public Beach-Town of Grayton & 12 & $1 / 28 / 11$ & 0 & 0.5 & III V A & H D V O G & - & - & 06 & $\mathrm{c}$ \\
\hline Total & & & & 495 & 1297.5 & & & & & & \\
\hline
\end{tabular}

${ }^{2}$ Please note that this survey was conducted outside the Census window. 


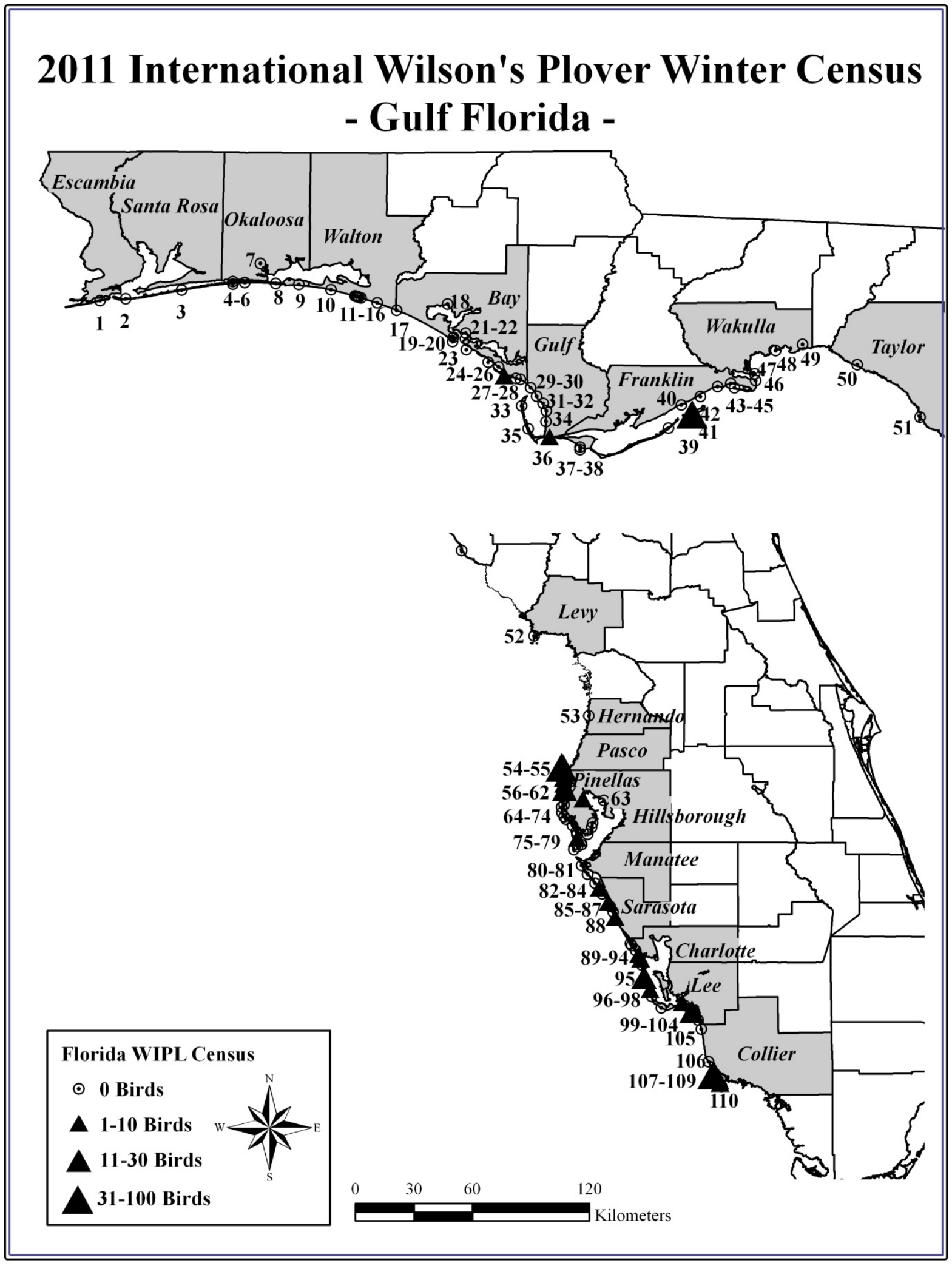




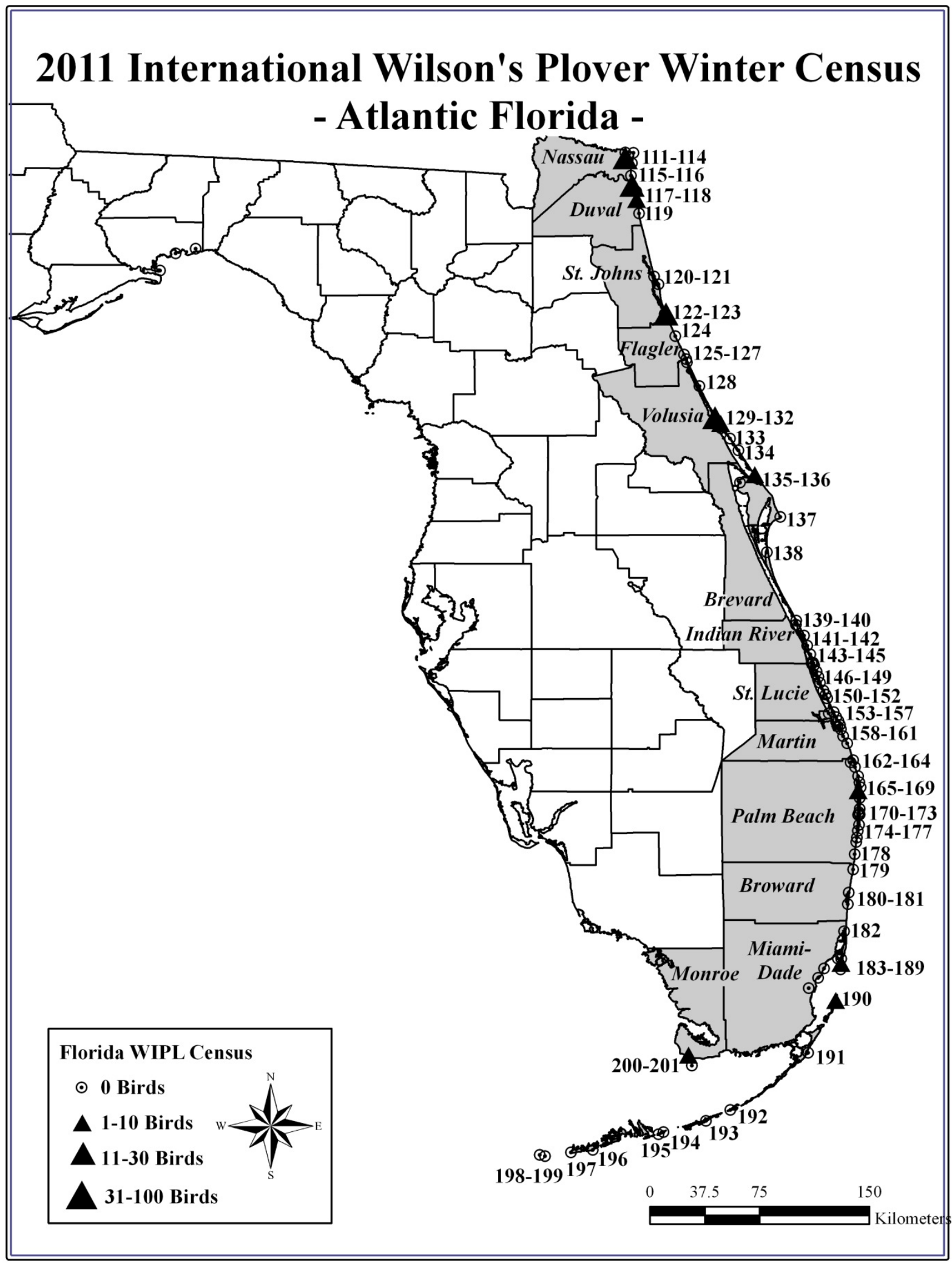


The 2011 International Wilson's Plover Winter Census in Florida

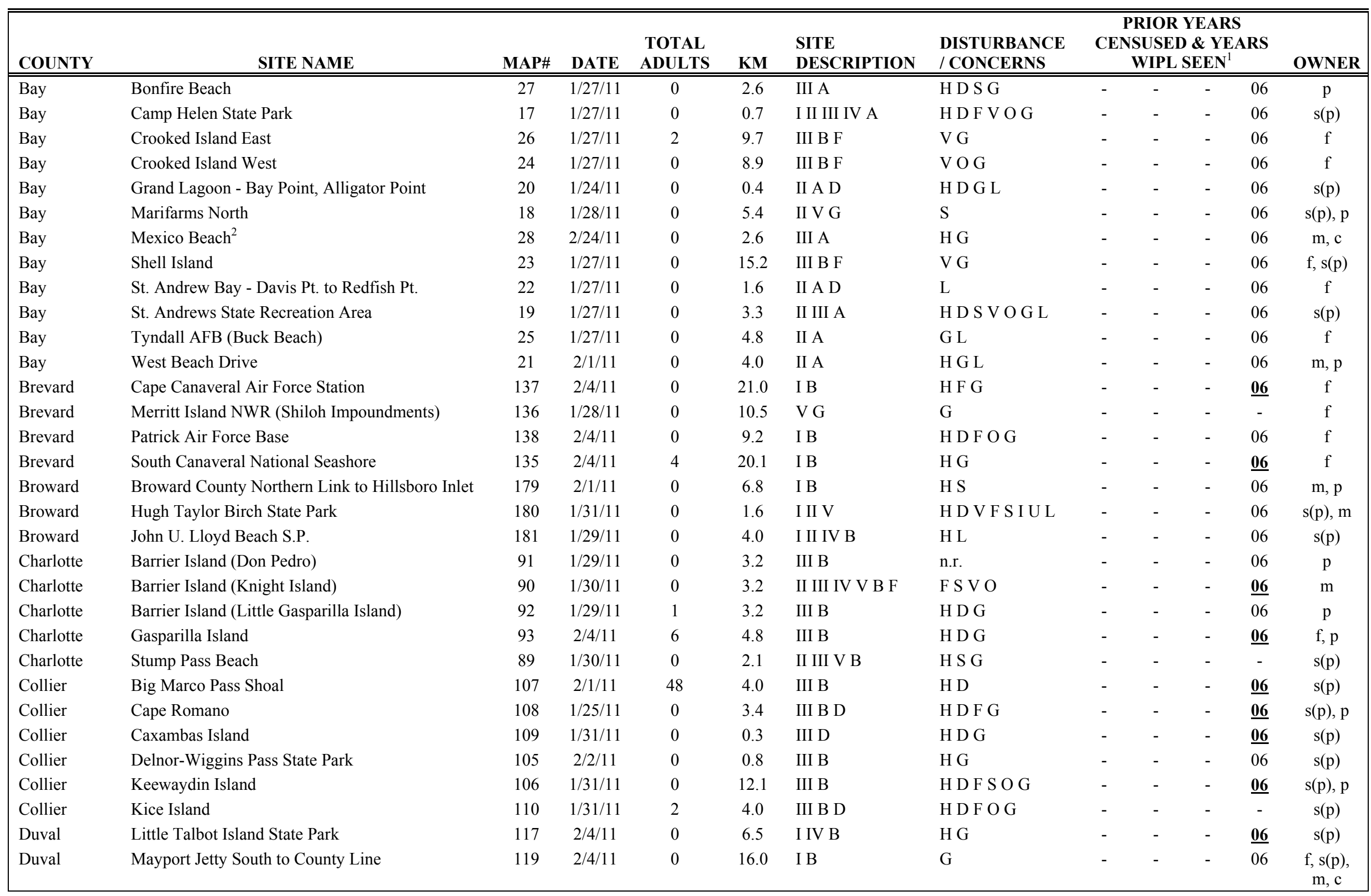


The 2011 International Wilson's Plover Winter Census in Florida

(Continued)

\begin{tabular}{|c|c|c|c|c|c|c|c|c|c|c|c|c|}
\hline \multirow{2}{*}{ COUNTY } & \multirow{2}{*}{$\begin{array}{r}\text { SITE NAME } \\
\text { Ward's Bank (Huguenot Park) }\end{array}$} & \multirow{2}{*}{$\begin{array}{c}\text { МАР\# } \\
118\end{array}$} & \multirow{2}{*}{$\begin{array}{c}\text { DATE } \\
2 / 4 / 11\end{array}$} & \multirow{2}{*}{$\begin{array}{c}\text { TOTAL } \\
\text { ADULTS } \\
7\end{array}$} & \multirow{2}{*}{$\frac{\mathbf{K M}}{26.4}$} & \multirow{2}{*}{$\begin{array}{l}\text { SITE } \\
\text { DESCRIPTION } \\
\text { I II IV A }\end{array}$} & \multirow{2}{*}{$\begin{array}{l}\text { DISTURBANCE } \\
\text { / CONCERNS } \\
\mathrm{VG}\end{array}$} & \multicolumn{4}{|c|}{$\begin{array}{c}\text { PRIOR YEARS } \\
\text { CENSUSED \& YEARS } \\
\text { WIPL SEEN }^{1}\end{array}$} & \multirow{2}{*}{$\frac{\text { OWNER }}{\text { OW, s(p) }}$} \\
\hline & & & & & & & & 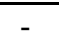 & 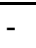 & 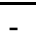 & 06 & \\
\hline Escambia & Fort Pickens Gulf Islands N.S. & 2 & $1 / 29 / 11$ & 0 & 24.1 & II III B & H V G & - & - & - & 06 & $f$ \\
\hline Escambia & Perdido Key Gulf Islands N.S. & 1 & $2 / 2 / 11$ & 0 & 26.1 & II B C & H V G & - & - & - & 06 & f \\
\hline Escambia & Santa Rosa Gulf Islands N.S. & 3 & $1 / 27 / 11$ & 0 & 25.6 & III B & H D V G & - & - & - & 06 & $\mathrm{f}$ \\
\hline Flagler & $\begin{array}{l}\text { Flagler Beach and ICW (Pier to Gamble Rogers } \\
\text { MSRA) }\end{array}$ & 125 & $2 / 4 / 11$ & 0 & 4.9 & I V B G & $\mathrm{H} \mathrm{G}$ & - & - & - & - & $\mathrm{m}, \mathrm{c}$ \\
\hline Flagler & Flagler Beach Pier to Marineland & 124 & $2 / 4 / 11$ & 0 & 22.3 & I B & H G & - & - & - & - & $\mathrm{m}, \mathrm{c}$ \\
\hline Flagler & Gamble Rogers Memorial SRA & 126 & $2 / 4 / 11$ & 0 & 3.4 & I II V B & $\mathrm{H} \mathrm{G}$ & - & - & - & 06 & $\mathrm{~s}(\mathrm{p}), \mathrm{m}$ \\
\hline Franklin & Bald Pt. State Park & 46 & $2 / 5 / 11$ & 0 & 1.5 & II III A & $\mathrm{H} \mathrm{G}$ & - & - & - & 06 & $\mathrm{~s}(\mathrm{p})$ \\
\hline Franklin & Carrabelle Beach & 40 & $2 / 1 / 11$ & 0 & 2.2 & II A & H D F G & - & - & - & 06 & $\mathrm{c}$ \\
\hline Franklin & Dog Island & 41 & $1 / 28 / 11$ & 0 & 13.7 & III V B & H F O G & - & - & - & $\underline{06}$ & $s(p), p$ \\
\hline Franklin & Flagg Island (Off St. Vincent Refuge) & 38 & $2 / 5 / 11$ & 0 & 2.3 & III G & $\mathrm{H} \mathrm{O} \mathrm{G}$ & - & - & - & - & $\mathrm{s}(\mathrm{p})$ \\
\hline Franklin & FSU Marine Lab & 43 & $2 / 1 / 11$ & 0 & 1.6 & III A & H D G & - & - & - & 06 & $\mathrm{p}$ \\
\hline Franklin & John S. Phipps Reserve (West end of Peninsula) & 45 & $1 / 29 / 11$ & 0 & 3.2 & II III G & G & - & - & - & 06 & $\mathrm{p}$ \\
\hline Franklin & Lanark Reef & 42 & $1 / 28 / 11$ & 0 & 1.6 & III V B & G & - & - & - & 06 & $\mathrm{~s}(\mathrm{p})$ \\
\hline Franklin & St. George Island State Park & 39 & $2 / 4 / 11$ & 0 & 18.0 & II III B & $\mathrm{H} \mathrm{V} \mathrm{O}$ & - & - & - & 06 & $\mathrm{~s}(\mathrm{p})$ \\
\hline Franklin & St. Vincent Island & 37 & $2 / 1 / 11$ & 0 & 19.8 & II III B D & G & - & - & - & 06 & $f$ \\
\hline Franklin & Turkey Point to St. Teresa Beach & 44 & $2 / 1 / 11$ & 0 & 8.8 & II A & H D V F G & - & - & - & 06 & $\mathrm{p}, \mathrm{c}$ \\
\hline Gulf & Highland View (Scamp St. to Port St. Joe) & 31 & $2 / 2 / 11$ & 0 & 1.6 & II A G & S L & - & - & - & 06 & n.r. \\
\hline Gulf & Indian Pass to Cape San Blas and Stump Hole & 36 & $2 / 2 / 11$ & 2 & 11.6 & III A & H D V G & - & - & - & 06 & $\mathrm{~m}, \mathrm{c}$ \\
\hline Gulf & NE St. Joe Bay Shoreline & 32 & $2 / 3 / 11$ & 0 & 3.2 & II A & $\mathrm{G}$ & - & - & - & - & $s(p)$ \\
\hline Gulf & Simmons Bayou & 34 & $2 / 3 / 11$ & 0 & 0.5 & II A & G & - & - & - & - & $\mathrm{s}(\mathrm{p})$ \\
\hline Gulf & St. Joe Beach (County Line to Pine St.) & 29 & $2 / 24 / 11$ & 0 & 4.0 & III A & H G & - & - & - & 06 & $\mathrm{~m}, \mathrm{c}$ \\
\hline Gulf & St. Joe Peninsula SP (Northern Portion) & 33 & $2 / 3 / 11$ & 0 & 17.3 & II III G & $\mathrm{H} \mathrm{V} \mathrm{O}$ & - & - & - & $\underline{06}$ & $\mathrm{~s}(\mathrm{p})$ \\
\hline Gulf & St. Joe Peninsula SP (Southern Portion) & 35 & $1 / 31 / 11$ & 0 & 9.5 & III G & H D G L & - & - & - & $\underline{06}$ & $\mathrm{~m}, \mathrm{c}$ \\
\hline Gulf & Windmark Beach (Pine St. to N Signal Ln Pier) & 30 & $1 / 28 / 11$ & 0 & 4.7 & II A & H G L & - & - & - & 06 & $\mathrm{p}$ \\
\hline Hernando & Pine Island & 53 & $1 / 28 / 11$ & 0 & 0.8 & II III B & H G & - & - & - & - & c \\
\hline Hillsborough & Cypress Point Park & 63 & $2 / 5 / 11$ & 0 & 1.0 & II A & $\mathrm{H} \mathrm{O} \mathrm{G}$ & - & - & - & - & $\mathrm{s}(\mathrm{p})$ \\
\hline Hillsborough & Egmont Key NWR \& State Park & 79 & $2 / 4 / 11$ & 0 & 4.8 & II III B & G & - & - & - & 06 & $\mathrm{f}$ \\
\hline Indian River & Indian River Co. Beaches & 143 & $2 / 3 / 11$ & 0 & 10.2 & I B & H D F S O G & - & - & - & 06 & $\mathrm{~m}, \mathrm{p}$ \\
\hline Indian River & Pelican Island NWR & 140 & $2 / 1 / 11$ & 0 & 21.7 & II V B C D E G & H F S V I O G & - & - & - & - & f \\
\hline Indian River & Round Island Conservation Area & 144 & $2 / 2 / 11$ & 0 & 1.6 & V G & H D O G & - & - & - & 06 & f, c \\
\hline Indian River & Round Island Park & 145 & $2 / 3 / 11$ & 0 & 0.7 & I B & H F G & - & - & - & 06 & $\mathrm{p}, \mathrm{c}$ \\
\hline
\end{tabular}


The 2011 International Wilson's Plover Winter Census in Florida

(Continued)

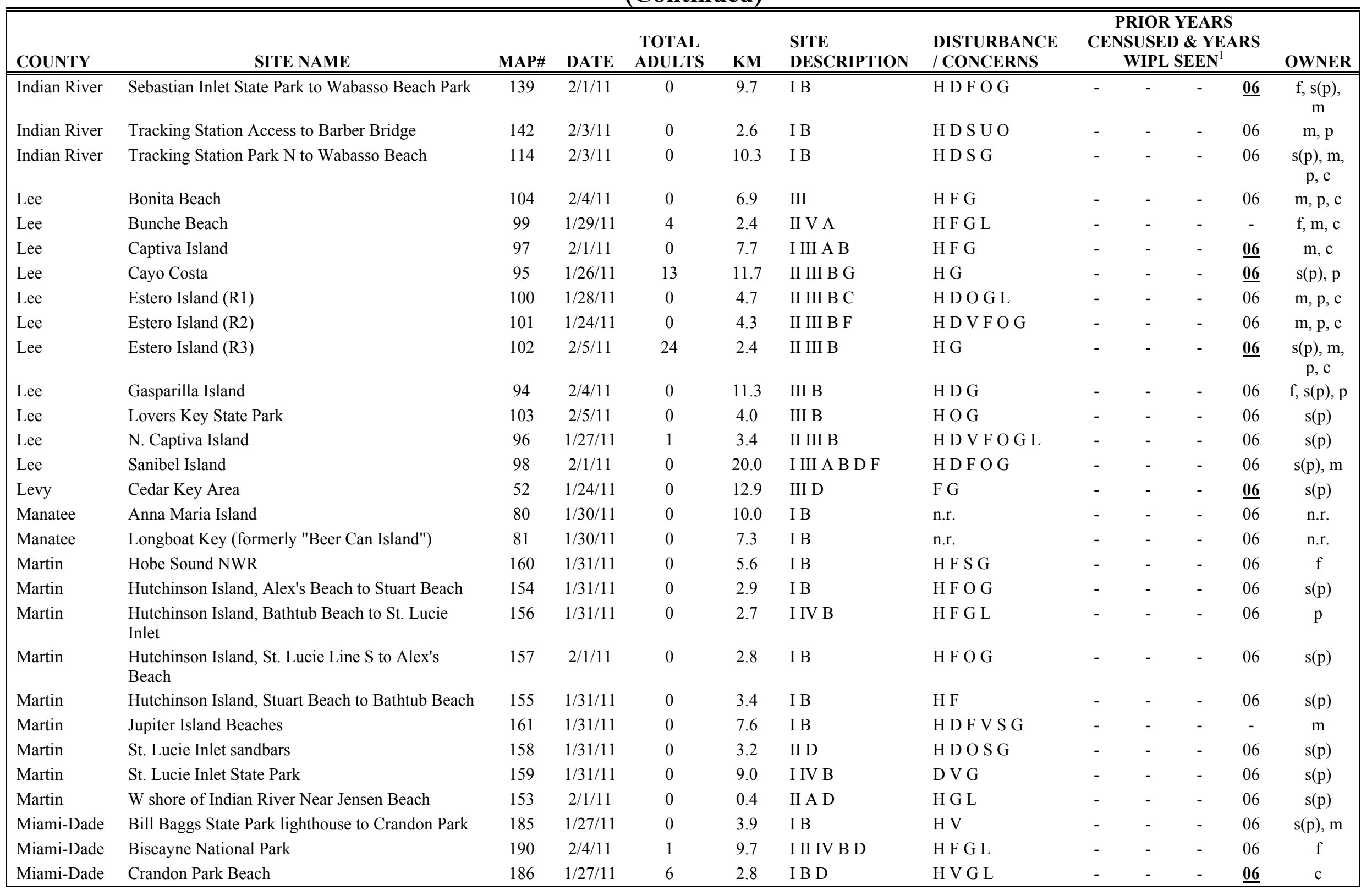


The 2011 International Wilson's Plover Winter Census in Florida

(Continued)

\begin{tabular}{|c|c|c|c|c|c|c|c|c|c|c|c|c|}
\hline \multirow{2}{*}{$\begin{array}{l}\text { COUNTY } \\
\text { Miami-Dade }\end{array}$} & \multirow[t]{2}{*}{ SITE NAME } & \multirow{2}{*}{$\begin{array}{c}\text { MAP } \\
\# \\
189\end{array}$} & \multirow{2}{*}{$\begin{array}{c}\text { DATE } \\
2 / 3 / 11\end{array}$} & \multirow{2}{*}{$\begin{array}{c}\text { TOTAL } \\
\text { ADULT } \\
\mathbf{S} \\
0\end{array}$} & \multirow{2}{*}{$\frac{\mathbf{K M}}{0.5}$} & \multirow{2}{*}{$\begin{array}{l}\text { SITE } \\
\text { DESCRIPTION } \\
\mathrm{VA}\end{array}$} & \multirow{2}{*}{$\begin{array}{l}\text { DISTURBANCE } \\
\text { / CONCERNS } \\
\mathrm{H} \mathrm{D} \mathrm{V}\end{array}$} & \multicolumn{4}{|c|}{$\begin{array}{c}\text { PRIOR YEARS } \\
\text { CENSUSED \& YEARS }^{\text {WIPL SEEN }}{ }^{1} \\
\text { WIPL }^{-}\end{array}$} & \multirow{2}{*}{$\frac{\text { OWNER }}{\mathrm{p}}$} \\
\hline & & & & & & & & - & - & - & - & \\
\hline Miami-Dade & Deering Estate and Chicken Key & 188 & $2 / 2 / 11$ & 0 & 3.1 & II A C G & H D F O G L & - & - & - & 06 & $s(p), c$ \\
\hline Miami-Dade & Matheson Hammock & 187 & $2 / 4 / 11$ & 0 & 1.2 & II A G & H D O G L & - & - & - & 06 & $\mathrm{c}$ \\
\hline Miami-Dade & Oleta River State Park & 182 & $2 / 4 / 11$ & 0 & 0.3 & II A & G & - & - & - & - & $\mathrm{s}(\mathrm{p})$ \\
\hline Miami-Dade & Rickenbacker Causeway Shoreline & 183 & $1 / 28 / 11$ & 0 & 1.7 & II E & H D F S I G & - & - & 01 & 06 & $\mathrm{c}$ \\
\hline Miami-Dade & Virginia Key Critical Wildlife Area & 184 & $1 / 28 / 11$ & 0 & 2.6 & II B & H S I & 91 & 96 & 01 & 06 & $\mathrm{~m}$ \\
\hline Monroe & Bahia Honda State Park & 195 & $1 / 24 / 11$ & 0 & 4.8 & I G & H F O G & - & - & - & $\underline{06}$ & $\mathrm{~s}(\mathrm{p})$ \\
\hline Monroe & Boca Chica Beach & 196 & $1 / 27 / 11$ & 0 & 1.3 & I E & H D V S G & - & - & - & 06 & $\mathrm{~s}(\mathrm{p})$ \\
\hline Monroe & Boca Grande Key & 199 & $1 / 25 / 11$ & 0 & 1.2 & V E G & H D G L & - & - & - & 06 & $\mathrm{f}$ \\
\hline Monroe & Curry Hammock State Park & 193 & $1 / 24 / 11$ & 0 & 0.4 & I G & $\mathrm{H} \mathrm{O} \mathrm{G}$ & - & - & - & 06 & $\mathrm{~s}(\mathrm{p})$ \\
\hline Monroe & Fort Taylor Historic State Park & 197 & $2 / 1 / 11$ & 0 & 0.8 & I III E & H G & - & - & - & 06 & $\mathrm{~s}(\mathrm{p})$ \\
\hline Monroe & $\begin{array}{l}\text { John D. Pennekamp state Park/ Carysfort Yacht } \\
\text { Club }\end{array}$ & 191 & 2/3/11 & 0 & 1.0 & I II A & H G & - & - & - & $\underline{06}$ & $\mathrm{~s}(\mathrm{p})$ \\
\hline Monroe & Lake Ingraham & 200 & $1 / 29 / 11$ & 5 & 1.6 & II & G L & - & - & - & - & $\mathrm{f}$ \\
\hline Monroe & Long Key State Park & 192 & $1 / 24 / 11$ & 0 & 1.6 & I G & H G L & - & - & - & 06 & $\mathrm{~s}(\mathrm{p})$ \\
\hline Monroe & Ohio Key & 194 & $1 / 27 / 11$ & 0 & 0.5 & I E G & H D G & - & - & - & 06 & $\mathrm{f}$ \\
\hline Monroe & Sandy Key to Carl Ross Key & 201 & $2 / 6 / 11$ & 0 & 1.5 & II E & G & - & - & - & - & $\mathrm{f}$ \\
\hline Monroe & Woman Key & 198 & $1 / 25 / 11$ & 0 & 1.3 & I E & H D G L & - & - & - & 06 & $\mathrm{f}$ \\
\hline Nassau & Amelia Island State Park & 116 & $2 / 4 / 11$ & 16 & 2.8 & I IV B & G & - & - & - & $\underline{06}$ & $\mathrm{~s}(\mathrm{p})$ \\
\hline Nassau & Bell River Spoil Island & 113 & $2 / 6 / 11$ & 13 & 0.4 & V C & $\mathrm{O} G$ & - & - & - & - & $\mathrm{p}$ \\
\hline Nassau & Fort Clinch State Park & 112 & $2 / 4 / 11$ & 0 & 6.4 & I II IV B & $\mathrm{H} \mathrm{S}$ & - & - & - & 06 & $\mathrm{~s}(\mathrm{p})$ \\
\hline Nassau & Little Tiger Island & 111 & $2 / 6 / 11$ & 0 & 2.4 & V E & $\mathrm{O}$ & - & - & - & $\underline{06}$ & $\mathrm{p}$ \\
\hline Nassau & North Fernandina Beach & 114 & $4 / 4 / 11$ & 0 & 11.0 & I B & H S G & - & - & - & 06 & $\mathrm{~s}(\mathrm{p})$ \\
\hline Nassau & South Fernandina Beach & 115 & $2 / 4 / 11$ & 0 & 7.4 & I B & $\mathrm{H}$ & - & - & - & - & $\mathrm{p}$ \\
\hline Okaloosa & $\begin{array}{l}\text { Eglin AFB (E restricted beach), Santa Rosa } \\
\text { Island }\end{array}$ & 6 & $1 / 27 / 11$ & 0 & 9.7 & III B & H V G & - & - & - & 06 & f \\
\hline Okaloosa & Eglin AFB (Public Beach), Okaloosa Island & 8 & $1 / 27 / 11$ & 0 & 7.4 & I IV B & H V S G & - & - & - & 06 & f \\
\hline Okaloosa & Henderson Beach State Park & 9 & $1 / 28 / 11$ & 0 & 2.2 & III A & H D V O G L & - & - & - & 06 & $\mathrm{~s}(\mathrm{p})$ \\
\hline Okaloosa & Okaloosa Holding Ponds & 7 & $1 / 25 / 11$ & 0 & 4.5 & V A & n.r. & - & - & - & - & n.r. \\
\hline $\begin{array}{l}\text { Okaloosa/ } \\
\text { Santa Rosa }\end{array}$ & $\begin{array}{l}\text { Eglin AFB (W restricted beach), Santa Rosa } \\
\text { Island }\end{array}$ & 4 & $1 / 27 / 11$ & 0 & 9.7 & III B & V G & - & - & - & 06 & $\mathrm{f}$ \\
\hline $\begin{array}{l}\text { Okaloosa/ } \\
\text { Santa Rosa }\end{array}$ & Eglin AFB (N restricted beach) & 5 & $2 / 2 / 11$ & 0 & 22.7 & II III B & G L & - & - & - & 06 & f \\
\hline Palm Beach & Boynton Inlet to Gulfstream Park & 175 & 2/1/11 & 0 & 4.8 & I IV A & H S O G & - & - & - & 06 & $\mathrm{~m}, \mathrm{p}, \mathrm{c}$ \\
\hline
\end{tabular}


The 2011 International Wilson's Plover Winter Census in Florida

(Continued)

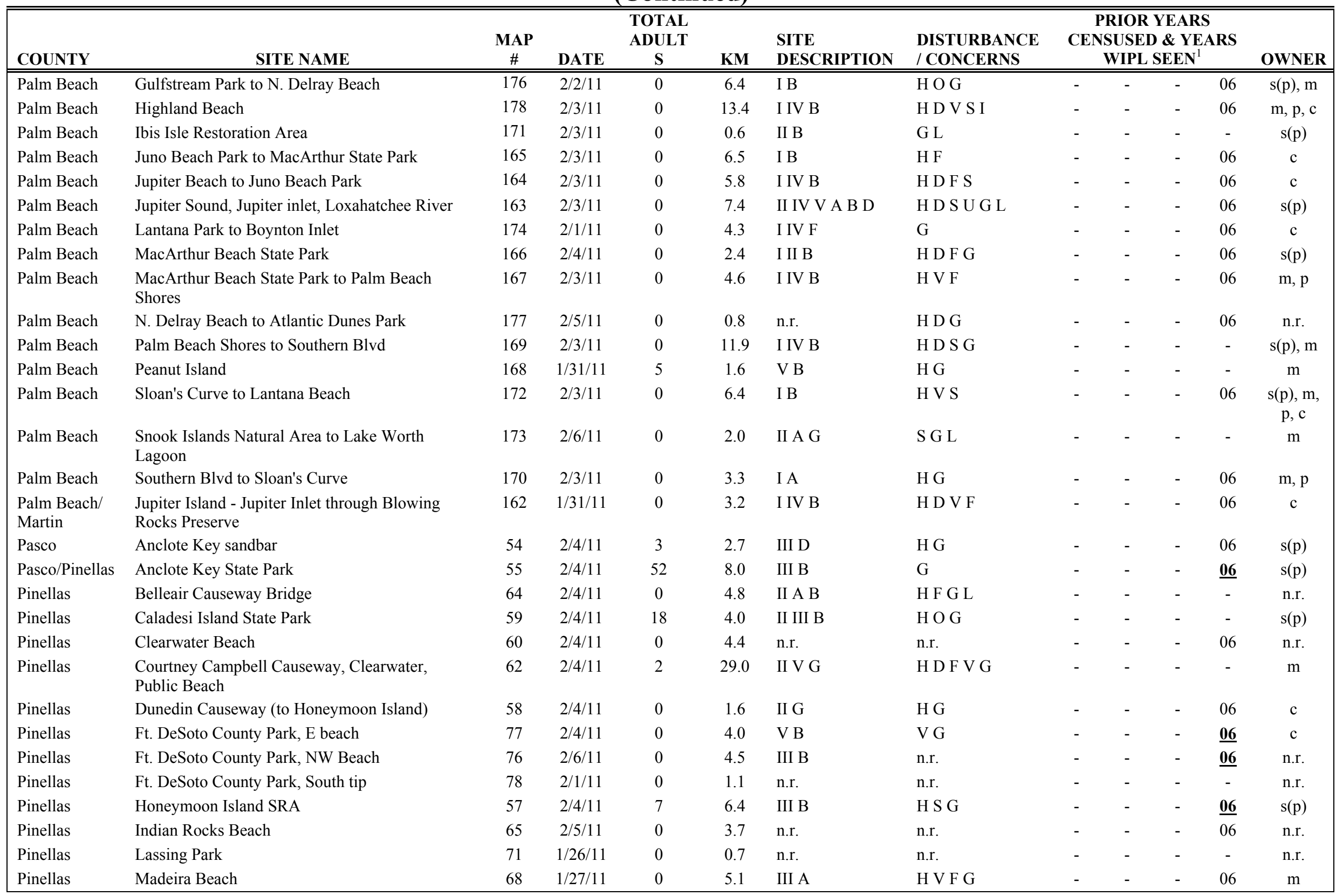


The 2011 International Wilson's Plover Winter Census in Florida

(Continued)

\begin{tabular}{|c|c|c|c|c|c|c|c|c|c|c|c|c|}
\hline \multirow{2}{*}{$\begin{array}{l}\text { COUNTY } \\
\text { Pinellas }\end{array}$} & \multirow{2}{*}{$\begin{array}{l}\text { SITE NAME } \\
\text { Pass-a-Grille Beach }\end{array}$} & \multirow{2}{*}{ MAP\# } & \multirow{2}{*}{$\frac{\text { DATE }}{2 / 5 / 11}$} & \multirow{2}{*}{$\begin{array}{c}\text { TOTAL } \\
\text { ADULTS } \\
0\end{array}$} & \multirow{2}{*}{$\frac{\mathbf{K M}}{2.7}$} & \multirow{2}{*}{$\begin{array}{l}\text { SITE } \\
\text { DESCRIPTION } \\
\text { III B }\end{array}$} & \multirow{2}{*}{$\begin{array}{l}\text { DISTURBANCE } \\
\text { / CONCERNS } \\
\mathrm{H} \mathrm{G}\end{array}$} & \multicolumn{4}{|c|}{$\begin{array}{c}\text { PRIOR YEARS } \\
\text { CENSUSED \& YEARS } \\
\text { WIPL SEEN }^{1} \\
\end{array}$} & \multirow{2}{*}{ OWNER } \\
\hline & & & & & & & & - & - & - & - & \\
\hline Pinellas & Pinellas Point & 73 & $1 / 30 / 11$ & 0 & 1.6 & V A & O G L & - & - & - & - & $\mathrm{m}$ \\
\hline Pinellas & Redington Beach/North Redington Beach & 67 & $2 / 6 / 11$ & 0 & 4.4 & III B & $\mathrm{HO} \mathrm{G}$ & - & - & - & 06 & $\mathrm{~s}(\mathrm{p})$ \\
\hline Pinellas & Sandy Park to Bellair Beach Morgan Dr. Park & 61 & $2 / 5 / 11$ & 0 & 3.4 & n.r. & n.r. & - & - & - & 06 & n.r. \\
\hline Pinellas & Shell Key & 75 & $2 / 6 / 11$ & 4 & 2.4 & II B & H G L & - & - & - & $\underline{06}$ & $\mathrm{c}$ \\
\hline Pinellas & St. Pete Beach & 72 & $2 / 4 / 11$ & 0 & 3.4 & n. $r$. & n.r. & - & - & - & - & n.r. \\
\hline Pinellas & St. Petersburg- North shore park area & 69 & $1 / 30 / 11$ & 0 & 0.8 & n.r. & n.r. & - & - & - & 06 & n.r. \\
\hline Pinellas & Three Rooker Bar & 56 & $2 / 4 / 11$ & 10 & 3.2 & III B & G & - & - & - & 06 & $\mathrm{~s}(\mathrm{p})$ \\
\hline Pinellas & Treasure Island & 70 & $2 / 6 / 11$ & 0 & 6.4 & III A G & H U G & - & - & - & 06 & $\mathrm{~m}$ \\
\hline Pinellas & Walsingham Road South to Park Blvd & 66 & $2 / 4 / 11$ & 0 & 3.0 & III B & H F G & - & - & - & 06 & $\mathrm{~m}$ \\
\hline Sarasota & Caspersen Beach (Venice Beach) & 88 & $2 / 5 / 11$ & 2 & 6.1 & III A & $\mathrm{H} \mathrm{S}$ & - & - & - & 06 & $\begin{array}{l}\mathrm{s}(\mathrm{p}), \mathrm{m} \\
\mathrm{p}, \mathrm{c}\end{array}$ \\
\hline Sarasota & Lido Beach & 83 & $1 / 29 / 11$ & 1 & 4.0 & III B & H S O G & - & - & - & 06 & $\mathrm{c}$ \\
\hline Sarasota & North Casey Key & 86 & $2 / 5 / 11$ & 0 & 4.8 & III B & H D S G & - & - & - & 06 & n.r. \\
\hline Sarasota & Siesta Key, N end to Point of Rocks & 84 & $2 / 5 / 11$ & 0 & 4.7 & III B & H D V G & - & - & - & 06 & $\mathrm{c}$ \\
\hline Sarasota & Siesta Key, Turtle Beach to Point of Rocks & 85 & $2 / 6 / 11$ & 1 & 3.1 & II III B F & H D G & - & - & - & 06 & $s(p), c$ \\
\hline Sarasota & South Casey Key & 87 & $2 / 5 / 11$ & 0 & 5.0 & III B & H D S O G & - & - & - & 06 & $\mathrm{p}, \mathrm{c}$ \\
\hline Sarasota & South Longboat Key & 82 & $2 / 5 / 11$ & 0 & 4.8 & III B & H S U O & - & - & - & 06 & $\mathrm{p}$ \\
\hline St. Johns & Anastasia State Recreation Area & 121 & $2 / 4 / 11$ & 0 & 7.9 & I IV B & $\mathrm{HO} \mathrm{G}$ & - & - & - & 06 & $\mathrm{~s}(\mathrm{p})$ \\
\hline St. Johns & Rattlesnake Island & 122 & $2 / 4 / 11$ & 0 & 1.0 & IV E & n.r. & - & - & - & - & n.r. \\
\hline St. Johns & St. Augustine Beach (Matanzas Inlet) & 123 & $2 / 4 / 11$ & 13 & 25.7 & I II IV V A B C D & H D V F S U G & - & - & - & $\underline{\mathbf{0 6}}$ & $\begin{array}{c}\mathrm{f}, \mathrm{s}(\mathrm{p}) \\
\mathrm{m}, \mathrm{c}\end{array}$ \\
\hline St. Johns & Vilano Point to North Beach & 120 & $2 / 4 / 11$ & 0 & 25.7 & I B & D G & - & - & - & 06 & $\mathrm{f}, \mathrm{c}$ \\
\hline St. Lucie & Avalon State Park & 146 & $2 / 3 / 11$ & 0 & 2.4 & I B & $\mathrm{H}$ & - & - & - & 06 & $\mathrm{~s}(\mathrm{p})$ \\
\hline St. Lucie & Fort Pierce Inlet State Park & 148 & $2 / 3 / 11$ & 0 & 1.4 & I IV B & H F G & - & - & - & 06 & $\mathrm{~s}(\mathrm{p})$ \\
\hline St. Lucie & Fort Pierce Inlet State Park to Avalon State Park & 147 & $1 / 28 / 11$ & 0 & 6.4 & I B & H G & - & - & - & 06 & $\mathrm{p}, \mathrm{c}$ \\
\hline St. Lucie & S Hutchinson Island & 149 & $1 / 31 / 11$ & 0 & 24.5 & I B & H D F & - & - & - & 06 & $\mathrm{~m}, \mathrm{p}, \mathrm{c}$ \\
\hline St. Lucie & $\begin{array}{l}\text { South Hutchinson Island- Little Mud Creek N to } \\
\text { Frederick Douglass Park }\end{array}$ & 151 & $1 / 31 / 11$ & 0 & 3.7 & I B & H D F & - & - & - & 06 & $\mathrm{~m}, \mathrm{p}, \mathrm{c}$ \\
\hline St. Lucie & $\begin{array}{l}\text { South Hutchinson Island- Little Mud Creek S to } \\
\text { the narrows }\end{array}$ & 152 & $1 / 31 / 11$ & 0 & 6.4 & I B & H D F & - & - & - & 06 & $\mathrm{~m}, \mathrm{p}, \mathrm{c}$ \\
\hline St. Lucie & $\begin{array}{l}\text { South Hutchinson Island-Fredrick Douglass Park } \\
\text { to Inlet }\end{array}$ & 150 & $1 / 31 / 11$ & 0 & 6.4 & I B & H D F & - & - & - & 06 & $\mathrm{~m}, \mathrm{p}, \mathrm{c}$ \\
\hline Taylor & Hagen's Cove & 51 & $2 / 4 / 11$ & 0 & 0.7 & n.r. & n.r. & - & - & - & 06 & n.r. \\
\hline
\end{tabular}


The 2011 International Wilson's Plover Winter Census in Florida

(Continued)

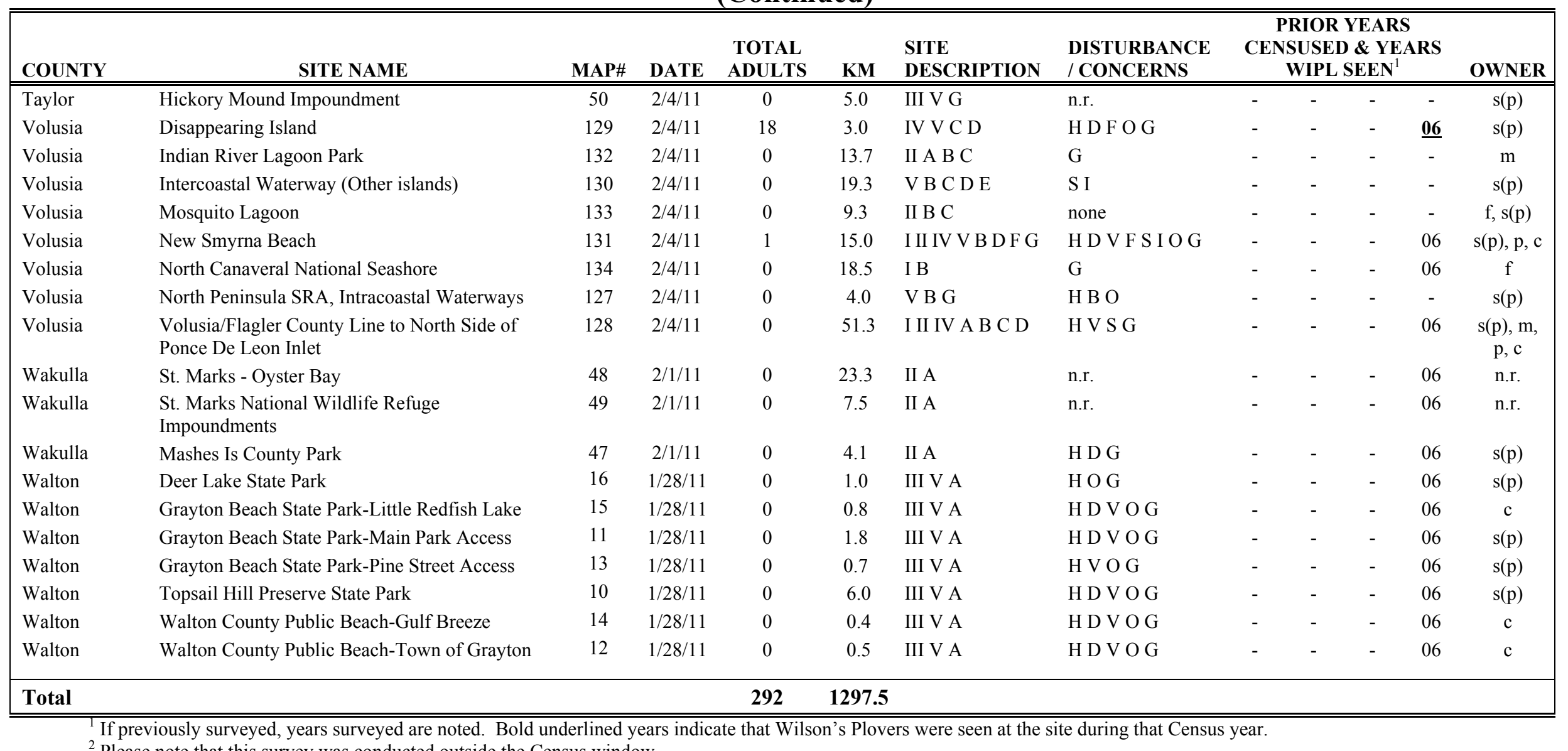

${ }^{2}$ Please note that this survey was conducted outside the Census window. 


\section{The 2011 International Piping Plover Winter Census in Alabama}

Roger Clay

Alabama Division of Wildlife and Freshwater

Fisheries

P.O. Box 247

Daphne, AL 36526

251-626-5474

Roger.Clay@denr.alabama.gov

Three census participants in two parties surveyed the six most important wintering Piping Plover sites in Alabama on 5 February 2011. One site in Baldwin County (Ft. Morgan Historic State Park) and four sites in Mobile County were surveyed on foot. Sites in Mobile County included Pelican Island, Little Dauphin Island, Katrina Cut-East (Dauphin Island), and Katrina Cut-West (Dauphin Island). Additionally, the undeveloped north shore of the western end of Dauphin Island was surveyed by boat. In total, $12.2 \mathrm{~km}$ (7.6 miles) were surveyed on foot while 12.6 ( 7.8 miles) were surveyed from boat. Conditions were generally overcast with light winds and temperatures in the lower 40's (Fahrenheit).

A total of 38 Piping Plovers were sighted along with 27 Snowy Plovers. Over half (21) of the Piping Plovers were spotted on Little Dauphin Island. Only two sites (Katrina Cut-East, Dauphin Island West End) had zero Piping Plovers and two sites (Little Dauphin Island, Dauphin Island West End) were absent of Snowy Plovers. Four color-banded Piping Plovers were spotted, three on Little Dauphin Island and one at Ft. Morgan Historic State Park. During the 2006 census, 29 total Piping Plovers were counted on Pelican and Dauphin Islands.
Historically Little Dauphin Island and Pelican Island have been the two most important sites for concentrations of Piping Plovers and that trend should continue. Pelican Island is now a peninsula connected to Dauphin Island which increases foot traffic but likely has little impact to wintering birds. The tidally exposed flats at the north end of Little Dauphin Island appear more suitable for plovers than they have been in several years giving evidence to the ever changing conditions of barrier islands. Katrina Cut, the breach of Dauphin Island made by Hurricane Katrina in 2005, has favorable plover feeding habitat on its east and west sides. Lack of any impacts by tropical storms or hurricanes since 2005 has likely been a detriment to plover habitat. Without the overwash and flooding of barrier islands in Mobile County, vegetative succession advances and beaches rise resulting in a loss of tidal flats, tidal pools, and washover zones. Of note in 2011 was a project closing the Katrina Cut with a milelong wall of rip-rap. Any impacts to plovers are unknown. Also, initial observations of the effects of the Deepwater Horizon oil spill of 2010 and subsequent cleanup operations on plovers appear negligible.

\section{Comparison of Census Numbers}

\begin{tabular}{|l|c|c|c|c|c|}
\hline Species & 1991 & 1996 & 2001 & 2006 & 2011 \\
\hline $\begin{array}{l}\text { Piping } \\
\text { Plover }\end{array}$ & 12 & 31 & 30 & 29 & 38 \\
\hline $\begin{array}{l}\text { Snowy } \\
\text { Plover }\end{array}$ & n.r. & n.r. & 0 & 6 & 27 \\
\hline $\begin{array}{l}\text { Wilson's } \\
\text { Plover }\end{array}$ & n.r. & n.r. & n.r. & 0 & 0 \\
\hline
\end{tabular}




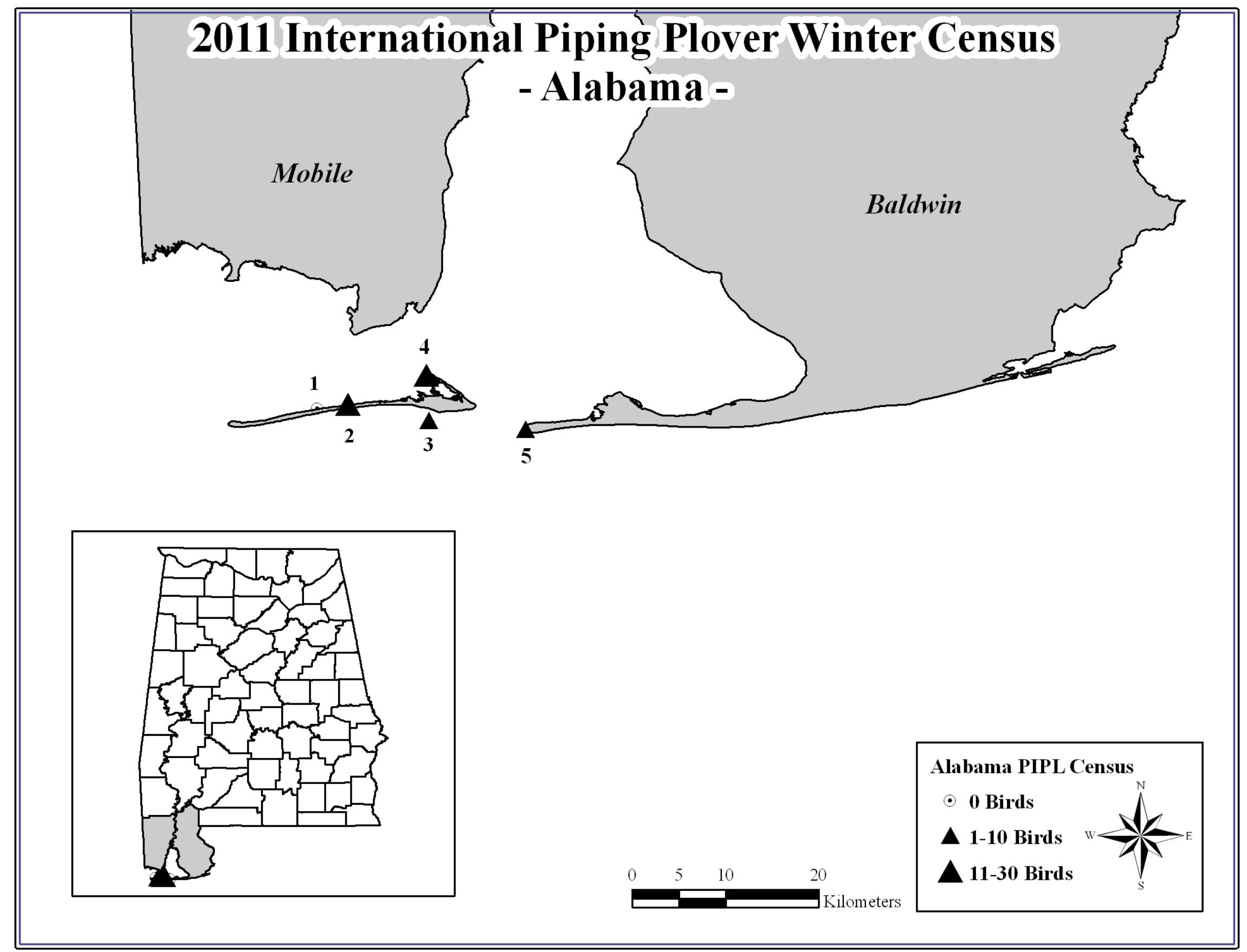


The 2011 International Piping Plover Winter Census in Alabama

\begin{tabular}{|c|c|c|c|c|c|c|c|c|c|c|c|c|}
\hline \multirow{2}{*}{$\begin{array}{l}\text { COUNTY } \\
\text { Baldwin }\end{array}$} & SITE NAME & MAP\# & DATE & \multirow{2}{*}{$\begin{array}{c}\text { TOTAL } \\
\text { ADULTS } \\
1\end{array}$} & \multirow{2}{*}{$\frac{\mathbf{K M}}{23.2}$} & \multirow{2}{*}{$\begin{array}{l}\text { SITE } \\
\text { DESCRIPTION } \\
\text { III IV A }\end{array}$} & \multirow{2}{*}{$\begin{array}{l}\text { DISTURBANCE } \\
\text { / CONCERNS } \\
\text { H D V P S G L }\end{array}$} & \multicolumn{4}{|c|}{$\begin{array}{c}\text { PRIOR YEARS } \\
\text { CENSUSED \& YEARS } \\
\text { PIPL SEEN }^{1} \\
\end{array}$} & \multirow{2}{*}{$\frac{\text { OWNER }}{\mathrm{f}, \mathrm{s}(\mathrm{p})}$} \\
\hline & Fort Morgan Historic State Park & 5 & $2 / 5 / 11$ & & & & & - & - & - & - & \\
\hline Mobile & Katrina Cut - East & 2 & $2 / 5 / 11$ & 11 & 1.3 & III IV V B & V S G L & - & - & - & - & $\mathrm{m}$ \\
\hline Mobile & Katrina Cut - West & 1 & $2 / 5 / 11$ & 0 & 0.5 & III IV V B & V S G & - & - & - & - & $\mathrm{p}$ \\
\hline Mobile & Little Dauphin Island & 4 & $2 / 5 / 11$ & 21 & 0.5 & IV V B & G L & 91 & $\underline{96}$ & $\underline{01}$ & $\underline{06}$ & f \\
\hline Mobile & Pelican Island (peninsula) & 3 & $2 / 5 / 11$ & 5 & 6.8 & II III B & H D G & 91 & $\underline{96}$ & 01 & $\underline{06}$ & $\mathrm{p}$ \\
\hline Total & & & & 38 & 12.3 & & & & & & & \\
\hline
\end{tabular}

If previously surveyed, years surveyed are noted. Bold underlined years indicate that Piping Plovers were seen at the site during that Census year. 


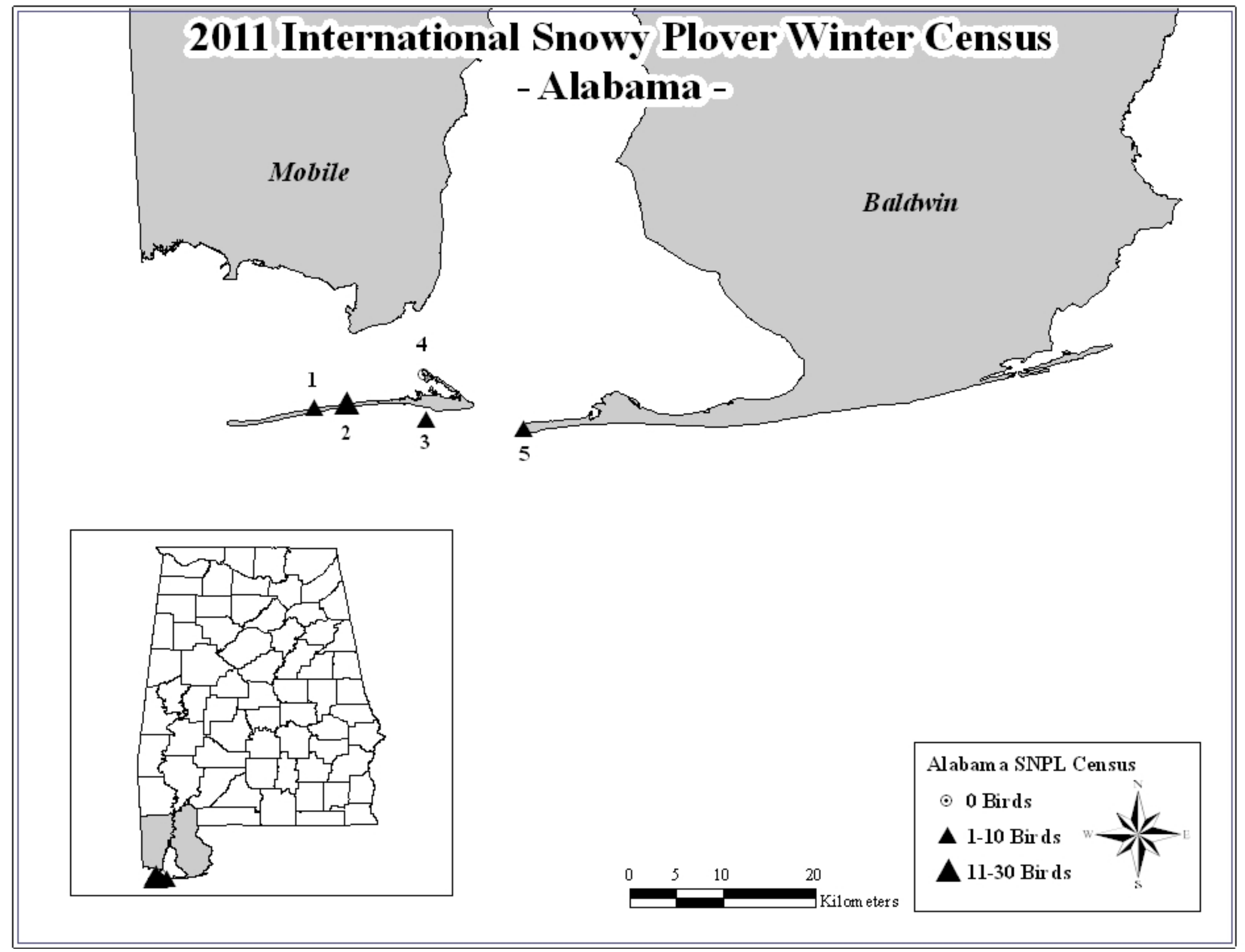


The 2011 International Snowy Plover Winter Census in Alabama

\begin{tabular}{|c|c|c|c|c|c|c|c|c|c|c|c|}
\hline COUNTY & SITE NAME & MAP\# & DATE & $\begin{array}{c}\text { TOTAL } \\
\text { ADULTS }\end{array}$ & KM & $\begin{array}{l}\text { SITE } \\
\text { DESCRIPTION }\end{array}$ & $\begin{array}{l}\text { DISTURBANCE } \\
\text { / CONCERNS }\end{array}$ & \multicolumn{3}{|c|}{$\begin{array}{c}\text { PRIOR YEARS } \\
\text { CENSUSED \& YEARS } \\
\text { SNPL SEEN }^{1} \\
\end{array}$} & \multirow{2}{*}{$\frac{\text { OWNER }}{\mathrm{f}, \mathrm{s}(\mathrm{p})}$} \\
\hline Baldwin & Fort Morgan Historic State Park & 5 & $2 / 5 / 11$ & 6 & 3.2 & III IV A & H D V P S G L & - & - & - & \\
\hline Mobile & Katrina Cut - East & 2 & $2 / 5 / 11$ & 11 & 1.3 & III IV V B & V S G L & - & - & - & $\mathrm{m}$ \\
\hline Mobile & Katrina Cut - West & 1 & $2 / 5 / 11$ & 4 & 0.5 & III IV V B & V S G & - & - & - & $\mathrm{p}$ \\
\hline Mobile & Little Dauphin Island & 4 & $2 / 5 / 11$ & 0 & 0.5 & IV V B & G L & - & - & 06 & $\mathrm{f}$ \\
\hline Mobile & Pelican Island (peninsula) & 3 & $2 / 5 / 11$ & 6 & 6.8 & II III B & H D G & - & - & $\underline{06}$ & $\mathrm{p}$ \\
\hline Total & & & & 27 & 12.3 & & & & & & \\
\hline
\end{tabular}

If previously surveyed, years surveyed are noted. Bold underlined years indicate that Snowy Plovers were seen at the site during that Census year. 


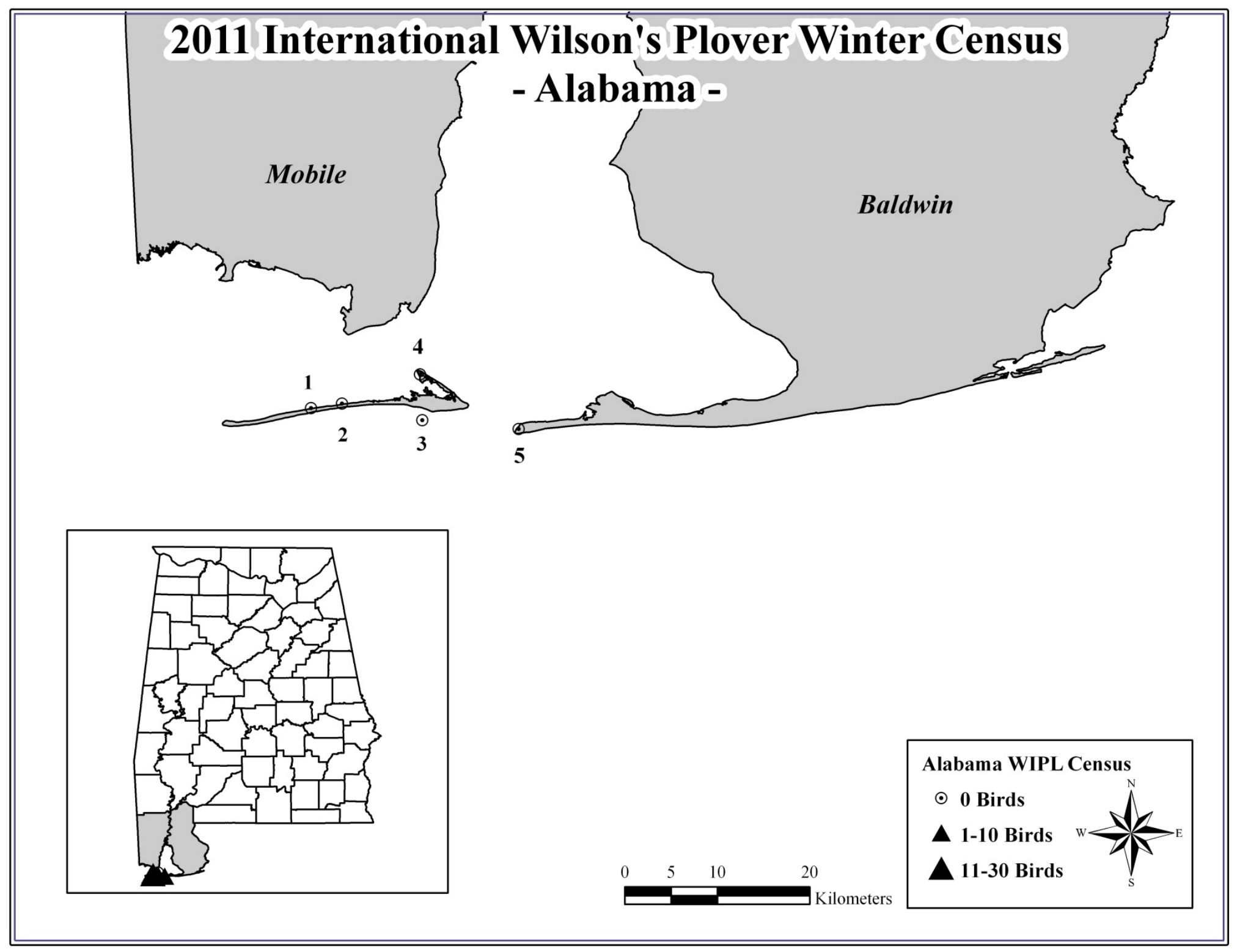


The 2011 International Wilson's Plover Winter Census in Alabama

\begin{tabular}{|c|c|c|c|c|c|c|c|c|c|c|c|}
\hline \multirow{2}{*}{$\begin{array}{l}\text { COUNTY } \\
\text { Baldwin }\end{array}$} & SITE NAME & MAP\# & DATE & $\begin{array}{c}\text { TOTAL } \\
\text { ADULTS } \\
\end{array}$ & KM & $\begin{array}{l}\text { SITE } \\
\text { DESCRIPTION }\end{array}$ & $\begin{array}{l}\text { DISTURBANCE } \\
\text { / CONCERNS } \\
\end{array}$ & \multicolumn{3}{|c|}{$\begin{array}{c}\text { PRIOR YEARS } \\
\text { CENSUSED \& YEARS } \\
\text { WIPL SEEN }^{1}\end{array}$} & \multirow{2}{*}{$\frac{\text { OWNER }}{\mathrm{f}_{\mathrm{f}, \mathrm{s}(\mathrm{p})}}$} \\
\hline & Fort Morgan Historic State Park & 5 & $2 / 5 / 11$ & 0 & 3.2 & III IV A & H D V P S G L & - & - & - & \\
\hline Mobile & Katrina Cut - East & 2 & $2 / 5 / 11$ & 0 & 1.3 & III IV V B & V S G L & - & - & - & $\mathrm{m}$ \\
\hline Mobile & Katrina Cut - West & 1 & $2 / 5 / 11$ & 0 & 0.5 & III IV V B & V S G & - & - & - & $\mathrm{p}$ \\
\hline Mobile & Little Dauphin Island & 4 & $2 / 5 / 11$ & 0 & 0.5 & IV V B & G L & - & - & 06 & $\mathrm{f}$ \\
\hline Mobile & Pelican Island (peninsula) & 3 & $2 / 5 / 11$ & 0 & 6.8 & II III B & H D G & - & - & 06 & $\mathrm{p}$ \\
\hline Total & & & & 0 & 12.3 & & & & & & \\
\hline
\end{tabular}

If previously surveyed, years surveyed are noted. Bold underlined years indicate that Wilson's Plovers were seen at the site during that Census year. 


\section{The 2011 International Piping Plover Winter Census in Mississippi}

Nick Winstead

Mississippi Museum of Natural Science 2148 Riverside Drive

Jackson, MS 39202

601-576-6000

nick.winstead@mmns.state.ms.us

The Mississippi census was conducted February 811, 2011 with the help of 21 people. We would like to thank to the National Wildlife Federation, Mississippi Department of Marine Resources, Mississippi Department of Environmental Quality, Harrison County Sheriff's Office and Gulf Islands National Seashore for assisting with funding, boats and access. Surveyors included birders and biologists from the Mississippi Museum of Natural Science, U.S. Fish and Wildlife Service, U.S. Forest Service and Mississippi Department of Marine Resources.

A total of 19 sites were surveyed during the Census and 88 Piping Plovers were observed. Island sites were surveyed on February 8th and mainland sites on February 9th. Island coverage was incomplete due to a shortage of boats and closures on parts of some islands, leaving several key sites un-surveyed. Important sites missed include most of East Ship and Deer Islands as well as all of Petit Bois Island (these sites had 7, 0, and 19 birds respectively during the 2006 Census). All key mainland sites were surveyed.
The main difference between this survey and prior ones was the presence of oil-spill clean-up crews, resulting in a large increase in numbers of people and vehicles on beaches. This was especially true on the islands where virtually no people or vehicles have been observed during past surveys. Some previously important sites had fewer or no birds possibly due to increased human disturbance; though some sites had birds in very close proximity to oil spill cleanup crews.

Comparison of Census Numbers

\begin{tabular}{|l|c|c|c|c|c|}
\hline Species & 1991 & 1996 & 2001 & 2006 & 2011 \\
\hline $\begin{array}{l}\text { Piping } \\
\text { Plover }\end{array}$ & 59 & 27 & 18 & 78 & 88 \\
\hline $\begin{array}{l}\text { Snowy } \\
\text { Plover }\end{array}$ & n.r. & n.r. & 13 & 36 & 49 \\
\hline $\begin{array}{l}\text { Wilson's } \\
\text { Plover }\end{array}$ & n.r. & n.r. & n.r. & 0 & 6 \\
\hline
\end{tabular}




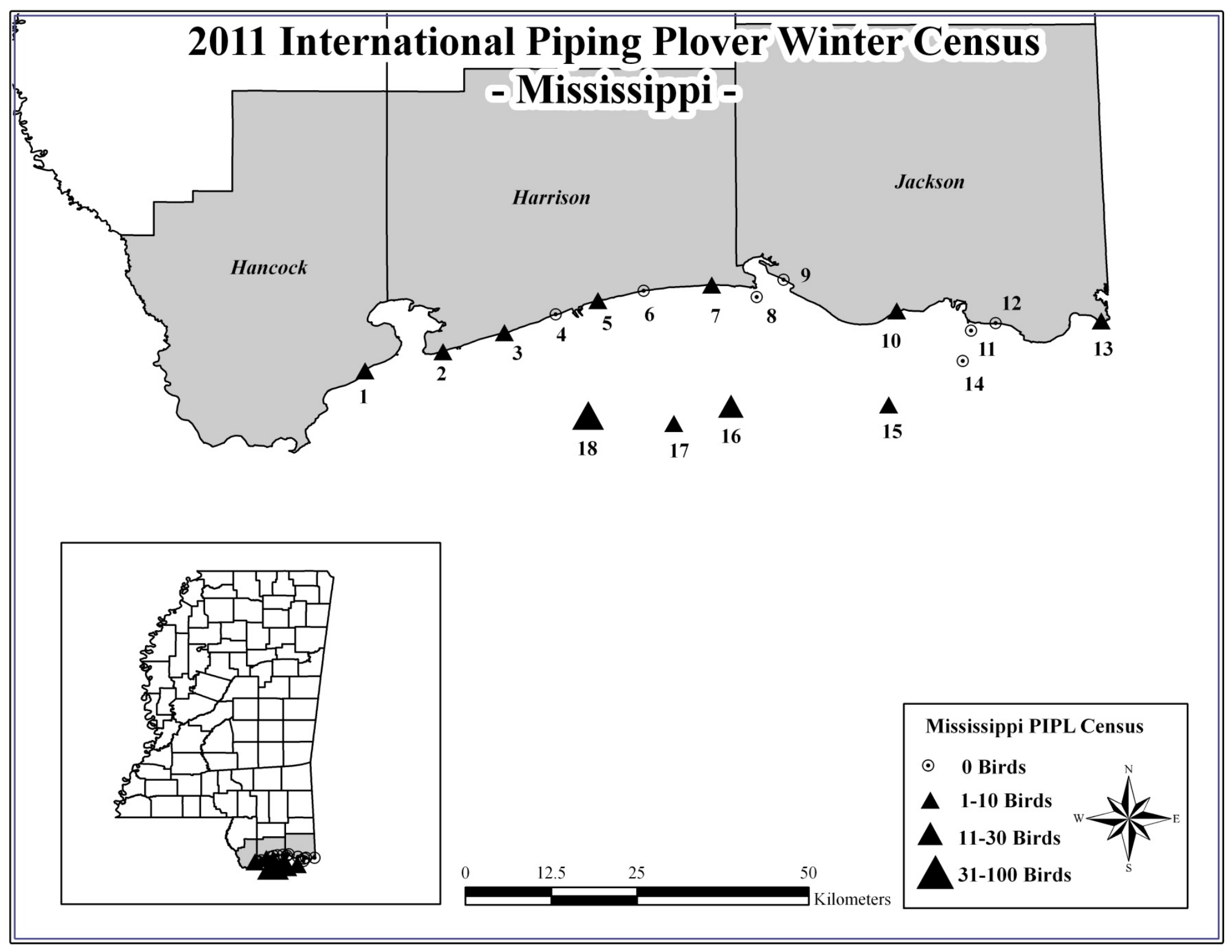


The 2011 International Piping Plover Winter Census in Mississippi

\begin{tabular}{|c|c|c|c|c|c|c|c|c|c|c|c|c|}
\hline \multirow{2}{*}{$\begin{array}{l}\text { COUNTY } \\
\text { Hancock }\end{array}$} & \multirow{2}{*}{$\begin{array}{l}\text { SITE NAME } \\
\text { Clermont Harbor (Lakeshore to Bay St. Louis }_{\text {Piers) }}^{3}\end{array}$} & \multirow{2}{*}{$\begin{array}{c}\text { MAP\# } \\
1\end{array}$} & \multirow{2}{*}{$\begin{array}{c}\text { DATE } \\
2 / 9 / 11\end{array}$} & \multirow{2}{*}{$\begin{array}{c}\text { TOTAL } \\
\text { ADULTS } \\
6\end{array}$} & \multirow{2}{*}{$\begin{array}{l}\text { KM } \\
12.9\end{array}$} & \multirow{2}{*}{$\begin{array}{l}\text { SITE } \\
\text { DESCRIPTION }\end{array}$} & \multirow{2}{*}{$\begin{array}{l}\text { DISTURBANCE } \\
\text { / CONCERNS } \\
\mathrm{H} \mathrm{D} \mathrm{V}\end{array}$} & \multicolumn{4}{|c|}{$\begin{array}{c}\text { PRIOR YEARS } \\
\text { CENSUSED \& YEARS } \\
\text { PIPL SEEN }^{1} \\
\end{array}$} & \multirow{2}{*}{$\frac{\text { OWNER }}{\mathrm{s}(\mathrm{p})}$} \\
\hline & & & & & & & & $\underline{91}$ & 96 & $\underline{01}$ & 06 & \\
\hline Harrison & Beauvoir Road to Point Cadet ${ }^{3}$ & 7 & 2/9/11 & 1 & 8.1 & II A & H D V & - & $\underline{96}^{2}$ & 01 & - & $\mathrm{s}(\mathrm{p})$ \\
\hline Harrison & Cat Island ${ }^{3}$ & 18 & $2 / 8 / 11$ & 45 & 22.5 & II III B & H V P & $\underline{91}$ & 96 & - & $\underline{06}$ & $f, p$ \\
\hline Harrison & Courthouse Road to Beauvoir Road ${ }^{3}$ & 6 & 2/9/11 & 0 & 7.7 & II A & H D V & - & $\underline{96}^{2}$ & 01 & 06 & $s(p)$ \\
\hline Harrison & Deer Island ${ }^{3}$ & 8 & $2 / 8 / 11$ & 0 & 9.7 & II E & H P S & $\underline{91}$ & 96 & - & 06 & $\mathrm{~s}(\mathrm{p})$ \\
\hline Harrison & East Ship Island ${ }^{3}$ & 16 & $2 / 8 / 11$ & 11 & 1.6 & II III B & H P S & 91 & $\underline{96}$ & 01 & $\underline{06}$ & $\mathrm{f}$ \\
\hline Harrison & Gulfport Harbor to Courthouse Road ${ }^{3}$ & 5 & 2/9/11 & 3 & 4.3 & II A & H D V & 91 & $\underline{96}^{2}$ & 01 & $\underline{06}$ & $\mathrm{~s}(\mathrm{p})$ \\
\hline Harrison & Long Beach Harbor to Gulfport Harbor ${ }^{3}$ & 4 & 2/9/11 & 0 & 4.3 & II A & H D V & $\underline{91}$ & $\underline{96}^{2}$ & $\underline{01}$ & 06 & $\mathrm{~s}(\mathrm{p})$ \\
\hline Harrison & Pass Christian Harbor to Long Beach Harbor ${ }^{3}$ & 3 & $2 / 9 / 11$ & 5 & 10.5 & II A & H D V & $\underline{91}$ & 96 & 01 & $\underline{06}$ & $\mathrm{~s}(\mathrm{p})$ \\
\hline Harrison & Henderson Point to Pass Christian Harbor ${ }^{3}$ & 2 & 2/9/11 & 1 & 4.8 & II A & H D V & $\underline{91}$ & 96 & 01 & $\underline{06}$ & $\mathrm{~s}(\mathrm{p})$ \\
\hline Harrison & West Ship Island ${ }^{3}$ & 17 & $2 / 8 / 11$ & 7 & 9.7 & II III B & H V S P & $\underline{91}$ & 96 & 01 & $\underline{06}$ & $f$ \\
\hline Jackson & Belle Fontaine Beach ${ }^{3}$ & 10 & 2/9/11 & 1 & 1.6 & II A & H D V & 91 & 96 & 01 & 06 & $\mathrm{p}$ \\
\hline Jackson & Grand Bay National Estuarine Research Reserve ${ }^{3}$ & 13 & $2 / 11 / 11$ & 1 & n.r. & II A & n.r. & 91 & 96 & 01 & $\underline{06}$ & $\mathrm{f}, \mathrm{s}(\mathrm{p})$ \\
\hline Jackson & Horn Island ${ }^{3}$ & 15 & $2 / 8 / 11$ & 7 & 38.6 & II III B & H V P & 91 & $\underline{96}$ & $\underline{01}$ & $\underline{06}$ & $f$ \\
\hline Jackson & Ocean Springs Beach ${ }^{3}$ & 9 & $2 / 9 / 11$ & 0 & 3.5 & II A & H D V L & $\underline{91}$ & 96 & 01 & 06 & $s(p)$ \\
\hline Jackson & Pascagoula Beach ${ }^{3}$ & 12 & $2 / 9 / 11$ & 0 & 3.2 & II A & H D V S L & 91 & 96 & - & 06 & $\mathrm{~m}$ \\
\hline Jackson & Round Island $^{3}$ & 14 & $2 / 8 / 11$ & 0 & 2.4 & II E & n.r. & 91 & 96 & 01 & 06 & $\mathrm{~m}$ \\
\hline Jackson & Singing River Island ${ }^{3}$ & 11 & $2 / 8 / 11$ & 0 & n.r. & II E & $\mathrm{L}$ & - & 96 & 01 & 06 & $\mathrm{~m}$ \\
\hline Total & & & & 88 & 145.5 & & & & & & & \\
\hline
\end{tabular}

${ }^{1}$ If previously surveyed, years surveyed are noted. Bold underlined years indicate that Piping Plovers were seen at the site during that Census year.

212 PIPL were seen at "Pt. Cadet to Long Beach Harbor" in 1996. Specific locations were unspecified and may have occurred along either "Beauvoir Road to Point Cadet," "Courthouse

Road to Beauvoir Road," "Gulfport Harbor to Courthouse Road" or "Long Beach Harbor to Gulfport Harbor".

${ }^{3}$ Please note that this survey was conducted outside the Census window. 


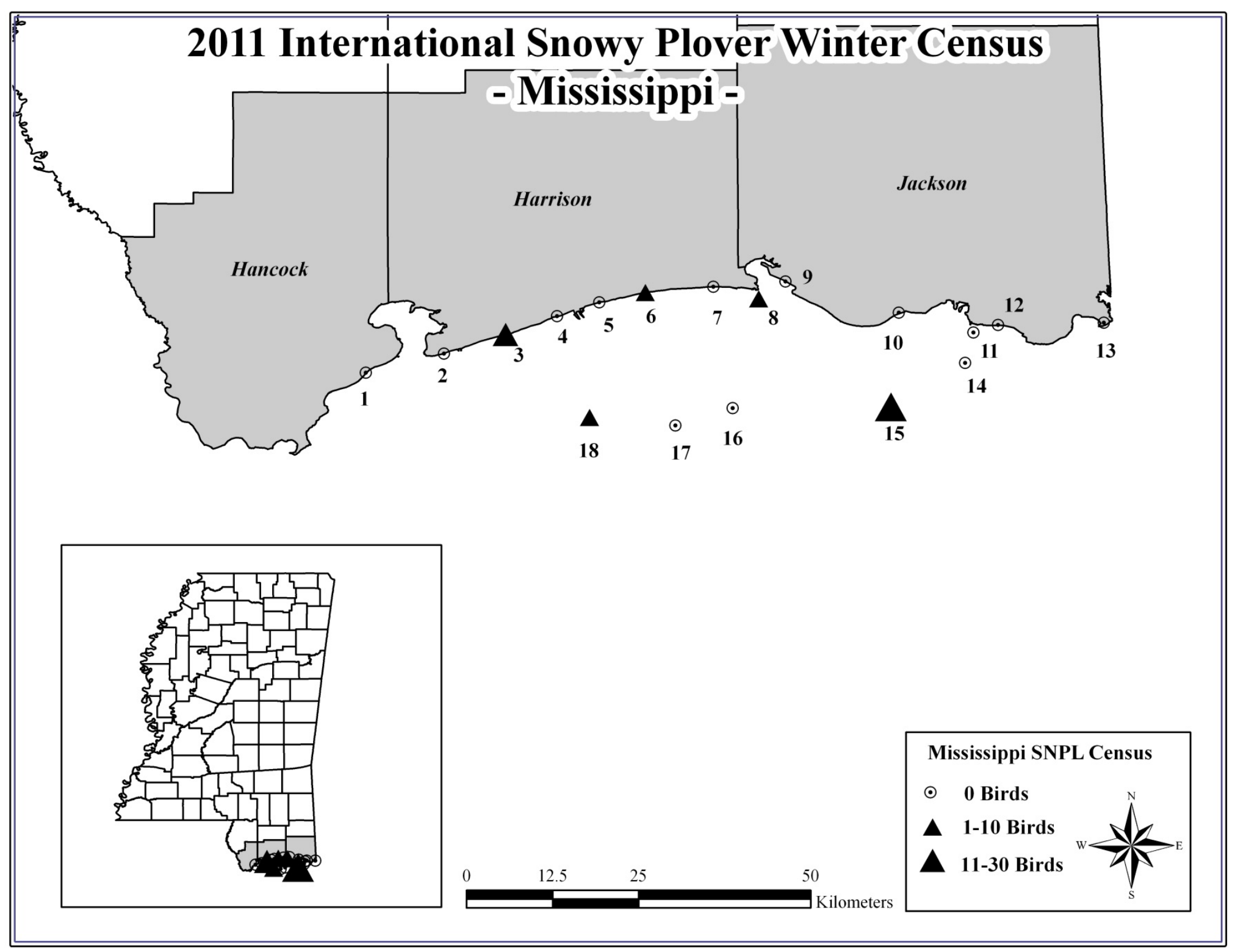


The 2011 International Snowy Plover Winter Census in Mississippi

\begin{tabular}{|c|c|c|c|c|c|c|c|c|c|c|c|}
\hline \multirow{2}{*}{$\begin{array}{l}\text { COUNTY } \\
\text { Hancock }\end{array}$} & \multirow{2}{*}{$\begin{array}{l}\text { SITE NAME } \\
\text { (Lakeshore to Bay St. Louis }\end{array}$} & \multirow{2}{*}{$\frac{\text { MAP\# }}{1}$} & \multirow{2}{*}{$\begin{array}{c}\text { DATE } \\
2 / 9 / 11\end{array}$} & \multirow{2}{*}{$\begin{array}{c}\text { TOTAL } \\
\text { ADULTS } \\
0\end{array}$} & \multirow{2}{*}{$\frac{\mathbf{K M}}{12.9}$} & \multirow{2}{*}{$\begin{array}{l}\text { SITE } \\
\text { DESCRIPTION } \\
\text { II A }\end{array}$} & \multirow{2}{*}{$\begin{array}{l}\text { DISTURBANCE } \\
\text { / CONCERNS } \\
\mathrm{H} \mathrm{D} \mathrm{V}\end{array}$} & \multicolumn{3}{|c|}{$\begin{array}{c}\text { PRIOR YEARS } \\
\text { CENSUSED \& YEARS } \\
\text { SNPL SEEN }^{1} \\
\end{array}$} & \multirow{2}{*}{$\frac{\text { OWNER }}{\mathrm{O}(\mathrm{p})}$} \\
\hline & & & & & & & & 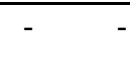 & 01 & 06 & \\
\hline Harrison & Beauvoir Road to Point Cadet $^{3}$ & 7 & 2/9/11 & 0 & 8.1 & II A & H D V & - & 01 & - & $\mathrm{s}(\mathrm{p})$ \\
\hline Harrison & Cat Island ${ }^{3}$ & 18 & $2 / 8 / 11$ & 4 & 22.5 & II III B & H V P & - & - & $\underline{06}$ & $\mathrm{f}, \mathrm{p}$ \\
\hline Harrison & Courthouse Road to Beauvoir Road ${ }^{3}$ & 6 & 2/9/11 & 4 & 7.7 & II A & H D V & - & 01 & 06 & $\mathrm{~s}(\mathrm{p})$ \\
\hline Harrison & Deer Island ${ }^{3}$ & 8 & $2 / 8 / 11$ & 4 & 9.7 & II E & H P S & - & - & 06 & $s(p)$ \\
\hline Harrison & East Ship Island ${ }^{3}$ & 16 & $2 / 8 / 11$ & 1 & 1.6 & II III B & H P S & - & 01 & $\underline{06}$ & $\mathrm{f}$ \\
\hline Harrison & Gulfport Harbor to Courthouse Road ${ }^{3}$ & 5 & 2/9/11 & 0 & 4.3 & II A & H D V & - & 01 & 06 & $\mathrm{~s}(\mathrm{p})$ \\
\hline Harrison & Long Beach Harbor to Gulfport Harbor ${ }^{3}$ & 4 & 2/9/11 & 0 & 4.3 & II A & H D V & - & $\underline{01}$ & 06 & $\mathrm{~s}(\mathrm{p})$ \\
\hline Harrison & Pass Christian Harbor to Long Beach Harbor ${ }^{3}$ & 3 & 2/9/11 & 10 & 10.5 & II A & H D V & - & $\overline{01}$ & $\underline{06}$ & $\mathrm{~s}(\mathrm{p})$ \\
\hline Harrison & Henderson Point to Pass Christian Harbor ${ }^{3}$ & 2 & 2/9/11 & 0 & 4.8 & II A & H D V & - & 01 & 06 & $\mathrm{~s}(\mathrm{p})$ \\
\hline Harrison & West Ship Island $^{3}$ & 17 & $2 / 8 / 11$ & 0 & 9.7 & II III B & H V S P & - & 01 & $\underline{06}$ & $\mathrm{f}$ \\
\hline Jackson & Belle Fontaine Beach ${ }^{3}$ & 10 & 2/9/11 & 0 & 1.6 & II A & H D V & - & 01 & $\overline{06}$ & $\mathrm{p}$ \\
\hline Jackson & Grand Bay National Estuarine Research Reserve ${ }^{3}$ & 13 & $2 / 11 / 11$ & 0 & n.r. & II A & n.r. & - & 01 & 06 & $\mathrm{f}, \mathrm{s}(\mathrm{p})$ \\
\hline Jackson & Horn Island ${ }^{3}$ & 15 & $2 / 8 / 11$ & 26 & 38.6 & II III B & H V P & - & $\underline{01}$ & $\underline{06}$ & $\mathrm{f}$ \\
\hline Jackson & Ocean Springs Beach ${ }^{3}$ & 9 & 2/9/11 & 0 & 3.5 & II A & H D V L & - & 01 & 06 & $\mathrm{~s}(\mathrm{p})$ \\
\hline Jackson & Pascagoula Beach ${ }^{3}$ & 12 & 2/9/11 & 0 & 3.2 & II A & H D V S L & - & - & 06 & $\mathrm{~m}$ \\
\hline Jackson & Round Island $^{3}$ & 14 & 2/8/11 & 0 & 2.4 & II E & n.r. & - & 01 & 06 & $\mathrm{~m}$ \\
\hline Jackson & Singing River Island ${ }^{3}$ & 11 & $2 / 8 / 11$ & 0 & n.r. & II E & $\mathrm{L}$ & - & 01 & 06 & $\mathrm{~m}$ \\
\hline Total & & & & 49 & 145.5 & & & & & & \\
\hline
\end{tabular}




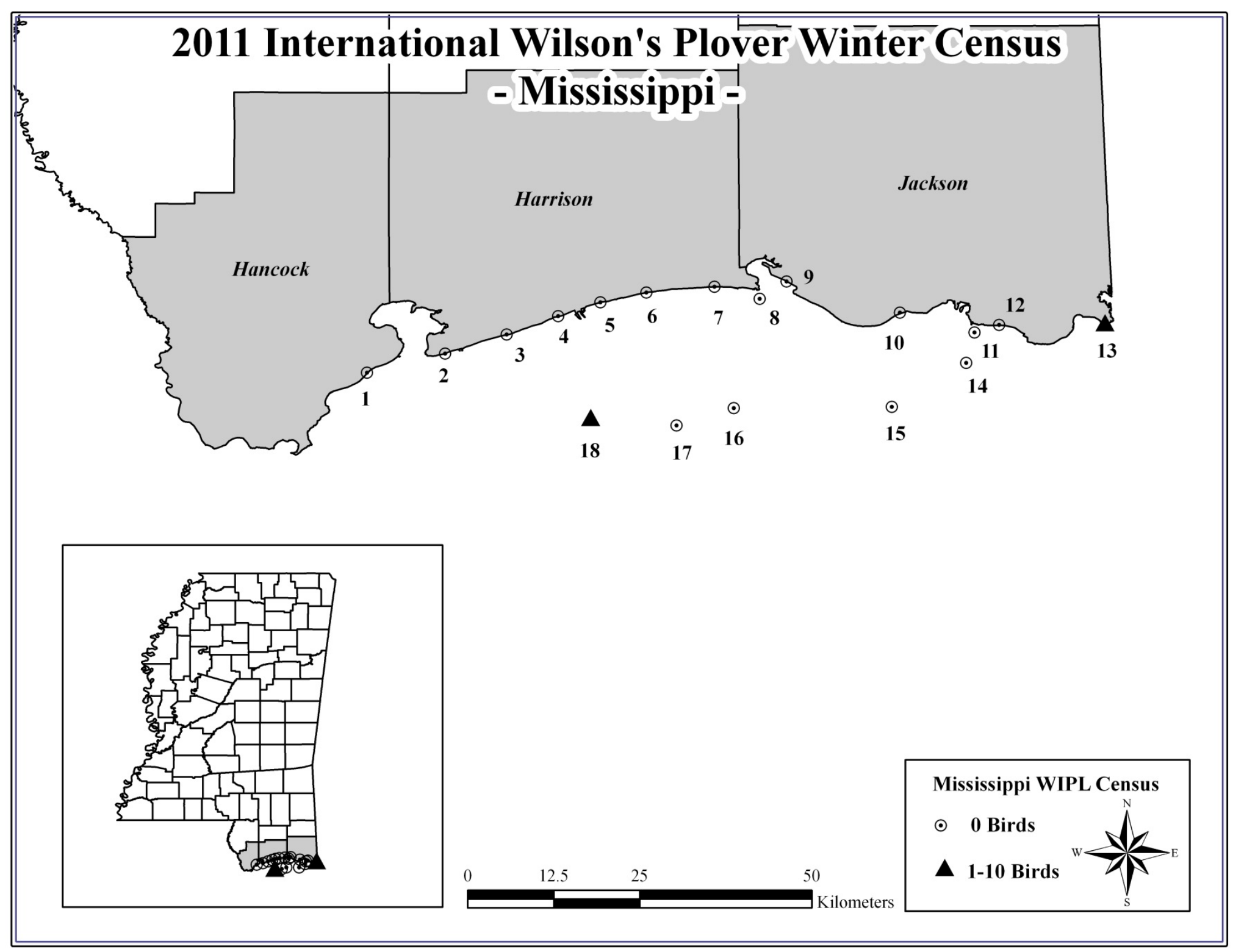


The 2011 International Wilson's Plover Winter Census in Mississippi

\begin{tabular}{|c|c|c|c|c|c|c|c|c|c|c|c|}
\hline \multirow{2}{*}{$\begin{array}{l}\text { COUNTY } \\
\text { Hancock }\end{array}$} & \multirow{2}{*}{$\begin{array}{l}\text { SITE NAME } \\
\text { (Lakeshore to Bay St. Louis }\end{array}$} & \multirow{2}{*}{$\frac{\text { MAP\# }}{1}$} & \multirow{2}{*}{$\begin{array}{c}\text { DATE } \\
2 / 9 / 11\end{array}$} & \multirow{2}{*}{$\begin{array}{c}\text { TOTAL } \\
\text { ADULTS } \\
0\end{array}$} & \multirow{2}{*}{$\frac{\mathbf{K M}}{12.9}$} & \multirow{2}{*}{$\begin{array}{l}\text { SITE } \\
\text { DESCRIPTION } \\
\text { II A }\end{array}$} & \multirow{2}{*}{$\begin{array}{l}\text { DISTURBANCE } \\
\text { / CONCERNS } \\
\mathrm{H} \mathrm{D} \mathrm{V}\end{array}$} & \multicolumn{3}{|c|}{$\begin{array}{c}\text { PRIOR YEARS } \\
\text { CENSUSED \& YEARS } \\
\text { WIPL SEEN }^{1} \\
\end{array}$} & \multirow{2}{*}{$\frac{\text { OWNER }}{\mathrm{O}(\mathrm{p})}$} \\
\hline & & & & & & & & $\overline{-}$ & $\overline{-}$ & 06 & \\
\hline Harrison & Beauvoir Road to Point Cadet $^{3}$ & 7 & 2/9/11 & 0 & 8.1 & II A & H D V & - & - & - & $\mathrm{s}(\mathrm{p})$ \\
\hline Harrison & Cat Island ${ }^{3}$ & 18 & $2 / 8 / 11$ & 1 & 22.5 & II III B & H V P & - & - & 06 & $\mathrm{f}, \mathrm{p}$ \\
\hline Harrison & Courthouse Road to Beauvoir Road ${ }^{3}$ & 6 & 2/9/11 & 0 & 7.7 & II A & H D V & - & - & 06 & $\mathrm{~s}(\mathrm{p})$ \\
\hline Harrison & Deer Island ${ }^{3}$ & 8 & $2 / 8 / 11$ & 0 & 9.7 & II E & H P S & - & - & 06 & $s(p)$ \\
\hline Harrison & East Ship Island ${ }^{3}$ & 16 & $2 / 8 / 11$ & 0 & 1.6 & II III B & H P S & - & - & 06 & $\mathrm{f}$ \\
\hline Harrison & Gulfport Harbor to Courthouse Road ${ }^{3}$ & 5 & 2/9/11 & 0 & 4.3 & II A & H D V & - & - & 06 & $\mathrm{~s}(\mathrm{p})$ \\
\hline Harrison & Long Beach Harbor to Gulfport Harbor ${ }^{3}$ & 4 & 2/9/11 & 0 & 4.3 & II A & H D V & - & - & 06 & $\mathrm{~s}(\mathrm{p})$ \\
\hline Harrison & Pass Christian Harbor to Long Beach Harbor ${ }^{3}$ & 3 & 2/9/11 & 0 & 10.5 & II A & H D V & - & - & 06 & $\mathrm{~s}(\mathrm{p})$ \\
\hline Harrison & Henderson Point to Pass Christian Harbor ${ }^{3}$ & 2 & 2/9/11 & 0 & 4.8 & II A & H D V & - & - & 06 & $\mathrm{~s}(\mathrm{p})$ \\
\hline Harrison & West Ship Island $^{3}$ & 17 & $2 / 8 / 11$ & 0 & 9.7 & II III B & H V S P & - & - & 06 & $\mathrm{f}$ \\
\hline Jackson & Belle Fontaine Beach ${ }^{3}$ & 10 & 2/9/11 & 0 & 1.6 & II A & H D V & - & - & 06 & $\mathrm{p}$ \\
\hline Jackson & Grand Bay National Estuarine Research Reserve ${ }^{3}$ & 13 & $2 / 11 / 11$ & 5 & n.r. & II A & n.r. & - & - & 06 & $\mathrm{f}, \mathrm{s}(\mathrm{p})$ \\
\hline Jackson & Horn Island ${ }^{3}$ & 15 & $2 / 8 / 11$ & 0 & 38.6 & II III B & H V P & - & - & 06 & $\mathrm{f}$ \\
\hline Jackson & Ocean Springs Beach ${ }^{3}$ & 9 & 2/9/11 & 0 & 3.5 & II A & H D V L & - & - & 06 & $\mathrm{~s}(\mathrm{p})$ \\
\hline Jackson & Pascagoula Beach ${ }^{3}$ & 12 & $2 / 9 / 11$ & 0 & 3.2 & II A & H D V S L & - & - & 06 & $\mathrm{~m}$ \\
\hline Jackson & Round Island $^{3}$ & 14 & 2/8/11 & 0 & 2.4 & II E & n.r. & - & - & 06 & $\mathrm{~m}$ \\
\hline Jackson & Singing River Island ${ }^{3}$ & 11 & $2 / 8 / 11$ & 0 & n.r. & II E & $\mathrm{L}$ & - & - & 06 & $\mathrm{~m}$ \\
\hline Total & & & & 6 & 145.5 & & & & & & \\
\hline
\end{tabular}




\section{The 2011 International Piping Plover Winter Census in Louisiana}

Michael Seymour

Louisiana Department of Wildlife and Fisheries Louisiana Natural Heritage Program

PO Box 98000

Baton Rouge, LA 70898

225-763-3554

mseymour@wlf.la.gov

Eleven surveyors in seven parties spent approximately 27 total party hours surveying about $94 \mathrm{~km}$ at 13 sites along the Louisiana coast and counted 86 Piping Plovers. The number of sites surveyed was greatly reduced from 2006 (13 sites in 2011 compared to 33 sites in 2006) and Piping Plover numbers were much lower in 2011 compared to 2006 (86 vs. 226). Thirteen sites in the Southeastern portion of the state which held 143 Piping Plovers during the 2006 Census could not be surveyed in 2011. Elsewhere in the state, coverage was comparable to 2006 and numbers of Piping Plovers were similar (83 birds in 2006 vs. 86 in 2011).

The Louisiana coastal zone can be a challenge to survey but the greatest hindrance to surveys in 2011 was the Deepwater Horizon oil spill. In Louisiana, road access points to sites are few and far between and many sites must be surveyed by boat. Some areas simply could not be accessed for surveys (e.g., the Chandeleur Island chain) during the survey window. However, the oil spill produced unforeseen access issues for several sites, particularly those historically utilized by Piping Plovers (e.g., much of SE Louisiana). In the case of areas around the oil spill impact zone, NRDA operations or oil spill response operations precluded the Louisiana Department of Wildlife and Fisheries's survey effort. At some time in the future, the data collected for NRDA will be released to both the LDWF and the USFWS's Field Office, and there will no longer be data gaps.
The 2011 survey effort would not have been possible without the assistance of the Louisiana Department of Wildlife and Fisheries and its many collaborators who provided surveyor time, boats, 4-wheel drive trucks and ATVs. In particular, we would like to thank the US Fish and Wildlife Service (USFWS), the National Audubon Society, Louisiana State University, LSU Museum of Natural Science, BaratariaTerrebonne National Estuary Program, Louisiana Bird Resource Center, and private citizens.

Comparison of Census Numbers

\begin{tabular}{|l|c|c|c|c|c|}
\hline Species & 1991 & 1996 & 2001 & 2006 & 2011 \\
\hline $\begin{array}{l}\text { Piping } \\
\text { Plover }\end{array}$ & 750 & 420 & 511 & 226 & 86 \\
\hline $\begin{array}{l}\text { Snowy } \\
\text { Plover }\end{array}$ & n.r. & n.r. & 36 & 207 & 74 \\
\hline $\begin{array}{l}\text { Wilson's } \\
\text { Plover }\end{array}$ & n.r. & n.r. & n.r. & 63 & 3 \\
\hline
\end{tabular}




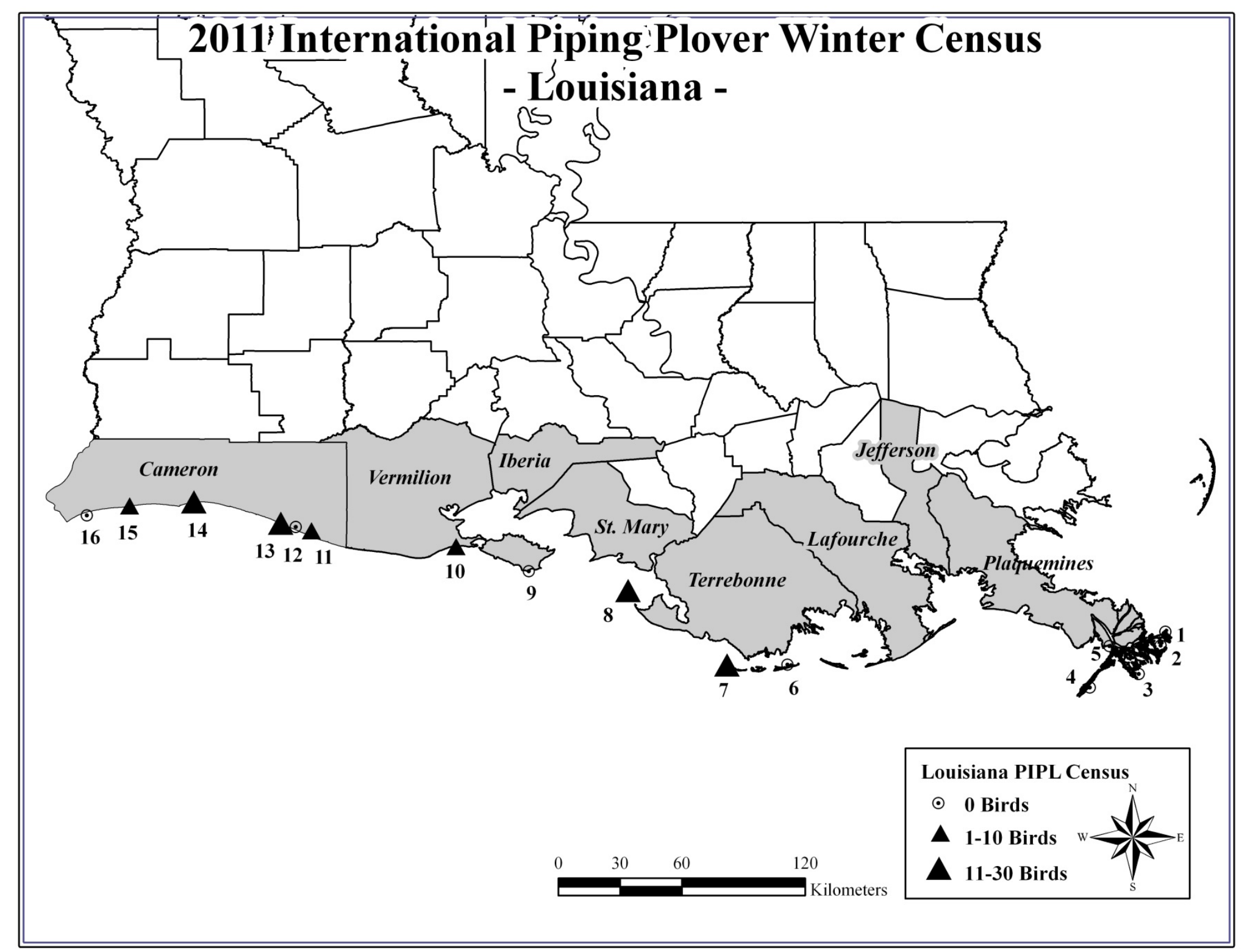


The 2011 International Piping Plover Winter Census in Louisiana

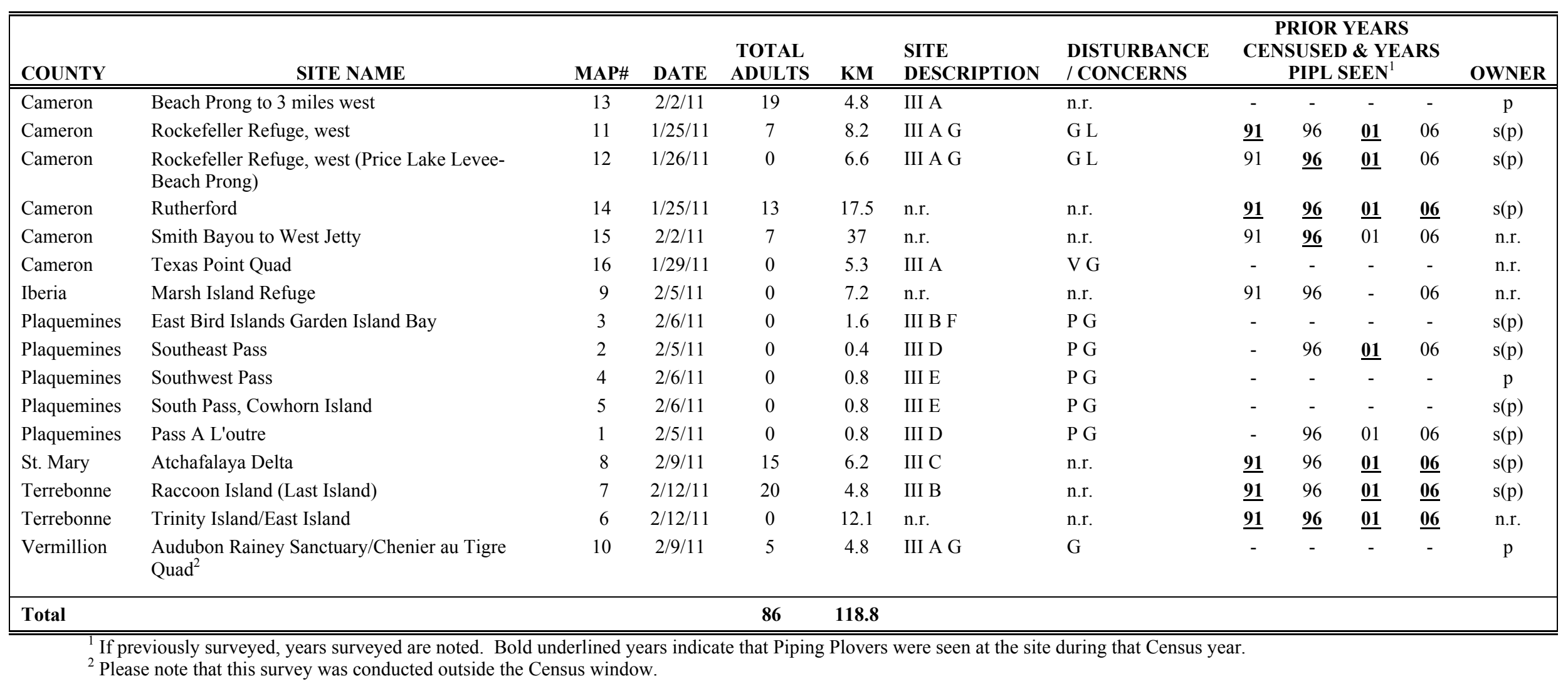




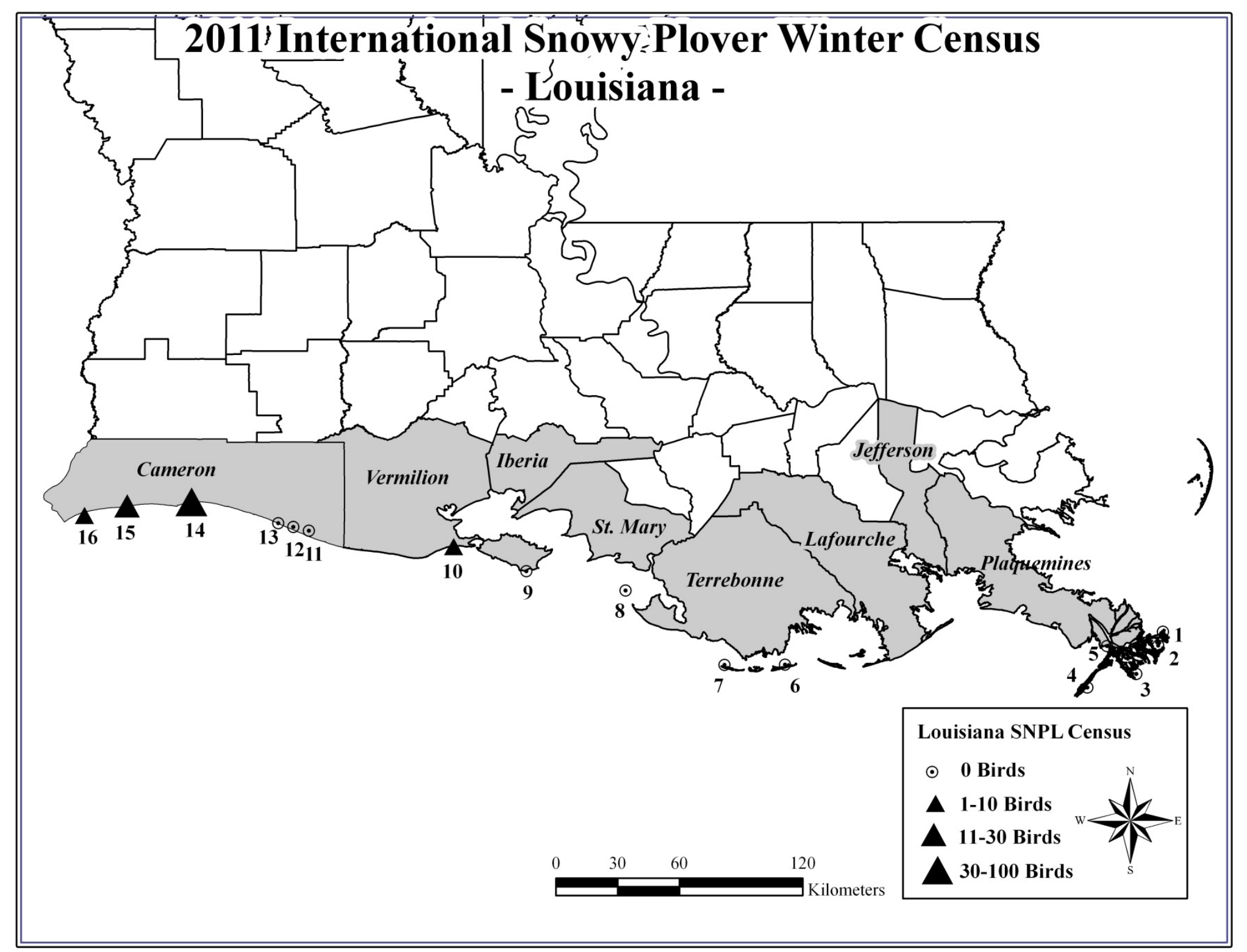


The 2011 International Snowy Plover Winter Census in Louisiana

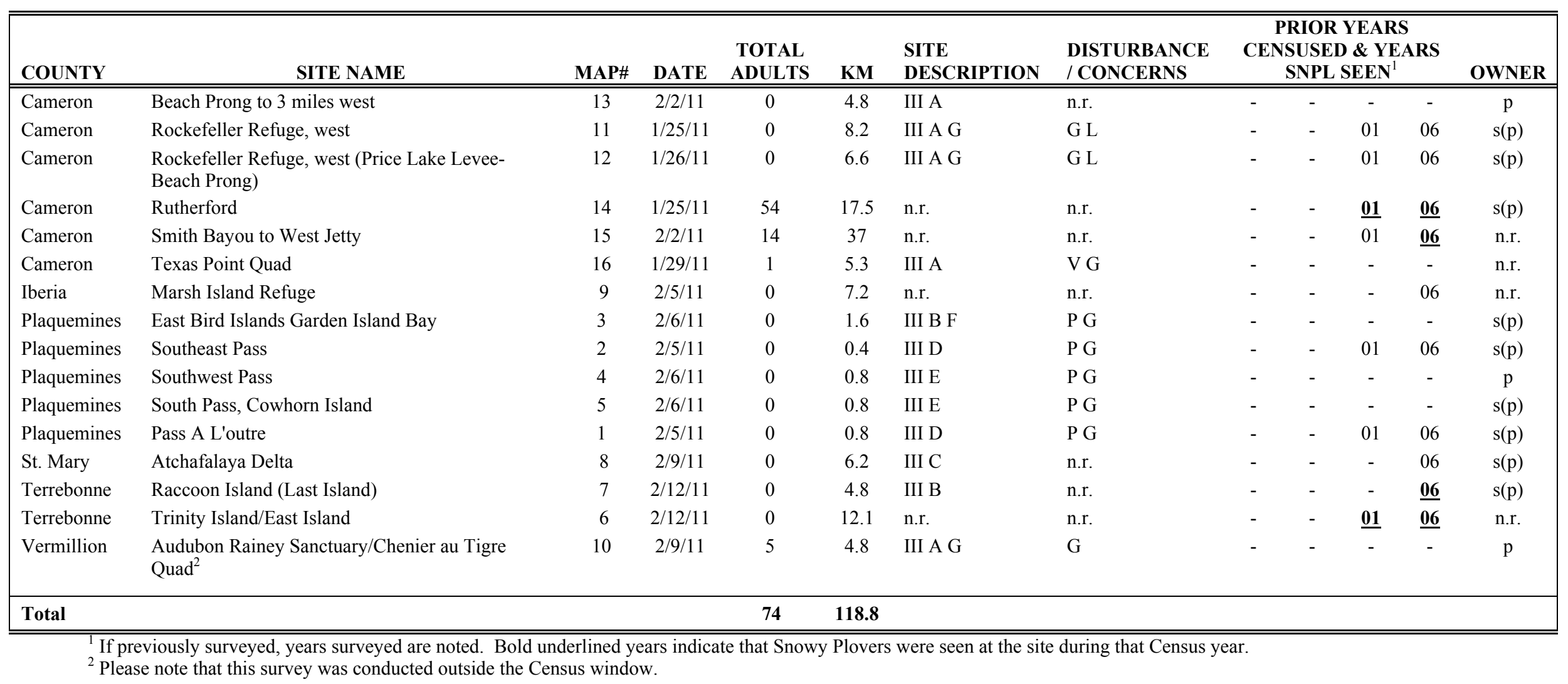




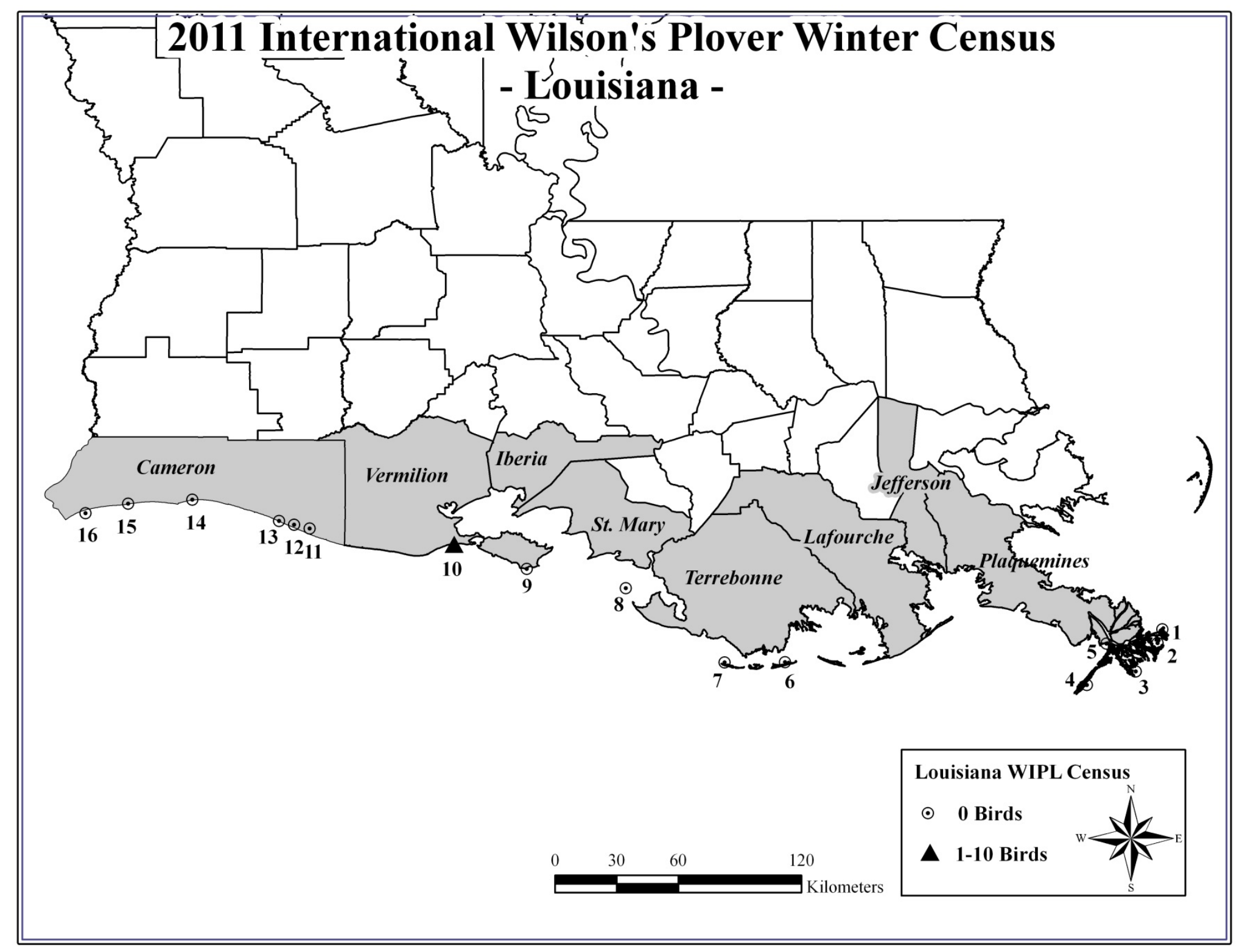


The 2011 International Wilson's Plover Winter Census in Louisiana

\begin{tabular}{|c|c|c|c|c|c|c|c|c|c|c|c|c|}
\hline COUNTY & SITE NAME & MAP\# & DATE & $\begin{array}{c}\text { TOTAL } \\
\text { ADULTS } \\
\end{array}$ & $\mathbf{K M}$ & $\begin{array}{l}\text { SITE } \\
\text { DESCRIPTION } \\
\end{array}$ & $\begin{array}{l}\text { DISTURBANCE } \\
\text { / CONCERNS } \\
\end{array}$ & \multicolumn{4}{|c|}{$\begin{array}{c}\text { PRIOR YEARS } \\
\text { CENSUSED \& YEARS } \\
\text { WIPL SEEN }^{1} \\
\end{array}$} & \multirow{2}{*}{$\frac{\text { OWNER }}{\mathrm{p}}$} \\
\hline Cameron & Beach Prong to 3 miles west & 13 & $2 / 2 / 11$ & 0 & 4.8 & III A & n.r. & - & - & - & - & \\
\hline Cameron & Rockefeller Refuge, west & 11 & $1 / 25 / 11$ & 0 & 8.2 & III A G & G L & - & - & - & 06 & $\mathrm{~s}(\mathrm{p})$ \\
\hline Cameron & $\begin{array}{l}\text { Rockefeller Refuge, west (Price Lake Levee- } \\
\text { Beach Prong) }\end{array}$ & 12 & $1 / 26 / 11$ & 0 & 6.6 & III A G & G L & - & - & - & 06 & $\mathrm{~s}(\mathrm{p})$ \\
\hline Cameron & Rutherford & 14 & $1 / 25 / 11$ & 0 & 17.5 & n.r. & n.r. & - & - & - & $\underline{06}$ & $\mathrm{~s}(\mathrm{p})$ \\
\hline Cameron & Smith Bayou to West Jetty & 15 & $2 / 2 / 11$ & 0 & 37 & n.r. & n.r. & - & - & - & 06 & n.r. \\
\hline Cameron & Texas Point Quad & 16 & $1 / 29 / 11$ & 0 & 5.3 & III A & V G & - & - & - & - & n.r. \\
\hline Iberia & Marsh Island Refuge & 9 & $2 / 5 / 11$ & 0 & 7.2 & n.r. & n.r. & - & - & - & 06 & n.r. \\
\hline Plaquemines & East Bird Islands Garden Island Bay & 3 & $2 / 6 / 11$ & 0 & 7.2 & III B F & P G & - & - & - & - & $\mathrm{s}(\mathrm{p})$ \\
\hline Plaquemines & Southeast Pass & 2 & $2 / 5 / 11$ & 0 & 1.6 & III D & P G & - & - & - & $\underline{06}$ & $\mathrm{~s}(\mathrm{p})$ \\
\hline Plaquemines & Southwest Pass & 4 & $2 / 6 / 11$ & 0 & 0.8 & III E & P G & - & - & - & - & $\mathrm{p}$ \\
\hline Plaquemines & South Pass, Cowhorn Island & 5 & $2 / 6 / 11$ & 0 & 0.4 & III E & P G & - & - & - & - & $\mathrm{s}(\mathrm{p})$ \\
\hline Plaquemines & Pass A L'outre & 1 & $2 / 5 / 11$ & 0 & 0.8 & III D & P G & - & - & - & 06 & $\mathrm{~s}(\mathrm{p})$ \\
\hline St. Mary & Atchafalaya Delta & 8 & $2 / 9 / 11$ & 0 & 0.8 & III C & n.r. & - & - & - & 06 & $\mathrm{~s}(\mathrm{p})$ \\
\hline Terrebonne & Raccoon Island (Last Island) & 7 & $2 / 12 / 11$ & 0 & 6.2 & III B & n.r. & - & - & - & 06 & $\mathrm{~s}(\mathrm{p})$ \\
\hline Terrebonne & Trinity Island/East Island & 6 & $2 / 12 / 11$ & 0 & 12.1 & n.r. & n.r. & - & - & - & 06 & n.r. \\
\hline Vermillion & $\begin{array}{l}\text { Audubon Rainey Sanctuary/Chenier au Tigre } \\
\text { Quad }^{2}\end{array}$ & 10 & 2/9/11 & 3 & 4.8 & III A G & G & - & - & - & - & $\mathrm{p}$ \\
\hline Total & & & & 3 & 118. & & & & & & & \\
\hline
\end{tabular}

${ }^{1}$ If previously surveyed, years surveyed are noted. Bold underlined years indicate that Wilson's Plovers were seen at the site during that Census year.

${ }^{2}$ Please note that this survey was conducted outside the Census window. 


\section{The 2011 International Piping Plover Winter Census in Texas}

As in 2001 and 2006, the Texas coast was split into three Census regions. The upper Texas coast covers habitat from the Louisiana border to Matagorda County. The central Texas coast includes Calhoun to Kenedy Counties. The third region, lower Texas, includes the remaining two counties, Willacy and Cameron. The total number of Piping Plovers estimated during the 2011 Census of Texas was 2,145. Additionally, 4,981 Snowy Plovers and 37 Wilson's Plovers were sighted on Texas beaches during the 2011 Census.

\section{Comparison of Census Numbers}

\begin{tabular}{|l|c|c|c|c|c|}
\hline Species & 1991 & 1996 & 2001 & 2006 & 2011 \\
\hline $\begin{array}{l}\text { Piping } \\
\text { Plover }\end{array}$ & 1,904 & 1,333 & 1,042 & 2,090 & 2,145 \\
\hline $\begin{array}{l}\text { Snowy } \\
\text { Plover }\end{array}$ & n.r. & n.r. & 690 & 1,340 & 4,981 \\
\hline $\begin{array}{l}\text { Wilson's } \\
\text { Plover }\end{array}$ & n.r. & n.r. & n.r. & 85 & 37 \\
\hline
\end{tabular}

\section{Upper Texas}

Donna Anderson

U.S. Fish and Wildlife Service

17629 El Camino Real, Suite 211

Houston, TX 77058

281-286-8282

Donna_anderson@fws.gov

Between January 24 and February 27, 2011, 19 people participated in the $5^{\text {th }}$ International Piping Plover Winter Census along the upper Texas Coast. The upper Texas coast region encompasses five bay systems: East Galveston Bay, West Galveston Bay, Chocolate Bay, Christmas Bay and Matagorda Bay.
The upper Texas coast experienced unusually cold temperatures and windy conditions caused by a series of low pressures beginning late January and lasting through mid-February. There was great concern that surveys would overly stress the plovers. Subsequently, we requested an extension of time to complete surveys. These conditions caused low tides for most of the survey period and exposed many tidal flats that are not normally seen.

Survey efforts by 19 participants spanned 408 $\mathrm{km}$ (253.5 miles) of the upper coast including bay shorelines, margins of bay spoil islands and beaches along the Gulf of Mexico. Surveyors conducted the census by foot, all terrain vehicle, boat and airboat. The low tides made surveying effort extremely challenging to get around in the bays. Due to the increased exposed tidal flats, portions of the bays were not surveyed.

A total of 254 Piping Plovers were seen during the 2011 Census in north Texas. The 2011 survey results were down significantly from previous census year totals. Due to the inclement weather experienced along the upper Texas coast during the survey, we are not sure if the low count numbers reflect a decrease in overall population, if the birds moved further south, or if the birds were able to find locations not normally surveyed and were just missed during the count. Pedestrians, vehicle traffic, and dogs were observed at some of the sites during the Census. We were unable to survey a few sites (Lavaca Bay, Carancahua, Tres Palacios (Oyster Lake area), West Matagorda Pensiula beach side, and Pelican Island; West and East Galveston Bay sandbar and placement areas could have been surveyed more thoroughly).

The lack of good quality beach habitat limits Piping Ploves along the upper Texas coast. From Texas Point NWR through a good portion of Galveston Island, the beaches are eroding due to increased storm intensity, frequency, 
development and human disturbance (vehicle traffic). The Service is working with partners to cost share the re-nourishment of beach along the upper portions of the Texas coast. The City of Galveston re-nourishes the beaches in front of the seawall which may not allow for adequate prey sources for the plovers. Additionally, the Texas General land Office is looking to mine sand from San Luis Pass. This area has provided habitat for many shorebirds.

\section{Central Texas}

Robyn Cobb and Loren Gallo U.S. Fish and Wildlife Service 6300 Ocean Drive, Campus Box 338 Corpus Christi, TX 78412 361-994-9005

Piping Plovers, Snowy Plovers, and Wilson's Plovers were counted on areas of suitable habitat within the central Texas coast between January $25^{\text {th }}$ and February $16^{\text {th }}, 2011$, for the $5^{\text {th }}$ International Piping Plover Winter Census. The central Texas coast, for purposes of this international effort, extends from Calhoun County in the north to Kenedy County in the south. Four main bay systems including San Antonio, Aransas, and Corpus Christi bays, and the Upper Laguna Madre, as well as numerous secondary and tertiary bay systems, make up this part of the Texas coast.

A total of 850 Piping Plovers, 1,522 Snowy Plovers, and 8 Wilson's Plovers were reported within the central Texas coast during the 2011 census. The 2011 Piping Plover numbers were similar to the 933 seen in 1991 when an airboat was used to survey the entire bay shoreline of the Texas barrier islands. The $1996(\mathrm{n}=611)$ and $2001(n=277)$ Piping Plovers numbers were much lower than the counts from 1991, 2006, and this year. The 2011 number of 850 Piping Plovers is approximately 230 birds less than what was reported from the central coast in $2006(n=1,080)$. One of the biggest differences in numbers was seen in the Espiritu Santo Bay system, west of Matagorda Island, where 427 Piping Plovers were counted in 2006 versus 132 seen in 2011. Snowy Plover numbers were the highest documented to date from any of the international wintering plover census efforts in this region. The number of Wilson's Plovers found during this census was negligible.

For the 2011 census, approximately $834.23 \mathrm{~km}$ (518.37 miles) were surveyed, including bay shorelines, islands within the bay systems, seasonally-exposed mud/sand flats within the bays, and the Gulf of Mexico beach. These areas were surveyed with the help of 31 participants over a 3-week period. The 2-week prescribed time frame for the census was exceeded because of unfavorable weather conditions that prohibited boat surveys, and in some cases precluded even vehicle and foot travel. Surveys were conducted using boats, trucks, foot travel, all-terrain vehicles, and one airboat.

Surveys for the three species were conducted at all sites known to be important Piping Plover habitat on the central Texas coast. Due to the immense effort, this census concentrated on those areas known to support Piping Plovers and Snowy Plovers were likely missed at some mainland sites. Participants surveyed all habitats within a given bay system in a one-day period to minimize double-counting. However, because some plover habitat sites in one bay system may occur in close proximity to sites in the adjoining system there was potential for some birds being either double-counted or missed completely. Weather conditions that were unsuitable for surveys further complicated scheduling and increased this potential overlap.

The largest areas excluded from the 2011 effort based on a lack of previous Piping Plover occurrence were the mainland shorelines surrounding Nueces Bay and Baffin Bay, and 
the Laguna Madre shoreline of Corpus Christi (known as Flour Bluff). In 2011, shallow water affected the ability to survey portions of bayside San Jose and Matagorda Islands, and some parts of the mud/sand flats between Padre Island National Seashore (PINS) and the Gulf Intracoastal Waterway (GIWW). Boat access to Nighthawk Bay flats, a known high use area for Piping Plovers, was also difficult and no plovers were seen on the day that area was surveyed. However, concentrations of Piping and Snowy Plovers have been documented using this area on a regular basis during the entire fall and winter of 2010/2011 (Tara Imlay, Virginia Polytechnic Institute, pers. comm. 2011).

A few new areas were surveyed during the 2011 census including the bay shore of southern North Padre Island (between the Land Cut and Mansfield Channel), the island (Decros Point) and surrounding shoals and flats just north of Matagorda Island, and the northern bay shoreline of San Jose Island. Extremely shallow water and abysmal conditions (high wind and turbid water) precluded observations of much of the south shoreline of North Padre Island yet 175 Piping Plovers and 36 Snowy Plovers were found at this site. The Gulf beach opposite this shoreline was surveyed by vehicle and adjacent to the north shore of Mansfield Channel yielded 114 Snowy Plovers observations. Decros Point's southern end was surveyed more comprehensively than prior efforts but no plovers were located. The northern bay shore of San Jose Island was surveyed by boat this year for the first time since 1991, but only 6 Piping Plovers and 6 Snowy Plovers were observed.

As was true in the 2006 census, the vast majority of Piping Plovers were located within the bay systems on barrier island bay shorelines and seasonally-exposed mud/sand flats. Bay water levels were very low during all of the 2011 census period making bay habitats available to foraging birds most of the time. Although $259.10 \mathrm{~km}$ (161 miles) of Gulf beach shoreline were surveyed, only 119 plovers (14 Piping Plovers and 105 Snowy Plovers) were found on the beach this year. Thirty-five Piping Plovers were also found on mainland bay shorelines at 4 sites; all of which have past records of Piping Plover occurrence. With very few exceptions, Piping Plovers were found in groups and not as individuals. Piping Plovers did occur in small groups at a number of sites, but were also found in several large aggregations where as many as 231 were together on one emergent mud flat.

The reasons for lower Piping Plover numbers in 2011 than 2006 are unknown. The survey effort in 2011 was as intensive as in 2006 and even covered new, previously unsurveyed sites. The lower number of Piping Plovers may have been partially attributable to unsuccessful survey results on days when winds associated with cold fronts inundated habitat that surveyors did visit, while simultaneously exposing other suitable habitat not surveyed on those days.

The one-day census provides only a snap-shot of any given area and has the potential to cause an underestimate of populations. In the future, more intense annual surveys of the most important sites (as defined by census and other survey data showing consistent use by larger groups of birds) might help to provide better population estimates. In the Texas central coast region, the results of the 5 international censuses, in conjunction with other information that has been compiled over time, has produced a fairly consistent picture of the significant Piping Plover sites that should receive this focused attention. 


\section{Lower Texas}

Margo Zdravkovic

Coastal Bird Conservation/Conservian

PO Box 430229

Big Pine Key, FL 33043

MargoZ@Coastalbird.org

561-504-4251

Biologists from Conservian/Coastal Bird Conservation conducted a late winter, nonbreeding survey of the Lower Laguna Madre Region of Texas from January 17 to February 15. A total of 1,047 Piping Plovers were observed during the survey period. All Piping Plovers with the exception of 21 birds were documented between January 27 and January 30,2011 . This total is higher than the 2001 or 2006 Census. The largest contiguous group of 557 Piping Plovers was documented on January 30 on South Padre Island at the Mansfield Channel (9 additional birds were seen just southwest of the channel).

During the 2011 late winter survey we also documented 3,295 Snowy Plovers and 8 Wilson's Plovers. All but 241 of the Snowy Plovers were located on South Padre Island during the same four day period.

While the Census is intended to be a count of wintering birds we found multiple Snowy Plover pairs defending territories at the inland lake sites in mid-February. This indicates that a January/February census window is likely too late to reflect exclusively wintering Snowy Plover populations in the Lower Laguna Madre Region of Texas.
We used multiple survey teams working simultaneously to cover all known and potential winter Piping Plover habitat in the region during good survey conditions. Surveys were conducted on foot but ATVs and airboats were used to access remote areas. Unlike more northerly locations in Texas, we were able to survey during mild weather with low winds and temperatures in the 60 's. 


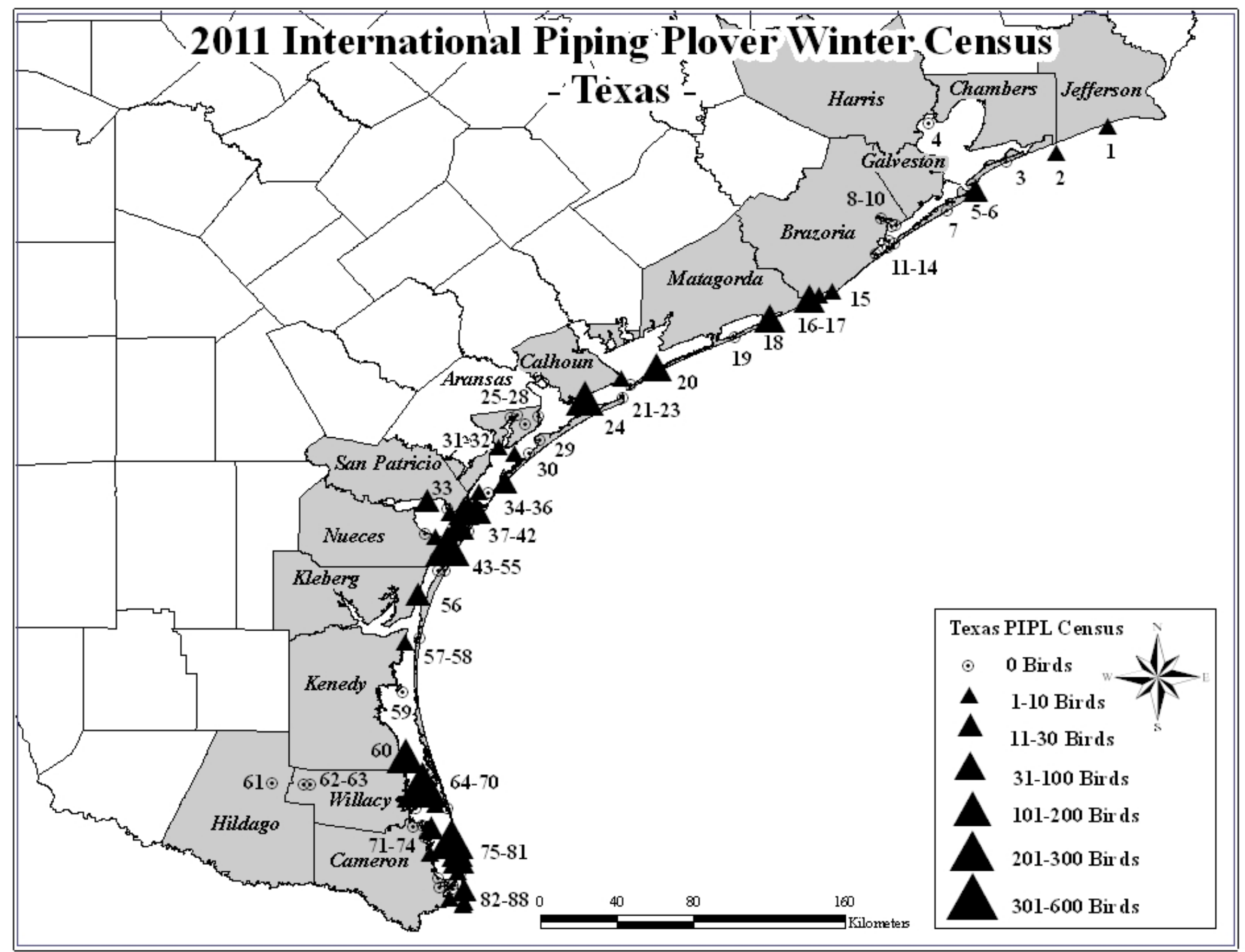


The 2011 International Piping Plover Winter Census in Texas

\begin{tabular}{|c|c|c|c|c|c|c|c|c|c|c|c|c|}
\hline \multirow{2}{*}{$\begin{array}{l}\text { COUNTY } \\
\text { Aransas }\end{array}$} & \multirow{2}{*}{$\begin{array}{r}\text { SITE NAME } \\
\text { Aransas Bay, Goose Island }^{33}\end{array}$} & \multirow{2}{*}{ MAP\# } & \multirow{2}{*}{$\begin{array}{c}\text { DATE } \\
1 / 1 / 11\end{array}$} & \multirow{2}{*}{$\begin{array}{c}\text { TOTAL } \\
\text { ADULTS } \\
4\end{array}$} & \multirow{2}{*}{$\frac{\mathbf{K M}}{20.8}$} & \multirow{2}{*}{$\begin{array}{l}\text { SITE } \\
\text { DESCRIPTION } \\
\text { II D E }\end{array}$} & \multirow{2}{*}{$\begin{array}{l}\text { DISTURBANCE } \\
\text { / CONCERNS } \\
\text { H F G L }\end{array}$} & \multicolumn{4}{|c|}{$\begin{array}{c}\text { PRIOR YEARS } \\
\text { CENSUSED \& YEARS } \\
\text { PIPL SEEN }^{1} \\
\end{array}$} & \multirow{2}{*}{$\begin{array}{c}\text { OWNER } \\
\mathrm{s}(\mathrm{p})\end{array}$} \\
\hline & & & & & & & & - & 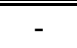 & - & $\underline{06}$ & \\
\hline Aransas & Burgentine Lake (Aransas NWR; W Blackjack) ${ }^{33}$ & 26 & $2 / 7 / 11$ & 0 & 3.8 & II A & $\mathrm{G}$ & - & - & - & 06 & $\mathrm{f}$ \\
\hline Aransas & E Blackjack (Aransas NWR Complex) ${ }^{33}$ & 28 & $2 / 7 / 11$ & 0 & 5.3 & II A & $\mathrm{H} \mathrm{G}$ & $\underline{91}$ & 96 & 01 & - & f \\
\hline Aransas & Fulton to Ingleside Point (Mainland) & 37 & $1 / 25 / 11$ & 0 & 42.6 & II A & $\mathrm{G}$ & $\underline{91}$ & $\underline{96}^{2}$ & 01 & 06 & $s(p), p$ \\
\hline Aransas & $\begin{array}{l}\text { N San Jose Island, Bayside (Big Island to Cedar } \\
\text { Bayou) }\end{array}$ & 32 & $1 / 28 / 11$ & 6 & 22.5 & II B & H G L & $\underline{91}^{3}$ & - & - & - & $\mathrm{s}(\mathrm{p}), \mathrm{p}$ \\
\hline Aransas & San Jose Island (Gulf Side) & 34 & $1 / 26 / 11$ & 14 & 64.4 & III B & n.r. & $\underline{91}^{4}$ & $\underline{96}^{5}$ & $\underline{01}$ & $\underline{06}$ & $\mathrm{p}$ \\
\hline Aransas & San Jose Island bayside (N Pass) & 36 & $1 / 28 / 11$ & 0 & 2.0 & II B & n.r. & $\underline{91}^{6}$ & $\underline{96}$ & 01 & $\underline{06}$ & $\mathrm{~s}(\mathrm{p})$ \\
\hline Aransas & Tatton Unit (Aransas NWR) ${ }^{33}$ & 25 & $2 / 7 / 11$ & 0 & 3.7 & II A & $\mathrm{G}$ & 91 & - & - & $\overline{06}$ & $\mathrm{f}$ \\
\hline Brazoria & Alligator Point ${ }^{33}$ & 9 & $2 / 11 / 11$ & 0 & 4.8 & II C D & S G L & - & - & - & - & $\mathrm{s}(\mathrm{p})$ \\
\hline Brazoria & Chocolate Bayou ${ }^{33}$ & 8 & $2 / 11 / 11$ & 0 & 4.8 & II C D & S G L & - & - & - & - & $\mathrm{s}(\mathrm{p})$ \\
\hline Brazoria & Christmas/Drum Bay ${ }^{32,33}$ & 14 & $2 / 15 / 11$ & 0 & 26.6 & II III IV A D E F & $\mathrm{G}$ & - & - & - & - & $\mathrm{f}, \mathrm{s}(\mathrm{p})$ \\
\hline Brazoria & Cold Pass & 13 & $1 / 27 / 11$ & 0 & 3.2 & II G & B F G L & - & - & - & - & $\mathrm{s}(\mathrm{p}), \mathrm{c}$ \\
\hline Brazoria & Sargent Beach (East) & 16 & $1 / 28 / 11$ & 10 & 6.4 & III A & none & $\underline{91}^{7}$ & 96 & $\underline{01}$ & - & $s(p)$ \\
\hline Brazoria & Sargent Beach (West) & 17 & $1 / 27 / 11$ & 38 & 4.2 & III IV A D E F & B G & $\overline{91}^{7}$ & 96 & $\underline{01}$ & $\underline{06}$ & $\mathrm{~s}(\mathrm{p})$ \\
\hline Brazoria & West Bay Bird Island & 12 & $1 / 27 / 11$ & 0 & 1.1 & II B E & G L & - & - & - & - & $\mathrm{s}(\mathrm{p})$ \\
\hline Brazoria & West Bay Mooring Area BU Site ${ }^{33}$ & 10 & $2 / 11 / 11$ & 0 & 4.8 & II C D & S G L & - & - & - & 06 & $\mathrm{~s}(\mathrm{p})$ \\
\hline Brazoria & Wolf Island & 15 & $1 / 28 / 11$ & 7 & 6.4 & III B & none & $\underline{91}$ & $\underline{96}$ & $\underline{01}$ & $\underline{06}$ & $\mathrm{~s}(\mathrm{p})$ \\
\hline Calhoun & $\begin{array}{l}\text { Cedar Bayou, Matagorda Island NWR (Gulf } \\
\text { Beach Route) }\end{array}$ & 30 & $2 / 7 / 11$ & 0 & 13.6 & I II B & $\mathrm{G}$ & $\underline{91}$ & $\underline{96}^{5}$ & $\underline{01}$ & $\underline{06}$ & $\mathrm{f}$ \\
\hline Calhoun & $\begin{array}{l}\text { Decros Point including Pass Cavallo and } \\
\text { Sundown Island }\end{array}$ & 22 & $2 / 14 / 11$ & 0 & 45.2 & II III IV B F & H B S G & $\underline{91}^{8}$ & - & $\underline{01}$ & $\underline{06}$ & $\mathrm{~s}(\mathrm{p}), \mathrm{p}$ \\
\hline Calhoun & Matagorda Island Inner Levee System ${ }^{33}$ & 29 & $2 / 7 / 11$ & 0 & 15.7 & II B & $\mathrm{G}$ & - & 96 & - & 06 & $f$ \\
\hline Calhoun & Matagorda Island NWR Beach (J-Hook) ${ }^{33}$ & 23 & $2 / 7 / 11$ & 0 & 11.4 & I II A & $\mathrm{G}$ & $\underline{91}^{9}$ & $\underline{96}^{5}$ & 01 & $\underline{06}$ & $\mathrm{f}$ \\
\hline Calhoun & Matagorda Island NWR Gulf Beach ${ }^{33}$ & 27 & $2 / 7 / 11$ & 0 & 33.0 & I B & $\mathrm{G}$ & $\underline{91}^{9}$ & $\underline{96}^{5}$ & $\underline{01}$ & $\underline{06}$ & $\mathrm{f}$ \\
\hline Calhoun & Port O'Conner Shoreline & 21 & $2 / 1 / 11$ & 6 & 2.0 & V A & S G L & 91 & - & 01 & $\underline{06}$ & $\mathrm{~m}$ \\
\hline Calhoun & $\begin{array}{l}\text { Welder Flats, Shoalwater Bay, The Lagoon- } \\
\text { Dewberry Island }{ }^{33}\end{array}$ & 24 & $2 / 8 / 11$ & 132 & 85.3 & II A E G & H B F G L & 91 & - & $\underline{01}$ & $\underline{06}$ & $\mathrm{p}$ \\
\hline Cameron & Bahia Grande & 83 & $2 / 3 / 11$ & 0 & 30.6 & V G & H F S & - & 96 & $\underline{01}$ & 06 & $\mathrm{f}$ \\
\hline Cameron & Boca Chica Beach ${ }^{33}$ & 87 & $1 / 18 / 11$ & 1 & 4.7 & III V A & H D V F G & $\underline{91}$ & 96 & 01 & 06 & $\mathrm{~s}(\mathrm{p})$ \\
\hline Cameron & Brazos Island Beach \& Flats ${ }^{33}$ & 85 & $1 / 21 / 11$ & 29 & 8.7 & III V A & H D V F G & $\underline{91}$ & 96 & 01 & 06 & $\mathrm{f}, \mathrm{s}(\mathrm{p})$ \\
\hline Cameron & Brownsville Ship Channel Spoil Cells ${ }^{33}$ & 84 & $1 / 23 / 11$ & 0 & 4.5 & III V B & V F G & 91 & 96 & - & 06 & $\mathrm{~s}(\mathrm{p}), \mathrm{m}$ \\
\hline Cameron & Buena Vista Ranch & 74 & $2 / 6 / 11$ & 0 & 9.7 & II A & V A G & $\underline{91}^{10}$ & 96 & 01 & 06 & $\mathrm{p}$ \\
\hline Cameron & Intracoastal Spoil Islands ${ }^{33}$ & 73 & $3 / 2 / 11$ & 18 & 11.9 & II C & $\mathrm{F}$ & - & - & - & - & $\mathrm{s}(\mathrm{p})$ \\
\hline
\end{tabular}


The 2011 International Piping Plover Winter Census in Texas

(Continued)

\begin{tabular}{|c|c|c|c|c|c|c|c|c|c|c|c|c|}
\hline \multirow{2}{*}{$\begin{array}{l}\text { COUNTY } \\
\text { Cameron }\end{array}$} & \multirow{2}{*}{$\begin{array}{l}\text { SITE NAME } \\
\text { Laguna Atascosa NWR Bayside Drive (Pelican } \\
\text { Lake, Plover Point, Moranco Blanco) }^{33}\end{array}$} & \multirow{2}{*}{ MAP\# } & \multirow{2}{*}{$\begin{array}{c}\text { DATE } \\
1 / 19 / 11\end{array}$} & \multirow{2}{*}{$\begin{array}{c}\text { TOTAL } \\
\text { ADULTS } \\
3\end{array}$} & \multirow{2}{*}{$\begin{array}{c}\text { KM } \\
14.3\end{array}$} & \multirow{2}{*}{$\begin{array}{l}\text { SITE } \\
\text { DESCRIPTION } \\
\text { II A }\end{array}$} & \multirow{2}{*}{$\begin{array}{l}\text { DISTURBANCE } \\
\text { / CONCERNS } \\
\text { F G }\end{array}$} & \multicolumn{4}{|c|}{$\begin{array}{c}\text { PRIOR YEARS } \\
\text { CENSUSED \& YEARS } \\
\text { PIPL SEEN }^{1} \\
\end{array}$} & \multirow{2}{*}{$\begin{array}{c}\text { OWNER } \\
\mathrm{f}\end{array}$} \\
\hline & & & & & & & & $\underline{91}$ & 96 & 01 & - & \\
\hline Cameron & Long Island Village/ Outdoor Resorts ${ }^{33}$ & 82 & $2 / 8 / 11$ & 0 & 4.5 & II V G & H V S U G & - & - & - & - & $\mathrm{p}$ \\
\hline Cameron & Mouth of the Rio Grande ${ }^{33}$ & 88 & $1 / 18 / 11$ & 8 & 3.2 & III A & V G & - & - & - & - & $\mathrm{f}$ \\
\hline Cameron & Port Isabel - Hwy 100 & 81 & $1 / 24 / 11$ & 0 & 14.5 & II A & H F S U G & - & $\underline{96}$ & - & - & $\mathrm{m}, \mathrm{p}$ \\
\hline Cameron & South Bay \& Boca Chica Flats ${ }^{33}$ & 86 & $1 / 17 / 11$ & 1 & 25.3 & II V A F & V G & $\underline{91}$ & $\underline{96}$ & 01 & 06 & $\mathrm{f}$ \\
\hline Cameron & South Padre Island Beach (North of Access 5) & 70 & $1 / 25 / 11$ & 0 & 43.5 & I III B & H D V F & $\underline{91}$ & 96 & 01 & - & $f, s(p), p$ \\
\hline Cameron & South Padre Island Beach (South of Access 5) & 80 & $1 / 25 / 11$ & 0 & 10.6 & I III B & H D V F S U G & - & - & - & - & $\mathrm{m}$ \\
\hline Cameron & $\begin{array}{l}\text { South Padre Island, lower middle of Laguna } \\
\text { Madre Side }\end{array}$ & 77 & $1 / 26 / 11$ & 51 & 7.7 & I III B & H D V G & - & $\underline{96}^{11}$ & $\underline{01}$ & $\underline{06}$ & f, s(p), p \\
\hline Cameron & South Padre Island, middle of Laguna Madre Side & 75 & $1 / 27 / 11$ & 217 & 15.3 & I III B & H D V G & $\underline{91}$ & $\underline{96}$ & 01 & $\underline{06}$ & $\mathrm{f}, \mathrm{s}(\mathrm{p}), \mathrm{p}$ \\
\hline Cameron & $\begin{array}{l}\text { South Padre Island, S end Laguna Madre Side } \\
\text { (Isla Blanca to N of Convention Ctr) }\end{array}$ & 79 & $1 / 24 / 11$ & 6 & 9.2 & II B & H D V F U G & $\underline{91}$ & $\underline{\mathbf{9 6}}^{11}$ & 01 & $\underline{06}$ & $\mathrm{p}$ \\
\hline Cameron & $\begin{array}{l}\text { South Padre Island, } \mathrm{S} \text { end Laguna Madre Side } \\
\text { (just } \mathrm{N} \text { of Convention Ctr) }\end{array}$ & 78 & $1 / 25 / 11$ & 51 & 5.2 & I III B & H D V G & - & $\underline{96}$ & 01 & 06 & f, s(p), p \\
\hline Cameron & Unit 4, Laguna Atascosa NWR ${ }^{33}$ & 68 & $3 / 2 / 11$ & 0 & 12.9 & II A & G & 91 & $\underline{96}$ & 01 & - & $\mathrm{f}$ \\
\hline Cameron & $\begin{array}{l}\text { Unit } 5 \text { (Horse Island Cove), Laguna Atascosa } \\
\text { NWR }\end{array}$ & 72 & $2 / 6 / 11$ & 0 & 8.9 & II A & G & - & $\underline{96}$ & 01 & 06 & f \\
\hline Cameron & Unit 8 (Cayo Flats), Laguna Atascosa NWR & 71 & $2 / 5 / 11$ & 0 & 9.7 & V A & $\mathrm{G}$ & - & - & - & - & $\mathrm{f}$ \\
\hline $\begin{array}{l}\text { Chambers/ } \\
\text { Jefferson }\end{array}$ & McFaddin NWR to High Island & 1 & $1 / 31 / 11$ & 3 & 51.5 & III A & G L & 91 & $\underline{96}$ & 01 & 06 & $\mathrm{f}, \mathrm{s}(\mathrm{p})$ \\
\hline Galveston & Big Reef; Galveston Island & 6 & $1 / 27 / 11$ & 30 & 4.0 & III B & H D V G L & $\underline{91}$ & 96 & $\underline{01}$ & 06 & $\mathrm{~s}(\mathrm{p})$ \\
\hline Galveston & Bolivar Flats $^{32}$ & 5 & $1 / 28 / 11$ & 0 & 3.2 & II III B & H D V G & $\underline{\mathbf{9 1}}^{12}$ & $\underline{\mathbf{9 6}}^{13}$ & $\underline{01}$ & $\underline{06}$ & $\mathrm{~s}(\mathrm{p}), \mathrm{p}$ \\
\hline Galveston & Galvston Island, E. Beach to end of Seawall & 7 & $1 / 27 / 11$ & 0 & 16.5 & III B & H D V F S G L & $\underline{\mathbf{9 1}}^{14}$ & 96 & 01 & $\underline{\mathbf{0 6}}^{15}$ & $\mathrm{~s}(\mathrm{p})$ \\
\hline Galveston & High Island to Bolivar Flats ${ }^{32}$ & 3 & $1 / 28 / 11$ & 0 & 43.5 & III B & H D V F G & $\underline{91}$ & $\underline{\mathbf{9 6}}^{13}$ & 01 & $\underline{06}$ & f, $m$ \\
\hline Galveston & Rollover Pass Flats ${ }^{32}$ & 2 & $1 / 28 / 11$ & 7 & 1.6 & II D & H F G & 91 & - & - & $\underline{06}$ & $\mathrm{~s}(\mathrm{p})$ \\
\hline Galveston & San Luis Pass; Galveston Island & 11 & $1 / 27 / 11$ & 0 & 2.9 & & $\mathrm{H} \mathrm{G}$ & $\underline{91}^{14}$ & $\underline{\mathbf{9 6}}^{16}$ & $\underline{01}$ & $\underline{\mathbf{0 6}}^{17}$ & $\mathrm{~s}(\mathrm{p})$ \\
\hline Harris & Atkinson Island Cells $5 \& 6^{32,33}$ & 4 & $2 / 11 / 11$ & 0 & 1.9 & II C & S G & - & 96 & - & - & $\mathrm{s}(\mathrm{p})$ \\
\hline Hidalgo & East Lake (La Sal Del Rey) ${ }^{33}$ & 61 & $2 / 14 / 11$ & 0 & 5.0 & V G & none & - & - & - & - & $\mathrm{f}$ \\
\hline Kenedy & South end 9-Mile Hole ${ }^{33}$ & 59 & $2 / 16 / 11$ & 0 & 6.0 & II G & G L & - & - & - & - & $\mathrm{s}(\mathrm{p})$ \\
\hline Kenedy & $\begin{array}{l}\text { Upper Laguna Madre, Flats at Land Cut, E \& W } \\
\text { of GIWW }\end{array}$ & 57 & $1 / 27 / 11$ & 1 & 49.6 & II A & n.r. & $\underline{91}$ & - & 01 & 06 & $\mathrm{~s}(\mathrm{p})$ \\
\hline $\begin{array}{l}\text { Kenedy/ } \\
\text { Kleberg }\end{array}$ & $\begin{array}{l}\text { Padre Island National Seashore (Bird Island basin } \\
\text { to landcut) }\end{array}$ & 56 & $1 / 27 / 11$ & 15 & 64.4 & II F & G & $\underline{\mathbf{9 1}}^{18}$ & 96 & 01 & $\underline{06}$ & $\mathrm{f}$ \\
\hline
\end{tabular}


The 2011 International Piping Plover Winter Census in Texas

(Continued)

\begin{tabular}{|c|c|c|c|c|c|c|c|c|c|c|c|c|}
\hline \multirow{2}{*}{$\begin{array}{l}\text { COUNTY } \\
\text { Kenedy/ } \\
\text { Kleberg }\end{array}$} & \multirow{2}{*}{ 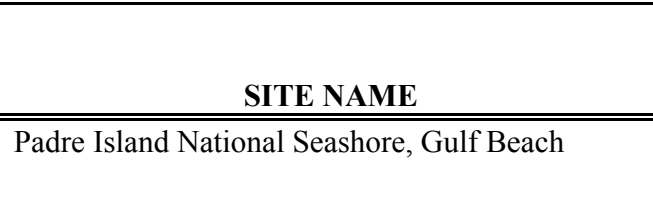 } & \multirow{2}{*}{ MAP\# } & \multirow{2}{*}{$\begin{array}{c}\text { DATE } \\
1 / 27 / 11\end{array}$} & \multirow{2}{*}{$\begin{array}{c}\text { TOTAL } \\
\text { ADULTS } \\
0\end{array}$} & \multirow{2}{*}{ KM } & \multirow{2}{*}{$\begin{array}{l}\text { SITE } \\
\text { DESCRIPTION } \\
\text { III B }\end{array}$} & \multirow{2}{*}{$\begin{array}{l}\text { DISTURBANCE } \\
\text { / CONCERNS } \\
\mathrm{H} \mathrm{V} \mathrm{S} \mathrm{G}\end{array}$} & \multicolumn{4}{|c|}{$\begin{array}{c}\text { PRIOR YEARS } \\
\text { CENSUSED \& YEARS } \\
\text { PIPL SEEN }^{1} \\
\end{array}$} & \multirow{2}{*}{$\frac{\text { OWNER }}{\mathrm{f}}$} \\
\hline & & & & & & & & $\underline{91}^{19}$ & $\underline{96}^{20}$ & 01 & $\underline{\underline{06}}$ & \\
\hline $\begin{array}{l}\text { Kenedy/ } \\
\text { Willacy }\end{array}$ & $\begin{array}{l}\text { Bayshore flat on S end of N Padre Island (S of } \\
\text { Land cut and N of Mansfield Channel in LLM) }\end{array}$ & 60 & $2 / 16 / 11$ & 175 & 34.6 & II B D & G L & $\underline{91}$ & $\underline{96}$ & - & - & $\mathrm{s}(\mathrm{p})$ \\
\hline $\begin{array}{l}\text { Kenedy/ } \\
\text { Willacy }\end{array}$ & Padre Island National Seashore/ 9-Mile Hole $\mathrm{SE}^{33}$ & 64 & $2 / 16 / 11$ & 0 & 54.7 & III B & G & $\underline{91}$ & $\underline{\mathbf{9 6}}^{20}$ & 01 & $\underline{06}$ & $\mathrm{f}, \mathrm{s}(\mathrm{p})$ \\
\hline Kleberg & Nighthawk Bay & 54 & $1 / 27 / 11$ & 0 & n.r. & II B & G L & 91 & $\underline{\mathbf{9 6}}^{21}$ & 01 & 06 & $\mathrm{f}, \mathrm{s}(\mathrm{p})$ \\
\hline $\begin{array}{l}\text { Kleberg/ } \\
\text { Nueces }\end{array}$ & Packery to PINS & 55 & $1 / 27 / 11$ & 0 & 22.5 & III B & H D V F G & $\underline{\mathbf{9 1}}^{19}$ & $\underline{\mathbf{9 6}}^{20}$ & 01 & $\underline{06}$ & $\mathrm{~s}(\mathrm{p})$ \\
\hline $\begin{array}{l}\text { Kleberg/ } \\
\text { Nueces }\end{array}$ & $\begin{array}{l}\text { Upper Laguna Madre (islands S of JFK Causeway } \\
\text { to Bird Island Basin) }\end{array}$ & 53 & $1 / 27 / 11$ & 0 & 1.9 & II C & n.r. & $\underline{91}^{22}$ & $\underline{\mathbf{9 6}}^{23}$ & 01 & $\underline{06}$ & $\mathrm{~s}(\mathrm{p})$ \\
\hline Matagorda & East Matagorda Bay ${ }^{33}$ & 18 & $2 / 25 / 11$ & 70 & 85.3 & II B & n.r. & - & - & - & - & $\mathrm{s}(\mathrm{p})$ \\
\hline Matagorda & East Matagorda Peninsula $^{32,33}$ & 19 & $2 / 18 / 11$ & 0 & 20.9 & III A D F & V G & $\underline{91}^{24}$ & 96 & 01 & 06 & $\mathrm{~s}(\mathrm{p})$ \\
\hline Matagorda & $\begin{array}{l}\text { Matagorda Peninsula, Bayside and Colorado } \\
\text { River Delta }^{33}\end{array}$ & 20 & $2 / 15 / 11$ & 89 & 140.0 & II B G & G L & $\underline{91}^{25}$ & - & - & $\underline{06}$ & $\mathrm{~s}(\mathrm{p})$ \\
\hline Nueces & Mollie Beattie & 52 & $1 / 27 / 11$ & 0 & 4.8 & II B & G & - & 96 & 01 & 06 & $\mathrm{~s}(\mathrm{p})$ \\
\hline Nueces & Mollie Beattie (North End) & 50 & $1 / 26 / 11$ & 0 & 2.8 & II B G & V G & - & 96 & 01 & - & $\mathrm{s}(\mathrm{p}), \mathrm{p}$ \\
\hline Nueces & $\begin{array}{l}\text { Mustang Island - Bay shoreline } \mathrm{N} \text { end to Wilson's } \\
\text { Cut and Shamrock Island }\end{array}$ & 42 & $1 / 26 / 11$ & 47 & 70.8 & II B & P S G L & $\underline{\mathbf{9 1}}^{26}$ & $\underline{96}$ & $\underline{01}$ & $\underline{06}$ & $\mathrm{~s}(\mathrm{p}), \mathrm{p}$ \\
\hline Nueces & Mustang Island - Charlie's Pasture & 41 & $1 / 26 / 11$ & 89 & 5.8 & II B & n.r. & - & - & - & - & $\mathrm{m}$ \\
\hline Nueces & Mustang Island - Port A to Packery (gulf side) & 44 & $1 / 26 / 11$ & 0 & 29.0 & III B & H D V G & $\underline{91}$ & 96 & 01 & 06 & $\mathrm{~s}(\mathrm{p})$ \\
\hline Nueces & $\begin{array}{l}\text { Mustang Island State Park (S Bayside and Fish } \\
\text { Pass) }\end{array}$ & 47 & $1 / 26 / 11$ & 0 & 1.6 & II B & H V F P G & 91 & $\underline{96}$ & $\underline{01}$ & $\underline{06}$ & $\mathrm{~s}(\mathrm{p})$ \\
\hline Nueces & Oso Bay - NAS CC & 46 & $1 / 26 / 11$ & 8 & n.r. & II A & H F G L & $\underline{91}$ & $\underline{\mathbf{9 6}}^{27}$ & - & 06 & $\mathrm{f}$ \\
\hline Nueces & Packery Channel Park & 49 & $1 / 26 / 11$ & 7 & 1.6 & II B & H V F G & - & - & 01 & 06 & $\mathrm{~s}(\mathrm{p})$ \\
\hline Nueces & Pelican Island & 40 & $1 / 26 / 11$ & 56 & n.r. & II C D E & S G L & $\underline{91}$ & - & - & $\underline{06}$ & $\mathrm{p}$ \\
\hline Nueces & Redfish Bay (N of causeway) & 35 & $1 / 28 / 11$ & 2 & 45.1 & II A B C D E & n.r. & 91 & $\underline{96}^{2}$ & - & $\underline{06}$ & $\mathrm{~s}(\mathrm{p})$ \\
\hline Nueces & $\begin{array}{l}\text { Redfish Bay (S of causeway including Harbor } \\
\text { Island) }\end{array}$ & 39 & $1 / 26 / 11$ & 8 & 28.6 & II A C E & H B F G L & $\underline{91}$ & $\underline{96}^{2}$ & $\underline{01}$ & 06 & $\mathrm{~s}(\mathrm{p})$ \\
\hline Nueces & $\begin{array}{l}\text { S side of JFK Causeway and Laguna Madre } \\
\text { Shoreline }\end{array}$ & 51 & $1 / 26 / 11$ & 22 & 3.0 & II A & H V F G & $\underline{\mathbf{9 1}}^{28}$ & - & - & 06 & $\mathrm{~s}(\mathrm{p})$ \\
\hline Nueces & $\begin{array}{l}\text { Upper Laguna Madre/S end of Corpus Christi Bay } \\
\text { (islands and flats) }\end{array}$ & 48 & $1 / 26 / 11$ & 233 & 11.9 & II C G & n.r. & $\underline{91}$ & $\underline{96}$ & $\underline{01}$ & $\underline{06}$ & $\mathrm{~s}(\mathrm{p})$ \\
\hline Nueces & Ward Island & 45 & $1 / 26 / 11$ & 0 & 2.0 & II A & I G & 91 & - & 01 & 06 & $\mathrm{~s}(\mathrm{p})$ \\
\hline Nueces & Wilson's Cut/Croaker Hole & 43 & $1 / 28 / 11$ & 0 & 1.6 & II B & $\mathrm{V}$ & - & - & $\underline{01}$ & $\underline{06}$ & $\mathrm{~s}(\mathrm{p})$ \\
\hline San Patricio & La Quinta Channel Islands & 38 & $1 / 26 / 11$ & 5 & 25.7 & II C & H S G & $\underline{91}$ & $\underline{96}^{2}$ & $\overline{01}$ & $\overline{06}$ & $\mathrm{~s}(\mathrm{p}), \mathrm{p}$ \\
\hline
\end{tabular}




\section{The 2011 International Piping Plover Winter Census in Texas}

(Continued)

\begin{tabular}{|c|c|c|c|c|c|c|c|c|c|c|c|c|}
\hline COUNTY & SITE NAME & \multirow{2}{*}{ MAP\# } & \multirow{2}{*}{$\begin{array}{c}\text { DATE } \\
1 / 28 / 11\end{array}$} & \multirow{2}{*}{$\begin{array}{c}\text { TOTAL } \\
\text { ADULTS } \\
14\end{array}$} & \multirow{2}{*}{$\frac{\mathbf{K M}}{0.1}$} & \multirow{2}{*}{$\begin{array}{l}\text { SITE } \\
\text { DESCRIPTION } \\
\text { II D }\end{array}$} & \multirow{2}{*}{$\begin{array}{l}\text { DISTURBANCE } \\
\text { / CONCERNS } \\
\text { H D F I G L }\end{array}$} & \multicolumn{4}{|c|}{$\begin{array}{c}\text { PRIOR YEARS } \\
\text { CENSUSED \& YEARS } \\
\text { PIPL SEEN }^{1} \\
\end{array}$} & \multirow{2}{*}{$\frac{\text { OWNER }}{\mathrm{m}}$} \\
\hline San Patricio & Sunset Lake & & & & & & & $\underline{91}^{29}$ & 96 & 01 & 06 & \\
\hline Willacy & East Lake $^{33}$ & 63 & $2 / 14 / 11$ & 0 & 5.6 & V G & $\mathrm{S}$ & 91 & - & 01 & - & $\mathrm{f}$ \\
\hline Willacy & East Lake (La Sal Vieja) ${ }^{33}$ & 62 & $2 / 15 / 11$ & 0 & 12.9 & V G & A I & - & - & 01 & - & $\mathrm{f}$ \\
\hline Willacy & Mansfield Channel Spoil Islands ${ }^{33}$ & 65 & $3 / 2 / 11$ & 0 & 3.7 & II C & $\mathrm{F}$ & 91 & - & - & - & $\mathrm{s}(\mathrm{p})$ \\
\hline Willacy & $\begin{array}{l}\text { South Padre Island, } \mathrm{N} \text { end flats by Port } \\
\text { Mansfield Channel }\end{array}$ & 66 & $1 / 30 / 11$ & 566 & 0.5 & I III B & H D V G & - & 96 & 01 & $\underline{06}$ & $f, s(p), p$ \\
\hline Willacy & South Padre Island, S of Mansfield Channel & 67 & $1 / 29 / 11$ & 87 & 11.1 & I III B & H D V G & $\underline{91}$ & 96 & 01 & $\underline{06}^{30}$ & $f, s(p), p$ \\
\hline Willacy & $\begin{array}{l}\text { South Padre Island, upper middle of Laguna } \\
\text { Madre Side }\end{array}$ & 69 & $1 / 28 / 11$ & 9 & 4.8 & I III B & H D V G & $\overline{91}$ & $\underline{96}$ & 01 & $\overline{\mathbf{0 6}}^{31}$ & $\mathrm{f}, \mathrm{s}(\mathrm{p}), \mathrm{p}$ \\
\hline Total & & & & 2145 & 1600.0 & & & & & & & \\
\hline
\end{tabular}

If previously surveyed, years surveyed are noted. Bold underlined years indicate that Piping Plovers were seen at the site during that Census year.

${ }^{2}$ This site was surveyed as a part of "Redfish Bay/ Harbor Island/ Ingleside Cove" in '96. The survey route and locations of the PIPL are unknown and may have occurred in an area along this 2011 survey route.

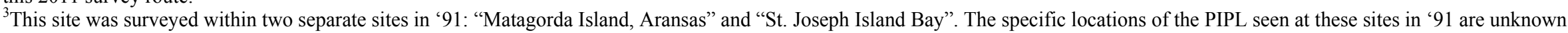
and may have occurred along the 2011 survey route.

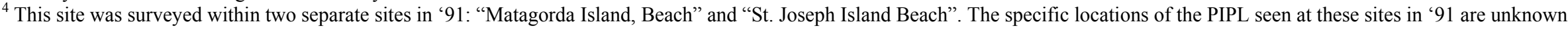
and may have occurred along the 2011 survey route.

${ }^{5}$ This site was surveyed as a part of "Matagorda Island Gulf Beach" in ' 96 . The specific locations of the 7 PIPL seen in '96 are unknown and may have occurred along the 2011 survey route.

${ }^{6}$ This site was surveyed as a part of "St Joseph Island Bay" in ' 91 . The specific locations of the PIPL seen in '91 are unknown and may have occurred along the 2011 survey route.

${ }^{7}$ This stretch was surveyed as a part of "Sargent Beach" in " 91 . The specific locations of the PIPL seen in ' 91 are unknown and may have occurred along the 2011 survey route.

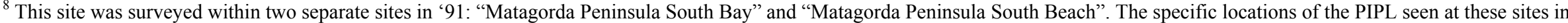

'91 are unknown and may have occurred along the 2011 survey route.

${ }^{9}$ This site was surveyed as a part of "Matagorda Island, Beach" in ' 91 . The specific locations of the PIPL seen in '91 are unknown and may have occurred along the 2011 survey route.


on January 6, 1991 (outside of the census window)

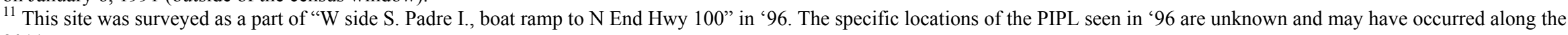
2011 survey route.

12 This site was surveyed as a part of "Bolivar Flats" in ' 91 . The specific locations of the PIPL seen in '91 are unknown and may have occurred along the 2011 survey route.

${ }^{13}$ This site was surveyed as a part of "Bolivar Peninsula" in ' 96 . The specific locations of the PIPL seen in " 96 are unknown and may have occurred along the 2011 survey route.

${ }_{14}^{14}$ This site was surveyed as a part of "Big Reef-San Luis" in ' 91 . The specific locations of the PIPL seen in ' 91 are unknown and may have occurred along the 2011 survey route.

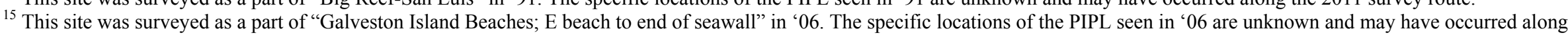
the 2011 survey route.

${ }^{16}$ This site was surveyed as a part of "San Luis Pass tidal delta" in '96. The specific locations of the PIPL seen in '96 are unknown and may have occurred along the 2011 survey route.

${ }^{17}$ This site was surveyed as a part of "San Luis Pass; Galveston Island" in ' 06 . The specific locations of the PIPL seen in '06 are unknown and may have occurred along the 2011 survey route.

${ }_{18}^{18}$ This site was surveyed as a part of "Padre Island Bayside" in '91. The specific locations of the PIPL seen in "91 are unknown and may have occurred along the 2011 survey route.

${ }^{19}$ This site was surveyed as a part of "Padre Island Beach" in ' 91 . The specific locations of the PIPL seen in " 91 are unknown and may have occurred along the 2011 survey route.

${ }^{20}$ This site was surveyed as a part of "Padre Island NS Beach" in ' 96 . The specific locations of the PIPL seen in "96 are unknown and may have occurred along the 2011 survey route. 
${ }^{21}$ This site was surveyed as a part of "Upper Laguna Madre: Bird I. Basin to JFK Causeway" in '96. The specific locations of PIPL seen in '96 are unknown and may have occurred along the 2011 survey route.

${ }^{22}$ This site was surveyed within two separate sites in '91: "Padre Island Bayside" and "South Bird Island". The specific locations of the PIPL seen in '91 are unknown and may have occurred along the 2011 survey route.

${ }^{23}$ This site was surveyed as a part of "Mudflat N boundary Padre Island NS" in ' 96. The specific locations of the PIPL seen in "96 are unknown and may have occurred along the 2011 survey route.

${ }^{24}$ This site may have been surveyed as a part of "Matagorda Peninsula North Beach" in ' 91 . The specific locations of the PIPL seen in '91 are unknown and may have occurred along the 2011 survey route.

${ }^{25}$ This site was surveyed as a part of "Matagorda Peninsula South Bay" in '91. The specific locations of the PIPL seen in '91 are unknown and may have occurred along the 2011 survey route.

${ }^{26}$ This site was surveyed as a part of "Mustang Island Bay" in ' 91 . The specific locations of the PIPL seen in '91 are unknown and may have occurred along the 2011 survey route.

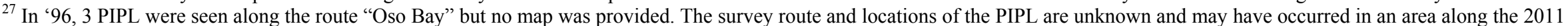
survey route.

${ }^{28}$ This site was surveyed as a part of "Flour Bluff" in ' 91 . The specific locations of the PIPL seen in '91 are unknown and may have occurred along the 2011 survey route.

${ }^{29}$ This site was surveyed as a part of "Indian Point" in ' 91 . The specific locations of the PIPL seen in "91 are unknown and may have occurred along the 2011 survey route.

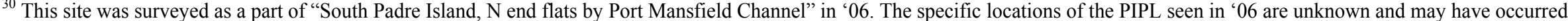
along the 2011 survey route.

${ }^{31}$ This site was surveyed as a part of "South Padre Island, Laguna Madre Side" in '06. The specific locations of the PIPL seen in '06 are unknown and may have occurred along the 2011 survey route.

${ }^{32}$ Specific survey route for this site is unknown - map illegible. Notations for sightings in prior Census years are based on an estimation of the 2011 survey route.

${ }^{33}$ Please note that this survey was conducted outside the Census window. 





The 2011 International Snowy Plover Winter Census in Texas

\begin{tabular}{|c|c|c|c|c|c|c|c|c|c|c|c|c|}
\hline \multirow{2}{*}{ COUNTY } & \multirow{2}{*}{$\begin{array}{r}\text { SITE NAME } \\
\text { Aransas Bay, Goose Island }^{33}\end{array}$} & \multirow{2}{*}{ MAP\# } & \multirow{2}{*}{$\frac{\text { DATE }}{1 / 1 / 11}$} & \multirow{2}{*}{$\begin{array}{c}\text { TOTAL } \\
\text { ADULTS } \\
0\end{array}$} & \multirow{2}{*}{ 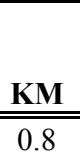 } & \multirow{2}{*}{$\begin{array}{l}\text { SITE } \\
\text { DESCRIPTION } \\
\text { II D E }\end{array}$} & \multirow{2}{*}{$\begin{array}{l}\text { DISTURBANCE } \\
\text { / CONCERNS } \\
\text { H F G L }\end{array}$} & \multicolumn{4}{|c|}{$\begin{array}{c}\text { PRIOR YEARS } \\
\text { CENSUSED \& YEARS } \\
\text { SNPL SEEN } \\
\end{array}$} & \multirow{2}{*}{$\frac{\text { OWNER }}{=\mathrm{s}(\mathrm{p})}$} \\
\hline & & & & & & & & 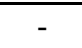 & 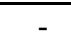 & 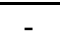 & 06 & \\
\hline Aransas & Burgentine Lake (Aransas NWR; W Blackjack) ${ }^{33}$ & 26 & $2 / 7 / 11$ & 1 & 3.8 & II A & $\mathrm{G}$ & - & - & - & 06 & $\mathrm{f}$ \\
\hline Aransas & E Blackjack (Aransas NWR Complex) ${ }^{33}$ & 28 & $2 / 7 / 11$ & 0 & 5.3 & II A & H G & 91 & 96 & 01 & - & $\mathrm{f}$ \\
\hline Aransas & Fulton to Ingleside Point (Mainland) & 37 & $1 / 25 / 11$ & 0 & 42.6 & II A & $\mathrm{G}$ & $\underline{91}$ & $\underline{96}^{2}$ & 01 & 06 & $s(p), p$ \\
\hline Aransas & $\begin{array}{l}\text { N San Jose Island, Bayside (Big Island to Cedar } \\
\text { Bayou) }\end{array}$ & 32 & $1 / 28 / 11$ & 6 & 22.5 & II B & H G L & $\underline{91}^{3}$ & - & - & - & $\mathrm{s}(\mathrm{p}), \mathrm{p}$ \\
\hline Aransas & San Jose Island (Gulf Side) & 34 & $1 / 26 / 11$ & 95 & 64.4 & III B & n.r. & $\underline{91}^{4}$ & 96 & $\underline{01}$ & $\underline{06}$ & $\mathrm{p}$ \\
\hline Aransas & San Jose Island bayside (N Pass) & 36 & $1 / 28 / 11$ & 0 & 2.0 & II B & n.r. & $\underline{91}^{5}$ & $\underline{96}$ & $\underline{\mathbf{0 1}}^{6}$ & 06 & $\mathrm{~s}(\mathrm{p})$ \\
\hline Aransas & Tatton Unit (Aransas NWR) ${ }^{33}$ & 25 & 2/7/11 & 0 & 3.7 & II A & G & 91 & - & - & 06 & $\mathrm{f}$ \\
\hline Brazoria & Alligator Point ${ }^{33}$ & 9 & $2 / 11 / 11$ & 0 & 4.8 & II C D & S G L & - & - & - & - & $\mathrm{s}(\mathrm{p})$ \\
\hline Brazoria & Chocolate Bayou ${ }^{33}$ & 8 & $2 / 11 / 11$ & 0 & 4.8 & II C D & S G L & - & - & - & - & $\mathrm{s}(\mathrm{p})$ \\
\hline Brazoria & Christmas/Drum Bay ${ }^{32,33}$ & 14 & $2 / 15 / 11$ & 0 & 26.6 & II III IV A D E F & $\mathrm{G}$ & - & - & - & - & $\mathrm{f}, \mathrm{s}(\mathrm{p})$ \\
\hline Brazoria & Cold Pass & 13 & $1 / 27 / 11$ & 0 & 3.2 & II G & B F G L & - & - & - & - & $\mathrm{s}(\mathrm{p}), \mathrm{c}$ \\
\hline Brazoria & Sargent Beach (East) & 16 & $1 / 28 / 11$ & 18 & 6.4 & III A & none & 91 & 96 & $\underline{01}$ & - & $\mathrm{s}(\mathrm{p})$ \\
\hline Brazoria & Sargent Beach (West) & 17 & $1 / 27 / 11$ & 32 & 4.2 & III IV A D E F & B G & 91 & 96 & $\underline{01}$ & $\underline{06}$ & $\mathrm{~s}(\mathrm{p})$ \\
\hline Brazoria & West Bay Bird Island & 12 & $1 / 27 / 11$ & 0 & 1.1 & II B E & G L & - & - & - & - & $\mathrm{s}(\mathrm{p})$ \\
\hline Brazoria & West Bay Mooring Area BU Site ${ }^{33}$ & 10 & $2 / 11 / 11$ & 0 & 4.8 & II C D & S G L & - & - & - & 06 & $\mathrm{~s}(\mathrm{p})$ \\
\hline Brazoria & Wolf Island & 15 & $1 / 28 / 11$ & 1 & 6.4 & III B & none & 91 & $\underline{96}$ & $\underline{01}$ & $\underline{06}$ & $\mathrm{~s}(\mathrm{p})$ \\
\hline Calhoun & $\begin{array}{l}\text { Cedar Bayou, Matagorda Island NWR (Gulf } \\
\text { Beach Route) }\end{array}$ & 30 & $2 / 7 / 11$ & 0 & 13.6 & I II B & G & 91 & $\overline{96}$ & $\underline{01}$ & $\underline{06}$ & $\mathrm{f}$ \\
\hline Calhoun & $\begin{array}{l}\text { Decros Point including Pass Cavallo and } \\
\text { Sundown Island } \\
\text { S3 }\end{array}$ & 22 & $2 / 14 / 11$ & 0 & 45.2 & II III IV B F & H B S G & $\underline{91}^{7}$ & - & 01 & $\underline{06}$ & $\mathrm{~s}(\mathrm{p}), \mathrm{p}$ \\
\hline Calhoun & Matagorda Island Inner Levee System ${ }^{33}$ & 29 & $2 / 7 / 11$ & 0 & 15.7 & II B & G & - & 96 & - & 06 & $\mathrm{f}$ \\
\hline Calhoun & Matagorda Island NWR Beach (J-Hook) $)^{33}$ & 23 & $2 / 7 / 11$ & 0 & 11.4 & I II A & G & $\underline{91}^{8}$ & 96 & 01 & $\underline{06}$ & $\mathrm{f}$ \\
\hline Calhoun & Matagorda Island NWR Gulf Beach ${ }^{33}$ & 27 & $2 / 7 / 11$ & 28 & 33.0 & I B & G & $\underline{91}^{8}$ & 96 & $\underline{01}$ & $\underline{06}$ & $\mathrm{f}$ \\
\hline Calhoun & Port O'Conner Shoreline & 21 & $2 / 1 / 11$ & 0 & 2.0 & V A & S G L & 91 & - & 01 & 06 & $\mathrm{~m}$ \\
\hline Calhoun & $\begin{array}{l}\text { Welder Flats, Shoalwater Bay, The Lagoon- } \\
\text { Dewberry Island }^{33}\end{array}$ & 24 & $2 / 8 / 11$ & 91 & 85.3 & II A E G & H B F G L & 91 & - & $\underline{01}$ & $\underline{06}$ & $\mathrm{p}$ \\
\hline Cameron & Bahia Grande & 83 & $2 / 3 / 11$ & 0 & 30.6 & V G & H F S & - & $\underline{96}^{9}$ & 01 & 06 & $\mathrm{f}$ \\
\hline Cameron & Boca Chica Beach ${ }^{33}$ & 87 & $1 / 18 / 11$ & 0 & 4.7 & III V A & H D V F G & 91 & 96 & 01 & 06 & $\mathrm{~s}(\mathrm{p})$ \\
\hline Cameron & Brazos Island Beach \& Flats ${ }^{33}$ & 85 & $1 / 21 / 11$ & 16 & 8.7 & III V A & H D V F G & 91 & $\underline{96}$ & 01 & 06 & $\mathrm{f}, \mathrm{s}(\mathrm{p})$ \\
\hline Cameron & Brownsville Ship Channel Spoil Cells ${ }^{33}$ & 84 & $1 / 23 / 11$ & 49 & 4.5 & III V B & V F G & 91 & 96 & - & 06 & $\mathrm{~s}(\mathrm{p}), \mathrm{m}$ \\
\hline Cameron & Buena Vista Ranch & 74 & $2 / 6 / 11$ & 0 & 9.7 & II A & V A G & $\underline{91}^{10}$ & 96 & 01 & 06 & $\mathrm{p}$ \\
\hline Cameron & Intracoastal Spoil Islands ${ }^{33}$ & 73 & $3 / 2 / 11$ & 0 & 11.9 & II C & $\mathrm{F}$ & - & - & - & - & $\mathrm{s}(\mathrm{p})$ \\
\hline
\end{tabular}


The 2011 International Snowy Plover Winter Census in Texas

(Continued)

\begin{tabular}{|c|c|c|c|c|c|c|c|c|c|c|c|c|}
\hline \multirow{2}{*}{$\begin{array}{l}\text { COUNTY } \\
\text { Cameron }\end{array}$} & \multirow{2}{*}{$\begin{array}{l}\text { SITE NAME } \\
\text { NWR Bayside Drive (Pelican } \\
\text { nt, Moranco Blanco) }\end{array}$} & \multirow{2}{*}{$\frac{\text { MAP\# }}{76}$} & \multirow{2}{*}{$\begin{array}{c}\text { DATE } \\
1 / 19 / 11\end{array}$} & \multirow{2}{*}{$\begin{array}{c}\text { TOTAL } \\
\text { ADULTS } \\
0\end{array}$} & \multirow{2}{*}{$\frac{\mathbf{K M}}{14.3}$} & \multirow{2}{*}{$\begin{array}{l}\text { SITE } \\
\text { DESCRIPTION } \\
\text { II A }\end{array}$} & \multirow{2}{*}{$\begin{array}{l}\text { DISTURBANCE } \\
\text { / CONCERNS } \\
\text { F G }\end{array}$} & \multicolumn{4}{|c|}{$\begin{array}{l}\text { PRIOR YEARS } \\
\text { CENSUSED \& YEARS } \\
\text { SNPL SEEN }^{1} \\
\end{array}$} & \multirow{2}{*}{$\begin{array}{c}\text { OWNER } \\
\mathrm{f}\end{array}$} \\
\hline & & & & & & & & $\underline{91}$ & 96 & 01 & - & \\
\hline Cameron & Long Island Village/ Outdoor Resorts ${ }^{33}$ & 82 & $2 / 8 / 11$ & 0 & 4.5 & II V G & H V S U G & - & - & - & - & $\mathrm{p}$ \\
\hline Cameron & Mouth of the Rio Grande ${ }^{33}$ & 88 & $1 / 18 / 11$ & 6 & 3.2 & III A & V G & - & - & - & - & $\mathrm{f}$ \\
\hline Cameron & Port Isabel - Hwy 100 & 81 & $1 / 24 / 11$ & 0 & 14.5 & II A & H F S U G & - & 96 & - & - & $\mathrm{m}, \mathrm{p}$ \\
\hline Cameron & South Bay \& Boca Chica Flats ${ }^{33}$ & 86 & $1 / 17 / 11$ & 23 & 25.3 & II V A F & V G & $\underline{91}$ & $\underline{96}$ & 01 & 06 & $\mathrm{f}$ \\
\hline Cameron & South Padre Island Beach (North of Access 5) & 70 & $1 / 25 / 11$ & 12 & 43.5 & I III B & H D V F & $\underline{91}$ & 96 & 01 & - & $f, s(p), p$ \\
\hline Cameron & South Padre Island Beach (South of Access 5) & 80 & $1 / 25 / 11$ & 0 & 10.6 & I III B & H D V F S U G & - & - & - & - & $\mathrm{m}$ \\
\hline Cameron & $\begin{array}{l}\text { South Padre Island, lower middle of Laguna } \\
\text { Madre Side }\end{array}$ & 77 & $1 / 26 / 11$ & 116 & 7.7 & I III B & H D V G & - & $\underline{\mathbf{9 6}}^{11}$ & $\underline{01}$ & 06 & f, s(p), p \\
\hline Cameron & South Padre Island, middle of Laguna Madre Side & 75 & $1 / 27 / 11$ & 296 & 15.3 & I III B & H D V G & $\underline{91}$ & $\underline{\mathbf{9 6}}^{12}$ & 01 & $\underline{\mathbf{0 6}}^{13}$ & $f, s(p), p$ \\
\hline Cameron & $\begin{array}{l}\text { South Padre Island, S end Laguna Madre Side } \\
\text { (Isla Blanca to N of Convention Ctr) }\end{array}$ & 79 & $1 / 24 / 11$ & 0 & 9.2 & II B & H D V F U G & 91 & $\underline{\mathbf{9 6}}^{11}$ & 01 & 06 & $\mathrm{p}$ \\
\hline Cameron & $\begin{array}{l}\text { South Padre Island, } \mathrm{S} \text { end Laguna Madre Side } \\
\text { (just } \mathrm{N} \text { of Convention Ctr) }\end{array}$ & 78 & $1 / 25 / 11$ & 26 & 5.2 & I III B & H D V G & - & $\underline{\mathbf{9 6}}^{11}$ & 01 & 06 & $\mathrm{f}, \mathrm{s}(\mathrm{p}), \mathrm{p}$ \\
\hline Cameron & Unit 4, Laguna Atascosa NWR ${ }^{33}$ & 68 & $3 / 2 / 11$ & 1 & 12.9 & II A & G & $\underline{91}$ & $\underline{96}$ & 01 & - & $\mathrm{f}$ \\
\hline Cameron & $\begin{array}{l}\text { Unit } 5 \text { (Horse Island Cove), Laguna Atascosa } \\
\text { NWR }\end{array}$ & 72 & $2 / 6 / 11$ & 0 & 8.9 & II A & $\mathrm{G}$ & - & $\underline{96}$ & 01 & 06 & $\mathrm{f}$ \\
\hline Cameron & Unit 8 (Cayo Flats), Laguna Atascosa NWR & 71 & $2 / 5 / 11$ & 0 & 9.7 & V A & G & - & - & - & - & $\mathrm{f}$ \\
\hline $\begin{array}{l}\text { Chambers/ } \\
\text { Jefferson }\end{array}$ & McFaddin NWR to High Island & 1 & $1 / 31 / 11$ & 4 & 51.5 & III A & G L & 91 & 96 & $\underline{\mathbf{0 1}}^{14}$ & 06 & $\mathrm{f}, \mathrm{s}(\mathrm{p})$ \\
\hline Galveston & Big Reef; Galveston Island & 6 & $1 / 27 / 11$ & 6 & 4.0 & III B & H D V G L & $\underline{91}$ & $\underline{96}$ & $\underline{01}$ & 06 & $\mathrm{~s}(\mathrm{p})$ \\
\hline Galveston & Bolivar Flats ${ }^{32}$ & 5 & $1 / 28 / 11$ & 0 & 3.2 & II III B & H D V G & $\underline{\mathbf{9 1}}^{15}$ & $\underline{\mathbf{9 6}}^{16}$ & $\overline{\mathbf{0 1}}$ & $\underline{06}$ & $\mathrm{~s}(\mathrm{p}), \mathrm{p}$ \\
\hline Galveston & Galvston Island, E. Beach to end of Seawall & 7 & $1 / 27 / 11$ & 0 & 16.5 & III B & H D V F S G L & 91 & 96 & 01 & 06 & $\mathrm{~s}(\mathrm{p})$ \\
\hline Galveston & High Island to Bolivar Flats ${ }^{32}$ & 3 & $1 / 28 / 11$ & 1 & 43.5 & III B & H D V F G & $\underline{91}$ & $\underline{\mathbf{9 6}}^{16}$ & 01 & $\underline{06}$ & $f, m$ \\
\hline Galveston & Rollover Pass Flats ${ }^{32}$ & 2 & $1 / 28 / 11$ & 6 & 1.6 & II D & H F G & 91 & - & - & 06 & $\mathrm{~s}(\mathrm{p})$ \\
\hline Galveston & San Luis Pass; Galveston Island & 11 & $1 / 27 / 11$ & 0 & 2.9 & & $\mathrm{H} \mathrm{G}$ & 91 & 96 & 01 & $\underline{\mathbf{0 6}}^{17}$ & $\mathrm{~s}(\mathrm{p})$ \\
\hline Harris & Atkinson Island Cells $5 \& 6^{32,33}$ & 4 & $2 / 11 / 11$ & 38 & 1.9 & II C & S G & - & $\underline{\mathbf{9 6}}^{18}$ & - & - & $\mathrm{s}(\mathrm{p})$ \\
\hline Hidalgo & East Lake (La Sal Del Rey) ${ }^{33}$ & 61 & $2 / 14 / 11$ & 94 & 5.0 & V G & none & - & - & - & - & $\mathrm{f}$ \\
\hline Kenedy & South end 9-Mile Hole ${ }^{33}$ & 59 & $2 / 16 / 11$ & 67 & 6.0 & II G & G L & - & - & - & - & $\mathrm{s}(\mathrm{p})$ \\
\hline Kenedy & $\begin{array}{l}\text { Upper Laguna Madre, Flats at Land Cut, E \& W } \\
\text { of GIWW }\end{array}$ & 57 & $1 / 27 / 11$ & 66 & 49.6 & II A & n.r. & $\underline{91}$ & - & 01 & 06 & $\mathrm{~s}(\mathrm{p})$ \\
\hline $\begin{array}{l}\text { Kenedy/ } \\
\text { Kleberg }\end{array}$ & $\begin{array}{l}\text { Padre Island National Seashore (Bird Island basin } \\
\text { to landcut) }\end{array}$ & 56 & $1 / 27 / 11$ & 767 & 64.4 & II F & $\mathrm{G}$ & $\underline{\mathbf{9 1}}^{19}$ & 96 & 01 & $\underline{06}$ & $\mathrm{f}$ \\
\hline
\end{tabular}


The 2011 International Snowy Plover Winter Census in Texas

(Continued)

\begin{tabular}{|c|c|c|c|c|c|c|c|c|c|c|c|c|}
\hline \multirow{2}{*}{$\begin{array}{l}\text { COUNTY } \\
\text { Kenedy/ } \\
\text { Kleberg }\end{array}$} & \multirow{2}{*}{$\frac{\text { SITE NAME }}{\text { Padre Island National Seashore, Gulf Beach }}$} & \multirow{2}{*}{ MAP\# } & \multirow{2}{*}{$\begin{array}{c}\text { DATE } \\
1 / 27 / 11\end{array}$} & \multirow{2}{*}{$\begin{array}{c}\text { TOTAL } \\
\text { ADULTS } \\
0\end{array}$} & \multirow{2}{*}{ KM } & \multirow{2}{*}{$\begin{array}{l}\text { SITE } \\
\text { DESCRIPTION } \\
\text { III B }\end{array}$} & \multirow{2}{*}{$\begin{array}{l}\text { DISTURBANCE } \\
\text { / CONCERNS } \\
\mathrm{H} \mathrm{V} \mathrm{S} \mathrm{G}\end{array}$} & \multicolumn{4}{|c|}{$\begin{array}{c}\text { PRIOR YEARS } \\
\text { CENSUSED \& YEARS } \\
\text { SNPL SEEN }^{1}\end{array}$} & \multirow{2}{*}{$\frac{\text { OWNER }}{\mathrm{f}}$} \\
\hline & & & & & & & & $\underline{91}^{20}$ & $\underline{96}^{21}$ & $\underline{\underline{01}}$ & 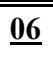 & \\
\hline $\begin{array}{l}\text { Kenedy/ } \\
\text { Willacy }\end{array}$ & $\begin{array}{l}\text { Bayshore flat on S end of N Padre Island (S of } \\
\text { Land cut and N of Mansfield Channel in LLM) }\end{array}$ & 60 & $2 / 16 / 11$ & 36 & 34.6 & II B D & G L & $\underline{91}$ & $\underline{\mathbf{9 6}}^{22}$ & - & - & $\mathrm{s}(\mathrm{p})$ \\
\hline $\begin{array}{l}\text { Kenedy/ } \\
\text { Willacy }\end{array}$ & Padre Island National Seashore/ 9-Mile Hole $\mathrm{SE}^{33}$ & 64 & $2 / 16 / 11$ & 114 & 54.7 & III B & G & $\underline{91}$ & 96 & 01 & $\underline{06}$ & $\mathrm{f}, \mathrm{s}(\mathrm{p})$ \\
\hline Kleberg & Nighthawk Bay & 54 & $1 / 27 / 11$ & 0 & n.r. & II B & G L & 91 & 96 & 01 & 06 & $\mathrm{f}, \mathrm{s}(\mathrm{p})$ \\
\hline $\begin{array}{l}\text { Kleberg/ } \\
\text { Nueces }\end{array}$ & Packery to PINS & 55 & $1 / 27 / 11$ & 10 & 22.5 & III B & H D V F G & $\underline{91}^{20}$ & $\underline{\mathbf{9 6}}^{21}$ & 01 & 06 & $\mathrm{~s}(\mathrm{p})$ \\
\hline $\begin{array}{l}\text { Kleberg/ } \\
\text { Nueces }\end{array}$ & $\begin{array}{l}\text { Upper Laguna Madre (islands S of JFK Causeway } \\
\text { to Bird Island Basin) }\end{array}$ & 53 & $1 / 27 / 11$ & 0 & 1.9 & II C & n.r. & $\underline{91}^{23}$ & $\underline{\mathbf{9 6}}^{24}$ & 01 & $\underline{06}$ & $\mathrm{~s}(\mathrm{p})$ \\
\hline Matagorda & East Matagorda Bay ${ }^{33}$ & 18 & $2 / 25 / 11$ & 3 & 85.3 & II B & n.r. & - & - & - & - & $\mathrm{s}(\mathrm{p})$ \\
\hline Matagorda & East Matagorda Peninsula $^{32,33}$ & 19 & $2 / 18 / 11$ & 0 & 20.9 & III A D F & V G & $\underline{91}^{25}$ & 96 & $\underline{01}$ & $\underline{06}$ & $\mathrm{~s}(\mathrm{p})$ \\
\hline Matagorda & $\begin{array}{l}\text { Matagorda Peninsula, Bayside and Colorado } \\
\text { River Delta }^{33}\end{array}$ & 20 & $2 / 15 / 11$ & 56 & 140.0 & II B G & G L & $\underline{91}^{26}$ & - & - & 06 & $\mathrm{~s}(\mathrm{p})$ \\
\hline Nueces & Mollie Beattie & 52 & $1 / 27 / 11$ & 0 & 4.8 & II B & G & - & 96 & 01 & $\underline{06}$ & $\mathrm{~s}(\mathrm{p})$ \\
\hline Nueces & Mollie Beattie (North End) & 50 & $1 / 26 / 11$ & 0 & 2.8 & II B G & V G & - & 96 & 01 & - & $\mathrm{s}(\mathrm{p}), \mathrm{p}$ \\
\hline Nueces & $\begin{array}{l}\text { Mustang Island - Bay shoreline N end to Wilson's } \\
\text { Cut and Shamrock Island }\end{array}$ & 42 & $1 / 26 / 11$ & 0 & 70.8 & II B & P S G L & $\underline{\mathbf{9 1}}^{27}$ & 96 & 01 & 06 & $\mathrm{~s}(\mathrm{p}), \mathrm{p}$ \\
\hline Nueces & Mustang Island - Charlie's Pasture & 41 & $1 / 26 / 11$ & 26 & 5.8 & II B & n.r. & - & - & - & - & $\mathrm{m}$ \\
\hline Nueces & Mustang Island - Port A to Packery (gulf side) & 44 & $1 / 26 / 11$ & 0 & 29.0 & III B & H D V G & $\underline{91}$ & 96 & 01 & 06 & $\mathrm{~s}(\mathrm{p})$ \\
\hline Nueces & $\begin{array}{l}\text { Mustang Island State Park (S Bayside and Fish } \\
\text { Pass) }\end{array}$ & 47 & $1 / 26 / 11$ & 0 & 1.6 & II B & H V F P G & 91 & 96 & 01 & $\underline{06}$ & $\mathrm{~s}(\mathrm{p})$ \\
\hline Nueces & Oso Bay - NAS CC & 46 & $1 / 26 / 11$ & 12 & n.r. & II A & H F G L & $\underline{91}$ & 96 & $\underline{\mathbf{0 1}}^{28}$ & 06 & $\mathrm{f}$ \\
\hline Nueces & Packery Channel Park & 49 & $1 / 26 / 11$ & 0 & 1.6 & II B & H V F G & - & - & 01 & 06 & $\mathrm{~s}(\mathrm{p})$ \\
\hline Nueces & Pelican Island & 40 & $1 / 26 / 11$ & 60 & n.r. & II C D E & S G L & $\underline{91}$ & - & - & $\underline{06}$ & $\mathrm{p}$ \\
\hline Nueces & Redfish Bay (N of causeway) & 35 & $1 / 28 / 11$ & 0 & 45.1 & II A B C D E & n.r. & 91 & $\underline{96}^{2}$ & - & 06 & $\mathrm{~s}(\mathrm{p})$ \\
\hline Nueces & $\begin{array}{l}\text { Redfish Bay (S of causeway including Harbor } \\
\text { Island) }\end{array}$ & 39 & $1 / 26 / 11$ & 112 & 28.6 & II A C E & H B F G L & $\underline{91}$ & $\underline{96}^{2}$ & 01 & 06 & $\mathrm{~s}(\mathrm{p})$ \\
\hline Nueces & $\begin{array}{l}\text { S side of JFK Causeway and Laguna Madre } \\
\text { Shoreline }\end{array}$ & 51 & $1 / 26 / 11$ & 0 & 3.0 & II A & H V F G & 91 & - & - & 06 & $\mathrm{~s}(\mathrm{p})$ \\
\hline Nueces & $\begin{array}{l}\text { Upper Laguna Madre/S end of Corpus Christi Bay } \\
\text { (islands and flats) }\end{array}$ & 48 & $1 / 26 / 11$ & 3 & 11.9 & II C G & n.r. & $\underline{91}$ & 96 & 01 & $\underline{06}$ & $\mathrm{~s}(\mathrm{p})$ \\
\hline Nueces & Ward Island & 45 & $1 / 26 / 11$ & 0 & 2.0 & II A & I G & 91 & - & $\underline{\mathbf{0 1}}^{28}$ & 06 & $\mathrm{~s}(\mathrm{p})$ \\
\hline Nueces & Wilson's Cut/Croaker Hole & 43 & $1 / 28 / 11$ & 0 & 1.6 & II B & $\mathrm{V}$ & - & - & 01 & 06 & $\mathrm{~s}(\mathrm{p})$ \\
\hline San Patricio & La Quinta Channel Islands & 38 & $1 / 26 / 11$ & 3 & 25.7 & II C & H S G & $\underline{91}$ & $\underline{96}^{2}$ & $\underline{01}$ & 06 & $\mathrm{~s}(\mathrm{p}), \mathrm{p}$ \\
\hline
\end{tabular}


The 2011 International Snowy Plover Winter Census in Texas

(Continued)

\begin{tabular}{|c|c|c|c|c|c|c|c|c|c|c|c|c|}
\hline \multirow{2}{*}{$\begin{array}{l}\text { COUNTY } \\
\text { San Patricio }\end{array}$} & \multirow[t]{2}{*}{ SITE NAME } & \multirow{2}{*}{ MAP\# } & \multirow{2}{*}{$\begin{array}{c}\text { DATE } \\
1 / 28 / 11\end{array}$} & \multirow{2}{*}{$\begin{array}{c}\text { TOTAL } \\
\text { ADULTS } \\
24\end{array}$} & \multirow{2}{*}{$\frac{\mathbf{K M}}{0.1}$} & \multirow{2}{*}{$\begin{array}{l}\text { SITE } \\
\text { DESCRIPTION } \\
\text { II D }\end{array}$} & \multirow{2}{*}{$\begin{array}{l}\text { DISTURBANCE } \\
\text { / CONCERNS } \\
\text { H D F I G L }\end{array}$} & \multicolumn{4}{|c|}{$\begin{array}{c}\text { PRIOR YEARS } \\
\text { CENSUSED \& YEARS } \\
\text { SNPL SEEN }^{1} \\
\end{array}$} & \multirow{2}{*}{$\frac{\text { OWNER }}{\mathrm{m}}$} \\
\hline & & & & & & & & $\underline{91}^{30}$ & 96 & 01 & 06 & \\
\hline Willacy & East Lake ${ }^{33}$ & 63 & $2 / 14 / 11$ & 33 & 5.6 & V G & $\mathrm{S}$ & $\underline{91}$ & - & $\underline{01}$ & - & $\mathrm{f}$ \\
\hline Willacy & East Lake (La Sal Vieja) ${ }^{33}$ & 62 & $2 / 15 / 11$ & 19 & 12.9 & V G & A I & - & - & 01 & - & $\mathrm{f}$ \\
\hline Willacy & Mansfield Channel Spoil Islands ${ }^{33}$ & 65 & $3 / 2 / 11$ & 0 & 3.7 & II C & $\mathrm{F}$ & $\underline{91}$ & - & - & - & $\mathrm{s}(\mathrm{p})$ \\
\hline Willacy & $\begin{array}{l}\text { South Padre Island, } \mathrm{N} \text { end flats by Port } \\
\text { Mansfield Channel }\end{array}$ & 66 & $1 / 30 / 11$ & 198 & 0.5 & I III B & H D V G & - & 96 & 01 & $\underline{06}$ & $f, s(p), p$ \\
\hline Willacy & South Padre Island, S of Mansfield Channel & 67 & $1 / 29 / 11$ & 1284 & 11.1 & I III B & H D V G & $\underline{91}$ & 96 & 01 & $\underline{06}^{31}$ & $f, s(p), p$ \\
\hline Willacy & $\begin{array}{l}\text { South Padre Island, upper middle of Laguna } \\
\text { Madre Side }\end{array}$ & 69 & $1 / 28 / 11$ & 1122 & 4.8 & I III B & H D V G & $\overline{91}$ & 96 & 01 & $\overline{\mathbf{0 6}}^{31}$ & $\mathrm{f}, \mathrm{s}(\mathrm{p}), \mathrm{p}$ \\
\hline Total & & & & 4981 & 1600.0 & & & & & & & \\
\hline
\end{tabular}

${ }^{1}$ If previously surveyed, years surveyed are noted. Bold underlined years indicate that Snowy Plovers were seen at the site during that Census year.

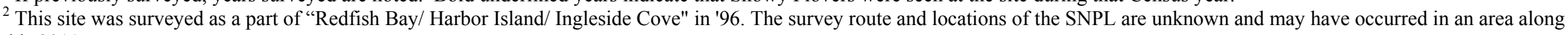
this 2011 survey route.

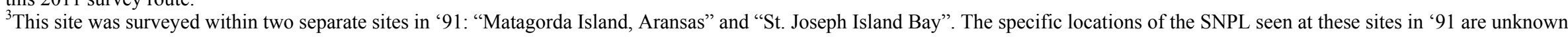
and may have occurred along the 2011 survey route.

${ }^{4}$ This site was surveyed within two separate sites in '91: "Matagorda Island, Beach" and "St. Joseph Island Beach". The specific locations of the SNPL seen at these sites in '91 are unknown and may have occurred along the 2011 survey route.

${ }^{5}$ This site was surveyed as a part of "St Joseph Island Bay" in ' 91 . The specific locations of the SNPL seen in '91 are unknown and may have occurred along the 2011 survey route.

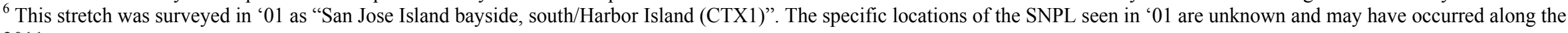
2011 survey route.

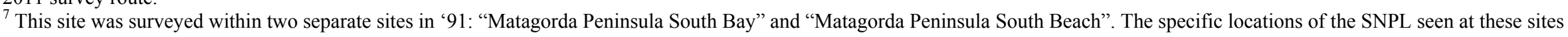
in '91 are unknown and may have occurred along the 2011 survey route.

${ }^{8}$ This site was surveyed as a part of "Matagorda Island, Beach" in ' 91 . The specific locations of the SNPL seen in '91 are unknown and may have occurred along the 2011 survey route.

${ }^{9}$ This site was surveyed as a part of "San Martin Lake \& Bahia Grande area" in '96. The specific locations of the SNPL seen in '96 are unknown and may have occurred along the 2011 survey route.

${ }^{10}$ This site was surveyed as a part of "Laguna Madre West" in ' 91 . No plovers were seen in the span of this 2011 survey route during the ' 91 census; however, 65 SNPL were seen in the area on January 6, 1991 (outside of the Census window).

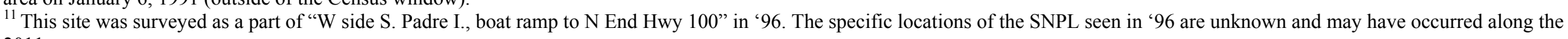
2011 survey route.

12 This site was surveyed as a part of "S. Padre Island" in ' 96 . The specific locations of the SNPL seen in '96 are unknown and may have occurred along the 2011 survey route.

${ }^{13}$ This site was surveyed as a part of "South Padre Island, Laguna Madre Side" in '06. The specific locations of the SNPL seen in '06 are unknown and may have occurred along the 2011 survey route.

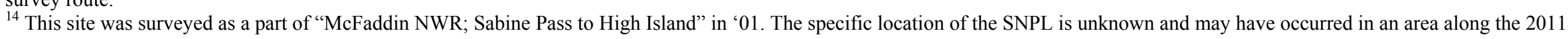
survey route.

${ }^{15}$ This site was surveyed as a part of "Bolivar Flats" in '91. The specific locations of the SNPL seen in '91 are unknown and may have occurred along the 2011 survey route.

${ }^{16}$ This site was surveyed as a part of "Bolivar Peninsula" in " 96 . The specific locations of the SNPL seen in "96 are unknown and may have occurred along the 2011 survey route.

${ }^{17}$ This site was surveyed as a part of "Big Reef-San Luis" in ' 91 . The specific locations of the SNPL seen in ' 91 are unknown and may have occurred along the 2011 survey route.

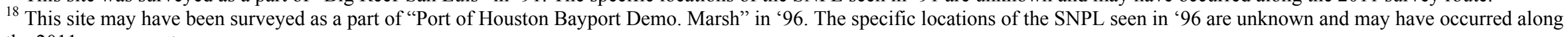
the 2011 survey route. 
19 This site was surveyed as a part of "Padre Island Bayside" in ' 91 . The specific locations of the SNPL seen in "91 are unknown and may have occurred along the 2011 survey route.

${ }^{20}$ This site was surveyed as a part of "Padre Island Beach" in " 91 . The specific locations of the SNPL seen in "91 are unknown and may have occurred along the 2011 survey route.

${ }^{21}$ This site was surveyed as a part of "Padre Island NS Beach" in ' 96 . The specific locations of the SNPL seen in ' 96 are unknown and may have occurred along the 2011 survey route.

${ }^{22}$ This site was surveyed as a part of "Southern Landcut, E" in " 96 . The specific locations of the SNPL are unknown and may have occurred along this 2011 survey route.

${ }^{23}$ This site was surveyed within two separate sites in '91: "Padre Island Bayside" and "South Bird Island". The specific locations of the SNPL seen in '91 are unknown and may have occurred along the 2011 survey route.

${ }^{24}$ This site was surveyed as a part of "Mudflat N boundary Padre Island NS" in ' 96 . The specific locations of the SNPL seen in '96 are unknown and may have occurred along the 2011 survey route.

${ }^{25}$ This site may have been surveyed as a part of "Matagorda Peninsula North Beach" in ' 91 . The specific locations of the SNPL seen in '91 are unknown and may have occurred along the 2011 survey route.

${ }^{26}$ This site was surveyed as a part of "Matagorda Peninsula South Bay" in '91. The specific locations of the SNPL seen in '91 are unknown and may have occurred along the 2011 survey route.

${ }^{27}$ This site was surveyed as a part of "Mustang Island Bay" in ' 91 . The specific locations of the SNPL seen in '91 are unknown and may have occurred along the 2011 survey route.

${ }^{29}$ This site was surveyed as a part of "Ward Island (CTX21)" in '01. The specific locations of the SNPL are unknown and may have occurred along this 2011 survey route.

${ }^{30}$ This site was surveyed as a part of "Indian Point" in " 91 . The specific locations of the PIPL seen in "91 are unknown and may have occurred along the 2011 survey route.

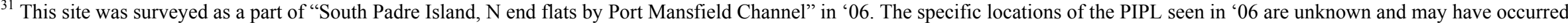
along the 2011 survey route.

${ }^{32}$ Specific survey route for this site is unknown - map illegible. Notations for sightings in prior Census years are based on an estimation of the 2011 survey route.

${ }^{33}$ Please note that this survey was conducted outside the Census window. 


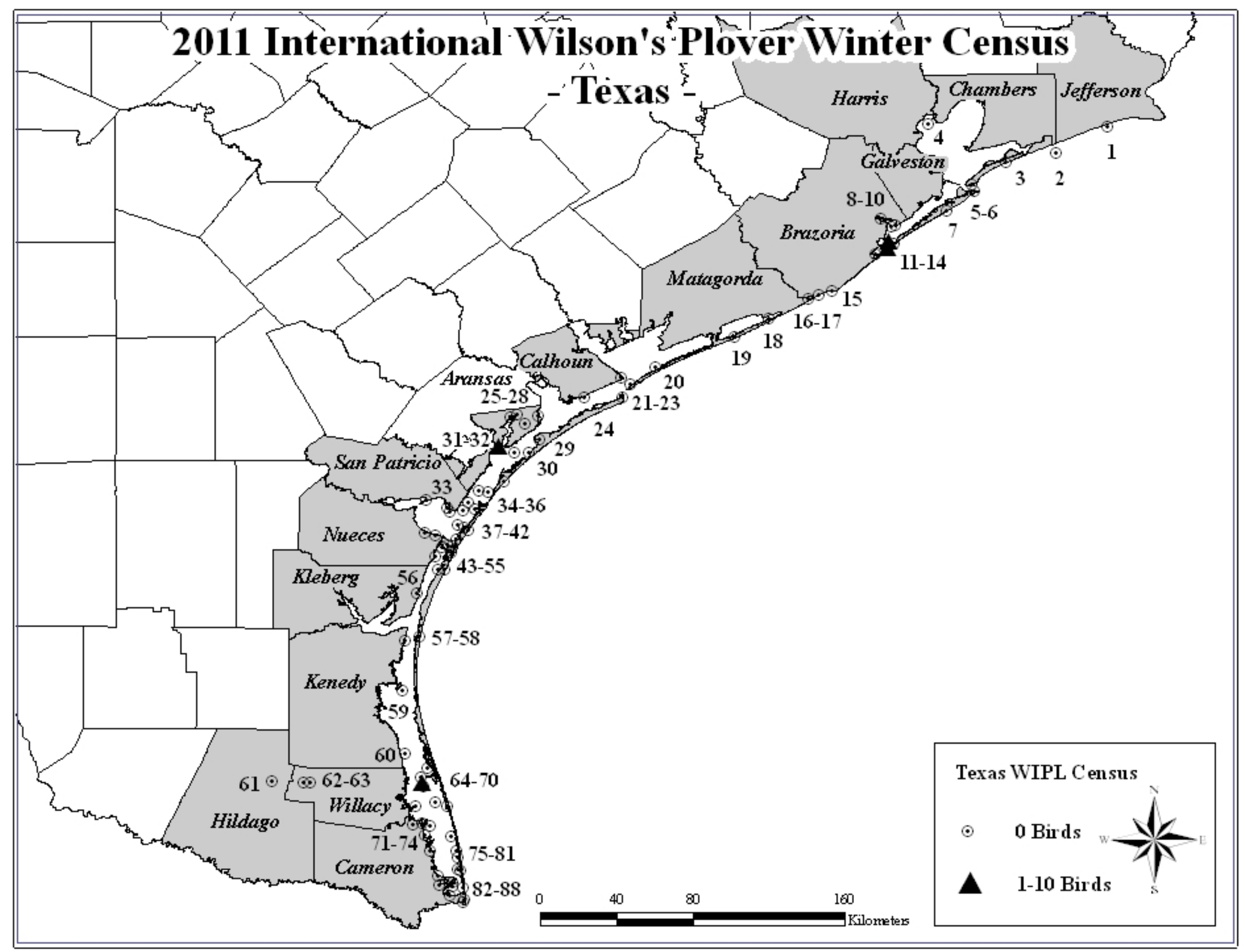


The 2011 International Wilson's Plover Winter Census in Texas

\begin{tabular}{|c|c|c|c|c|c|c|c|c|c|c|c|c|}
\hline \multirow{2}{*}{ COUNTY } & \multirow{2}{*}{$\begin{array}{c}\text { SITE NAME } \\
{\text { Aransas Bay, Goose } \text { Island }^{4}}^{4}\end{array}$} & \multirow{2}{*}{ MAP\# } & \multirow{2}{*}{$\begin{array}{c}\text { DATE } \\
1 / 1 / 11\end{array}$} & \multirow{2}{*}{$\begin{array}{c}\text { TOTAL } \\
\text { ADULTS } \\
7\end{array}$} & \multirow{2}{*}{ 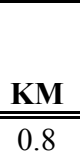 } & \multirow{2}{*}{$\begin{array}{l}\text { SITE } \\
\text { DESCRIPTION } \\
\text { II D E }\end{array}$} & \multirow{2}{*}{$\begin{array}{l}\text { DISTURBANCE } \\
\text { / CONCERNS } \\
\text { H F G L }\end{array}$} & \multicolumn{4}{|c|}{$\begin{array}{c}\text { PRIOR YEARS } \\
\text { CENSUSED \& YEARS } \\
\text { WIPL SEEN }^{1} \\
\end{array}$} & \multirow{2}{*}{$\frac{\text { OWNER }}{=\mathrm{s}(\mathrm{p})}$} \\
\hline & & & & & & & & 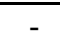 & 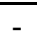 & - & 06 & \\
\hline Aransas & Burgentine Lake (Aransas NWR; W Blackjack) ${ }^{4}$ & 26 & $2 / 7 / 11$ & 0 & 3.8 & II A & $\mathrm{G}$ & - & - & - & $\underline{06}$ & $\mathrm{f}$ \\
\hline Aransas & E Blackjack (Aransas NWR Complex) ${ }^{4}$ & 28 & $2 / 7 / 11$ & 0 & 5.3 & II A & H G & - & - & 01 & - & $\mathrm{f}$ \\
\hline Aransas & Fulton to Ingleside Point (Mainland) & 37 & $1 / 25 / 11$ & 1 & 42.6 & II A & $\mathrm{G}$ & - & - & 01 & 06 & $\mathrm{~s}(\mathrm{p}), \mathrm{p}$ \\
\hline Aransas & $\begin{array}{l}\text { N San Jose Island, Bayside (Big Island to Cedar } \\
\text { Bayou) }\end{array}$ & 32 & $1 / 28 / 11$ & 0 & 22.5 & II B & H G L & - & - & - & - & $\mathrm{s}(\mathrm{p}), \mathrm{p}$ \\
\hline Aransas & San Jose Island (Gulf Side) & 34 & $1 / 26 / 11$ & 0 & 64.4 & III B & n.r. & - & - & 01 & 06 & $\mathrm{p}$ \\
\hline Aransas & San Jose Island bayside (N Pass) & 36 & $1 / 28 / 11$ & 0 & 2.0 & II B & n.r. & - & - & 01 & 06 & $\mathrm{~s}(\mathrm{p})$ \\
\hline Aransas & Tatton Unit (Aransas NWR) ${ }^{4}$ & 25 & 2/7/11 & 0 & 3.7 & II A & G & - & - & - & 06 & $\mathrm{f}$ \\
\hline Brazoria & Alligator Point ${ }^{4}$ & 9 & $2 / 11 / 11$ & 0 & 4.8 & II C D & S G L & - & - & - & - & $\mathrm{s}(\mathrm{p})$ \\
\hline Brazoria & Chocolate Bayou $^{4}$ & 8 & $2 / 11 / 11$ & 0 & 4.8 & II C D & S G L & - & - & - & - & $\mathrm{s}(\mathrm{p})$ \\
\hline Brazoria & Christmas/Drum Bay ${ }^{3,4}$ & 14 & $2 / 15 / 11$ & 0 & 26.6 & II III IV A D E F & G & - & - & - & - & $\mathrm{f}, \mathrm{s}(\mathrm{p})$ \\
\hline Brazoria & Cold Pass & 13 & $1 / 27 / 11$ & 9 & 3.2 & II G & B F G L & - & - & - & - & $\mathrm{s}(\mathrm{p}), \mathrm{c}$ \\
\hline Brazoria & Sargent Beach (East) & 16 & $1 / 28 / 11$ & 0 & 6.4 & III A & none & - & - & 01 & - & $\mathrm{s}(\mathrm{p})$ \\
\hline Brazoria & Sargent Beach (West) & 17 & $1 / 27 / 11$ & 0 & 4.2 & III IV A D E F & B G & - & - & 01 & $\underline{06}$ & $\mathrm{~s}(\mathrm{p})$ \\
\hline Brazoria & West Bay Bird Island & 12 & $1 / 27 / 11$ & 10 & 1.1 & II B E & G L & - & - & - & - & $\mathrm{s}(\mathrm{p})$ \\
\hline Brazoria & West Bay Mooring Area BU Site ${ }^{4}$ & 10 & $2 / 11 / 11$ & 0 & 4.8 & II C D & S G L & - & - & - & $\underline{06}$ & $\mathrm{~s}(\mathrm{p})$ \\
\hline Brazoria & Wolf Island & 15 & $1 / 28 / 11$ & 0 & 6.4 & III B & none & - & - & 01 & 06 & $\mathrm{~s}(\mathrm{p})$ \\
\hline Calhoun & $\begin{array}{l}\text { Cedar Bayou, Matagorda Island NWR (Gulf } \\
\text { Beach Route) }\end{array}$ & 30 & $2 / 7 / 11$ & 0 & 13.6 & I II B & G & - & - & 01 & 06 & $\mathrm{f}$ \\
\hline Calhoun & $\begin{array}{l}\text { Decros Point including Pass Cavallo and } \\
\text { Sundown Island }\end{array}$ & 22 & $2 / 14 / 11$ & 0 & 45.2 & II III IV B F & H B S G & - & - & 01 & $\underline{06}$ & $\mathrm{~s}(\mathrm{p}), \mathrm{p}$ \\
\hline Calhoun & Matagorda Island Inner Levee System ${ }^{4}$ & 29 & 2/7/11 & 0 & 15.7 & II B & G & - & - & - & 06 & $\mathrm{f}$ \\
\hline Calhoun & Matagorda Island NWR Beach (J-Hook $)^{4}$ & 23 & $2 / 7 / 11$ & 0 & 11.4 & I II A & $\mathrm{G}$ & - & - & 01 & 06 & $\mathrm{f}$ \\
\hline Calhoun & Matagorda Island NWR Gulf Beach ${ }^{4}$ & 27 & $2 / 7 / 11$ & 0 & 33.0 & I B & G & - & - & 01 & 06 & $\mathrm{f}$ \\
\hline Calhoun & Port O'Conner Shoreline & 21 & $2 / 1 / 11$ & 0 & 2.0 & V A & S G L & - & - & 01 & 06 & $\mathrm{~m}$ \\
\hline Calhoun & $\begin{array}{l}\text { Welder Flats, Shoalwater Bay, The Lagoon- } \\
\text { Dewberry Island }{ }^{4}\end{array}$ & 24 & $2 / 8 / 11$ & 0 & 85.3 & II A E G & H B F G L & - & - & 01 & 06 & $\mathrm{p}$ \\
\hline Cameron & Bahia Grande & 83 & $2 / 3 / 11$ & 0 & 30.6 & V G & H F S & - & - & 01 & 06 & $\mathrm{f}$ \\
\hline Cameron & Boca Chica Beach ${ }^{4}$ & 87 & $1 / 18 / 11$ & 0 & 4.7 & III V A & H D V F G & - & - & 01 & 06 & $\mathrm{~s}(\mathrm{p})$ \\
\hline Cameron & Brazos Island Beach \& Flats ${ }^{4}$ & 85 & $1 / 21 / 11$ & 0 & 8.7 & III V A & H D V F G & - & - & 01 & 06 & $\mathrm{f}, \mathrm{s}(\mathrm{p})$ \\
\hline Cameron & Brownsville Ship Channel Spoil Cells ${ }^{4}$ & 84 & $1 / 23 / 11$ & 0 & 4.5 & III V B & V F G & - & - & - & 06 & $\mathrm{~s}(\mathrm{p}), \mathrm{m}$ \\
\hline Cameron & Buena Vista Ranch & 74 & $2 / 6 / 11$ & 0 & 9.7 & II A & V A G & - & - & 01 & 06 & $\mathrm{p}$ \\
\hline Cameron & Intracoastal Spoil Islands ${ }^{4}$ & 73 & $3 / 2 / 11$ & 2 & 11.9 & II C & $\mathrm{F}$ & - & - & - & - & $\mathrm{s}(\mathrm{p})$ \\
\hline
\end{tabular}


The 2011 International Wilson's Plover Winter Census in Texas

(Continued)

\begin{tabular}{|c|c|c|c|c|c|c|c|c|c|c|c|c|}
\hline \multirow{2}{*}{$\begin{array}{l}\text { COUNTY } \\
\text { Cameron }\end{array}$} & \multirow{2}{*}{$\begin{array}{l}\text { SITE NAME } \\
\text { Laguna Atascosa NWR Bayside Drive (Pelican } \\
\text { Lake, Plover Point, Moranco Blanco) }^{4}\end{array}$} & \multirow{2}{*}{ MAP\# } & \multirow{2}{*}{$\begin{array}{c}\text { DATE } \\
1 / 19 / 11\end{array}$} & \multirow{2}{*}{$\begin{array}{c}\text { TOTAL } \\
\text { ADULTS } \\
0\end{array}$} & \multirow{2}{*}{$\begin{array}{c}\text { KM } \\
14.3\end{array}$} & \multirow{2}{*}{$\begin{array}{l}\text { SITE } \\
\text { DESCRIPTION } \\
\text { II A }\end{array}$} & \multirow{2}{*}{$\begin{array}{l}\text { DISTURBANCE } \\
\text { / CONCERNS } \\
\text { F G }\end{array}$} & \multicolumn{4}{|c|}{$\begin{array}{c}\text { PRIOR YEARS } \\
\text { CENSUSED \& YEARS } \\
\text { WIPL SEEN }^{1} \\
\end{array}$} & \multirow{2}{*}{$\begin{array}{c}\text { OWNER } \\
\mathrm{f}\end{array}$} \\
\hline & & & & & & & & - & - & 01 & - & \\
\hline Cameron & Long Island Village/ Outdoor Resorts ${ }^{4}$ & 82 & 2/8/11 & 0 & 4.5 & II V G & H V S U G & - & - & - & - & $\mathrm{p}$ \\
\hline Cameron & Mouth of the Rio Grande ${ }^{4}$ & 88 & $1 / 18 / 11$ & 0 & 3.2 & III A & V G & - & - & - & - & $\mathrm{f}$ \\
\hline Cameron & Port Isabel - Hwy 100 & 81 & $1 / 24 / 11$ & 0 & 14.5 & II A & H F S U G & - & - & - & - & $\mathrm{m}, \mathrm{p}$ \\
\hline Cameron & South Bay \& Boca Chica Flats ${ }^{4}$ & 86 & $1 / 17 / 11$ & 0 & 25.3 & II V A F & V G & - & - & 01 & 06 & f \\
\hline Cameron & South Padre Island Beach (North of Access 5) & 70 & $1 / 25 / 11$ & 0 & 43.5 & I III B & H D V F & - & - & 01 & - & $f, s(p), p$ \\
\hline Cameron & South Padre Island Beach (South of Access 5) & 80 & $1 / 25 / 11$ & 0 & 10.6 & I III B & H D V F S U G & - & - & - & - & $\mathrm{m}$ \\
\hline Cameron & $\begin{array}{l}\text { South Padre Island, lower middle of Laguna } \\
\text { Madre Side }\end{array}$ & 77 & $1 / 26 / 11$ & 0 & 7.7 & I III B & H D V G & - & - & 01 & 06 & $f, s(p), p$ \\
\hline Cameron & South Padre Island, middle of Laguna Madre Side & 75 & $1 / 27 / 11$ & 0 & 15.3 & I III B & H D V G & - & - & 01 & 06 & $\mathrm{f}, \mathrm{s}(\mathrm{p}), \mathrm{p}$ \\
\hline Cameron & $\begin{array}{l}\text { South Padre Island, S end Laguna Madre Side } \\
\text { (Isla Blanca to } \mathrm{N} \text { of Convention Ctr) }\end{array}$ & 79 & $1 / 24 / 11$ & 0 & 9.2 & II B & H D V F U G & - & - & 01 & 06 & $\mathrm{p}$ \\
\hline Cameron & $\begin{array}{l}\text { South Padre Island, S end Laguna Madre Side } \\
\text { (just } \mathrm{N} \text { of Convention Ctr) }\end{array}$ & 78 & $1 / 25 / 11$ & 0 & 5.2 & I III B & H D V G & - & - & 01 & 06 & $\mathrm{f}, \mathrm{s}(\mathrm{p}), \mathrm{p}$ \\
\hline Cameron & Unit 4, Laguna Atascosa NWR ${ }^{4}$ & 68 & $3 / 2 / 11$ & 0 & 12.9 & II A & G & - & - & 01 & - & f \\
\hline Cameron & $\begin{array}{l}\text { Unit } 5 \text { (Horse Island Cove), Laguna Atascosa } \\
\text { NWR }\end{array}$ & 72 & $2 / 6 / 11$ & 0 & 8.9 & II A & G & - & - & 01 & 06 & $\mathrm{f}$ \\
\hline Cameron & Unit 8 (Cayo Flats), Laguna Atascosa NWR & 71 & $2 / 5 / 11$ & 0 & 9.7 & V A & G & - & - & - & - & $\mathrm{f}$ \\
\hline $\begin{array}{l}\text { Chambers/ } \\
\text { Jefferson }\end{array}$ & McFaddin NWR to High Island & 1 & $1 / 31 / 11$ & 1 & 51.5 & III A & G L & - & - & 01 & 06 & $\mathrm{f}, \mathrm{s}(\mathrm{p})$ \\
\hline Galveston & Big Reef; Galveston Island & 6 & $1 / 27 / 11$ & 0 & 4.0 & III B & H D V G L & - & - & 01 & 06 & $\mathrm{~s}(\mathrm{p})$ \\
\hline Galveston & Bolivar Flats $^{3}$ & 5 & $1 / 28 / 11$ & 0 & 3.2 & II III B & H D V G & - & - & 01 & $\underline{06}$ & $\mathrm{~s}(\mathrm{p}), \mathrm{p}$ \\
\hline Galveston & Galvston Island, E. Beach to end of Seawall & 7 & $1 / 27 / 11$ & 0 & 16.5 & III B & H D V F S G L & - & - & 01 & 06 & $s(p)$ \\
\hline Galveston & High Island to Bolivar Flats ${ }^{3}$ & 3 & $1 / 28 / 11$ & 0 & 43.5 & III B & H D V F G & - & - & 01 & $\underline{06}$ & $\mathrm{f}, \mathrm{m}$ \\
\hline Galveston & Rollover Pass Flats ${ }^{3}$ & 2 & $1 / 28 / 11$ & 0 & 1.6 & II D & H F G & - & - & - & $\underline{06}$ & $\mathrm{~s}(\mathrm{p})$ \\
\hline Galveston & San Luis Pass; Galveston Island & 11 & $1 / 27 / 11$ & 0 & 2.9 & & H G & - & - & 01 & 06 & $\mathrm{~s}(\mathrm{p})$ \\
\hline Harris & Atkinson Island Cells $5 \& 6^{3,4}$ & 4 & $2 / 11 / 11$ & 0 & 1.9 & II C & $\mathrm{S} \mathrm{G}$ & - & - & - & - & $\mathrm{s}(\mathrm{p})$ \\
\hline Hidalgo & East Lake (La Sal Del Rey) ${ }^{4}$ & 61 & $2 / 14 / 11$ & 0 & 5.0 & V G & none & - & - & - & - & f \\
\hline Kenedy & South end 9-Mile Hole ${ }^{4}$ & 59 & $2 / 16 / 11$ & 0 & 6.0 & II G & G L & - & - & - & - & $\mathrm{s}(\mathrm{p})$ \\
\hline Kenedy & $\begin{array}{l}\text { Upper Laguna Madre, Flats at Land Cut, E \& W } \\
\text { of GIWW }\end{array}$ & 57 & $1 / 27 / 11$ & 0 & 49.6 & II A & n.r. & - & - & 01 & 06 & $\mathrm{~s}(\mathrm{p})$ \\
\hline $\begin{array}{l}\text { Kenedy/ } \\
\text { Kleberg }\end{array}$ & $\begin{array}{l}\text { Padre Island National Seashore (Bird Island basin } \\
\text { to landcut) }\end{array}$ & 56 & $1 / 27 / 11$ & 0 & 64.4 & II F & G & - & - & 01 & 06 & $f$ \\
\hline
\end{tabular}


The 2011 International Wilson's Plover Winter Census in Texas

(Continued)

\begin{tabular}{|c|c|c|c|c|c|c|c|c|c|c|c|c|}
\hline \multirow{2}{*}{$\begin{array}{l}\text { COUNTY } \\
\text { Kenedy/ } \\
\text { Kleberg }\end{array}$} & \multirow{2}{*}{$\frac{\text { SITE NAME }}{\text { National Seashore, Gulf Beach }}$} & \multirow{2}{*}{ MAP\# } & \multirow{2}{*}{$\begin{array}{c}\text { DATE } \\
1 / 27 / 11\end{array}$} & \multirow{2}{*}{$\begin{array}{c}\text { TOTAL } \\
\text { ADULTS } \\
0\end{array}$} & \multirow{2}{*}{$\begin{array}{l}\text { KM } \\
48.3\end{array}$} & \multirow{2}{*}{$\begin{array}{l}\text { SITE } \\
\text { DESCRIPTION } \\
\text { III B }\end{array}$} & \multirow{2}{*}{$\begin{array}{l}\text { DISTURBANCE } \\
\text { / CONCERNS } \\
\text { H V S G }\end{array}$} & \multicolumn{4}{|c|}{$\begin{array}{c}\text { PRIOR YEARS } \\
\text { CENSUSED \& YEARS } \\
\text { WIPL SEEN }^{1} \\
\end{array}$} & \multirow{2}{*}{$\frac{\text { OWNER }}{\mathrm{f}}$} \\
\hline & & & & & & & & - & - & 01 & 06 & \\
\hline $\begin{array}{l}\text { Kenedy/ } \\
\text { Willacy }\end{array}$ & $\begin{array}{l}\text { Bayshore flat on S end of } \mathrm{N} \text { Padre Island ( } \mathrm{S} \text { of } \\
\text { Land cut and } \mathrm{N} \text { of Mansfield Channel in LLM) }\end{array}$ & 60 & $2 / 16 / 11$ & 0 & 34.6 & II B D & G L & - & - & - & - & $\mathrm{s}(\mathrm{p})$ \\
\hline $\begin{array}{l}\text { Kenedy/ } \\
\text { Willacy }\end{array}$ & Padre Island National Seashore/ 9-Mile Hole SE ${ }^{4}$ & 64 & $2 / 16 / 11$ & 0 & 54.7 & III B & G & - & - & 01 & 06 & $\mathrm{f}, \mathrm{s}(\mathrm{p})$ \\
\hline Kleberg & Nighthawk Bay & 54 & $1 / 27 / 11$ & 0 & n.r. & II B & G L & - & - & 01 & 06 & $f, s(p)$ \\
\hline $\begin{array}{l}\text { Kleberg/ } \\
\text { Nueces }\end{array}$ & Packery to PINS & 55 & $1 / 27 / 11$ & 0 & 22.5 & III B & H D V F G & - & - & 01 & 06 & $\mathrm{~s}(\mathrm{p})$ \\
\hline $\begin{array}{l}\text { Kleberg/ } \\
\text { Nueces }\end{array}$ & $\begin{array}{l}\text { Upper Laguna Madre (islands S of JFK Causeway } \\
\text { to Bird Island Basin) }\end{array}$ & 53 & $1 / 27 / 11$ & 0 & 1.9 & II C & n.r. & - & - & 01 & 06 & $s(p)$ \\
\hline Matagorda & East Matagorda Bay ${ }^{4}$ & 18 & $2 / 25 / 11$ & 0 & 85.3 & II B & n.r. & - & - & - & - & $\mathrm{s}(\mathrm{p})$ \\
\hline Matagorda & East Matagorda Peninsula ${ }^{3,4}$ & 19 & $2 / 18 / 11$ & 0 & 20.9 & III A D F & V G & - & - & 01 & 06 & $\mathrm{~s}(\mathrm{p})$ \\
\hline Matagorda & $\begin{array}{l}\text { Matagorda Peninsula, Bayside and Colorado } \\
\text { River Delta }^{4}\end{array}$ & 20 & $2 / 15 / 11$ & 0 & 140.0 & II B G & G L & - & - & - & 06 & $\mathrm{~s}(\mathrm{p})$ \\
\hline Nueces & Mollie Beattie & 52 & $1 / 27 / 11$ & 0 & 4.8 & II B & G & - & $\underline{96}^{2}$ & 01 & 06 & $\mathrm{~s}(\mathrm{p})$ \\
\hline Nueces & Mollie Beattie (North End) & 50 & $1 / 26 / 11$ & 0 & 2.8 & II B G & V G & - & $\overline{96}^{2}$ & 01 & - & $s(p), p$ \\
\hline Nueces & $\begin{array}{l}\text { Mustang Island - Bay shoreline } \mathrm{N} \text { end to Wilson's } \\
\text { Cut and Shamrock Island }\end{array}$ & 42 & $1 / 26 / 11$ & 0 & 70.8 & II B & P S G L & - & - & 01 & 06 & $s(p), p$ \\
\hline Nueces & Mustang Island - Charlie's Pasture & 41 & $1 / 26 / 11$ & 1 & 5.8 & II B & n.r. & - & - & - & - & $\mathrm{m}$ \\
\hline Nueces & Mustang Island - Port A to Packery (gulf side) & 44 & $1 / 26 / 11$ & 0 & 29.0 & III B & H D V G & - & - & 01 & 06 & $\mathrm{~s}(\mathrm{p})$ \\
\hline Nueces & $\begin{array}{l}\text { Mustang Island State Park (S Bayside and Fish } \\
\text { Pass) }\end{array}$ & 47 & $1 / 26 / 11$ & 0 & 1.6 & II B & H V F P G & - & - & 01 & 06 & $\mathrm{~s}(\mathrm{p})$ \\
\hline Nueces & Oso Bay - NAS CC & 46 & $1 / 26 / 11$ & 0 & n.r. & II A & H F G L & - & - & - & 06 & $\mathrm{f}$ \\
\hline Nueces & Packery Channel Park & 49 & $1 / 26 / 11$ & 0 & 1.6 & II B & H V F G & - & - & 01 & 06 & $\mathrm{~s}(\mathrm{p})$ \\
\hline Nueces & Pelican Island & 40 & $1 / 26 / 11$ & 0 & n.r. & II C D E & S G L & - & - & - & 06 & $\mathrm{p}$ \\
\hline Nueces & Redfish Bay (N of causeway) & 35 & $1 / 28 / 11$ & 0 & 45.1 & II A B C D E & n.r. & - & - & - & 06 & $\mathrm{~s}(\mathrm{p})$ \\
\hline Nueces & $\begin{array}{l}\text { Redfish Bay (S of causeway including Harbor } \\
\text { Island) }\end{array}$ & 39 & $1 / 26 / 11$ & 0 & 28.6 & II A C E & H B F G L & - & - & 01 & 06 & $\mathrm{~s}(\mathrm{p})$ \\
\hline Nueces & $\begin{array}{l}\text { S side of JFK Causeway and Laguna Madre } \\
\text { Shoreline }\end{array}$ & 51 & $1 / 26 / 11$ & 0 & 3.0 & II A & H V F G & - & - & - & 06 & $\mathrm{~s}(\mathrm{p})$ \\
\hline Nueces & $\begin{array}{l}\text { Upper Laguna Madre/S end of Corpus Christi Bay } \\
\text { (islands and flats) }\end{array}$ & 48 & $1 / 26 / 11$ & 0 & 11.9 & II C G & n.r. & - & - & 01 & 06 & $\mathrm{~s}(\mathrm{p})$ \\
\hline Nueces & Ward Island & 45 & $1 / 26 / 11$ & 0 & 2.0 & II A & I G & - & - & 01 & 06 & $\mathrm{~s}(\mathrm{p})$ \\
\hline Nueces & Wilson's Cut/Croaker Hole & 43 & $1 / 28 / 11$ & 0 & 1.6 & II B & $\mathrm{V}$ & - & - & 01 & 06 & $\mathrm{~s}(\mathrm{p})$ \\
\hline San Patricio & La Quinta Channel Islands & 38 & $1 / 26 / 11$ & 0 & 25.7 & II C & H S G & - & - & 01 & 06 & $\mathrm{~s}(\mathrm{p}), \mathrm{p}$ \\
\hline
\end{tabular}


The 2011 International Wilson's Plover Winter Census in Texas

(Continued)

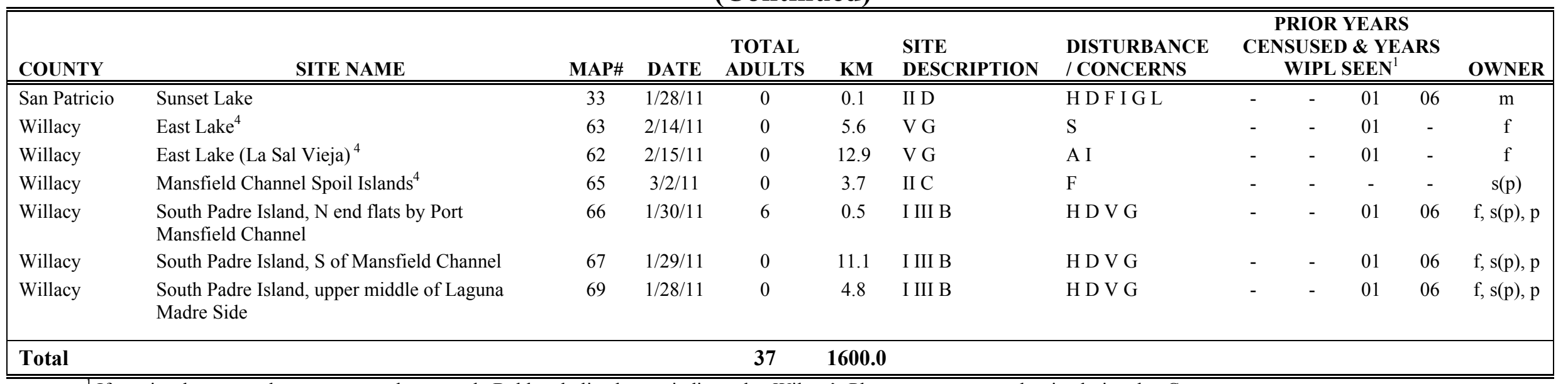

${ }^{1}$ If previously surveyed, years surveyed are noted. Bold underlined years indicate that Wilson's Plovers were seen at the site during that Census year.

${ }^{2}$ This site was surveyed as a part of "Packery \& Newport Pass" in '96. The specific locations of the WIPL seen in '96 are unknown and may have occurred along the 2011 survey route.

${ }^{3}$ Specific survey route for this site is unknown - map illegible. Notations for sightings in prior Census years are based on an estimation of the 2011 survey route.

${ }^{4}$ Please note that this survey was conducted outside the Census window. 


\section{The 2011 International Piping Plover Winter Census in Mexico}

\author{
Alfonso Banda and German Garcia \\ Pronatura Noreste A.C. \\ Loma Larga 235 \\ Col. Loma Larga C.P. 64710 \\ Monterrey, Nuevo León, Mexico \\ 52 (81) 8345-1015 \\ ggarcia@pronaturane.org
}

We surveyed three municipalities along the Tamaulipas coast: Soto La Marina, San Fernando and Matamoros. In total, we counted 82 individuals of the three species. Most abundant species was Snowy Plover (46), then Piping Plover (30) and Wilson's Plover (6). San Fernando held the biggest numbers (61 individuals), then Matamoros (21) and we recorded no plovers in Soto La Marina.

In Soto La Marina, numbers of plovers and shorebirds in general are small. Habitat is mostly beach and some seasonal mudflats (these were dry at the time of census).

San Fernando has been usually the most productive municipality in terms of numbers. Beach is the main type of habitat. This site formerly supported mudflats, sandflats, algal flats and others, but in recent years has experienced loss of habitat because of dredging in the surroundings.
Compared to 2006, we counted fewer Piping Plovers but surveyed more habitat. We were able to expand our surveys south to La Pesca (20 Piping Plovers seen) and Boca de Catan (no Piping Plovers). Whereas in 2006 we counted 19 Piping Plovers in Puerto El Mezquital al Sur we were unable to survey this portion in 2011. In Matamoros, we missed about $30 \mathrm{~km}$ because of open natural canals, the result of windy conditions.

In future Census years, a much larger effort in Tamaulipas may be warranted. Given the number of Piping Plovers in the Lower Laguna Madre Region of Texas and results from prior incomplete surveys in Mexico (prior Census efforts; Mabee et al. 2001), the northern portion of Tamaulipas has the potential to support many Piping Plovers and Snowy Plovers. An international effort with biologists from Mexico, the U.S., and Canada including resources for multiple ATV's would likely be the most successful Census approach. However, given safety concerns in 2011 a comprehensive effort was impossible. 


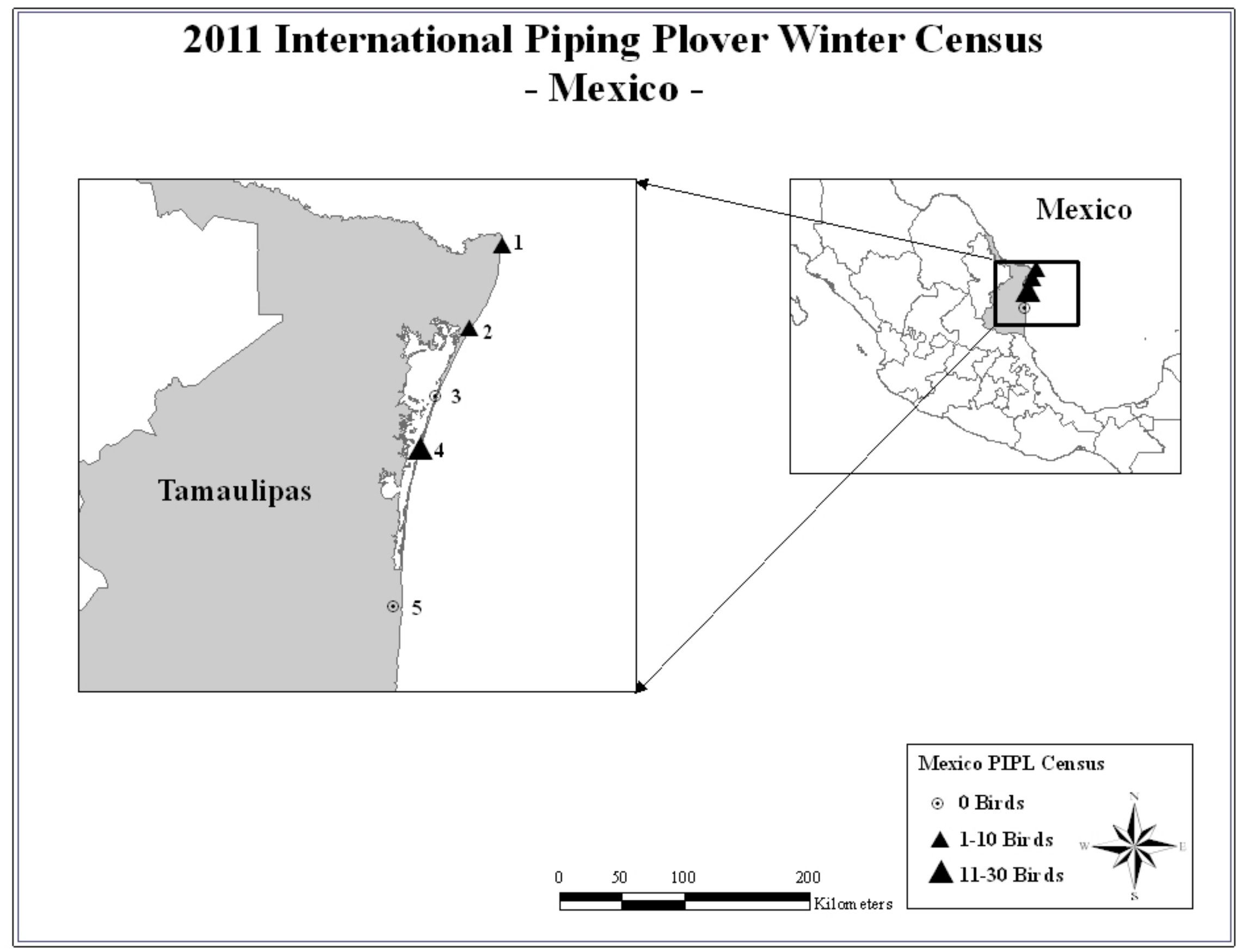


The 2011 International Piping Plover Winter Census in Mexico

\begin{tabular}{|c|c|c|c|c|c|c|c|c|c|c|c|c|}
\hline \multirow{2}{*}{$\begin{array}{l}\text { STATE } \\
\text { Tamaulipas }\end{array}$} & \multirow{2}{*}{$\begin{array}{l}\text { SITE NAME } \\
\text { Barra Boca Ciega }\end{array}$} & \multirow{2}{*}{ MAP\# } & \multirow{2}{*}{ 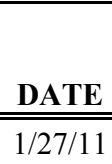 } & \multirow{2}{*}{$\begin{array}{c}\text { TOTAL } \\
\text { ADULTS } \\
0\end{array}$} & \multirow{2}{*}{ KM } & \multirow{2}{*}{$\begin{array}{l}\text { SITE } \\
\text { DESCRIPTION }\end{array}$} & \multirow{2}{*}{$\begin{array}{l}\text { DISTURBANCE } \\
\text { / CONCERNS } \\
\text { H F S I G L }\end{array}$} & \multicolumn{4}{|c|}{$\begin{array}{c}\text { PRIOR YEARS } \\
\text { CENSUSED \& YEARS } \\
\text { PIPL SEEN }^{1} \\
\end{array}$} & \multirow{2}{*}{ OWNER } \\
\hline & & & & & & & & 91 & $\underline{96}$ & - & $\underline{06}$ & \\
\hline Tamaulipas & Boca de Catan & 4 & $1 / 26 / 11$ & 20 & 70.0 & III B 4 & F A I G L & - & - & - & - & $\mathrm{f}$ \\
\hline Tamaulipas & La Pesca & 5 & $1 / 21 / 11$ & 0 & 65.0 & III B 4 & H D V S U G L & - & - & - & - & $\mathrm{f}$ \\
\hline Tamaulipas & Playa Bagdad $^{2}$ & 1 & $2 / 8 / 11$ & 5 & 23.0 & III B 4 & H F G L & - & - & - & $\underline{06}$ & $\mathrm{f}$ \\
\hline Tamaulipas & Puerto El Mezquital al Norte ${ }^{2}$ & 2 & $2 / 9 / 11$ & 5 & 17.0 & III B 4 & D I G L & - & - & - & $\underline{06}$ & $\mathrm{f}$ \\
\hline Total & & & & 30 & 175.0 & & & & & & & \\
\hline
\end{tabular}

If previously surveyed, years surveyed are noted. Bold underlined years indicate that Piping Plovers were seen at the site during that Census year.

${ }^{2}$ Please note that this survey was conducted outside the Census window. 


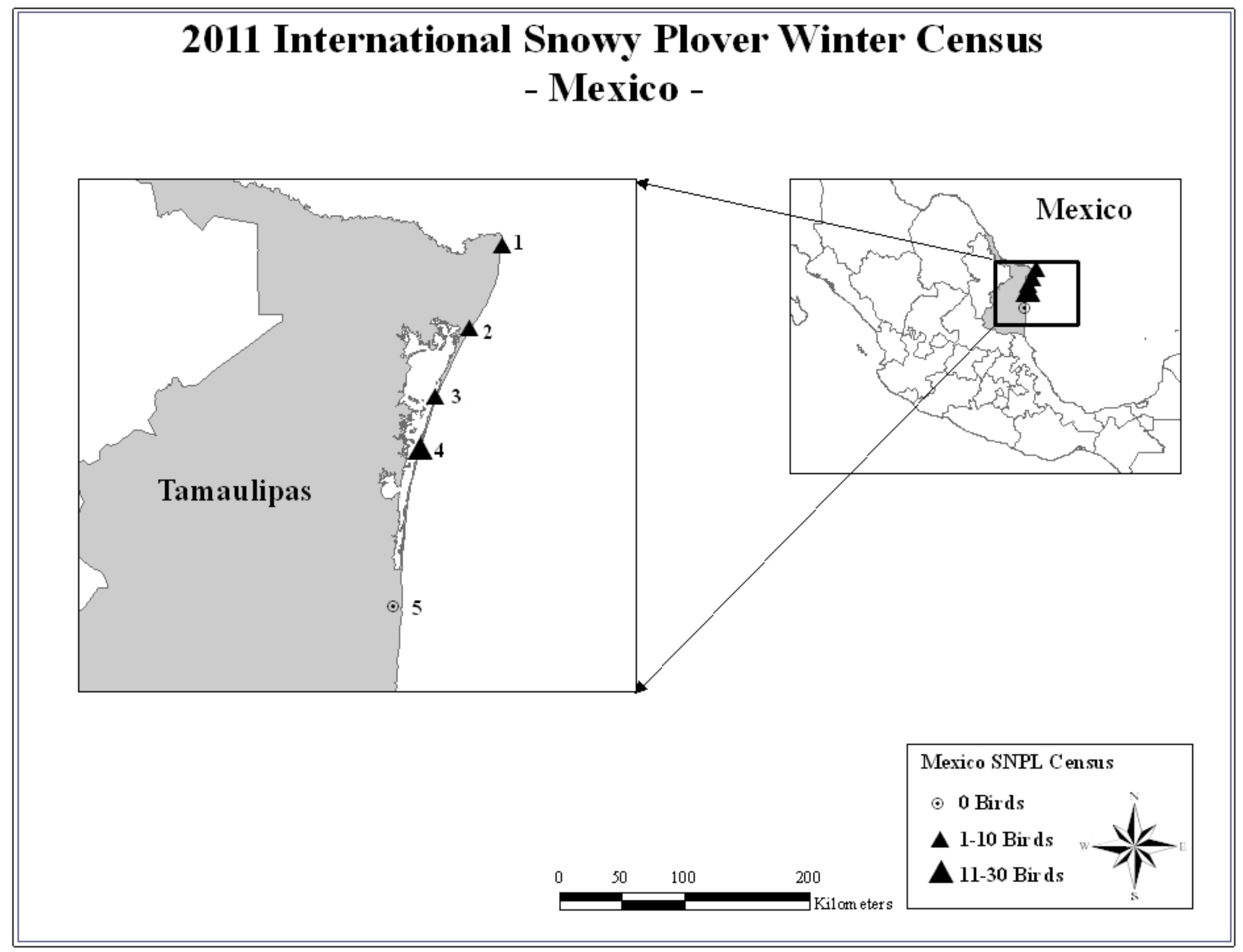


The 2011 International Snowy Plover Winter Census in Mexico



If previously surveyed, years surveyed are noted. Bold underlined years indicate that Snowy Plovers were seen at the site during that Census year.

${ }^{2}$ Please note that this survey was conducted outside the Census window. 


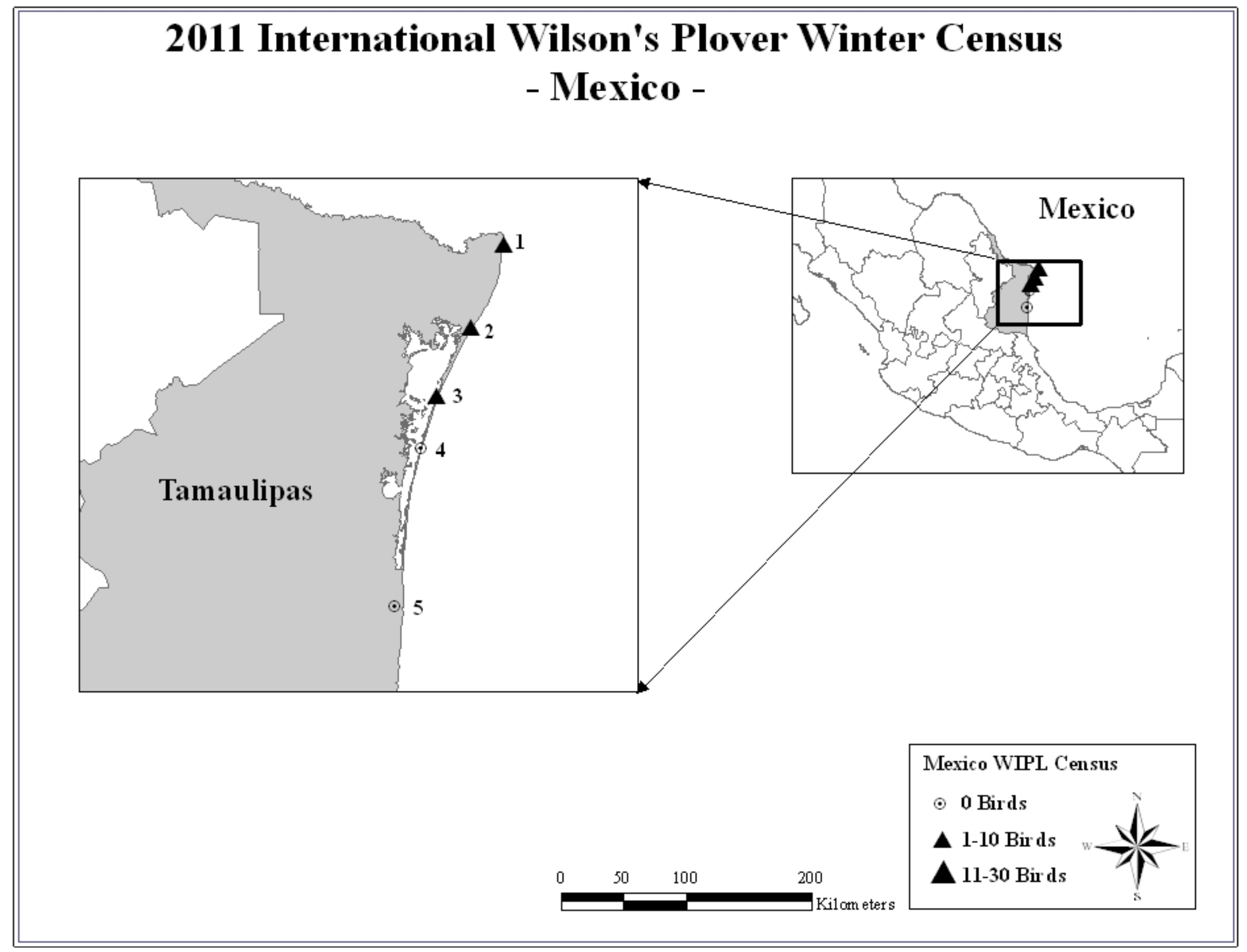


The 2011 International Wilson's Plover Winter Census in Mexico

\begin{tabular}{|c|c|c|c|c|c|c|c|c|c|c|c|}
\hline \multirow{2}{*}{$\begin{array}{l}\text { STATE } \\
\text { Tamaulipas }\end{array}$} & \multirow{2}{*}{$\begin{array}{l}\text { SITE NAME } \\
\text { Barra Boca Ciega }\end{array}$} & \multirow{2}{*}{ MAP\# } & \multirow{2}{*}{ 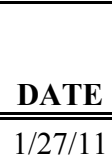 } & \multirow{2}{*}{$\begin{array}{c}\text { TOTAL } \\
\text { ADULTS } \\
2\end{array}$} & \multirow{2}{*}{ KM } & \multirow{2}{*}{$\begin{array}{l}\text { SITE } \\
\text { DESCRIPTION }\end{array}$} & \multirow{2}{*}{$\begin{array}{l}\text { DISTURBANCE } \\
\text { CONCERNS } \\
\text { H F S I G L }\end{array}$} & \multicolumn{3}{|c|}{$\begin{array}{c}\text { PRIOR YEARS } \\
\text { CENSUSED \& YEARS } \\
\text { WIPL SEEN }^{1} \\
\end{array}$} & \multirow{2}{*}{ OWNER } \\
\hline & & & & & & & & - & - & 06 & \\
\hline Tamaulipas & Boca de Catan & 4 & $1 / 26 / 11$ & 3 & 70.0 & III B 4 & F A I G L & - & - & - & $\mathrm{f}$ \\
\hline Tamaulipas & La Pesca & 5 & $1 / 21 / 11$ & 0 & 65.0 & III B 4 & H D V S U G L & - & - & - & $\mathrm{f}$ \\
\hline Tamaulipas & Playa Bagdad ${ }^{2}$ & 1 & $2 / 8 / 11$ & 1 & 23.0 & III B 4 & H F G L & - & - & 06 & $\mathrm{f}$ \\
\hline Tamaulipas & Puerto El Mezquital al Norte ${ }^{2}$ & 2 & $2 / 9 / 11$ & 0 & 17.0 & III B 4 & D I G L & - & - & 06 & $\mathrm{f}$ \\
\hline Total & & & & 6 & 175.0 & & & & & & \\
\hline
\end{tabular}

${ }^{1}$ If previously surveyed, years surveyed are noted. Bold underlined years indicate that Wilson's Plovers were seen at the site during that Census year.

${ }^{2}$ Please note that this survey was conducted outside the Census window. 


\section{The 2011 International Piping Plover Winter Census in The Bahamas}

\author{
Predensa Moore \\ Bahamas National Trust \\ PO Box N-9500 \\ Nassau, Bahamas \\ 242-393-1317 \\ pmoore@bnt.bs
}

The 2011 International Winter Census effort in The Bahamas was carried out between January 23 and February 6, 2011, at 198 sites. In addition, 5 sites were surveyed outside the census window but during winter (February). In total, 203 sites were surveyed by 29 observers. Coordination was a collective effort led by The Bahamas National Trust (BNT; Predensa Moore) and USGS FRESC (E. Elliott-Smith). Participants included local bird watchers, BNT Park Wardens, biologists from the USFWS, Canadian Wildlife Service, National Audubon, Bird Studies Canada, Massachusetts Audubon, Conservian, Conserve Wildlife Foundation (New Jersey), and volunteer bird watchers from the US. A total of 1,066 Piping Plovers were observed during the 203 site visits on 12 island groups.

Compared to previous Censuses, we greatly increased our survey effort in The Bahamas. Prior to 2006, reports from The Bahamas had been few and were incidental. Numbers from the early Census years were 35 birds observed in 2001, 25 in 1996, and 29 in 1991. The 2006 Census represented the first coordinated effort to survey Piping Plovers in The Bahamas. That effort resulted in the detection of 417 Piping Plovers and it was suspected to be an underestimate because not all potential habitat had been surveyed. We surveyed over five times the amount of shoreline in 2011 (678 km vs. $128 \mathrm{~km}$ in 2006). Hence, the 1,066 Piping Plovers observed in 2011 is substantially higher than previous counts but is almost certainly due to our increased effort and not reflective of an increase in the wintering population.
The number of sites surveyed and Bahamas coverage in general during the 2011 census far exceeded what had been previously surveyed. Locations such as the Berry Islands, Joulter Cays, Bimini Islands, San Salvador, Crooked and Acklins Islands had never been surveyed and other islands had greatly increased coverage in 2011 relative to 2006 . Roughly $40 \%$ of the sites surveyed had Piping Plovers. Locations with high counts included 255 Piping Plovers near the southeast tip of Ambergris Cay, 44 at an unnamed sandbar south of Fish Cays, and 27 at a tidal flat on the northwest side of Chub Cay, all on the Berry Islands; 83 at the northern end of Andros and Blanket Sound, 100 in the Joulter Cays, all on North Andros; 46 at Manowar Cay on Exuma; 36 at Gold Rock Creek, 31 at East End Cays, and 20 between Pelican Point and Rocky Point Flats, all on Grand Bahama; 26 at Island Palm Shores on Abaco; 24 at Joe Sound Harbor on Long Island; and 21 at Water Cays on South Andros.

Overall, 2011 Census coverage was comprehensive on Grand Bahama, the Bimini Islands, New Providence, and San Salvador. Most potential habitat was surveyed on Eleuthera, Long Island and Great Exuma. Many sites were covered on Abaco but habitat remains to be explored particularly in cays to the northeast and flats off the west side of the island ("the Marls"). Surveys of the north Berry Islands were comprehensive but we were only able to survey about half the south Berry Islands and none of the central islands (a subsequent, more comprehensive survey of the southern and mid- Berry Islands resulted in similar numbers to the 2011 Census, suggesting that the 2011 census found most of the plover hot spots, but we have not directly compared the geographic extent or region of overlap for our respective survey efforts). Many sites were surveyed on North Andros during the 2011 Census but only a 
portion of the Joulter Cays was surveyed. An expanded effort in the Joulter Cays during winter 2012 documented over 300 Piping Plovers. More than 100 Piping Plovers were seen in Central Andros during the same expedition (Matt Jeffery, unpublished data). Many sites on South Andros were surveyed in 2011 but the southern tip and southwest portion of the island look to have the most promissing habitat in aerial and satellite imagery, and we were not able to survey there (an incidental report of 21 Piping Plovers was provided by a birder who was bone fishing off the south side of the island). It is uncertain whether the west side of Andros would have habitat but it is largely unexplored. We were unable to coordinate surveys on most of the cays in the Exuma chain in 2011 and a 2012 expedition documented over 100 Piping Plovers on habitat that had not been surveyed in 2011 (Sidney Maddock, unpublished data). Although we visited Crooked and Acklins Islands in 2011 our visit was ill-timed and we were unable to access any habitat by boat due to a Ministry of Tourism fly fishing/boating workshop which involved all the local fishermen. Aerial photography of both Crooked and Acklins Islands suggest there is much promising habitat which we were unable to explore. Surveys were comprehensive on the populated portion of Great Inagua but we were unable to survey the remaining three-quarters (however local BNT warden and aerial photography do not suggest optimal plover habitat exists in those areas). We did not visit Cat Island in 2011 but no Piping Plovers were recorded there in 2006, so it is unlikely that our failure to survey there in 2011 missed many birds. We did receive some incidental sightings in 2006 from the Ragged Island chain but we were unable to survey there in 2011. Other islands that have never been surveyed include Mayaguana, Rum Cay, and Conception.

Surveyors noted that habitat management and control of feral animals may be required to protect plovers and their habitat on most of the islands.

Invasive plant species Casuarina (Casuarina equisetifolia) and Scaevola (Scaevola taccada) are the primary threats to the Piping Plover high tide roosting habitats. They out-compete native vegetation which is better able to trap sand and offers some beach protection during storm events. Hence, invasion by Casaurina and Scaevola leads to erosion and narrowing of beaches. They may also provide cover and perching habitat in proximity to tidal flats for shorebird predators such as Peregrine Falcons and Merlins (Predensa Moore, unpublished data). The removal and management of these plants is a very expensive and labor intensive prospect and the job is made more difficult due to the archipelagic nature of the Bahama Islands. Feral animals, both dogs and cats, appear to be a present across the islands even at some remote sites and how large of a threat they pose to wintering plovers is unknown. Sites located closer to urban areas may face habitat loss and disturbance from development and human use.

Outreach and education can contribute to improving plover awareness and habitat management. Through our many conversations, it was clear that people know very little about Piping Plovers but are interested to learn about plovers and the importance of habitats in The Bahamas. Most had no knowledge about shorebirds, yet they were familiar with more high profile species, like flamingo, or more visible coastal species, like herons, egrets, and Osprey. Outreach materials with pictures of Piping Plover (and other plovers) in non-breeding plumage, habitats, and maps showing breeding and wintering areas would be an asset for future surveys to provide to guides and coastal landowners. No doubt our Census effort raised awareness on some islands and on Abaco a local filmmaker accompanied the survey crew, producing a piece that appeared on local television.

Due to the convergence in some areas between bonefish and shorebird habitats, experienced bonefishing guides could be excellent resources for future surveys, conservation, and research efforts. Special shorebird identification and shorebird habitat training sessions for bonefishing 
guides would be a possible opportunity for enhancing awareness and engaging guides in conservation at high priority wintering areas. Encouraging guides to check on the status of known Piping Plover (and other shorebird) wintering sites could be worthwhile.

Subsequent to the 2011 Bahamas Census there has been much interest in additional explorations, outreach, and conservation efforts. Follow-up expanded surveys have been made in the Berry Islands, Joulter Cays, and Exuma Cays. Joulter Cays and the northern Berry Islands have been included as an Important Bird Area and National Audubon is working with BNT to formally protect this region. The 2006 and 2011 Censuses have been stepping stones bringing us closer to understanding Piping Plover distribution, habitat preferences, behavior, threats, and management challenges. Much work remains to be done in The Bahamas.

We wish to thank the USFWS for largely funding the Census effort in The Bahamas. The Canadian Wildlife Service and National Audubon also contributed substantially to the effort. Many others donated time and expertise to make this effort successful.

Summarized by E. Elliott-Smith with imput from surveyors, in particular P. Moore and S. Abbott

\section{Comparison of Census Numbers}

\begin{tabular}{|l|c|c|c|c|c|}
\hline Species & 1991 & 1996 & 2001 & 2006 & 2011 \\
\hline $\begin{array}{l}\text { Piping } \\
\text { Plover }\end{array}$ & 29 & 25 & $35^{*}$ & 417 & 1,066 \\
\hline $\begin{array}{l}\text { Snowy } \\
\text { Plover }\end{array}$ & n.r. & n.r. & n.r. & 13 & 38 \\
\hline $\begin{array}{l}\text { Wilson's } \\
\text { Plover }\end{array}$ & n.r. & n.r. & n.r. & 218 & 446 \\
\hline
\end{tabular}

*No official survey was coordinated in 2001, but Piping Plovers were reported by local birders and through the National Audubon Society's Annual Christmas Bird Count.

\section{Grand Bahama and Abaco}

\author{
Ellen Jedrey \\ Massachusetts Audubon Society \\ P.O. Box 275 \\ Cummaquid, MA 2637 \\ U.S.A. \\ ejedrey@massaudubon.org \\ Gabrielle Gareau \\ Massachusetts Audubon Society \\ P.O. Box 275 \\ Cummaquid, MA 2637 \\ U.S.A. \\ gagareau@yahoo.ca
}

Between January 24-31, 2011, we (Ellen Jedrey and Gabrielle Gareau) surveyed the southern coastline of Grand Bahama from the west end (Old Bahama Bay) to the east end (including the Eastern Cays) for Piping Plovers, Wilson's Plovers and Snowy Plovers as part of the International Piping Plover Winter Census. In total, we surveyed 25 sites that covered approximately 179.3 $\mathrm{km}$ (111.4 mi) of shoreline, including some areas by foot/boat and that were not suitable habitat. Prescott Gay, of Bahamas National Trust, provided a tremendous amount of logistical support; local volunteers also provided support. On January 30, Edie Ray arrived, and the group travelled to Abaco on January 31. From February 1-5, our group surveyed 38 sites on Abaco Island, approximately $128 \mathrm{~km}$ (79 mi) of coastline (including some areas that were boated/ driven). We surveyed with Todd Pover, of Conserve Wildlife Foundation of New Jersey, and other volunteers (Woody Bracey in particular) while on Abaco. On February 6, we (Ellen Jedrey, Edie Ray, Gabrielle Gareau) travelled back to Grand Bahama to Great Sale Cay, which is included in the overall totals for Grand Bahama. We departed on February 7, 2011. 
On Grand Bahama, we observed a total of 163 individual Piping Plovers, 1 Snowy Plover, and 86 Wilson's Plovers. The highest number of Piping Plovers observed at any site was 36 individuals observed at Gold Rock Creek and eastward (approximately $8.6 \mathrm{~km}$ ). In addition, a total of 11 color-banded Piping Plovers were observed and reported.

Threats recorded on the great majority of beaches included presence of Casaurina, feral cat tracks, and feral dog tracks. Casaurina appears to have resulted in loss of a great deal of beach/berm habitat, and beaches were generally very narrow on Grand Bahama. In addition, coastal development and armoring (bulkheads, revetments, jetties) were also recorded at a number of sites, particularly around Freeport and adjacent areas east and west.

On Abaco, we observed a total of 76 Piping Plovers (not including one observed on Sandy Point west beach, which flew north and we couldn't be sure we didn't double count), 0 Snowy Plovers, and 66 Wilsons Plovers. The site with the single highest count of Piping Plovers (26) was Island Palms Shores on February 3, 2011.

Threats recorded included feral cat tracks (on almost all beaches) and development at many sites, particularly those that had the highest number of Piping Plovers/roosting tracks (i.e. Schooner Bay, Bahama Palms Shores, Island Palms Shores). In addition, feral dog tracks were recorded at a number of sites. Casaurina is present, and appears to be increasing on Abaco, however the problem appears not to be as severe compared to Grand Bahama.

Coverage was complete along the entire south side of Grand Bahama but there is likely good habitat in Abaco that remains to be surveyed. In general, our coverage of Grand Bahama was comprehensive and it is not likely that many birds were missed. The "Marls" region on the west side of Abaco presents a challenge to survey but it could be very suitable for Piping Plovers. Cays to the northwest of Abaco were not surveyed and are definitely worth exploring.

\section{Bimini Islands}

Margo Zdravkovic

Coastal Bird Conservation/Conservian

610 Wilder Road

Big Pine Key, FL 33043

MargoZ@Coastalbird.org

The 2011 International Winter Census effort on the Bimini Islands was carried out over two days (February 4-5, 2011) at three sites by two observers. A total of 9 Piping Plovers were reported on the Bimini Islands. All potential shorebird habitat was surveyed on North and South Bimini and all the small Cays $45 \mathrm{~km}$ (28 miles) south to Ocean Cay.

Promising areas were surveyed at both high and low tides. All known sand flats habitat were located and surveyed. Substantial sand flats were found and appeared to be good habitat but shorebird numbers were low. Small flocks of Ruddy Turnstones, Blackbellied Plovers, Willets and Sanderlings were also observed.

Piping Plovers were observed on all three sites. Four Piping Plovers were reported at East Wells, North Bimini, described as remote habitat, sand spit associated with mangrove tidal creek. Four Piping Plovers were reported on South Cat Cay, described as natural and artificial habitat, sand shoreline associated with sand flats and armored wall (part of airport runway). One Piping Plover was reported on a small island just south of Ocean Cay called Brown Water Rocks, described as remote habitat, sand flat associated with small limestone island.

The Bimini Islands in general supported very low numbers of any type shorebirds. The beaches are very narrow. Coastlines have been impacted by development and growth of Casaurina. 


\section{North Andros}

Walker Golder

Audubon

7741 Market Street, Unit D

Wilmington, NC 28411-9444

U.S.A.

wgolder@audubon.org

Matt Jeffrey

Audubon

1150 Connecticut Ave., NW \#600

Washington D.C.

U.S.A.

mjeffery@audubon.org

The 2011 International Piping Plover Winter

Census on North Andros was conducted from January 27 to February 2, 2011. Thirteen sites were visited, most of which were on the eastern, northern, and southern coastline of the island. The western coast is largely inaccessible. Piping Plovers were found at six sites and Wilson's Plovers were found at ten sites. In total, 217 Piping Plovers and 180 Wilson's Plovers were recorded. The majority of the Piping Plovers were found at two sites, the Joulter Cays off the northern end of Andros and Blanket Sound in the central eastern coast region, where 100 and 83 individuals were counted, respectively. The majority of Wilson's Plovers were found at four sites, Joulter Cays, Lowe Sound, southwest of Mastic Cay, and Plum Cay, with 54, 40, 26, and 21 individuals, respectively.

The Joulter Cays had the greatest number of both Piping and Wilson's Plovers. The Joulter Cays are a vast area of tidal flats and islands located off the northern end of Andros. They are remote and accessible only by boat. The survey team included five participants that spread out over the northern and southern regions of the Joulter Cays to cover as much of the area as possible. Even with this broad coverage, an estimated $30 \%$ of the suitable habitat was covered. The survey was complicated by a midday low tide, which reduced the total potential habitat that could be covered. A total of 100 Piping Plovers and 54 Wilson's plovers were recorded. It is very likely that this site supports additional Piping and Wilson's Plovers.

Lowe Sound is located on the northern end of Andros. The area has large tidal flats and suitable high tide resting and roosting sites. A total of 14 Piping Plovers and 40 Wilson's Plovers were recorded.

Red Bays is located on the northwest end of Andros. This was the only site that was able to be surveyed on the western coastline of Andros. A road leads through the community of Red Bays to a boat launching site. The area south of the boat launching to Loggerhead Point site had no suitable habitat. The tidal flats north of the boat launching site were suitable for plovers; one Piping Plover and 13 Wilson's Plovers were recorded. Further exploration of the northwest region would likely result in additional plovers being discovered.

The area from Stafford Creek, north of Forfar Field Station, north to Mastic Bay appeared to have extensive tidal flats and suitable habitat. The area has suitable foraging habitat at low tide, but little, if any, suitable high tide resting or roosting habitats. The offshore cays were surveyed as well as the mainland shoreline. The mainland shoreline and the shoreline of the offshore cays were heavily vegetated with Casuarina and Scaevola. No Piping Plovers and only one Wilson's Plover were observed.

The region from Stafford Creek to Stanyard Creek (also spelled Staniard) supported the second highest concentration of Piping Plovers on northern Andros. This area includes Forfar Field Station and the associated Forfar flats, Blanket Sound and the associated flats, and Kamalame Cay. This area was covered thoroughly and observed through all tidal stages. Piping Plovers were observed on the tidal flats south of Forfar Field Station, north Blanket Sound, south Blanket Sound, and the sound 
side of Kamalame Cay. It is likely that the plovers using these locations are the same local population. It appeared that Piping Plovers dispersed to the tidal flats south of Forfar Field Station and throughout Blanket Sound during low tides when flats in these areas were exposed and then concentrated on the flats at the southern end of Blanket Sound and the sound side of Kamalame Cay during higher tides. Piping Plovers were observed on the ocean beach of Kamalame Cay in 2010. Our survey team walked the entire length of the ocean and sound side shoreline of Kamalame Cay at the same time. While no Piping Plovers were observed on the ocean beach, the habitat appeared suitable as a high tide resting or roosting site. It is possible that the ocean beach is used at times when the sound side habitats are not accessible. A total of 83 Piping Plovers and 6 Wilson's Plovers were recorded.

Stanyard Creek flats and Stanyard Creek beach are located south of Blanket Sound and Kamalame Cay. The beach is narrow and is popular among local beachgoers. The tidal flats appeared to have suitable foraging habitat at low tide, but no resting or roosting habitat at high tide. Both sites were covered thoroughly and no Piping Plovers or Wilson's Plovers were observed.

The beach at Small Hope Bay was surveyed thoroughly. Piping Plovers were observed on the beach in this area in 2010, but no Piping Plovers were observed during the 2011 survey. Two Wilson's Plovers were observed near Small Hope Bay lodge.

Several sites that appeared to have suitable habitat between Fresh Creek and Cargill Creek were surveyed. These included the extensive flats south of AUTEC, near Plum Cay, and the extensive flats southwest of Mastic Cay. While the habitat appeared suitable for Piping Plovers, no Piping Plovers were observed. Wilson's Plovers were recorded on the tidal flats associated with Plum Cay and southwest of Mastic Cay; 24 and 26 individuals, respectively. The area is worthy of further exploration.
Cargill Creek is located in the southeastern area of North Andros. The tidal flats south of Cargill Creek have suitable foraging habitat during low tide and adequate resting and roosting habitat during high tide. Thirteen Piping Plovers and four Wilson's Plovers were recorded.

Bigwood Cay is a remote cay, accessible only by boat, located in the central region of Andros between north and south Andros. The area consists of a large cay (Bigwood Cay) and many smaller cays. The survey team covered the eastern and northern shorelines and the associated tidal flats. No Piping Plovers were observed on the eastern shoreline. All of the Piping Plovers recorded on Bigwood Cay were found on the tidal flats on northern shoreline. The survey covered as much of the area as possible, but more extensive exploration is needed. The survey team was not able to get to the western or southern areas of Bigwood Cay, both of which appear to have suitable habitat for Piping Plovers and Wilson's Plovers. Further exploration of Bigwood Cay and the associated tidal flats and cays is warranted.

Human disturbance appeared to be minimal at most sites where Piping Plovers were observed. Evidence of the presence of freeroaming dogs was observed on some beaches and tidal flats. Invasive Casuarina and Scaevola were present at every site that was surveyed. At some locations these plants dominated the shoreline vegetation and occurred to the mean high water line, greatly reducing or eliminating potential high tide resting and roosting area.

The 2011 International Piping Plover Winter Census on North Andros provided a more comprehensive survey of the island and associated flats than any prior effort. However, complete coverage of all potential habitats on North Andros was limited by accessibility to remote areas, boat transportation, funding, and time. A subsequent survey effort in 2012 (by 
Audubon, USGS, and USFWS biologists)

documented over 300 Piping Plovers in the Joulters and over 100 on North Andros. The area is worthy of additional exploration in the future.

\section{Eleuthera}

Patrick R. Leary

1291 S 3rd Street

Fernandina Beach, FL 32034

U.S.A.

pleary@bellsouth.net

The 2011 International Winter Census effort on Eleuthera was carried out between January 25 and January 31, 2011, at 23 sites by two observers. Seventeen Piping Plovers were reported on Eleuthera Island and 13 Piping Plovers were reported on Harbor Island (off northern Eleuthera). Observers drove a total distance of $970 \mathrm{~km}$ to access remote beaches and shorelines along all coasts from the north end of Eleuthera south to Rock Sound. Surveys were conducted on foot at all sites. Severe weather or unfavorable tides required repeat surveys at Spanish Wells, Current, and Savannah Sound.

Of the 23 sites surveyed, we recorded Piping Plover at only five locations. These included 5 at Spanish Wells, 1 at Man Island, 13 at Harbor Island (all North Eleuthera), 3 at James Point (Wreck) Beach, and 8 at Savannah Sound (both Atlantic Coast). Somewhat confusing this total were an additional 13 Piping Plovers recorded on the west side of Harbor Island following the east side beach survey and 8 Piping Plovers roosting on the Atlantic shore north of Grinder's Point the day preceding the second Savannah Sound survey. Due to the spatial and temporal proximity of these sightings and their precise duplication, observers assumed they represented the same populations in both circumstances.

Most Piping Plovers were observed on the north end of Eleuthera (19 birds). At Spanish Wells, despite initially recording 4 Piping Plover on the east end flats, adverse weather interrupted the survey. The repeat survey was performed on an ebbing tide, finding 5 Piping Plover on the east end flats. No plovers were seen on the expansive exposed habitats within view of the island, including tidal flats adjoining both sides of Spanish Well's entrance channel and similar flats adjoining Gun Point across the inlet. Observers found an expansive sand spit adjoining the north inlet on Man Island, but reported only 1 Piping Plover and 1 Blackbellied Plover. At Harbor Island, 13 plovers were initially sighted on the Atlantic beach (Pink Sands) on the first of the ebb tide shortly after dawn. It is likely the plovers roosted on the high beach during the night and briefly lingered there before beach activities compelled them to shift to the harbor side to rest until the primary forage habitat (harbor side flats) became exposed. We were unable to survey the inter-tidal flats evident in Inner Sound north of the airport. This remote area requires a vessel to investigate, but appears highly favorable as shorebird foraging habitat.

We observed 11 Piping Plovers along the Atlantic beaches of Eleuthera's main island, but habitat there proved difficult to access and highly problematic to survey by foot due to steep slopes, very soft substrate, and a multitude of rocky points. Most of the lime rock, beach access, roads running east from the Queen's Highway were unmarked, unmaintained and in poor to bad condition. Generally, the Atlantic beaches became less sloping progressing south, but few shorebirds were present and no species were observed foraging in the intertidal zone. Piping Plovers were observed at three spots on the Atlantic Coast during the Census: James Point (Wreck) Beach (3 birds), Savannah Sound and Grinder's Point (we suspect the same 8 birds were sighted in both locations). At James Point (Wreck) Beach, a small flock of unidentified mixed shorebird species were found roosting on a derelict hulk of a wreck off the beach before being flushed but 3 Piping Plover were seen foraging in abundant Sargasso weed on the adjoining high beach. Prior to the Census 
we received two reports of small numbers of Piping Plovers near Club Med Beach (Tippy's). Both were of non-foraging birds, and one observation was on a rocky point. Offshore rocks and rocky islets are common along Eleuthera's Atlantic shore and contribute to the difficulties of searching for Piping Plover along that coast.

No Piping Plovers were observed on Eleuthera's west shore (Bight of Eleuthera). In contrast to Atlantic beaches, the west shore offers gently sloping or near-flat beaches, but beaches are fewer in number and more widely separated along a predominantly rocky shoreline. Ten Bay Beach and Cocadimama Beach appeared to be most favorable for Piping Plover due their expansive low tide habitats, yet no Piping Plover were found at either beach. Ten Bay appeared to be a popular beach for recreationists but Cocadimama Beach had but one couple during our survey. Low numbers of shorebirds (Black-bellied Plover, Semipalmated Plover, Willets, Ruddy Turnstones, Killdeer, Sanderling, and America Oystercatchers) were observed most frequently on narrow, rocky shores near towns and harbors (most characterized by algal growth on the substrate not seen elsewhere on that coast).

We observed no Piping Plovers on southern Eleuthera, but our surveys were limited to Rock Sound proper which offered very limited intertidal habitat. Insight gained from local residents suggested that other potential sites in the region would be unfavorable for Piping Plover. Although access may be challenging, future surveys might investigate the series of small inlets and shallow bays along the island's southernmost shore (Deep, Rollins, Rock, Hartford's and John Millar's Creek).

In conclusion, Eleuthera appears to support only small numbers of wintering Piping Plovers. In many areas foraging habitat is limited and shorelines are predominantly rocky. Seemingly ideal foraging habitat in several locations (Upper Cove Beach at Current, Man Island spit, Cocodimama Beach, Windermere Island Beach) supported few or no Piping Plovers. Although dog tracks were found at all survey sites, cat tracks on others, and ATV tracks on Spanish Well's north beach, it's not clear that these factors contributed to the paucity of plover sightings. At two sites Piping Plovers were observed in close proximity to human activity and in many locations Piping Plovers could avoid adverse disturbances by shifting to an adjoining beach or offshore roost site.

\section{Berry Islands}

Sue Abbott

Bird Studies Canada

45 Alderney Dr, 16 Floor

Dartmouth NS B2Y 2N6

sabbott@birdscanada.org

Caleb Spiegel

U.S. Fish and Wildlife Service

300 Westgate Center Dr.

Hadley, MA 01035

413-253-8490

caleb_spiegel@fws.gov

Two biologists (from U.S. Fish \& Wildlife Service (FWS) and Bird Studies Canada (BSC)) conducted the census of Piping, Wilson's, and Snowy Plovers on the Berry Islands from January 23 to 27, 2011. The Berry Islands were surveyed for the first time in 2011 and proved to be exceptional. Surveyors found extensive, minimallydisturbed tidal flats with an abundance of shorebirds and waterbirds, including the largest single flock of Piping Plovers of all areas surveyed during the 2011 Census. Thirty Berry Island sites were surveyed by foot, power boat, and kayak for a total of $19.4 \mathrm{~km}$ covered, including the entire east coast of Great Harbour Cay, the western pocket beaches of Great Harbour Cay to Little Stirrup Cay, Ambergris Cay and other cays south of Great Harbour Cay, Haines Cay and small cays near Shelling Beach. The south and central Berry Islands were only partially surveyed due to limited time. 
Bonefish boat charter captain Percy Darville and Inspector James Moss of the Royal Bahamas Police Force were pivotal to the successful census of the Berry Islands.

A total of 341 Piping Plovers and 40 Wilson's Plovers were seen on the Berry Islands. No Snowy Plovers were observed. The greatest concentration of Piping Plovers (255) seen anywhere in The Bahamas was among a mixed flock of roosting shorebirds on a small sand spit between East Caesar Cay Spit to SE tip Ambergris Cay. Rain and thunderstorms forced us to cancel a boat survey on one day, but weather did not appear to affect the survey results on other days. A subsequent visit was made in 2012, but fewer birds were detected perhaps due to less favorable tidal conditions.

In general, our coverage of the northern Berry Islands was very comprehensive. No Piping Plovers were observed on Great Harbour Cay, though we observed large tidal flats at Shelling Beach that appeared to be good foraging habitat (a few Piping Plovers were spotted there on a subsequent visit in 2012). This area is best surveyed at low, rising tide. We found 16 Wilson's Plovers along Great Harbour Cay's long, eastern sandy beach. Two small islands north of Great Harbour Cay (Big \& Little Stirrup Cays) are owned by cruise ship companies and are regularly overwhelmed with boat tourists. We surveyed Little Stirup Cay, which is intensively developed, but found no Piping or Wilson's Plovers. We did not survey Big Stirrup Cay, but it is probably not suitable habitat for plovers due to development and disturbance. We do not recommend expending future survey effort at these sites.

Future censuses should focus efforts on the sandy cays and tidal flats south of Great Harbour Cay (Ambergris Cay and surrounding small cays) and the southern Berry islands, which are part of the northeast corner of the Great Bahama Bank and only accessible by boat. Large areas of flats are exposed at low tide making detectability and boat access challenging, thus we recommend engaging an experienced bonefishing guide, timing surveys to mid and rising tides, and targeting potential shorebird roost sites (e.g., spits, bars, beaches and rocky areas adjacent to tidal flats). Tidal flat habitat appeared limited in the central Berry Islands, however, conditions could change and they should be surveyed, particularly the area near Comfort Cay. A rapid, one-day survey of the southern Berry Islands yielded 86 Piping Plovers, but time restrictions limited our survey effort.

We observed very little disturbance overall on the Berry Islands aside from dense stands of Casuarina backing beaches on numerous cays. In addition to habitat deterioration, we discovered that Casuarina may serve as predator perches near roosting and foraging habitat, as an unidentified falcon flushed roosting shorebird flocks twice during surveys. The islands and cays surveyed were relatively undeveloped and free of hard infrastructure on the coast. Residential houses were present along Great Harbour Cay's long sand beach, but there was little evidence of shoreline hardening. Great Harbour Cay residents with whom we spoke were unfamiliar with Piping Plover, but were very interested in the Census efforts.

General results from our surveys suggest that large tidal flats (muddy sand and sandy) as well as intertidal rocky sand habitats with tide pools and submerged aquatic vegetation seemed to support larger feeding flocks of Piping Plover than sandy beaches. Roosting flocks of Piping Plover tended to be closely associated with other shorebirds on open, dry sand, such as sand bars and sand spits. On at least one occasion we observed Piping Plovers roosting with other shorebirds on dark rock in the south Berry Islands.

Wilson's Plover tended to prefer sandy beaches with abundant, dark wrack or rocky intertidal habitat and rarely co-ocurred with Piping Plover (these general observations held true for our surveys on other islands). 


\section{Long Island}

Sue Abbott

Bird Studies Canada

45 Alderney Dr, 16 Floor

Dartmouth NS B2Y 2N6

sabbott@birdscanada.org

The census at Long Island was conducted 28-31

January by two biologists from Bahamas National Trust and Birds Studies Canada. We received assistance from two local volunteers, Olga Stokes, who assisted with most surveys, and Ruth Martonbourough who provided a car shuttle at Pinders. The census effort resulted in a total of 42 Piping Plovers and 6 Wilson's Plovers. No Snowy Plovers were observed. The largest flock of Piping Plovers observed was 24 birds that were seen foraging with other shorebirds on tidal flats of Joe Harbor Sound. A flock of 8 Piping Plovers were found foraging in rocky intertidal habitat with mats of aquatic vegetation at Duncanson's Point. Boat surveys of Conch, Dollar and Sandy Cays and surrounding tidal flats resulted in flocks of shorebirds but only two Piping Plovers. Sand beaches along the Atlantic Coast from Pinders to Salt Pond $(6.5 \mathrm{~km})$ and the alkali pond of Red Pond $(1.1 \mathrm{~km})$ were surveyed on foot and resulted in only one Piping Plover and one Wilson's Plover.

All sites on Long Island surveyed in 2006 were again surveyed in 2011. However, we were unable to confidently relocate the 2006 end point at Pinders so coverage of that region of the Atlantic Coast may have differed slightly. We also surveyed one new site at Diamond Salt Works, which had no suitable habitat.

\section{South Andros and New Providence}

Sue Abbott

Bird Studies Canada

45 Alderney Dr, 16 Floor

Dartmouth NS B2Y 2N6

sabbott@birdscanada.org

Caleb Spiegel

U.S. Fish and Wildlife Service

300 Westgate Center Dr.

Hadley, MA 01035

413-253-8490

caleb_spiegel@fws.gov

The census at South Andros was conducted by three biologists from Bahamas National Trust, Bird Studies Canada, and the US Fish and Wildlife Sevice. In total, 70 Piping Plovers and 40 Wilson's Plovers were observed but no Snowy Plovers were seen. Thanks to additional surveyors and time, substantially more habitat was surveyed in $2011(29.9 \mathrm{~km})$ than in $2006(3.6 \mathrm{~km})$. Overall, the road-accessible east side of South Andros was surveyed comprehensively. Small flocks of Piping Plovers (4-16 birds) were observed at multiple sites on the east coast, often with other shorebirds.

Despite separate attempts over two days with different guides and boats, we were unable to survey the remote and roadless south or west shores and tidal flats of South Andros. Our attempts were thwarted by motor failure and shallow conditions of Little Creek which connects east and west shores via extensive wetlands. We also attempted to follow Grassy Creek to reach the western side, but rough ocean conditions forced us to return to Pleasant Bay. During 
a visit to Water Cay on 6 February, John Cox found 21 Piping Plovers, highlighting the potentially suitable habitat that may have been missed in the southwest. Engaging an experienced guide with knowledge of tidal and water depth conditions (and a seaworthy boat) is critical for accessing potential habitat along remote southern and western shores.

The only evidence of vehicle disturbance on South Andros was tracks observed on the beach at Kemp's Bay. Other human-related disturbances (e.g., dogs off-leash and development) were limited to habitats around settlements. Pastor James Knowles assisted with logistics, including an unexpected shuttle after boat motor failure, and is a good contact in the area.

\section{New Providence}

\author{
Predensa Moore \\ Bahamas National Trust \\ PO Box N-9500 \\ Nassau, Bahamas \\ 242-393-1317 \\ pmoore@bnt.bs
}

The census at New Providence was conducted by three biologists from Bahamas National Trust, Bird Studies Canada, and the US Fish and Wildlife Sevice. It was limited to one site, South Beach, which is an Important Bird Area and has the only habitat suitable for Piping Plovers on the island. Most other coastal sites are heavily developed. This site was surveyed in 2006 but more habitat was covered in 2011. A total of 11 Piping Plovers were found in a single flock, including five of six birds banded there in 2010. The resighting of these banded individuals suggests high site fidelity. Access to the site requires careful timing with tides. Future surveyors should consult first with Predensa Moore at BNT. No Wilson's or Snowy Plovers were observed on New Providence.

\section{Great Exuma}

Will Mackin

3913 Sterling Ridge Ln

Durham, NC 27707

919-491-6127

willmackin@gmail.com

With a great deal of help from Bailey Smith and Lorraine Minns, I surveyed accessible beaches and flats at Great Exuma for Piping, Snowy, and Wilson's Plovers from January 27-29, 2011. I surveyed 15 different coastal areas and found good habitat for Plovers at 6 sites. All sites surveyed on Great Exuma during the 2006 Census were revisited. Snowy Plovers were found and photographed among the Piping Plovers at one of the sites. In total, I saw 91 Piping Plovers at 5 locations around Great Exuma. There was one additional account of 2 Piping Plovers on Bells Cay which brings the total to 93 Piping Plovers. I also counted 27 Wilson's Plovers at 5 locations and 2 Snowy Plovers at one site.

Within the Exumas there is likely quite a bit of suitable plover habitat that was not surveyed during the Census. In the winter of 2012, an excursion covering the Exuma Cays turned up a little over 100 Piping Plovers and none of the habitat covered had been surveyed as part of the 2011 Census (Sidney Maddock, unpublished data). There may be some additional habitat in the Cays not yet covered and there are a few potential sites on Great Exuma (Southwest Spur, Calvin Hill Spur, Brigantines Flats, and Cocoplum Beach) and Little Exuma (Southeast Beach and C-shaped Bay) that were not covered during the 2011 Census. Another potential site is Conception Island in Exuma Sound. 
Sea level rise, development, and feral animals are some of the potential threats to plover habitat on Great Exuma. The mainland flats are bordered by sharp rock ledges, such that there would be no appropriate habitat at low tide at higher sea levels. The only flats where habitat may remain are on Sandy Cay, Moriah Harbour Cay, and Manowar Cay. Feral dogs are likely a more immediate threat. At several sights including Wolf Dame's Back Landing and all the mainland beaches dog prints were crisscrossing the area. Many other flats are adjacent to roads and housing or condominium developments that are mostly abandoned but may be restarted in the future. Other sites including Manowar Cay and Moriah Harbour Cay and the flats at Sea View Drive are open to development. Bailey and Lorraine and their family along with other local residents have been trying to protect Moriah Harbour as a national park and no take zone for several decades. While they have made progress, the areas are not protected currently.

\section{San Salvador, Crooked and Acklins Island}

Julie McKnight

Canadian Wildlife Service

Environment Canada

45 Alderney Drive, floor 16

Dartmouth, (NS) B2Y 2N6

902-426-4196

Julie.mcknight@ec.gc.ca

Jen Rock

Canadian Wildlife Service

Environment Canada

17 Waterfowl Lane

Sackville, (NB) E4L 1G6

506-364-5078

jen.rock@ec.gc.ca

We spent three days surveying San Salvador and counted 4 Piping Plovers, 26 Snowy Plovers, and 6 Wilson's Plovers. We surveyed a total of 6 sites and comprehensively covered all potential plover habitat on the island except one 0.4 mile section of beach, at the southern end of Sand Bay.
Our surveys of Crooked and Acklins Islands were not as successful as San Salvador surveys. In total we counted 4 Piping Plovers, 9 Snowy Plovers, and 4 Wilson's Plovers on Acklins Island and no plovers on Crooked Island. Low plover numbers could be due to our limited survey coverage. Aerial photography and views from the plane suggest that there is some promising habitat on both islands. However, these islands are large and road access to the coastline is limited. It was our intent to access habitat by boat but all boat drivers on the island were involved in a boating course during the week we were on the island and it was not possible to charter a boat. An expanded effort should be made to survey these two islands.

\section{Great Inagua}

Caleb S. Spiegel

U.S. Fish and Wildlife Service, Migratory Birds

300 Westgate Center Dr.

Hadley, MA 01035

413-253-8490

caleb_spiegel@fws.gov

Between January 28th and 31st, Caleb Spiegel (FWS) and BNT warden Henry Nixon comprehensively surveyed around $14.2 \mathrm{~km}$ of coastline and $1.2 \mathrm{~km}$ of impounded salt pond shoreline on foot. This distance, divided among nine coastal sites, and one inland impounded salt pond site makes up the majority of potential plover habitat on the populated western quarter of Great Inagua. The only area not comprehensively covered on the west end of Great Inagua included some of the old Morton impounded salt ponds, which do not seem like ideal Piping Plover habitat and would require many days to thoroughly survey. However, these ponds provide extensive habitat for other shorebird species (we noted over 1,600 Calidrid sandpipers, 
mostly Semipalmated Sandpipers using the ponds, and extensive numbers of Lesser Yellowlegs). In addition, according to Henry Nixon, up to a dozen Snowy Plovers are regularly seen along the salt pond access roads, or in other salt pond habitat. Great Inagua is huge, and decent roads only exist on the populated quarter we surveyed. Habitat surveyed on Great Inagua was not as suitable for wintering Piping Plovers as habitat in many other parts of The Bahamas such as the Berry Islands or Andros Island. There were few extensive sand flats, steeper ocean drop offs, and strong wave action on north- and west-facing beaches.

Five Piping Plovers were seen on Great Inagua at a single site on the south end of the island, within 3 $\mathrm{km}$ of where the only two Piping Plovers were observed in 2006. A total of three Wilson's Plovers were counted on Great Inagua at two different sites on the south side of the island. The south side of western Great Inagua has the most extensive contiguous stretches of beach with adjacent tidal flats that are exposed at low tide, and minimal wave action. While no Snowy Plovers were seen during the survey, Henry Nixon reported seeing four of them on January 26 along the roads of the Morton Salt ponds (near Maroon Hill Pond).

Some plover habitat may have been missed on other parts of the island. However, Henry Nixon, a lifetime Inagua resident, did not know of any areas with potential high-quality plover habitat in the non-populated backcountry of the island and aerial imagery does not look as promising as other nearby islands (e.g., Crooked and Acklins Islands, Turks and Caicos). If the island is to be thoroughly surveyed, the census effort would need to be increased. An exploratory mission into the backcountry would require preplanning, including camping logistics for several days, a hardy $4 \times 4$ vehicle(s), and a safety backup plan. Depending on road conditions, a thorough survey of backcountry areas could take up to a week. Survey resources are probably best spent elsewhere if the aim is to locate large numbers of Piping Plovers. 


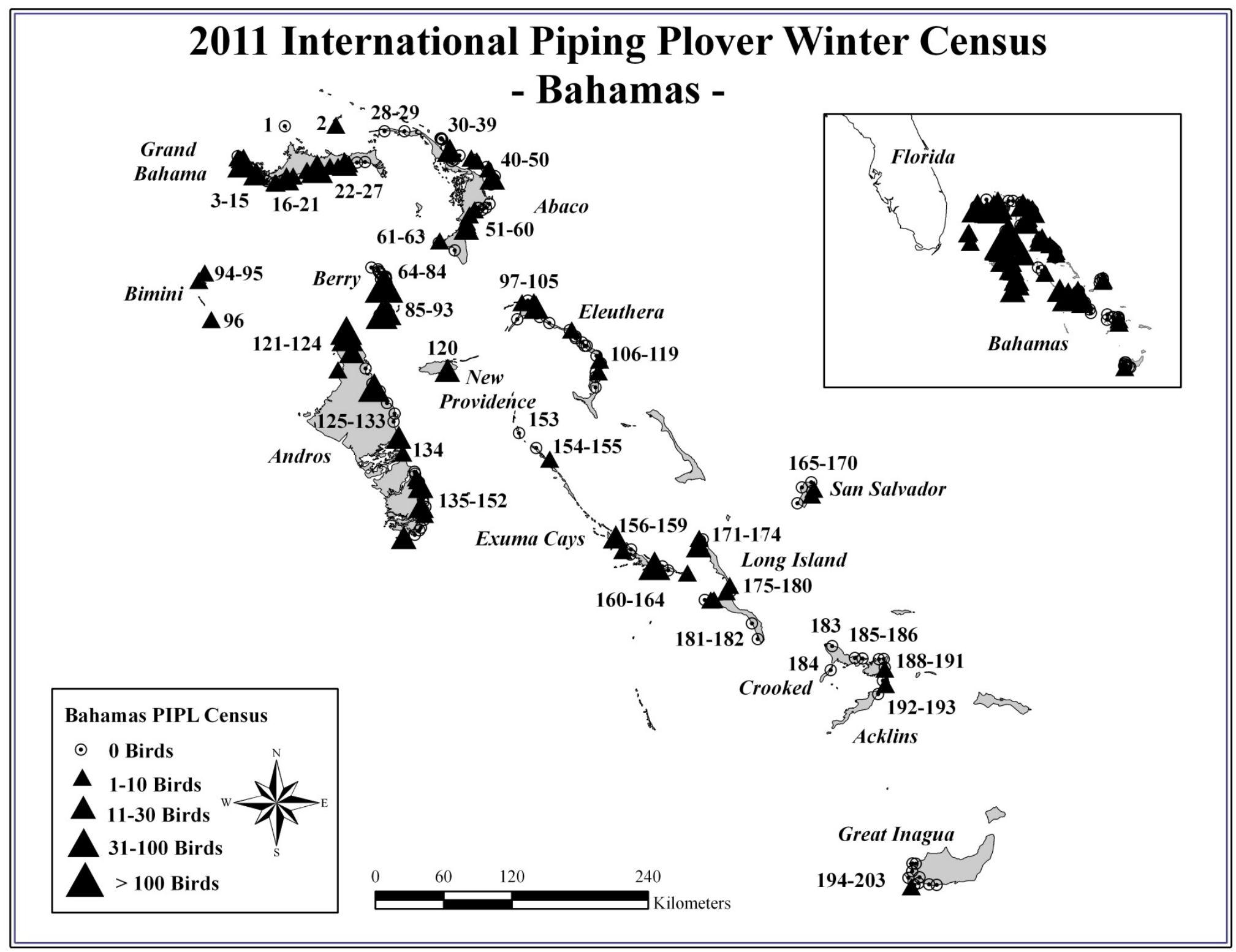


The 2011 International Piping Plover Winter Census in The Bahamas

\begin{tabular}{|c|c|c|c|c|c|c|c|c|c|c|c|c|}
\hline \multirow{2}{*}{$\begin{array}{l}\text { COUNTY } \\
\text { Abaco }\end{array}$} & \multirow{2}{*}{$\begin{array}{l}\text { SITE NAME } \\
\text { ores to the Delphi Club }\end{array}$} & \multirow{2}{*}{ MAP\# } & \multirow{2}{*}{$\begin{array}{c}\text { DATE } \\
2 / 1 / 11\end{array}$} & \multirow{2}{*}{$\begin{array}{c}\text { TOTAL } \\
\text { ADULTS } \\
2\end{array}$} & \multirow{2}{*}{$\frac{\mathbf{K M}}{10.5}$} & \multirow{2}{*}{$\begin{array}{l}\text { SITE } \\
\text { DESCRIPTION } \\
\text { I A }\end{array}$} & \multirow{2}{*}{$\begin{array}{l}\text { DISTURBANCE } \\
\text { / CONCERNS } \\
\text { H D V S I U G }\end{array}$} & \multicolumn{4}{|c|}{$\begin{array}{c}\text { PRIOR YEARS } \\
\text { CENSUSED \& YEARS } \\
\text { PIPL SEEN }^{1} \\
\end{array}$} & \multirow{2}{*}{$\frac{\text { OWNER }}{\mathrm{f}}$} \\
\hline & & & & & & & & - & - & - & - & \\
\hline Abaco & Bahama Palms Shores North (Eight Mile Bay) & 56 & $2 / 1 / 11$ & 4 & 3.0 & I A & D I G & - & - & - & - & f, p \\
\hline Abaco & Cannon Bay and Point & 37 & $2 / 5 / 11$ & 0 & 3.2 & II A & I G L & - & - & - & - & $\mathrm{f}$ \\
\hline Abaco & Casaurina Bay, Town Beach, Casaurina Pt. W & 55 & $2 / 1 / 11$ & 0 & 1.6 & II A & H D U G & - & - & - & - & $\mathrm{m}, \mathrm{p}$ \\
\hline Abaco & Casaurina Point & 54 & $2 / 1 / 11$ & 0 & 0.7 & II A & H D U G & - & - & - & - & $\mathrm{p}$ \\
\hline Abaco & Cherokee Sound & 53 & $2 / 3 / 11$ & 0 & 1.1 & II A & G & - & - & - & - & $\mathrm{m}$ \\
\hline Abaco & Crossing Harbor & 63 & $2 / 3 / 11$ & 0 & $<0.1$ & II A & I G L & - & - & - & - & f \\
\hline Abaco & Crown Haven to S Coopers Town & 29 & $2 / 4 / 11$ & 0 & 36.4 & I II A G & H D F P S I L & - & - & - & - & $\mathrm{m}, \mathrm{p}$ \\
\hline Abaco & Durkey Beach, Elbow Cay & 47 & $1 / 31 / 11$ & 0 & 0.4 & I B & $\mathrm{H}$ & - & - & - & - & $\mathrm{f}$ \\
\hline Abaco & Elbow Cay, Southern Oceanside & 48 & $1 / 31 / 11$ & 0 & 1.4 & I B & H D S & - & - & - & - & f \\
\hline Abaco & Flats North of Sandy Point & 61 & $2 / 3 / 11$ & 3 & 0.2 & II G & H F G L & - & - & - & - & $\mathrm{f}$ \\
\hline Abaco & Great Guana Cay (Middle Oceanfront) & 41 & $1 / 29 / 11$ & 0 & 1.2 & I B & n.r. & - & - & - & - & $\mathrm{m}$ \\
\hline Abaco & Great Guana Cay (Northern Oceanfront) & 40 & $1 / 30 / 11$ & 1 & 6.4 & I B & V S G & - & - & - & - & $\mathrm{m}, \mathrm{p}$ \\
\hline Abaco & Great Guana Cay (Southern Oceanfront) & 42 & $1 / 30 / 11$ & 3 & 2.7 & I B & H D & - & - & - & - & $\mathrm{m}$ \\
\hline Abaco & Green Turtle Cay & 35 & $2 / 2 / 11$ & 11 & 2.1 & II B & H D F G & - & - & $\underline{01}$ & $\underline{\mathbf{0 6}}^{2}$ & $\mathrm{f}$ \\
\hline Abaco & Island Palm Shores & 60 & $2 / 3 / 11$ & 26 & 2.1 & I B & D V I G & - & - & - & - & $\mathrm{f}$ \\
\hline Abaco & Junk Beach, Tilloo Cay & 50 & $2 / 4 / 11$ & 0 & 0.8 & I B & H D P I & - & - & - & - & $f$ \\
\hline Abaco & Little Harbor & 51 & $2 / 3 / 11$ & 0 & 0.2 & II A & H U G L & - & - & - & - & $\mathrm{p}$ \\
\hline Abaco & Manjack Cay, NE Beach & 31 & $2 / 2 / 11$ & 0 & 0.5 & I B & H D I G & - & - & - & - & $\mathrm{f}$ \\
\hline Abaco & Manjack Cay, North Tip & 30 & $2 / 2 / 11$ & 0 & 1.9 & I B & n.r. & - & - & - & - & $\mathrm{p}$ \\
\hline Abaco & Manjack Cay, NW Cove & 32 & $2 / 2 / 11$ & 0 & 1.5 & I B & G L & - & - & - & - & $\mathrm{p}$ \\
\hline Abaco & Manjack Cay, SE Beach & 33 & $2 / 2 / 11$ & 0 & 1.9 & I B & I & - & - & - & - & f \\
\hline Abaco & Man-O-War Cay (North Tip) & 43 & $2 / 3 / 11$ & 0 & 1.1 & I B & H S U & - & - & - & - & $\mathrm{p}$ \\
\hline Abaco & Man-O-War Cay (Oceanfront) & 44 & $2 / 3 / 11$ & 5 & 3.0 & I B & H S U & - & - & - & - & $\mathrm{m}$ \\
\hline Abaco & North End Beach, Elbow Cay & 45 & $1 / 31 / 11$ & 0 & 1.6 & I B & H D & - & - & - & - & $\mathrm{f}$ \\
\hline Abaco & Orphans, Smith and Water Cays (off Little Abaco) & 28 & $2 / 4 / 11$ & 0 & 13.6 & II E & I G L & - & - & - & - & $f$ \\
\hline Abaco & $\begin{array}{l}\text { Schooner Bay: Serenity Point S. to Island Palms } \\
\text { near Crossing Rocks }\end{array}$ & 59 & $2 / 3 / 11$ & 7 & 4.0 & I A & H D V S I U G & - & - & - & - & $f, p$ \\
\hline Abaco & Serenity Point & 58 & 2/1/11 & 2 & 2.8 & I A & H D V S I U G & - & - & - & - & f, p \\
\hline Abaco & Small Beach on Green Turtle Cay & 34 & $2 / 2 / 11$ & 0 & 0.2 & II B & $\mathrm{G}$ & - & - & - & - & f \\
\hline Abaco & Tahiti Beach, Elbow Cay & 49 & $1 / 31 / 11$ & 0 & 0.7 & II IV B F & H D G & - & - & - & - & f \\
\hline Abaco & Treasure Cay Beach - East Half & 38 & $2 / 5 / 11$ & 0 & 2.8 & II B & H D V S I U G & - & - & - & - & $\mathrm{f}$ \\
\hline Abaco & Treasure Cay Beach - West Half & 36 & $2 / 5 / 11$ & 0 & 2.5 & I II A & H D I U G & - & - & - & - & $\mathrm{p}, \mathrm{c}$ \\
\hline
\end{tabular}


The 2011 International Piping Plover Winter Census in The Bahamas

(Continued)

\begin{tabular}{|c|c|c|c|c|c|c|c|c|c|c|c|c|}
\hline \multirow{2}{*}{ COUNTY } & \multirow{2}{*}{ 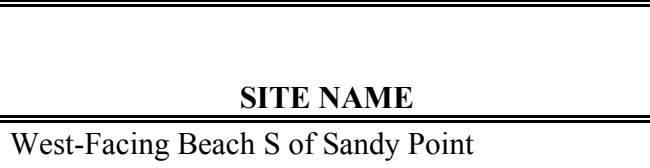 } & \multirow{2}{*}{ MAP\# } & \multirow{2}{*}{$\begin{array}{c}\text { DATE } \\
2 / 3 / 11\end{array}$} & \multirow{2}{*}{$\begin{array}{c}\text { TOTAL } \\
\text { ADULTS } \\
0\end{array}$} & \multirow{2}{*}{$\frac{\mathbf{K M}}{2.4}$} & \multirow{2}{*}{$\begin{array}{l}\text { SITE } \\
\text { DESCRIPTION } \\
\text { II A }\end{array}$} & \multirow{2}{*}{$\begin{array}{l}\text { DISTURBANCE } \\
\text { / CONCERNS } \\
\text { H D V F S I U L }\end{array}$} & \multicolumn{4}{|c|}{$\begin{array}{c}\text { PRIOR YEARS } \\
\text { CENSUSED \& YEARS } \\
\text { PIPL SEEN }^{1} \\
\end{array}$} & \multirow{2}{*}{$\frac{\text { OWNER }}{\mathrm{P}}$} \\
\hline & & & & & & & & 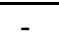 & - & 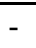 & 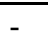 & \\
\hline Abaco & Whale Cay & 39 & $2 / 2 / 11$ & 0 & 0.9 & I B & $\mathrm{L}$ & - & - & - & - & n.r. \\
\hline Abaco & White Sound, Elbow Cay & 46 & $1 / 31 / 11$ & 12 & 0.4 & II B & B S G & - & - & - & - & $f$ \\
\hline Abaco & Winding Bay & 52 & $2 / 3 / 11$ & 0 & 2.6 & II A & H U G & - & - & - & - & $\mathrm{p}$ \\
\hline Acklins & Beach $\mathrm{N}$ of Creek Point ${ }^{10}$ & 190 & 2/7/11 & 1 & 7.0 & I A & H V S & - & - & - & - & n.r. \\
\hline Acklins & Beach S of Creek Point and N of Salt Pond ${ }^{10}$ & 192 & 2/8/11 & 3 & 4.8 & I A & P G L & - & - & - & - & n.r. \\
\hline Acklins & Florida $^{10}$ & 193 & 2/8/11 & 0 & 1.5 & I A & n.r. & - & - & - & - & n.r. \\
\hline Acklins & Small beach SE of Pinefield Settlement ${ }^{10}$ & 189 & $2 / 7 / 11$ & 0 & 0.2 & I A & G L & - & - & - & - & n.r. \\
\hline Acklins & Snug Corner Settlement (past cemetery) ${ }^{10}$ & 191 & 2/7/11 & 0 & 0.3 & IV A & G L & - & - & - & - & n.r. \\
\hline Acklins & $\begin{array}{l}\text { Unnamed off-shore Cay (NE of Chester's } \\
\text { Settlement) }\end{array}$ & 187 & $2 / 6 / 11$ & 0 & 0.4 & I E & A G L & - & - & - & - & n.r. \\
\hline Acklins & $\begin{array}{l}\text { W beach on Lady Slipper Cay (S of Atwood } \\
\text { Harbour) }\end{array}$ & 188 & $2 / 6 / 11$ & 0 & 1.5 & I E & H D U G L & - & - & - & - & n.r. \\
\hline Berry & Ambergris Cay (E side) & 83 & $1 / 24 / 11$ & 0 & 0.3 & I E & I L & - & - & - & - & n.r. \\
\hline Berry & Chub Cay - NW side tidal flat & 91 & $1 / 27 / 11$ & 27 & 0.9 & I E & G L & - & - & - & - & n.r. \\
\hline Berry & Cockroach Cay (NW side) & 92 & $1 / 27 / 11$ & 0 & 0.5 & I E & I & - & - & - & - & n.r. \\
\hline Berry & Cormorant Cay (Sapphire Cays) & 86 & $1 / 27 / 11$ & 0 & 0.1 & I E & I G & - & - & - & - & n.r. \\
\hline Berry & East Caesar Cay Spit to SE tip Ambergris Cay & 82 & $1 / 24 / 11$ & 255 & 0.2 & I E & I G & - & - & - & - & n.r. \\
\hline Berry & Fanny Cay (East Side) & 81 & $1 / 24 / 11$ & 0 & $<1$ & I E & $\mathrm{L}$ & - & - & - & - & n.r. \\
\hline Berry & Great Harbour Cay - "Shelling Beach" & 74 & $1 / 23 / 11$ & 0 & 0.4 & II G & H G L & - & - & - & - & n.r. \\
\hline Berry & Great Harbour Cay - "Sugar Beach Caves" & 66 & $1 / 23 / 11$ & 0 & 0.9 & I E & $\mathrm{H}$ & - & - & - & - & n.r. \\
\hline Berry & $\begin{array}{l}\text { Great Harbour Cay - North Beach (Just before } \\
\text { point at mid-beach) }\end{array}$ & 69 & $1 / 23 / 11$ & 0 & 0.3 & I E & $\mathrm{L}$ & - & - & - & - & n.r. \\
\hline Berry & $\begin{array}{l}\text { Great Harbour Cay - North Beach (Start at } \\
\text { Purple/blue house w/ Pelican statues at edge of } \\
\text { driveway) }\end{array}$ & 67 & $1 / 23 / 11$ & 0 & 1.0 & I E & H D & - & - & - & - & n.r. \\
\hline Berry & $\begin{array}{l}\text { Great Harbour Cay - North Beach (start at Yellow } \\
\text { House - Northernmost house on beach) }\end{array}$ & 65 & $1 / 23 / 11$ & 0 & 1.6 & I E & none & - & - & - & - & n.r. \\
\hline Berry & $\begin{array}{l}\text { Great Harbour Cay - North Beach (Villa Allegria } \\
\text { House) }\end{array}$ & 68 & $1 / 23 / 11$ & 0 & 2.2 & I E & H D U & - & - & - & - & n.r. \\
\hline Berry & $\begin{array}{l}\text { Great Harbour Cay - South Beach (Main crescent- } \\
\text { shaped beach) }\end{array}$ & 70 & $1 / 23 / 11$ & 0 & 4.0 & I E & H D I U G & - & - & - & - & n.r. \\
\hline Berry & Great Harbour Cay (SW Side) & 72 & $1 / 24 / 11$ & 0 & 0.1 & I E & none & - & - & - & - & n.r. \\
\hline Berry & Haines Cay - entire E side of beach & 75 & $1 / 25 / 11$ & 0 & 3.5 & I E & I G & - & - & - & - & n.r. \\
\hline
\end{tabular}


The 2011 International Piping Plover Winter Census in The Bahamas

(Continued)

\begin{tabular}{|c|c|c|c|c|c|c|c|c|c|c|c|c|}
\hline \multirow{2}{*}{$\begin{array}{l}\text { COUNTY } \\
\text { Berry }\end{array}$} & \multirow{2}{*}{$\begin{array}{l}\text { SITE NAME } \\
\text { ll beach on NW side (across flat } \\
\text { ach) }\end{array}$} & \multirow{2}{*}{ MAP\# } & \multirow{2}{*}{$\begin{array}{l}\text { DATE } \\
1 / 25 / 11\end{array}$} & \multirow{2}{*}{$\begin{array}{c}\text { TOTAL } \\
\text { ADULTS } \\
0\end{array}$} & \multirow{2}{*}{$\frac{\mathbf{K M}}{0.1}$} & \multirow{2}{*}{$\begin{array}{l}\text { SITE } \\
\text { DESCRIPTION } \\
\text { I E }\end{array}$} & \multirow{2}{*}{$\begin{array}{l}\text { DISTURBANCE } \\
\text { / CONCERNS } \\
\text { I L }\end{array}$} & \multicolumn{4}{|c|}{$\begin{array}{c}\text { PRIOR YEARS } \\
\text { CENSUSED \& YEARS } \\
\text { PIPL SEEN }^{1} \\
\end{array}$} & \multirow{2}{*}{$\begin{array}{c}\text { OWNER } \\
\text { n.r. }\end{array}$} \\
\hline & & & & & & & & - & - & - & - & \\
\hline Berry & Haines Cay (SW End) & 76 & $1 / 24 / 11$ & 0 & 0.0 & I E & G L & - & - & - & - & n.r. \\
\hline Berry & $\begin{array}{l}\text { Islet of N. Haines Cay \& W. of Great Harbour } \\
\text { Cay (across flat from Shelling Beach) }\end{array}$ & 71 & $1 / 25 / 11$ & 0 & 0.4 & I E & I & - & - & - & - & n.r. \\
\hline Berry & Little Cormorant Cay & 87 & $1 / 27 / 11$ & 0 & 0.3 & I E & I G & - & - & - & - & n.r. \\
\hline Berry & $\begin{array}{l}\text { Little Stirrup Cay a.k.a. "Coco Cay" (S. end } \\
\text { beaches) }\end{array}$ & 64 & $1 / 24 / 11$ & 0 & 1.0 & I E & H S I & - & - & - & - & n.r. \\
\hline Berry & Money Cay & 84 & $1 / 24 / 11$ & 0 & 0.1 & I E & G & - & - & - & - & n.r. \\
\hline Berry & S. side Sandy Cay (Sapphire Cay) & 85 & $1 / 27 / 11$ & 10 & n.r. & I E & G & - & - & - & - & n.r. \\
\hline Berry & Sand Islet btwn Chub Cay \& Fish Cays & 90 & $1 / 27 / 11$ & 0 & 0.0 & I E & G & - & - & - & - & n.r. \\
\hline Berry & Spit off E. Caesar Cay & 78 & $1 / 24 / 11$ & 0 & 0.2 & I E & I G & - & - & - & - & n.r. \\
\hline Berry & $\begin{array}{l}\text { Tidal Flat between Fanny \& Caesar Cays (S of } \\
\text { Berry Island) }\end{array}$ & 80 & $1 / 24 / 11$ & 0 & 0.0 & I D & G L & - & - & - & - & n.r. \\
\hline Berry & Tidal Sandbar near Caesar Cay & 79 & $1 / 24 / 11$ & 0 & 0.0 & I D & G L & - & - & - & - & n.r. \\
\hline Berry & Unnamed Sand Bar S. of Fish Cays & 89 & $1 / 27 / 11$ & 44 & 0.1 & I D & G & - & - & - & - & n.r. \\
\hline Berry & Unnamed Tiny Sand Bar btwn Fish Cays & 88 & $1 / 27 / 11$ & 0 & 0.0 & I D & G & - & - & - & - & n.r. \\
\hline Berry & Vigilant Cay (entire shoreline) & 93 & $1 / 27 / 11$ & 5 & 1.2 & I E & G & - & - & - & - & n.r. \\
\hline Berry & Water Cay (W End) & 77 & $1 / 24 / 11$ & 0 & 0.0 & I E & $\mathrm{L}$ & - & - & - & - & n.r. \\
\hline Bimini & East Wells & 95 & $2 / 5 / 11$ & 4 & 35.4 & IV V G & I & - & - & - & - & $\mathrm{f}$ \\
\hline Bimini & Ocean Cay & 96 & 2/4/11 & 1 & 6.4 & I G & G & - & - & - & - & f \\
\hline Bimini & South Cat Cay & 94 & $2 / 4 / 11$ & 4 & 62.8 & II E G & $\mathrm{S}$ & - & - & - & - & f, p \\
\hline Crooked & Beach E of Brown's Settlement & 186 & $2 / 4 / 11$ & 0 & 0.8 & I A & $\mathrm{P} \mathrm{G}$ & - & - & - & - & n.r. \\
\hline Crooked & Beach N of Majors, E of Bullet Hill Settlement & 185 & $2 / 4 / 11$ & 0 & 2.0 & I II A & G & - & - & - & - & n.r. \\
\hline Crooked & Beach NW of Seaview Settlement & 183 & $2 / 5 / 11$ & 0 & 2.0 & I A & D I G & - & - & - & - & n.r. \\
\hline Crooked & Long Cay & 184 & $2 / 5 / 11$ & 0 & 14.0 & I IV A & H I A L & - & - & - & - & n.r. \\
\hline Eleuthera & Airport Beach / Govenors Harbor & 108 & $1 / 27 / 11$ & 0 & 3.2 & I A & H D & - & - & - & - & n.r. \\
\hline Eleuthera & Atlantic Beach N of Grinder's Pt. & 116 & $1 / 27 / 11$ & $0^{3}$ & 0.4 & I E & none & - & - & - & - & n.r. \\
\hline Eleuthera & Bottom Harbour & 103 & $1 / 26 / 11$ & 0 & 1.6 & II E G & I L & - & - & - & - & n.r. \\
\hline Eleuthera & Club Med / French Leave Beach & 112 & $1 / 27 / 11$ & 0 & 1.6 & I A & H D & - & - & - & - & n.r. \\
\hline Eleuthera & Cocodimama Beach & 109 & $1 / 31 / 11$ & 0 & 0.8 & II G & D I G L & - & - & - & - & n.r. \\
\hline Eleuthera & Gaulding Cay Beach & 104 & $1 / 25 / 11$ & 0 & 0.8 & V E & G L & - & - & - & - & n.r. \\
\hline Eleuthera & Governor's Harbour & 111 & $1 / 27 / 11$ & 0 & 1.6 & V G & H D V S & - & - & - & - & n.r. \\
\hline Eleuthera & Hut Point Beach & 110 & $1 / 27 / 11$ & 0 & 0.8 & I A & H D & - & - & - & - & n.r. \\
\hline
\end{tabular}


The 2011 International Piping Plover Winter Census in The Bahamas

(Continued)

\begin{tabular}{|c|c|c|c|c|c|c|c|c|c|c|c|c|}
\hline \multirow{2}{*}{$\begin{array}{l}\text { COUNTY } \\
\text { Eleuthera }\end{array}$} & \multirow{2}{*}{$\begin{array}{c}\text { SITE NAME } \\
\text { James Cistern Wharf off Queen's Highway }\end{array}$} & \multirow{2}{*}{ MAP\# } & \multirow{2}{*}{$\begin{array}{l}\text { DATE } \\
1 / 27 / 11\end{array}$} & \multirow{2}{*}{$\begin{array}{c}\text { TOTAL } \\
\text { ADULTS } \\
0\end{array}$} & \multirow{2}{*}{$\frac{\mathbf{K M}}{20.2}$} & \multirow{2}{*}{$\begin{array}{l}\text { SITE } \\
\text { DESCRIPTION } \\
\text { II A }\end{array}$} & \multirow{2}{*}{$\begin{array}{l}\text { DISTURBANCE } \\
\text { / CONCERNS } \\
\text { H D V F S }\end{array}$} & \multicolumn{4}{|c|}{$\begin{array}{c}\text { PRIOR YEARS } \\
\text { CENSUSED \& YEARS } \\
\text { PIPL SEEN }^{1} \\
\end{array}$} & \multirow{2}{*}{$\begin{array}{c}\text { OWNER } \\
\text { n.r. }\end{array}$} \\
\hline & & & & & & & & - & 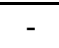 & 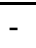 & 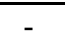 & \\
\hline Eleuthera & Man Island Spit and Picnic Beach & 100 & $1 / 29 / 11$ & 1 & 0.2 & II IV G & G & - & - & - & - & n.r. \\
\hline Eleuthera & Preacher's Cave Beach & 99 & $1 / 25 / 11$ & 0 & 0.8 & IG & n.r. & - & - & - & - & n.r. \\
\hline Eleuthera & Rock Sound & 119 & $1 / 31 / 11$ & 0 & n.r. & II G & n.r. & - & - & - & - & n.r. \\
\hline Eleuthera & Savannah Sound (W. Shore) & 114 & $1 / 28 / 11$ & 8 & 1.6 & II G & H F G L & - & - & - & - & n.r. \\
\hline Eleuthera & $\begin{array}{l}\text { Shore } \mathrm{N} \text { of Barge Landing, } \mathrm{N} \text { of Water Taxi Port } \\
\text { (Three Islands) }\end{array}$ & 101 & $1 / 30 / 11$ & 0 & 3.2 & II E & H F G & - & - & - & - & n.r. \\
\hline Eleuthera & Spanish Wells & 98 & $1 / 30 / 11$ & 5 & 3.2 & I IV D G & H D V F S G L & - & - & - & $\underline{06}$ & n.r. \\
\hline Eleuthera & Surfer's Beach, Gregory Town & 105 & $1 / 25 / 11$ & 0 & 0.8 & I E & $\mathrm{H}$ & - & - & - & - & n.r. \\
\hline Eleuthera & Tarpum Bay & 117 & $1 / 27 / 11$ & 0 & 0.8 & V G & H D V S & - & - & - & - & n.r. \\
\hline Eleuthera & Ten Bay Beach & 113 & $1 / 31 / 11$ & 0 & 1.6 & II G & H D G L & - & - & - & - & n.r. \\
\hline Eleuthera & Upper Cove Beach (E of Current) & 97 & $1 / 25 / 11$ & 0 & 0.4 & II V G & D G L & - & - & - & - & n.r. \\
\hline Eleuthera & Windermere Island & 115 & $1 / 28 / 11$ & 0 & 8.0 & I II E & H D G L & - & - & - & - & $\mathrm{p}$ \\
\hline Eleuthera & Winding Bay & 118 & $1 / 31 / 11$ & 0 & 3.2 & II G & H D I U G L & - & - & - & $\underline{06}^{4}$ & n.r. \\
\hline Eleuthera & Wreck Beach/James Cistern & 107 & $1 / 26 / 11$ & 3 & 1.6 & I E & n.r. & - & - & - & - & n.r. \\
\hline Exuma & Beaches E of Sea View Drive to Sunset Bluff & 159 & $1 / 29 / 11$ & 0 & 10.0 & II A & H D F L & - & - & - & - & $f, p$ \\
\hline Exuma & Bell Island (all major beaches) & 155 & $1 / 24 / 11$ & 2 & 1.8 & II E & $\mathrm{L}$ & - & - & - & - & $\mathrm{p}$ \\
\hline Exuma & East of 3 Sisters Rocks & 158 & $1 / 28 / 11$ & 0 & 0.2 & I A & H D & - & - & - & - & $\mathrm{p}$ \\
\hline Exuma & Exuma Point & 156 & $1 / 28 / 11$ & 18 & 0.5 & II A & H D I G L & - & - & - & $\underline{06}$ & f \\
\hline Exuma & Hawksbill Cay \& Shroud Cay & 153 & $1 / 29 / 11$ & 0 & 9.0 & I II IV A & n.r. & - & $\underline{96}$ & - & 06 & f \\
\hline Exuma & Leaf Cay/White Cay & 164 & $1 / 28 / 11$ & 4 & 2.9 & I E & H G L & - & - & - & $\underline{06}$ & f \\
\hline Exuma & Little Exuma Beaches \& Access Points & 162 & $1 / 27 / 11$ & 0 & 2.0 & I A & H D I U & - & - & - & - & $\mathrm{p}$ \\
\hline Exuma & Manowar Cay & 160 & $1 / 27 / 11$ & 46 & 4.0 & II E & H D V F I & - & - & - & - & $\mathrm{p}$ \\
\hline Exuma & Moriah Harbour Cay, Great Exuma & 161 & $1 / 28 / 11$ & 18 & 1.0 & II E & H D G & - & - & - & $06^{5}$ & $f, p$ \\
\hline Exuma & Sea Way Drive, Great Exuma & 157 & $1 / 29 / 11$ & 5 & 2.8 & II A & H D I G L & - & - & - & $\underline{06}$ & $\mathrm{p}$ \\
\hline Exuma & $\begin{array}{l}\text { Warderick Wells Cay (Career, Powerful, } \\
\text { Causeway and Boo Boo Beaches) }\end{array}$ & 154 & $1 / 29 / 11$ & 0 & 0.5 & II A & H G L & - & $\underline{96}$ & - & $\underline{06}^{6}$ & f \\
\hline Exuma & Wolf Dames Back Landing, Little Exuma & 163 & $1 / 29 / 11$ & 0 & 1.6 & I A & D L & - & - & - & 06 & $\mathrm{p}$ \\
\hline Grand Bahama & 8 Mile Rock (including Lover's Beach) & 11 & $1 / 27 / 11$ & 0 & 5.4 & I A & $\mathrm{H} \mathrm{S}$ & - & - & - & - & $\mathrm{f}$ \\
\hline Grand Bahama & $\begin{array}{l}\text { Bahama Beach/Bahama Bay (aka "Seward of } \\
\text { Grand Bahama") }\end{array}$ & 8 & $1 / 26 / 11$ & 0 & 1.8 & I A & S I G L & - & - & - & - & $\mathrm{f}$ \\
\hline Grand Bahama & $\begin{array}{l}\text { Barbary Beach (Discovery Bay Canal to White } \\
\text { Beach) }\end{array}$ & 19 & $1 / 25 / 11$ & 3 & 12.5 & I A & H D V S I L & - & - & - & $\underline{06}$ & $f, p$ \\
\hline
\end{tabular}


The 2011 International Piping Plover Winter Census in The Bahamas

(Continued)

\begin{tabular}{|c|c|c|c|c|c|c|c|c|c|c|c|c|}
\hline \multirow{2}{*}{$\begin{array}{l}\text { COUNTY } \\
\text { Grand Bahama }\end{array}$} & \multirow{2}{*}{$\begin{array}{l}\text { SITE NAME } \\
\text { (Blue Marlin Cove) S and E of inlet } \\
\text { Beach inlet }\end{array}$} & \multirow{2}{*}{ MAP\# } & \multirow{2}{*}{$\begin{array}{c}\text { DATE } \\
1 / 26 / 11\end{array}$} & \multirow{2}{*}{$\begin{array}{c}\text { TOTAL } \\
\text { ADULTS } \\
8\end{array}$} & \multirow{2}{*}{$\frac{\mathbf{K M}}{26.5}$} & \multirow{2}{*}{$\begin{array}{l}\text { SITE } \\
\text { DESCRIPTION } \\
\text { I A }\end{array}$} & \multirow{2}{*}{$\begin{array}{l}\text { DISTURBANCE } \\
\text { / CONCERNS } \\
\text { S I }\end{array}$} & \multicolumn{4}{|c|}{$\begin{array}{c}\text { PRIOR YEARS } \\
\text { CENSUSED \& YEARS } \\
\text { PIPL SEEN }^{1} \\
\end{array}$} & \multirow{2}{*}{$\frac{\text { OWNER }}{\mathrm{f}}$} \\
\hline & & & & & & & & - & - & - & - & \\
\hline Grand Bahama & $\begin{array}{l}\text { Discovery Beach (Freeport Bay Canal to } \\
\text { Discovery Bay Canal) }\end{array}$ & 18 & $1 / 24 / 11$ & 19 & 5.7 & I A & H D V S I U G & - & - & - & $\underline{06}$ & $\mathrm{f}$ \\
\hline Grand Bahama & $\begin{array}{l}\text { East End Cays (incldg Sweeting's, Lightbourne, } \\
\text { Redshank, Cross, and unnamed Cays/flats) }\end{array}$ & 6 & $1 / 30 / 11$ & 31 & 60.0 & I II IV V A E F & F I G & - & - & - & - & $\mathrm{f}$ \\
\hline Grand Bahama & Gold Rock Creek to High Rock & 21 & $1 / 28 / 11$ & 36 & 5.4 & I A & H D S I G & - & - & $\underline{01}$ & - & f \\
\hline Grand Bahama & Great Sale Cay & 2 & $2 / 6 / 11$ & 1 & 7.5 & I E F & H D P I G & - & - & - & - & $\mathrm{f}$ \\
\hline Grand Bahama & High Rock (Rocky Cliff to Oil Transfer Facility) & 22 & $1 / 28 / 11$ & 5 & 4.5 & I A & H D V S I G & - & - & - & $\underline{06}$ & $\mathrm{f}, \mathrm{p}$ \\
\hline Grand Bahama & Holmes Rock (E to 8 Mile Rock) & 10 & $1 / 27 / 11$ & 14 & 3.4 & I A & H I L & - & - & - & - & f \\
\hline Grand Bahama & Island Seas - Silver Point Beach into Jetty & 15 & $1 / 27 / 11$ & 5 & 3.2 & I A & H D S I G & - & - & - & $\underline{06}$ & f, p \\
\hline Grand Bahama & Lucaya Beach & 16 & $1 / 30 / 11$ & 0 & 2.4 & I A & n.r. & - & - & - & - & n.r. \\
\hline Grand Bahama & Mangrove Cay & 1 & $2 / 6 / 11$ & 0 & 1.5 & I E & G & - & - & - & - & $\mathrm{f}$ \\
\hline Grand Bahama & McLean's Town Cemetery & 27 & $1 / 29 / 11$ & 0 & 0.7 & I II A & H D I G & - & - & - & - & $\mathrm{f}$ \\
\hline Grand Bahama & $\begin{array}{l}\text { Old Bahama Bay - Ginn Sur Mer (Canal E to } \\
\text { Bootle Bay/Blue Marlin Cove) }\end{array}$ & 5 & $1 / 26 / 11$ & 4 & 4.4 & I A & D S I G L & - & - & - & - & f, p \\
\hline Grand Bahama & $\begin{array}{l}\text { Old Bahama Bay - Ginn Sur Mer (NW end, S to } \\
\text { canal) }\end{array}$ & 4 & $1 / 26 / 11$ & 5 & 2.0 & I A & D S P I U & - & - & - & - & f, p \\
\hline Grand Bahama & Pelican Point - E of Rocky Point & 25 & $1 / 29 / 11$ & 3 & 5.7 & I A & H D I U G & - & - & - & - & f \\
\hline Grand Bahama & Pelican Point - Rocky Point Flats & 24 & $1 / 29 / 11$ & 20 & 3.2 & I A & H D I G & - & - & - & $\underline{06}$ & $\mathrm{f}$ \\
\hline Grand Bahama & Pinder's Point to Hunter's & 12 & $1 / 27 / 11$ & 0 & 4.7 & I A & H D S P I G & - & - & - & - & f \\
\hline Grand Bahama & Rocky Creek and areas W of McLean's Town & 26 & $1 / 30 / 11$ & 0 & 11.6 & I V A & F I G L & - & - & - & - & f \\
\hline Grand Bahama & Running Mon & 14 & $1 / 27 / 11$ & 2 & 1.1 & I A & H S G & - & - & - & - & f \\
\hline Grand Bahama & Seaward at Bahama Bay to Holmes Rock & 9 & $1 / 27 / 11$ & 0 & 5.8 & I A & H D S I U G L & - & - & - & - & f \\
\hline Grand Bahama & Taino Beach & 17 & $2 / 3 / 11$ & 0 & 1.6 & I A & n.r. & - & - & - & - & n.r. \\
\hline Grand Bahama & $\begin{array}{l}\text { West End, Old Bahama Bay (Small beach on } \\
\text { NW side) }\end{array}$ & 3 & $1 / 26 / 11$ & 0 & 0.8 & I A & H V S I U G & - & $\underline{96}$ & - & - & $\mathrm{p}$ \\
\hline Grand Bahama & West of Pelican Point Flats to Oil Terminal & 23 & $1 / 28 / 11$ & 1 & 7.0 & I A & H D S I G & - & - & - & $\underline{06}$ & $\mathrm{f}$ \\
\hline Grand Bahama & $\begin{array}{l}\text { White (aka "Nudie") Beach to Gold Rocks Inlet } \\
\text { (W side) }\end{array}$ & 20 & $1 / 28 / 11$ & 6 & 7.8 & I A & H S I G & - & - & $\underline{01}$ & 06 & f \\
\hline Grand Bahama & Xanadu Beach and Bahama Princess Beach & 13 & $1 / 27 / 11$ & 0 & 4.5 & I A & H S I U G & - & - & - & - & $\mathrm{f}$ \\
\hline Great Inagua & Blackwood Beach (SW side of Island) & 202 & $1 / 30 / 11$ & 0 & 2.5 & I A & none & - & - & - & - & n.r. \\
\hline Great Inagua & $\begin{array}{l}\text { Bluff Beach, East of Conch Shell Pt. (S. side of } \\
\text { island to limestone outcrop on beach) }\end{array}$ & 203 & $1 / 30 / 11$ & 0 & 1.2 & I A & H D L & - & - & - & - & n.r. \\
\hline Great Inagua & Craig's Bight East & 201 & $1 / 29 / 11$ & 0 & 3.6 & I E & G L & - & - & - & 06 & n.r. \\
\hline
\end{tabular}


The 2011 International Piping Plover Winter Census in The Bahamas

(Continued)

\begin{tabular}{|c|c|c|c|c|c|c|c|c|c|c|c|c|}
\hline \multirow{2}{*}{$\begin{array}{l}\text { COUNTY } \\
\text { Great Inagua }\end{array}$} & \multirow{2}{*}{$\begin{array}{r}\text { SITE NAME } \\
\text { est to Crossing }\end{array}$} & \multirow{2}{*}{ MAP\# } & \multirow{2}{*}{$\begin{array}{l}\text { DATE } \\
1 / 29 / 11\end{array}$} & \multirow{2}{*}{$\begin{array}{c}\text { TOTAL } \\
\text { ADULTS } \\
0\end{array}$} & \multirow{2}{*}{$\frac{\mathbf{K M}}{2.5}$} & \multirow{2}{*}{$\begin{array}{l}\text { SITE } \\
\text { DESCRIPTION } \\
\text { I E }\end{array}$} & \multirow{2}{*}{$\begin{array}{l}\text { DISTURBANCE } \\
\text { / CONCERNS } \\
\text { D P G }\end{array}$} & \multicolumn{4}{|c|}{$\begin{array}{c}\text { PRIOR YEARS } \\
\text { CENSUSED \& YEARS } \\
\text { PIPL SEEN }^{1} \\
\end{array}$} & \multirow{2}{*}{$\frac{\text { OWNER }}{\text { n.r. }}$} \\
\hline & & & & & & & & - & - & - & $\underline{06}$ & \\
\hline Great Inagua & Man of War Bay & 196 & $1 / 29 / 11$ & 0 & 1.0 & I A & none & - & - & - & $\overline{06}$ & n.r. \\
\hline Great Inagua & Maroon Hill Pond & 198 & $1 / 31 / 11$ & 0 & 1.2 & V A & S G & - & - & - & - & $\mathrm{p}$ \\
\hline Great Inagua & Red Pond West & 194 & $1 / 29 / 11$ & 0 & 0.5 & I IV E & G L & - & - & - & 06 & n.r. \\
\hline Great Inagua & The Tunnel Beach & 197 & $1 / 29 / 11$ & 0 & 0.8 & I IV E & none & - & - & - & 06 & n.r. \\
\hline Great Inagua & Vandaxville Beach to Lighthouse & 199 & $1 / 28 / 11$ & 5 & 4.5 & I E & H D V P U & - & - & - & 06 & n.r. \\
\hline Great Inagua & Well Road Beach & 195 & $1 / 29 / 11$ & 0 & 1.2 & I E & none & - & - & - & 06 & n.r. \\
\hline Harbour & Pink Sand Beach (E) and Harbor Side (W) & 102 & $1 / 29 / 11$ & 13 & 4.0 & I II G & H D S G L & - & - & - & - & n.r. \\
\hline Long Island & Atlantic Coast from Pinders to Salt Pond & 175 & $1 / 31 / 11$ & 1 & 6.5 & I E & H I & - & - & - & 06 & n.r. \\
\hline Long Island & Cape Santa Maria Dev., Hoosie Harbor & 172 & $1 / 28 / 11$ & 0 & 0.5 & II E & H S G & - & - & - & 06 & n.r. \\
\hline Long Island & Conch Cay (off Long Island) & 178 & $1 / 30 / 11$ & 1 & 1.8 & I D E & G L & - & - & - & $\underline{06}$ & n.r. \\
\hline Long Island & Cove near C.C. Monument, Newton Cay & 171 & $1 / 28 / 11$ & 7 & 0.7 & II E & H G & - & - & - & $\underline{06}$ & n.r. \\
\hline Long Island & Diamond Salt Works & 181 & $1 / 29 / 11$ & 0 & 0.2 & V G & S G & - & - & - & - & n.r. \\
\hline Long Island & Dollar Cay Tidal Flats & 179 & $1 / 30 / 11$ & 1 & 0.9 & I D & G & - & - & - & 06 & n.r. \\
\hline Long Island & Duncansons Point & 177 & $1 / 30 / 11$ & 8 & 2.0 & I E & H V G & - & - & - & 06 & n.r. \\
\hline Long Island & Gordon's & 182 & $1 / 29 / 11$ & 0 & 1.9 & I E & I & - & - & - & 06 & n.r. \\
\hline Long Island & Joe Sound Harbor & 174 & $1 / 28 / 11$ & 24 & 0.2 & II E & G L & - & - & - & $\underline{06}$ & n.r. \\
\hline Long Island & Newton Cay, W Side & 173 & $1 / 28 / 11$ & 0 & 0.6 & II E & None & - & - & - & 06 & n.r. \\
\hline Long Island & Red Pond & 176 & $1 / 31 / 11$ & 0 & 1.1 & V G & H G & - & - & - & $\underline{06}$ & n.r. \\
\hline Long Island & Sandy Cay North \& Tidal Flats & 180 & $1 / 30 / 11$ & 0 & 0.9 & I D E & G & - & - & - & 06 & n.r. \\
\hline $\begin{array}{l}\text { New } \\
\text { Providence }\end{array}$ & South Beach & 120 & $2 / 5 / 11$ & 11 & 3.2 & II A & H I L & - & - & $\underline{01}$ & $\underline{06}$ & n.r. \\
\hline North Andros & Bigwood Cay & 134 & $1 / 28 / 11$ & 6 & 14.0 & I II E & H F I G L & - & - & - & - & n.r. \\
\hline North Andros & Joulter's Cays (North) & 121 & $1 / 29 / 11$ & 65 & 5.6 & I E F G & G L & - & - & - & - & $f$ \\
\hline North Andros & Joulter's Cays (South) & 122 & $1 / 29 / 11$ & 35 & n.r. & I E & H F I G L & - & - & - & $\underline{06}$ & f \\
\hline North Andros & Kamalame Cay - Blanket Sound & 127 & $2 / 1 / 11$ & 83 & 3.7 & I II B & H D G L & - & - & - & $\underline{06}^{7}$ & $f$ \\
\hline North Andros & Lowe's Sound Mangrove Flats & 123 & $1 / 31 / 11$ & 14 & 10.9 & I A E G & H D F S I G L & - & - & - & $\underline{\mathbf{0 6}}^{8}$ & $\mathrm{f}, \mathrm{m}, \mathrm{p}$ \\
\hline North Andros & Mastic Bay and Rat Cay & 125 & $1 / 31 / 11$ & 0 & 7.5 & I II D E & I G L & - & - & - & - & $\mathrm{f}$ \\
\hline North Andros & N ForFar to Saddleback Cay & 126 & $1 / 27 / 11$ & 0 & 4.2 & I A E & I G & - & - & $\underline{01}$ & - & n.r. \\
\hline North Andros & Plum Cay & 131 & $1 / 30 / 11$ & 0 & 2.4 & I II E & G L & - & - & - & - & $f$ \\
\hline North Andros & Red Bays & 124 & $1 / 31 / 11$ & 1 & 11.6 & I II A & G L & - & - & - & - & n.r. \\
\hline North Andros & Small Hope Bay & 130 & $1 / 30 / 11$ & 0 & 0.6 & I A & H D S I G L & - & - & - & - & n.r. \\
\hline North Andros & South of Cargill Creek & 133 & $1 / 28 / 11$ & 13 & 0.3 & I A & H D F G L & - & - & - & - & $f$ \\
\hline
\end{tabular}


The 2011 International Piping Plover Winter Census in The Bahamas

(Continued)

\begin{tabular}{|c|c|c|c|c|c|c|c|c|c|c|c|}
\hline \multirow{2}{*}{$\begin{array}{l}\text { COUNTY } \\
\text { North Andros }\end{array}$} & \multirow{2}{*}{$\begin{array}{r}\text { SITE NAME } \\
\text { Southwest of Mastic Cay }\end{array}$} & \multirow{2}{*}{ MAP\# } & \multirow{2}{*}{$\begin{array}{l}\text { DATE } \\
1 / 30 / 11\end{array}$} & \multirow{2}{*}{$\begin{array}{c}\text { TOTAL } \\
\text { ADULTS } \\
0\end{array}$} & \multirow{2}{*}{ 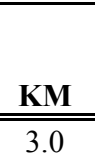 } & \multirow{2}{*}{$\begin{array}{l}\text { SITE } \\
\text { DESCRIPTION } \\
\text { I II D E }\end{array}$} & \multirow{2}{*}{$\begin{array}{l}\text { DISTURBANCE } \\
\text { / CONCERNS } \\
\mathrm{GL}\end{array}$} & \multicolumn{3}{|c|}{$\begin{array}{c}\text { PRIOR YEARS } \\
\text { CENSUSED \& YEARS } \\
\text { PIPL SEEN }^{1} \\
\end{array}$} & \multirow{2}{*}{$\begin{array}{c}\text { OWNER } \\
\text { n.r. }\end{array}$} \\
\hline & & & & & & & & - & 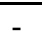 & 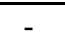 & \\
\hline North Andros & Staniard Creek & 129 & $1 / 27 / 11$ & 0 & 4.1 & I A & H D I U G & - & - & - & $f$ \\
\hline North Andros & Staniard Creek Flats & 128 & $1 / 30 / 11$ & 0 & 0.3 & II A & D G & - & - & 06 & n.r. \\
\hline San Salvadore & Bonefish Bay (Club Med Beach) & 166 & $2 / 1 / 11$ & 0 & 1.6 & I A & H D V S U & - & - & - & n.r. \\
\hline San Salvadore & Dim Bay and Greens Bay to Crab Cay & 168 & $1 / 31 / 11$ & 0 & 2.7 & I A & G & - & - & - & n.r. \\
\hline San Salvadore & East Beach & 167 & $2 / 2 / 11$ & 4 & 3.5 & I A & D G & - & - & - & n.r. \\
\hline San Salvadore & Holiday Track Settlement (The Thumb) & 169 & $2 / 1 / 11$ & 1 & 3.0 & I A & G L & - & - & - & n.r. \\
\hline San Salvadore & Rice Bay & 165 & $2 / 2 / 11$ & 0 & 0.5 & I A & H V U L & - & - & - & n.r. \\
\hline San Salvadore & Sandy Point & 170 & $2 / 1 / 11$ & 0 & 0.1 & I A & $\mathrm{H}$ & - & - & - & n.r. \\
\hline South Andros & Congo Town & 137 & $2 / 3 / 11$ & 4 & 0.1 & I E & I U G & - & - & 06 & n.r. \\
\hline South Andros & Deep Creek to Little Creek & 144 & $2 / 3 / 11$ & 0 & 2.8 & I E & G L & - & - & - & n.r. \\
\hline South Andros & Driggs Hill (at cemetery) & 135 & $2 / 3 / 11$ & 0 & 0.1 & I E & I L & - & - & - & n.r. \\
\hline South Andros & $\begin{array}{l}\text { Driggs Hill (Lighthouse Pt to Long Bay } \\
\text { Settlement) }\end{array}$ & 136 & $2 / 3 / 11$ & 0 & 0.1 & I E & $\mathrm{H}$ & - & - & - & n.r. \\
\hline South Andros & Kemps Bay & 142 & $2 / 3 / 11$ & 0 & 4.6 & I E & D V S I U & - & - & 06 & n.r. \\
\hline South Andros & Kemp's Bay Complex to Smith's Hill Settlement & 140 & $2 / 1 / 11$ & 13 & 3.7 & I E & G & - & - & - & n.r. \\
\hline South Andros & Mars Bay Settlement (North of Wharf) & 147 & $2 / 1 / 11$ & 7 & 0.4 & II E & H F I U G L & - & - & 06 & n.r. \\
\hline South Andros & North of Hawks Nest (Hawksbill Creek) & 149 & $2 / 2 / 11$ & 0 & 0.6 & I E & I L & - & - & - & n.r. \\
\hline South Andros & Northern Deep Creek Settlement at Cemetery & 143 & $2 / 3 / 11$ & 0 & 0.1 & I E & G L & - & - & - & n.r. \\
\hline South Andros & $\begin{array}{l}\text { Old Pier S of Congo Town to the Bluff } \\
\text { Settlement (Mt. Sinai Baptist Church) }\end{array}$ & 138 & $2 / 3 / 11$ & 9 & 2.7 & I E & H D U G & - & - & - & n.r. \\
\hline South Andros & Sand Bar (2 miles NE of Top Cay) & 151 & $2 / 2 / 11$ & 0 & 0.6 & I D & G L & - & - & - & n.r. \\
\hline South Andros & Sand Bar $\sim 3 \mathrm{~km}$ E of Little Creek ${ }^{11}$ & 146 & $2 / 4 / 11$ & 0 & 0.4 & I D & G & - & - & - & n.r. \\
\hline South Andros & South of Hawks Nest to Snap Pt. & 150 & $2 / 2 / 11$ & 0 & 2.6 & I E & none & - & - & - & n.r. \\
\hline South Andros & $\begin{array}{l}\text { South of Mars Bay: Flats at S end of white } \\
\text { gravel road }\end{array}$ & 148 & $2 / 2 / 11$ & 0 & 3.0 & I E & H F G L & - & - & $\underline{\mathbf{0 6}}^{9}$ & n.r. \\
\hline South Andros & $\begin{array}{l}\text { South Smith's Hill Settlement to North Kemp's } \\
\text { Bay Settlement }\end{array}$ & 141 & $2 / 1 / 11$ & 0 & 1.0 & I E & D G & - & - & - & n.r. \\
\hline South Andros & The Bluff Settlement & 139 & $2 / 1 / 11$ & 0 & 1.3 & I E & I G & - & - & - & n.r. \\
\hline South Andros & Tidal Flat Slightly N of Pleasant Bay & 145 & $2 / 3 / 11$ & 16 & 0.5 & I E & G L & - & - & - & n.r. \\
\hline South Andros & Water Cays $^{10}$ & 152 & $2 / 6 / 11$ & 21 & 0.4 & II D & H F G L & - & - & - & n.r. \\
\hline Total & & & & 1066 & 678.4 & & & & & & \\
\hline
\end{tabular}


${ }^{1}$ If previously surveyed, years surveyed are noted. Bold underlined years indicate that Piping Plovers were seen at the site during that Census year.

${ }^{2}$ Exact locations of PIPLs were not specified in 2006 and may have occurred along any point $\sim 1.2$ km north of the 2011 Green Turtle Cay census route (2006 route covered more area).

8 PIPL were see at this site, but they were believed to be the same 8 PIPL seen foraging in Savannah Sound on 1/28/2011.

${ }^{4}$ Exact locations of PIPLs were not specified in 2006 and may have occurred along any point $\sim 3 \mathrm{~km}$ north of the 2011 Winding Bay census route (2006 route covered more area).

${ }^{5} 2$ PIPL were seen in $2006 \sim 0.7$ miles east of where the 2011 census ended. The 2011 survey was cut short due to dwindling light at the end of the day, so the complete area could not be covered.

${ }^{6}$ In 2006, 3 PIPL were seen on Careen Beach and 2 were seen on Powerful Beach. The 2006 and 2011 survey routes were not specified, but by name only, I assume these were overlap.

768 PIPL were seen in 2006 under the site name "Staniard Creek" which closely follows the 2011 "Kamalame Cay - Blanket Sound" route.

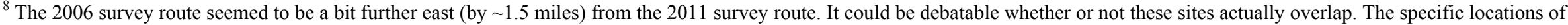
the PIPL seen in 2006 were not given.

98 PIPL were seen $\sim 0.25$ miles from thus survey route (within the 2006 Mars Bay survey route).

${ }^{10}$ Please note that this survey was conducted outside the Census window.

1114 PIPL were seen, but they were believed to be the same PIPL as seen at Kemp's Bay Complex to Smith's Hill Settlement. 


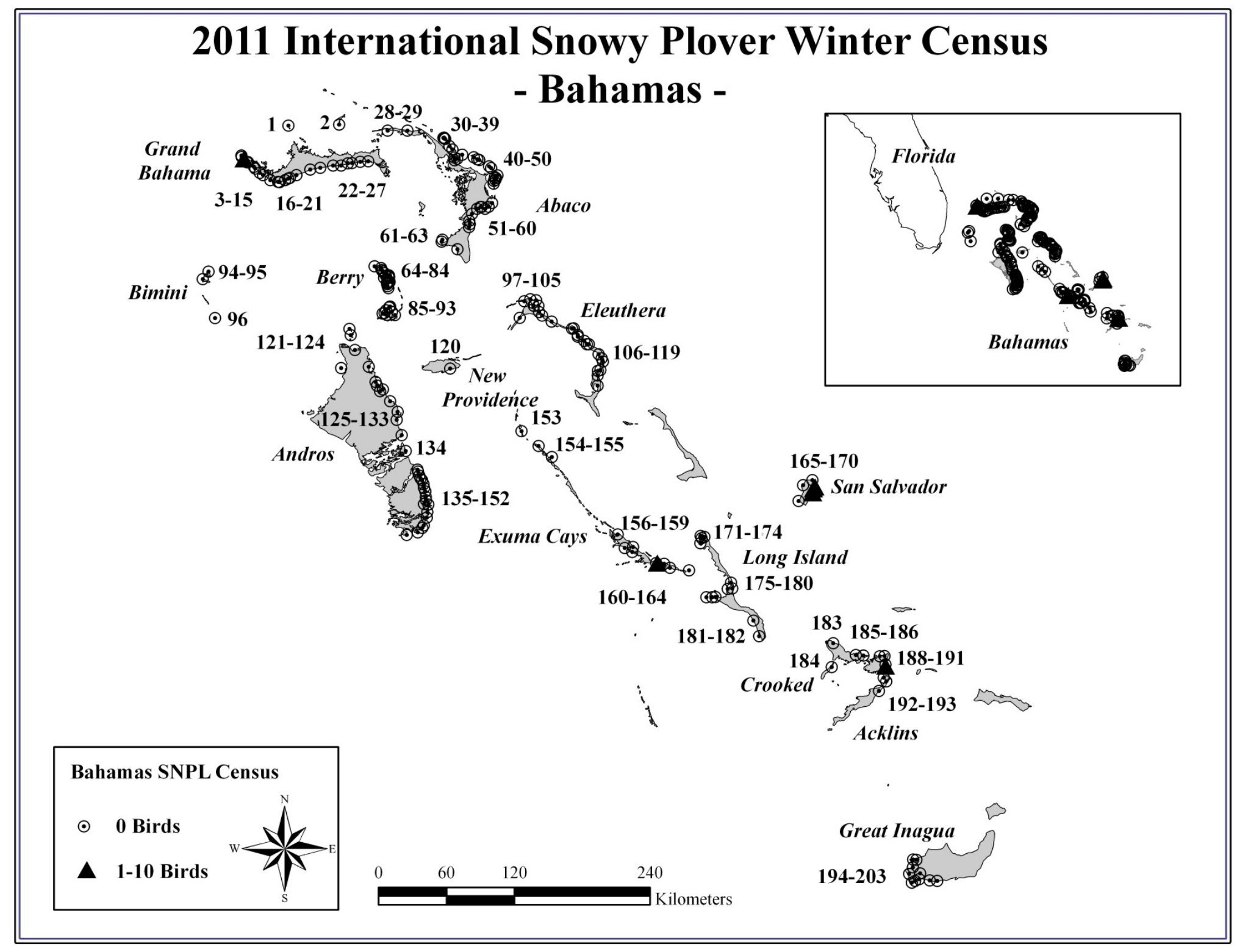


The 2011 International Snowy Plover Winter Census in The Bahamas

\begin{tabular}{|c|c|c|c|c|c|c|c|c|c|c|c|c|}
\hline \multirow{2}{*}{$\begin{array}{l}\text { COUNTY } \\
\text { Abaco }\end{array}$} & \multirow{2}{*}{$\begin{array}{l}\text { SITE NAME } \\
\text { ores to the Delphi Club }\end{array}$} & \multirow{2}{*}{ MAP\# } & \multirow{2}{*}{$\begin{array}{c}\text { DATE } \\
2 / 1 / 11\end{array}$} & \multirow{2}{*}{$\begin{array}{c}\text { TOTAL } \\
\text { ADULTS } \\
0\end{array}$} & \multirow{2}{*}{$\frac{\mathbf{K M}}{10.5}$} & \multirow{2}{*}{$\begin{array}{l}\text { SITE } \\
\text { DESCRIPTION } \\
\text { I A }\end{array}$} & \multirow{2}{*}{$\begin{array}{l}\text { DISTURBANCE } \\
\text { / CONCERNS } \\
\text { H D V S I U G }\end{array}$} & \multicolumn{4}{|c|}{$\begin{array}{c}\text { PRIOR YEARS } \\
\text { CENSUSED \& YEARS }^{\text {PNPL SEEN }}{ }^{1} \\
\text { SNPL S }^{-}\end{array}$} & \multirow{2}{*}{$\frac{\text { OWNER }}{\mathrm{f}}$} \\
\hline & & & & & & & & - & - & - & - & \\
\hline Abaco & Bahama Palms Shores North (Eight Mile Bay) & 56 & $2 / 1 / 11$ & 0 & 3.0 & I A & D I G & - & - & - & - & f, p \\
\hline Abaco & Cannon Bay and Point & 37 & $2 / 5 / 11$ & 0 & 3.2 & II A & I G L & - & - & - & - & $\mathrm{f}$ \\
\hline Abaco & Casaurina Bay, Town Beach, Casaurina Pt. W & 55 & $2 / 1 / 11$ & 0 & 1.6 & II A & H D U G & - & - & - & - & $\mathrm{m}, \mathrm{p}$ \\
\hline Abaco & Casaurina Point & 54 & $2 / 1 / 11$ & 0 & 0.7 & II A & H D U G & - & - & - & - & $\mathrm{p}$ \\
\hline Abaco & Cherokee Sound & 53 & $2 / 3 / 11$ & 0 & 1.1 & II A & G & - & - & - & - & $\mathrm{m}$ \\
\hline Abaco & Crossing Harbor & 63 & $2 / 3 / 11$ & 0 & $<0.1$ & II A & I G L & - & - & - & - & f \\
\hline Abaco & Crown Haven to S Coopers Town & 29 & $2 / 4 / 11$ & 0 & 36.4 & I II A G & H D F P S I L & - & - & - & - & $\mathrm{m}, \mathrm{p}$ \\
\hline Abaco & Durkey Beach, Elbow Cay & 47 & $1 / 31 / 11$ & 0 & 0.4 & I B & $\mathrm{H}$ & - & - & - & - & $\mathrm{f}$ \\
\hline Abaco & Elbow Cay, Southern Oceanside & 48 & $1 / 31 / 11$ & 0 & 1.4 & I B & H D S & - & - & - & - & f \\
\hline Abaco & Flats North of Sandy Point & 61 & $2 / 3 / 11$ & 0 & 0.2 & II G & H F G L & - & - & - & - & $\mathrm{f}$ \\
\hline Abaco & Great Guana Cay (Middle Oceanfront) & 41 & $1 / 29 / 11$ & 0 & 1.2 & I B & n.r. & - & - & - & - & $\mathrm{m}$ \\
\hline Abaco & Great Guana Cay (Northern Oceanfront) & 40 & $1 / 30 / 11$ & 0 & 6.4 & I B & V S G & - & - & - & - & $\mathrm{m}, \mathrm{p}$ \\
\hline Abaco & Great Guana Cay (Southern Oceanfront) & 42 & $1 / 30 / 11$ & 0 & 2.7 & I B & H D & - & - & - & - & $\mathrm{m}$ \\
\hline Abaco & Green Turtle Cay & 35 & $2 / 2 / 11$ & 0 & 2.1 & II B & H D F G & - & - & - & 06 & $\mathrm{f}$ \\
\hline Abaco & Island Palm Shores & 60 & $2 / 3 / 11$ & 0 & 2.1 & I B & D V I G & - & - & - & - & $\mathrm{f}$ \\
\hline Abaco & Junk Beach, Tilloo Cay & 50 & $2 / 4 / 11$ & 0 & 0.8 & I B & H D P I & - & - & - & - & $f$ \\
\hline Abaco & Little Harbor & 51 & $2 / 3 / 11$ & 0 & 0.2 & II A & H U G L & - & - & - & - & $\mathrm{p}$ \\
\hline Abaco & Manjack Cay, NE Beach & 31 & $2 / 2 / 11$ & 0 & 0.5 & I B & H D I G & - & - & - & - & $\mathrm{f}$ \\
\hline Abaco & Manjack Cay, North Tip & 30 & $2 / 2 / 11$ & 0 & 1.9 & I B & n.r. & - & - & - & - & $\mathrm{p}$ \\
\hline Abaco & Manjack Cay, NW Cove & 32 & $2 / 2 / 11$ & 0 & 1.5 & I B & G L & - & - & - & - & $\mathrm{p}$ \\
\hline Abaco & Manjack Cay, SE Beach & 33 & $2 / 2 / 11$ & 0 & 1.9 & I B & I & - & - & - & - & f \\
\hline Abaco & Man-O-War Cay (North Tip) & 43 & $2 / 3 / 11$ & 0 & 1.1 & I B & H S U & - & - & - & - & $\mathrm{p}$ \\
\hline Abaco & Man-O-War Cay (Oceanfront) & 44 & $2 / 3 / 11$ & 0 & 3.0 & I B & H S U & - & - & - & - & $\mathrm{m}$ \\
\hline Abaco & North End Beach, Elbow Cay & 45 & $1 / 31 / 11$ & 0 & 1.6 & I B & H D & - & - & - & - & $\mathrm{f}$ \\
\hline Abaco & Orphans, Smith and Water Cays (off Little Abaco) & 28 & $2 / 4 / 11$ & 0 & 13.6 & II E & I G L & - & - & - & - & $f$ \\
\hline Abaco & $\begin{array}{l}\text { Schooner Bay: Serenity Point S. to Island Palms } \\
\text { near Crossing Rocks }\end{array}$ & 59 & $2 / 3 / 11$ & 0 & 4.0 & I A & H D V S I U G & - & - & - & - & $f, p$ \\
\hline Abaco & Serenity Point & 58 & 2/1/11 & 0 & 2.8 & I A & H D V S I U G & - & - & - & - & f, p \\
\hline Abaco & Small Beach on Green Turtle Cay & 34 & $2 / 2 / 11$ & 0 & 0.2 & II B & G & - & - & - & - & $\mathrm{f}$ \\
\hline Abaco & Tahiti Beach, Elbow Cay & 49 & $1 / 31 / 11$ & 0 & 0.7 & II IV B F & H D G & - & - & - & - & f \\
\hline Abaco & Treasure Cay Beach - East Half & 38 & $2 / 5 / 11$ & 0 & 2.8 & II B & H D V S I U G & - & - & - & - & f \\
\hline Abaco & Treasure Cay Beach - West Half & 36 & $2 / 5 / 11$ & 0 & 2.5 & I II A & H D I U G & - & - & - & - & $\mathrm{p}, \mathrm{c}$ \\
\hline
\end{tabular}


The 2011 International Snowy Plover Winter Census in The Bahamas

(Continued)

\begin{tabular}{|c|c|c|c|c|c|c|c|c|c|c|c|c|}
\hline COUNTY & SITE NAME & MAP\# & $\begin{array}{l}\text { DATE } \\
\end{array}$ & \multirow{2}{*}{$\begin{array}{c}\text { TOTAL } \\
\text { ADULTS } \\
0\end{array}$} & \multirow{2}{*}{$\frac{\mathbf{K M}}{2.4}$} & \multirow{2}{*}{$\begin{array}{l}\text { SITE } \\
\text { DESCRIPTION } \\
\text { II A }\end{array}$} & \multirow{2}{*}{$\begin{array}{l}\text { DISTURBANCE } \\
\text { / CONCERNS } \\
\text { H D V F S I U L }\end{array}$} & \multicolumn{4}{|c|}{$\begin{array}{l}\text { PRIOR YEARS } \\
\text { CENSUSED \& YEARS } \\
\text { SNPL SEEN }^{1} \\
\end{array}$} & \multirow{2}{*}{$\frac{\text { OWNER }}{\mathrm{f}}$} \\
\hline Abaco & West-Facing Beach S of Sandy Point & 62 & $2 / 3 / 11$ & & & & & - & - & - & - & \\
\hline Abaco & Whale Cay & 39 & $2 / 2 / 11$ & 0 & 0.9 & I B & $\mathrm{L}$ & - & - & - & - & n.r. \\
\hline Abaco & White Sound, Elbow Cay & 46 & $1 / 31 / 11$ & 0 & 0.4 & II B & B S G & - & - & - & - & f \\
\hline Abaco & Winding Bay & 52 & $2 / 3 / 11$ & 0 & 2.6 & II A & $\mathrm{H} \mathrm{U} \mathrm{G}$ & - & - & - & - & $\mathrm{p}$ \\
\hline Acklins & Beach $N$ of Creek Point ${ }^{3}$ & 190 & $2 / 7 / 11$ & 9 & 7.0 & I A & H V S & - & - & - & - & n.r. \\
\hline Acklins & Beach S of Creek Point and N of Salt Pond ${ }^{3}$ & 192 & 2/8/11 & 0 & 4.8 & I A & P G L & - & - & - & - & n.r. \\
\hline Acklins & Florida $^{3}$ & 193 & 2/8/11 & 0 & 1.5 & I A & n.r. & - & - & - & - & n.r. \\
\hline Acklins & Small beach SE of Pinefield Settlement ${ }^{3}$ & 189 & $2 / 7 / 11$ & 0 & 0.2 & I A & G L & - & - & - & - & n.r. \\
\hline Acklins & Snug Corner Settlement (past cemetery) ${ }^{3}$ & 191 & 2/7/11 & 0 & 0.3 & IV A & G L & - & - & - & - & n.r. \\
\hline Acklins & $\begin{array}{l}\text { Unnamed off-shore Cay (NE of Chester's } \\
\text { Settlement) }\end{array}$ & 187 & $2 / 6 / 11$ & 0 & 0.4 & I E & A G L & - & - & - & - & n.r. \\
\hline Acklins & $\begin{array}{l}\text { W beach on Lady Slipper Cay ( } \mathrm{S} \text { of Atwood } \\
\text { Harbour) }\end{array}$ & 188 & $2 / 6 / 11$ & 0 & 1.5 & I E & H D U G L & - & - & - & - & n.r. \\
\hline Berry & Ambergris Cay (E side) & 83 & $1 / 24 / 11$ & 0 & 0.3 & I E & I L & - & - & - & - & n.r. \\
\hline Berry & Chub Cay - NW side tidal flat & 91 & $1 / 27 / 11$ & 0 & 0.9 & I E & G L & - & - & - & - & n.r. \\
\hline Berry & Cockroach Cay (NW side) & 92 & $1 / 27 / 11$ & 0 & 0.5 & I E & I & - & - & - & - & n.r. \\
\hline Berry & Cormorant Cay (Sapphire Cays) & 86 & $1 / 27 / 11$ & 0 & 0.1 & I E & I G & - & - & - & - & n.r. \\
\hline Berry & East Caesar Cay Spit to SE tip Ambergris Cay & 82 & $1 / 24 / 11$ & 0 & 0.2 & I E & I G & - & - & - & - & n.r. \\
\hline Berry & Fanny Cay (East Side) & 81 & $1 / 24 / 11$ & 0 & $<1$ & I E & $\mathrm{L}$ & - & - & - & - & n.r. \\
\hline Berry & Great Harbour Cay - "Shelling Beach" & 74 & $1 / 23 / 11$ & 0 & 0.4 & II G & H G L & - & - & - & - & n.r. \\
\hline Berry & Great Harbour Cay - "Sugar Beach Caves" & 66 & $1 / 23 / 11$ & 0 & 0.9 & I E & $\mathrm{H}$ & - & - & - & - & n.r. \\
\hline Berry & $\begin{array}{l}\text { Great Harbour Cay - North Beach (Just before } \\
\text { point at mid-beach) }\end{array}$ & 69 & $1 / 23 / 11$ & 0 & 0.3 & I E & $\mathrm{L}$ & - & - & - & - & n.r. \\
\hline Berry & $\begin{array}{l}\text { Great Harbour Cay - North Beach (Start at } \\
\text { Purple/blue house w/ Pelican statues at edge of } \\
\text { driveway) }\end{array}$ & 67 & $1 / 23 / 11$ & 0 & 1.0 & I E & H D & - & - & - & - & n.r. \\
\hline Berry & $\begin{array}{l}\text { Great Harbour Cay - North Beach (start at Yellow } \\
\text { House - Northernmost house on beach) }\end{array}$ & 65 & $1 / 23 / 11$ & 0 & 1.6 & I E & none & - & - & - & - & n.r. \\
\hline Berry & $\begin{array}{l}\text { Great Harbour Cay - North Beach (Villa Allegria } \\
\text { House) }\end{array}$ & 68 & $1 / 23 / 11$ & 0 & 2.2 & I E & H D U & - & - & - & - & n.r. \\
\hline Berry & $\begin{array}{l}\text { Great Harbour Cay - South Beach (Main crescent- } \\
\text { shaped beach) }\end{array}$ & 70 & $1 / 23 / 11$ & 0 & 4.0 & I E & H D I U G & - & - & - & - & n.r. \\
\hline Berry & Great Harbour Cay (SW Side) & 72 & $1 / 24 / 11$ & 0 & 0.1 & I E & none & - & - & - & - & n.r. \\
\hline Berry & Haines Cay - entire E side of beach & 75 & $1 / 25 / 11$ & 0 & 3.5 & I E & I G & - & - & - & - & n.r. \\
\hline
\end{tabular}


The 2011 International Snowy Plover Winter Census in The Bahamas

(Continued)

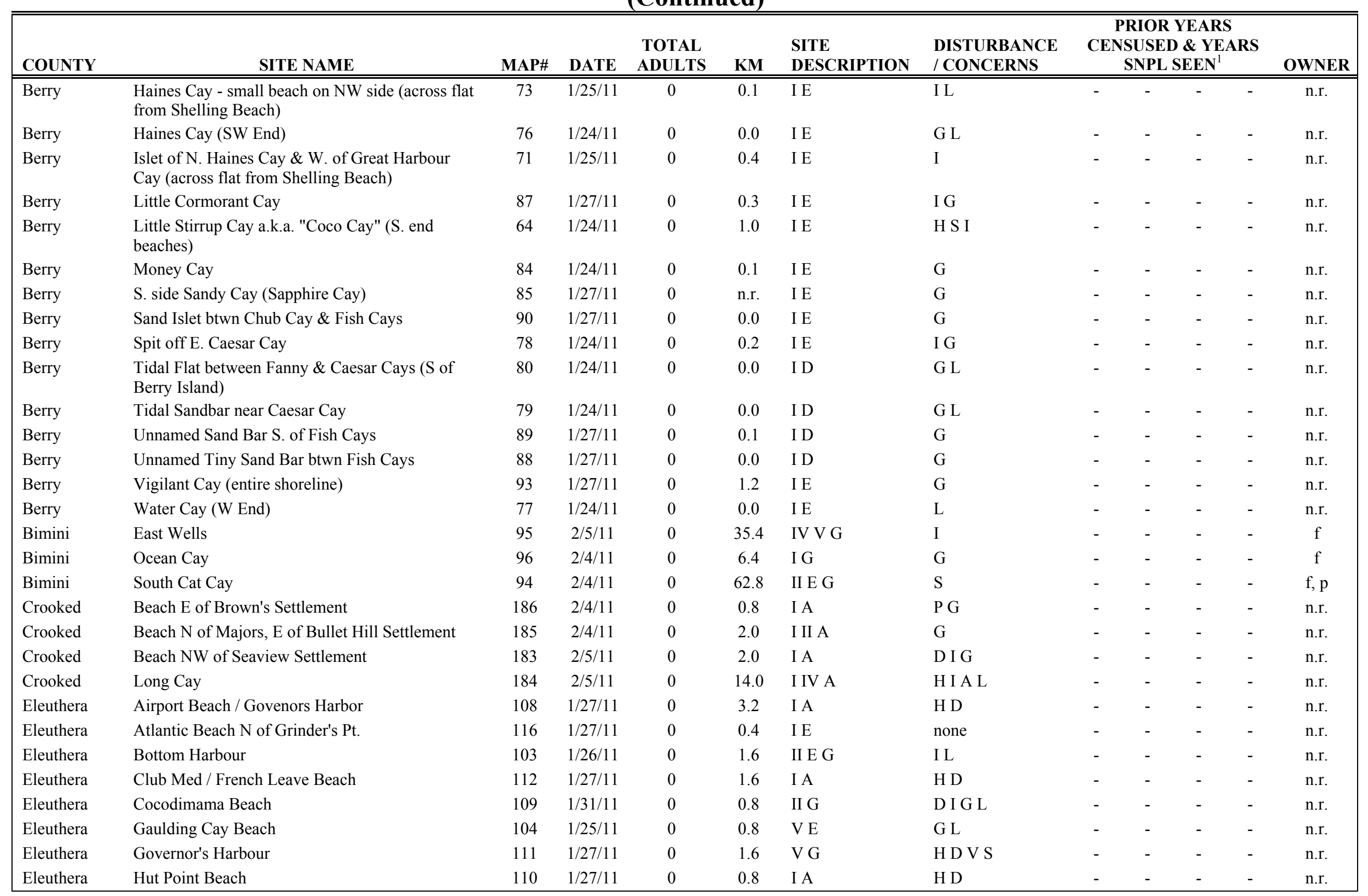


The 2011 International Snowy Plover Winter Census in The Bahamas

(Continued)

\begin{tabular}{|c|c|c|c|c|c|c|c|c|c|c|c|c|}
\hline \multirow{2}{*}{$\begin{array}{l}\text { COUNTY } \\
\text { Eleuthera }\end{array}$} & \multirow{2}{*}{ 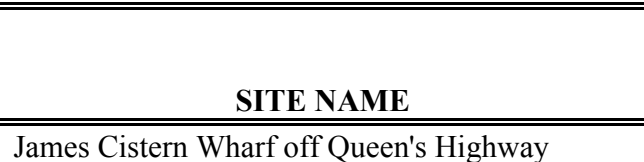 } & \multirow{2}{*}{ MAP\# } & \multirow{2}{*}{$\begin{array}{l}\text { DATE } \\
1 / 27 / 11\end{array}$} & \multirow{2}{*}{$\begin{array}{c}\text { TOTAL } \\
\text { ADULTS } \\
0\end{array}$} & \multirow{2}{*}{$\frac{\mathbf{K M}}{20.2}$} & \multirow{2}{*}{$\begin{array}{l}\text { SITE } \\
\text { DESCRIPTION } \\
\text { II A }\end{array}$} & \multirow{2}{*}{$\begin{array}{l}\text { DISTURBANCE } \\
\text { / CONCERNS } \\
\text { H D V F S }\end{array}$} & \multicolumn{4}{|c|}{$\begin{array}{c}\text { PRIOR YEARS } \\
\text { CENSUSED \& YEARS }^{\text {SNPL SEEN }}{ }^{1} \\
\text { SNPL S }^{2}\end{array}$} & \multirow{2}{*}{$\begin{array}{c}\text { OWNER } \\
\text { n.r. }\end{array}$} \\
\hline & & & & & & & & - & 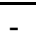 & 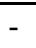 & 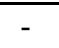 & \\
\hline Eleuthera & Man Island Spit and Picnic Beach & 100 & $1 / 29 / 11$ & 0 & 0.2 & II IV G & G & - & - & - & - & n.r. \\
\hline Eleuthera & Preacher's Cave Beach & 99 & $1 / 25 / 11$ & 0 & 0.8 & IG & n.r. & - & - & - & - & n.r. \\
\hline Eleuthera & Rock Sound & 119 & $1 / 31 / 11$ & 0 & n.r. & II G & n.r. & - & - & - & - & n.r. \\
\hline Eleuthera & Savannah Sound (W. Shore) & 114 & $1 / 28 / 11$ & 0 & 1.6 & II G & H F G L & - & - & - & - & n.r. \\
\hline Eleuthera & $\begin{array}{l}\text { Shore } \mathrm{N} \text { of Barge Landing, } \mathrm{N} \text { of Water Taxi Port } \\
\text { (Three Islands) }\end{array}$ & 101 & $1 / 30 / 11$ & 0 & 3.2 & II E & H F G & - & - & - & - & n.r. \\
\hline Eleuthera & Spanish Wells & 98 & $1 / 30 / 11$ & 0 & 3.2 & I IV D G & H D V F S G L & - & - & - & 06 & n.r. \\
\hline Eleuthera & Surfer's Beach, Gregory Town & 105 & $1 / 25 / 11$ & 0 & 0.8 & I E & $\mathrm{H}$ & - & - & - & - & n.r. \\
\hline Eleuthera & Tarpum Bay & 117 & $1 / 27 / 11$ & 0 & 0.8 & V G & H D V S & - & - & - & - & n.r. \\
\hline Eleuthera & Ten Bay Beach & 113 & $1 / 31 / 11$ & 0 & 1.6 & II G & H D G L & - & - & - & - & n.r. \\
\hline Eleuthera & Upper Cove Beach (E of Current) & 97 & $1 / 25 / 11$ & 0 & 0.4 & II V G & D G L & - & - & - & - & n.r. \\
\hline Eleuthera & Windermere Island & 115 & $1 / 28 / 11$ & 0 & 8.0 & I II E & H D G L & - & - & - & - & $\mathrm{p}$ \\
\hline Eleuthera & Winding Bay & 118 & $1 / 31 / 11$ & 0 & 3.2 & II G & H D I U G L & - & - & - & 06 & n.r. \\
\hline Eleuthera & Wreck Beach/James Cistern & 107 & $1 / 26 / 11$ & 0 & 1.6 & I E & n.r. & - & - & - & - & n.r. \\
\hline Exuma & Beaches E of Sea View Drive to Sunset Bluff & 159 & $1 / 29 / 11$ & 0 & 10.0 & II A & H D F L & - & - & - & - & f, p \\
\hline Exuma & Bell Island (all major beaches) & 155 & $1 / 24 / 11$ & 0 & 1.8 & II E & $\mathrm{L}$ & - & - & - & - & $\mathrm{p}$ \\
\hline Exuma & East of 3 Sisters Rocks & 158 & $1 / 28 / 11$ & 0 & 0.2 & I A & H D & - & - & - & - & $\mathrm{p}$ \\
\hline Exuma & Exuma Point & 156 & $1 / 28 / 11$ & 0 & 0.5 & II A & H D I G L & - & - & - & 06 & f \\
\hline Exuma & Hawksbill Cay \& Shroud Cay & 153 & $1 / 29 / 11$ & 0 & 9.0 & I II IV A & n.r. & - & - & - & 06 & f \\
\hline Exuma & Leaf Cay/White Cay & 164 & $1 / 28 / 11$ & 0 & 2.9 & I E & H G L & - & - & - & 06 & f \\
\hline Exuma & Little Exuma Beaches \& Access Points & 162 & $1 / 27 / 11$ & 0 & 2.0 & I A & H D I U & - & - & - & - & $\mathrm{p}$ \\
\hline Exuma & Manowar Cay & 160 & $1 / 27 / 11$ & 0 & 4.0 & II E & H D V F I & - & - & - & - & $\mathrm{p}$ \\
\hline Exuma & Moriah Harbour Cay, Great Exuma & 161 & $1 / 28 / 11$ & 2 & 1.0 & II E & H D G & - & - & - & 06 & f, p \\
\hline Exuma & Sea Way Drive, Great Exuma & 157 & $1 / 29 / 11$ & 0 & 2.8 & II A & H D I G L & - & - & - & 06 & $\mathrm{p}$ \\
\hline Exuma & $\begin{array}{l}\text { Warderick Wells Cay (Career, Powerful, } \\
\text { Causeway and Boo Boo Beaches) }\end{array}$ & 154 & $1 / 29 / 11$ & 0 & 0.5 & II A & H G L & - & - & - & 06 & $\mathrm{f}$ \\
\hline Exuma & Wolf Dames Back Landing, Little Exuma & 163 & $1 / 29 / 11$ & 0 & 1.6 & I A & D L & - & - & - & 06 & $\mathrm{p}$ \\
\hline Grand Bahama & 8 Mile Rock (including Lover's Beach) & 11 & $1 / 27 / 11$ & 0 & 5.4 & I A & $\mathrm{H} \mathrm{S}$ & - & - & - & - & $\mathrm{f}$ \\
\hline Grand Bahama & $\begin{array}{l}\text { Bahama Beach/Bahama Bay (aka "Seward of } \\
\text { Grand Bahama") }\end{array}$ & 8 & $1 / 26 / 11$ & 0 & 1.8 & I A & S I G L & - & - & - & - & $\mathrm{f}$ \\
\hline Grand Bahama & $\begin{array}{l}\text { Barbary Beach (Discovery Bay Canal to White } \\
\text { Beach) }\end{array}$ & 19 & $1 / 25 / 11$ & 0 & 12.5 & I A & H D V S I L & - & - & - & 06 & $f, p$ \\
\hline
\end{tabular}


The 2011 International Snowy Plover Winter Census in The Bahamas

(Continued)

\begin{tabular}{|c|c|c|c|c|c|c|c|c|c|c|c|c|}
\hline \multirow{2}{*}{$\begin{array}{l}\text { COUNTY } \\
\text { Grand Bahama }\end{array}$} & \multirow{2}{*}{$\begin{array}{l}\text { SITE NAME } \\
\text { Bootle Bay (Blue Marlin Cove) S and E of inlet } \\
\text { to Bahama Beach inlet }\end{array}$} & \multirow{2}{*}{ MAP\# } & \multirow{2}{*}{$\begin{array}{c}\text { DATE } \\
1 / 26 / 11\end{array}$} & \multirow{2}{*}{$\begin{array}{c}\text { TOTAL } \\
\text { ADULTS } \\
0\end{array}$} & \multirow{2}{*}{$\frac{\mathbf{K M}}{6.5}$} & \multirow{2}{*}{$\begin{array}{l}\text { SITE } \\
\text { DESCRIPTION }\end{array}$} & \multirow{2}{*}{$\begin{array}{l}\text { DISTURBANCE } \\
\text { / CONCERNS } \\
\text { S I }\end{array}$} & \multicolumn{4}{|c|}{$\begin{array}{l}\text { PRIOR YEARS } \\
\text { CENSUSED \& YEARS } \\
\text { SNPL SEEN }^{1} \\
\end{array}$} & \multirow{2}{*}{$\frac{\text { OWNER }}{\mathrm{f}}$} \\
\hline & & & & & & & & - & - & 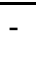 & - & \\
\hline Grand Bahama & $\begin{array}{l}\text { Discovery Beach (Freeport Bay Canal to } \\
\text { Discovery Bay Canal) }\end{array}$ & 18 & $1 / 24 / 11$ & 0 & 5.7 & I A & H D V S I U G & - & - & - & 06 & $\mathrm{f}$ \\
\hline Grand Bahama & $\begin{array}{l}\text { East End Cays (incldg Sweeting's, Lightbourne, } \\
\text { Redshank, Cross, and unnamed Cays/flats) }\end{array}$ & 6 & $1 / 30 / 11$ & 0 & 60.0 & I II IV V A E F & F I G & - & - & - & - & $f$ \\
\hline Grand Bahama & Gold Rock Creek to High Rock & 21 & $1 / 28 / 11$ & 0 & 5.4 & I A & H D S I G & - & - & - & - & f \\
\hline Grand Bahama & Great Sale Cay & 2 & $2 / 6 / 11$ & 0 & 7.5 & I E F & H D P I G & - & - & - & - & $f$ \\
\hline Grand Bahama & High Rock (Rocky Cliff to Oil Transfer Facility) & 22 & $1 / 28 / 11$ & 0 & 4.5 & I A & H D V S I G & - & - & - & 06 & f, p \\
\hline Grand Bahama & Holmes Rock (E to 8 Mile Rock) & 10 & $1 / 27 / 11$ & 0 & 3.4 & I A & H I L & - & - & - & - & f \\
\hline Grand Bahama & Island Seas - Silver Point Beach into Jetty & 15 & $1 / 27 / 11$ & 0 & 3.2 & I A & H D S I G & - & - & - & 06 & $f, p$ \\
\hline Grand Bahama & Lucaya Beach & 16 & $1 / 30 / 11$ & 0 & 2.4 & I A & n.r. & - & - & - & - & n.r. \\
\hline Grand Bahama & Mangrove Cay & 1 & $2 / 6 / 11$ & 0 & 1.5 & I E & G & - & - & - & - & $\mathrm{f}$ \\
\hline Grand Bahama & McLean's Town Cemetery & 27 & $1 / 29 / 11$ & 0 & 0.7 & I II A & H D I G & - & - & - & - & $f$ \\
\hline Grand Bahama & $\begin{array}{l}\text { Old Bahama Bay - Ginn Sur Mer (Canal E to } \\
\text { Bootle Bay/Blue Marlin Cove) }\end{array}$ & 5 & $1 / 26 / 11$ & 1 & 4.4 & I A & D S I G L & - & - & - & - & $f, p$ \\
\hline Grand Bahama & $\begin{array}{l}\text { Old Bahama Bay - Ginn Sur Mer (NW end, S to } \\
\text { canal) }\end{array}$ & 4 & $1 / 26 / 11$ & 0 & 2.0 & I A & D S P I U & - & - & - & - & f, p \\
\hline Grand Bahama & Pelican Point - E of Rocky Point & 25 & $1 / 29 / 11$ & 0 & 5.7 & I A & H D I U G & - & - & - & - & f \\
\hline Grand Bahama & Pelican Point - Rocky Point Flats & 24 & $1 / 29 / 11$ & 0 & 3.2 & I A & H D I G & - & - & - & 06 & $\mathrm{f}$ \\
\hline Grand Bahama & Pinder's Point to Hunter's & 12 & $1 / 27 / 11$ & 0 & 4.7 & I A & H D S P I G & - & - & - & - & f \\
\hline Grand Bahama & Rocky Creek and areas W of McLean's Town & 26 & $1 / 30 / 11$ & 0 & 11.6 & I V A & F I G L & - & - & - & - & $\mathrm{f}$ \\
\hline Grand Bahama & Running Mon & 14 & $1 / 27 / 11$ & 0 & 1.1 & I A & H S G & - & - & - & - & $f$ \\
\hline Grand Bahama & Seaward at Bahama Bay to Holmes Rock & 9 & $1 / 27 / 11$ & 0 & 5.8 & I A & H D S I U G L & - & - & - & - & f \\
\hline Grand Bahama & Taino Beach & 17 & $2 / 3 / 11$ & 0 & 1.6 & I A & n.r. & - & - & - & - & n.r. \\
\hline Grand Bahama & $\begin{array}{l}\text { West End, Old Bahama Bay (Small beach on } \\
\text { NW side) }\end{array}$ & 3 & $1 / 26 / 11$ & 0 & 0.8 & I A & H V S I U G & - & - & - & - & $\mathrm{p}$ \\
\hline Grand Bahama & West of Pelican Point Flats to Oil Terminal & 23 & $1 / 28 / 11$ & 0 & 7.0 & I A & H D S I G & - & - & - & 06 & f \\
\hline Grand Bahama & $\begin{array}{l}\text { White (aka "Nudie") Beach to Gold Rocks Inlet } \\
\text { (W side) }\end{array}$ & 20 & $1 / 28 / 11$ & 0 & 7.8 & I A & H S I G & - & - & - & 06 & $\mathrm{f}$ \\
\hline Grand Bahama & Xanadu Beach and Bahama Princess Beach & 13 & $1 / 27 / 11$ & 0 & 4.5 & I A & H S I U G & - & - & - & - & f \\
\hline Great Inagua & Blackwood Beach (SW side of Island) & 202 & $1 / 30 / 11$ & 0 & 2.5 & I A & none & - & - & - & - & n.r. \\
\hline Great Inagua & $\begin{array}{l}\text { Bluff Beach, East of Conch Shell Pt. (S. side of } \\
\text { island to limestone outcrop on beach) }\end{array}$ & 203 & $1 / 30 / 11$ & 0 & 1.2 & I A & H D L & - & - & - & - & n.r. \\
\hline Great Inagua & Craig's Bight East & 201 & $1 / 29 / 11$ & 0 & 3.6 & I E & G L & - & - & - & 06 & n.r. \\
\hline
\end{tabular}


The 2011 International Snowy Plover Winter Census in The Bahamas

(Continued)

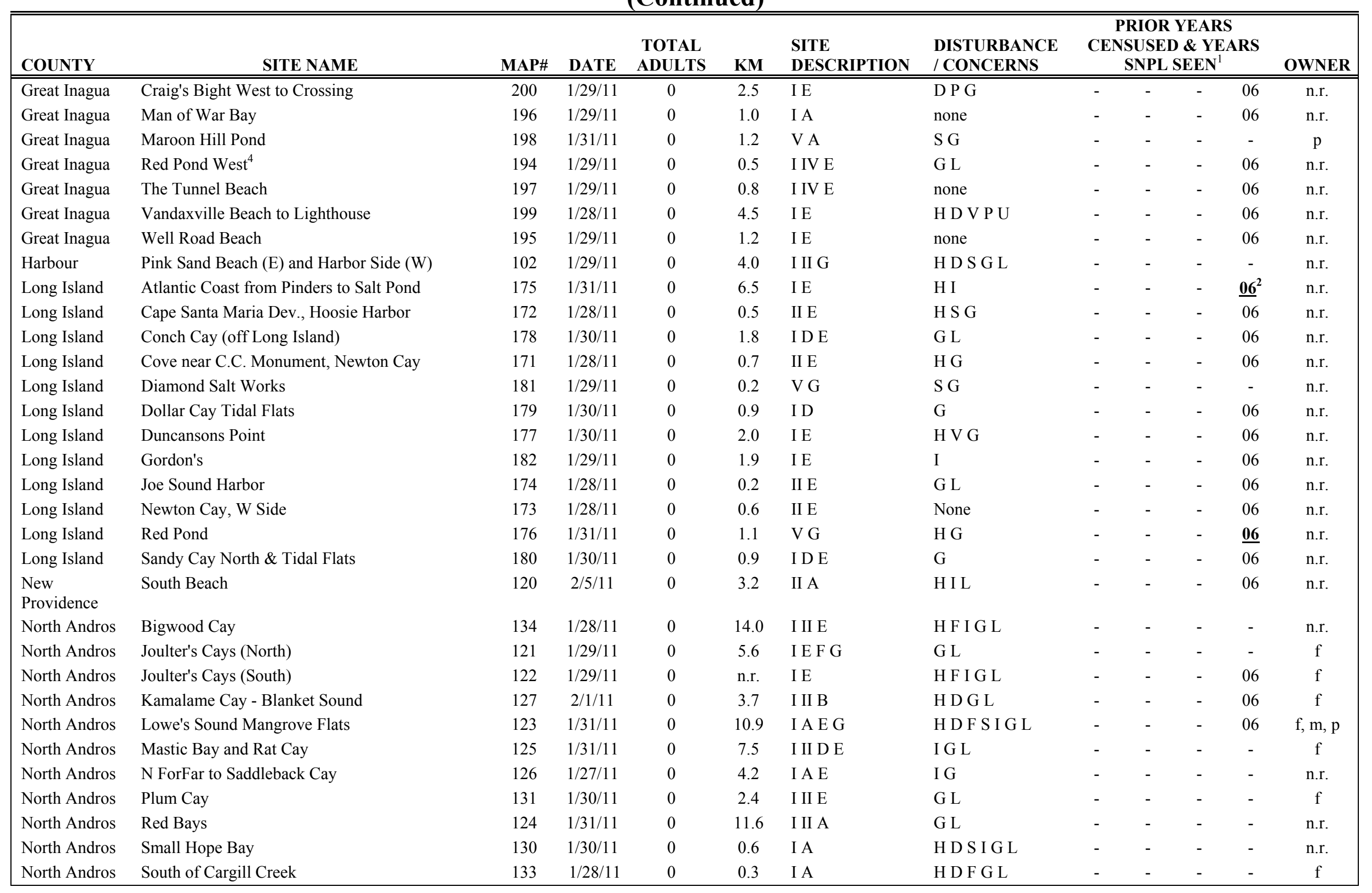


The 2011 International Snowy Plover Winter Census in The Bahamas

(Continued)

\begin{tabular}{|c|c|c|c|c|c|c|c|c|c|c|c|c|}
\hline \multirow{2}{*}{$\begin{array}{l}\text { COUNTY } \\
\text { North Andros }\end{array}$} & \multirow{2}{*}{$\begin{array}{r}\text { SITE NAME } \\
\text { Southwest of Mastic Cay }\end{array}$} & \multirow{2}{*}{ MAP\# } & \multirow{2}{*}{$\frac{\text { DATE }}{1 / 30 / 11}$} & \multirow{2}{*}{$\begin{array}{c}\text { TOTAL } \\
\text { ADULTS } \\
0\end{array}$} & \multirow{2}{*}{ 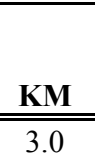 } & \multirow{2}{*}{$\begin{array}{l}\text { SITE } \\
\text { DESCRIPTION } \\
\text { I II D E }\end{array}$} & \multirow{2}{*}{$\begin{array}{l}\text { DISTURBANCE } \\
\text { / CONCERNS } \\
\mathrm{G} \mathrm{L}\end{array}$} & \multicolumn{4}{|c|}{$\begin{array}{c}\text { PRIOR YEARS } \\
\text { CENSUSED \& YEARS }^{\text {SNPL SEEN }}{ }^{1} \\
\text { SNPL S }^{2}\end{array}$} & \multirow{2}{*}{$\begin{array}{c}\text { OWNER } \\
\text { n.r. }\end{array}$} \\
\hline & & & & & & & & - & 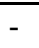 & 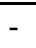 & 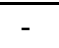 & \\
\hline North Andros & Staniard Creek & 129 & $1 / 27 / 11$ & 0 & 4.1 & I A & H D I U G & - & - & - & 06 & $f$ \\
\hline North Andros & Staniard Creek Flats & 128 & $1 / 30 / 11$ & 0 & 0.3 & II A & D G & - & - & - & - & n.r. \\
\hline San Salvadore & Bonefish Bay (Club Med Beach) & 166 & $2 / 1 / 11$ & 0 & 1.6 & I A & H D V S U & - & - & - & - & n.r. \\
\hline San Salvadore & Dim Bay and Greens Bay to Crab Cay & 168 & $1 / 31 / 11$ & 8 & 2.7 & I A & G & - & - & - & - & n.r. \\
\hline San Salvadore & East Beach & 167 & $2 / 2 / 11$ & 9 & 3.5 & I A & D G & - & - & - & - & n.r. \\
\hline San Salvadore & Holiday Track Settlement (The Thumb) & 169 & $2 / 1 / 11$ & 9 & 3.0 & I A & G L & - & - & - & - & n.r. \\
\hline San Salvadore & Rice Bay & 165 & $2 / 2 / 11$ & 0 & 0.5 & I A & H V U L & - & - & - & - & n.r. \\
\hline San Salvadore & Sandy Point & 170 & $2 / 1 / 11$ & 0 & 0.1 & I A & $\mathrm{H}$ & - & - & - & - & n.r. \\
\hline South Andros & Congo Town & 137 & $2 / 3 / 11$ & 0 & 0.1 & I E & I U G & - & - & - & 06 & n.r. \\
\hline South Andros & Deep Creek to Little Creek & 144 & $2 / 3 / 11$ & 0 & 2.8 & I E & G L & - & - & - & - & n.r. \\
\hline South Andros & Driggs Hill (at cemetery) & 135 & $2 / 3 / 11$ & 0 & 0.1 & I E & I L & - & - & - & - & n.r. \\
\hline South Andros & $\begin{array}{l}\text { Driggs Hill (Lighthouse Pt to Long Bay } \\
\text { Settlement) }\end{array}$ & 136 & $2 / 3 / 11$ & 0 & 0.1 & I E & $\mathrm{H}$ & - & - & - & - & n.r. \\
\hline South Andros & Kemps Bay & 142 & $2 / 3 / 11$ & 0 & 4.6 & I E & D V S I U & - & - & - & 06 & n.r. \\
\hline South Andros & Kemp's Bay Complex to Smith's Hill Settlement & 140 & $2 / 1 / 11$ & 0 & 3.7 & I E & G & - & - & - & - & n.r. \\
\hline South Andros & Mars Bay Settlement (North of Wharf) & 147 & $2 / 1 / 11$ & 0 & 0.4 & II E & H F I U G L & - & - & - & 06 & n.r. \\
\hline South Andros & North of Hawks Nest (Hawksbill Creek) & 149 & $2 / 2 / 11$ & 0 & 0.6 & I E & I L & - & - & - & - & n.r. \\
\hline South Andros & Northern Deep Creek Settlement at Cemetery & 143 & $2 / 3 / 11$ & 0 & 0.1 & I E & G L & - & - & - & - & n.r. \\
\hline South Andros & $\begin{array}{l}\text { Old Pier S of Congo Town to the Bluff } \\
\text { Settlement (Mt. Sinai Baptist Church) }\end{array}$ & 138 & $2 / 3 / 11$ & 0 & 2.7 & I E & H D U G & - & - & - & - & n.r. \\
\hline South Andros & Sand Bar (2 miles NE of Top Cay) & 151 & $2 / 2 / 11$ & 0 & 0.6 & I D & G L & - & - & - & - & n.r. \\
\hline South Andros & Sand Bar $\sim 3 \mathrm{~km}$ E of Little Creek & 146 & $2 / 4 / 11$ & 0 & 0.4 & I D & G & - & - & - & - & n.r. \\
\hline South Andros & South of Hawks Nest to Snap Pt. & 150 & $2 / 2 / 11$ & 0 & 2.6 & I E & none & - & - & - & - & n.r. \\
\hline South Andros & $\begin{array}{l}\text { South of Mars Bay: Flats at S end of white } \\
\text { gravel road }\end{array}$ & 148 & $2 / 2 / 11$ & 0 & 3.0 & I E & H F G L & - & - & - & 06 & n.r. \\
\hline South Andros & $\begin{array}{l}\text { South Smith's Hill Settlement to North Kemp's } \\
\text { Bay Settlement }\end{array}$ & 141 & $2 / 1 / 11$ & 0 & 1.0 & I E & D G & - & - & - & - & n.r. \\
\hline South Andros & The Bluff Settlement & 139 & $2 / 1 / 11$ & 0 & 1.3 & I E & I G & - & - & - & - & n.r. \\
\hline South Andros & Tidal Flat Slightly N of Pleasant Bay & 145 & $2 / 3 / 11$ & 0 & 0.5 & I E & G L & - & - & - & - & n.r. \\
\hline South Andros & Water Cays $^{3}$ & 152 & $2 / 6 / 11$ & 0 & 0.4 & II D & H F G L & - & - & - & - & n.r. \\
\hline Total & & & & 38 & 678.4 & & & & & & & \\
\hline
\end{tabular}


${ }^{1}$ If previously surveyed, years surveyed are noted. Bold underlined years indicate that Snowy Plovers were seen at the site during that Census year.

${ }^{2}$ The 2006 route extended further south and was longer than the 2011 route. The SNPL seen in 2006 were $\sim 0.15 \mathrm{~km}$ south of the starting location for the 2011 census.

${ }^{3}$ Please note that this survey was conducted outside the Census window.

${ }^{4}$ Four Snowy Plovers were observed near this site on 26 January (not part of the official Census but during the census period). 


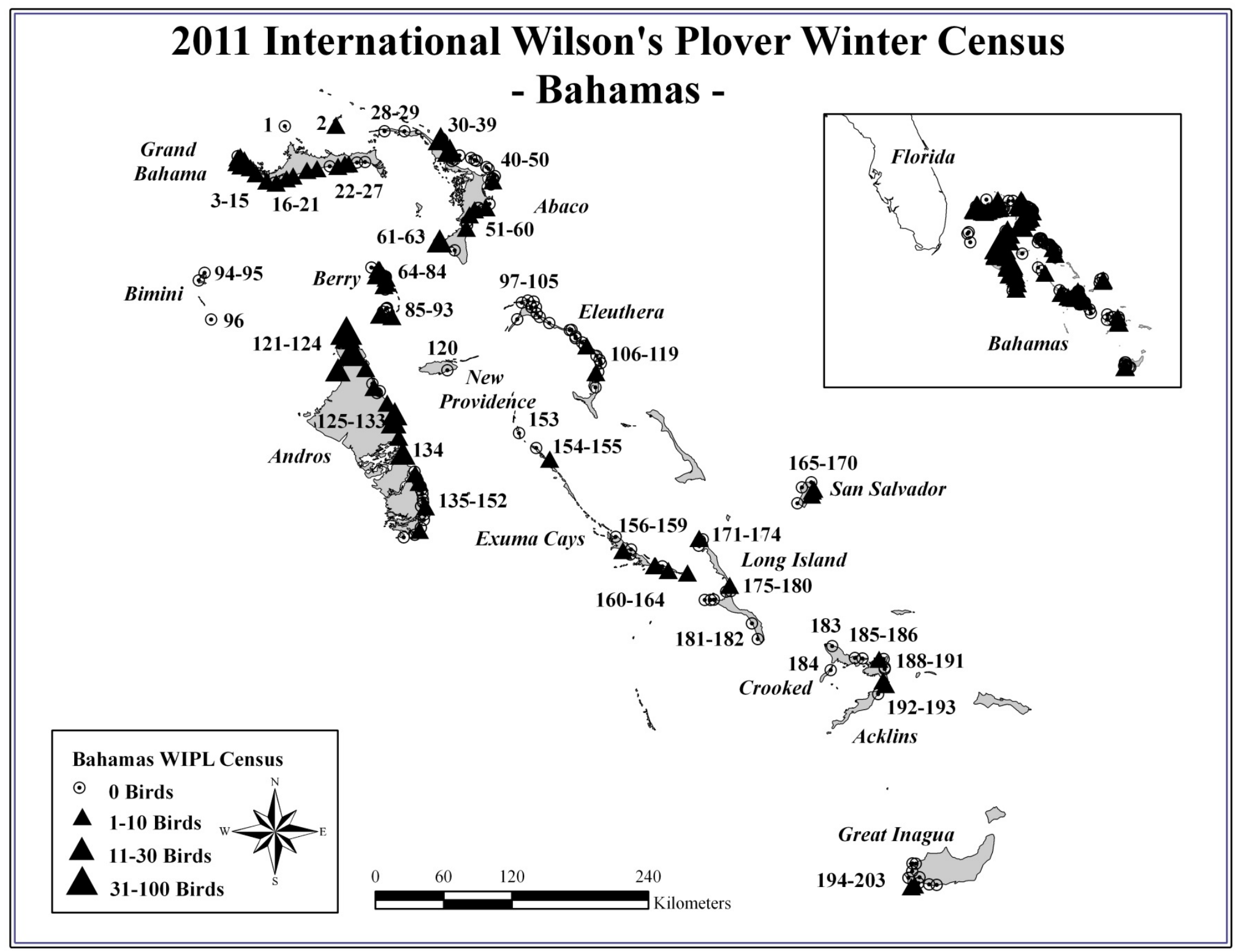


The 2011 International Wilson's Plover Winter Census in The Bahamas

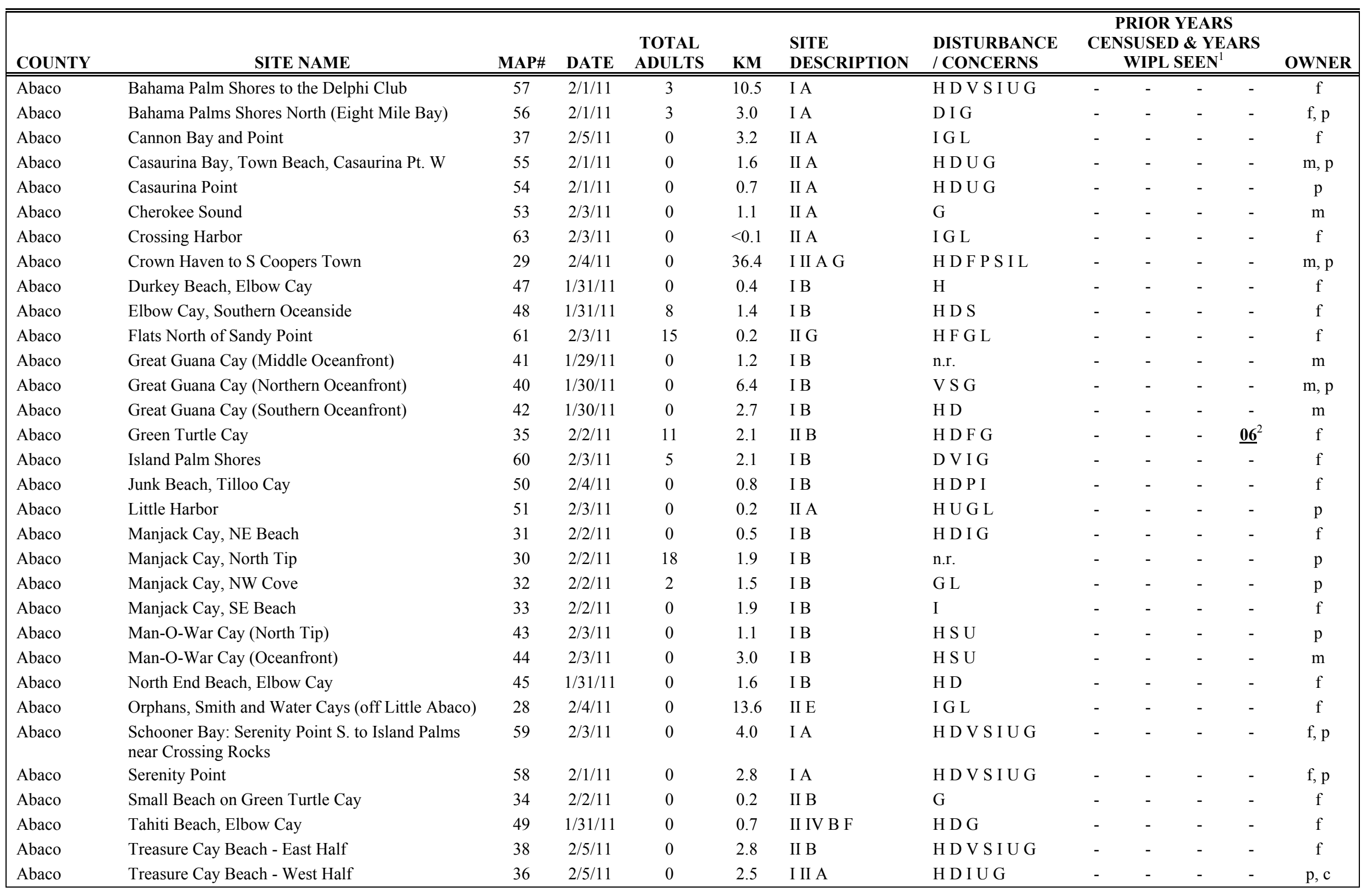


The 2011 International Wilson's Plover Winter Census in The Bahamas

(Continued)

\begin{tabular}{|c|c|c|c|c|c|c|c|c|c|c|c|c|}
\hline \multirow{2}{*}{$\begin{array}{l}\text { COUNTY } \\
\text { Abaco }\end{array}$} & \multirow{2}{*}{$\begin{array}{l}\text { SITE NAME } \\
\text { ich S of Sandy Point }\end{array}$} & \multirow{2}{*}{ MAP\# } & \multirow{2}{*}{$\begin{array}{c}\text { DATE } \\
2 / 3 / 11\end{array}$} & \multirow{2}{*}{$\begin{array}{c}\text { TOTAL } \\
\text { ADULTS } \\
0\end{array}$} & \multirow{2}{*}{$\frac{\mathbf{K M}}{2.4}$} & \multirow{2}{*}{$\begin{array}{l}\text { SITE } \\
\text { DESCRIPTION } \\
\text { II A }\end{array}$} & \multirow{2}{*}{$\begin{array}{l}\text { DISTURBANCE } \\
\text { / CONCERNS } \\
\text { H D V F S I U L }\end{array}$} & \multicolumn{4}{|c|}{$\begin{array}{c}\text { PRIOR YEARS } \\
\text { CENSUSED \& YEARS } \\
\text { WIPL SEEN }^{1} \\
\end{array}$} & \multirow{2}{*}{$\frac{\text { OWNER }}{\mathrm{f}}$} \\
\hline & & & & & & & & - & - & - & - & \\
\hline Abaco & Whale Cay & 39 & $2 / 2 / 11$ & 0 & 0.9 & I B & $\mathrm{L}$ & - & - & - & - & n.r. \\
\hline Abaco & White Sound, Elbow Cay & 46 & $1 / 31 / 11$ & 0 & 0.4 & II B & B S G & - & - & - & - & $f$ \\
\hline Abaco & Winding Bay & 52 & $2 / 3 / 11$ & 2 & 2.6 & II A & $\mathrm{H} \mathrm{U} \mathrm{G}$ & - & - & - & - & $\mathrm{p}$ \\
\hline Acklins & Beach N of Creek Point ${ }^{8}$ & 190 & 2/7/11 & 0 & 7.0 & I A & H V S & - & - & - & - & n.r. \\
\hline Acklins & Beach S of Creek Point and N of Salt Pond ${ }^{8}$ & 192 & 2/8/11 & 1 & 4.8 & I A & P G L & - & - & - & - & n.r. \\
\hline Acklins & Florida $^{8}$ & 193 & $2 / 8 / 11$ & 0 & 1.5 & I A & n.r. & - & - & - & - & n.r. \\
\hline Acklins & Small beach SE of Pinefield Settlement ${ }^{8}$ & 189 & $2 / 7 / 11$ & 0 & 0.2 & I A & G L & - & - & - & - & n.r. \\
\hline Acklins & Snug Corner Settlement (past cemetery) ${ }^{8}$ & 191 & 2/7/11 & 2 & 0.3 & IV A & G L & - & - & - & - & n.r. \\
\hline Acklins & $\begin{array}{l}\text { Unnamed off-shore Cay (NE of Chester's } \\
\text { Settlement) }\end{array}$ & 187 & $2 / 6 / 11$ & 3 & 0.4 & I E & A G L & - & - & - & - & n.r. \\
\hline Acklins & $\begin{array}{l}\text { W beach on Lady Slipper Cay (S of Atwood } \\
\text { Harbour) }\end{array}$ & 188 & $2 / 6 / 11$ & 0 & 1.5 & I E & H D U G L & - & - & - & - & n.r. \\
\hline Berry & Ambergris Cay (E side) & 83 & $1 / 24 / 11$ & 0 & 0.3 & I E & I L & - & - & - & - & n.r. \\
\hline Berry & Chub Cay - NW side tidal flat & 91 & $1 / 27 / 11$ & 0 & 0.9 & I E & G L & - & - & - & - & n.r. \\
\hline Berry & Cockroach Cay (NW side) & 92 & $1 / 27 / 11$ & 0 & 0.5 & I E & I & - & - & - & - & n.r. \\
\hline Berry & Cormorant Cay (Sapphire Cays) & 86 & $1 / 27 / 11$ & 0 & 0.1 & I E & I G & - & - & - & - & n.r. \\
\hline Berry & East Caesar Cay Spit to SE tip Ambergris Cay & 82 & $1 / 24 / 11$ & 8 & 0.2 & I E & I G & - & - & - & - & n.r. \\
\hline Berry & Fanny Cay (East Side) & 81 & $1 / 24 / 11$ & 0 & $<1$ & I E & $\mathrm{L}$ & - & - & - & - & n.r. \\
\hline Berry & Great Harbour Cay - "Shelling Beach" & 74 & $1 / 23 / 11$ & 0 & 0.4 & II G & H G L & - & - & - & - & n.r. \\
\hline Berry & Great Harbour Cay - "Sugar Beach Caves" & 66 & $1 / 23 / 11$ & 0 & 0.9 & I E & $\mathrm{H}$ & - & - & - & - & n.r. \\
\hline Berry & $\begin{array}{l}\text { Great Harbour Cay - North Beach (Just before } \\
\text { point at mid-beach) }\end{array}$ & 69 & $1 / 23 / 11$ & 0 & 0.3 & I E & $\mathrm{L}$ & - & - & - & - & n.r. \\
\hline Berry & $\begin{array}{l}\text { Great Harbour Cay - North Beach (Start at } \\
\text { Purple/blue house w/ Pelican statues at edge of } \\
\text { driveway) }\end{array}$ & 67 & $1 / 23 / 11$ & 0 & 1.0 & I E & H D & - & - & - & - & n.r. \\
\hline Berry & $\begin{array}{l}\text { Great Harbour Cay - North Beach (start at Yellow } \\
\text { House - Northernmost house on beach) }\end{array}$ & 65 & $1 / 23 / 11$ & 3 & 1.6 & I E & none & - & - & - & - & n.r. \\
\hline Berry & $\begin{array}{l}\text { Great Harbour Cay - North Beach (Villa Allegria } \\
\text { House) }\end{array}$ & 68 & $1 / 23 / 11$ & 13 & 2.2 & I E & H D U & - & - & - & - & n.r. \\
\hline Berry & $\begin{array}{l}\text { Great Harbour Cay - South Beach (Main crescent- } \\
\text { shaped beach) }\end{array}$ & 70 & $1 / 23 / 11$ & 0 & 4.0 & I E & H D I U G & - & - & - & - & n.r. \\
\hline Berry & Great Harbour Cay (SW Side) & 72 & $1 / 24 / 11$ & 0 & 0.1 & I E & none & - & - & - & - & n.r. \\
\hline Berry & Haines Cay - entire E side of beach & 75 & $1 / 25 / 11$ & 1 & 3.5 & I E & I G & - & - & - & - & n.r. \\
\hline
\end{tabular}


The 2011 International Wilson's Plover Winter Census in The Bahamas

(Continued)

\begin{tabular}{|c|c|c|c|c|c|c|c|c|c|c|c|c|}
\hline \multirow{2}{*}{$\begin{array}{l}\text { COUNTY } \\
\text { Berry }\end{array}$} & \multirow{2}{*}{$\begin{array}{l}\text { SITE NAME } \\
\text { Haines Cay - small beach on NW side (across flat } \\
\text { from Shelling Beach) }\end{array}$} & \multirow{2}{*}{ MAP\# } & \multirow{2}{*}{$\begin{array}{c}\text { DATE } \\
1 / 25 / 11\end{array}$} & \multirow{2}{*}{$\begin{array}{c}\text { TOTAL } \\
\text { ADULTS } \\
0\end{array}$} & \multirow{2}{*}{$\frac{\mathbf{K M}}{0.1}$} & \multirow{2}{*}{$\begin{array}{l}\text { SITE } \\
\text { DESCRIPTION } \\
\text { I E }\end{array}$} & \multirow{2}{*}{$\begin{array}{l}\text { DISTURBANCE } \\
\text { / CONCERNS } \\
\text { I L }\end{array}$} & \multicolumn{4}{|c|}{$\begin{array}{c}\text { PRIOR YEARS } \\
\text { CENSUSED \& YEARS } \\
\text { WIPL SEEN }^{1} \\
\end{array}$} & \multirow{2}{*}{$\frac{\text { OWNER }}{\text { O.r. }}$} \\
\hline & & & & & & & & - & - & - & - & \\
\hline Berry & Haines Cay (SW End) & 76 & $1 / 24 / 11$ & 3 & 0.0 & I E & G L & - & - & - & - & n.r. \\
\hline Berry & $\begin{array}{l}\text { Islet of N. Haines Cay \& W. of Great Harbour } \\
\text { Cay (across flat from Shelling Beach) }\end{array}$ & 71 & $1 / 25 / 11$ & 0 & 0.4 & I E & I & - & - & - & - & n.r. \\
\hline Berry & Little Cormorant Cay & 87 & $1 / 27 / 11$ & 0 & 0.3 & I E & I G & - & - & - & - & n.r. \\
\hline Berry & $\begin{array}{l}\text { Little Stirrup Cay a.k.a. "Coco Cay" (S. end } \\
\text { beaches) }\end{array}$ & 64 & $1 / 24 / 11$ & 0 & 1.0 & I E & H S I & - & - & - & - & n.r. \\
\hline Berry & Money Cay & 84 & $1 / 24 / 11$ & 0 & 0.1 & I E & G & - & - & - & - & n.r. \\
\hline Berry & S. side Sandy Cay (Sapphire Cay) & 85 & $1 / 27 / 11$ & 0 & n.r. & I E & $\mathrm{G}$ & - & - & - & - & n.r. \\
\hline Berry & Sand Islet btwn Chub Cay \& Fish Cays & 90 & $1 / 27 / 11$ & 5 & 0.0 & I E & G & - & - & - & - & n.r. \\
\hline Berry & Spit off E. Caesar Cay & 78 & $1 / 24 / 11$ & 0 & 0.2 & I E & I G & - & - & - & - & n.r. \\
\hline Berry & $\begin{array}{l}\text { Tidal Flat between Fanny \& Caesar Cays (S of } \\
\text { Berry Island) }\end{array}$ & 80 & $1 / 24 / 11$ & 0 & 0.0 & I D & G L & - & - & - & - & n.r. \\
\hline Berry & Tidal Sandbar near Caesar Cay & 79 & $1 / 24 / 11$ & 0 & 0.0 & I D & G L & - & - & - & - & n.r. \\
\hline Berry & Unnamed Sand Bar S. of Fish Cays & 89 & $1 / 27 / 11$ & 2 & 0.1 & I D & G & - & - & - & - & n.r. \\
\hline Berry & Unnamed Tiny Sand Bar btwn Fish Cays & 88 & $1 / 27 / 11$ & 0 & 0.0 & I D & $\mathrm{G}$ & - & - & - & - & n.r. \\
\hline Berry & Vigilant Cay (entire shoreline) & 93 & $1 / 27 / 11$ & 5 & 1.2 & I E & G & - & - & - & - & n.r. \\
\hline Berry & Water Cay (W End) & 77 & $1 / 24 / 11$ & 0 & 0.0 & I E & $\mathrm{L}$ & - & - & - & - & n.r. \\
\hline Bimini & East Wells & 95 & $2 / 5 / 11$ & 0 & 35.4 & IV V G & I & - & - & - & - & $\mathrm{f}$ \\
\hline Bimini & Ocean Cay & 96 & $2 / 4 / 11$ & 0 & 6.4 & I G & G & - & - & - & - & $\mathrm{f}$ \\
\hline Bimini & South Cat Cay & 94 & $2 / 4 / 11$ & 0 & 62.8 & II E G & $\mathrm{S}$ & - & - & - & - & $\mathrm{f}, \mathrm{p}$ \\
\hline Crooked & Beach E of Brown's Settlement & 186 & $2 / 4 / 11$ & 0 & 0.8 & I A & P G & - & - & - & - & n.r. \\
\hline Crooked & Beach N of Majors, E of Bullet Hill Settlement & 185 & $2 / 4 / 11$ & 0 & 2.0 & I II A & $\mathrm{G}$ & - & - & - & - & n.r. \\
\hline Crooked & Beach NW of Seaview Settlement & 183 & $2 / 5 / 11$ & 0 & 2.0 & I A & D I G & - & - & - & - & n.r. \\
\hline Crooked & Long Cay & 184 & $2 / 5 / 11$ & 0 & 14.0 & I IV A & H I A L & - & - & - & - & n.r. \\
\hline Eleuthera & Airport Beach / Govenors Harbor & 108 & $1 / 27 / 11$ & 0 & 3.2 & I A & H D & - & - & - & - & n.r. \\
\hline Eleuthera & Atlantic Beach N of Grinder's Pt. & 116 & $1 / 27 / 11$ & 0 & 0.4 & I E & none & - & - & - & - & n.r. \\
\hline Eleuthera & Bottom Harbour & 103 & $1 / 26 / 11$ & 0 & 1.6 & II E G & I L & - & - & - & - & n.r. \\
\hline Eleuthera & Club Med / French Leave Beach & 112 & $1 / 27 / 11$ & 3 & 1.6 & I A & H D & - & - & - & - & n.r. \\
\hline Eleuthera & Cocodimama Beach & 109 & $1 / 31 / 11$ & 0 & 0.8 & II G & D I G L & - & - & - & - & n.r. \\
\hline Eleuthera & Gaulding Cay Beach & 104 & $1 / 25 / 11$ & 0 & 0.8 & V E & G L & - & - & - & - & n.r. \\
\hline Eleuthera & Governor's Harbour & 111 & $1 / 27 / 11$ & 0 & 1.6 & V G & H D V S & - & - & - & - & n.r. \\
\hline Eleuthera & Hut Point Beach & 110 & $1 / 27 / 11$ & 0 & 0.8 & I A & H D & - & - & - & - & n.r. \\
\hline
\end{tabular}


The 2011 International Wilson's Plover Winter Census in The Bahamas

(Continued)

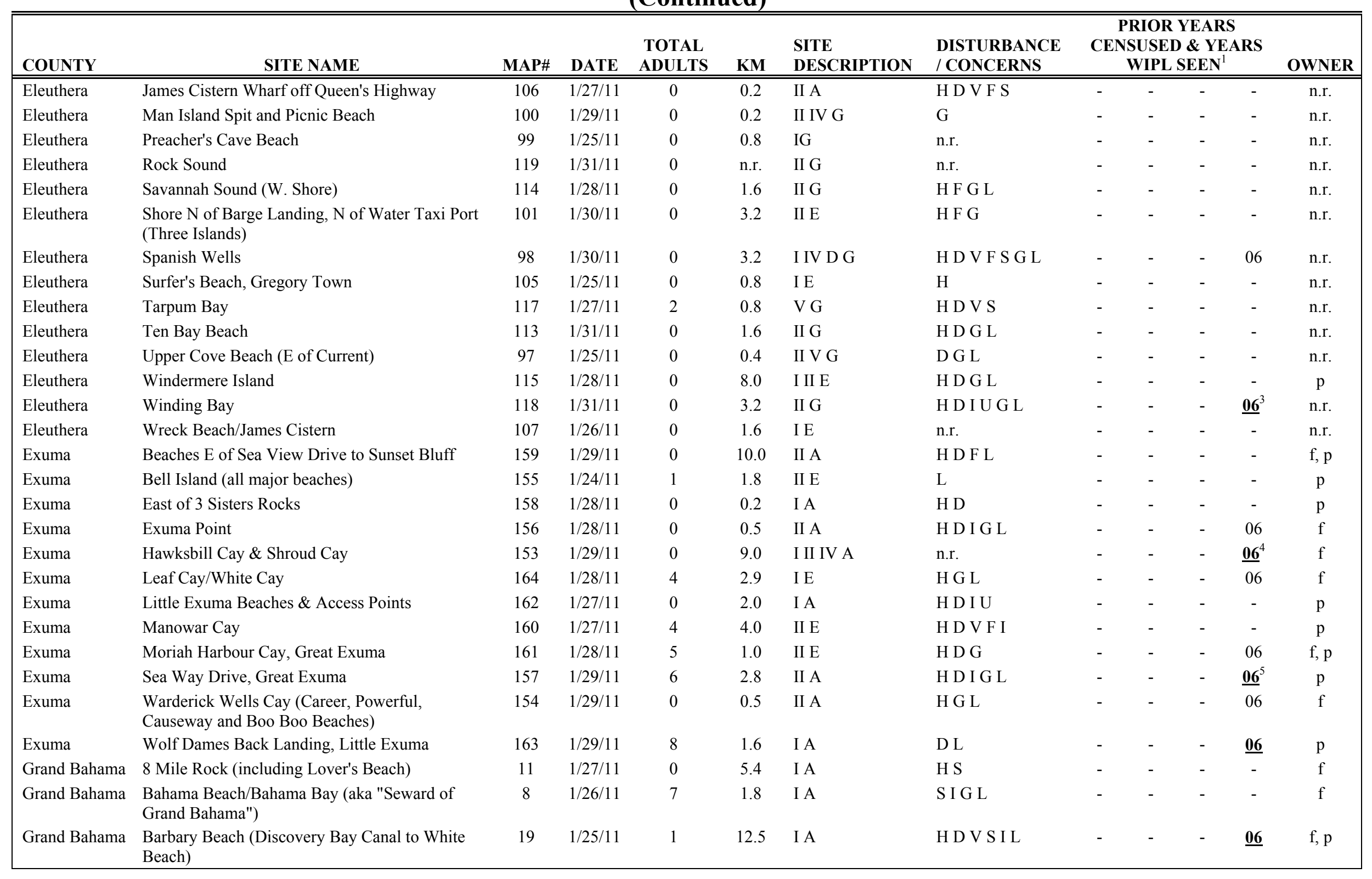




\section{The 2011 International Wilson's Plover Winter Census in The Bahamas}

(Continued)

\begin{tabular}{|c|c|c|c|c|c|c|c|c|c|c|c|c|}
\hline \multirow{2}{*}{$\begin{array}{l}\text { COUNTY } \\
\text { Grand Bahama }\end{array}$} & \multirow{2}{*}{$\begin{array}{l}\text { SITE NAME } \\
\text { Bootle Bay (Blue Marlin Cove) S and E of inlet } \\
\text { to Bahama Beach inlet }\end{array}$} & \multirow{2}{*}{ MAP\# } & \multirow{2}{*}{$\begin{array}{l}\text { DATE } \\
1 / 26 / 11\end{array}$} & \multirow{2}{*}{$\begin{array}{c}\text { TOTAL } \\
\text { ADULTS } \\
12\end{array}$} & \multirow{2}{*}{$\frac{\mathbf{K M}}{6.5}$} & \multirow{2}{*}{$\begin{array}{l}\text { SITE } \\
\text { DESCRIPTION }\end{array}$} & \multirow{2}{*}{$\begin{array}{l}\text { DISTURBANCE } \\
\text { / CONCERNS } \\
\text { S I }\end{array}$} & \multicolumn{4}{|c|}{$\begin{array}{c}\text { PRIOR YEARS } \\
\text { CENSUSED \& YEARS } \\
\text { WIPL SEEN }^{1} \\
\end{array}$} & \multirow{2}{*}{$\frac{\text { OWNER }}{\mathrm{f}}$} \\
\hline & & & & & & & & 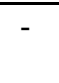 & - & 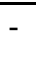 & - & \\
\hline Grand Bahama & $\begin{array}{l}\text { Discovery Beach (Freeport Bay Canal to } \\
\text { Discovery Bay Canal) }\end{array}$ & 18 & $1 / 24 / 11$ & 6 & 5.7 & I A & H D V S I U G & - & - & - & $\underline{06}$ & $\mathrm{f}$ \\
\hline Grand Bahama & $\begin{array}{l}\text { East End Cays (incldg Sweeting's, Lightbourne, } \\
\text { Redshank, Cross, and unnamed Cays/flats) }\end{array}$ & 6 & $1 / 30 / 11$ & 6 & 60.0 & I II IV V A E F & F I G & - & - & - & - & $f$ \\
\hline Grand Bahama & Gold Rock Creek to High Rock & 21 & $1 / 28 / 11$ & 9 & 5.4 & I A & H D S I G & - & - & - & - & f \\
\hline Grand Bahama & Great Sale Cay & 2 & $2 / 6 / 11$ & 6 & 7.5 & I E F & H D P I G & - & - & - & - & $f$ \\
\hline Grand Bahama & High Rock (Rocky Cliff to Oil Transfer Facility) & 22 & $1 / 28 / 11$ & 0 & 4.5 & I A & H D V S I G & - & - & - & $\underline{06}$ & f, p \\
\hline Grand Bahama & Holmes Rock (E to 8 Mile Rock) & 10 & $1 / 27 / 11$ & 1 & 3.4 & I A & H I L & - & - & - & - & f \\
\hline Grand Bahama & Island Seas - Silver Point Beach into Jetty & 15 & $1 / 27 / 11$ & 1 & 3.2 & I A & H D S I G & - & - & - & 06 & $f, p$ \\
\hline Grand Bahama & Lucaya Beach & 16 & $1 / 30 / 11$ & 0 & 2.4 & I A & n.r. & - & - & - & - & n.r. \\
\hline Grand Bahama & Mangrove Cay & 1 & $2 / 6 / 11$ & 0 & 1.5 & I E & G & - & - & - & - & $\mathrm{f}$ \\
\hline Grand Bahama & McLean's Town Cemetery & 27 & $1 / 29 / 11$ & 0 & 0.7 & I II A & H D I G & - & - & - & - & $f$ \\
\hline Grand Bahama & $\begin{array}{l}\text { Old Bahama Bay - Ginn Sur Mer (Canal E to } \\
\text { Bootle Bay/Blue Marlin Cove) }\end{array}$ & 5 & $1 / 26 / 11$ & 13 & 4.4 & I A & D S I G L & - & - & - & - & $f, p$ \\
\hline Grand Bahama & $\begin{array}{l}\text { Old Bahama Bay - Ginn Sur Mer (NW end, S to } \\
\text { canal) }\end{array}$ & 4 & $1 / 26 / 11$ & 8 & 2.0 & I A & D S P I U & - & - & - & - & f, p \\
\hline Grand Bahama & Pelican Point - E of Rocky Point & 25 & $1 / 29 / 11$ & 5 & 5.7 & I A & H D I U G & - & - & - & - & f \\
\hline Grand Bahama & Pelican Point - Rocky Point Flats & 24 & $1 / 29 / 11$ & 1 & 3.2 & I A & H D I G & - & - & - & $\underline{06}^{5}$ & f \\
\hline Grand Bahama & Pinder's Point to Hunter's & 12 & $1 / 27 / 11$ & 1 & 4.7 & I A & H D S P I G & - & - & - & - & f \\
\hline Grand Bahama & Rocky Creek and areas W of McLean's Town & 26 & $1 / 30 / 11$ & 0 & 11.6 & I V A & F I G L & - & - & - & - & $\mathrm{f}$ \\
\hline Grand Bahama & Running Mon & 14 & $1 / 27 / 11$ & 0 & 1.1 & I A & H S G & - & - & - & - & $f$ \\
\hline Grand Bahama & Seaward at Bahama Bay to Holmes Rock & 9 & $1 / 27 / 11$ & 0 & 5.8 & I A & H D S I U G L & - & - & - & - & f \\
\hline Grand Bahama & Taino Beach & 17 & $2 / 3 / 11$ & 0 & 1.6 & I A & n.r. & - & - & - & - & n.r. \\
\hline Grand Bahama & $\begin{array}{l}\text { West End, Old Bahama Bay (Small beach on } \\
\text { NW side) }\end{array}$ & 3 & $1 / 26 / 11$ & 0 & 0.8 & I A & H V S I U G & - & - & - & - & $\mathrm{p}$ \\
\hline Grand Bahama & West of Pelican Point Flats to Oil Terminal & 23 & $1 / 28 / 11$ & 5 & 7.0 & I A & H D S I G & - & - & - & $\underline{06}$ & f \\
\hline Grand Bahama & $\begin{array}{l}\text { White (aka "Nudie") Beach to Gold Rocks Inlet } \\
\text { (W side) }\end{array}$ & 20 & $1 / 28 / 11$ & 4 & 7.8 & I A & H S I G & - & - & - & $\underline{06}$ & f \\
\hline Grand Bahama & Xanadu Beach and Bahama Princess Beach & 13 & $1 / 27 / 11$ & 0 & 4.5 & I A & H S I U G & - & - & - & - & f \\
\hline Great Inagua & Blackwood Beach (SW side of Island) & 202 & $1 / 30 / 11$ & 0 & 2.5 & I A & none & - & - & - & - & n.r. \\
\hline Great Inagua & $\begin{array}{l}\text { Bluff Beach, East of Conch Shell Pt. (S. side of } \\
\text { island to limestone outcrop on beach) }\end{array}$ & 203 & $1 / 30 / 11$ & 0 & 1.2 & I A & H D L & - & - & - & - & n.r. \\
\hline Great Inagua & Craig's Bight East & 201 & $1 / 29 / 11$ & 0 & 3.6 & I E & G L & - & - & - & 06 & n.r. \\
\hline
\end{tabular}


The 2011 International Wilson's Plover Winter Census in The Bahamas

(Continued)

\begin{tabular}{|c|c|c|c|c|c|c|c|c|c|c|c|c|}
\hline \multirow{2}{*}{$\begin{array}{l}\text { COUNTY } \\
\text { Great Inagua }\end{array}$} & \multirow{2}{*}{$\begin{array}{r}\text { SITE NAME } \\
\text { Craig's Bight West to Crossing }\end{array}$} & \multirow{2}{*}{$\frac{\text { MAP\# }}{200}$} & \multirow{2}{*}{$\frac{\text { DATE }}{1 / 29 / 11}$} & \multirow{2}{*}{$\begin{array}{c}\text { TOTAL } \\
\text { ADULTS } \\
2\end{array}$} & \multirow{2}{*}{$\frac{\mathbf{K M}}{2.5}$} & \multirow{2}{*}{$\begin{array}{l}\text { SITE } \\
\text { DESCRIPTION } \\
\text { I E }\end{array}$} & \multirow{2}{*}{$\begin{array}{l}\text { DISTURBANCE } \\
\text { / CONCERNS } \\
\text { D P G }\end{array}$} & \multicolumn{4}{|c|}{$\begin{array}{c}\text { PRIOR YEARS } \\
\text { CENSUSED \& YEARS } \\
\text { WIPL SEEN }^{1} \\
\end{array}$} & \multirow{2}{*}{$\frac{\text { OWNER }}{\text { OW.r. }}$} \\
\hline & & & & & & & & 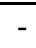 & 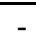 & 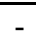 & $\underline{06}^{6}$ & \\
\hline Great Inagua & Man of War Bay & 196 & $1 / 29 / 11$ & 0 & 1.0 & I A & none & - & - & - & 06 & n.r. \\
\hline Great Inagua & Maroon Hill Pond & 198 & $1 / 31 / 11$ & 0 & 1.2 & V A & $\mathrm{S} \mathrm{G}$ & - & - & - & - & $\mathrm{p}$ \\
\hline Great Inagua & Red Pond West & 194 & $1 / 29 / 11$ & 0 & 0.5 & I IV E & G L & - & - & - & 06 & n.r. \\
\hline Great Inagua & The Tunnel Beach & 197 & $1 / 29 / 11$ & 0 & 0.8 & I IV E & none & - & - & - & 06 & n.r. \\
\hline Great Inagua & Vandaxville Beach to Lighthouse & 199 & $1 / 28 / 11$ & 1 & 4.5 & I E & H D V P U & - & - & - & 06 & n.r. \\
\hline Great Inagua & Well Road Beach & 195 & $1 / 29 / 11$ & 0 & 1.2 & I E & none & - & - & - & 06 & n.r. \\
\hline Harbour & Pink Sand Beach (E) and Harbor Side (W) & 102 & $1 / 29 / 11$ & 0 & 4.0 & I II G & H D S G L & - & - & - & - & n.r. \\
\hline Long Island & Atlantic Coast from Pinders to Salt Pond & 175 & $1 / 31 / 11$ & 1 & 6.5 & I E & $\mathrm{H} \mathrm{I}$ & - & - & - & $\underline{06}^{7}$ & n.r. \\
\hline Long Island & Cape Santa Maria Dev., Hoosie Harbor & 172 & $1 / 28 / 11$ & 0 & 0.5 & II E & H S G & - & - & - & $\underline{06}$ & n.r. \\
\hline Long Island & Conch Cay (off Long Island) & 178 & $1 / 30 / 11$ & 0 & 1.8 & I D E & G L & - & - & - & 06 & n.r. \\
\hline Long Island & Cove near C.C. Monument, Newton Cay & 171 & $1 / 28 / 11$ & 5 & 0.7 & II E & H G & - & - & - & $\underline{06}$ & n.r. \\
\hline Long Island & Diamond Salt Works & 181 & $1 / 29 / 11$ & 0 & 0.2 & V G & $\mathrm{S} \mathrm{G}$ & - & - & - & - & n.r. \\
\hline Long Island & Dollar Cay Tidal Flats & 179 & $1 / 30 / 11$ & 0 & 0.9 & I D & $\mathrm{G}$ & - & - & - & 06 & n.r. \\
\hline Long Island & Duncansons Point & 177 & $1 / 30 / 11$ & 0 & 2.0 & I E & H V G & - & - & - & 06 & n.r. \\
\hline Long Island & Gordon's & 182 & $1 / 29 / 11$ & 0 & 1.9 & I E & I & - & - & - & 06 & n.r. \\
\hline Long Island & Joe Sound Harbor & 174 & $1 / 28 / 11$ & 0 & 0.2 & II E & G L & - & - & - & $\underline{06}$ & n.r. \\
\hline Long Island & Newton Cay, W Side & 173 & $1 / 28 / 11$ & 0 & 0.6 & II E & None & - & - & - & 06 & n.r. \\
\hline Long Island & Red Pond & 176 & $1 / 31 / 11$ & 0 & 1.1 & V G & $\mathrm{H} \mathrm{G}$ & - & - & - & 06 & n.r. \\
\hline Long Island & Sandy Cay North \& Tidal Flats & 180 & $1 / 30 / 11$ & 0 & 0.9 & I D E & $\mathrm{G}$ & - & - & - & 06 & n.r. \\
\hline $\begin{array}{l}\text { New } \\
\text { Providence }\end{array}$ & South Beach & 120 & $2 / 5 / 11$ & 0 & 3.2 & II A & H I L & - & - & - & 06 & n.r. \\
\hline North Andros & Bigwood Cay & 134 & $1 / 28 / 11$ & 13 & 14.0 & I II E & H F I G L & - & - & - & - & n.r. \\
\hline North Andros & Joulter's Cays (North) & 121 & $1 / 29 / 11$ & 33 & 5.6 & I E F G & G L & - & - & - & - & $\mathrm{f}$ \\
\hline North Andros & Joulter's Cays (South) & 122 & $1 / 29 / 11$ & 21 & n.r. & I E & H F I G L & - & - & - & $\underline{06}$ & $\mathrm{f}$ \\
\hline North Andros & Kamalame Cay - Blanket Sound & 127 & $2 / 1 / 11$ & 6 & 3.7 & I II B & H D G L & - & - & - & 06 & $\mathrm{f}$ \\
\hline North Andros & Lowe's Sound Mangrove Flats & 123 & $1 / 31 / 11$ & 40 & 10.9 & I A E G & H D F S I G L & - & - & - & 06 & $\mathrm{f}, \mathrm{m}, \mathrm{p}$ \\
\hline North Andros & Mastic Bay and Rat Cay & 125 & $1 / 31 / 11$ & 1 & 7.5 & I II D E & I G L & - & - & - & - & $\mathrm{f}$ \\
\hline North Andros & N ForFar to Saddleback Cay & 126 & $1 / 27 / 11$ & 0 & 4.2 & I A E & I G & - & - & - & - & n.r. \\
\hline North Andros & Plum Cay & 131 & $1 / 30 / 11$ & 21 & 2.4 & I II E & G L & - & - & - & - & $\mathrm{f}$ \\
\hline North Andros & Red Bays & 124 & $1 / 31 / 11$ & 13 & 11.6 & I II A & G L & - & - & - & - & n.r. \\
\hline North Andros & Small Hope Bay & 130 & $1 / 30 / 11$ & 2 & 0.6 & I A & H D S I G L & - & - & - & - & n.r. \\
\hline North Andros & South of Cargill Creek & 133 & $1 / 28 / 11$ & 4 & 0.3 & I A & H D F G L & - & - & - & - & $\mathrm{f}$ \\
\hline
\end{tabular}


The 2011 International Wilson's Plover Winter Census in The Bahamas

(Continued)

\begin{tabular}{|c|c|c|c|c|c|c|c|c|c|c|c|c|}
\hline \multirow{2}{*}{$\begin{array}{l}\text { COUNTY } \\
\text { North Andros }\end{array}$} & \multirow{2}{*}{$\begin{array}{r}\text { SITE NAME } \\
\text { Southwest of Mastic Cay }\end{array}$} & \multirow{2}{*}{ MAP\# } & \multirow{2}{*}{$\frac{\text { DATE }}{1 / 30 / 11}$} & \multirow{2}{*}{$\begin{array}{c}\text { TOTAL } \\
\text { ADULTS } \\
26\end{array}$} & \multirow{2}{*}{ 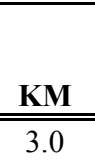 } & \multirow{2}{*}{$\begin{array}{l}\text { SITE } \\
\text { DESCRIPTION } \\
\text { I II D E }\end{array}$} & \multirow{2}{*}{$\begin{array}{l}\text { DISTURBANCE } \\
\text { / CONCERNS } \\
\mathrm{G} \mathrm{L}\end{array}$} & \multicolumn{4}{|c|}{$\begin{array}{c}\text { PRIOR YEARS } \\
\text { CENSUSED \& YEARS }^{\text {WIPL SEEN }}{ }^{1} \\
\end{array}$} & \multirow{2}{*}{$\begin{array}{c}\text { OWNER } \\
\text { n.r. }\end{array}$} \\
\hline & & & & & & & & 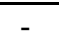 & 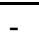 & 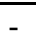 & 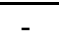 & \\
\hline North Andros & Staniard Creek & 129 & $1 / 27 / 11$ & 0 & 4.1 & I A & H D I U G & - & - & - & 06 & $f$ \\
\hline North Andros & Staniard Creek Flats & 128 & $1 / 30 / 11$ & 0 & 0.3 & II A & D G & - & - & - & - & n.r. \\
\hline San Salvadore & Bonefish Bay (Club Med Beach) & 166 & $2 / 1 / 11$ & 0 & 1.6 & I A & H D V S U & - & - & - & - & n.r. \\
\hline San Salvadore & Dim Bay and Greens Bay to Crab Cay & 168 & $1 / 31 / 11$ & 1 & 2.7 & I A & G & - & - & - & - & n.r. \\
\hline San Salvadore & East Beach & 167 & $2 / 2 / 11$ & 3 & 3.5 & I A & D G & - & - & - & - & n.r. \\
\hline San Salvadore & Holiday Track Settlement (The Thumb) & 169 & $2 / 1 / 11$ & 2 & 3.0 & I A & G L & - & - & - & - & n.r. \\
\hline San Salvadore & Rice Bay & 165 & $2 / 2 / 11$ & 0 & 0.5 & I A & H V U L & - & - & - & - & n.r. \\
\hline San Salvadore & Sandy Point & 170 & $2 / 1 / 11$ & 0 & 0.1 & I A & $\mathrm{H}$ & - & - & - & - & n.r. \\
\hline South Andros & Congo Town & 137 & $2 / 3 / 11$ & 2 & 0.1 & I E & I U G & - & - & - & 06 & n.r. \\
\hline South Andros & Deep Creek to Little Creek & 144 & $2 / 3 / 11$ & 0 & 2.8 & I E & G L & - & - & - & - & n.r. \\
\hline South Andros & Driggs Hill (at cemetery) & 135 & $2 / 3 / 11$ & 0 & 0.1 & I E & I L & - & - & - & - & n.r. \\
\hline South Andros & $\begin{array}{l}\text { Driggs Hill (Lighthouse Pt to Long Bay } \\
\text { Settlement) }\end{array}$ & 136 & $2 / 3 / 11$ & 2 & 0.1 & I E & $\mathrm{H}$ & - & - & - & - & n.r. \\
\hline South Andros & Kemps Bay & 142 & $2 / 3 / 11$ & 0 & 4.6 & I E & D V S I U & - & - & - & 06 & n.r. \\
\hline South Andros & Kemp's Bay Complex to Smith's Hill Settlement & 140 & $2 / 1 / 11$ & 0 & 3.7 & I E & G & - & - & - & - & n.r. \\
\hline South Andros & Mars Bay Settlement (North of Wharf) & 147 & $2 / 1 / 11$ & 0 & 0.4 & II E & H F I U G L & - & - & - & 06 & n.r. \\
\hline South Andros & North of Hawks Nest (Hawksbill Creek) & 149 & $2 / 2 / 11$ & 0 & 0.6 & I E & I L & - & - & - & - & n.r. \\
\hline South Andros & Northern Deep Creek Settlement at Cemetery & 143 & $2 / 3 / 11$ & 0 & 0.1 & I E & G L & - & - & - & - & n.r. \\
\hline South Andros & $\begin{array}{l}\text { Old Pier S of Congo Town to the Bluff } \\
\text { Settlement (Mt. Sinai Baptist Church) }\end{array}$ & 138 & $2 / 3 / 11$ & 0 & 2.7 & I E & H D U G & - & - & - & - & n.r. \\
\hline South Andros & Sand Bar (2 miles NE of Top Cay) & 151 & $2 / 2 / 11$ & 0 & 0.6 & I D & G L & - & - & - & - & n.r. \\
\hline South Andros & Sand Bar $\sim 3 \mathrm{~km}$ E of Little Creek & 146 & $2 / 4 / 11$ & 6 & 0.4 & I D & G & - & - & - & - & n.r. \\
\hline South Andros & South of Hawks Nest to Snap Pt. & 150 & $2 / 2 / 11$ & 5 & 2.6 & I E & none & - & - & - & - & n.r. \\
\hline South Andros & $\begin{array}{l}\text { South of Mars Bay: Flats at S end of white } \\
\text { gravel road }\end{array}$ & 148 & $2 / 2 / 11$ & 0 & 3.0 & I E & H F G L & - & - & - & 06 & n.r. \\
\hline South Andros & $\begin{array}{l}\text { South Smith's Hill Settlement to North Kemp's } \\
\text { Bay Settlement }\end{array}$ & 141 & $2 / 1 / 11$ & 0 & 1.0 & I E & D G & - & - & - & - & n.r. \\
\hline South Andros & The Bluff Settlement & 139 & $2 / 1 / 11$ & 4 & 1.3 & I E & I G & - & - & - & - & n.r. \\
\hline South Andros & Tidal Flat Slightly N of Pleasant Bay & 145 & $2 / 3 / 11$ & 0 & 0.5 & I E & G L & - & - & - & - & n.r. \\
\hline South Andros & Water Cays $^{8}$ & 152 & $2 / 6 / 11$ & 0 & 0.4 & II D & H F G L & - & - & - & - & n.r. \\
\hline Total & & & & 446 & 678.4 & & & & & & & \\
\hline
\end{tabular}


${ }^{1}$ If previously surveyed, years surveyed are noted. Bold underlined years indicate that Wilson's Plovers were seen at the site during that Census year.

${ }^{2}$ Exact locations of WIPLs were not specified in 2006 and may have occurred along any point $\sim 1.2 \mathrm{~km}$ north of the 2011 Green Turtle Cay census route (2006 route covered more area).

${ }^{3}$ Exact locations of WIPLs were not specified in 2006 and may have occurred along any point $\sim 3 \mathrm{~km}$ north of the 2011 Winding Bay census route (2006 route covered more area).

${ }^{4}$ Hawksbill Cay was surveyed in 2006, but the exact route covered was not specified nor were the exact locations of the WIPLs.

${ }^{5}$ The 2006 Sea Way Drive route was much smaller than the 2011 route. The 2011 route fully encompassed the 2006 route. Exact locations of WIPLs seen in 2011 were not specified and may have occurred outside the range of the 2006 survey route, but WIPLs seen in 2006 were definitiely within the 2011 route.

${ }^{6}$ Exact location of the WIPL in 2011 was not specified, but the WIPL seen in 2006 occurred within the range of the 2011 census route, even though it was spotted under the site name "Vandaxville Beach".

7 Exact location of the WIPL in 2011 was not specified, but the WIPL seen in 2006 occurred within the range of the 2011 census route.

${ }^{8}$ Please note that this survey was conducted outside the Census window. 


\section{The 2011 International Piping Plover Winter Census in the Cuba}

Pedro Blanco Rodriguez

Instituto de Ecologia y Sistematica

Carretera de Varona km 3 1⁄2, Capdevila, Boyeros

A.P. 8029 P.O. Box 10800

La Havana, Cuba

The 2011 International Winter Census in Cuba was conducted from January 25 to February 8 . A total of $45.4 \mathrm{~km}$ of beach and lagoon habitat was covered at ten sites in seven provinces of the country.

Given limited resources, surveys were less extensive than in prior census years, and we surveyed fewer sites and less shoreline in 2011 relative to other recent Census years (ten sites and $45.4 \mathrm{~km}$ in 2011 compared to 22 and $123.6 \mathrm{~km}$ in 2006). However, we were able to survey some important Piping Plover winter sites in Cuba, located in Peninsula de Hicacos in Matanzas province and Coco-Paredón keys in the SabanaCamaguey Archipelago where 15 individuals of this species were counted.

In 2011, a total of 19 Piping Plover were counted in Cuba, down from the 89 birds observed in 2006, 55 in 2001, and 64 in 1996. As mentioned above, the decline in numbers of birds seen is likely due to reduced habitat coverage during the 2011 Census and does not likely reflect a decline in Piping Plovers wintering in Cuba. There has however been a shift in habitat use, with Piping Plovers dispersing from the larger keys which are more developed and experience higher levels of tourism, to smaller less developed keys nearby. Habitat changes associated with continued tourism development and climate change may further affect Piping Plover distribution and threaten their future use of Cuba as a winter area.
Although Piping Plover numbers were low relative to other Census years, Snowy and Wilson's Plovers were higher than any prior Census year. Prior studies suggested that the coastal sector of northeast Cuba between the Ciego de Avila and Holguin provinces are the most important region for these species. Hence we surveyed three new sites, two in Holguin province and one in Las Tunas. In total during the 2011 Census we saw 54 Snowy Plovers and 159 Wilson's Plovers.

Comparison of Census Numbers

\begin{tabular}{|l|c|c|c|c|c|}
\hline Species & 1991 & 1996 & 2001 & 2006 & 2011 \\
\hline $\begin{array}{l}\text { Piping } \\
\text { Plover }\end{array}$ & 11 & 64 & 55 & 89 & 19 \\
\hline $\begin{array}{l}\text { Snowy } \\
\text { Plover }\end{array}$ & n.r. & n.r. & 16 & 0 & 54 \\
\hline $\begin{array}{l}\text { Wilson's } \\
\text { Plover }\end{array}$ & n.r. & n.r. & n.r. & 57 & 159 \\
\hline
\end{tabular}




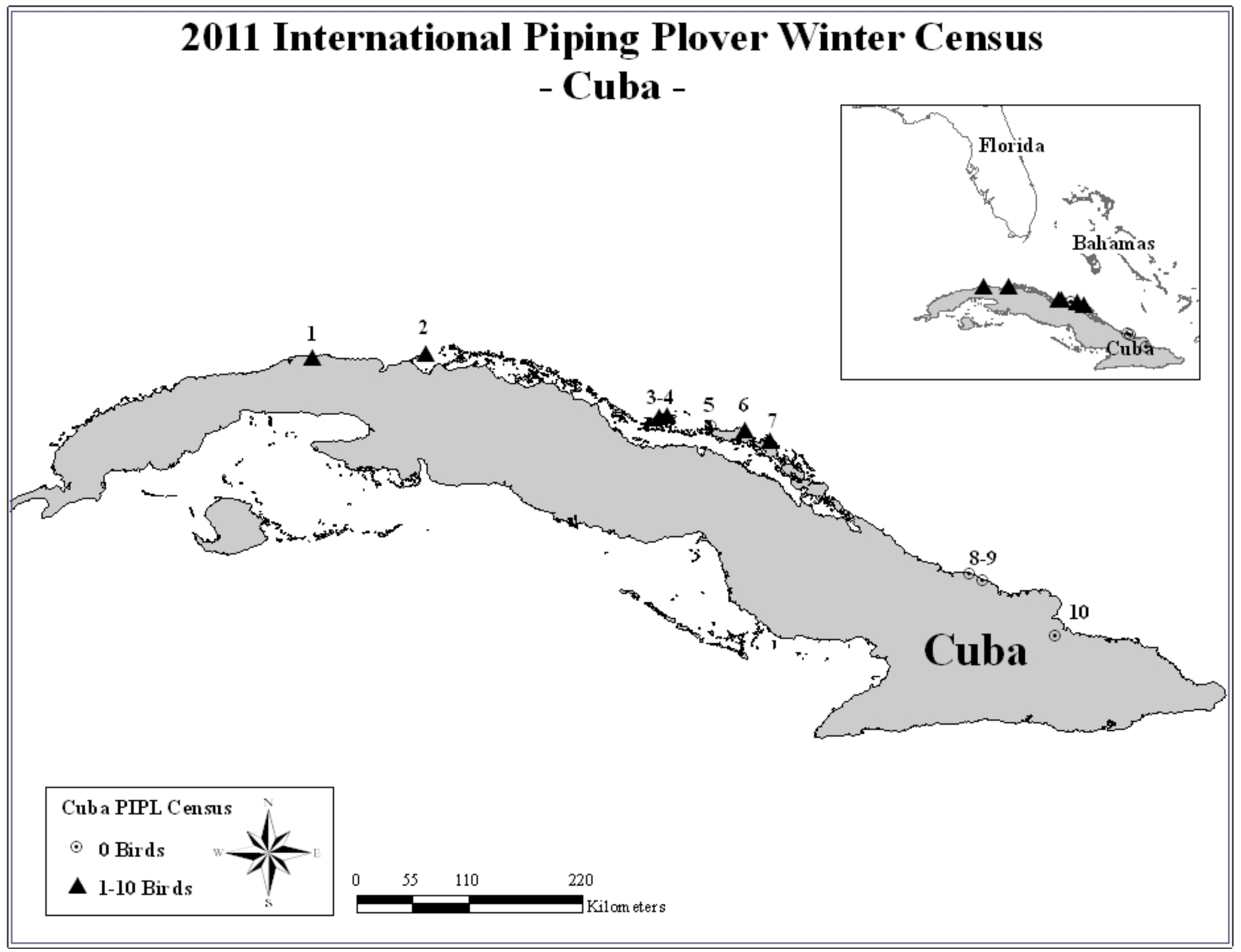


The 2011 International Piping Plover Winter Census in Cuba

\begin{tabular}{|c|c|c|c|c|c|c|c|c|c|c|c|c|}
\hline \multirow{2}{*}{$\begin{array}{l}\text { PROVINCE } \\
\text { Camagüey }\end{array}$} & \multirow{2}{*}{ 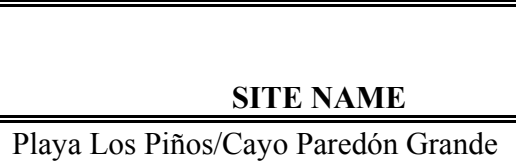 } & \multirow{2}{*}{ MAP\# } & \multirow{2}{*}{$\begin{array}{c}\text { DATE } \\
1 / 30 / 11\end{array}$} & \multirow{2}{*}{$\begin{array}{c}\text { TOTAL } \\
\text { ADULTS } \\
5\end{array}$} & \multirow{2}{*}{$\frac{\mathbf{K M}}{4.0}$} & \multirow{2}{*}{$\begin{array}{l}\text { SITE } \\
\text { DESCRIPTION } \\
\text { IV A }\end{array}$} & \multirow{2}{*}{$\begin{array}{l}\text { DISTURBANCE } \\
\text { CONCERNS } \\
\text { H D V F U G L }\end{array}$} & \multicolumn{4}{|c|}{$\begin{array}{c}\text { PRIOR YEARS } \\
\text { CENSUSED \& YEARS } \\
\text { PIPL SEEN }^{1} \\
\end{array}$} & \multirow{2}{*}{$\begin{array}{c}\text { OWNER } \\
\mathrm{s}(\mathrm{p})\end{array}$} \\
\hline & & & & & & & & $\underline{91}$ & $\underline{96}$ & $\underline{01}$ & 06 & \\
\hline Ciego de Ávila & Playa Las Coloradas/Cayo Coco & 6 & $1 / 30 / 11$ & 6 & 3.0 & IV A & H D V F U G L & - & $\underline{96}$ & $\underline{01}$ & $\underline{06}$ & $\mathrm{~s}(\mathrm{p})$ \\
\hline Ciego de Ávila & Playa Pilar/Cayo Guillermo & 5 & $2 / 5 / 11$ & 0 & 1.9 & IV A & H V U G & - & - & 01 & $\underline{06}$ & $\mathrm{~s}(\mathrm{p})$ \\
\hline $\begin{array}{l}\text { Ciudad de } \\
\text { Habana }\end{array}$ & Habana del Este (Playa Guanabo) & 1 & $1 / 25 / 11$ & 1 & 10.0 & I A & H V F U G L & - & 96 & 01 & $\overline{06}$ & $\mathrm{~s}(\mathrm{p})$ \\
\hline Holguín & Lagunas Costeras del Delta del Mayari & 10 & $1 / 24 / 11$ & 0 & 3.0 & II A & H V F G L & - & - & - & - & $\mathrm{s}(\mathrm{p})$ \\
\hline Holguín & Lagunas de Juan Antonio & 9 & $1 / 24 / 11$ & 0 & 3.2 & II A & H V F G L & - & - & - & - & $\mathrm{s}(\mathrm{p})$ \\
\hline Las Tunas & Playas Las Azules & 8 & $1 / 24 / 11$ & 0 & 3.0 & I A & H V F G L & - & - & - & - & $\mathrm{s}(\mathrm{p})$ \\
\hline Matanzas & Península de Hicacos & 2 & $2 / 2 / 11$ & 4 & 4.0 & I A & H V B U G L & - & 96 & $\underline{01}$ & 06 & $\mathrm{~s}(\mathrm{p})$ \\
\hline Villa Clara & Playa Ensenachos \#1/Cayo Ensenachos & 3 & $1 / 28 / 11$ & 1 & 2.3 & I A & H V U G L & - & - & 01 & 06 & $\mathrm{~s}(\mathrm{p})$ \\
\hline Villa Clara & Playa Estrella/Cayo Santa Maria & 4 & $1 / 29 / 11$ & 2 & 11.0 & IV A & H V U G L & - & $\underline{96}$ & $\underline{01}$ & 06 & $\mathrm{~s}(\mathrm{p})$ \\
\hline Total & & & & 19 & 45.4 & & & & & & & \\
\hline
\end{tabular}

If previously surveyed, years surveyed are noted. Bold underlined years indicate that Piping Plovers were seen at the site during that Census year. 





The 2011 International Snowy Plover Winter Census in Cuba

\begin{tabular}{|c|c|c|c|c|c|c|c|c|c|c|c|c|}
\hline \multirow{2}{*}{$\begin{array}{l}\text { PROVINCE } \\
\text { Camagüey }\end{array}$} & \multirow{2}{*}{ 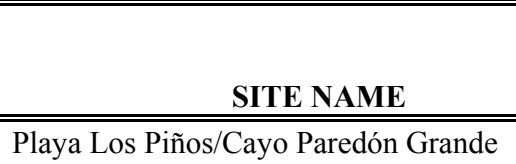 } & \multirow{2}{*}{ MAP\# } & \multirow{2}{*}{$\frac{\text { DATE }}{1 / 30 / 11}$} & \multirow{2}{*}{$\begin{array}{c}\text { TOTAL } \\
\text { ADULTS } \\
0\end{array}$} & \multirow{2}{*}{$\frac{\mathbf{K M}}{4.0}$} & \multirow{2}{*}{$\begin{array}{l}\text { SITE } \\
\text { DESCRIPTION } \\
\text { IV A }\end{array}$} & \multirow{2}{*}{$\begin{array}{l}\text { DISTURBANCE } \\
\text { CONCERNS } \\
\text { H D V F U G L }\end{array}$} & \multicolumn{4}{|c|}{$\begin{array}{c}\text { PRIOR YEARS } \\
\text { CENSUSED \& YEARS } \\
\text { SNPL SEEN }^{1} \\
\end{array}$} & \multirow{2}{*}{$\frac{\text { OWNER }}{\mathrm{s}(\mathrm{p})}$} \\
\hline & & & & & & & & 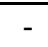 & - & 01 & 06 & \\
\hline Ciego de Ávila & Playa Las Coloradas/Cayo Coco & 6 & $1 / 30 / 11$ & 1 & 3.0 & IV A & H D V F U G L & - & - & 01 & 06 & $\mathrm{~s}(\mathrm{p})$ \\
\hline Ciego de Ávila & Playa Pilar/Cayo Guillermo & 5 & $2 / 5 / 11$ & 1 & 1.9 & IV A & H V U G & - & - & 01 & 06 & $\mathrm{~s}(\mathrm{p})$ \\
\hline $\begin{array}{l}\text { Ciudad de } \\
\text { Habana }\end{array}$ & Habana del Este (Playa Guanabo) & 1 & $1 / 25 / 11$ & 1 & 10.0 & I A & H V F U G L & - & - & 01 & 06 & $\mathrm{~s}(\mathrm{p})$ \\
\hline Holguín & Lagunas Costeras del Delta del Mayari & 10 & $1 / 24 / 11$ & 7 & 3.0 & II A & H V F G L & - & - & - & - & $\mathrm{s}(\mathrm{p})$ \\
\hline Holguín & Lagunas de Juan Antonio & 9 & $1 / 24 / 11$ & 10 & 3.2 & II A & H V F G L & - & - & - & - & $\mathrm{s}(\mathrm{p})$ \\
\hline Las Tunas & Playas Las Azules & 8 & $1 / 24 / 11$ & 34 & 3.0 & I A & H V F G L & - & - & - & - & $\mathrm{s}(\mathrm{p})$ \\
\hline Matanzas & Península de Hicacos & 2 & $2 / 2 / 11$ & 0 & 4.0 & I A & H V B U G L & - & - & $\underline{01}$ & 06 & $\mathrm{~s}(\mathrm{p})$ \\
\hline Villa Clara & Playa Ensenachos \#1/Cayo Ensenachos & 3 & $1 / 28 / 11$ & 0 & 2.3 & I A & H V U G L & - & - & 01 & 06 & $\mathrm{~s}(\mathrm{p})$ \\
\hline Villa Clara & Playa Estrella/Cayo Santa Maria & 4 & $1 / 29 / 11$ & 0 & 11.0 & IV A & H V U G L & - & - & 01 & 06 & $\mathrm{~s}(\mathrm{p})$ \\
\hline Total & & & & 54 & 45.4 & & & & & & & \\
\hline
\end{tabular}

If previously surveyed, years surveyed are noted. Bold underlined years indicate that Snowy Plovers were seen at the site during that Census year. 


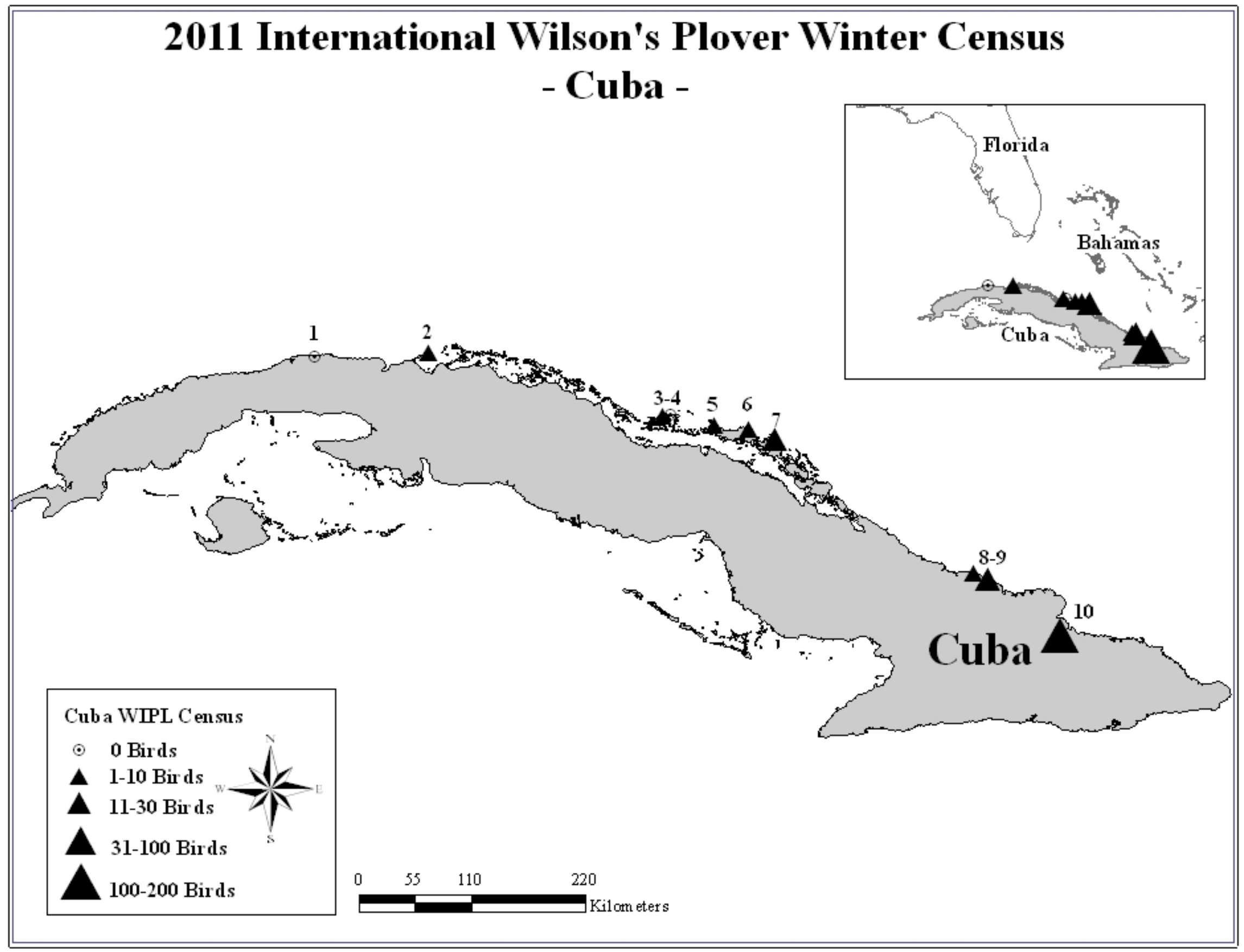


The 2011 International Wilson's Plover Winter Census in Cuba

\begin{tabular}{|c|c|c|c|c|c|c|c|c|c|c|c|c|}
\hline \multirow{2}{*}{$\begin{array}{l}\text { PROVINCE } \\
\text { Camagüey }\end{array}$} & \multirow{2}{*}{ 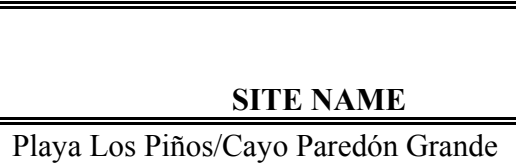 } & \multirow{2}{*}{ MAP\# } & \multirow{2}{*}{$\begin{array}{c}\text { DATE } \\
1 / 30 / 11\end{array}$} & \multirow{2}{*}{$\begin{array}{c}\text { TOTAL } \\
\text { ADULTS } \\
12\end{array}$} & \multirow{2}{*}{$\frac{\mathbf{K M}}{4.0}$} & \multirow{2}{*}{$\begin{array}{l}\text { SITE } \\
\text { DESCRIPTION } \\
\text { IV A }\end{array}$} & \multirow{2}{*}{$\begin{array}{l}\text { DISTURBANCE } \\
\text { CONCERNS } \\
\text { H D V F U G L }\end{array}$} & \multicolumn{4}{|c|}{$\begin{array}{c}\text { PRIOR YEARS } \\
\text { CENSUSED \& YEARS } \\
\text { WIPL SEEN }^{1} \\
\end{array}$} & \multirow{2}{*}{$\begin{array}{c}\text { OWNER } \\
\mathrm{s}(\mathrm{p})\end{array}$} \\
\hline & & & & & & & & - & - & - & 06 & \\
\hline Ciego de Ávila & Playa Las Coloradas/Cayo Coco & 6 & $1 / 30 / 11$ & 1 & 3.0 & IV A & H D V F U G L & - & - & - & $\underline{06}$ & $\mathrm{~s}(\mathrm{p})$ \\
\hline Ciego de Ávila & Playa Pilar/Cayo Guillermo & 5 & $2 / 5 / 11$ & 5 & 1.9 & IV A & H V U G & - & - & - & 06 & $\mathrm{~s}(\mathrm{p})$ \\
\hline $\begin{array}{l}\text { Ciudad de } \\
\text { Habana }\end{array}$ & Habana del Este (Playa Guanabo) & 1 & $1 / 25 / 11$ & 0 & 10.0 & I A & H V F U G L & - & - & - & 06 & $\mathrm{~s}(\mathrm{p})$ \\
\hline Holguín & Lagunas Costeras del Delta del Mayari & 10 & $1 / 24 / 11$ & 110 & 3.0 & II A & H V F G L & - & - & - & - & $\mathrm{s}(\mathrm{p})$ \\
\hline Holguín & Lagunas de Juan Antonio & 9 & $1 / 24 / 11$ & 23 & 3.2 & II A & H V F G L & - & - & - & - & $\mathrm{s}(\mathrm{p})$ \\
\hline Las Tunas & Playas Las Azules & 8 & $1 / 24 / 11$ & 3 & 3.0 & I A & H V F G L & - & - & - & - & $\mathrm{s}(\mathrm{p})$ \\
\hline Matanzas & Península de Hicacos & 2 & $2 / 2 / 11$ & 2 & 4.0 & I A & H V B U G L & - & - & - & 06 & $\mathrm{~s}(\mathrm{p})$ \\
\hline Villa Clara & Playa Ensenachos \#1/Cayo Ensenachos & 3 & $1 / 28 / 11$ & 3 & 2.3 & I A & H V U G L & - & - & - & 06 & $\mathrm{~s}(\mathrm{p})$ \\
\hline Villa Clara & Playa Estrella/Cayo Santa Maria & 4 & $1 / 29 / 11$ & 0 & 11.0 & IV A & H V U G L & - & - & - & 06 & $\mathrm{~s}(\mathrm{p})$ \\
\hline Total & & & & 159 & 45.4 & & & & & & & \\
\hline
\end{tabular}

If previously surveyed, years surveyed are noted. Bold underlined years indicate that Wilson's Plovers were seen at the site during that Census year. 


\section{The 2011 International Piping Plover Winter Census in Puerto Rico}

No coordinated survey effort was conducted on Puerto Rico in 2011. However, we did contact Alcides Morales Pérez, president of the Sociedad Ornitológica Puertorriqueña (SOPI). SOPI was unable to conduct any formal surveys and did not provide any sightings but we did retreive plover sightings from SOPI on ebird (http://ebird.org).

Comparison of Census Numbers

\begin{tabular}{|l|c|c|c|c|c|}
\hline Species & 1991 & 1996 & 2001 & 2006 & 2011 \\
\hline $\begin{array}{l}\text { Piping } \\
\text { Plover }\end{array}$ & 0 & 0 & 6 & 2 & 2 \\
\hline $\begin{array}{l}\text { Snowy } \\
\text { Plover }\end{array}$ & n.r. & n.r. & 17 & 1 & 3 \\
\hline $\begin{array}{l}\text { Wilson's } \\
\text { Plover }\end{array}$ & n.r. & n.r. & n.r. & 63 & 16 \\
\hline
\end{tabular}

Summarized by E. Elliott-Smith 


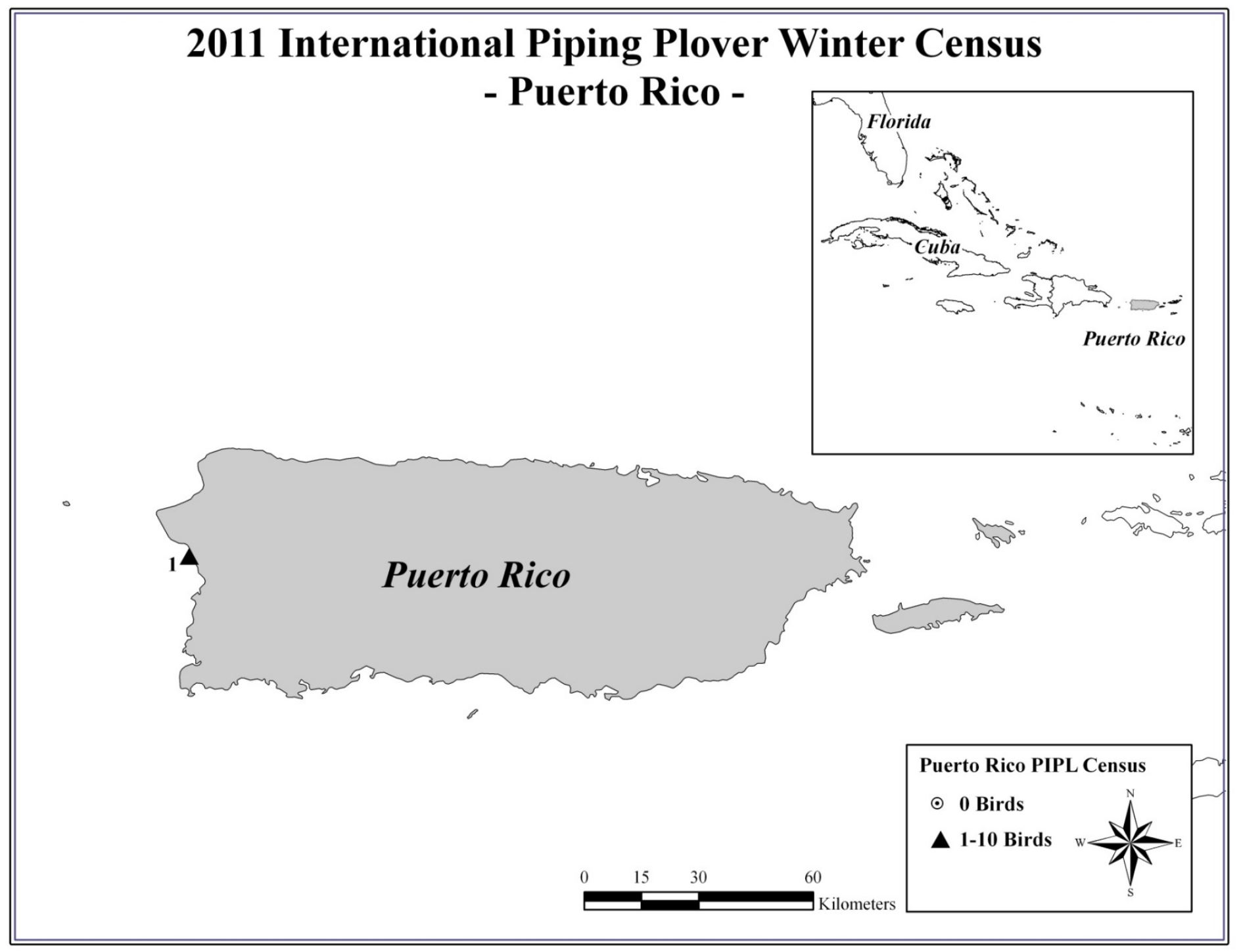


The 2011 International Piping Plover Winter Census in Puerto Rico

\begin{tabular}{|c|c|c|c|c|c|c|c|c|c|c|c|c|}
\hline \multirow{2}{*}{$\begin{array}{l}\text { MUNICIPALITY } \\
\text { Anasco }\end{array}$} & \multirow{2}{*}{$\frac{\text { SITE NAME }}{\text { Beach by mouth of Anasco River }^{2}}$} & \multirow{2}{*}{ MAP\# } & \multirow{2}{*}{$\begin{array}{c}\text { DATE } \\
1 / 1 / 11\end{array}$} & \multirow{2}{*}{$\begin{array}{c}\text { TOTAL } \\
\text { ADULTS } \\
2\end{array}$} & \multirow{2}{*}{$\begin{array}{c}\mathbf{K M} \\
0.0\end{array}$} & \multirow{2}{*}{$\begin{array}{l}\text { SITE } \\
\text { DESCRIPTION } \\
\text { n.r. }\end{array}$} & \multirow{2}{*}{$\begin{array}{l}\text { DISTURBANCE } \\
\text { / CONCERNS } \\
\text { n.r. }\end{array}$} & \multicolumn{4}{|c|}{$\begin{array}{c}\text { PRIOR YEARS } \\
\text { CENSUSED \& YEARS }^{\text {PIPL SEEN }}{ }^{1} \\
\text { PIPL }^{2}\end{array}$} & \multirow{2}{*}{$\frac{\text { OWNER }}{\text { unk }}$} \\
\hline & & & & & & & & - & - & - & 06 & \\
\hline Cabo Rojo & Cabo Rojo NWR & & $2 / 1 / 11$ & 0 & 4.8 & n.r. & n.r. & - & - & - & - & unk \\
\hline Cabo Rojo & Cabo Rojo Salt Flats ${ }^{2}$ & & $2 / 20 / 11$ & 0 & 3.2 & n.r. & n.r. & 91 & 96 & 01 & $\underline{06}$ & unk \\
\hline Cabo Rojo & Charca de Combate ${ }^{2}$ & & $2 / 13 / 11$ & 0 & 0.0 & n.r. & n.r. & - & - & - & - & unk \\
\hline Guanica & La Parguera-Villa Parguera & & $1 / 31 / 11$ & 0 & 4.8 & n.r. & n.r. & - & - & - & - & unk \\
\hline Mayaguez & Combate-Moja Casabe & & $2 / 8 / 11$ & 0 & 0.2 & n.r. & n.r. & - & - & - & - & unk \\
\hline Total & & & & 2 & 13.0 & & & & & & & \\
\hline
\end{tabular}

${ }^{1}$ If previously surveyed, years surveyed are noted. Bold underlined years indicate that Piping Plovers were seen at the site during that Census year.

${ }^{2}$ Please note that this survey was conducted outside the Census window. 


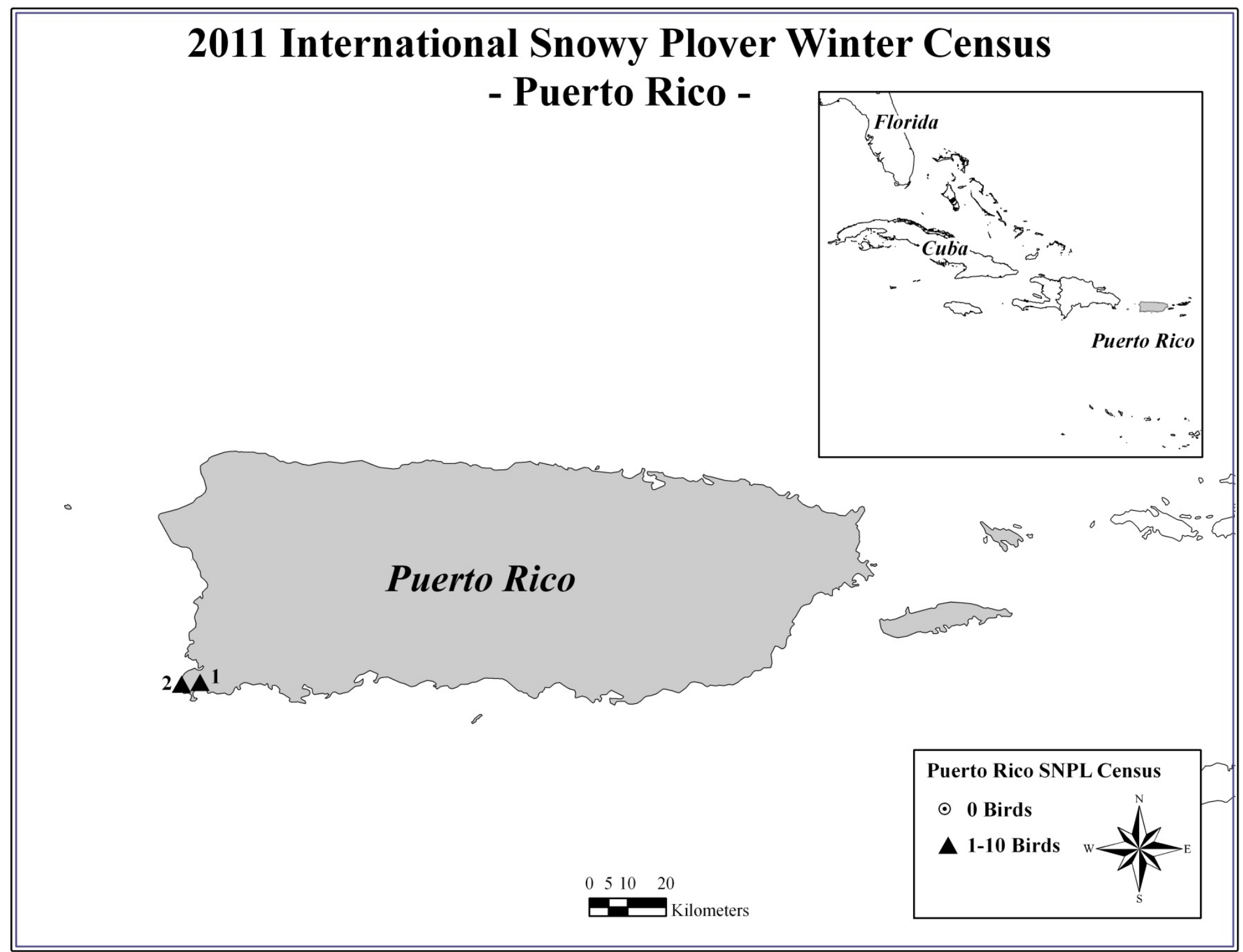


The 2011 International Snowy Plover Winter Census in Puerto Rico

\begin{tabular}{|c|c|c|c|c|c|c|c|c|c|c|c|}
\hline \multirow{2}{*}{$\begin{array}{l}\text { MUNICIPALITY } \\
\text { Anasco }\end{array}$} & \multirow{2}{*}{$\frac{\text { SITE NAME }}{\text { Beach by mouth of Anasco River }^{2}}$} & \multirow[t]{2}{*}{ MAP\# } & \multirow{2}{*}{$\begin{array}{c}\text { DATE } \\
1 / 1 / 11\end{array}$} & \multirow{2}{*}{$\begin{array}{c}\text { TOTAL } \\
\text { ADULTS } \\
0\end{array}$} & \multirow{2}{*}{$\frac{\mathbf{K M}}{0.0}$} & \multirow{2}{*}{$\begin{array}{l}\text { SITE } \\
\text { DESCRIPTION } \\
\text { n.r. }\end{array}$} & \multirow{2}{*}{$\begin{array}{l}\text { DISTURBANCE } \\
\text { / CONCERNS } \\
\text { n.r. }\end{array}$} & \multicolumn{3}{|c|}{$\begin{array}{c}\text { PRIOR YEARS } \\
\text { CENSUSED \& YEARS } \\
\text { SNPL SEEN }^{1} \\
\end{array}$} & \multirow{2}{*}{$\frac{\text { OWNER }}{\text { unk }}$} \\
\hline & & & & & & & & - $-\quad-$ & 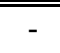 & 06 & \\
\hline Cabo Rojo & Cabo Rojo NWR & 1 & $2 / 1 / 11$ & 2 & 4.8 & n.r. & n.r. & - & - & - & unk \\
\hline Cabo Rojo & Cabo Rojo Salt Flats ${ }^{2}$ & & $2 / 20 / 11$ & 0 & 3.2 & n.r. & n.r. & - & 01 & 06 & unk \\
\hline Cabo Rojo & Charca de Combate ${ }^{2}$ & 2 & $2 / 13 / 11$ & 1 & 0.0 & n.r. & n.r. & - & - & - & unk \\
\hline Guanica & La Parguera-Villa Parguera & & $1 / 31 / 11$ & 0 & 4.8 & n.r. & n.r. & - & - & - & unk \\
\hline Mayaguez & Combate-Moja Casabe & & $2 / 8 / 11$ & 0 & 0.2 & n.r. & n.r. & - & - & - & unk \\
\hline Total & & & & 3 & 13.0 & & & & & & \\
\hline
\end{tabular}

If previously surveyed, years surveyed are noted. Bold underlined years indicate that Snowy Plovers were seen at the site during that Census year.

${ }^{2}$ Please note that this survey was conducted outside the Census window. 


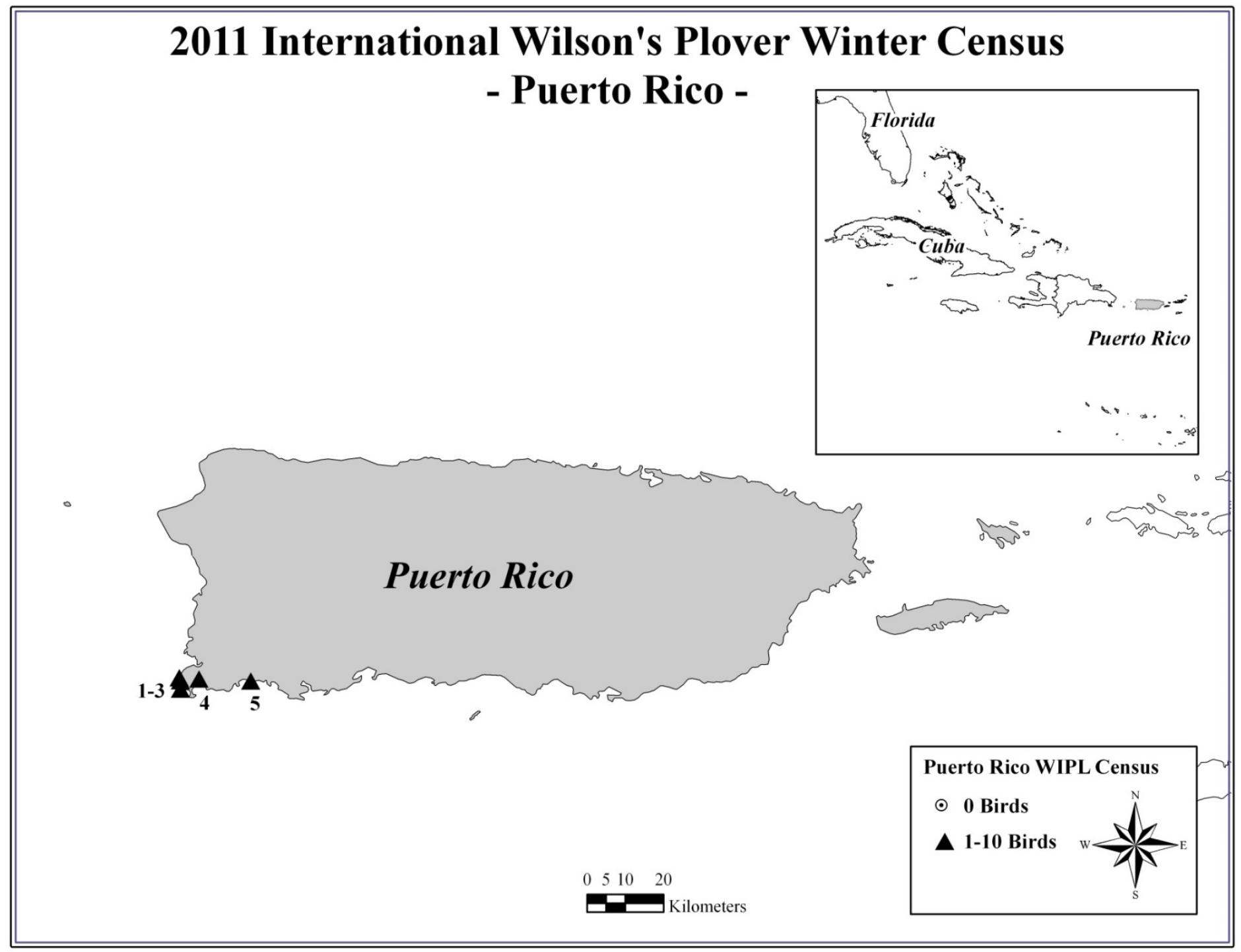


The 2011 International Wilson's Plover Winter Census in Puerto Rico

\begin{tabular}{|c|c|c|c|c|c|c|c|c|c|c|c|}
\hline \multirow{2}{*}{$\begin{array}{l}\text { MUNICIPALITY } \\
\text { Anasco }\end{array}$} & \multirow{2}{*}{$\begin{array}{c}\text { SITE NAME } \\
\text { Beach by mouth of Anasco River }^{2}\end{array}$} & \multirow[t]{2}{*}{ MAP\# } & \multirow{2}{*}{$\begin{array}{c}\text { DATE } \\
1 / 1 / 11\end{array}$} & \multirow{2}{*}{$\begin{array}{c}\text { TOTAL } \\
\text { ADULTS } \\
0\end{array}$} & \multirow{2}{*}{$\begin{array}{c}\mathbf{K M} \\
0.0\end{array}$} & \multirow{2}{*}{$\begin{array}{l}\text { SITE } \\
\text { DESCRIPTION } \\
\text { n.r. }\end{array}$} & \multirow{2}{*}{$\begin{array}{l}\text { DISTURBANCE } \\
\text { / CONCERNS } \\
\text { n.r. }\end{array}$} & \multicolumn{3}{|c|}{$\begin{array}{c}\text { PRIOR YEARS } \\
\text { CENSUSED \& YEARS } \\
\text { WIPL SEEN }^{1} \\
\end{array}$} & \multirow{2}{*}{$\frac{\text { OWNER }}{\text { unk }}$} \\
\hline & & & & & & & & - & - & $\underline{06}$ & \\
\hline Cabo Rojo & Cabo Rojo NWR & 4 & $2 / 1 / 11$ & 2 & 4.8 & n.r. & n.r. & - & - & - & unk \\
\hline Cabo Rojo & Cabo Rojo Salt Flats ${ }^{2}$ & 2 & $2 / 20 / 11$ & 9 & 3.2 & n.r. & n.r. & - & - & $\underline{06}$ & unk \\
\hline Cabo Rojo & Charca de Combate ${ }^{2}$ & 1 & $2 / 13 / 11$ & 3 & 0.0 & n.r. & n.r. & - & - & - & unk \\
\hline Guanica & La Parguera-Villa Parguera & 5 & $1 / 31 / 11$ & 1 & 4.8 & n.r. & n.r. & - & - & - & unk \\
\hline Mayaguez & Combate-Moja Casabe & 3 & $2 / 8 / 11$ & 1 & 0.2 & n.r. & n.r. & - & - & - & unk \\
\hline Total & & & & 16 & 13.0 & & & & & & \\
\hline
\end{tabular}

If previously surveyed, years surveyed are noted. Bold underlined years indicate that Wilson's Plovers were seen at the site during that Census year.

${ }^{2}$ Please note that this survey was conducted outside the Census window. 
This page left intentionally blank 


\section{The 2011 International Piping Plover Breeding Census in St. Pierre and Miquelon, France}

Roger Etcheberry

P.O. Box 8216

24 bd des Terre-Neuvas

Miquelon

Îles Saint-Pierre et Miquelon, France

retchebe@cheznoo.net

The International Census on Saint-Pierre and Miquelon resulted in the detection of four Piping Plovers, including one nesting pair. Three of four sites on the islands of Saint-Pierre and Miquelon were censused on June 13, 2011, by Lison Yon, Idir Alliche, Danielle Lebollocq and Roger Etcheberry. Two birds were seen on Gully of Grand Barachois, but pair status could not be determined. A fourth site was censused on June 11, 2011, by Laurent Jackman and Joël Detcheverry, and a breeding pair was reported. A four-egg nest was found on this initial visit but later it only had one egg. Gilles Gloaguen also visited this site and a second nest was located later in the season. No young were seen on any subsequent visit so it is unlikely that birds successfully bred on Saint Pierre or Miquelon in 2011.

\section{Comparison of Census Numbers}

\begin{tabular}{|l|c|c|c|c|c|}
\hline & 1991 & 1996 & 2001 & 2006 & 2011 \\
\hline $\begin{array}{l}\text { Total } \\
\text { Adults }\end{array}$ & 4 & 6 & 9 & 8 & 4 \\
\hline
\end{tabular}

${ }^{\mathrm{I}}$ This is the total from a single survey at each site; if more than one survey was conducted, we count only results from the first survey during the census window. 


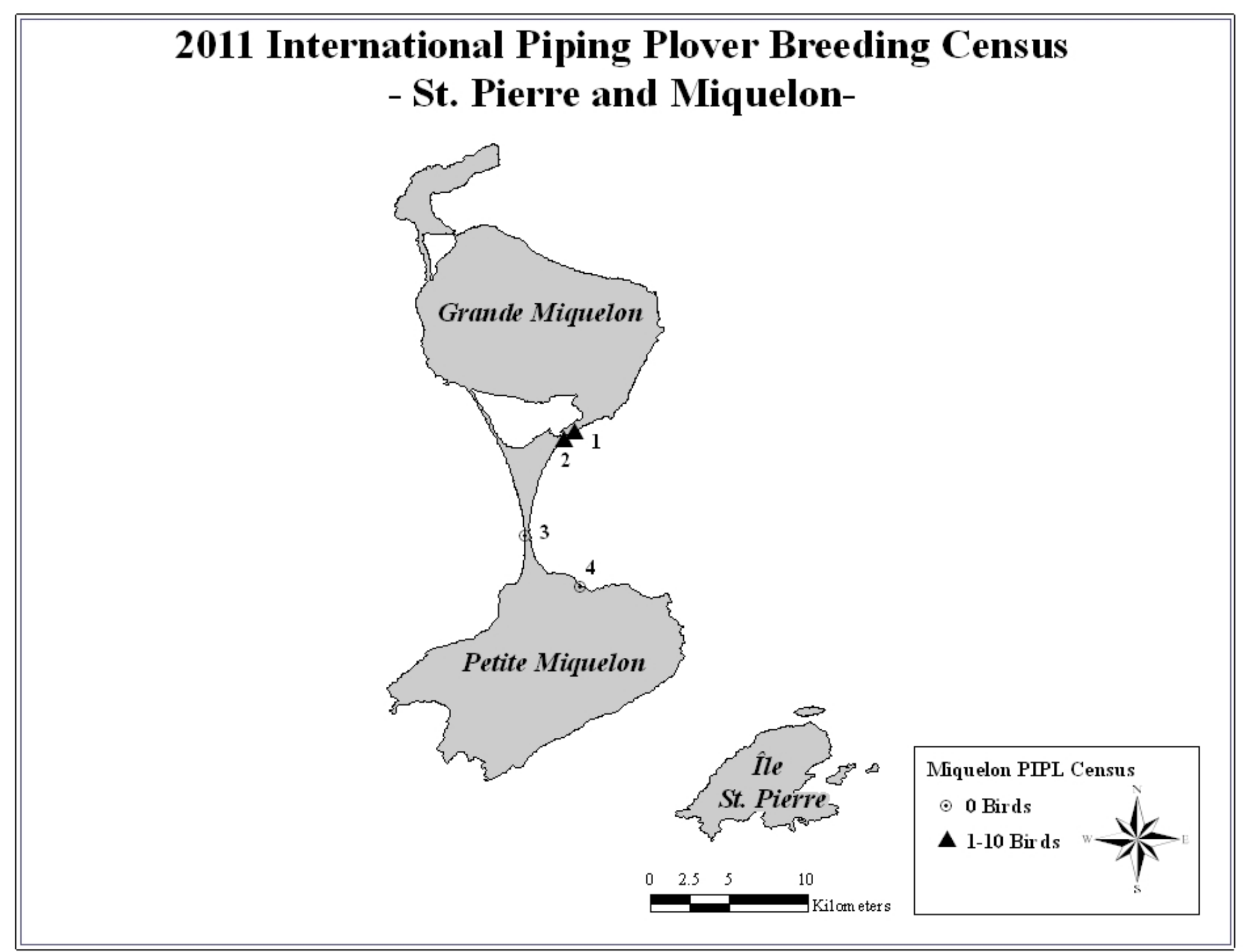


The 2011 International Piping Plover Breeding Census in St. Pierre and Miquelon

\begin{tabular}{|c|c|c|c|c|c|c|c|c|c|c|c|c|}
\hline \multirow{2}{*}{$\begin{array}{l}\text { SITE NAME } \\
\text { Gully of Grand Barachois }\end{array}$} & \multirow{2}{*}{ MAP\# } & \multirow{2}{*}{$\frac{\text { DATE }}{6 / 13 / 11}$} & \multirow{2}{*}{$\begin{array}{c}\begin{array}{c}\text { BREED- } \\
\text { ING } \\
\text { PAIRS }\end{array} \\
0\end{array}$} & \multirow{2}{*}{$\begin{array}{c}\text { TOTAL } \\
\text { PIPL } \\
\text { ADULTS } \\
2\end{array}$} & \multirow{2}{*}{$\frac{\mathbf{K M}}{29.0}$} & \multirow{2}{*}{$\begin{array}{l}\text { SITE } \\
\text { DESCRIPTION } \\
\text { I A }\end{array}$} & \multirow{2}{*}{$\begin{array}{l}\text { DISTURBANCE } \\
\text { CONCERNS } \\
\text { n.r. }\end{array}$} & \multicolumn{4}{|c|}{$\begin{array}{c}\text { PRIOR YEARS } \\
\text { CENSUSED \& YEARS } \\
\text { PIPL SEEN }^{1} \\
\end{array}$} & \multirow{2}{*}{$\frac{\text { OWNER }}{\mathrm{s}(\mathrm{p})}$} \\
\hline & & & & & & & & 991 & 96 & $\underline{\underline{01}}$ & $\underline{06}$ & \\
\hline Northeast of Gully of Grand Barachois & 1 & $6 / 11 / 11$ & 1 & 2 & 2.4 & I A & n.r. & 91 & 96 & $\overline{01}$ & $\overline{06}$ & $\mathrm{~s}(\mathrm{p})$ \\
\hline South of L'isthme & 4 & $6 / 13 / 11$ & 0 & 0 & 1.2 & I A & $\mathrm{H}$ & - & - & - & - & $\mathrm{s}(\mathrm{p})$ \\
\hline West Side of Isthme de Langlade & 3 & $6 / 13 / 11$ & 0 & 0 & 6.0 & I A & n.r. & $\underline{91}$ & $\underline{96}$ & $\underline{01}$ & 06 & $\mathrm{~s}(\mathrm{p})$ \\
\hline Total & & & 1 & 4 & 18.6 & & & & & & & \\
\hline
\end{tabular}

${ }^{1}$ Bold years indicate that adults were seen. Bold and underlined years indicate that pairs were seen. 


\section{The 2011 International Piping Plover Breeding Census in Newfoundland}

Krista Baker

Canadian Wildlife Service

Environmental Stewardship Branch

Environment Canada

6 Bruce St.

Mount Pearl, NL

A1N 4T3

709-772-3739

krista.baker@ec.gc.ca

A total of 103 beaches were surveyed in Newfoundland and Labrador (100) and Northern Quebec (3) by 29 staff and volunteers (Quebec beaches are reported in the Quebec section of this report). Throughout

Newfoundland and Labrador the census was carried out by many groups, including Parks Canada, Newfoundland and Labrador Parks and Natural Areas Division, Newfoundland and Labrador Department of Natural Resources, Newfoundland and Labrador Wildlife Division, Environment Canada (Canadian Wildlife Service), Nature Conservancy Canada, Codroy Valley Area Development Association, and Mi'kmaq Alsumk Mowimsikik Koqoey Association (MAMKA).
The 2011 beach list was based on sites visited during the census in 2006 and new potential sites noted by various groups. It is believed that all known sites with Piping Plovers were surveyed. Nevertheless, several sites with suitable habitat that were surveyed in 2006 (but had no Piping Plovers) could not be surveyed this year due to poor weather conditions including Cowlest Beach, Connoire Bay North West Arm Sand Bar, and Wreck Island Beach. Three other beaches (First Beach, Second Beach, and Fourth Beach - Sandbanks Provincial Park) were surveyed prior to the census and no Piping Plovers were found, but they were not surveyed again during the census window.

A total of 51 Piping Plovers were counted on 16 beaches in Newfoundland during the breeding census: 21 pairs and 9 singles. Counts have exhibited a general increasing trend, with 2011 marking the highest count since the census began in 1991. This year's census results are likely representative of the population in Newfoundland, but may slightly underestimate the actual total due to the inconspicuous nature of Piping Plovers. All terrain vehicles, predation, and adverse weather continue to threaten Piping Plovers in Newfoundland.

Comparison of Census Numbers

\begin{tabular}{|l|c|c|c|c|c|}
\hline & 1991 & 1996 & 2001 & 2006 & 2011 \\
\hline $\begin{array}{l}\text { Total } \\
\text { Adults }\end{array}$ & 7 & 27 & 39 & $48^{1}$ & $51^{1}$ \\
\hline $\begin{array}{l}\text { Beaches } \\
\text { with } \\
\text { plovers }\end{array}$ & 1 & 7 & 12 & 12 & 16 \\
\hline $\begin{array}{l}\text { Beaches } \\
\text { surveyed }\end{array}$ & 14 & 24 & 35 & 73 & 100 \\
\hline
\end{tabular}

${ }^{1}$ This is the total from a single survey at each site; if more than one survey was conducted, we count only results from the first survey during the census window. 
Detectability Study

\begin{tabular}{|l|c|c|}
\hline \multicolumn{1}{|c|}{ Sites Included } & $\begin{array}{c}\text { First } \\
\text { Count }\end{array}$ & $\begin{array}{c}\text { Second } \\
\text { Count }\end{array}$ \\
\hline 2nd Beach, Grand Bay West & 6 & 4 \\
\hline Burntwood Point & 0 & 0 \\
\hline Kelby Cove & 0 & 0 \\
\hline Little Barachois & 0 & 0 \\
\hline Osmond Beach & 0 & 2 \\
\hline Parson's Pond & 0 & 0 \\
\hline $\begin{array}{l}\text { Pinware Prov. Park (French } \\
\text { Cove Beach) }\end{array}$ & 0 & 0 \\
\hline Point Au Mal & 0 & 0 \\
\hline Port Saunders & 0 & 1 \\
\hline $\begin{array}{l}\text { Rocky Barachois (Bottle's } \\
\text { Barachois) }\end{array}$ & 2 & 2 \\
\hline Short Sand Beach & 0 & 0 \\
\hline Spirity Cove & 0 & 0 \\
\hline St. Paul's Point & 0 & 0 \\
\hline Stephenville Crossing & 1 & 2 \\
\hline $\begin{array}{l}\text { Stephenville Crossing - South } \\
\text { side of bridge }\end{array}$ & 2 & 2 \\
\hline $\begin{array}{l}\text { Stephenville Crossing - Main } \\
\text { Gut }\end{array}$ & 0 & 0 \\
\hline West Bay - Port au Port & \\
\hline
\end{tabular}




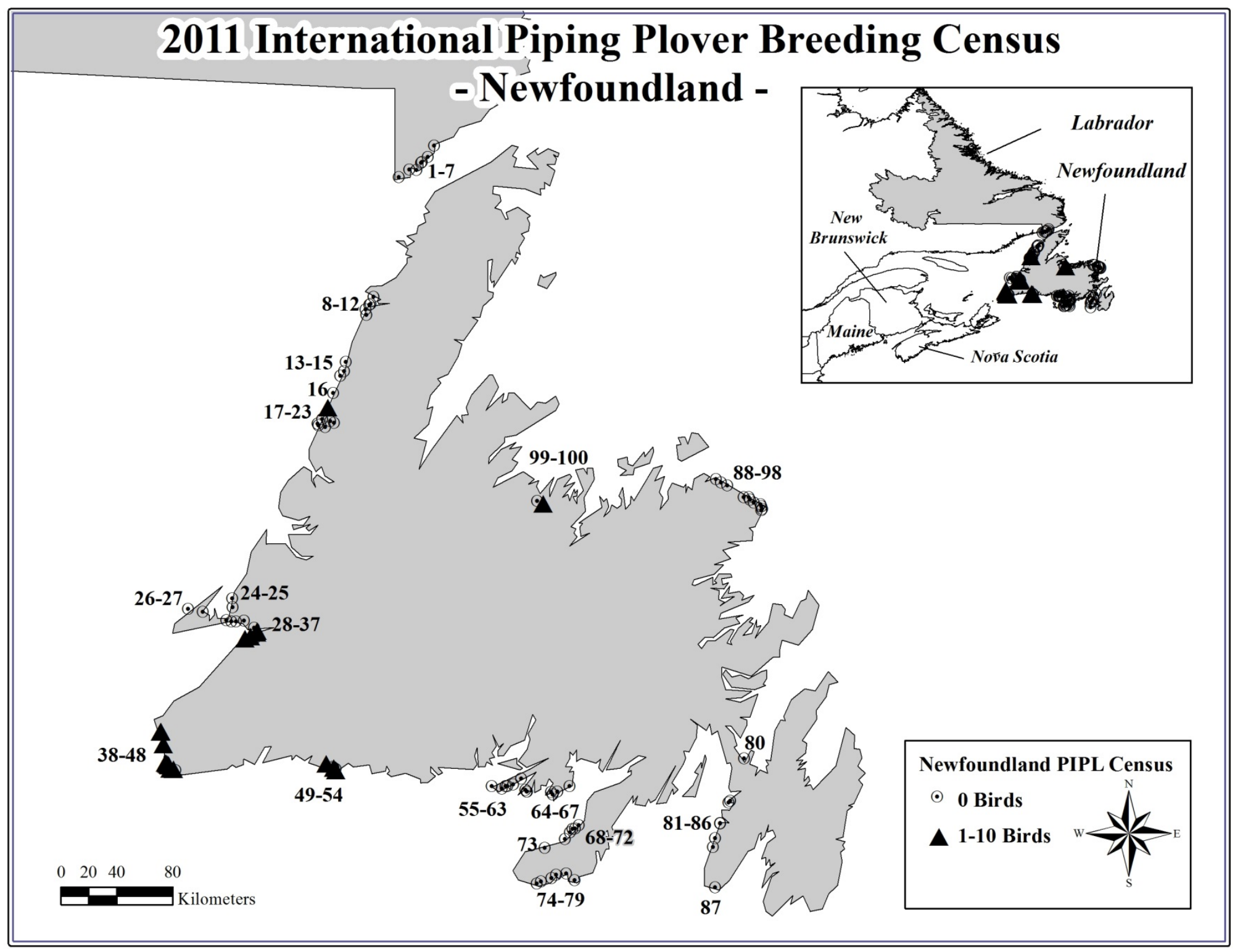


The 2011 International Piping Plover Breeding Census in Newfoundland

\begin{tabular}{|c|c|c|c|c|c|c|c|c|c|c|c|c|c|}
\hline \multirow{2}{*}{$\begin{array}{l}\text { REGION } \\
\text { Labrador }\end{array}$} & \multirow{2}{*}{$\begin{array}{l}\text { SITE NAME } \\
\text { Forteau Beach }\end{array}$} & \multirow{2}{*}{ MAP\# } & \multirow{2}{*}{$\begin{array}{c}\text { DATE } \\
6 / 15 / 11\end{array}$} & \multirow{2}{*}{ 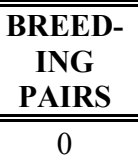 } & \multirow{2}{*}{$\begin{array}{c}\begin{array}{c}\text { TOTAL } \\
\text { PIPL } \\
\text { ADULTS }\end{array} \\
0\end{array}$} & \multirow{2}{*}{$\frac{\mathbf{K M}}{1.1}$} & \multirow{2}{*}{$\begin{array}{l}\text { SITE } \\
\text { DESCRIPTION } \\
\text { I A }\end{array}$} & \multirow{2}{*}{$\begin{array}{l}\text { DISTURBANCE } \\
\text { CONCERNS } \\
\mathrm{V}\end{array}$} & \multicolumn{4}{|c|}{$\begin{array}{c}\text { PRIOR YEARS } \\
\text { CENSUSED \& YEARS } \\
\text { PIPL SEEN }^{1} \\
\end{array}$} & \multirow{2}{*}{$\begin{array}{c}\text { OWNER } \\
\mathrm{s}(\mathrm{p}), \mathrm{m}\end{array}$} \\
\hline & & & & & & & & & 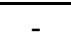 & 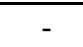 & 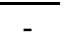 & - & \\
\hline Labrador & L'anse Amour & 5 & $6 / 15 / 11$ & 0 & 0 & 1.1 & I A & $\mathrm{V}$ & - & - & - & - & $\mathrm{s}(\mathrm{p})$ \\
\hline Labrador & L'anse au Clair & 7 & $6 / 14 / 11$ & 0 & 0 & 0.5 & I III A D & $\mathrm{V}$ & - & - & - & - & $\mathrm{s}(\mathrm{p}), \mathrm{m}$ \\
\hline Labrador & L'anse au Loup 1 & 3 & $6 / 15 / 11$ & 0 & 0 & 0.9 & I A & $\mathrm{U}$ & - & - & - & - & $\mathrm{s}(\mathrm{p}), \mathrm{m}$ \\
\hline Labrador & L'anse au Loup 2 & 4 & $6 / 15 / 11$ & 0 & 0 & 0.3 & I A & $\mathrm{U}$ & - & - & - & - & $\mathrm{s}(\mathrm{p})$ \\
\hline Labrador & L'anse un Diable & 2 & $6 / 15 / 11$ & 0 & 0 & 0.2 & I A & $\mathrm{N}$ & - & - & - & - & $\mathrm{s}(\mathrm{p})$ \\
\hline Labrador & $\begin{array}{l}\text { Pinware River Prov. Park } \\
\text { (French Cove Beach) }\end{array}$ & 1 & $6 / 5 / 11$ & 0 & 0 & 2.0 & I A & n.r. & - & - & - & - & $\mathrm{s}(\mathrm{p})$ \\
\hline Newfoundland & 1st Beach, Grand Bay West & 48 & $6 / 5 / 11$ & 0 & 0 & 0.4 & I A & n.r. & - & - & 01 & 06 & $s(p)$ \\
\hline Newfoundland & 2nd Beach, Grand Bay West ${ }^{2}$ & 47 & $6 / 5 / 11$ & 3 & 6 & n.r. & I A & n.r. & - & 96 & 01 & $\underline{06}$ & $s(p)$ \\
\hline Newfoundland & Alex Cove & 23 & $6 / 14 / 11$ & 0 & 0 & 0.7 & IV A & n.r. & - & - & - & - & f \\
\hline Newfoundland & Banting Memorial Park & 97 & $6 / 7 / 11$ & 0 & 0 & 1.5 & I A & n.r. & - & - & - & 06 & unk \\
\hline Newfoundland & Beck Bay & 55 & $6 / 6 / 11$ & 0 & 0 & 0.8 & I B & $\mathrm{V}$ & - & - & - & 06 & unk \\
\hline Newfoundland & Bellevue Beach & 80 & $6 / 13 / 11$ & 0 & 0 & 3.8 & I IV A B & n.r. & - & - & - & 06 & $\mathrm{~s}(\mathrm{p})$ \\
\hline Newfoundland & Big Barachois & 44 & $6 / 5 / 11$ & 1 & 3 & 1.7 & I A & $\mathrm{V}$ & 91 & $\underline{96}$ & $\underline{01}$ & $\underline{06}$ & $\mathrm{~s}(\mathrm{p})$ \\
\hline Newfoundland & Big Barasway & 49 & $6 / 4 / 11$ & 1 & 5 & 6.1 & I B & $\mathrm{V}$ & $\underline{91}$ & 96 & $\underline{01}$ & 06 & unk \\
\hline Newfoundland & $\begin{array}{l}\text { Big Barasway - Seal Cove } \\
\text { Beach }\end{array}$ & 57 & $6 / 6 / 11$ & 0 & 0 & 1.3 & I B & n.r. & 91 & 96 & 01 & 06 & unk \\
\hline Newfoundland & Big Seal Cove, Ship Harbour & 81 & $6 / 6 / 11$ & 0 & 0 & 0.3 & I A & n.r. & - & - & - & 06 & $\mathrm{~s}(\mathrm{p})$ \\
\hline Newfoundland & Black Island Cove & 62 & $6 / 6 / 11$ & 0 & 0 & 0.6 & I A & $\mathrm{V}$ & - & - & - & 06 & unk \\
\hline Newfoundland & BlackBrook, SPI & 19 & $6 / 14 / 11$ & 0 & 0 & 0.7 & IV A & n.r. & - & - & - & - & $\mathrm{f}$ \\
\hline Newfoundland & Boxey Harbour & 66 & $6 / 6 / 11$ & 0 & 0 & 0.7 & I A & $\mathrm{VN}$ & - & - & - & 06 & unk \\
\hline Newfoundland & Broom Point & 21 & $6 / 9 / 11$ & 0 & 0 & 0.1 & I A & n.r. & 91 & 96 & 01 & 06 & $\mathrm{f}$ \\
\hline Newfoundland & Burntwood Point & 11 & $6 / 6 / 11$ & 0 & 0 & 0.9 & I A & $\mathrm{O}$ & - & - & - & - & unk \\
\hline Newfoundland & Cape Freels & 89 & $6 / 8 / 11$ & 0 & 0 & 1.6 & I A & n.r. & 91 & 96 & 01 & 06 & $\mathrm{~m}$ \\
\hline Newfoundland & Cape Freels 2 & 88 & $6 / 8 / 11$ & 0 & 0 & 1.8 & I A & n.r. & - & 96 & 01 & 06 & $\mathrm{~m}$ \\
\hline Newfoundland & Cape Freels 3 & 90 & $6 / 8 / 11$ & 0 & 0 & 0.7 & I A & n.r. & - & 96 & 01 & 06 & $\mathrm{~m}$ \\
\hline Newfoundland & Cape Freels 4 & 91 & $6 / 8 / 11$ & 0 & 0 & 0.9 & I A & n.r. & - & 96 & 01 & 06 & $\mathrm{~m}$ \\
\hline Newfoundland & $\begin{array}{l}\text { Cape Ray Beach, J.T. } \\
\text { Cheeseman Provincial Park }\end{array}$ & 41 & $6 / 7 / 11$ & 2 & 6 & 2.4 & I IV IX A B D & n.r. & - & $\underline{96}$ & $\underline{01}$ & $\underline{06}$ & $\mathrm{~s}(\mathrm{p})$ \\
\hline Newfoundland & Chappie Cove- Deadman's Bight & 63 & $6 / 6 / 11$ & 0 & 0 & 0.3 & I A & $\mathrm{V}$ & - & - & - & 06 & unk \\
\hline Newfoundland & Coombes Head & 52 & $6 / 5 / 11$ & 0 & 1 & 1.0 & I B & n.r. & - & - & - & - & unk \\
\hline Newfoundland & Crow Head West Beach & 50 & $6 / 4 / 11$ & 0 & 0 & 0.9 & I B & n.r. & - & - & 01 & 06 & unk \\
\hline Newfoundland & Daniel's Harbour & 13 & $6 / 16 / 11$ & 0 & 0 & 0.0 & I A & n.r. & 91 & 96 & - & - & $\mathrm{s}(\mathrm{p})$ \\
\hline
\end{tabular}


The 2011 International Piping Plover Breeding Census in Newfoundland (Continued)

\begin{tabular}{|c|c|c|c|c|c|c|c|c|c|c|c|c|c|}
\hline \multirow{2}{*}{$\begin{array}{l}\text { REGION } \\
\text { Newfoundland }\end{array}$} & $\begin{array}{l}\text { SITE NAME } \\
\end{array}$ & \multirow{2}{*}{$\frac{\text { MAP\# }}{100}$} & \multirow{2}{*}{ 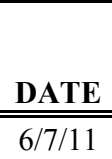 } & \multirow{2}{*}{ 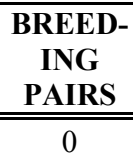 } & \multirow{2}{*}{ 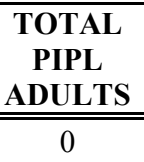 } & \multirow{2}{*}{$\frac{\mathbf{K M}}{3.0}$} & \multirow{2}{*}{$\begin{array}{l}\text { SITE } \\
\text { DESCRIPTION } \\
\text { I A }\end{array}$} & \multirow{2}{*}{$\begin{array}{l}\text { DISTURBANCE } \\
\text { CONCERNS } \\
\mathrm{V}\end{array}$} & \multicolumn{4}{|c|}{$\begin{array}{c}\text { PRIOR YEARS } \\
\text { CENSUSED \& YEARS }^{\text {PIPL SEEN }}{ }^{1} \\
\text { PIPL }^{-}\end{array}$} & \multirow{2}{*}{$\begin{array}{c}\text { OWNER } \\
\text { unk }\end{array}$} \\
\hline & Deadman's Bay & & & & & & & & 91 & 96 & 01 & 06 & \\
\hline Newfoundland & East of Coomb's Cove & 64 & $6 / 6 / 11$ & 0 & 0 & 0.8 & I A B & $\mathrm{V}$ & - & - & 01 & 06 & unk \\
\hline Newfoundland & Eastern Brook, SPI & 20 & $6 / 14 / 11$ & 0 & 0 & 1.1 & IV A & n.r. & - & - & - & - & $\mathrm{f}$ \\
\hline Newfoundland & Eastern Cove - Dog Cove & 59 & $6 / 6 / 11$ & 0 & 0 & 0.7 & I A & n.r. & - & - & - & 06 & unk \\
\hline Newfoundland & Flat Bay & 37 & $6 / 6 / 11$ & 5 & 10 & 4.0 & I IV A E & n.r. & - & - & $\underline{01}$ & 06 & $\mathrm{~s}(\mathrm{p})$ \\
\hline Newfoundland & Fox Island River & 24 & $6 / 12 / 11$ & 0 & 0 & 2.0 & I A E & n.r. & - & - & 01 & 06 & $\mathrm{~s}(\mathrm{p})$ \\
\hline Newfoundland & $\begin{array}{l}\text { Frenchman's Cove } 3 \text { (White } \\
\text { Point) }\end{array}$ & 71 & $6 / 13 / 11$ & 0 & 0 & 1.9 & I A B & $\mathrm{V}$ & - & - & 01 & 06 & $\mathrm{~s}(\mathrm{p})$ \\
\hline Newfoundland & Frenchman's Cove East & 69 & $6 / 10 / 11$ & 0 & 0 & 2.3 & I IV A B D & n.r. & - & - & 01 & 06 & $\mathrm{~s}(\mathrm{p})$ \\
\hline Newfoundland & Frenchman's Cove West & 70 & $6 / 10 / 11$ & 0 & 0 & 2.6 & I A & V U & - & - & 01 & 06 & unk \\
\hline Newfoundland & Garnish Beach & 68 & $6 / 14 / 11$ & 0 & 0 & 1.5 & I A & $\mathrm{V}$ & - & - & 01 & 06 & unk \\
\hline Newfoundland & Gooseberry Cove Beach & 86 & $6 / 6 / 11$ & 0 & 0 & 0.3 & I A & $\mathrm{O}$ & - & - & - & 06 & $\mathrm{~s}(\mathrm{p})$ \\
\hline Newfoundland & Grand Beach & 72 & $6 / 13 / 11$ & 0 & 0 & 4.9 & I A B & $\mathrm{VO}$ & - & - & 01 & 06 & $\mathrm{~s}(\mathrm{p})$ \\
\hline Newfoundland & Great Barasway Beach & 85 & $6 / 6 / 11$ & 0 & 0 & 0.2 & I A B & n.r. & 91 & 96 & 01 & 06 & $\mathrm{~s}(\mathrm{p})$ \\
\hline Newfoundland & Green Point (Point Verte) & 84 & $6 / 6 / 11$ & 0 & 0 & 1.0 & I A B & $\mathrm{V}$ & - & - & - & 06 & $\mathrm{~s}(\mathrm{p})$ \\
\hline Newfoundland & Kelby Cove & 46 & $6 / 6 / 11$ & 0 & 0 & 0.5 & I A & n.r. & - & - & - & - & $\mathrm{s}(\mathrm{p})$ \\
\hline Newfoundland & Kippens & 30 & $6 / 8 / 11$ & 0 & 0 & 0.0 & I A & $\mathrm{U}$ & - & - & - & - & $\mathrm{s}(\mathrm{p})$ \\
\hline Newfoundland & L'anse au Loup & 73 & $6 / 14 / 11$ & 0 & 0 & 2.7 & I B & $\mathrm{V}$ & - & - & 01 & 06 & unk \\
\hline Newfoundland & Lansey Bank Cove & 77 & $6 / 13 / 11$ & 0 & 0 & 0.2 & I A & $\mathrm{V}$ & - & - & - & 06 & unk \\
\hline Newfoundland & Little Barachois & 35 & $6 / 12 / 11$ & 0 & 0 & 1.0 & I IV A E & n.r. & - & - & - & - & $\mathrm{s}(\mathrm{p})$ \\
\hline Newfoundland & Little Barasway & 51 & $6 / 4 / 11$ & 0 & 0 & 1.5 & I A B & n.r. & - & - & - & 06 & unk \\
\hline Newfoundland & Little Barasway - Seal Cove & 58 & $6 / 6 / 11$ & 0 & 0 & 0.7 & I A B & n.r. & - & - & - & - & unk \\
\hline Newfoundland & Little Codroy/St. Andrew's Gut & 40 & $6 / 6 / 11$ & 1 & 2 & 4.9 & I A & n.r. & - & - & $\underline{01}$ & $\underline{06}$ & $\mathrm{~s}(\mathrm{p})$ \\
\hline Newfoundland & Little Lawn & 78 & $6 / 13 / 11$ & 0 & 0 & 0.5 & I B & $\mathrm{V}$ & - & - & - & 06 & unk \\
\hline Newfoundland & Lumsden & 93 & $6 / 8 / 11$ & 0 & 0 & 1.1 & I III A & $\mathrm{V}$ & 91 & - & - & 06 & unk \\
\hline Newfoundland & Lumsden Head East & 94 & $6 / 8 / 11$ & 0 & 0 & 1.7 & I A & $\mathrm{V}$ & 91 & 96 & 01 & 06 & unk \\
\hline Newfoundland & Lumsden Head West & 99 & $6 / 8 / 11$ & 0 & 1 & 1.8 & I A & $\mathrm{V}$ & 91 & 96 & 01 & 06 & unk \\
\hline Newfoundland & $\begin{array}{l}\text { Millville Beach, Grand Codroy } \\
\text { Provincial Park }\end{array}$ & 39 & $6 / 14 / 11$ & 2 & 4 & 1.8 & I IV A B D I & $\mathrm{O}$ & 91 & 96 & 01 & 06 & $\mathrm{~s}(\mathrm{p})$ \\
\hline Newfoundland & Musgrave Harbour & 98 & $6 / 7 / 11$ & 0 & 0 & 3.6 & I A & n.r. & 91 & 96 & 01 & 06 & unk \\
\hline Newfoundland & Osmond Beach & 42 & $6 / 14 / 11$ & 1 & 2 & 0.6 & I A & n.r. & - & 96 & 01 & 06 & unk \\
\hline Newfoundland & Parson's Pond & 16 & $6 / 8 / 11$ & 0 & 0 & 0.0 & I A & n.r. & 91 & 96 & - & - & $\mathrm{s}(\mathrm{p})$ \\
\hline Newfoundland & Partridge Cove & 60 & $6 / 6 / 11$ & 0 & 0 & 0.4 & I B & n.r. & - & - & - & 06 & $\mathrm{~m}$ \\
\hline Newfoundland & Pennybeck & 95 & $6 / 7 / 11$ & 0 & 0 & 1.4 & I A & n.r. & - & - & - & 06 & unk \\
\hline
\end{tabular}


The 2011 International Piping Plover Breeding Census in Newfoundland (Continued)

\begin{tabular}{|c|c|c|c|c|c|c|c|c|c|c|c|c|c|}
\hline \multirow{2}{*}{$\begin{array}{l}\text { REGION } \\
\text { Newfoundland }\end{array}$} & \multirow{2}{*}{$\begin{array}{r}\text { SITE NAME } \\
\text { Picadilly Beach }\end{array}$} & \multirow{2}{*}{ MAP\# } & \multirow{2}{*}{$\begin{array}{c}\text { DATE } \\
6 / 8 / 11\end{array}$} & \multirow{2}{*}{$\begin{array}{c}\text { BREED- } \\
\text { ING } \\
\text { PAIRS } \\
0\end{array}$} & \multirow{2}{*}{$\begin{array}{c}\text { TOTAL } \\
\text { PIPL } \\
\text { ADULTS } \\
0\end{array}$} & \multirow{2}{*}{$\frac{\mathbf{K M}}{1.5}$} & \multirow{2}{*}{$\begin{array}{l}\text { SITE } \\
\text { DESCRIPTION } \\
\text { IV E }\end{array}$} & \multirow{2}{*}{$\begin{array}{l}\text { DISTURBANCE } \\
\text { CONCERNS } \\
\text { n.r. }\end{array}$} & \multicolumn{4}{|c|}{$\begin{array}{c}\text { PRIOR YEARS } \\
\text { CENSUSED \& YEARS } \\
\text { PIPL SEEN }^{1} \\
\end{array}$} & \multirow{2}{*}{$\frac{\text { OWNER }}{\mathrm{s}(\mathrm{p})}$} \\
\hline & & & & & & & & & - & - & - & - & \\
\hline Newfoundland & Point au Gaul & 75 & $6 / 13 / 11$ & 0 & 0 & 2.1 & I A & $\mathrm{V}$ & - & - & - & 06 & unk \\
\hline Newfoundland & Point Au Mal & 25 & $6 / 12 / 11$ & 0 & 0 & 2.0 & I E & n.r. & - & - & 01 & 06 & $\mathrm{~s}(\mathrm{p})$ \\
\hline Newfoundland & Point Lance Beach & 87 & $6 / 6 / 11$ & 0 & 0 & 1.5 & I A & $\mathrm{V}$ & - & - & - & 06 & $\mathrm{~s}(\mathrm{p})$ \\
\hline Newfoundland & Point Verde & 83 & $6 / 6 / 11$ & 0 & 0 & 2.3 & I A B & $\mathrm{VN}$ & - & - & - & 06 & $\mathrm{~s}(\mathrm{p})$ \\
\hline Newfoundland & Port au Port & 28 & $6 / 8 / 11$ & 0 & 0 & 0.0 & I A & $\mathrm{N}$ & - & - & - & - & $\mathrm{s}(\mathrm{p})$ \\
\hline Newfoundland & Port Saunders & 8 & $6 / 6 / 11$ & 0 & 0 & 0.5 & I A & $\mathrm{O}$ & - & - & - & - & unk \\
\hline Newfoundland & Portland Creek & 14 & $6 / 8 / 11$ & 0 & 0 & 1.6 & I A & $\mathrm{V}$ & - & - & - & 06 & $\mathrm{~s}(\mathrm{p})$ \\
\hline Newfoundland & Portland Hill & 15 & $6 / 16 / 11$ & 0 & 0 & 0.0 & I A & n.r. & - & - & - & - & $\mathrm{s}(\mathrm{p})$ \\
\hline Newfoundland & Red Head - Burgeo & 53 & $6 / 5 / 11$ & 0 & 0 & 1.2 & I A & n.r. & - & - & - & - & $\mathrm{s}(\mathrm{p})$ \\
\hline Newfoundland & River of Ponds & 12 & $6 / 7 / 11$ & 0 & 0 & 0.9 & I A & $\mathrm{O}$ & - & - & - & - & unk \\
\hline Newfoundland & $\begin{array}{l}\text { Rocky Barachois (Bottle's } \\
\text { Barachois) }{ }^{2}\end{array}$ & 45 & $6 / 14 / 11$ & 0 & 1 & 0.7 & I A & $\mathrm{V} \mathrm{O}$ & - & $\underline{96}$ & $\underline{01}$ & $\underline{06}$ & $\mathrm{~s}(\mathrm{p})$ \\
\hline Newfoundland & Romaines & 29 & $6 / 8 / 11$ & 0 & 0 & 0.0 & I A & A U & - & - & - & - & $\mathrm{s}(\mathrm{p})$ \\
\hline Newfoundland & Saltwater Cove & 56 & $6 / 6 / 11$ & 0 & 0 & 0.5 & I A & $\mathrm{VO}$ & - & - & 01 & 06 & unk \\
\hline Newfoundland & Saltwater Cove - St. John's Bay & 65 & $6 / 6 / 11$ & 0 & 0 & 0.7 & I A B & $\mathrm{V}$ & - & - & - & 06 & unk \\
\hline Newfoundland & Sandbanks Park, 3rd Beach & 54 & $6 / 12 / 11$ & 1 & 2 & n.r. & n.r. & n.r. & - & - & - & $\underline{06}$ & $\mathrm{~s}(\mathrm{p})$ \\
\hline Newfoundland & Sandy Cove & 76 & $6 / 13 / 11$ & 0 & 0 & 0.4 & I A B & $\mathrm{V}$ & - & - & 01 & 06 & $\mathrm{~s}(\mathrm{p})$ \\
\hline Newfoundland & Sandy Point & 36 & $6 / 9 / 11$ & 1 & 2 & 2.0 & I A E & n.r. & 91 & 96 & 01 & 06 & $\mathrm{~s}(\mathrm{p})$ \\
\hline Newfoundland & Searston Beach & 38 & $6 / 5 / 11$ & 0 & 0 & 0.4 & I A & $\mathrm{V}$ & 91 & 96 & $\underline{01}$ & 06 & $\mathrm{~s}(\mathrm{p})$ \\
\hline Newfoundland & Shallow Bay & 17 & $6 / 16 / 11$ & 1 & 2 & 5.0 & I A & n.r. & 91 & 96 & $\overline{01}$ & 06 & unk \\
\hline Newfoundland & Shalloway Bay & 96 & $6 / 7 / 11$ & 0 & 0 & 1.2 & I A & $\mathrm{U}$ & - & 96 & 01 & 06 & unk \\
\hline Newfoundland & Ship Harbour Point & 82 & $6 / 6 / 11$ & 0 & 0 & 1.0 & I A & $\mathrm{V}$ & - & - & - & 06 & unk \\
\hline Newfoundland & Shoal Cove Beach & 79 & $6 / 13 / 11$ & 0 & 0 & 0.4 & I A & $\mathrm{V}$ & - & - & - & - & unk \\
\hline Newfoundland & Short Sand Beach & 43 & $6 / 5 / 11$ & 1 & 2 & 0.5 & I A & n.r. & 91 & 96 & 01 & $\underline{06}$ & $\mathrm{~s}(\mathrm{p})$ \\
\hline Newfoundland & Spirity Cove & 10 & $6 / 6 / 11$ & 0 & 0 & 1.0 & I A & $\mathrm{O}$ & - & - & - & - & unk \\
\hline Newfoundland & St. Jacques Harbour & 67 & $6 / 6 / 11$ & 0 & 0 & 0.5 & I A B & n.r. & - & - & - & 06 & unk \\
\hline Newfoundland & St. Paul's Point & 18 & $6 / 8 / 11$ & 0 & 0 & 0.9 & I IV A D & $\mathrm{V}$ & 91 & 96 & 01 & 06 & $\mathrm{~s}(\mathrm{p})$ \\
\hline Newfoundland & Stephenville Crossing & 32 & $6 / 11 / 11$ & 0 & 0 & 1.0 & I A & n.r. & 91 & 96 & $\underline{01}$ & $\underline{06}$ & $\mathrm{~s}(\mathrm{p})$ \\
\hline Newfoundland & $\begin{array}{l}\text { Stephenville Crossing - South } \\
\text { side of bridge }\end{array}$ & 34 & $6 / 15 / 11$ & 1 & 2 & 1.5 & I A & n.r. & 91 & 96 & $\overline{01}$ & 06 & $\mathrm{~s}(\mathrm{p})$ \\
\hline Newfoundland & $\begin{array}{l}\text { Stephenville Crossing- Main } \\
\text { Gut }\end{array}$ & 33 & $6 / 5 / 11$ & 1 & 2 & n.r. & I A & n.r. & 91 & 96 & 01 & 06 & unk \\
\hline Newfoundland & Taylor's Bay & 74 & $6 / 13 / 11$ & 0 & 0 & 0.3 & I B & $\mathrm{V}$ & - & - & 01 & 06 & unk \\
\hline
\end{tabular}


The 2011 International Piping Plover Breeding Census in Newfoundland

(Continued)

\begin{tabular}{|c|c|c|c|c|c|c|c|c|c|c|c|c|c|}
\hline \multirow{2}{*}{$\begin{array}{l}\text { REGION } \\
\text { Newfoundland }\end{array}$} & $\begin{array}{r}\text { SITE NAME } \\
\end{array}$ & \multirow{2}{*}{$\frac{\text { MAP\# }}{26}$} & \multirow{2}{*}{$\begin{array}{l}\text { DATE } \\
6 / 8 / 11\end{array}$} & \multirow{2}{*}{$\begin{array}{c}\text { BREED- } \\
\text { ING } \\
\text { PAIRS } \\
0\end{array}$} & \multirow{2}{*}{$\begin{array}{c}\text { TOTAL } \\
\text { PIPL } \\
\text { ADULTS } \\
0\end{array}$} & \multirow{2}{*}{$\begin{array}{r}\mathbf{K M} \\
3.0\end{array}$} & \multirow{2}{*}{$\begin{array}{l}\text { SITE } \\
\text { DESCRIPTION } \\
\text { I A }\end{array}$} & \multirow{2}{*}{$\begin{array}{l}\text { DISTURBANCE } \\
\text { CONCERNS } \\
\text { n.r. }\end{array}$} & \multicolumn{4}{|c|}{$\begin{array}{c}\text { PRIOR YEARS } \\
\text { CENSUSED \& YEARS } \\
\text { PIPL SEEN }^{1} \\
\end{array}$} & \multirow{2}{*}{$\frac{\text { OWNER }}{\mathrm{OW}(\mathrm{p})}$} \\
\hline & Three Rock Cove & & & & & & & & - & - & - & - & \\
\hline Newfoundland & Trappers Cove & 9 & $6 / 6 / 11$ & 0 & 0 & 1.0 & I A & n.r. & - & - & - & - & unk \\
\hline Newfoundland & West Bay - Port au Port & 27 & $6 / 8 / 11$ & 0 & 0 & 1.0 & I IV A D & n.r. & - & - & - & - & $\mathrm{s}(\mathrm{p})$ \\
\hline Newfoundland & Western Brook Beach & 22 & $6 / 9 / 11$ & 0 & 0 & 1.6 & I A & n.r. & 91 & 96 & 01 & 06 & $\mathrm{f}$ \\
\hline Newfoundland & Western Cove & 61 & $6 / 6 / 11$ & 0 & 0 & 1.6 & I A & n.r. & - & - & - & 06 & unk \\
\hline Newfoundland & Windmill Bight & 92 & $6 / 8 / 11$ & 0 & 0 & 0.7 & I A B & n.r. & - & - & 01 & 06 & $\mathrm{~s}(\mathrm{p})$ \\
\hline Total & & & & 22 & 53 & 126.1 & & & & & & & \\
\hline
\end{tabular}

Bold years indicate that adults were seen. Bold and underlined years indicate that pairs were seen.

${ }^{2}$ This total is the "high count"; since two surveys were conducted at some sites for the detectability study, this total includes the highest count at each site. 


\section{Recensement International du Pluvier Siffleur au Québec, en 2011}

\author{
François Shaffer \\ Canadian Wildlife Service \\ 801 - 1550, avenue d'Estimauville, \\ Québe, Québec G1J 0C3 \\ 418-649-6864 \\ francois.shaffer@ec.gc.ca
}

Toutes les plages des Îles-de-la-Madeleine ont été couvertes lors de l'inventaire de 2011, à l'exception de la plage de l'île Brion. Mis à part la plage de l'Ouest qui a été inventoriée le 7 juin, toutes les autres plages ont été visitées le 4 juin. Contrairement aux inventaires de 1991, 1996 et 2001, les plages de la Gaspésie n'ont pas été recensées. Compte tenu qu'aucun oiseau n'y avait été vu lors des trois premiers recensements, il ne nous apparaissait pas pertinent de couvrir ces plages. Pour ce qui est de la Côte-Nord, seulement trois plages ont été inventoriées. Ces plages n'avaient jamais été visitées lors des inventaires précédents.

Au total, 66 Pluviers siffleurs ont été dénombrés sur les 127 km de plages des Îles-de-laMadeleine parcourus par 25 participants. Tout comme en 2006, les plages de l'Hôpital et de la Dune du Sud totalisent plus de la moitié des pluviers observés $(56,1 \%)$.

Le nombre de Pluviers siffleurs dénombrés est supérieur à ce qui a été dénombré en 1991, 2001 et 2006, mais demeure inférieur aux résultats de 1996. La population de Pluviers siffleurs au Québec ne démontre par une tendance continue à la hausse malgré des efforts de conservation importants au cours des deux dernières décades.

\section{The 2011 International Piping Plover Breeding Census in Quebec}

All Magdalen Islands beaches were surveyed in 2011, except Brion Island beach. Apart from Plage de l'Ouest surveyed on June 7, all the other beaches were checked on June 4. Unlike surveys done in 1991, 1996, and 2001 beaches of the Gaspé Peninsula were not included in the 2011 survey. Taking into account that Piping Plovers were absent from those areas on the three years mentioned it did not appear essential to survey those beaches this year. Regarding the St.Lawrence River North Shore (Côte-Nord), only three beaches were surveyed. These beaches have never been visited in previous census.

A total of 66 Piping Plovers were counted on the $127 \mathrm{~km}$ (78.9 mile) stretch of Magdalen Island shoreline covered by 25 participants. Additionally, 3 beaches were surveyed in Northern Quebec as part of the Newfoundland effort but none had plovers. As in 2006, more than half $(56.1 \%)$ of the birds were observed on two beaches namely those referred to as Dune du Sud and Plage de l'Hôpital.

The number of birds counted is greater than in the 1991, 2001 and 2006 surveys but lower than in 1996. The Québec Piping Plover population does not show any evidence of steady rising trend despite important conservation efforts over the last two decades. 


\section{Comparaison de Nombres du Recensement/ Comparison of Census Numbers}

\begin{tabular}{|l|c|c|c|c|c|}
\hline & 1991 & 1996 & 2001 & 2006 & 2011 \\
\hline $\begin{array}{l}\text { Total } \\
\text { Adults }\end{array}$ & $61^{2}$ & $87^{2}$ & $55^{2}$ & $63^{1}$ & $66^{1}$ \\
\hline
\end{tabular}

${ }^{\mathrm{I}}$ This is the total from a single survey at each site; if more than one survey was conducted, we count only results from the first survey during the census window.

${ }^{2}$ These totals differ slightly from numbers reported in previous

Census reports. They represent totals from a single count.

Etude de Détectabilité/

Detectability Study

\begin{tabular}{|l|c|c|}
\hline \multicolumn{1}{|c|}{ Sites Included } & $\begin{array}{c}\text { First } \\
\text { Count }\end{array}$ & $\begin{array}{c}\text { Second } \\
\text { Count }\end{array}$ \\
\hline La Pointe et La Digue & 2 & 1 \\
\hline Pointe de la Grande-Entrée & 2 & 1 \\
\hline Sandy Hook & 5 & 1 \\
\hline
\end{tabular}







The 2011 International Piping Plover Breeding Census in Quebec

\begin{tabular}{|c|c|c|c|c|c|c|c|c|c|c|c|c|c|}
\hline REGION & SITE NAME & \multirow{2}{*}{$\frac{\text { MAP\# }}{15}$} & \multirow{2}{*}{$\begin{array}{c}\text { DATE } \\
6 / 15 / 11\end{array}$} & \multirow{2}{*}{$\begin{array}{c}\text { BREED- } \\
\text { ING } \\
\text { PAIRS } \\
0\end{array}$} & \multirow{2}{*}{ 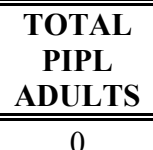 } & \multirow{2}{*}{$\frac{\mathbf{K M}}{1.0}$} & \multirow{2}{*}{$\begin{array}{l}\text { SITE } \\
\text { DESCRIPTION }\end{array}$} & \multirow{2}{*}{$\begin{array}{l}\text { DISTURBANCE } \\
\text { CONCERNS } \\
\mathrm{UV}\end{array}$} & \multicolumn{4}{|c|}{$\begin{array}{c}\text { PRIOR YEARS } \\
\text { CENSUSED \& YEARS } \\
\text { PIPL SEEN }^{1} \\
\end{array}$} & \multirow{2}{*}{$\begin{array}{c}\text { OWNER } \\
\mathrm{s}(\mathrm{p}), \mathrm{m}\end{array}$} \\
\hline Côte-Nord & Brador Beach & & & & & & & & - & - & 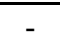 & - & \\
\hline Côte-Nord & L'Anse Morel & 17 & $6 / 15 / 11$ & 0 & 0 & 0.6 & I A & none & - & - & - & - & $\mathrm{s}(\mathrm{p}), \mathrm{m}$ \\
\hline Côte-Nord & Lourdes de Blanc Sablon & 16 & $6 / 15 / 11$ & 0 & 0 & 1.9 & I A & $\mathrm{H}$ & - & - & - & - & $\mathrm{s}(\mathrm{p}), \mathrm{m}$ \\
\hline Îles-de-la-Madeleine & Bassin aux Huîtres (Est) & 2 & $6 / 4 / 11$ & 2 & 2 & 1.7 & I E & n.r. & 91 & 96 & $\underline{01}$ & $\underline{06}$ & $\mathrm{~s}(\mathrm{p})$ \\
\hline Îles-de-la-Madeleine & Bassin aux Huitres (Ouest) & 3 & $6 / 4 / 11$ & 0 & 0 & 0.6 & I E & n.r. & 91 & $\underline{96}$ & 01 & 06 & $\mathrm{~s}(\mathrm{p})$ \\
\hline Îles-de-la-Madeleine & Dune du Bassin & 12 & $6 / 4 / 11$ & 0 & 1 & 3.2 & I E & n.r. & 91 & 96 & 01 & 06 & $\mathrm{~s}(\mathrm{p})$ \\
\hline Îles-de-la-Madeleine & Dune du Nord & 5 & $6 / 4 / 11$ & 0 & 0 & 16.0 & I E & n.r. & 91 & $\underline{96}$ & $\underline{01}$ & 06 & $\mathrm{~s}(\mathrm{p})$ \\
\hline Îles-de-la-Madeleine & Dune du Sud & 6 & $6 / 4 / 11$ & 8 & 21 & 22.0 & I II E & n.r. & 91 & $\underline{96}$ & $\underline{01}$ & $\underline{06}$ & $\mathrm{~s}(\mathrm{p})$ \\
\hline Îles-de-la-Madeleine & La Pointe et La Digue & 8 & $6 / 4 / 11$ & 1 & 2 & 3.0 & I E & S & 91 & $\underline{96}$ & 01 & $\overline{06}$ & $s(p), p$ \\
\hline Îles-de-la-Madeleine & $\begin{array}{l}\text { Les plages de Cap-aux- } \\
\text { Meules, L'Etang a Procul- } \\
\text { Bourgeois, et La Digue a } \\
\text { Fernand }\end{array}$ & 9 & $6 / 4 / 11$ & 0 & 0 & 3.5 & I E & n.r. & 91 & $\underline{96}$ & 01 & 06 & $\mathrm{~s}(\mathrm{p})$ \\
\hline Îles-de-la-Madeleine & Plage de l'Hôpital & 7 & $6 / 4 / 11$ & 5 & 16 & 18.0 & I E & n.r. & 91 & $\underline{96}$ & $\underline{01}$ & $\underline{06}$ & $\mathrm{~s}(\mathrm{p})$ \\
\hline Îles-de-la-Madeleine & Plage de l'Ouest & 10 & $6 / 4 / 11$ & 1 & 3 & 10.5 & I E & $\mathrm{V}$ & 91 & $\underline{96}$ & $\underline{01}$ & $\underline{06}$ & $\mathrm{~s}(\mathrm{p})$ \\
\hline Îles-de-la-Madeleine & Plage du Havre & 13 & $6 / 4 / 11$ & 0 & 1 & 4.5 & I E & n.r. & 91 & 96 & 01 & 06 & $\mathrm{~s}(\mathrm{p})$ \\
\hline Îles-de-la-Madeleine & $\begin{array}{l}\text { Plage Martinique-Havre } \\
\text { Aubert }\end{array}$ & 11 & $6 / 4 / 11$ & 2 & 8 & 13.0 & I II E & $\mathrm{V}$ & 91 & 96 & $\underline{01}$ & 06 & $\mathrm{~s}(\mathrm{p})$ \\
\hline Îles-de-la-Madeleine & Pointe de l'Est & 1 & $6 / 4 / 11$ & 1 & 5 & 19.0 & I E & $\mathrm{V}$ & 91 & $\underline{96}$ & 01 & $\underline{06}$ & $\mathrm{~s}(\mathrm{p})$ \\
\hline Îles-de-la-Madeleine & Pointe de la Grande-Entrée & 4 & $6 / 4 / 11$ & 1 & 2 & 1.0 & I E & n.r. & 91 & 96 & 01 & $\underline{06}$ & $\mathrm{~s}(\mathrm{p})$ \\
\hline Îles-de-la-Madeleine & Sandy Hook & 14 & $6 / 4 / 11$ & 1 & 5 & 11.0 & II E & n.r. & 91 & $\underline{96}$ & $\underline{01}$ & $\underline{06}$ & $\mathrm{~s}(\mathrm{p})$ \\
\hline Total & & & & 22 & 66 & 130.5 & & & & & & & \\
\hline
\end{tabular}

${ }^{1}$ Bold years indicate that adults were seen. Bold and underlined years indicate that pairs were seen. 


\section{The 2011 International Piping Plover Breeding Census in Nova Scotia}

\author{
Sue Abbott \\ Bird Studies Canada \\ 45 Alderney Drive \\ Dartmouth, NS B2Y 2N6 \\ sabbott@bsc-eoc.org \\ Karen Potter \\ Canadian Wildlife Service \\ Environment Canada \\ 45 Alderney Drive \\ Dartmouth, NS B2Y 2N6 \\ 902-426-2578 \\ Karen.Potter@ec.gc.ca
}

In Nova Scotia (NS), 128 out of 130 beach sites selected for census were surveyed by 36 individuals: 13 volunteers from Bird Studies Canada (BSC), and 23 staff from BSC, NS Department of Natural Resources (DNR), Environment Canada (EC), and Parks Canada Agency (PCA). Sites were selected for the 2011 census based on the 2006 census site list. Additionally we surveyed some potential habitat identified through annual surveys, local knowledge of volunteers and staff, and Google Earth aerial imagery. All selected sites were surveyed during the census period with the exception of two, which did not have suitable plover habitat: Little Harbour, Halifax County and Rafuse Island, Lunenburg County. We believe, therefore, that the 2011 census represents a comprehensive survey of Nova Scotia's potential suitable plover habitat.
Thirty sites were surveyed twice during the census period for the detectability study. Herein, we report results from all first surveys. A total of 92 adult plovers were observed at 31 of the 128 census sites in 2011 . This marks a 7\% increase in the total count since the 2006 census. Annual monitoring efforts in NS suggest an $18 \%$ increase in adults (sum of pairs and singles tallied annually at end of breeding season) between 2006 and 2011. Census results over the 20 year period between the first census in 1991 and 2011 indicate a 19\% decline in total adults.

Within Atlantic Canada and Québec, Piping Plovers in the Gulf of St. Lawrence region, including northern NS, are believed to be reproductively isolated from plovers in the southern NS (Atlantic Coast) region ${ }^{1}$. Of the 92 adults observed during the 2011 census, 64 $(70 \%)$ were located in southern NS and 28 $(30 \%)$ in northern NS. Regional proportions are equal to those of 2011 year-end population counts. The annual year-end count of 99 adults was higher than the census count. International Census counts are typically lower than year-end counts as some plovers arrive on NS beaches after the census survey period. In addition, the proportion of plover pairs is usually lower because of census timing and survey methodology. In 2011, 37 pairs were observed during the census representing $80 \%$ of total adults. This is lower than the $88 \%$ (SD 4\%) average observed in previous four census counts. Cold, wet weather in the 2011 spring and summer was likely a key factor explaining the higher proportion of singles relative to other census years. Fewer nest attempts and lower than average chick survival resulted in one of the lowest productivity rates on record (1.23 fledglings per monitored pair) for the province. The number of sites occupied by one or more adults (31) was the highest since 1991 (35).

\footnotetext{
${ }^{1}$ Amirault-Langlais, D.L., T.L. Imlay, and A.W. Boyne. Dispersal patterns suggest two breeding populations of Piping Plovers in Eastern Canada. The Wilson Journal of Ornithology, submitted.
} 
There was a net increase in occupation of four sites compared to 2006: eleven sites newly occupied (nine within southern NS) and seven no longer occupied (five within southern NS). Of the 31 occupied sites, 23 (74\%) supported one or more pairs. Since 2006, average number of sites occupied by pairs in NS was 24 (SD 2).

A coordinated team of skilled volunteers and partners were pivotal to the successful completion of the 2011 International Census. We thank participants for their time and effort in reaching far flung beaches from Cape Sable Island to Cape North.

\section{Comparison of Census Numbers}

\begin{tabular}{|l|c|c|c|c|c|}
\hline & 1991 & 1996 & 2001 & 2006 & 2011 \\
\hline $\begin{array}{l}\text { Total } \\
\text { Adults }\end{array}$ & 113 & 79 & 93 & $86^{1}$ & $92^{1}$ \\
\hline
\end{tabular}

${ }^{\text {I }}$ This is the total from a single survey at each site; if more than one survey was conducted, we count only results from the first survey during the census window.
Detectability Study

\begin{tabular}{|l|c|c|}
\hline \multicolumn{1}{|c|}{ Sites Included } & $\begin{array}{c}\text { First } \\
\text { Count }\end{array}$ & $\begin{array}{c}\text { Second } \\
\text { Count }\end{array}$ \\
\hline $\begin{array}{l}\text { Captain's Pond \& Monk's } \\
\text { Pond (Monk's Head) }\end{array}$ & 2 & 1 \\
\hline Dunns Beach & 0 & 0 \\
\hline Mahoney's Beach & 2 & 1 \\
\hline Pomquet Beach Park & 6 & 5 \\
\hline Dominion (Lingan) Beach & 0 & 0 \\
\hline Glace Bay Bar & 3 & 2 \\
\hline Shipping Point & 1 & 1 \\
\hline Hirtle's Beach & 0 & 0 \\
\hline Oxner's Beach & 0 & 0 \\
\hline $\begin{array}{l}\text { James Beach and Little } \\
\text { Harbour Spit }\end{array}$ & 0 & 2 \\
\hline $\begin{array}{l}\text { Pictou Bar Spit (Pictou } \\
\text { Landing, Lighthouse Beach) }\end{array}$ & 2 & 0 \\
\hline Beach Meadows Beach & 0 & 0 \\
\hline Little Port Joli Beach & 2 & 2 \\
\hline Port Joli, Goose Haven Beach & 2 & 0 \\
\hline Ragged Harbor Beach & 2 & 2 \\
\hline St. Catherine's Beach & 7 & 5 \\
\hline Summerville Beach & 0 & 0 \\
\hline Black Point Beach & 2 & 2 \\
\hline Crow Neck (Baccaro) & 11 & 12 \\
\hline Fox Bar Beach & 1 & 1 \\
\hline Goose Point & 1 & 1 \\
\hline Hawk Point & 1 & 0 \\
\hline Johnston's Pond Beach & 2 & 1 \\
\hline Louis Head Beach & & 4 \\
\hline Red Head Beach & 2 \\
\hline The Hawk Beach & 2 \\
\hline North Harbour Beach & 2 \\
\hline
\end{tabular}







The 2011 International Piping Plover Breeding Census in Nova Scotia

\begin{tabular}{|c|c|c|c|c|c|c|c|c|c|c|c|c|c|}
\hline \multirow{2}{*}{$\begin{array}{l}\text { REGION } \\
\text { Antigonish }\end{array}$} & SITE NAME & \multirow{2}{*}{ MAP\# } & \multirow{2}{*}{$\frac{\text { DATE }}{6 / 6 / 11}$} & \multirow{2}{*}{ 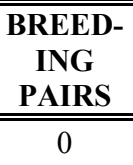 } & \multirow{2}{*}{ 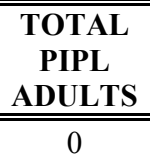 } & \multirow{2}{*}{$\frac{\mathbf{K M}}{1.1}$} & \multirow{2}{*}{$\begin{array}{l}\text { SITE } \\
\text { DESCRIPTION } \\
\text { I A B }\end{array}$} & \multirow{2}{*}{$\begin{array}{l}\text { DISTURBANCE } \\
\text { CONCERNS } \\
\mathrm{UV}\end{array}$} & \multicolumn{4}{|c|}{$\begin{array}{c}\text { PRIOR YEARS } \\
\text { CENSUSED \& YEARS } \\
\text { PIPL SEEN }^{1} \\
\end{array}$} & \multirow{2}{*}{$\begin{array}{c}\text { OWNER } \\
\mathrm{s}(\mathrm{p})\end{array}$} \\
\hline & Bayfield Beach & & & & & & & & 91 & 96 & 01 & 06 & \\
\hline Antigonish & $\begin{array}{l}\text { Captain's Pond \& Monk's Pond } \\
\text { (Monk's Head) }{ }^{2}\end{array}$ & 33 & $6 / 6 / 11$ & 1 & 2 & 1.2 & I B & $\mathrm{V}$ & 91 & $\underline{96}$ & 01 & 06 & $\mathrm{~s}(\mathrm{p})$ \\
\hline Antigonish & Dunns Beach & 32 & $6 / 6 / 11$ & 0 & 0 & 1.1 & I B & $\mathrm{V}$ & 91 & 96 & 01 & 06 & $\mathrm{~s}(\mathrm{p})$ \\
\hline Antigonish & Graham's Cove/ Ferry Road & 35 & $6 / 11 / 11$ & 0 & 0 & 1.0 & I A & $\mathrm{U}$ & 91 & 96 & 01 & - & $\mathrm{p}$ \\
\hline Antigonish & Jimtown & 30 & $6 / 17 / 11$ & 0 & 0 & 0.7 & II B & H D & - & 96 & - & 06 & $\mathrm{p}$ \\
\hline Antigonish & Linwood Beach & 40 & $6 / 8 / 11$ & 0 & 0 & 3.0 & II E & $\mathrm{V}$ & - & 96 & 01 & - & $\mathrm{p}$ \\
\hline Antigonish & Mahoney's Beach ${ }^{2}$ & 31 & $6 / 9 / 11$ & 0 & 2 & 1.4 & I B C & H D U & 91 & $\underline{96}$ & $\underline{01}$ & $\underline{06}$ & $\mathrm{p}$ \\
\hline Antigonish & Ogdens Pond Beach & 29 & $6 / 17 / 11$ & 0 & 0 & 1.0 & II B & H D & 91 & 96 & 01 & 06 & $\mathrm{p}$ \\
\hline Antigonish & Pomquet Beach Park ${ }^{2}$ & 34 & $6 / 9 / 11$ & 1 & 6 & 3.1 & I A & H D & $\underline{91}$ & $\underline{96}$ & $\underline{01}$ & $\underline{06}$ & $\mathrm{~s}(\mathrm{p})$ \\
\hline Antigonish & South Lakevale & 28 & $6 / 12 / 11$ & 0 & 0 & 0.5 & I A B & H U V & 91 & 96 & 01 & 06 & $\mathrm{p}$ \\
\hline Antigonish & $\begin{array}{l}\text { Tracadie Big Island/Delorey } \\
\text { Island }\end{array}$ & 39 & $6 / 8 / 11$ & 0 & 0 & 0.5 & I A I & U V & 91 & 96 & 01 & - & $\mathrm{p}$ \\
\hline Antigonish & Tracadie West Arm & 38 & $6 / 8 / 11$ & 0 & 0 & 0.7 & I B & U V & 91 & 96 & 01 & - & $\mathrm{p}$ \\
\hline Antigonish & Tracadie-West & 37 & $6 / 8 / 11$ & 0 & 0 & 1.0 & I C & UV S & - & - & - & - & $\mathrm{p}$ \\
\hline Cape Breton & Belfry Beach to Winging Point & 58 & $6 / 9 / 11$ & 0 & 0 & 3.0 & I A B & n.r. & - & - & 01 & - & $\mathrm{s}(\mathrm{p})$ \\
\hline Cape Breton & Dominion (Lingan) Beach & 53 & $6 / 8 / 11$ & 0 & 0 & 1.0 & I II A B & H U V & 91 & 96 & 01 & 06 & $\mathrm{~s}(\mathrm{p})$ \\
\hline Cape Breton & Glace Bay Bar ${ }^{2}$ & 54 & $6 / 9 / 11$ & 1 & 3 & 1.0 & I A B & H D V & 91 & 96 & 01 & $\underline{06}$ & $\mathrm{f}$ \\
\hline Cape Breton & Kennington Cove & 57 & $6 / 8 / 11$ & 0 & 0 & 0.1 & I II A & n.r. & 91 & 96 & - & - & $\mathrm{f}$ \\
\hline Cape Breton & Port Morien Beach & 56 & $6 / 13 / 11$ & 0 & 0 & 0.8 & I II A & n.r. & - & - & - & 06 & $\mathrm{p}$ \\
\hline Cape Breton & Schooner Pond Beach (Donkin) & 55 & $6 / 13 / 11$ & 0 & 0 & 0.0 & I A B & $\mathrm{S}$ & - & - & - & - & $\mathrm{p}$ \\
\hline Cape Breton & South Bar Beach & 52 & $6 / 21 / 11$ & 0 & 0 & 0.0 & I II A B & n.r. & 91 & 96 & 01 & 06 & $\mathrm{p}$ \\
\hline Colchester & Sand Point - Five Islands & 1 & $6 / 17 / 11$ & 0 & 0 & 0.3 & II B & n.r. & - & 96 & 01 & 06 & $\mathrm{p}$ \\
\hline Cumberland & Cameron Beach & 2 & $6 / 11 / 11$ & 0 & 0 & 0.0 & I A & S V & 91 & 96 & 01 & 06 & $\mathrm{p}$ \\
\hline Cumberland & Hortons Point (Beach) & 6 & $6 / 6 / 11$ & 0 & 0 & 1.3 & I E & $\mathrm{V}$ & 91 & 96 & 01 & 06 & $\mathrm{p}$ \\
\hline Cumberland & Long Point (Beach) & 5 & $6 / 11 / 11$ & 0 & 0 & 0.8 & I A & n.r. & 91 & 96 & 01 & 06 & $\mathrm{~s}(\mathrm{p})$ \\
\hline Cumberland & Oak Island Beach & 4 & $6 / 16 / 11$ & 0 & 0 & 1.2 & I C & n.r. & 91 & $\underline{96}$ & 01 & 06 & $\mathrm{p}$ \\
\hline Cumberland & Treen Point (Malagash Mines) & 7 & $6 / 6 / 11$ & 0 & 0 & 1.5 & I A & n.r. & 91 & $\overline{96}$ & 01 & 06 & $\mathrm{p}$ \\
\hline Cumberland & West Pugwash Beach & 3 & $6 / 5 / 11$ & 0 & 0 & 1.0 & I B & None & 91 & 96 & 01 & 06 & $\mathrm{p}$ \\
\hline Guysborough & Clam Pond & 68 & $6 / 11 / 11$ & 0 & 0 & 2.0 & I B & V U & 91 & 96 & - & - & $\mathrm{p}$ \\
\hline Guysborough & Ragged Head Pond & 67 & $6 / 11 / 11$ & 0 & 0 & 5.0 & I B & $\mathrm{V}$ & 91 & 96 & - & - & $\mathrm{s}(\mathrm{p})$ \\
\hline Guysborough & Tor Bay Provincial Park Beach & 69 & $6 / 11 / 11$ & 0 & 0 & 2.0 & I B & $\mathrm{O}$ & - & 96 & 01 & 06 & $\mathrm{~s}(\mathrm{p})$ \\
\hline Halifax & Bull Beach & 71 & $6 / 8 / 11$ & 0 & 0 & 0.9 & I A & n.r. & - & 96 & 01 & 06 & $\mathrm{~s}(\mathrm{p})$ \\
\hline Halifax & Clam Harbour Beach & 73 & $6 / 16 / 11$ & 0 & 0 & 3.0 & I A B & H D & 91 & 96 & 01 & 06 & $\mathrm{~s}(\mathrm{p})$ \\
\hline
\end{tabular}


The 2011 International Piping Plover Breeding Census in Nova Scotia (Continued)

\begin{tabular}{|c|c|c|c|c|c|c|c|c|c|c|c|c|c|}
\hline \multirow{2}{*}{$\begin{array}{l}\text { REGION } \\
\text { Halifax }\end{array}$} & \multirow{2}{*}{ 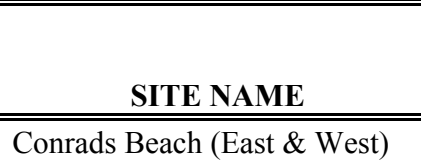 } & \multirow{2}{*}{ MAP\# } & \multirow{2}{*}{$\frac{\text { DATE }}{6 / 14 / 11}$} & \multirow{2}{*}{$\begin{array}{c}\text { BREED- } \\
\text { ING } \\
\text { PAIRS } \\
0\end{array}$} & \multirow{2}{*}{ 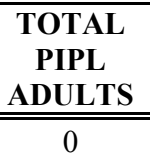 } & \multirow{2}{*}{$\frac{\mathbf{K M}}{2.0}$} & \multirow{2}{*}{$\begin{array}{l}\text { SITE } \\
\text { DESCRIPTION } \\
\text { I A }\end{array}$} & \multirow{2}{*}{$\begin{array}{l}\text { DISTURBANCE } \\
\text { CONCERNS } \\
\text { H D }\end{array}$} & \multicolumn{4}{|c|}{$\begin{array}{c}\text { PRIOR YEARS } \\
\text { CENSUSED \& YEARS }^{\text {PIPL SEEN }}{ }^{1} \\
\text { PIPL }^{-}\end{array}$} & \multirow{2}{*}{$\frac{\text { OWNER }}{\mathrm{s}(\mathrm{p}), \mathrm{p}}$} \\
\hline & & & & & & & & & 91 & 96 & 01 & 06 & \\
\hline Halifax & Conrods's Beach & 76 & $6 / 16 / 11$ & 0 & 0 & 1.5 & II A & H F V & $\underline{91}$ & $\underline{96}$ & 01 & - & $\mathrm{p}$ \\
\hline Halifax & Cow Bay Beach (Silver Sands) & 83 & $6 / 14 / 11$ & 0 & 0 & 1.0 & I B & $\mathrm{V}$ & 91 & $\overrightarrow{96}$ & 01 & - & $\mathrm{m}$ \\
\hline Halifax & Lawrencetown Beach & 78 & $6 / 14 / 11$ & 0 & 0 & 0.3 & I A & $\mathrm{H} \mathrm{U}$ & - & 96 & 01 & 06 & $s(p), p$ \\
\hline Halifax & Long/Meiser's Beach & 77 & $6 / 17 / 11$ & 0 & 0 & 0.9 & I B & n.r. & - & 96 & 01 & - & $s(p)$ \\
\hline Halifax & Martinique Beach & 75 & $6 / 10 / 11$ & 0 & 1 & 3.5 & I B & $\mathrm{V}$ & $\underline{91}$ & 96 & $\underline{01}$ & $\underline{06}$ & $\mathrm{~s}(\mathrm{p})$ \\
\hline Halifax & $\begin{array}{l}\text { Maugher's Beach, McNabs } \\
\text { Island }\end{array}$ & 84 & $6 / 17 / 11$ & 0 & 0 & 1.5 & I II D E & n.r. & 91 & 96 & $\overline{01}$ & $\overline{06}$ & $s(p)$ \\
\hline Halifax & $\begin{array}{l}\text { McCormack's Beach (Eastern } \\
\text { Passage) }\end{array}$ & 82 & $6 / 14 / 11$ & 0 & 0 & 0.2 & II D & $\mathrm{HU}$ & - & 96 & 01 & - & $s(p)$ \\
\hline Halifax & $\begin{array}{l}\text { Rainbow Haven Beach (Cole } \\
\text { Harbour) }\end{array}$ & 81 & $6 / 14 / 11$ & 0 & 0 & 1.8 & I A & $\mathrm{HU}$ & 91 & 96 & 01 & 06 & $\mathrm{~s}(\mathrm{p})$ \\
\hline Halifax & Sober Island / Red Cliff & 70 & $6 / 8 / 11$ & 0 & 0 & 0.0 & I D & n.r. & - & - & - & - & $\mathrm{p}$ \\
\hline Halifax & $\begin{array}{l}\text { Stoney Beach (Lawrencetown } \\
\text { Head) }\end{array}$ & 79 & $6 / 14 / 11$ & 0 & 0 & 0.5 & I A & $\mathrm{H} \mathrm{U}$ & $\underline{91}$ & 96 & 01 & 06 & $s(p)$ \\
\hline Halifax & Taylor Head Beach & 72 & $6 / 8 / 11$ & 0 & 0 & 1.2 & I A D & n.r. & 91 & 96 & 01 & 06 & $\mathrm{~s}(\mathrm{p})$ \\
\hline Halifax & West March / Seapool Beach & 74 & $6 / 16 / 11$ & 0 & 0 & 1.3 & I A & H D U & 91 & 96 & 01 & 06 & $\mathrm{p}$ \\
\hline Inverness & Belle Cote Beach & 48 & $6 / 7 / 01$ & 0 & 0 & 0.0 & I A B & S & - & - & - & 06 & $\mathrm{~s}(\mathrm{p})$ \\
\hline Inverness & Big Rory's Point/Emerson Point & 41 & $6 / 15 / 11$ & 0 & 0 & 0.5 & I A B & n.r. & 91 & 96 & 01 & 06 & $\mathrm{p}$ \\
\hline Inverness & Colindale Beach & 44 & $6 / 8 / 11$ & 0 & 0 & 0.5 & I II A D & n.r. & 91 & 96 & 01 & 06 & $\mathrm{p}$ \\
\hline Inverness & Inverness Beach & 47 & $6 / 7 / 11$ & 0 & 0 & 3.7 & I A B & $\mathrm{UN}$ & - & - & - & 06 & $\mathrm{p}$ \\
\hline Inverness & Little Judique Harbour & 42 & $6 / 9 / 11$ & 0 & 0 & 1.4 & I A & n.r. & 91 & 96 & 01 & 06 & $\mathrm{p}$ \\
\hline Inverness & Margaree Harbour Beach & 46 & $6 / 7 / 11$ & 0 & 0 & 0.4 & I A B & None & - & - & - & 06 & $\mathrm{p}$ \\
\hline Inverness & Shipping Point & 43 & $6 / 8 / 11$ & 0 & 1 & 1.8 & I A & $\mathrm{V}$ & 91 & 96 & 01 & $\underline{06}$ & $\mathrm{p}$ \\
\hline Inverness & South West Mabou Beach & 45 & $6 / 8 / 11$ & 2 & 4 & 1.8 & I A B & None & - & - & 01 & $\underline{06}$ & $\mathrm{~s}(\mathrm{p})$ \\
\hline Lunenburg & Bayswater & 85 & $6 / 10 / 11$ & 0 & 0 & 0.6 & I A & H D U & 91 & 96 & 01 & - & $\mathrm{s}(\mathrm{p})$ \\
\hline Lunenburg & Cape Bay Beach & 91 & $6 / 16 / 11$ & 1 & 2 & 1.0 & I E & $\mathrm{H}$ & $\underline{91}$ & $\underline{96}$ & 01 & $\underline{06}$ & $s(p)$ \\
\hline Lunenburg & Cherry Hill Beach & 93 & $6 / 7 / 11$ & 3 & 7 & 2.5 & I B & D V & $\underline{91}$ & 96 & $\underline{01}$ & $\underline{06}$ & $\mathrm{~s}(\mathrm{p})$ \\
\hline Lunenburg & Conrad Island Causeway & 86 & $6 / 15 / 11$ & 0 & 0 & 1.5 & I II A D F I & H D & - & - & - & - & $\mathrm{s}(\mathrm{p}), \mathrm{p}$ \\
\hline Lunenburg & Green Bay & 92 & $6 / 7 / 11$ & 0 & 0 & 0.8 & I A & H D S U & - & - & - & - & $\mathrm{p}$ \\
\hline Lunenburg & $\begin{array}{l}\text { Halibut Bay, Cape LaHave } \\
\text { Island }\end{array}$ & 90 & $6 / 16 / 11$ & 0 & 0 & 0.8 & I E & n.r. & 91 & 96 & 01 & - & $s(p)$ \\
\hline Lunenburg & Hirtle's Beach & 88 & $6 / 15 / 11$ & 0 & 0 & 3.3 & I A B & H D U & 91 & 96 & 01 & 06 & $\mathrm{~s}(\mathrm{p}), \mathrm{m}, \mathrm{p}$ \\
\hline Lunenburg & Kingsburg Beach & 87 & $6 / 15 / 11$ & 0 & 0 & 1.9 & I II A D & $\mathrm{U}$ & - & 96 & 01 & 06 & $\mathrm{~s}(\mathrm{p}), \mathrm{p}$ \\
\hline
\end{tabular}


The 2011 International Piping Plover Breeding Census in Nova Scotia (Continued)

\begin{tabular}{|c|c|c|c|c|c|c|c|c|c|c|c|c|c|}
\hline \multirow{2}{*}{$\begin{array}{l}\text { REGION } \\
\text { Lunenburg }\end{array}$} & \multirow{2}{*}{$\begin{array}{r}\text { SITE NAME } \\
\text { Oxner's Beach }\end{array}$} & \multirow{2}{*}{ MAP\# } & \multirow{2}{*}{$\begin{array}{c}\text { DATE } \\
6 / 15 / 11\end{array}$} & \multirow{2}{*}{ 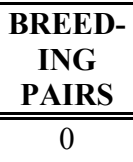 } & \multirow{2}{*}{ 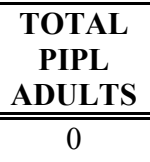 } & \multirow{2}{*}{$\begin{array}{c}\text { KM } \\
1.1\end{array}$} & \multirow{2}{*}{$\begin{array}{l}\text { SITE } \\
\text { DESCRIPTION } \\
\text { I II A D }\end{array}$} & \multirow{2}{*}{$\begin{array}{l}\text { DISTURBANCE } \\
\text { CONCERNS } \\
\text { H D }\end{array}$} & \multicolumn{4}{|c|}{$\begin{array}{c}\text { PRIOR YEARS } \\
\text { CENSUSED \& YEARS }^{\text {PIPL SEEN }}{ }^{1} \\
\text { PIPL }^{-}\end{array}$} & \multirow{2}{*}{$\frac{\text { OWNER }}{\mathrm{s}(\mathrm{p}), \mathrm{p}}$} \\
\hline & & & & & & & & & - & - & $\underline{01}$ & 06 & \\
\hline Pictou & Big Merigomish Island Beach & 27 & $6 / 13 / 11$ & 0 & 0 & 5.0 & I B F & S U & 91 & 96 & 01 & 06 & $\mathrm{p}$ \\
\hline Pictou & Bowen Island & 23 & $6 / 12 / 11$ & 0 & 0 & 0.1 & II C & None & $\underline{91}$ & 96 & $\underline{01}$ & 06 & $\mathrm{p}$ \\
\hline Pictou & Cape John, Megs Cove & 9 & $6 / 9 / 11$ & 0 & 0 & 0.8 & I A & S V & - & - & 01 & 06 & $\mathrm{p}$ \\
\hline Pictou & $\begin{array}{l}\text { Caribou Island, Black Point to } \\
\text { Hawksbill Point }\end{array}$ & 12 & $6 / 9 / 11$ & 0 & 0 & 1.0 & I C & H D & - & 96 & 01 & - & $\mathrm{p}$ \\
\hline Pictou & Caribou Island, Caribou Reef & 13 & $6 / 9 / 11$ & 0 & 0 & 1.2 & I C & $\mathrm{H}$ & 91 & 96 & 01 & 06 & $\mathrm{p}$ \\
\hline Pictou & Caribou Island, Narrows & 11 & $6 / 9 / 11$ & 0 & 0 & 0.5 & I C & S V & - & - & 01 & - & $\mathrm{p}$ \\
\hline Pictou & Chance Harbour Beach & 20 & $6 / 14 / 11$ & 0 & 0 & 0.0 & I A & U V & - & 96 & 01 & 06 & $\mathrm{p}$ \\
\hline Pictou & $\begin{array}{l}\text { James Beach and Little Harbour } \\
\text { Spit }^{2}\end{array}$ & 22 & $6 / 14 / 11$ & 1 & 2 & 0.7 & II A & $\mathrm{U}$ & 91 & 96 & 01 & $\underline{06}$ & $\mathrm{p}$ \\
\hline Pictou & Kings Head (Chisholm Beach) & 25 & $6 / 10 / 11$ & 0 & 0 & 0.5 & II A & n.r. & 91 & 96 & 01 & 06 & $\mathrm{p}$ \\
\hline Pictou & Melmerbey Beach & 24 & $6 / 10 / 11$ & 0 & 0 & 2.2 & I A B & $\mathrm{H} \mathrm{V} \mathrm{S}$ & 91 & 96 & 01 & $\underline{06}$ & $\mathrm{~s}(\mathrm{p})$ \\
\hline Pictou & Murray Beach, Rushtons Park & 8 & $6 / 7 / 11$ & 0 & 0 & 2.5 & I A & S U & 91 & 96 & 01 & 06 & $\mathrm{~s}(\mathrm{p})$ \\
\hline Pictou & $\begin{array}{l}\text { Pictou Bar Spit (Pictou } \\
\text { Landing, Lighthouse Beach }\end{array}$ & 19 & $6 / 14 / 11$ & 1 & 2 & 1.5 & I A & D V S & 91 & 96 & 01 & 06 & $\mathrm{~s}(\mathrm{p}), \mathrm{p}$ \\
\hline Pictou & Pictou Island (East end) & 17 & $6 / 10 / 11$ & 0 & 0 & 0.5 & I E & n.r. & - & - & 01 & 06 & $\mathrm{p}$ \\
\hline Pictou & Pictou Island (West end) & 14 & $6 / 10 / 11$ & 0 & 0 & 0.2 & I E & $\mathrm{H}$ & - & - & 01 & - & $\mathrm{p}$ \\
\hline Pictou & Pictou Island John Dans Cove & 16 & $6 / 10 / 11$ & 0 & 0 & 0.7 & I E & $\mathrm{V}$ & - & - & 01 & 06 & $\mathrm{p}$ \\
\hline Pictou & Roger Point, Pictou Island & 18 & $6 / 10 / 11$ & 0 & 0 & 1.5 & I E & $\mathrm{H}$ & - & - & 01 & 06 & $\mathrm{p}$ \\
\hline Pictou & $\begin{array}{l}\text { Savage Point, Big Merigomish } \\
\text { Island }\end{array}$ & 26 & $6 / 13 / 11$ & 0 & 0 & 0.4 & II B & n.r. & 91 & 96 & 01 & 06 & $\mathrm{p}$ \\
\hline Pictou & Sinclair's Island & 21 & $6 / 12 / 11$ & 0 & 0 & 0.8 & I A & None & 91 & 96 & 01 & 06 & $\mathrm{p}$ \\
\hline Pictou & Waterside Beach & 10 & $6 / 9 / 11$ & 0 & 0 & 1.4 & I C & n.r. & - & - & 01 & 06 & $\mathrm{~s}(\mathrm{p})$ \\
\hline Pictou & Wharf Beach, Pictou Island & 15 & $6 / 10 / 11$ & 0 & 0 & 0.3 & I E & $\mathrm{U}$ & - & - & 01 & - & $\mathrm{p}$ \\
\hline Queens & $\begin{array}{l}\text { Back Beach, Port Mouton } \\
\text { Island }\end{array}$ & 97 & $6 / 17 / 11$ & 1 & 2 & 0.5 & II E & None & 91 & 96 & 01 & 06 & $\mathrm{p}$ \\
\hline Queens & Beach Meadows Beach & 95 & $6 / 16 / 11$ & 0 & 0 & 1.1 & I A & $\mathrm{U}$ & $\underline{91}$ & 96 & 01 & 06 & $\mathrm{~m}$ \\
\hline Queens & Carter's/Wobamkek Beach & 98 & $6 / 17 / 11$ & 1 & 2 & 1.1 & II A & $\mathrm{H}$ & $\underline{91}$ & $\underline{96}$ & 01 & 06 & $\mathrm{~s}(\mathrm{p})$ \\
\hline Queens & Cranberry Pond & 99 & $6 / 17 / 11$ & 0 & 0 & 0.8 & II A & H V U & $\underline{91}$ & $\underline{96}$ & - & 06 & $\mathrm{p}$ \\
\hline Queens & Little Port Joli Beach ${ }^{2}$ & 100 & $6 / 16 / 11$ & 1 & 2 & 1.5 & I B & n.r. & $\underline{91}$ & $\overline{96}$ & 01 & 06 & $\mathrm{f}$ \\
\hline Queens & Port Joli, Durham Lane Beach & 102 & $6 / 9 / 11$ & 0 & 1 & 0.4 & I II A & n.r. & - & - & - & - & $\mathrm{p}$ \\
\hline Queens & Port Joli, Goose Haven Beach ${ }^{2}$ & 103 & $6 / 6 / 11$ & 1 & 2 & 0.4 & II A D & n.r. & $\underline{91}$ & 96 & 01 & 06 & $\mathrm{p}$ \\
\hline Queens & Ragged Harbor Beach & 94 & $6 / 9 / 11$ & 1 & 2 & 1.6 & I A & None & 91 & $\underline{96}$ & $\underline{01}$ & 06 & $\mathrm{p}$ \\
\hline Queens & Sandy Bay Beach & 104 & $6 / 17 / 11$ & 1 & 2 & 1.2 & I A & None & $\underline{91}$ & $\underline{96}$ & 01 & 06 & $\mathrm{~s}(\mathrm{p}), \mathrm{p}$ \\
\hline Queens & St. Catherine's Beach ${ }^{2}$ & 101 & $6 / 8 / 11$ & 3 & 7 & 2.0 & I B & n.r. & $\overline{91}$ & $\underline{\overline{96}}$ & $\underline{01}$ & $\underline{06}$ & $\mathrm{f}$ \\
\hline
\end{tabular}


The 2011 International Piping Plover Breeding Census in Nova Scotia (Continued)

\begin{tabular}{|c|c|c|c|c|c|c|c|c|c|c|c|c|c|}
\hline \multirow{2}{*}{$\begin{array}{l}\text { REGION } \\
\text { Queens }\end{array}$} & \multirow{2}{*}{$\begin{array}{c}\text { SITE NAME } \\
\text { Summerville Beach }\end{array}$} & \multirow{2}{*}{$\begin{array}{c}\text { МАР\# } \\
96\end{array}$} & \multirow{2}{*}{$\frac{\text { DATE }}{6 / 8 / 11}$} & \multirow{2}{*}{$\begin{array}{c}\begin{array}{c}\text { BREED- } \\
\text { ING } \\
\text { PAIRS }\end{array} \\
0\end{array}$} & \multirow{2}{*}{$\begin{array}{c}\text { TOTAL } \\
\text { PIPL } \\
\text { ADULTS } \\
0\end{array}$} & \multirow{2}{*}{$\frac{\mathbf{K M}}{1.1}$} & \multirow{2}{*}{$\begin{array}{l}\text { SITE } \\
\text { DESCRIPTION } \\
\text { II B }\end{array}$} & \multirow{2}{*}{$\begin{array}{l}\text { DISTURBANCE } \\
\text { CONCERNS } \\
\text { n.r. }\end{array}$} & \multicolumn{4}{|c|}{$\begin{array}{c}\text { PRIOR YEARS } \\
\text { CENSUSED \& YEARS } \\
\text { PIPL SEEN }^{1} \\
\end{array}$} & \multirow{2}{*}{$\begin{array}{c}\text { OWNER } \\
\mathrm{s}(\mathrm{p})\end{array}$} \\
\hline & & & & & & & & & 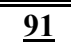 & 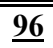 & $\overline{\underline{01}}$ & "06 & \\
\hline Richmond & Crossroads/L'Ardoise Beach & 62 & $6 / 14 / 11$ & 0 & 0 & 3.5 & I A & n.r. & - & - & 01 & - & $\mathrm{p}$ \\
\hline Richmond & Grand Greve Beach & 64 & $6 / 12 / 11$ & 0 & 0 & 0.8 & I B & n.r. & - & - & 01 & - & $\mathrm{p}$ \\
\hline Richmond & Morrison Beach, Framboise & 59 & $6 / 13 / 11$ & 0 & 0 & 3.3 & I B & $\mathrm{V}$ & & - & 01 & - & $\mathrm{s}(\mathrm{p}), \mathrm{p}$ \\
\hline Richmond & Point Michaud Beach & 60 & $6 / 13 / 11$ & 0 & 0 & 2.5 & I A E & $\mathrm{V}$ & - & - & 01 & - & $\mathrm{s}(\mathrm{p})$ \\
\hline Richmond & Pondville Beach & 66 & $6 / 12 / 11$ & 0 & 0 & 0.8 & I B & n.r. & - & - & 01 & - & $\mathrm{s}(\mathrm{p})$ \\
\hline Richmond & Rear Point Michaud Beach & 61 & $6 / 13 / 11$ & 0 & 0 & 2.0 & I A E & $\mathrm{V}$ & - & - & 01 & - & $\mathrm{p}$ \\
\hline Richmond & Rockdale beach & 63 & $6 / 12 / 11$ & 0 & 0 & 1.5 & I A & $\mathrm{H} \mathrm{V} \mathrm{U}$ & - & - & 01 & - & $\mathrm{p}$ \\
\hline Richmond & Rocky Bay Beach & 65 & $6 / 12 / 11$ & 0 & 0 & 0.8 & I A & $\mathrm{U}$ & - & - & 01 & - & $\mathrm{p}$ \\
\hline Shelburne & Black Point Beach & 107 & $6 / 8 / 11$ & 1 & 2 & 1.0 & I A B & n.r. & $\underline{91}$ & 96 & 01 & 06 & $\mathrm{p}$ \\
\hline Shelburne & Blanche Pointe & 113 & $6 / 12 / 11$ & 0 & 0 & 0.0 & I B & n.r. & $\overline{91}$ & 96 & 01 & - & $\mathrm{p}$ \\
\hline Shelburne & Bull's Head & 120 & $6 / 16 / 11$ & 0 & 0 & 0.8 & I A & $\mathrm{V}$ & - & $\underline{96}$ & - & 06 & $\mathrm{p}$ \\
\hline Shelburne & Burk's Point & 115 & $6 / 16 / 11$ & 0 & 0 & 1.5 & I A & None & 91 & $\overline{96}$ & 01 & $\underline{06}$ & $\mathrm{p}$ \\
\hline Shelburne & Clam Point & 119 & $6 / 16 / 11$ & 0 & 0 & 0.9 & I A & None & $\underline{91}$ & 96 & $\underline{01}$ & $\overline{06}$ & $\mathrm{~s}(\mathrm{p})$ \\
\hline Shelburne & Cranes Point & 109 & $6 / 17 / 11$ & 0 & 0 & 2.3 & I A & None & - & - & - & - & $\mathrm{p}$ \\
\hline Shelburne & Crescent Beach & 108 & $6 / 4 / 11$ & 0 & 0 & 0.8 & I A B & H D U & 91 & 96 & 01 & $\underline{06}$ & $\mathrm{~m}$ \\
\hline Shelburne & Crow Neck (Baccaro ${ }^{2}$ & 114 & $6 / 13 / 11$ & 5 & 12 & 3.0 & I A & $\mathrm{V}$ & $\underline{91}$ & $\underline{96}$ & $\underline{01}$ & $\underline{06}$ & $\mathrm{~s}(\mathrm{p}), \mathrm{p}$ \\
\hline Shelburne & Daniels Head/ Southside & 122 & $6 / 8 / 11$ & 1 & 3 & 2.7 & I A & None & $\overline{91}$ & $\underline{96}$ & $\overline{01}$ & $\underline{06}$ & $\mathrm{p}$ \\
\hline Shelburne & Fish Island & 127 & $6 / 17 / 11$ & 0 & 0 & 0.8 & I E & None & - & & 01 & - & $\mathrm{s}(\mathrm{p})$ \\
\hline Shelburne & Fox Bar Beach & 110 & $6 / 7 / 11$ & 0 & 1 & 3.1 & I A & $\mathrm{V}$ & $\underline{91}$ & $\underline{96}$ & $\underline{01}$ & $\underline{06}$ & $\mathrm{p}$ \\
\hline Shelburne & Goose Point & 116 & $6 / 16 / 11$ & 0 & 1 & 1.2 & I A & None & 91 & 96 & 01 & 06 & $\mathrm{p}$ \\
\hline Shelburne & Hawk Point ${ }^{2}$ & 124 & $6 / 6 / 11$ & 1 & 2 & 1.6 & I A & None & 91 & 96 & 01 & $\underline{06}$ & $\mathrm{p}$ \\
\hline Shelburne & Johnston's Pond Beach ${ }^{2}$ & 105 & $6 / 6 / 11$ & 1 & 2 & 1.0 & I A B & None & $\underline{91}$ & $\underline{96}$ & $\underline{01}$ & $\overline{\mathbf{0 6}}$ & $\mathrm{s}(\mathrm{p})$ \\
\hline Shelburne & Louis Head Beach & 106 & $6 / 4 / 11$ & 0 & 1 & 1.8 & I A & $\mathrm{U}$ & $\underline{91}$ & $\underline{96}$ & 01 & $\underline{06}$ & $\mathrm{~s}(\mathrm{p}), \mathrm{p}$ \\
\hline Shelburne & North East Point Beach & 118 & $6 / 6 / 11$ & 0 & 0 & 1.1 & I A & $\mathrm{H}$ & $\underline{91}$ & $\overline{96}$ & 01 & $\overline{06}$ & $\mathrm{p}$ \\
\hline Shelburne & Ratcliffe Hills Beach & 126 & $6 / 17 / 11$ & 0 & 0 & 1.1 & I E & None & - & - & 01 & - & $\mathrm{s}(\mathrm{p}), \mathrm{p}$ \\
\hline Shelburne & Red Head Beach & 112 & $6 / 7 / 11$ & 2 & 4 & 2.6 & I A & $\mathrm{V}$ & $\underline{91}$ & 96 & $\underline{01}$ & $\underline{06}$ & $\mathrm{p}$ \\
\hline Shelburne & Round Bay & 111 & $6 / 7 / 11$ & 1 & 2 & 3.0 & I A & n.r. & $\underline{91}$ & $\underline{96}$ & $\underline{01}$ & 06 & $\mathrm{~s}(\mathrm{p}), \mathrm{p}$ \\
\hline Shelburne & $\begin{array}{l}\text { Sand Hills Beach (Sebim } \\
\text { Beach) }\end{array}$ & 117 & $6 / 6 / 11$ & 3 & 6 & 2.3 & I A & n.r. & $\underline{91}$ & $\overline{96}$ & $\underline{01}$ & $\underline{06}$ & $\mathrm{~s}(\mathrm{p})$ \\
\hline Shelburne & Stoney Island & 121 & $6 / 6 / 11$ & 0 & 0 & 3.0 & I A & $\mathrm{V}$ & 91 & 96 & $\underline{01}$ & $\underline{06}$ & $\mathrm{p}$ \\
\hline Shelburne & The Cape, Inner Beach & 125 & $6 / 17 / 11$ & 0 & 0 & 2.8 & I E & $\mathrm{S}$ & 91 & 96 & 01 & - & $\mathrm{s}(\mathrm{p})$ \\
\hline Shelburne & The Hawk Beach & 123 & $6 / 6 / 11$ & 0 & 0 & 2.1 & I A & None & 91 & $\underline{96}$ & $\underline{01}$ & 06 & $\mathrm{p}$ \\
\hline
\end{tabular}


The 2011 International Piping Plover Breeding Census in Nova Scotia (Continued)

\begin{tabular}{|c|c|c|c|c|c|c|c|c|c|c|c|c|c|}
\hline REGION & SITE NAME & MAP\# & DATE & $\begin{array}{c}\text { BREED- } \\
\text { ING } \\
\text { PAIRS } \\
\end{array}$ & $\begin{array}{c}\text { TOTAL } \\
\text { PIPL } \\
\text { ADULTS } \\
\end{array}$ & $\mathbf{K M}$ & $\begin{array}{l}\text { SITE } \\
\text { DESCRIPTION } \\
\end{array}$ & $\begin{array}{l}\text { DISTURBANCE } \\
\text { CONCERNS } \\
\end{array}$ & \multicolumn{4}{|c|}{$\begin{array}{c}\text { PRIOR YEARS } \\
\text { CENSUSED \& YEARS }^{\text {PIPL SEEN }}{ }^{1}\end{array}$} & \multirow{2}{*}{$\frac{\text { OWNER }}{\mathrm{p}}$} \\
\hline Victoria & Middle Harbour Beach & 50 & $6 / 7 / 11$ & 0 & $\overline{0}$ & 0.8 & I A B & n.r. & - & - & - & - & \\
\hline Victoria & North Harbour Beach & 49 & $6 / 9 / 11$ & 1 & 2 & 5.0 & I A B & $\mathrm{V}$ & 91 & 96 & 01 & 06 & $\mathrm{~s}(\mathrm{p}), \mathrm{p}$ \\
\hline Victoria & South Harbour Beach & 51 & $6 / 9 / 11$ & 3 & 6 & 2.5 & I A B & None & 91 & $\underline{96}$ & $\underline{01}$ & $\underline{06}$ & $s(p), p$ \\
\hline Total & & & & 39 & 96 & 383.5 & & & & & & & \\
\hline
\end{tabular}

Bold years indicate that adults were seen. Bold and underlined years indicate that pairs were seen.

2 This total is the "high count"; since two surveys were conducted at some sites for the detectability study, this total includes the highest count at each site. 


\section{The 2011 International Piping Plover Breeding Census on Prince Edward Island}

\author{
Jen Rock \\ Canadian Wildlife Service \\ Environment Canada \\ 17 Waterfowl Lane \\ Sackville, NB E4L $1 \mathrm{G} 6$ \\ 506-364-5078 \\ jen.rock@ec.gc.ca
}

In Prince Edward Island 76 beaches ${ }^{1}$ were surveyed by 18 volunteers and staff from Island Nature Trust, Parks Canada and the Prince Edward Island government. The 2011 beach list was based on sites visited during the last census (2006) and it included all known sites with suitable plover habitat. All beaches on the list were surveyed apart from Poverty Island which was missed because of logistics involved with accessing the site.

No new areas were identified for future consideration but because of the potential for winter storms to change coastal habitat in Prince Edward Island, new sites should always be considered, especially in years with significant winter weather events.

A total of 67 Piping Plovers were counted on 21 beaches in Prince Edward Island during the breeding census, including 29 pairs and 9 singles. The 2011 population on Prince Edward Island is low compared to recent census years and the decline observed since the 2006 census is consistent with trends observed from annual year-end population totals.
Census results are considered representative of the actual population in Prince Edward Island but are a slight underestimate the actual total. Detection of birds can be a challenge and on average ( \pm SD) Prince Edward Island census counts have represented $91 \pm 7 \%$ of the estimated year-end population totals.

Predation, adverse weather and human disturbance (e.g., vehicle traffic and dogs on beaches) are likely the biggest factors affecting Piping Plover numbers during the breeding season on Prince Edward Island. Population declines on the Island may be attributed to successive years of low productivity with many eggs lost before hatch (due to predation and floods).

The distribution of birds on Prince Edward Island has changed over the past 20 years, with a shift from west to east and a significant decrease in the proportion of Prince Edward Island birds located in the National Park (located approximately in the center of the island's north coast). West coast beaches are subject to considerable off-highway vehicle traffic, which may explain why fewer birds are now found at these sites. Declines of breeding birds in the National Park (supporting 50\% of pairs in 1991 and $<20 \%$ in 2011) may be explained by the popularity of National Park beaches for dog walking (a prohibited activity) or by elevated predation. However, reason for the decline in Prince Edward Island National Park is poorly understood at this time. Low survival of post fledgling chicks and adults during the non-breeding season may also be factors contributing to declines in the Prince Edward Island population. Conservation groups, provincial and federal governments are working together to identify and address threats.

\footnotetext{
${ }^{1}$ In some cases the number of sites does not exactly match the number of beaches. Beaches were sometimes split or combined based on how they were surveyed in this and/or prior censuses.
} 
Comparison of Census Numbers

\begin{tabular}{|l|c|c|c|c|c|}
\hline & 1991 & 1996 & 2001 & 2006 & 2011 \\
\hline $\begin{array}{l}\text { Total } \\
\text { Adults }\end{array}$ & 110 & 66 & 112 & $93^{1}$ & $67^{1}$ \\
\hline
\end{tabular}

${ }^{\text {I }}$ This is the total from a single survey at each site; if more than one survey was conducted, we count only results from the first survey during the census window.

\section{Detectability Study}

\begin{tabular}{|l|c|c|}
\hline \multicolumn{1}{|c|}{ Sites Included } & $\begin{array}{c}\text { First } \\
\text { Count }\end{array}$ & $\begin{array}{c}\text { Second } \\
\text { Count }\end{array}$ \\
\hline Basin Head (Bothwell) & 1 & 0 \\
\hline Boughton Island & 3 & 2 \\
\hline Eglington Cove & 4 & 2 \\
\hline Lake Run (Saint Peter's) & 6 & 6 \\
\hline North Rustico Sandbar & 6 & 6 \\
\hline Panmure Island & 2 & 2 \\
\hline Saint Peter's Harbour & 0 & 0 \\
\hline South Lake & 2 & 3 \\
\hline Spry Cove/ Sally's Beach & 0 & 0 \\
\hline Tracadie Sandbar & 0 & 0 \\
\hline Wood Islands & 6 & 6 \\
\hline Covehead Harbour West & 0 & 0 \\
\hline Robinson's Island Sandspit & 0 & 3 \\
\hline Rustico Causeway & 2 & 2 \\
\hline $\begin{array}{l}\text { Tracadie Beach to Covehead } \\
\text { Harbour }\end{array}$ & 0 & 0 \\
\hline
\end{tabular}




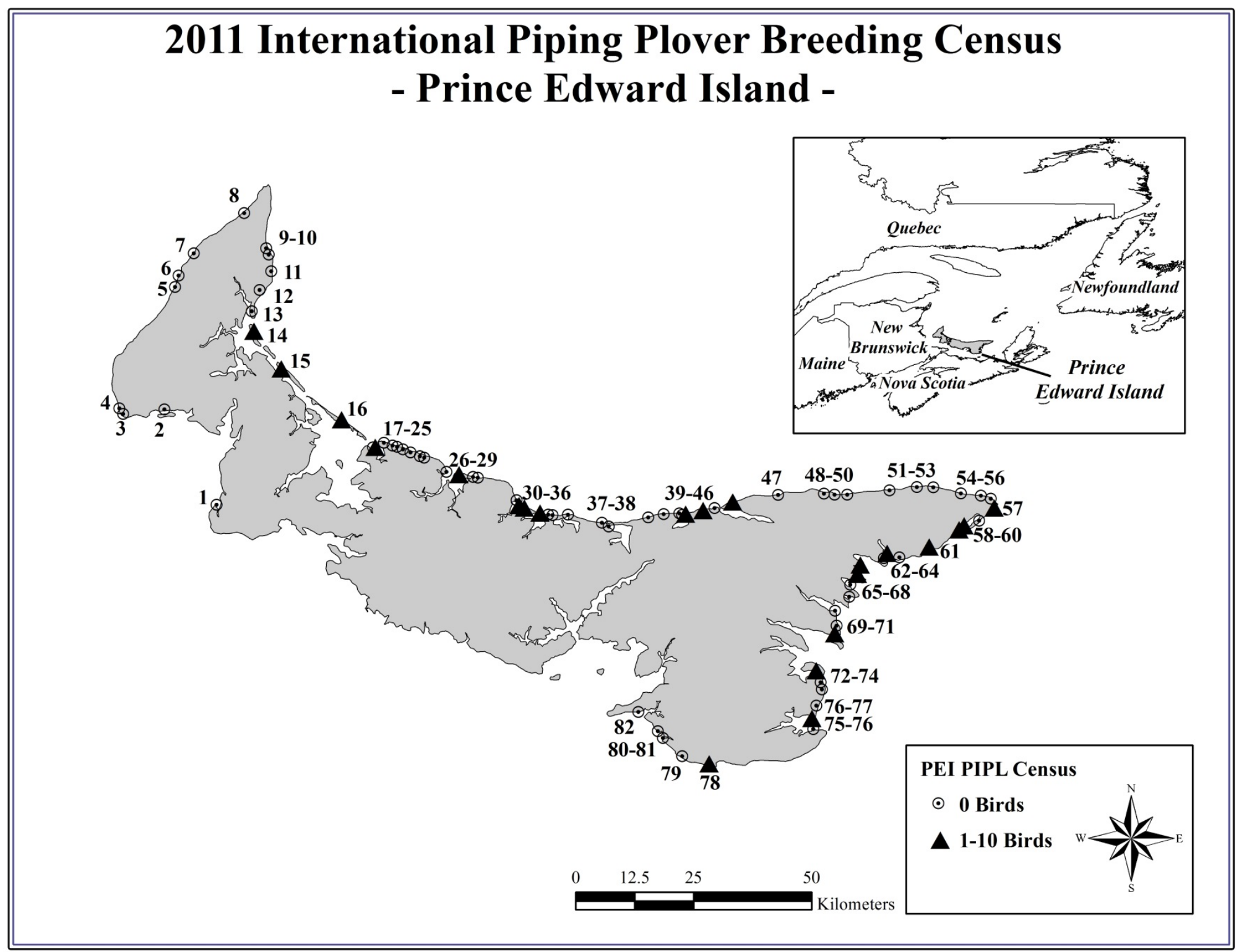


The 2011 International Piping Plover Breeding Census in Prince Edward Island

\begin{tabular}{|c|c|c|c|c|c|c|c|c|c|c|c|c|c|}
\hline \multirow{2}{*}{$\begin{array}{l}\text { REGION } \\
\text { Kings }\end{array}$} & \multirow{2}{*}{$\frac{\text { SITE NAME }}{\text { Basin Head (Bothwell) }^{2}}$} & \multirow{2}{*}{$\begin{array}{c}\text { МАР\# } \\
60\end{array}$} & \multirow{2}{*}{$\begin{array}{c}\text { DATE } \\
6 / 8 / 11\end{array}$} & \multirow{2}{*}{ 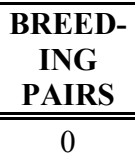 } & \multirow{2}{*}{$\begin{array}{c}\text { TOTAL } \\
\text { PIPL } \\
\text { ADULTS } \\
1\end{array}$} & \multirow{2}{*}{$\frac{\mathbf{K M}}{3.5}$} & \multirow{2}{*}{$\begin{array}{l}\text { SITE } \\
\text { DESCRIPTION } \\
\text { I A }\end{array}$} & \multirow{2}{*}{$\begin{array}{l}\text { DISTURBANCE } \\
\text { CONCERNS } \\
\text { n.r. }\end{array}$} & \multicolumn{4}{|c|}{$\begin{array}{c}\text { PRIOR YEARS } \\
\text { CENSUSED \& YEARS } \\
\text { PIPL SEEN }^{1} \\
\end{array}$} & \multirow{2}{*}{$\frac{\text { OWNER }}{\mathrm{s}(\mathrm{p})}$} \\
\hline & & & & & & & & & 91 & 96 & $\underline{01}$ & $\underline{06}$ & \\
\hline Kings & Beach Point & 77 & $6 / 5 / 11$ & 0 & 0 & 0.8 & I A & n.r. & 91 & 96 & 01 & 06 & unk \\
\hline Kings & Black Pond & 61 & $6 / 8 / 11$ & 1 & 3 & 2.3 & I A & n.r. & - & 96 & $\underline{01}$ & $\underline{06}$ & $\mathrm{~s}(\mathrm{p})$ \\
\hline Kings & Boughton Bay (Old Ferry Spit) & 69 & $6 / 10 / 11$ & 0 & 0 & 1.5 & I A E & n.r. & 91 & 96 & $\underline{01}$ & 06 & $\mathrm{~s}(\mathrm{p})$ \\
\hline Kings & Boughton Island ${ }^{2}$ & 71 & $6 / 10 / 11$ & 1 & 3 & 3.5 & I A & n.r. & 91 & 96 & $\underline{01}$ & $\underline{06}$ & $\mathrm{~s}(\mathrm{p})$ \\
\hline Kings & Cable Head & 47 & $6 / 9 / 11$ & 0 & 0 & 1.0 & I A & n.r. & 91 & 96 & 01 & 06 & $\mathrm{~s}(\mathrm{p})$ \\
\hline Kings & Campbell's Cove & 53 & $6 / 11 / 11$ & 0 & 0 & 1.0 & I A & n.r. & - & - & 01 & 06 & $\mathrm{~s}(\mathrm{p})$ \\
\hline Kings & Canavoy (Savage Harbour East) & 43 & $6 / 9 / 11$ & 3 & 6 & 3.5 & I A & n.r. & $\underline{91}$ & $\underline{96}$ & $\underline{01}$ & $\underline{06}$ & $\mathrm{~s}(\mathrm{p})$ \\
\hline Kings & Condons Pond & 75 & $6 / 4 / 11$ & 0 & 0 & 2.2 & I A & n.r. & - & - & 01 & 06 & $\mathrm{~s}(\mathrm{p})$ \\
\hline Kings & Cow River & 48 & $6 / 11 / 11$ & 0 & 0 & 0.3 & I A & n.r. & 91 & - & 01 & 06 & $\mathrm{~s}(\mathrm{p})$ \\
\hline Kings & Cross River (Big Pond) & 51 & $6 / 11 / 11$ & 0 & 0 & 0.5 & I A & n.r. & 91 & 96 & 01 & 06 & unk \\
\hline Kings & Diligent Pond & 57 & $6 / 8 / 11$ & 1 & 2 & 1.3 & I A & n.r. & 91 & 96 & $\underline{01}$ & $\underline{06}$ & $\mathrm{~s}(\mathrm{p})$ \\
\hline Kings & East Lake & 55 & $6 / 7 / 11$ & 0 & 0 & 2.0 & I A & n.r. & 91 & 96 & 01 & 06 & $\mathrm{~s}(\mathrm{p})$ \\
\hline Kings & East Point & 56 & $6 / 7 / 11$ & 0 & 0 & 1.0 & I A & $\mathrm{V}$ & - & 96 & 01 & 06 & unk \\
\hline Kings & Eglington Cove ${ }^{2}$ & 66 & $6 / 6 / 11$ & 1 & 4 & 1.0 & I A & n.r. & $\underline{91}$ & 96 & $\underline{01}$ & $\underline{06}$ & $\mathrm{~s}(\mathrm{p})$ \\
\hline Kings & Fortune Beach & 65 & $6 / 6 / 11$ & 1 & 2 & 1.0 & I A & n.r. & - & - & 01 & 06 & $\mathrm{p}$ \\
\hline Kings & Grahams Pond & 73 & $6 / 4 / 11$ & 0 & 0 & 0.8 & I VIII B & n.r. & - & - & 01 & 06 & $\mathrm{~s}(\mathrm{p})$ \\
\hline Kings & $\begin{array}{l}\text { Greenwich Peninsula/ Schooner } \\
\text { PEINP }\end{array}$ & 46 & $6 / 6 / 11$ & 2 & 5 & 6.0 & I A & n.r. & $\underline{91}$ & - & $\underline{01}$ & 06 & $\mathrm{f}$ \\
\hline Kings & Howe Bay & 67 & $6 / 6 / 11$ & 0 & 0 & 1.5 & I A & n.r. & $\underline{91}$ & 96 & 01 & 06 & $\mathrm{~s}(\mathrm{p})$ \\
\hline Kings & Lake Run (Saint Peter's) & 44 & $6 / 10 / 11$ & 3 & 6 & 1.5 & I A & n.r. & $\underline{91}$ & $\underline{96}$ & $\underline{01}$ & $\underline{06}$ & $\mathrm{~s}(\mathrm{p})$ \\
\hline Kings & Launching Point & 70 & $6 / 10 / 11$ & 0 & 0 & 1.0 & I A & H D & 91 & 96 & 01 & 06 & $\mathrm{~s}(\mathrm{p})$ \\
\hline Kings & Naufrage & 49 & $6 / 11 / 11$ & 0 & 0 & 1.0 & I A & $\mathrm{V}$ & $\underline{91}$ & 96 & 01 & 06 & $\mathrm{~s}(\mathrm{p})$ \\
\hline Kings & Norris Pond & 62 & $6 / 7 / 11$ & 0 & 0 & 0.5 & I A & $\mathrm{V}$ & - & - & 01 & 06 & $\mathrm{~s}(\mathrm{p})$ \\
\hline Kings & North Lake & 54 & $6 / 7 / 11$ & 0 & 0 & 0.8 & I A & $\mathrm{V}$ & 91 & 96 & 01 & 06 & $\mathrm{~s}(\mathrm{p})$ \\
\hline Kings & Panmure Island & 72 & $6 / 4 / 11$ & 1 & 2 & 2.5 & I A & $\mathrm{H}$ & 91 & 96 & 01 & $\underline{06}$ & $\mathrm{~s}(\mathrm{p})$ \\
\hline Kings & Pigots Pond & 41 & $6 / 10 / 11$ & 0 & 0 & 0.8 & I A E & n.r. & - & - & 01 & 06 & $\mathrm{~s}(\mathrm{p})$ \\
\hline Kings & Poverty Beach & 76 & $6 / 4 / 11$ & 1 & 2 & 1.2 & I A & n.r. & 91 & 96 & $\underline{01}$ & 06 & $\mathrm{~s}(\mathrm{p})$ \\
\hline Kings & Priest Pond & 52 & $6 / 11 / 11$ & 0 & 0 & 0.8 & I A & n.r. & 91 & 96 & 01 & 06 & $\mathrm{p}$ \\
\hline Kings & Saint Margaret's & 50 & $6 / 11 / 11$ & 0 & 0 & 1.0 & I A & n.r. & 91 & 96 & 01 & 06 & $\mathrm{~s}(\mathrm{p})$ \\
\hline Kings & Saint Peter's Harbour & 45 & $6 / 10 / 11$ & 0 & 0 & 2.5 & I A & n.r. & 91 & 96 & $\underline{01}$ & $\underline{06}$ & $\mathrm{~s}(\mathrm{p})$ \\
\hline Kings & Savage Harbour West & 42 & $6 / 10 / 11$ & 0 & 0 & 0.3 & I A & n.r. & $\underline{91}$ & 96 & $\underline{01}$ & 06 & $\mathrm{p}$ \\
\hline Kings & Sheep Pond & 64 & $6 / 7 / 11$ & 0 & 0 & 0.8 & I A & H D & - & - & 01 & 06 & $\mathrm{~s}(\mathrm{p})$ \\
\hline
\end{tabular}


The 2011 International Piping Plover Breeding Census in Prince Edward Island

(Continued)

\begin{tabular}{|c|c|c|c|c|c|c|c|c|c|c|c|c|c|}
\hline \multirow{2}{*}{$\begin{array}{l}\text { REGION } \\
\text { Kings }\end{array}$} & \multirow{2}{*}{$\begin{array}{c}\text { SITE NAME } \\
\text { Souris Causeway }\end{array}$} & \multirow{2}{*}{ MAP\# } & \multirow{2}{*}{$\frac{\text { DATE }}{6 / 7 / 11}$} & \multirow{2}{*}{$\begin{array}{c}\begin{array}{c}\text { BREED- } \\
\text { ING } \\
\text { PAIRS }\end{array} \\
1\end{array}$} & \multirow{2}{*}{$\begin{array}{c}\text { TOTAL } \\
\text { PIPL } \\
\text { ADULTS } \\
2\end{array}$} & \multirow{2}{*}{$\begin{array}{r}\mathbf{K M} \\
1.0\end{array}$} & \multirow{2}{*}{$\begin{array}{l}\text { SITE } \\
\text { DESCRIPTION } \\
\text { I IVA E }\end{array}$} & \multirow{2}{*}{$\begin{array}{l}\text { DISTURBANCE } \\
\text { CONCERNS } \\
\text { H D }\end{array}$} & \multicolumn{4}{|c|}{$\begin{array}{c}\text { PRIOR YEARS } \\
\text { CENSUSED \& YEARS } \\
\text { PIPL SEEN }^{1} \\
\end{array}$} & \multirow{2}{*}{$\frac{\text { OWNER }}{\mathrm{O}(\mathrm{p})}$} \\
\hline & & & & & & & & & 91 & 96 & $\overline{\underline{01}}$ & 06 & \\
\hline Kings & South Lake ${ }^{2}$ & 59 & $6 / 16 / 11$ & 1 & 3 & 6.0 & I IV A & n.r. & 91 & 96 & $\overline{01}$ & $\underline{06}$ & $\mathrm{~s}(\mathrm{p})$ \\
\hline Kings & Spry Cove/ Sally's Beach & 68 & $6 / 6 / 11$ & 0 & 0 & 3.0 & I A & n.r. & $\overline{91}$ & 96 & $\overline{01}$ & $\underline{06}$ & $\mathrm{~s}(\mathrm{p})$ \\
\hline Kings & Steele's Pond & 74 & $6 / 4 / 11$ & 0 & 0 & 0.8 & I A B & n.r. & - & - & 01 & $\overrightarrow{06}$ & $\mathrm{~s}(\mathrm{p})$ \\
\hline Prince & Black Pond West & 7 & $6 / 14 / 11$ & 0 & 0 & 1.0 & I A & $\mathrm{V}$ & - & $\underline{96}$ & 01 & 06 & $\mathrm{~s}(\mathrm{p})$ \\
\hline Prince & Cabot Provincial Park & 17 & $6 / 17 / 11$ & 0 & 0 & 1.5 & I C & n.r. & 91 & 96 & $\underline{01}$ & 06 & $\mathrm{~s}(\mathrm{p})$ \\
\hline Prince & Cascumpec Sand Hills ${ }^{3}$ & 14 & $6 / 22 / 11$ & 1 & 2 & 3.5 & I A & n.r. & $\overline{91}$ & 96 & $\underline{01}$ & $\underline{06}$ & $\mathrm{f}$ \\
\hline Prince & Cedar Dunes Park ${ }^{3}$ & 3 & $6 / 18 / 11$ & 0 & 0 & 1.0 & I A & $\mathrm{V}$ & 91 & 96 & $\overline{01}$ & $\overline{06}$ & $\mathrm{~s}(\mathrm{p})$ \\
\hline Prince & Cedar Dunes West $^{3}$ & 4 & $6 / 18 / 11$ & 0 & 0 & 2.0 & I E & $\mathrm{V}$ & 91 & 96 & 01 & 06 & $s(p), p$ \\
\hline Prince & Conway Island ${ }^{3}$ & 15 & $6 / 22 / 11$ & 1 & 2 & 8.5 & I A & n.r. & $\underline{91}$ & $\underline{96}$ & $\underline{01}$ & $\underline{06}$ & $\mathrm{~s}(\mathrm{p})$ \\
\hline Prince & Darnley Point & 18 & $6 / 17 / 11$ & 1 & 3 & 2.0 & I A & n.r. & $\overline{91}$ & $\overline{96}$ & $\overline{01}$ & $\overline{06}$ & $\mathrm{~s}(\mathrm{p})$ \\
\hline Prince & Foley's Pond (The Gap) & 12 & $6 / 16 / 11$ & 0 & 0 & 0.5 & I E & H U V & - & $\overline{96}$ & 01 & $\overrightarrow{06}$ & $\mathrm{p}$ \\
\hline Prince & Hog Island ${ }^{3}$ & 16 & $6 / 22 / 11$ & 1 & 2 & 12.0 & I II A C & n.r. & $\underline{91}$ & $\underline{96}$ & $\underline{01}$ & $\underline{06}$ & $\mathrm{~s}(\mathrm{p})$ \\
\hline Prince & Indian Point Sand Hills & 2 & $6 / 16 / 11$ & 0 & 0 & 7.0 & I A & $\mathrm{V}$ & $\overline{91}$ & $\overline{96}$ & $\overline{01}$ & $\overline{06}$ & $\mathrm{~s}(\mathrm{p})$ \\
\hline Prince & Jacques Cartier East & 13 & $6 / 16 / 11$ & 0 & 0 & 5.5 & I A & H D U V & $\overline{91}$ & $\underline{96}$ & 01 & 06 & $\mathrm{~s}(\mathrm{p})$ \\
\hline Prince & Kildare Capes & 11 & $6 / 16 / 11$ & 0 & 0 & 3.0 & I A & H D & 91 & $\overline{96}$ & 01 & 06 & $\mathrm{p}$ \\
\hline Prince & Little Miminegash & 5 & $6 / 14 / 11$ & 0 & 0 & 3.0 & I A & V & - & 96 & 01 & 06 & $\mathrm{~s}(\mathrm{p})$ \\
\hline Prince & Maximeville $^{3}$ & 1 & $6 / 18 / 11$ & 0 & 0 & 2.0 & I A & n.r. & - & 96 & 01 & 06 & $\mathrm{~s}(\mathrm{p})$ \\
\hline Prince & Miminegash Pond & 6 & $6 / 14 / 11$ & 0 & 0 & 1.0 & I A & $\mathrm{V}$ & 91 & 96 & 01 & 06 & $\mathrm{~s}(\mathrm{p})$ \\
\hline Prince & Morrisons Pond & 20 & $6 / 15 / 11$ & 0 & 0 & 1.2 & I A & H D U & - & 96 & 01 & 06 & $\mathrm{p}$ \\
\hline Prince & Nail Pond & 8 & $6 / 14 / 11$ & 0 & 0 & 3.0 & I A & $\mathrm{V}$ & 91 & 96 & 01 & 06 & $s(p), p$ \\
\hline Prince & Profitts Point (Twin Shores) ${ }^{3}$ & 19 & $6 / 18 / 11$ & 0 & 0 & 1.0 & I A & $\mathrm{H} \mathrm{U}$ & - & 96 & 01 & 06 & $\mathrm{p}$ \\
\hline Prince & Round Pond & 10 & $6 / 16 / 11$ & 0 & 0 & 3.0 & I A & $\mathrm{H} \mathrm{V}$ & - & 96 & 01 & 06 & $\mathrm{p}$ \\
\hline Prince & Tignish Shore & 9 & $6 / 16 / 11$ & 0 & 0 & 1.8 & I A & H D V & - & 96 & 01 & 06 & $\mathrm{~s}(\mathrm{p}), \mathrm{p}$ \\
\hline Queen & Adams Cottages & 21 & $6 / 15 / 11$ & 0 & 0 & 0.8 & I A & H D & - & - & 01 & 06 & $\mathrm{p}$ \\
\hline Queen & Adams Pond & 22 & $6 / 15 / 11$ & 0 & 0 & 0.4 & I A & H D & - & 96 & 01 & 06 & $\mathrm{p}$ \\
\hline Queens & Bell Point & 79 & $6 / 5 / 11$ & 0 & 0 & 1.5 & I II B C & n.r. & 91 & 96 & 01 & 06 & $\mathrm{p}$ \\
\hline Queens & Blooming Point PEINP & 58 & $6 / 9 / 11$ & 0 & 0 & 7.5 & I A & n.r. & $\underline{91}$ & 96 & $\underline{01}$ & $\underline{06}$ & $\mathrm{f}$ \\
\hline Queens & Brackley Main PEINP & 34 & $6 / 6 / 11$ & 0 & 0 & 1.2 & I A & n.r. & $\overline{91}$ & 96 & $\overline{01}$ & $\overline{06}$ & $\mathrm{f}$ \\
\hline Queens & Brandors Pond & 23 & $6 / 15 / 11$ & 0 & 0 & 0.5 & I A & H D & - & 96 & 01 & 06 & $\mathrm{p}$ \\
\hline Queens & Campbells Pond & 25 & $6 / 15 / 11$ & 0 & 0 & 0.7 & I II A & H D & - & $\underline{96}$ & 01 & 06 & $\mathrm{p}$ \\
\hline Queens & Cavendish Campground PEINP & 28 & $6 / 6 / 11$ & 0 & 0 & 1.1 & I A & $\mathrm{V}$ & - & $\overline{96}$ & 01 & $\underline{06}$ & $\mathrm{f}$ \\
\hline
\end{tabular}


The 2011 International Piping Plover Breeding Census in Prince Edward Island (Continued)

\begin{tabular}{|c|c|c|c|c|c|c|c|c|c|c|c|c|c|}
\hline \multirow{2}{*}{$\begin{array}{l}\text { REGION } \\
\text { Queens }\end{array}$} & \multirow{2}{*}{$\begin{array}{l}\text { SITE NAME } \\
\text { ish Main }\end{array}$} & \multirow{2}{*}{ MAP\# } & \multirow{2}{*}{$\begin{array}{c}\text { DATE } \\
6 / 6 / 11\end{array}$} & \multirow{2}{*}{$\begin{array}{c}\text { BREED- } \\
\text { ING } \\
\text { PAIRS } \\
0\end{array}$} & \multirow{2}{*}{ 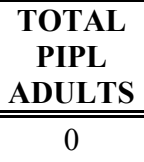 } & \multirow{2}{*}{$\frac{\mathbf{K M}}{1.1}$} & \multirow{2}{*}{$\begin{array}{l}\text { SITE } \\
\text { DESCRIPTION } \\
\text { I B }\end{array}$} & \multirow{2}{*}{$\begin{array}{l}\text { DISTURBANCE } \\
\text { CONCERNS } \\
\mathrm{V}\end{array}$} & \multicolumn{4}{|c|}{$\begin{array}{c}\text { PRIOR YEARS } \\
\text { CENSUSED \& YEARS } \\
\text { PIPL SEEN }^{1} \\
\end{array}$} & \multirow{2}{*}{$\frac{\text { OWNER }}{\mathrm{f}}$} \\
\hline & & & & & & & & & - & 96 & 01 & 06 & \\
\hline Queens & Cavendish Sandspit & 27 & $6 / 6 / 11$ & 0 & 4 & 10.0 & I A & n.r. & $\underline{91}$ & $\underline{96}$ & $\underline{01}$ & $\underline{06}$ & $\mathrm{f}$ \\
\hline Queens & Cousin's Pond & 24 & $6 / 15 / 11$ & 0 & 0 & 0.8 & I II A & H D V F & $\underline{91}$ & $\underline{96}$ & $\underline{01}$ & 06 & $\mathrm{~s}(\mathrm{p})$ \\
\hline Queens & Covehead Harbour West & 36 & $6 / 14 / 11$ & 0 & 0 & 3.5 & I II A & n.r. & $\underline{91}$ & $\underline{96}$ & $\underline{01}$ & $\underline{06}$ & $\mathrm{f}$ \\
\hline Queens & Deroche Pond & 39 & $6 / 8 / 11$ & 0 & 0 & 5.0 & I A & n.r. & 91 & 96 & 01 & 06 & $\mathrm{~s}(\mathrm{p})$ \\
\hline Queens & Feehan's Point & 40 & $6 / 13 / 11$ & 0 & 0 & 2.6 & I A & $\mathrm{D}$ & - & - & 01 & 06 & $\mathrm{~s}(\mathrm{p})$ \\
\hline Queens & Gascoigne Cove East & 80 & $6 / 15 / 11$ & 0 & 0 & 1.0 & I A & n.r. & 91 & 96 & 01 & 06 & $\mathrm{~s}(\mathrm{p})$ \\
\hline Queens & Gascoigne Cove West & 81 & $6 / 5 / 11$ & 0 & 0 & 2.0 & I A & n.r. & 91 & 96 & 01 & 06 & $\mathrm{~s}(\mathrm{p})$ \\
\hline Queens & North Rustico PEINP & 30 & $6 / 6 / 11$ & 0 & 0 & 1.0 & I IV A B E & $\mathrm{V}$ & - & - & - & - & $\mathrm{f}$ \\
\hline Queens & North Rustico Sandbar & 31 & $6 / 9 / 11$ & 3 & 6 & 2.0 & I A & n.r. & 91 & $\underline{96}$ & $\underline{01}$ & $\underline{06}$ & $\mathrm{~s}(\mathrm{p})$ \\
\hline Queens & Pond Point & 82 & $6 / 15 / 11$ & 0 & 0 & 1.0 & I II A B & n.r. & 91 & - & 01 & 06 & $\mathrm{p}$ \\
\hline Queens & Robinson's Island Sandspit ${ }^{2}$ & 32 & $6 / 12 / 11$ & 0 & 3 & 4.1 & I II A B & n.r. & 91 & $\underline{96}$ & $\underline{01}$ & $\underline{06}$ & $\mathrm{f}$ \\
\hline Queens & Rustico Causeway & 33 & $6 / 9 / 11$ & 1 & 2 & 2.3 & I A & n.r. & $\underline{91}$ & 96 & $\underline{01}$ & 06 & $\mathrm{f}$ \\
\hline Queens & Shaw's Beach & 35 & $6 / 6 / 11$ & 0 & 0 & 1.2 & I A & V & 91 & 96 & 01 & 06 & f \\
\hline Queens & $\begin{array}{l}\text { Tracadie Beach to Covehead } \\
\text { Harbour }\end{array}$ & 37 & $6 / 8 / 11$ & 0 & 0 & 8.8 & I A & $\mathrm{V}$ & 91 & 96 & $\underline{01}$ & $\underline{06}$ & $\mathrm{f}$ \\
\hline Queens & Tracadie Sandbar & 38 & $6 / 8 / 11$ & 0 & 0 & 2.0 & I II A E & $\mathrm{V}$ & 91 & 96 & 01 & $\underline{06}$ & $\mathrm{~s}(\mathrm{p})$ \\
\hline Queens & Wood Islands & 78 & $6 / 5 / 11$ & 3 & 6 & 3.0 & I A E & n.r. & 91 & 96 & 01 & 06 & $\mathrm{~s}(\mathrm{p}), \mathrm{p}$ \\
\hline Queens & Yankee Beach & 26 & $6 / 15 / 11$ & 0 & 0 & 0.7 & I A & H D V & - & 96 & 01 & 06 & $\mathrm{~s}(\mathrm{p})$ \\
\hline Total & & & & 28 & 71 & 189.3 & & & & & & & \\
\hline
\end{tabular}




\section{The 2011 International Piping Plover Breeding Census in New Brunswick}

\author{
Jen Rock \\ Canadian Wildlife Service \\ Environment Canada \\ 17 Waterfowl Lane \\ Sackville, NB E4L $1 \mathrm{G} 6$ \\ 506-364-5078 \\ jen.rock@ec.gc.ca
}

In New Brunswick (NB), 63 beaches ${ }^{1}$ were surveyed by 41 participants. Staff and volunteers from Nature New Brunswick Irving Eco-Centre / Dune de Bouctouche, the Canadian Wildlife Service (Environment Canada), and Parks Canada visited New Brunswick beaches between the $4^{\text {th }}$ and $17^{\text {th }}$ June. The 2011 list of beaches was based on sites visited during the last census in 2006 and included all known suitable plover habitat.

Two sites were deemed unsuitable for nesting plovers: Carron Point, because the shoreline has been hardened to the water's edge and Maisonnette Beach, because it was inundated by winter storms. Although Middle Miscou beach and Petit Barachois beach are on the list of beaches to check, site visits were not conducted in 2011. The north and south sections of Middle Miscou beach have been severely eroded with no plover habitat remaining. It is possible that a small patch of suitable habitat exists in the center of this site however it was not accessible in 2011. Visits to Petit Barachois were delayed due to limited access restricted by tide; this beach was visited after the census period with no plovers counted. Grande Digue was split into two separate sites and the southern portion is now an island, accessible only by boat (now respectively: Pointe Grande Digue and Grande Digue Island). Similarly, Tabusintac Dune was split in to two (now Tabusintac nord and Tabusintac sud).

No new areas were identified for future consideration but because of the potential for winter storms to change coastal habitat in New Brunswick, new sites should always be considered, especially in years with significant winter weather events.

In 2011, 130 Piping Plovers were counted on 32 beaches in New Brunswick during the breeding census, including 48 pairs and 34 singles. Despite a general increase in the number of beaches surveyed across years, the number of beaches with plovers has remained relatively stable and the number of adults counted has decreased, with the fewest number of birds counted in 2011.

Census results are representative of the actual population in New Brunswick but are likely a slight underestimate of the population total. For example, on average ( \pm SD) New Brunswick census counts have represented $95 \pm 3 \%$ of year-end estimated population totals. Census counts are lower than year-end totals because during a census, a few beaches may be missed (e.g. in 2011, two sites were not surveyed; see above for explanation) and detection of birds can also be a challenge. The latter is especially true in northern New Brunswick where many beaches are characterized by extensive washover areas in which birds are especially difficult to find. Given that the number of beaches surveyed has generally increased across years, we might expect a subsequent bias towards counting more birds however this has not been the case for New Brunswick. 
Major winter storm events in December 2010 affected extensive areas of the New Brunswick coastline, eroding shoreline at some sites and creating large wash-over areas of 'ideal' plover habitat at others. Due to the latter, habitat does not appear to be limiting for Piping Plovers in New Brunswick especially in northern regions. Human disturbance, habitat degradation, adverse weather and predation likely pose the biggest threats to Piping Plovers in New Brunswick. Some of the principle concerns directly related to human activities are: widespread use of vehicles on beaches, coastal development and building projects that compromise dune integrity (e.g. hardening of shorelines, erosion prevention initiatives, removal of sand), and off-leash dogs that disturb birds. Conservation groups, provincial and federal governments are working together to identify and address threats.

${ }^{1}$ In some cases the number of sites does not exactly match the number of beaches. Beaches were sometimes split or combined based on how they were surveyed in this and/or prior censuses.
Comparison of Census Numbers

\begin{tabular}{|l|c|c|c|c|c|}
\hline & 1991 & 1996 & 2001 & 2006 & 2011 \\
\hline $\begin{array}{l}\text { Total } \\
\text { Adults }\end{array}$ & 203 & 146 & 167 & $166^{1}$ & $130^{1}$ \\
\hline
\end{tabular}

${ }^{1}$ This is the total from a single survey at each site; if more than one survey was conducted, we count only results from the first survey during the census window.

Detectability Study

\begin{tabular}{|l|c|c|}
\hline \multicolumn{1}{|c|}{ Sites Included } & $\begin{array}{c}\text { First } \\
\text { Count }\end{array}$ & $\begin{array}{c}\text { Second } \\
\text { Count }\end{array}$ \\
\hline Baie-de-Petit-Pokemouche & 1 & 0 \\
\hline Grand Lac (Lameque) & 0 & 0 \\
\hline Grand Passage & 3 & 4 \\
\hline Green Point & 1 & 0 \\
\hline Miscou Beach & 3 & 5 \\
\hline Pointe-à-Bouleau & 1 & 0 \\
\hline Tracadie Dune & 4 & 5 \\
\hline Chockpish & 4 & 4 \\
\hline Escuminac Beaches & 13 & 10 \\
\hline North Kouchibouguac Dune & 7 & 3 \\
\hline South Kouchibouguac Dune & 2 & 3 \\
\hline $\begin{array}{l}\text { Blacklands Sandspit (Crab } \\
\text { Island) }\end{array}$ & 0 & 0 \\
\hline Cedar Road Beach South & 5 & 10 \\
\hline
\end{tabular}




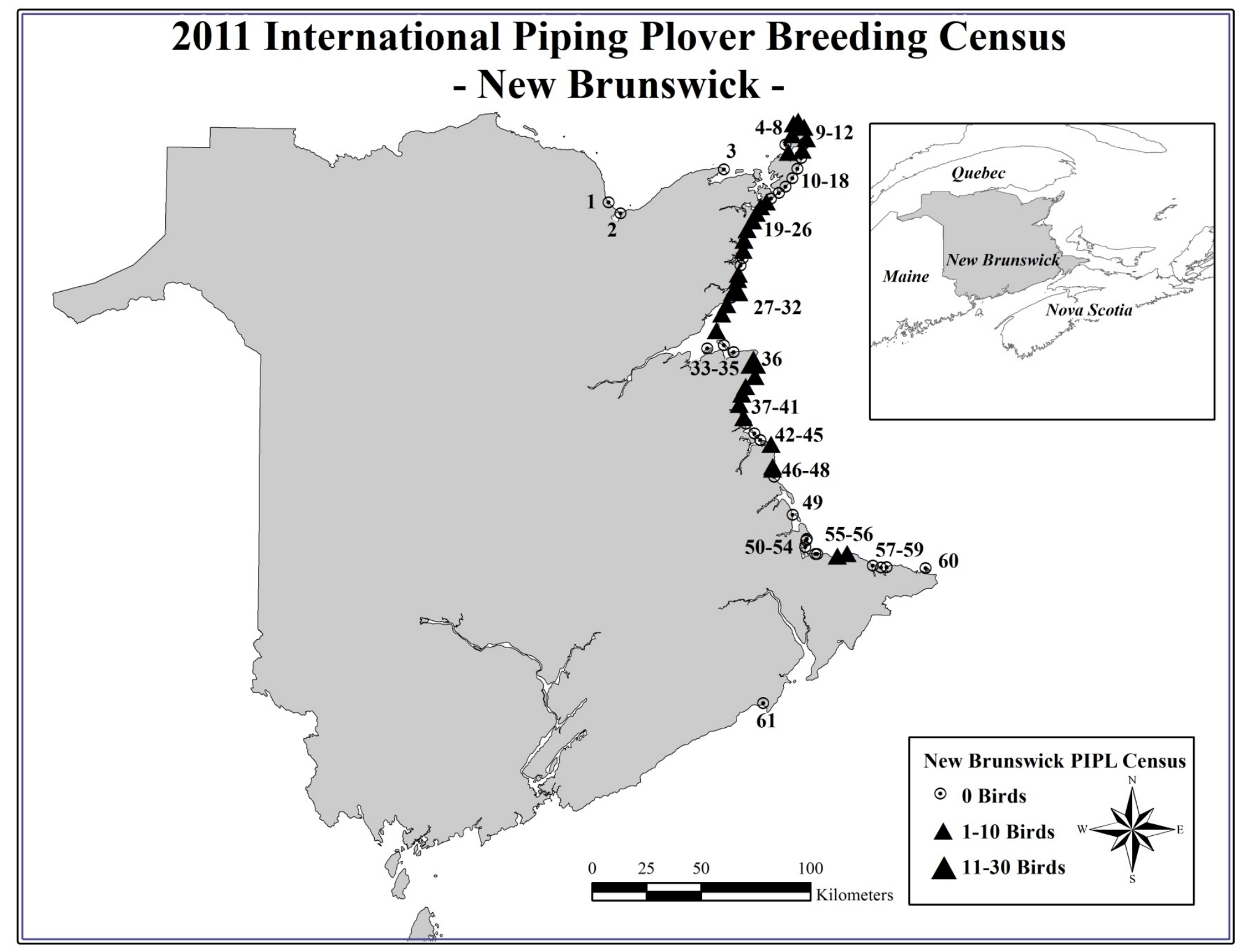


The 2011 International Piping Plover Breeding Census in New Brunswick

\begin{tabular}{|c|c|c|c|c|c|c|c|c|c|c|c|c|c|}
\hline \multirow{2}{*}{$\begin{array}{l}\text { REGION } \\
\text { Albert }\end{array}$} & \multirow{2}{*}{$\begin{array}{r}\text { SITE NAME } \\
\end{array}$} & \multirow{2}{*}{$\frac{\text { MAP\# }}{61}$} & \multirow{2}{*}{$\begin{array}{c}\text { DATE } \\
6 / 17 / 11\end{array}$} & \multirow{2}{*}{ 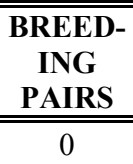 } & \multirow{2}{*}{ 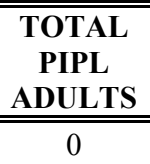 } & \multirow{2}{*}{$\frac{\text { KM }}{23.5}$} & \multirow{2}{*}{$\begin{array}{l}\text { SITE } \\
\text { DESCRIPTION } \\
\text { I A }\end{array}$} & \multirow{2}{*}{$\begin{array}{l}\text { DISTURBANCE } \\
\text { CONCERNS } \\
\mathrm{V}\end{array}$} & \multicolumn{4}{|c|}{$\begin{array}{c}\text { PRIOR YEARS } \\
\text { CENSUSED \& YEARS } \\
\text { PIPL SEEN }^{1} \\
\end{array}$} & \multirow{2}{*}{$\frac{\text { OWNER }}{\mathrm{s}(\mathrm{p})}$} \\
\hline & & & & & & & & & $9 \underline{91}$ & 96 & 01 & 06 & \\
\hline Gloucester & Baie-de-Petit-Pokemouche ${ }^{2}$ & 19 & $6 / 4 / 11$ & 0 & 1 & 3.5 & I B & n.r. & $\overline{91}$ & $\underline{96}$ & $\underline{01}$ & $\underline{06}$ & $\mathrm{p}$ \\
\hline Gloucester & Beresford Beach & 1 & $6 / 14 / 11$ & 0 & 0 & 0.3 & II B & n.r. & - & $\overline{96}$ & $\overline{01}$ & $\overrightarrow{06}$ & $\mathrm{p}$ \\
\hline Gloucester & Cap Bateau & 14 & $6 / 15 / 11$ & 0 & 0 & 1.5 & I B & n.r. & - & 96 & 01 & 06 & $s(p), p$ \\
\hline Gloucester & Carron Point & 2 & $6 / 14 / 11$ & 0 & 0 & 0.2 & II B & n.r. & 91 & 96 & 01 & 06 & $\mathrm{p}$ \\
\hline Gloucester & Chiasson Office & 17 & $6 / 15 / 11$ & 0 & 0 & 2.2 & I B & n.r. & - & $\underline{96}$ & 01 & 06 & $f, p$ \\
\hline Gloucester & École-La-Vague & 18 & $6 / 15 / 11$ & 0 & 0 & 4.5 & I B & n.r. & - & $\underline{96}$ & $\underline{01}$ & 06 & $\mathrm{f}, \mathrm{m}, \mathrm{p}$ \\
\hline Gloucester & Grand Lac (Lameque) & 16 & $6 / 14 / 11$ & 0 & 0 & 1.0 & I B & n.r. & - & - & $\overline{01}$ & $\underline{06}$ & $s(p)$ \\
\hline Gloucester & Grand Passage $^{2}$ & 20 & $6 / 15 / 11$ & 2 & 4 & 5.7 & I A B & $\mathrm{V}$ & $\underline{91}$ & $\underline{96}$ & $\underline{01}$ & $\overline{06}$ & $\mathrm{~s}(\mathrm{p}), \mathrm{p}$ \\
\hline Gloucester & Grande Plaine & 7 & $6 / 13 / 11$ & 4 & 8 & 4.5 & I A & $\mathrm{V}$ & - & - & $\underline{01}$ & $\underline{06}$ & $\mathrm{~s}(\mathrm{p}), \mathrm{p}$ \\
\hline Gloucester & Green Point ${ }^{2}$ & 23 & $6 / 15 / 11$ & 0 & 1 & 8.5 & I B & $\mathrm{V}$ & $\underline{91}$ & $\underline{96}$ & $\underline{01}$ & $\overline{06}$ & $\mathrm{f}, \mathrm{p}$ \\
\hline Gloucester & Lac Frye & 8 & $6 / 14 / 11$ & 0 & 1 & 1.3 & I A & $\mathrm{V}$ & $\underline{91}$ & $\underline{96}$ & $\underline{01}$ & - & $\mathrm{p}$ \\
\hline Gloucester & Miscou Beach ${ }^{2}$ & 9 & $6 / 16 / 11$ & 2 & 5 & 8.0 & I II A B & V S & $\underline{91}$ & $\underline{96}$ & 01 & $\underline{06}$ & $f, s(p), p$ \\
\hline Gloucester & Miscou Centre Beach & 5 & $6 / 14 / 11$ & 0 & 0 & 6.0 & I A & $\mathrm{V}$ & - & $\underline{96}$ & 01 & $\overrightarrow{06}$ & $s(p), p$ \\
\hline Gloucester & $\begin{array}{l}\text { Miscou Harbour South, Marks } \\
\text { Point South }\end{array}$ & 4 & $6 / 14 / 11$ & 1 & 2 & 2.5 & I A B & $\mathrm{U}$ & - & - & 01 & 06 & $\mathrm{f}, \mathrm{p}$ \\
\hline Gloucester & Pigeon Hill Sandspit (Fox Den) & 12 & $6 / 12 / 11$ & 4 & 8 & 7.2 & I II C & none & 91 & - & $\underline{01}$ & 06 & $\mathrm{~s}(\mathrm{p})$ \\
\hline Gloucester & Pigeon Hill Beach & 13 & $6 / 15 / 11$ & 0 & 0 & 3.0 & I B & n.r. & 91 & $\underline{96}$ & $\overline{01}$ & 06 & $\mathrm{~s}(\mathrm{p}), \mathrm{p}$ \\
\hline Gloucester & Plover Ground North & 21 & $6 / 13 / 11$ & 2 & 4 & 4.4 & I A B & $\mathrm{V}$ & $\overline{91}$ & $\overline{96}$ & 01 & 06 & $\mathrm{p}$ \\
\hline Gloucester & Plover Ground South & 22 & $6 / 13 / 11$ & 0 & 1 & 2.5 & I A & $\mathrm{V}$ & $\underline{91}$ & $\underline{96}$ & $\underline{01}$ & 06 & $\mathrm{p}$ \\
\hline Gloucester & Pointe de Maisonnette & 3 & $6 / 4 / 11$ & 0 & 0 & 0.9 & II B & n.r. & 91 & 96 & 01 & 06 & $\mathrm{~s}(\mathrm{p})$ \\
\hline Gloucester & Pointe-à-Bouleau ${ }^{2}$ & 25 & $6 / 7 / 11$ & 0 & 1 & 2.9 & I II C & n.r. & $\underline{91}$ & $\underline{96}$ & $\underline{01}$ & $\underline{06}$ & $f, s(p), p$ \\
\hline Gloucester & $\begin{array}{l}\text { Ruisseau Cheniere (Miscou } \\
\text { Island) }\end{array}$ & 6 & $6 / 14 / 11$ & 1 & 2 & 3.7 & I A & $\mathrm{V}$ & - & $\underline{96}$ & $\underline{01}$ & 06 & $\mathrm{~s}(\mathrm{p}), \mathrm{p}$ \\
\hline Gloucester & St. Raphael, St. Marie & 15 & $6 / 6 / 11$ & 0 & 0 & 1.2 & I A & S & - & - & - & 06 & $\mathrm{~s}(\mathrm{p}), \mathrm{p}$ \\
\hline Gloucester & Tracadie Dune ${ }^{2}$ & 24 & $6 / 10 / 11$ & 2 & 5 & 4.7 & I II C & $\mathrm{U}$ & $\underline{91}$ & $\underline{96}$ & $\underline{01}$ & $\underline{06}$ & $\mathrm{p}$ \\
\hline Gloucester & Val Comeau & 26 & $6 / 6 / 11$ & 0 & 0 & 3.3 & I B & n.r. & $\underline{91}$ & $\underline{96}$ & $\underline{01}$ & $\overrightarrow{06}$ & $\mathrm{~s}(\mathrm{p}), \mathrm{p}$ \\
\hline Gloucester & Wilson Point North (Miscou) & 10 & $6 / 15 / 11$ & 1 & 5 & 3.2 & I A & $\mathrm{V}$ & $\underline{91}$ & $\underline{96}$ & $\underline{01}$ & $\underline{06}$ & $\mathrm{~s}(\mathrm{p}), \mathrm{p}$ \\
\hline Gloucester & Wilson Point South (Miscou) & 11 & $6 / 12 / 11$ & 0 & 0 & 2.9 & I A E & $\mathrm{V}$ & $\underline{91}$ & - & 01 & $\overline{06}$ & $f, s(p), p$ \\
\hline Kent & Bouctouche Dune & 46 & $6 / 8 / 11$ & 1 & 3 & 12.2 & IX B & none & $\overline{91}$ & $\underline{96}$ & $\underline{01}$ & $\underline{06}$ & $\mathrm{p}$ \\
\hline Kent & Chockpish $^{2}$ & 47 & $6 / 10 / 11$ & 2 & 4 & 3.7 & IX A & $\mathrm{V} \mathrm{O}$ & - & - & $\underline{01}$ & $\underline{06}$ & unk \\
\hline Kent & Cocagne Island & 49 & $6 / 14 / 11$ & 0 & 0 & 8.0 & I E & n.r. & 91 & - & 01 & 06 & $\mathrm{p}$ \\
\hline Kent & Cote-Sainte-Anne & 48 & $6 / 10 / 11$ & 0 & 0 & 5.0 & IX A & H S & - & - & 01 & 06 & unk \\
\hline Kent & Escuminac Beaches $^{2}$ & 36 & $6 / 14 / 11$ & 5 & 13 & 10.0 & IX A & $\mathrm{V}$ & - & $\underline{96}$ & $\underline{01}$ & $\underline{06}$ & unk \\
\hline
\end{tabular}


The 2011 International Piping Plover Breeding Census in New Brunswick (Continued)

\begin{tabular}{|c|c|c|c|c|c|c|c|c|c|c|c|c|c|}
\hline \multirow{2}{*}{ REGION } & \multirow{2}{*}{$\begin{array}{c}\text { SITE NAME } \\
\text { North Kouchibouguac Dune }^{2}\end{array}$} & \multirow{2}{*}{ MAP\# } & \multirow{2}{*}{$\begin{array}{c}\text { DATE } \\
6 / 7 / 11\end{array}$} & \multirow{2}{*}{ 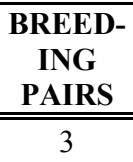 } & \multirow{2}{*}{ 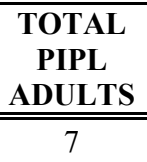 } & \multirow{2}{*}{$\frac{\mathbf{K M}}{3.0}$} & \multirow{2}{*}{$\begin{array}{l}\text { SITE } \\
\text { DESCRIPTION } \\
\text { I B }\end{array}$} & \multirow{2}{*}{$\begin{array}{l}\text { DISTURBANCE } \\
\text { CONCERNS } \\
\text { none }\end{array}$} & \multicolumn{4}{|c|}{$\begin{array}{c}\text { PRIOR YEARS } \\
\text { CENSUSED \& YEARS } \\
\text { PIPL SEEN }^{1} \\
\end{array}$} & \multirow{2}{*}{$\frac{\text { OWNER }}{\mathrm{f}}$} \\
\hline & & & & & & & & & $\underline{91}$ & $\underline{96}$ & $\underline{01}$ & $\underline{06}$ & \\
\hline Kent & North Richibucto Dune & 43 & $6 / 15 / 11$ & 0 & 0 & 15.0 & I C & none & - & 96 & 01 & 06 & $\mathrm{f}$ \\
\hline Kent & Pointe Grande-Digue (North) & 50 & $6 / 14 / 11$ & 0 & 0 & 1.5 & I II A B & $\mathrm{DO}$ & 91 & 96 & 01 & - & up \\
\hline Kent & Pointe Sapin Beach & 37 & $6 / 16 / 11$ & 0 & 1 & 4.8 & IX A & none & - & - & 01 & 06 & unk \\
\hline Kent & Pointe-Sapin Dune & 38 & $6 / 5 / 11$ & 2 & 4 & 3.0 & I A & none & - & $\underline{96}$ & $\underline{01}$ & $\underline{06}$ & $\mathrm{f}$ \\
\hline Kent & Portage River Dune & 39 & $6 / 5 / 11$ & 3 & 7 & 3.0 & I II A B & none & - & $\underline{96}$ & $\underline{01}$ & $\underline{06}$ & $\mathrm{f}$ \\
\hline Kent & South Kouchibouguac Dune ${ }^{2}$ & 41 & $6 / 7 / 11$ & 1 & 3 & 6.0 & I B & none & $\underline{91}$ & $\underline{96}$ & $\underline{01}$ & $\underline{06}$ & $\mathrm{f}$ \\
\hline Kent & South Richibucto Beach & 45 & $6 / 7 / 11$ & 0 & 1 & 6.2 & IX B & none & $\underline{91}$ & 96 & 01 & $\underline{06}$ & unk \\
\hline Kent & $\begin{array}{l}\text { South Richibucto Dune } \\
\text { (Barrier Island) }\end{array}$ & 44 & $6 / 15 / 11$ & 0 & 0 & 3.5 & IX C & none & $\underline{91}$ & 96 & $\underline{01}$ & - & unk \\
\hline Kent & Tern Islands & 42 & $6 / 15 / 11$ & 0 & 0 & 1.5 & II C & none & - & 96 & - & - & $\mathrm{f}$ \\
\hline Northumberland & Bay du Vin Island & 35 & $6 / 8 / 11$ & 0 & 0 & 5.8 & I II D & $\mathrm{H} \mathrm{U}$ & - & - & - & - & $\mathrm{s}(\mathrm{p})$ \\
\hline Northumberland & $\begin{array}{l}\text { Blacklands Sandspit (Crab } \\
\text { Island) }\end{array}$ & 31 & $6 / 8 / 11$ & 0 & 0 & 1.5 & I E & n.r. & $\underline{91}$ & 96 & - & - & $\mathrm{s}(\mathrm{p})$ \\
\hline Northumberland & $\begin{array}{l}\text { Blacklands Sandspit (Swinging } \\
\text { Point) }\end{array}$ & 32 & $6 / 8 / 11$ & 2 & 5 & 3.0 & I II E & n.r. & $\underline{91}$ & 96 & $\underline{01}$ & 06 & $\mathrm{~s}(\mathrm{p})$ \\
\hline Northumberland & Cedar Road Beach South ${ }^{2}$ & 28 & $6 / 17 / 11$ & 4 & 10 & 5.0 & I B & n.r. & $\underline{91}$ & $\underline{96}$ & $\underline{01}$ & $\underline{06}$ & $f, s(p), p$ \\
\hline Northumberland & Cedar Road Spit & 29 & $6 / 9 / 11$ & 3 & 6 & 3.1 & I II C & n.r. & $\underline{91}$ & $\underline{96}$ & $\underline{01}$ & $\underline{06}$ & $\mathrm{f}$ \\
\hline Northumberland & $\begin{array}{l}\text { Dune de Neguac, Neguac } \\
\text { Beach }\end{array}$ & 33 & $6 / 16 / 11$ & 1 & 3 & 6.5 & I II C & n.r. & $\underline{91}$ & $\underline{96}$ & $\underline{01}$ & $\underline{06}$ & $\mathrm{~s}(\mathrm{p}), \mathrm{p}$ \\
\hline Northumberland & Fox Island & 36 & $6 / 8 / 11$ & 0 & 0 & 13.0 & I II B C D E & U V & 91 & 96 & 01 & 06 & $\mathrm{f}, \mathrm{p}$ \\
\hline Northumberland & Pointe à Barreau & 27 & $6 / 5 / 11$ & 0 & 0 & 2.4 & I B & n.r. & 91 & $\underline{96}$ & $\underline{01}$ & $\underline{06}$ & $\mathrm{p}$ \\
\hline Northumberland & $\begin{array}{l}\text { Portage Island National } \\
\text { Wildlife Area }\end{array}$ & 34 & $6 / 7 / 11$ & 0 & 2 & 14.5 & I II B C D & $\mathrm{V}$ & $\underline{91}$ & $\underline{96}$ & $\underline{01}$ & $\underline{06}$ & $\mathrm{f}$ \\
\hline Northumberland & Preston Beach & 35 & $6 / 14 / 11$ & 0 & 0 & 2.3 & IX B & none & 91 & 96 & 01 & 06 & unk \\
\hline Northumberland & Tabusintac Dune & 30 & $6 / 8 / 11$ & 8 & 21 & 6.0 & I II C & n.r. & $\underline{91}$ & $\underline{96}$ & $\underline{01}$ & $\underline{06}$ & $\mathrm{f}$ \\
\hline Westmorland & Cadman Beach & 59 & $6 / 8 / 11$ & 0 & 0 & 2.3 & IX A & none & 91 & 96 & 01 & 06 & unk \\
\hline Westmorland & Cape Bimet West & 54 & $6 / 7 / 11$ & 0 & 0 & 0.8 & I A & H S U & 91 & 96 & 01 & 06 & $\mathrm{p}$ \\
\hline Westmorland & Cape Brule East & 53 & $6 / 7 / 11$ & 0 & 0 & 0.8 & I A & none & 91 & 96 & 01 & 06 & $\mathrm{p}$ \\
\hline Westmorland & $\begin{array}{l}\text { Cape Jourmain National } \\
\text { Widlife Area }\end{array}$ & 60 & $6 / 10 / 11$ & 0 & 0 & 1.5 & I A & $\mathrm{O}$ & - & - & $\underline{01}$ & 06 & $\mathrm{f}$ \\
\hline Westmorland & Cap-Pelé & 56 & $6 / 8 / 11$ & 0 & 1 & 1.0 & IX A & none & - & - & - & - & unk \\
\hline Westmorland & $\begin{array}{l}\text { Grand Digue South (Island } \\
\text { Segment) }\end{array}$ & 51 & $6 / 8 / 11$ & 0 & 0 & 1.0 & I E & none & 91 & 96 & 01 & 06 & $\mathrm{p}$ \\
\hline Westmorland & Johnston Point & 58 & $6 / 8 / 11$ & 0 & 0 & 1.5 & IX A & none & 91 & 96 & 01 & 06 & unk \\
\hline
\end{tabular}


The 2011 International Piping Plover Breeding Census in New Brunswick

(Continued)

\begin{tabular}{|c|c|c|c|c|c|c|c|c|c|c|c|c|c|}
\hline \multirow{2}{*}{$\begin{array}{l}\text { REGION } \\
\text { Westmorland }\end{array}$} & $\begin{array}{r}\text { SITE NAME } \\
\end{array}$ & \multirow{2}{*}{$\frac{\text { MAP\# }}{255}$} & \multirow{2}{*}{$\begin{array}{c}\text { DATE } \\
6 / 8 / 11\end{array}$} & \multirow{2}{*}{ 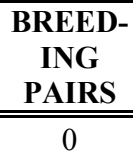 } & \multirow{2}{*}{$\begin{array}{c}\text { TOTAL } \\
\text { PIPL } \\
\text { ADULTS } \\
1\end{array}$} & \multirow{2}{*}{$\frac{\mathbf{K M}}{28.0}$} & \multirow{2}{*}{$\begin{array}{l}\text { SITE } \\
\text { DESCRIPTION } \\
\text { I A }\end{array}$} & \multirow{2}{*}{$\begin{array}{l}\text { DISTURBANCE } \\
\text { CONCERNS } \\
\mathrm{H} \mathrm{D} \mathrm{V}\end{array}$} & \multicolumn{4}{|c|}{$\begin{array}{c}\text { PRIOR YEARS } \\
\text { CENSUSED \& YEARS } \\
\text { PIPL SEEN }^{1} \\
\end{array}$} & \multirow{2}{*}{$\frac{\text { OWNER }}{\mathrm{p}}$} \\
\hline & Landry East & & & & & & & & 91 & 96 & 01 & 06 & \\
\hline Westmorland & Little Cape & 57 & $6 / 8 / 11$ & 0 & 0 & 1.3 & IX B & none & $\underline{91}$ & 96 & 01 & 06 & unk \\
\hline Westmorland & Shediac Island & 52 & $6 / 8 / 11$ & 0 & 0 & 2.5 & I C & none & - & - & 01 & 06 & $\mathrm{~m}, \mathrm{p}$ \\
\hline Total & & & & 54 & 140 & 263.1 & & & & & & & \\
\hline
\end{tabular}

${ }^{1}$ Bold years indicate that adults were seen. Bold and underlined years indicate that pairs were seen.

2 This total is the "high count"; since two surveys were conducted at some sites for the detectability study, this total includes the highest count at each site. 


\section{The 2011 International Piping Plover Breeding Census at Great Lakes sites in Michigan, Wisconsin, Illinois, Indiana, and Pennsylvania}

Vince Cavalieri

U.S.Fish and Wildlife Service

East Lansing Field Office

2651 Coolidge Road

East Lansing, MI 48823

517-351-5467

vincent_cavalieri@fws.gov

The 2011 International Piping Plover Breeding Census in the U.S. Great Lakes was completed during the 4 June to 17 June census period. Surveys of known and/or potential breeding habitat for the Great Lakes population of the Piping Plover (Charadrius melodus) covered a six state area that included Michigan, Wisconsin, Illinois, Indiana, Pennsylvania and New York. A total of 72 coastal sites were visited one or more times, including 56 sites in Michigan. Some areas were reported as a single site in 2011 but were broken down into two or more sites in 2006; likewise, a few sites that were reported as a single site in 2006 were broken down into two or more sites in 2011. Sites selected for survey in Michigan and Wisconsin were based primarily on the results of the 2006 International Piping Plover Breeding Census. These sites included nearly all of the currently known breeding locations in the U.S. Great Lakes. Some sites surveyed in 2006 were not included in the 2011 census due to lack of access, or the current lack of habitat. Alternately, a small number of new sites were added to the effort in 2011 as a result of recent observation of Piping Plover presence.
Census locations selected for survey in the other Great Lakes states were based primarily on designated critical habitat areas (USFWS May 7,2001). These sites are generally considered the best potential Piping Plover habitat outside their current range in Michigan and Wisconsin.

A total of 98 Piping Plovers were observed in the U.S. Great Lakes during the census period. This was 11 fewer birds than observed during the 2006 Census. Of the 2011 total, 8 were recorded in Wisconsin, with the remainder in Michigan. No observations of Piping Plovers were recorded for the other states.

The number of Piping Plovers tallied for the 2011 International Breeding Census varied, however, from the number recorded during the annual monitoring program in the Great Lakes. Annual monitoring efforts reported a total of 50 breeding pairs in the U.S. portion of the Great Lakes. This tally is the result of intense survey efforts and nearly daily monitoring of active breeding locations. The discrepancy in the number of Piping Plovers counted in 2011 may have been due to weather conditions during the census period or movement patterns of birds. As many of the observers who participated in the International Census were the same as those employed for the seasonal monitoring program, observer bias is not a likely cause of the discrepancy.

In the Great Lakes we have intense survey efforts and monitoring programs every year. During the time since the 2006 census, the Great Lakes population of Piping Plovers continued to rise and the highest numbers recorded since listing occurred during 2009, when there were 71 pairs counted across the basin. During the last two years there have been declines. We are currently investigating causes of the recent decline and exploring further management options. 
Comparison of Census Numbers - Michigan

\begin{tabular}{|l|c|c|c|c|c|}
\hline & 1991 & 1996 & 2001 & 2006 & 2011 \\
\hline $\begin{array}{l}\text { Total } \\
\text { Adults }\end{array}$ & 39 & 47 & 65 & $101^{1}$ & $90^{1}$ \\
\hline
\end{tabular}

${ }^{\text {I }}$ This is the total from a single survey at each site; if more than one survey was conducted, we count only results from the first survey during the census window.

\section{Comparison of Census Numbers - Wisconsin}

\begin{tabular}{|l|c|c|c|c|c|}
\hline & 1991 & 1996 & 2001 & 2006 & 2011 \\
\hline $\begin{array}{l}\text { Total } \\
\text { Adults }\end{array}$ & 1 & 0 & 6 & $8^{1}$ & $8^{1}$ \\
\hline
\end{tabular}

${ }^{1}$ This is the total from a single survey at each site; if more than one survey was conducted, we count only results from the first survey during the census window.

\section{Comparison of Census Numbers - Illinois,} Indiana, and Pennsylvania

\begin{tabular}{|l|c|c|c|c|c|}
\hline & 1991 & 1996 & 2001 & 2006 & 2011 \\
\hline $\begin{array}{l}\text { Total } \\
\text { Adults }\end{array}$ & n.a. & n.a. & 0 & 0 & 0 \\
\hline
\end{tabular}




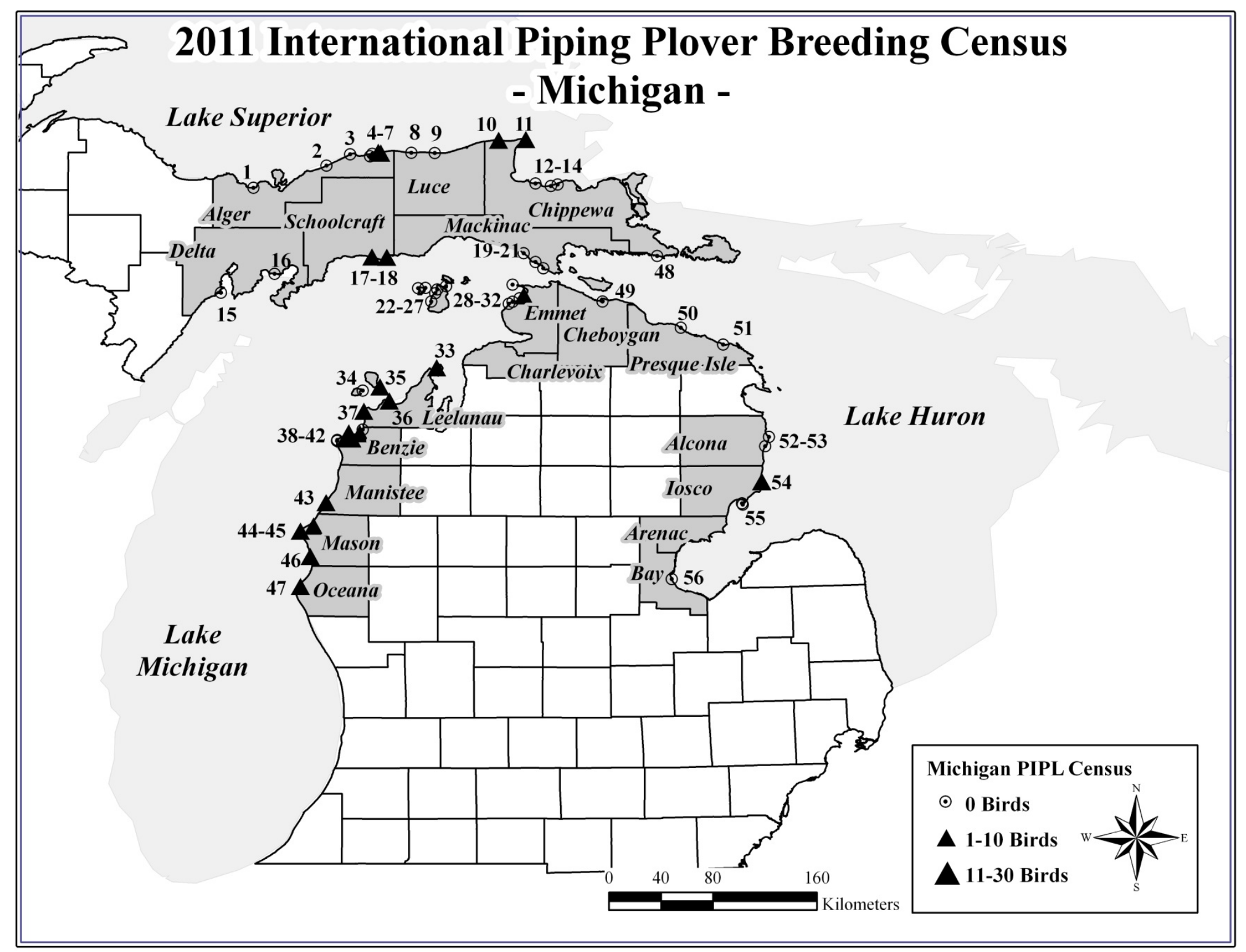


The 2011 International Piping Plover Breeding Census in Michigan

\begin{tabular}{|c|c|c|c|c|c|c|c|c|c|c|c|c|c|}
\hline \multirow{2}{*}{$\begin{array}{l}\text { REGION } \\
\text { Alcona }\end{array}$} & \multirow{2}{*}{$\begin{array}{c}\text { SITE NAME } \\
\text { ille State Park }\end{array}$} & \multirow{2}{*}{$\begin{array}{c}\text { MAP\# } \\
53\end{array}$} & \multirow{2}{*}{$\frac{\text { DATE }}{6 / 12 / 11}$} & \multirow{2}{*}{$\begin{array}{c}\text { BREED- } \\
\text { ING } \\
\text { PAIRS } \\
0\end{array}$} & \multirow{2}{*}{$\begin{array}{c}\text { TOTAL } \\
\text { PIPL } \\
\text { ADULTS } \\
0\end{array}$} & \multirow{2}{*}{$\frac{\mathbf{K M}}{0.8}$} & \multirow{2}{*}{$\begin{array}{l}\text { SITE } \\
\text { DESCRIPTION } \\
\mathrm{VA}\end{array}$} & \multirow{2}{*}{$\begin{array}{l}\text { DISTURBANCE } \\
\text { CONCERNS } \\
\text { n.r. }\end{array}$} & \multicolumn{4}{|c|}{$\begin{array}{c}\text { PRIOR YEARS } \\
\text { CENSUSED \& YEARS } \\
\text { PIPL SEEN }^{1} \\
\end{array}$} & \multirow{2}{*}{$\frac{\text { OWNER }}{\mathrm{s}(\mathrm{p})}$} \\
\hline & & & & & & & & & 91 & 96 & 01 & 06 & \\
\hline Alcona & Sturgeon Point & 52 & $6 / 12 / 11$ & 0 & 0 & 0.8 & V A & n.r. & 91 & 96 & 01 & 06 & $\mathrm{~m}$ \\
\hline Alger & 12 Mile Beach to Beaver Creek & 2 & $6 / 15 / 11$ & 0 & 0 & 6.5 & V A & n.r. & - & 96 & 01 & 06 & unk \\
\hline Alger & Au Train River Mouth & 1 & $6 / 17 / 11$ & 0 & 0 & 1.2 & V A & n.r. & - & - & 01 & 06 & $\mathrm{~s}(\mathrm{p})$ \\
\hline Alger & Grand Marais (Inner Bay) & 7 & $6 / 8 / 11$ & 1 & 2 & 2.4 & III V A D & V H & 91 & 96 & 01 & $\underline{06}$ & $\mathrm{~m}, \mathrm{p}$ \\
\hline Alger & Grand Marais (West Bay) & 6 & $6 / 5 / 11$ & 1 & 3 & 1.6 & III V A & H I & 91 & 96 & 01 & 06 & $\mathrm{p}$ \\
\hline Alger & Grand Sable Lake & 4 & $6 / 10 / 11$ & 0 & 0 & 0.8 & V A & $\mathrm{O}$ & - & 96 & 01 & 06 & unk \\
\hline Alger & $\begin{array}{l}\text { Hurricane River to } 12 \text { Mile } \\
\text { Beach CG }\end{array}$ & 3 & $6 / 13 / 11$ & 0 & 0 & 3.2 & V A & n.r. & - & 96 & 01 & 06 & unk \\
\hline Alger & Sable Falls & 5 & $6 / 9 / 11$ & 0 & 0 & 2.5 & V A & n.r. & - & 96 & 01 & - & unk \\
\hline Bay & South Linwood Beach & 56 & $6 / 17 / 11$ & 0 & 0 & 0.8 & V A & D V H & - & - & - & - & $\mathrm{p}$ \\
\hline Benzie & Elberta Beach & 42 & $6 / 17 / 11$ & 0 & 0 & 1.5 & V A & $\mathrm{O}$ & - & 96 & 01 & 06 & $\mathrm{~m}$ \\
\hline Benzie & Esch to Platte Point & 39 & $6 / 17 / 11$ & 3 & 6 & 8.3 & V A & n.r. & 91 & 96 & $\underline{01}$ & $\underline{06}$ & unk \\
\hline Benzie & Point Betsie & 41 & $6 / 17 / 11$ & 0 & 0 & 1.8 & V A & n.r. & - & 96 & 01 & 06 & unk \\
\hline Benzie & $\begin{array}{l}\text { S Sleeping Bear Dunes to Platte } \\
\text { Point }\end{array}$ & 40 & $6 / 16 / 11$ & 6 & 14 & 3.0 & V A & n.r. & 91 & 96 & $\underline{01}$ & $\underline{06}$ & unk \\
\hline Charlevoix & $\begin{array}{l}\text { Bonner's Bluff/Landing, Beaver } \\
\text { Island }\end{array}$ & 26 & $6 / 11 / 11$ & 0 & 0 & 3.7 & V E & $\mathrm{H} \mathrm{I}$ & - & 96 & $\underline{01}$ & 06 & $\mathrm{~s}(\mathrm{p})$ \\
\hline Charlevoix & $\begin{array}{l}\text { Donegal Bay and McCauley } \\
\text { Point }\end{array}$ & 25 & $6 / 9 / 11$ & 0 & 0 & 3.2 & V E & H I & $\underline{91}$ & 96 & $\underline{01}$ & 06 & $\mathrm{~s}(\mathrm{p}), \mathrm{p}$ \\
\hline Charlevoix & High Island NE Spit & 23 & $6 / 5 / 11$ & 0 & 0 & 2.0 & V E & I & 91 & 96 & 01 & $\underline{06}^{3}$ & $s(p), p$ \\
\hline Charlevoix & High Island NW Side & 22 & $6 / 5 / 11$ & 0 & 0 & 3.5 & V E & I & $\underline{91}$ & 96 & 01 & $\underline{06}^{3}$ & $s(p), p$ \\
\hline Charlevoix & Lookout Point, Beaver Island & 24 & $6 / 9 / 11$ & 0 & 0 & 1.0 & V E I & I & - & 96 & 01 & 06 & $\mathrm{~s}(\mathrm{p}), \mathrm{p}$ \\
\hline Charlevoix & $\begin{array}{l}\text { McFaddin Pt./Green's Bay, } \\
\text { Beaver Island }\end{array}$ & 27 & $6 / 15 / 11$ & 0 & 0 & 2.0 & V E & H I & 91 & 96 & 01 & 06 & $\mathrm{~s}(\mathrm{p}), \mathrm{p}$ \\
\hline Cheboygan & Cheboygan State Park & 49 & $6 / 13 / 11$ & 0 & 0 & 1.6 & V A & n.r. & 91 & 96 & 01 & 06 & $\mathrm{~s}(\mathrm{p})$ \\
\hline Chippewa & Bay View Campground & 13 & $6 / 15 / 11$ & 0 & 0 & 6.4 & V A & n.r. & - & - & - & - & $\mathrm{p}$ \\
\hline Chippewa & Big Pine Picnic Area & 14 & $6 / 15 / 11$ & 0 & 0 & 1.6 & V A & n.r. & - & - & - & - & unk \\
\hline Chippewa & De Tour Beach & 48 & $6 / 16 / 11$ & 0 & 0 & 2.2 & V A & $\mathrm{V}$ & - & 96 & $\underline{01}$ & 06 & $\mathrm{~s}(\mathrm{p})$ \\
\hline Chippewa & Naomikong & 12 & $6 / 14 / 11$ & 0 & 0 & 5.6 & V A & n.r. & - & - & - & - & $\mathrm{p}$ \\
\hline Chippewa & Vermilion Beach & 10 & $6 / 4 / 11$ & 2 & 4 & 8.9 & V A & n.r. & $\underline{91}$ & 96 & 01 & 06 & $\mathrm{~s}(\mathrm{p}), \mathrm{p}$ \\
\hline Chippewa & Whitefish Point & 11 & $6 / 4 / 11$ & 1 & 3 & 3.2 & V A & n.r. & 91 & 96 & 01 & - & $\mathrm{s}(\mathrm{p}), \mathrm{p}$ \\
\hline Delta & Indian Point, E side & 16 & $6 / 9 / 11$ & 0 & 0 & 3.2 & VI A E & $\mathrm{V}$ & - & - & - & $\underline{06}$ & unk \\
\hline Delta & Portage Point/Aronson Island & 15 & $6 / 11 / 11$ & 0 & 0 & 4.8 & V A B & V I & - & - & - & - & unk \\
\hline
\end{tabular}


The 2011 International Piping Plover Breeding Census in Michigan (Continued)

\begin{tabular}{|c|c|c|c|c|c|c|c|c|c|c|c|c|c|}
\hline \multirow{2}{*}{$\begin{array}{l}\text { REGION } \\
\text { Emmet }\end{array}$} & \multirow{2}{*}{$\begin{array}{r}\text { SITE NAME } \\
\text { Bliss Township Beach }\end{array}$} & \multirow{2}{*}{ MAP\# } & \multirow{2}{*}{$\begin{array}{c}\text { DATE } \\
6 / 9 / 11\end{array}$} & \multirow{2}{*}{$\begin{array}{c}\begin{array}{c}\text { BREED- } \\
\text { ING } \\
\text { PAIRS }\end{array} \\
1\end{array}$} & \multirow{2}{*}{$\begin{array}{c}\text { TOTAL } \\
\text { PIPL } \\
\text { ADULTS } \\
2\end{array}$} & \multirow{2}{*}{$\frac{\mathbf{K M}}{3.2}$} & \multirow{2}{*}{$\begin{array}{l}\text { SITE } \\
\text { DESCRIPTION } \\
\mathrm{V} \mathrm{A}\end{array}$} & \multirow{2}{*}{$\begin{array}{l}\text { DISTURBANCE } \\
\text { CONCERNS } \\
\text { n.r. }\end{array}$} & \multicolumn{4}{|c|}{$\begin{array}{c}\text { PRIOR YEARS } \\
\text { CENSUSED \& } \\
\text { YEARS } \\
\text { PIPL SEEN }^{1} \\
\end{array}$} & \multirow{2}{*}{  } \\
\hline & & & & & & & & & - & - & $\underline{01}$ & 06 & \\
\hline Emmet & Cross Village Central & 31 & $6 / 9 / 11$ & 0 & 0 & 1.6 & V A & n.r. & $\underline{91}$ & 96 & $\underline{01}$ & 06 & $\mathrm{p}$ \\
\hline Emmet & Cross Village North & 30 & $6 / 9 / 11$ & 0 & 0 & 1.6 & V A & n.r. & $\underline{91}$ & 96 & $\underline{01}$ & $\underline{06}$ & $\mathrm{p}$ \\
\hline Emmet & Cross Village South & 32 & $6 / 9 / 11$ & 0 & 0 & 1.6 & V A & n.r. & $\underline{91}$ & 96 & 01 & 06 & $\mathrm{p}$ \\
\hline Emmet & $\begin{array}{l}\text { Temperance/Waugoshance/Crane } \\
\text { Island }\end{array}$ & 28 & $6 / 5 / 11$ & 0 & 0 & 8.1 & V A & n.r. & - & 96 & $\underline{01}$ & 06 & $\mathrm{~s}(\mathrm{p})$ \\
\hline Iosco & $\begin{array}{l}\text { Au Sable River Mouth/Lake } \\
\text { Huron Beach }\end{array}$ & 54 & $6 / 12 / 11$ & 1 & 2 & 0.4 & V A & n.r. & - & 96 & 01 & 06 & $\mathrm{~s}(\mathrm{p})$ \\
\hline Iosco & Tawas Point, Tawas State Park & 55 & $6 / 12 / 11$ & 0 & 0 & 4.0 & V A & n.r. & 91 & 96 & 01 & - & $\mathrm{s}(\mathrm{p})$ \\
\hline Leelanau & Leelanau State Park & 33 & $6 / 11 / 11$ & 0 & 1 & 2.4 & V A & n.r. & 91 & 96 & 01 & 06 & $\mathrm{~s}(\mathrm{p})$ \\
\hline Leelanau & Sleeping Bear Point/Glen Haven & 37 & $6 / 15 / 11$ & 3 & 8 & 13.7 & V A & n.r. & - & - & - & $\underline{06}$ & unk \\
\hline Leelanau & South Manitou Island & 34 & $6 / 16 / 11$ & 0 & 0 & 20.9 & V E & n.r. & 91 & 96 & 01 & 06 & unk \\
\hline $\begin{array}{l}\text { Leelanau/ } \\
\text { Benzie }\end{array}$ & Empire to Esch & 38 & $6 / 16 / 11$ & 0 & 0 & 5.6 & VA & n.r. & - & - & - & - & unk \\
\hline Lelanau & $\begin{array}{l}\text { E Sleeping Bear Bay/W Good } \\
\text { Harbor Bay }\end{array}$ & 36 & $6 / 14 / 11$ & 1 & 2 & 16.1 & V A & n.r. & - & - & - & - & unk \\
\hline Lelenau & North Manitou Island & 35 & $6 / 15 / 11$ & 1 & 10 & 38.6 & V E & n.r. & 91 & 96 & $\underline{01}$ & $\underline{06}$ & unk \\
\hline Luce & Deer Park & 9 & $6 / 4 / 11$ & 0 & 0 & 9.7 & V A & $\mathrm{O}$ & 91 & 96 & 01 & 06 & $\mathrm{~s}(\mathrm{p})$ \\
\hline Luce & $\begin{array}{l}\text { Lake Superior State Forest } \\
\text { Campground }\end{array}$ & 8 & $6 / 5 / 11$ & 0 & 0 & 4.8 & V A & n.r. & - & 96 & 01 & 06 & $\mathrm{~s}(\mathrm{p})$ \\
\hline Mackinac & $\begin{array}{l}\text { Brevort River to Pointe aux } \\
\text { Chenes }\end{array}$ & 21 & $6 / 8 / 11$ & 0 & 0 & 3.2 & V A & n.r. & - & - & - & $\underline{06}$ & $\mathrm{p}$ \\
\hline Mackinac & $\begin{array}{l}\text { Lake MI Campground/West } \\
\text { Brevoort River }\end{array}$ & 19 & $6 / 9 / 11$ & 0 & 0 & 6.0 & V A & n.r. & 91 & - & - & 06 & $\mathrm{p}$ \\
\hline Mackinac & Point Aux Chenes Bay & 20 & $6 / 7 / 11$ & 0 & 0 & 1.6 & V A & n.r. & $\underline{91}$ & 96 & $\underline{01}$ & $\underline{06}$ & $\mathrm{p}$ \\
\hline Manistee & Manistee City Beach & 43 & $6 / 4 / 11$ & 2 & 4 & 3.2 & V A & n.r. & - & - & - & - & $\mathrm{m}$ \\
\hline Mason & Buttersville Park & 46 & $6 / 4 / 11$ & 2 & 4 & 3.2 & V A & n.r. & - & - & - & - & $\mathrm{m}, \mathrm{p}$ \\
\hline Mason & Ludington State Park & 45 & $6 / 4 / 11$ & 2 & 8 & 11.3 & V A & I & 91 & 96 & 01 & 06 & $\mathrm{~s}(\mathrm{p})$ \\
\hline Mason & Nordhouse Dunes Wilderness & 44 & $6 / 7 / 11$ & 1 & 2 & 6.4 & V A & I & - & - & - & $\underline{06}$ & unk \\
\hline Oceana & Silver Lake State Park & 47 & $6 / 4 / 11$ & 1 & 4 & 4.8 & V A & n.r. & - & - & - & - & $\mathrm{m}, \mathrm{p}$ \\
\hline Presque Isle & Hoeft State Park & 50 & $6 / 13 / 11$ & 0 & 0 & 1.0 & V A & n.r. & - & - & 01 & 06 & $\mathrm{~s}(\mathrm{p})$ \\
\hline Presque Isle & Thompson's Harbor State Park & 51 & $6 / 13 / 11$ & 0 & 0 & 1.5 & V A & n.r. & - & 96 & 01 & 06 & $\mathrm{~s}(\mathrm{p})$ \\
\hline
\end{tabular}


The 2011 International Piping Plover Breeding Census in Michigan

(Continued)

\begin{tabular}{|c|c|c|c|c|c|c|c|c|c|c|c|c|}
\hline REGION & SITE NAME & МАР\# & DATE & $\begin{array}{c}\text { BREED- } \\
\text { ING } \\
\text { PAIRS } \\
\end{array}$ & $\begin{array}{c}\text { TOTAL } \\
\text { PIPL } \\
\text { ADULTS } \\
\end{array}$ & $\mathbf{K M}$ & $\begin{array}{l}\text { SITE } \\
\text { DESCRIPTION }\end{array}$ & $\begin{array}{l}\text { DISTURBANCE } \\
\text { CONCERNS }\end{array}$ & $\begin{array}{r}\text { PRIOF } \\
\text { CENSUSE } \\
\text { PIPI } \\
\end{array}$ & $\begin{array}{l}\text { EAR: } \\
\text { \& YE } \\
\text { EEN } \\
\end{array}$ & RS & OWNER \\
\hline Schoolcraft & Gulliver & 17 & $6 / 6 / 16 / 11$ & 2 & 4 & 12.9 & "V A & $\overline{\mathrm{H}}$ & - & - & - & $\overline{s(p)}$ \\
\hline Schoolcraft & Seul Choix Bay & 18 & $6 / 17 / 11$ & 2 & 7 & 7.2 & V A & I & - & - & - & $\mathrm{p}$ \\
\hline Total & & & & 33 & 90 & 283.0 & & & & & & \\
\hline
\end{tabular}

${ }^{1}$ Bold years indicate that adults were seen. Bold and underlined years indicate that pairs were seen.

${ }^{2}$ This total is the "high count"; since two surveys were conducted at some sites for the detectability study, this total includes the highest count at each site.

${ }^{3}$ High Island was not officially censused in 2006, but the site was checked and a pair was observed; however, the specific location of the pair along the survey route is unknown.

The pair may have occurred along either the NW Side or the NE Spit. 


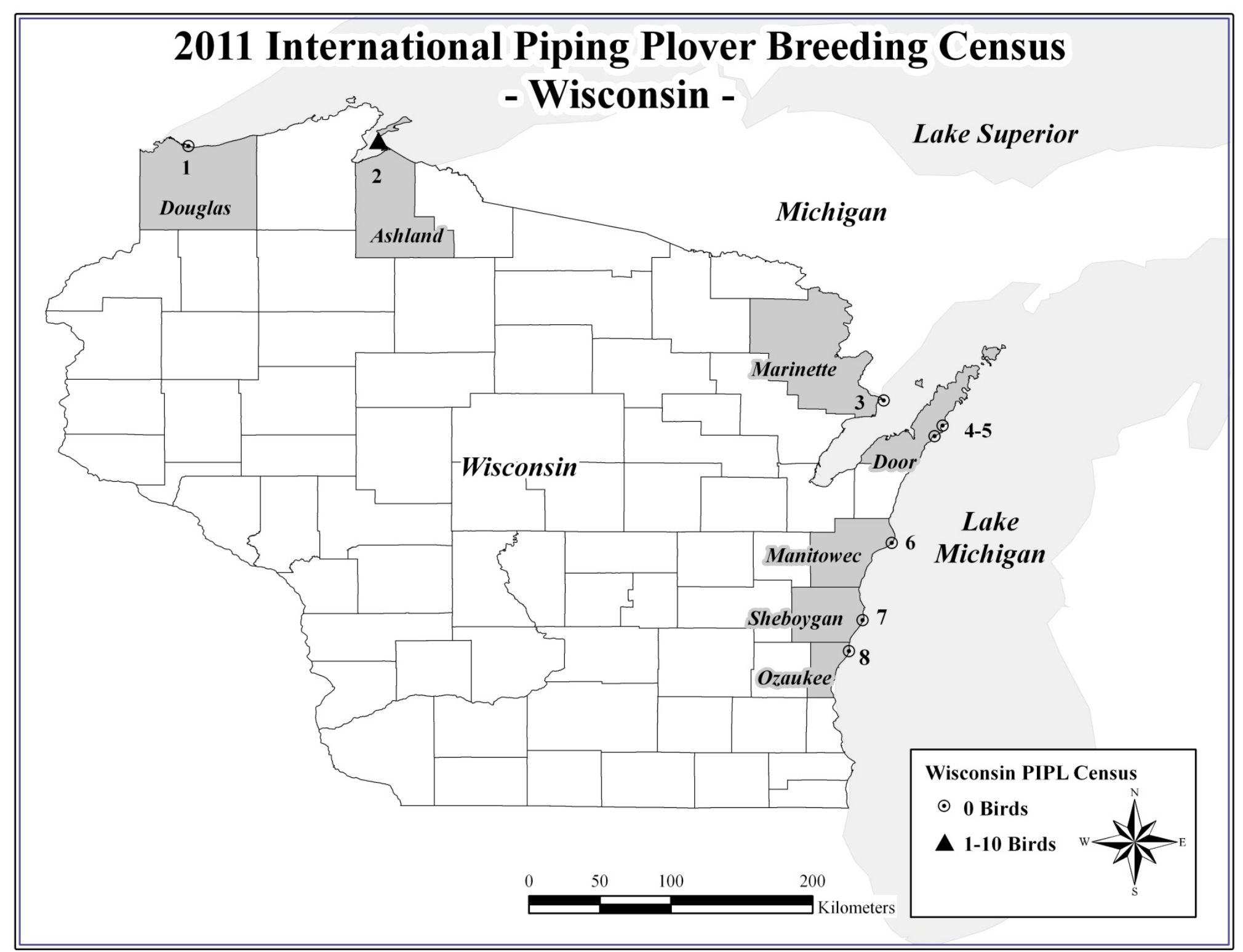


The 2011 International Piping Plover Breeding Census in Wisconsin

\begin{tabular}{|c|c|c|c|c|c|c|c|c|c|c|c|c|c|}
\hline \multirow{2}{*}{$\begin{array}{l}\text { REGION } \\
\text { Ashland }\end{array}$} & \multirow{2}{*}{$\begin{array}{c}\text { SITE NAME } \\
\text { land (sand cut) }\end{array}$} & \multirow{2}{*}{ MAP\# } & \multirow{2}{*}{$\begin{array}{c}\text { DATE } \\
6 / 10 / 11\end{array}$} & \multirow{2}{*}{ 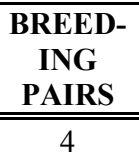 } & \multirow{2}{*}{ 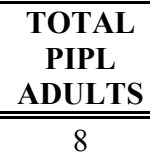 } & \multirow{2}{*}{$\frac{\mathbf{K M}}{7.3}$} & \multirow{2}{*}{$\begin{array}{l}\text { SITE } \\
\text { DESCRIPTION } \\
\mathrm{V} \mathrm{B}\end{array}$} & \multirow{2}{*}{$\begin{array}{l}\text { DISTURBANCE } \\
\text { CONCERNS } \\
\mathrm{H} \mathrm{B}\end{array}$} & \multicolumn{4}{|c|}{$\begin{array}{c}\text { PRIOR YEARS } \\
\text { CENSUSED \& YEARS } \\
\text { PIPL SEEN }^{1} \\
\end{array}$} & \multirow{2}{*}{$\frac{\text { OWNER }}{\mathrm{f}, \mathrm{p}}$} \\
\hline & & & & & & & & & 91 & 96 & $\underline{01}$ & $\underline{06}$ & \\
\hline Door & Lily Bay & 5 & $6 / 8 / 11$ & 0 & 0 & 1.2 & V A & H D & 91 & 96 & $\overline{01}$ & $\overline{06}$ & $s(p), p$ \\
\hline Door & Whitefish Dunes State Park & 4 & $6 / 16 / 11$ & 0 & 0 & 6.5 & V A & V U I & 91 & 96 & 01 & 06 & $\mathrm{~s}(\mathrm{p}), \mathrm{m}, \mathrm{p}$ \\
\hline Douglas & Wisconsin Point & 1 & $6 / 10 / 11$ & 0 & 0 & 6.5 & III V B E & none & 91 & 96 & 01 & 06 & $\mathrm{~m}$ \\
\hline Manitowoc & Point Beach & 6 & $6 / 9 / 11$ & 0 & 0 & 5.6 & V A & n.r. & 91 & 96 & 01 & 06 & $\mathrm{~s}(\mathrm{p})$ \\
\hline Marinette & Seagull Bar (Marinette) & 3 & $6 / 14 / 11$ & 0 & 0 & 2.9 & V IX E & I & 91 & 96 & $\underline{01}$ & 06 & $\mathrm{~s}(\mathrm{p}), \mathrm{m}$ \\
\hline Ozaukee & Harrington Beach State Park & 8 & $6 / 28 / 11$ & 0 & 0 & 1.8 & V A & $\mathrm{H} \mathrm{D}$ & 91 & 96 & 01 & 06 & $\mathrm{~s}(\mathrm{p})$ \\
\hline Sheboygan & Kohler-Andrae State Park & 7 & $6 / 9 / 11$ & 0 & 0 & 3.3 & V A & n.r. & 91 & 96 & 01 & 06 & $\mathrm{~s}(\mathrm{p})$ \\
\hline Total & & & & 4 & 8 & 35.0 & & & & & & & \\
\hline
\end{tabular}




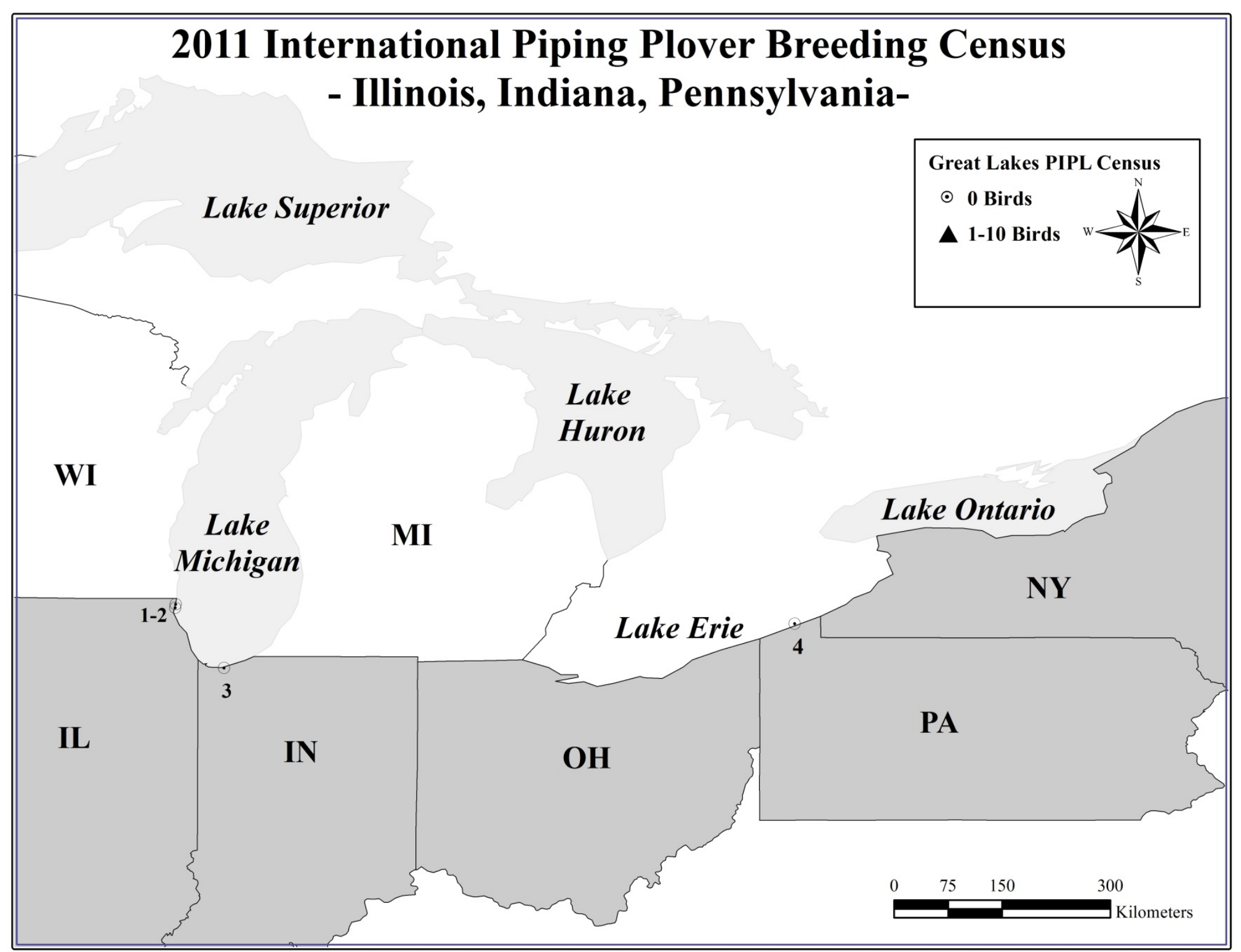


The 2011 International Piping Plover Breeding Census at other Great Lakes sites in Illinois, Indiana, and Pennsylvania



${ }^{1}$ Bold years indicate that adults were seen. Bold and underlined years indicate that pairs were seen. 


\section{The 2011 International Piping Plover Breeding Census in Ontario}

\author{
Stuart A. Mackenzie \\ Bird Studies Canada (Long Point Bird \\ Observatory) \\ P.O. Box 160, 115 Front Rd. \\ Port Rowan, ON NOE 1M0 \\ 519-586-3531 \\ smackenzie@birdscanada.org
}

As part of the 2011 International Piping Plover Census, former, existing, and potential breeding locations of the Piping Plover in Ontario were censused. A total of 62 sites were surveyed in Ontario up from 45 sites in 2006 and 37 sites in 2001. All of the locations were along the shorelines of the Great Lakes (Superior, Huron (Georgian Bay), Erie, Ontario), and Lake of the Woods. In total, 16 adult plovers were reported on the census. An additional 4 adult plovers, likely spring migrants, were observed outside the census.

In general, census coverage was comprehensive. Some remote island sites on Lake Superior were not surveyed due to difficult access and bad weather. Some small beaches on Manitoulin Island, Pinery Provincial Park, Myles Bay (Black Creek Provincial Park), and a few other sites were not surveyed due to a lack of volunteer or staff support.

There were 14 known breeding adults (7 pairs) observed during the 2011 Census, including 4 pairs at Wasaga Beach and 2 at Sauble Beach on Georgian Bay and Lake Huron, respectively. Another pair was observed at Windy Point (Lake of the Woods) on June 6, but only a single bird remained on June 17. A single male was on territory at Carter's Bay on Manitoulin Island.
This is the largest recorded population of Piping Plovers in Ontario since the census began in 1991. Five adults were observed in 1991 (all from Sable Islands -Lake of the Woods), four adults were observed in 1996 (3 from Lake of the Woods), two adults were observed in the 2001 census ( 1 from Long Point, 1 from Windy Point - Lake of the Woods), and only two adults were observed in the 2006 census ( 1 from Windy Point and 1 from Presqu'ile Provincial Park) despite an attempted nesting at Wasaga Beach in 2005. The increase in plover numbers during the 2011 census reflects a true increase in the population rather than census coverage, as all occupied sites were surveyed in previous census years back to 2001 .

The increase observed in the 2011 Census is primarily due to the recently established populations at Wasaga and Sauble Beach on Lake Huron and Georgian Bay. Since the 2006 census, breeding pairs were discovered at three locations in the Great Lakes region. The first attempt to nest was at Wasaga Beach in 2005, followed by a successful nesting in 2007. Since 2007 , pairs have annually nested successfully at Wasaga Beach and Sauble Beach with another pair at Oliphant in 2008.

Threats to Piping Plovers in Ontario include human recreation, water levels, dogs, feral cats, natural predators, beach raking, and invasive species (Phragmites australis). Increased cottage and residential development along shorelines and beaches was one of the dominant threats identified in Ontario in 2011. The development itself is not necessarily problematic, but the associated increase in beach access and recreation is a concern. High water levels on Lake Erie and Lake Ontario reduced the amount of potential habitat particularly at Point Pelee, Rondeau Provincial 
Park, and parts of Long Point. Persistent low water levels at some locations on Lake Huron and Georgian Bay allowed vegetation to reestablish in some low lying beach areas and pools.

Given the small but apparently stable or increasing population of Piping Plovers along the Lake Huron/Georgian Bay shoreline it would be prudent to expand the census in future years to as many locations as possible. The amount or suitability of Piping Plover habitat can be highly variable from year to year both across the province and at individual locations. Therefore, even though some locations may not have been suitable during prior surveys, an effort should be made to census and track potential changes in habitat over time.

A slowly increasing, but vulnerable, population is persisting at prime locations along the Lake Huron and Georgian Bay shorelines and there still appears to be a possibile remnant population in Lake of the Woods. Provided that conservation actions, most notably mitigation of human disturbance, are successful at these locations, the outlook is positive for Piping Plovers in Ontario.

\section{Comparison of Census Numbers}

\begin{tabular}{|l|c|c|c|c|c|}
\hline & 1991 & 1996 & 2001 & 2006 & 2011 \\
\hline $\begin{array}{l}\text { Total } \\
\text { Adults }\end{array}$ & 5 & 4 & 2 & $2^{1}$ & 16 \\
\hline
\end{tabular}

${ }^{1}$ These birds were seen just prior to the official Census period

\section{Detectability Study}

\begin{tabular}{|c|c|c|}
\hline Sites Included & $\begin{array}{c}\text { First } \\
\text { Count }\end{array}$ & $\begin{array}{c}\text { Second } \\
\text { Count }\end{array}$ \\
\hline Providence Bay & 0 & 0 \\
\hline
\end{tabular}




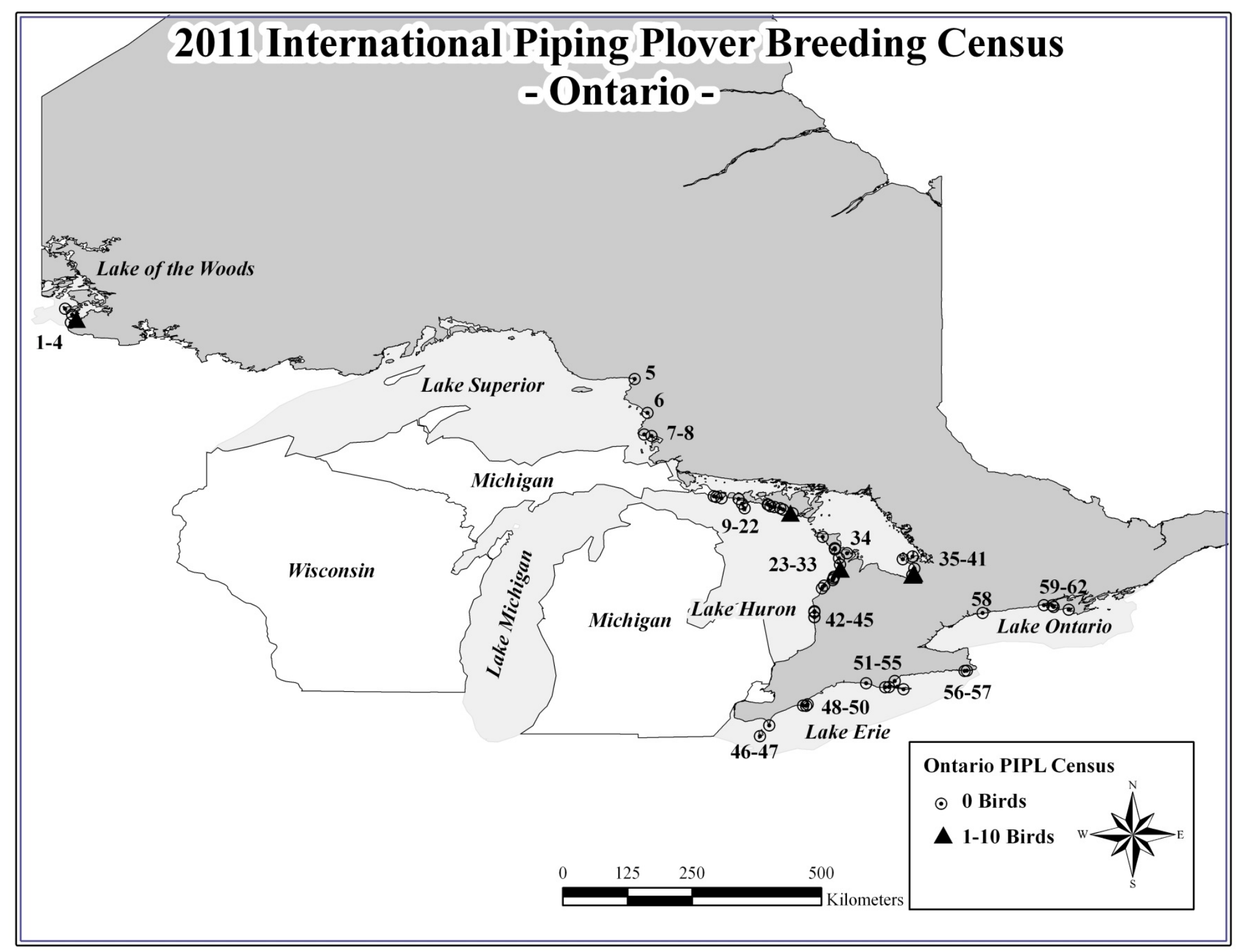


The 2011 International Piping Plover Breeding Census in Ontario

\begin{tabular}{|c|c|c|c|c|c|c|c|c|c|c|c|c|c|}
\hline \multirow{2}{*}{$\frac{\text { REGION }}{\text { Lake Erie }}$} & \multirow{2}{*}{$\begin{array}{l}\text { SITE NAME } \\
\text { Beach }\end{array}$} & \multirow{2}{*}{ MAP\# } & \multirow{2}{*}{$\begin{array}{c}\text { DATE } \\
6 / 6 / 11\end{array}$} & \multirow{2}{*}{$\begin{array}{c}\text { BREED- } \\
\text { ING } \\
\text { PAIRS } \\
0\end{array}$} & \multirow{2}{*}{$\begin{array}{c}\text { TOTAL } \\
\text { PIPL } \\
\text { ADULTS } \\
0\end{array}$} & \multirow{2}{*}{$\frac{\text { KM }}{20.7}$} & \multirow{2}{*}{$\begin{array}{l}\text { SITE } \\
\text { DESCRIPTION } \\
\mathrm{VA}\end{array}$} & \multirow{2}{*}{$\begin{array}{l}\text { DISTURBANCE } \\
\text { CONCERNS } \\
\mathrm{H}\end{array}$} & \multicolumn{4}{|c|}{$\begin{array}{c}\text { PRIOR YEARS } \\
\text { CENSUSED \& YEARS } \\
\text { PIPL SEEN }^{1} \\
\end{array}$} & \multirow{2}{*}{$\frac{\text { OWNER }}{\mathrm{m}}$} \\
\hline & & & & & & & & & - & - & - & 06 & \\
\hline Lake Erie & $\begin{array}{l}\text { Fish Point Provincial Nature } \\
\text { Reserve }\end{array}$ & 46 & $6 / 6 / 11$ & 0 & 0 & 2.5 & V A & none & - & - & - & - & $\mathrm{s}(\mathrm{p}), \mathrm{p}$ \\
\hline Lake Erie & $\begin{array}{l}\text { Hahn Woods to Hastings } \\
\text { Drive*** }\end{array}$ & 52 & $6 / 22 / 11$ & 0 & 0 & 5.3 & V A & I & - & - & 01 & 06 & $\mathrm{f}$ \\
\hline Lake Erie & Long Point, Courtright Ridge E & 54 & $6 / 14 / 11$ & 0 & 0 & 18.0 & V E & I & 91 & 96 & 01 & 06 & $\mathrm{f}, \mathrm{s}(\mathrm{p})$ \\
\hline Lake Erie & Long Point, Courtright Ridge W & 53 & $6 / 16 / 11$ & 0 & 0 & 7.0 & V A D & $\mathrm{H} \mathrm{U}$ & - & - & 01 & 06 & $\mathrm{~s}(\mathrm{p}), \mathrm{m}, \mathrm{p}$ \\
\hline Lake Erie & Point Abino East & 57 & $6 / 8 / 11$ & 0 & 0 & 2.0 & V A & H D & - & - & - & - & $\mathrm{m}, \mathrm{p}$ \\
\hline Lake Erie & Point Abino West & 56 & $6 / 8 / 11$ & 0 & 0 & 3.5 & V A & H D W & - & - & 01 & 06 & $\mathrm{~m}, \mathrm{p}$ \\
\hline Lake Erie & Point Pelee National Park & 47 & $6 / 17 / 11$ & 0 & 0 & 8.0 & V A E & $\mathrm{W}$ & - & - & - & 06 & $f$ \\
\hline Lake Erie & Port Burwell Provincial Park & 51 & $6 / 4 / 11$ & 0 & 0 & 2.5 & V A & I O & - & - & - & 06 & $\mathrm{~s}(\mathrm{p})$ \\
\hline Lake Erie & $\begin{array}{l}\text { Rondeau Provincial Park E } \\
\text { Beach }\end{array}$ & 50 & $6 / 13 / 11$ & 0 & 0 & 9.0 & V A D & $\mathrm{H} \mathrm{U}$ & - & - & 01 & - & $f, s(p)$ \\
\hline Lake Erie & $\begin{array}{l}\text { Rondeau Provincial Park S } \\
\text { Beach }\end{array}$ & 49 & $6 / 10 / 11$ & 0 & 0 & 4.0 & V A D & $\mathrm{O}$ & - & - & 01 & 06 & $f, s(p)$ \\
\hline Lake Erie & Sandbanks Provincial Park & & $6 / 17 / 11$ & 0 & 0 & 8.0 & V A B & H D V W O & - & - & - & - & $\mathrm{s}(\mathrm{p})$ \\
\hline Lake Erie & Turkey Point Beach & 55 & $6 / 16 / 11$ & 0 & 0 & 3.0 & II V A D & H U W O & - & - & - & 06 & $\mathrm{~s}(\mathrm{p})$ \\
\hline Lake Huron & Awenda Provincal Park & 35 & $6 / 16 / 11$ & 0 & 0 & 3.0 & V A & $\mathrm{I}$ & - & - & - & - & $\mathrm{s}(\mathrm{p})$ \\
\hline Lake Huron & Baie du Dore / Douglas Point & 32 & $6 / 5 / 11$ & 0 & 0 & 5.0 & V A & $\mathrm{UO}$ & - & - & 01 & 06 & $\mathrm{~m}, \mathrm{p}$ \\
\hline Lake Huron & Carter Bay & 21 & $6 / 6 / 11$ & 0 & 1 & 1.5 & II V D & n.r. & - & - & 01 & 06 & $f, s(p)$ \\
\hline Lake Huron & Chief's Point & 27 & $6 / 15 / 11$ & 0 & 0 & 5.0 & II V A & H D & - & - & 01 & 06 & $\mathrm{p}$ \\
\hline Lake Huron & $\begin{array}{l}\text { Christian Island (Hope and } \\
\text { Beckwith) }\end{array}$ & 36 & $6 / 7 / 11$ & 0 & 0 & 5.0 & V E & $\mathrm{HO}$ & - & - & - & - & $\mathrm{p}$ \\
\hline Lake Huron & Dean Bay, Manitoulin & 19 & $6 / 15 / 11$ & 0 & 0 & 0.6 & II V A E & $\mathrm{H} \mathrm{UO}$ & - & - & - & - & $\mathrm{m}, \mathrm{p}$ \\
\hline Lake Huron & $\begin{array}{l}\text { Desert Point, Great Duck } \\
\text { Island*** }\end{array}$ & 14 & $7 / 14 / 11$ & 0 & 0 & 1.5 & V A E & $\mathrm{O}$ & - & 96 & 01 & 06 & $\mathrm{p}$ \\
\hline Lake Huron & Dominion Bay & 18 & $6 / 6 / 11$ & 0 & 0 & 1.0 & II A & $\mathrm{U}$ & - & - & - & - & $\mathrm{m}, \mathrm{p}$ \\
\hline Lake Huron & Dorcas Bay & 23 & $6 / 7 / 11$ & 0 & 0 & 1.0 & V A & n.r. & - & - & 01 & 06 & $\mathrm{~m}, \mathrm{p}$ \\
\hline Lake Huron & $\begin{array}{l}\text { Golf Course Road N to Point } \\
\text { Farms Park*** }\end{array}$ & 44 & $6 / 3 / 11$ & 0 & 0 & 0.8 & V A & H D U & - & - & 01 & 06 & $\mathrm{~s}(\mathrm{p}), \mathrm{m}, \mathrm{p}$ \\
\hline Lake Huron & $\begin{array}{l}\text { Golf Course Road S to Sunset } \\
\text { Beach }\end{array}$ & 45 & $6 / 9 / 11$ & 0 & 0 & 1.5 & V A & $\mathrm{H} \mathrm{U}$ & - & - & 01 & 06 & $\mathrm{~s}(\mathrm{p}), \mathrm{m}, \mathrm{p}$ \\
\hline Lake Huron & Hope Bay & 34 & $6 / 9 / 11$ & 0 & 0 & 2.0 & II V A D & $\mathrm{U}$ & - & - & 01 & 06 & $\mathrm{~s}(\mathrm{p}), \mathrm{m}$ \\
\hline Lake Huron & $\begin{array}{l}\text { Hyndman Bay, Cockburn } \\
\text { Island*** }\end{array}$ & 10 & $7 / 15 / 11$ & 0 & 0 & 0.4 & II A & none & - & - & - & - & $\mathrm{s}(\mathrm{p}), \mathrm{m}$ \\
\hline
\end{tabular}


The 2011 International Piping Plover Breeding Census in Ontario (Continued)

\begin{tabular}{|c|c|c|c|c|c|c|c|c|c|c|c|c|c|}
\hline \multirow{2}{*}{ 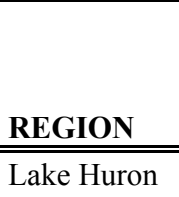 } & \multirow{2}{*}{$\begin{array}{c}\text { SITE NAME } \\
\text { on Provincial Park }\end{array}$} & \multirow{2}{*}{ MAP\# } & \multirow{2}{*}{$\frac{\text { DATE }}{26 / 4 / 11}$} & \multirow{2}{*}{$\begin{array}{c}\text { BREED- } \\
\text { ING } \\
\text { PAIRS } \\
0\end{array}$} & \multirow{2}{*}{$\begin{array}{c}\begin{array}{c}\text { TOTAL } \\
\text { PIPL } \\
\text { ADULTS }\end{array} \\
0\end{array}$} & \multirow{2}{*}{$\frac{\mathbf{K M}}{5.0}$} & \multirow{2}{*}{$\begin{array}{l}\text { SITE } \\
\text { DESCRIPTION } \\
\mathrm{VA}\end{array}$} & \multirow{2}{*}{$\begin{array}{l}\text { DISTURBANCE } \\
\text { CONCERNS } \\
\mathrm{H} \mathrm{S} \mathrm{O}\end{array}$} & \multicolumn{4}{|c|}{$\begin{array}{c}\text { PRIOR YEARS } \\
\text { CENSUSED \& } \\
\text { YEARS } \\
\text { PIPL SEEN }^{1} \\
\end{array}$} & \multirow{2}{*}{$\frac{\text { OWNER }}{\mathrm{s}(\mathrm{p}), \mathrm{p}}$} \\
\hline & & & & & & & & & - & - & - & 06 & \\
\hline Lake Huron & Michael's Bay & 22 & $6 / 17 / 11$ & 0 & 0 & 0.0 & II III V A D & $\mathrm{O}$ & - & - & 01 & 06 & $\mathrm{~s}(\mathrm{p})$ \\
\hline Lake Huron & Miramichi Bay & 30 & $6 / 9 / 11$ & 0 & 0 & 1.5 & V A & n.r. & - & - & 01 & 06 & $\mathrm{~m}, \mathrm{p}$ \\
\hline Lake Huron & Myles Bay & 25 & $6 / 9 / 11$ & 0 & 0 & 0.5 & II V A & $\mathrm{UO}$ & - & - & 01 & 06 & $\mathrm{~s}(\mathrm{p})$ \\
\hline Lake Huron & $\begin{array}{l}\text { Port Albert } \mathrm{N} \text { to Mid Huron } \\
\text { Beach Road }^{2}\end{array}$ & 42 & $6 / 3 / 11$ & 0 & 0 & 1.0 & V A & H D U W & - & - & 01 & 06 & $\mathrm{~m}, \mathrm{p}$ \\
\hline Lake Huron & $\begin{array}{l}\text { Port Albert S to Brindley Beach } \\
\operatorname{Road}^{2}\end{array}$ & 43 & $9 / 6 / 11$ & 0 & 0 & 5.0 & V A & n.r. & - & - & 01 & 06 & $\mathrm{~m}, \mathrm{p}$ \\
\hline Lake Huron & Port Elgin & 31 & $6 / 9 / 11$ & 0 & 0 & 4.0 & V A & H U V O & - & - & 01 & 06 & $\mathrm{~m}, \mathrm{p}$ \\
\hline Lake Huron & Portage Bay E Beach & 16 & $6 / 16 / 11$ & 0 & 0 & 1.0 & V A & $\mathrm{H} \mathrm{U}$ & - & - & - & - & $\mathrm{s}(\mathrm{p}), \mathrm{m}, \mathrm{p}$ \\
\hline Lake Huron & Portage Bay W Beach ${ }^{2}$ & 15 & $6 / 27 / 11$ & 0 & 0 & 1.4 & V A & H U V & - & - & - & - & $\mathrm{s}(\mathrm{p}), \mathrm{m}, \mathrm{p}$ \\
\hline Lake Huron & Providence Bay & 20 & $6 / 6 / 11$ & 0 & 0 & 2.0 & V A D E & $\mathrm{H} \mathrm{U}$ & - & - & 01 & 06 & $\mathrm{~m}, \mathrm{p}$ \\
\hline Lake Huron & Red Bay/Howdenvale & 26 & $6 / 7 / 11$ & 0 & 0 & 2.5 & II V A D & n.r. & - & - & 01 & 06 & $\mathrm{~m}, \mathrm{p}$ \\
\hline Lake Huron & Sand Bay, Cockburn Island ${ }^{2}$ & 11 & $7 / 15 / 11$ & 0 & 0 & 1.5 & III A & U V & - & - & - & - & $\mathrm{m}$ \\
\hline Lake Huron & Sauble Beach & 28 & $6 / 10 / 11$ & 2 & 5 & 11.0 & V A & $\mathrm{H} \mathrm{U}$ & - & - & 01 & 06 & $\mathrm{~s}(\mathrm{p}), \mathrm{m}, \mathrm{p}$ \\
\hline Lake Huron & Shrigley Bay & 17 & $6 / 16 / 11$ & 0 & 0 & 0.8 & V A & U V & - & - & - & - & $\mathrm{s}(\mathrm{p}), \mathrm{m}, \mathrm{p}$ \\
\hline Lake Huron & Southhampton & 29 & $6 / 9 / 11$ & 0 & 0 & 5.0 & V A & H U V & - & - & 01 & 06 & $\mathrm{~m}, \mathrm{p}$ \\
\hline Lake Huron & Stokes Bay & 24 & $6 / 9 / 11$ & 0 & 0 & 2.0 & V A & $\mathrm{U}$ & - & - & 01 & 06 & $\mathrm{~m}, \mathrm{p}$ \\
\hline Lake Huron & Tiny Beaches & 37 & $6 / 17 / 11$ & 0 & 0 & 5.0 & V A & H U D O & - & - & - & - & $\mathrm{m}$ \\
\hline Lake Huron & Wagosh Bay, Cockburn Island ${ }^{2}$ & 9 & $7 / 15 / 11$ & 0 & 0 & 1.0 & II D E & $\mathrm{U}$ & - & - & - & - & $\mathrm{s}(\mathrm{p})$ \\
\hline Lake Huron & Wasaga Beach - Site \# 1 & 38 & $6 / 14 / 11$ & 1 & 2 & 3.5 & II A & H U D O & - & - & - & 06 & $s(p)$ \\
\hline Lake Huron & Wasaga Beach - Site \# 2 & 39 & $6 / 17 / 11$ & 1 & 2 & 0.5 & II A I & $\mathrm{H} \mathrm{I} \mathrm{O}$ & - & 96 & - & 06 & $\mathrm{~s}(\mathrm{p})$ \\
\hline Lake Huron & Wasaga Beach - Site \# 3 & 40 & $6 / 12 / 11$ & 2 & 4 & 1.0 & II V A & $\mathrm{H} \mathrm{U}$ & - & - & - & 06 & $s(p)$ \\
\hline Lake Huron & Wasaga Beach - Site \# 4 & 41 & $6 / 7 / 11$ & 0 & 0 & 7.5 & II A & $\mathrm{U}$ & - & - & 01 & 06 & $s(p)$ \\
\hline Lake Huron & $\begin{array}{l}\text { West Belanger Bay, Manitoulin } \\
\text { Island }\end{array}$ & 12 & $6 / 17 / 11$ & 0 & 0 & 0.0 & V D & $\mathrm{V}$ & - & - & - & - & $\mathrm{m}, \mathrm{p}$ \\
\hline Lake Huron & 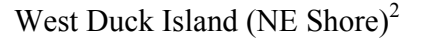 & 13 & $7 / 14 / 11$ & 0 & 0 & 1.7 & V IX A E & none & - & 96 & 01 & - & $\mathrm{s}(\mathrm{p}), \mathrm{p}$ \\
\hline Lake Ontario & Darlington Provincial Park & 58 & $6 / 8 / 11$ & 0 & 0 & 2.0 & V A & $\mathrm{H}$ & - & - & - & 06 & $\mathrm{~s}(\mathrm{p}), \mathrm{m}$ \\
\hline Lake Ontario & North Beach Provincial Park & 61 & $6 / 16 / 11$ & 0 & 0 & 4.0 & V A B & H D V W & - & - & - & - & $\mathrm{s}(\mathrm{p})$ \\
\hline
\end{tabular}


The 2011 International Piping Plover Breeding Census in Ontario (Continued)

\begin{tabular}{|c|c|c|c|c|c|c|c|c|c|c|c|c|c|}
\hline \multirow{2}{*}{$\begin{array}{l}\text { REGION } \\
\text { Lake Ontario }\end{array}$} & \multirow{2}{*}{$\begin{array}{c}\text { SITE NAME } \\
\text { Presqu'ile Provincial Park }\end{array}$} & \multirow{2}{*}{$\frac{\text { MAP\# }}{259}$} & \multirow{2}{*}{$\frac{\text { DATE }}{6 / 15 / 11}$} & \multirow{2}{*}{ 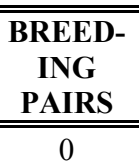 } & \multirow{2}{*}{$\begin{array}{c}\text { TOTAL } \\
\text { PIPL } \\
\text { ADULTS } \\
0\end{array}$} & \multirow{2}{*}{$\frac{\mathbf{K M}}{3.5}$} & \multirow{2}{*}{$\begin{array}{l}\text { SITE } \\
\text { DESCRIPTION } \\
\text { V IX A }\end{array}$} & \multirow{2}{*}{$\begin{array}{l}\text { DISTURBANCE } \\
\text { CONCERNS } \\
\mathrm{H} \mathrm{I} \mathrm{O}\end{array}$} & \multicolumn{4}{|c|}{$\begin{array}{c}\text { PRIOR YEARS } \\
\text { CENSUSED \& YEARS } \\
\text { PIPL SEEN }^{1} \\
\end{array}$} & \multirow{2}{*}{ 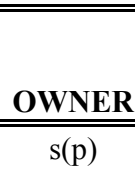 } \\
\hline & & & & & & & & & - & - & - & $\overline{06^{3}}$ & \\
\hline Lake Ontario & Sandbanks Provincial Park & 62 & $6 / 17 / 11$ & 0 & 0 & 8.0 & V B & H D V & - & - & - & - & \\
\hline Lake Ontario & $\begin{array}{l}\text { Weller's Bay National Wildlife } \\
\text { Area }\end{array}$ & 60 & $6 / 15 / 11$ & 0 & 0 & 8.0 & VIII B & $\mathrm{W}$ & - & - & - & 06 & $\mathrm{f}, \mathrm{s}(\mathrm{p})$ \\
\hline Lake Superior & Agawa Bay & 6 & $6 / 15 / 11$ & 0 & 0 & 4.0 & II V A & $\mathrm{H}$ & - & 96 & - & 06 & $\mathrm{~s}(\mathrm{p})$ \\
\hline Lake Superior & $\begin{array}{l}\text { Batchawana Bay Provincial } \\
\text { Park }\end{array}$ & 7 & n.r. & 0 & 0 & 3.0 & II V A & $\mathrm{H}$ & - & 96 & - & - & $\mathrm{s}(\mathrm{p})$ \\
\hline Lake Superior & $\begin{array}{l}\text { Driftwood Beach, Michipicoten } \\
\text { Post Provincial Park }\end{array}$ & 5 & $6 / 12 / 11$ & 0 & 0 & 2.4 & V A & n.r. & - & - & 01 & 06 & $\mathrm{~s}(\mathrm{p})$ \\
\hline Lake Superior & Pancake Bay & 8 & $6 / 13 / 11$ & 0 & 0 & 6.0 & II V A & $\mathrm{H}$ & - & - & - & - & $\mathrm{s}(\mathrm{p})$ \\
\hline $\begin{array}{l}\text { Lake of the } \\
\text { Woods }\end{array}$ & Big Island - Oshie Bay & 1 & $6 / 6 / 11$ & 0 & 0 & 0.0 & V A B & n.r. & - & 96 & 01 & 06 & $\mathrm{~s}(\mathrm{p})$ \\
\hline $\begin{array}{l}\text { Lake of the } \\
\text { Woods }\end{array}$ & Bigsby Island - Deep Bay & 2 & $6 / 6 / 11$ & 0 & 0 & 2.5 & V A B & $\mathrm{O}$ & - & 96 & 01 & 06 & $\mathrm{~s}(\mathrm{p})$ \\
\hline $\begin{array}{l}\text { Lake of the } \\
\text { Woods }\end{array}$ & $\begin{array}{l}\text { Sable Islands Prov. Nature } \\
\text { Reserve }\end{array}$ & 4 & $6 / 7 / 11$ & 0 & 0 & 6.0 & V A C & $\mathrm{O}$ & $\underline{91}$ & 96 & 01 & 06 & $\mathrm{~s}(\mathrm{p})$ \\
\hline $\begin{array}{l}\text { Lake of the } \\
\text { Woods }\end{array}$ & Windy Point & 3 & $6 / 6 / 11$ & 1 & 2 & 1.0 & V A C E & none & 91 & $\underline{96}$ & 01 & $06^{4}$ & $\mathrm{p}$ \\
\hline Total & & & & 7 & 16 & 216.6 & & & & & & & \\
\hline
\end{tabular}

Bold years indicate that adults were seen. Bold and underlined years indicate that pairs were seen.

${ }^{2}$ Please note that these surveys were conducted outside the Census window.

31 banded PIPL was observed at this site outside the 2006 Census window on May 29th and 30th, 2006.

${ }^{4} 1$ PIPL was seen along this site in 2006, but it was observed outside the census window. 


\section{The 2011 International Piping Plover Breeding Census in Minnesota}

Katie Haws

Minnesota DNR

2115 Birchmont Beach. Rd. NE

Bemidji, MN 56601

218-308-2641

katie.haws@state.mn.us

Coverage during the 2011 Census in Minnesota was minimal, given that we only had three surveyors. Even with the small effort, all sites which had been active in the past 20 years were surveyed. However, we didn't check any potential north shore sites, as we had done in 2006. Sites we did check included Lake of the Woods: Stony Point, Garden Island, Rocky Point, Pine/Curry Island and Morris Point.

The Census effort was likely adequate to monitor the known population. Most other possible areas such as the northwest angle of Lake of the Woods extensive beaches, and north shore sites on Lake Superior have previously been searched when the state population was larger, and did not result in additional detections. Given the continual decline of the Piping Plover population in Minnesota it is unlikely that any birds were missed by not surveying these "potential" sites.

Census results are very similar to the 2006 survey, showing a small decrease in population. The 2006 population was two nesting pairs, and in 2011 we found one nesting pair. The results likely represent the actual population in Minnesota, as we have observers in the field that would report additional pairs, were they present.
Population trends appear to be related to habitat quality. On Lake of the Woods, factors affecting plover habitat include water level and erosion. At Duluth, issues are increased harbor development and effects on suitable habitat in the St. Louis River estuary.

\section{Comparison of Census Numbers}

\begin{tabular}{|l|c|c|c|c|c|}
\hline & 1991 & 1996 & 2001 & 2006 & 2011 \\
\hline $\begin{array}{l}\text { Total } \\
\text { Adults }\end{array}$ & 13 & 10 & 7 & $4^{1}$ & $2^{1}$ \\
\hline
\end{tabular}

${ }^{\mathrm{I}}$ This is the total from a single survey at each site; if more than one survey was conducted, we count only results from the first survey during the census window. 


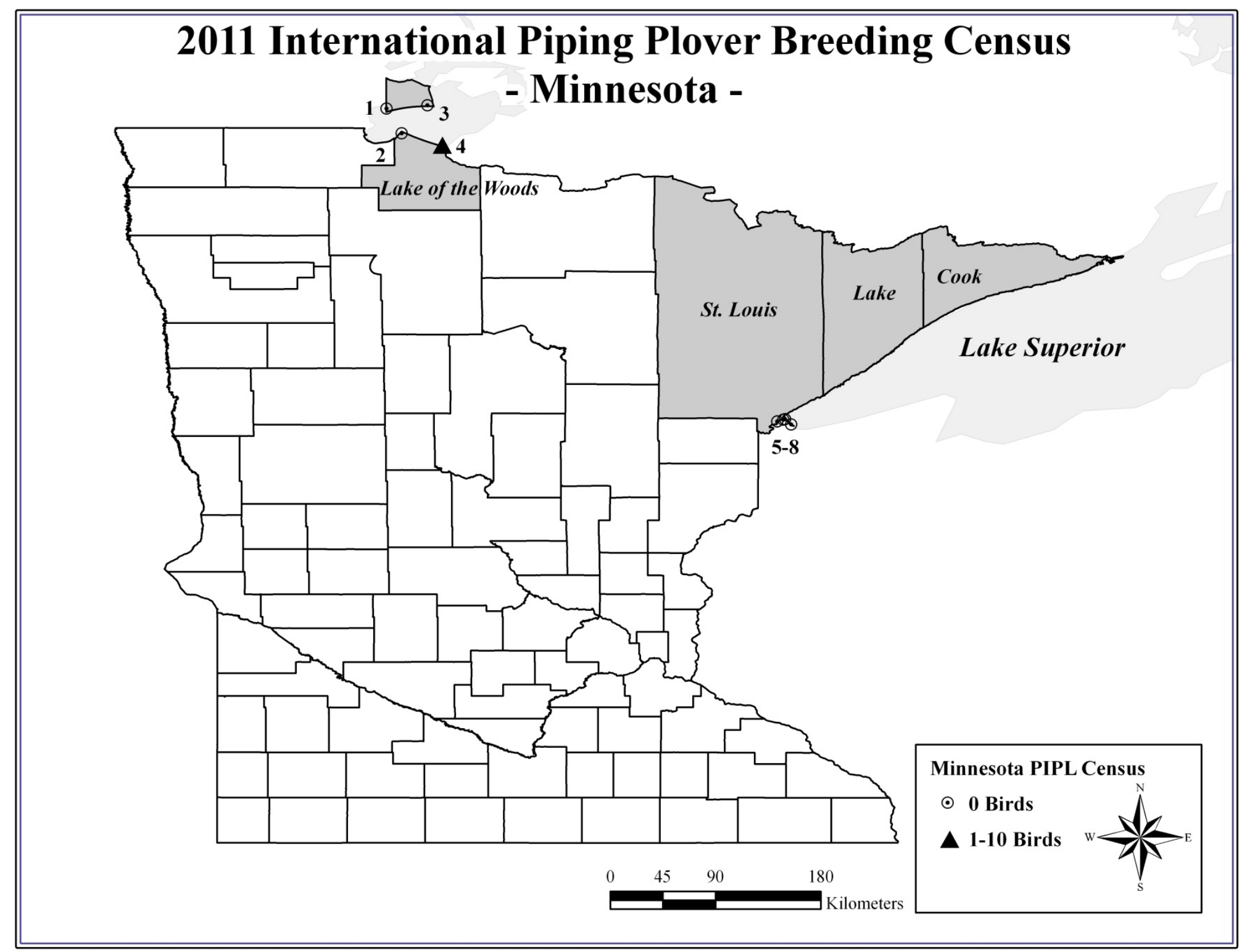


The 2011 International Piping Plover Breeding Census in Minnesota

\begin{tabular}{|c|c|c|c|c|c|c|c|c|c|c|c|c|c|}
\hline \multirow{2}{*}{$\begin{array}{l}\text { REGION } \\
\text { Lake of the } \\
\text { Woods }\end{array}$} & \multirow{2}{*}{$\begin{array}{l}\text { SITE NAME } \\
\text { Island State Recreation }\end{array}$} & \multirow{2}{*}{ MAP\# } & \multirow{2}{*}{$\begin{array}{c}\text { DATE } \\
6 / 16 / 11\end{array}$} & \multirow{2}{*}{ 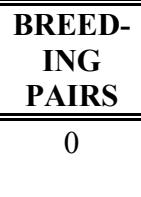 } & \multirow{2}{*}{ 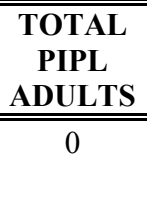 } & \multirow{2}{*}{$\frac{\mathbf{K M}}{1.0}$} & \multirow{2}{*}{$\begin{array}{l}\text { SITE } \\
\text { DESCRIPTION } \\
\mathrm{VE}\end{array}$} & \multirow{2}{*}{$\begin{array}{l}\text { DISTURBANCE } \\
\text { CONCERNS } \\
\text { none }\end{array}$} & \multicolumn{4}{|c|}{$\begin{array}{c}\text { PRIOR YEARS } \\
\text { CENSUSED \& YEARS } \\
\text { PIPL SEEN }^{1} \\
\end{array}$} & \multirow{2}{*}{$\frac{\text { OWNER }}{\mathrm{O}}$} \\
\hline & & & & & & & & & - & - & - & $\underline{06}$ & \\
\hline $\begin{array}{l}\text { Lake of the } \\
\text { Woods }\end{array}$ & $\begin{array}{l}\text { Pine and Curry Island, Morris } \\
\text { Point }\end{array}$ & 4 & $6 / 2 / 11$ & 1 & 2 & 3.2 & $\mathrm{~V} \mathrm{C}$ & n.r. & $\underline{91}$ & $\underline{96}$ & 01 & 06 & n.r. \\
\hline $\begin{array}{l}\text { Lake of the } \\
\text { Woods }\end{array}$ & Rocky Point & 2 & $6 / 2 / 11$ & 0 & 0 & 1.1 & V A & n.r. & 91 & 96 & $\underline{01}$ & $\underline{06}$ & $\mathrm{~s}(\mathrm{p})$ \\
\hline $\begin{array}{l}\text { Lake of the } \\
\text { Woods }\end{array}$ & Stony Point & 1 & $6 / 16 / 11$ & 0 & 0 & 1.0 & II C E & $\mathrm{W}$ & - & - & - & 06 & $\mathrm{p}$ \\
\hline St. Loius & Hearding Island & 7 & $6 / 8 / 11$ & 0 & 0 & 0.6 & II E & $\mathrm{PO}$ & - & - & - & 06 & $\mathrm{~s}(\mathrm{p})$ \\
\hline St. Louis & Duluth Port Terminal & 6 & $6 / 8 / 11$ & 0 & 0 & 0.4 & II A I & $\mathrm{HNO}$ & 91 & - & - & 06 & n.r. \\
\hline St. Louis & Duluth T49 R14 Section 8 & 5 & $6 / 8 / 11$ & 0 & 0 & 0.1 & II VIII I & $\mathrm{N}$ & - & - & - & 06 & n.r. \\
\hline St. Louis & $\begin{array}{l}\text { MN Point (Canal Park \& end of } \\
\text { Peninsula) }\end{array}$ & 8 & $6 / 8 / 11$ & 0 & 0 & 3.2 & II V C D & H D S O & - & - & - & 06 & n.r. \\
\hline Total & & & & 1 & 2 & 10.6 & & & & & & & \\
\hline
\end{tabular}

Bold years indicate that adults were seen. Bold and underlined years indicate that pairs were seen. 


\section{The 2011 International Piping Plover Breeding Census in Manitoba}

Ken Porteous

Department of Conservation

200 Saulteaux Crescent

Winnipeg MB R3J 3W3

204-898-2654

kcporteous@me.com

Only one pair of breeding Piping Plovers was detected during the 2011 census period. The two plovers observed were nesting at Grand Beach in the south basin of Lake Winnipeg, a traditional breeding site for many years. Several single birds were seen outside the census window and given they were marked, we were certain that at least a few additional birds used Manitoba shores duing the 2011 breeding season. However, even with these additional observations, Piping Plover numbers in Manitoba hit an all-time low in 2011. Numbers have declined, census to census, since the inception of the International Census in 1991. These critically low and declining numbers suggest the species could be extirpated from Manitoba within the next decade.

In part, low numbers reflect a decline of Piping Plovers in Manitoba, but water levels were also extremely high in 2011. High water levels reduce the availability and quality of nesting habitat on beaches surrounding the south basins of Lake Winnipeg and Lake Manitoba. High water levels on these two lakes continue to be the most limiting factor in Manitoba recovery efforts for this species. Aside from Grand Beach, most areas around Lake Winnipeg were completely flooded in 2011 or high water levels narrowed beaches to the point where they were unsuitable for nesting.
Unfortunately, high water has been a common problem on Lake Winnepeg due to flooding of inflows and it being regulated as a giant reservoir. In the past 17 years, the Red River, one of the three major inflows into Lake Winnipeg, has flooded 14 times, whether during the spring melt or a major precipitation event during June or July. This includes the infamous "Flood of the Century" in 1997. Four International Censuses were conducted in flood years. The 2011 census was conducted shortly after the third worst flood since 1995.

Compounding the situation on Lake Winnipeg is flooding along the Assiniboine River, which normally empties into the Red, but can be, and is, diverted into Lake Manitoba. Therefore, nesting habitat around its south basin is also flooded and greatly reduced.

Other sites were also unsuitable in 2011 due to high water. Record high flow on the Waterhen River inundated Salt Point road at the bridge rendering access impossible. We were also unable to survey Katimik Lake and Kaweenakumik Lake due to very high water levels. Wells Harbour was not surveyed in 2011 due to high water. Until water levels drop significantly, exposing more shoreline and beach, it is unlikely breeding Piping Plover will find suitable habitat to nest in Manitoba.

\section{Comparison of Census Numbers}

\begin{tabular}{|l|c|c|c|c|c|}
\hline & 1991 & 1996 & 2001 & 2006 & 2011 \\
\hline $\begin{array}{l}\text { Total } \\
\text { Adults }\end{array}$ & 80 & 60 & 16 & $8^{1}$ & $2^{1}$ \\
\hline
\end{tabular}

${ }^{1}$ This is the total from a single survey at each site; if more than one survey was conducted, we count only results from the first survey during the census window.

\section{Detectability Study}

\begin{tabular}{|l|c|c|}
\hline \multicolumn{1}{|c|}{ Sites Included } & $\begin{array}{c}\text { First } \\
\text { Count }\end{array}$ & $\begin{array}{c}\text { Second } \\
\text { Count }\end{array}$ \\
\hline Elk Island & 0 & 0 \\
\hline Gimli Beach & 0 & 0 \\
\hline Grand Beach & 2 & 2 \\
\hline Grand Marais Spit & 0 & 0 \\
\hline Hillside Beach & 0 & 0 \\
\hline
\end{tabular}




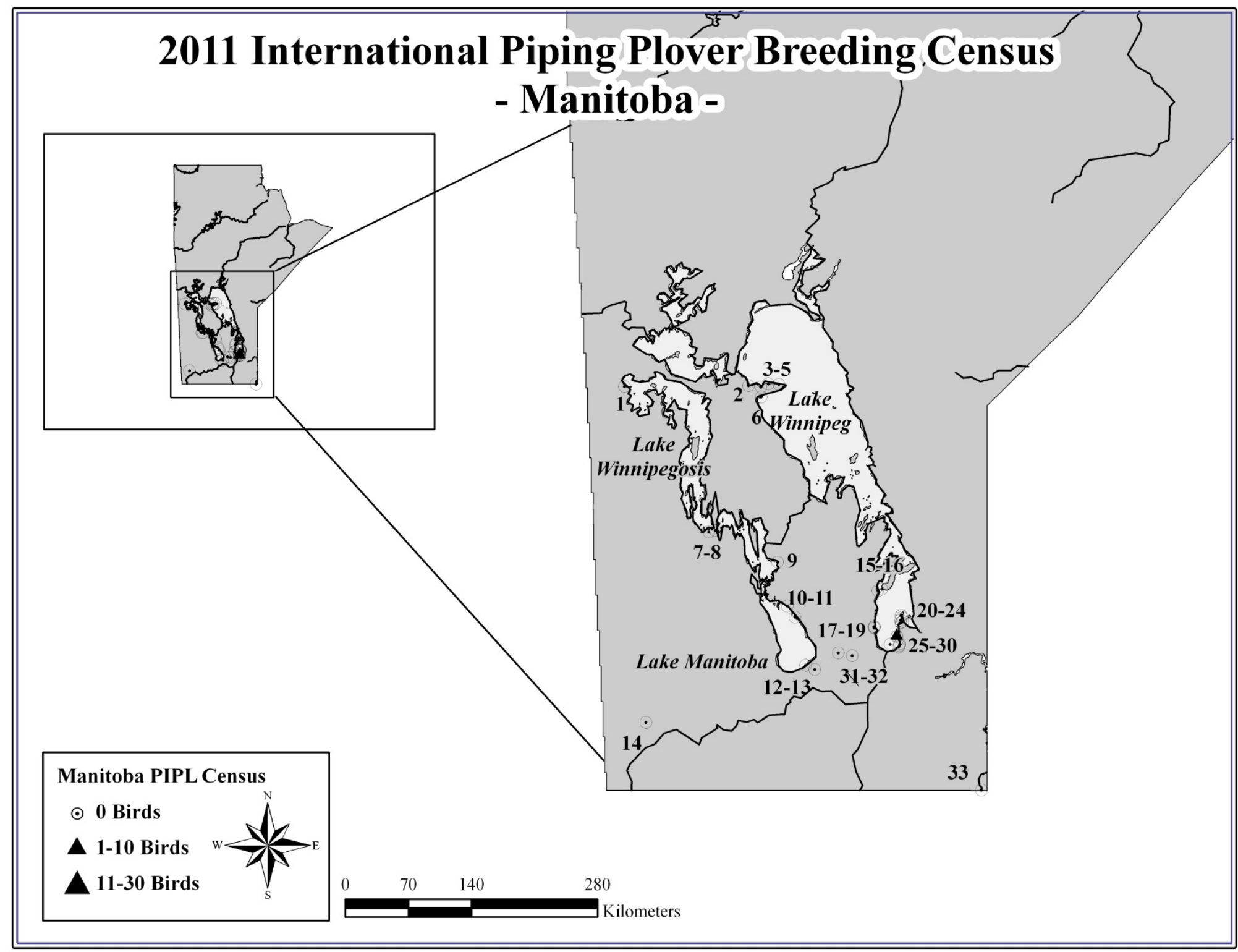


The 2011 International Piping Plover Breeding Census in Manitoba

\begin{tabular}{|c|c|c|c|c|c|c|c|c|c|c|c|c|c|}
\hline \multirow{2}{*}{$\begin{array}{l}\text { REGION } \\
\text { Lake Manitoba }\end{array}$} & SITE NAME & \multirow{2}{*}{ MAP\# } & \multirow{2}{*}{$\frac{\text { DATE }}{6 / 17 / 11}$} & \multirow{2}{*}{$\begin{array}{c}\text { BREED- } \\
\text { ING } \\
\text { PAIRS } \\
0\end{array}$} & \multirow{2}{*}{$\begin{array}{c}\text { TOTAL } \\
\text { PIPL } \\
\text { ADULTS } \\
0\end{array}$} & \multirow{2}{*}{$\frac{\mathbf{K M}}{0.3}$} & \multirow{2}{*}{$\begin{array}{l}\text { SITE } \\
\text { DESCRIPTION } \\
\mathrm{V} \mathrm{B}\end{array}$} & \multirow{2}{*}{$\begin{array}{l}\text { DISTURBANCE } \\
\text { CONCERNS } \\
\mathrm{W}\end{array}$} & \multicolumn{4}{|c|}{$\begin{array}{c}\text { PRIOR YEARS } \\
\text { CENSUSED \& YEARS } \\
\text { PIPL SEEN }^{1} \\
\end{array}$} & \multirow{2}{*}{ 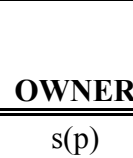 } \\
\hline & Clandeboye Bay & & & & & & & & 91 & $\underline{96}$ & $\underline{01}$ & 06 & \\
\hline Lake Manitoba & Elm Point & 10 & $6 / 10 / 11$ & 0 & 0 & 0.5 & V A & $\mathrm{W}$ & - & - & - & 06 & $\mathrm{p}$ \\
\hline Lake Manitoba & Lundar Beach Provincial Park & 11 & $6 / 10 / 11$ & 0 & 0 & 0.0 & V A & W & - & - & - & 06 & $\mathrm{~s}(\mathrm{p})$ \\
\hline Lake Manitoba & Twin Lakes Beach & 13 & $6 / 4 / 11$ & 0 & 0 & 0.0 & V A & $\mathrm{W}$ & 91 & 96 & 01 & 06 & $\mathrm{~s}(\mathrm{p}), \mathrm{m}, \mathrm{p}$ \\
\hline Lake Manitoba & Watchorn Provincial Park & 9 & $6 / 10 / 11$ & 0 & 0 & 0.1 & V A & H U V W & - & - & - & 06 & $\mathrm{~s}(\mathrm{p})$ \\
\hline $\begin{array}{l}\text { Lake of the } \\
\text { Woods }\end{array}$ & Buffalo Point $^{2}$ & & $6 / 19 / 11$ & 0 & 0 & 0.0 & V A & $\mathrm{H} \mathrm{U}$ & - & - & - & 06 & $\mathrm{~m}, \mathrm{p}$ \\
\hline Lake Winnipeg & Albert Beach & 23 & $6 / 7 / 11$ & 0 & 0 & 0.5 & V A & none & - & - & 01 & 06 & $\mathrm{~s}(\mathrm{p})$ \\
\hline Lake Winnipeg & Beaconia Beach & 29 & $6 / 4 / 11$ & 0 & 0 & 0.0 & V A B & W & - & - & 01 & 06 & $\mathrm{~s}(\mathrm{p})$ \\
\hline Lake Winnipeg & Chalet Beach & 27 & $6 / 16 / 11$ & 0 & 0 & 0.0 & V A & $\mathrm{W} \mathrm{O}$ & $\underline{91}$ & - & - & 06 & $\mathrm{~s}(\mathrm{p})$ \\
\hline Lake Winnipeg & Elk Island & 20 & $6 / 10 / 11$ & 0 & 0 & n.r. & V E & none & - & $\underline{96}$ & 01 & 06 & $\mathrm{~s}(\mathrm{p})$ \\
\hline Lake Winnipeg & Gimli Beach & 17 & $6 / 14 / 11$ & 0 & 0 & 0.0 & V A & W & - & - & - & - & n.r. \\
\hline Lake Winnipeg & Grand Beach & 25 & $6 / 4 / 11$ & 1 & 2 & 3.0 & V A & $\mathrm{U}$ & $\underline{91}$ & $\underline{96}$ & $\underline{01}$ & $\underline{06}$ & $\mathrm{~s}(\mathrm{p})$ \\
\hline Lake Winnipeg & Grand Marais Spit & 26 & $6 / 6 / 11$ & 0 & 0 & 1.0 & V B & W & - & $\underline{96}$ & - & 06 & $\mathrm{~s}(\mathrm{p})$ \\
\hline Lake Winnipeg & Hecla Island Sand Spit & 15 & $6 / 6 / 11$ & 0 & 0 & 0.1 & V E & W & $\underline{91}$ & $\underline{96}$ & 01 & 06 & $\mathrm{~s}(\mathrm{p})$ \\
\hline Lake Winnipeg & Hillside Beach & 24 & $6 / 7 / 11$ & 0 & 0 & 1.0 & V A & none & - & - & 01 & 06 & $\mathrm{~m}$ \\
\hline Lake Winnipeg & Island Beach & 28 & $6 / 4 / 11$ & 0 & 0 & 0.5 & V A & W & - & - & - & 06 & $\mathrm{p}$ \\
\hline Lake Winnipeg & Longpoint - Hole in the Wall & 3 & $6 / 15 / 11$ & 0 & 0 & 0.0 & V A & $\mathrm{W}$ & - & - & - & 06 & $\mathrm{~s}(\mathrm{p})$ \\
\hline Lake Winnipeg & Longpoint - Little Moose Lake & 5 & $6 / 15 / 11$ & 0 & 0 & 0.0 & V A & $\mathrm{W}$ & - & - & - & 06 & $\mathrm{~s}(\mathrm{p})$ \\
\hline Lake Winnipeg & $\begin{array}{l}\text { Longpoint - Saskachayweow } \\
\text { Bar }\end{array}$ & 2 & $6 / 15 / 11$ & 0 & 0 & 0.0 & V A & W & - & - & - & 06 & $\mathrm{~s}(\mathrm{p})$ \\
\hline Lake Winnipeg & Longpoint - Sturgeon Skin Point & 4 & $6 / 15 / 11$ & 0 & 0 & 0.0 & V A & W & - & - & - & 06 & $\mathrm{~s}(\mathrm{p})$ \\
\hline Lake Winnipeg & North Gull Bay Spit & 6 & $6 / 12 / 11$ & 0 & 0 & 5.5 & V A & V W & $\underline{91}$ & $\underline{96}$ & $\underline{01}$ & 06 & unk \\
\hline Lake Winnipeg & Patricia Beach & 30 & $6 / 4 / 11$ & 0 & 0 & 0.8 & V A & W & $\underline{91}$ & $\underline{96}$ & $\underline{01}$ & 06 & $\mathrm{~s}(\mathrm{p})$ \\
\hline Lake Winnipeg & Riverton Sand Bar \& Sandspit & 16 & $6 / 6 / 11$ & 0 & 0 & 0.3 & V E & W & $\underline{91}$ & 96 & 01 & 06 & $\mathrm{~s}(\mathrm{p})$ \\
\hline Lake Winnipeg & Sandy Bay & 21 & $6 / 7 / 11$ & 0 & 0 & 0.5 & V A & none & - & - & 01 & 06 & $\mathrm{~m}$ \\
\hline Lake Winnipeg & South Beach & 19 & $6 / 14 / 11$ & 0 & 0 & 0.0 & V A & $\mathrm{V}$ & - & - & - & - & $\mathrm{s}(\mathrm{p}), \mathrm{m}$ \\
\hline Lake Winnipeg & Victoria Beach & 22 & $6 / 7 / 11$ & 0 & 0 & 0.0 & V A & W & $\underline{91}$ & - & 01 & 06 & $\mathrm{~s}(\mathrm{p})$ \\
\hline Lake Winnipeg & Willow Point & 18 & $6 / 14 / 11$ & 0 & 0 & 0.0 & V A & $\mathrm{HW}$ & - & - & 01 & 06 & $\mathrm{~s}(\mathrm{p}), \mathrm{p}$ \\
\hline $\begin{array}{l}\text { Lake } \\
\text { Winnipegosis }\end{array}$ & $\begin{array}{l}\text { Overflowing River Salt Flat } \\
\text { Ecological Preserve }^{2}\end{array}$ & 1 & $6 / 19 / 11$ & 0 & 0 & 0.5 & V A & W & - & - & - & 06 & $\mathrm{~s}(\mathrm{p})$ \\
\hline Lawrence Lake & Lawrence Lake & 7 & $6 / 10 / 11$ & 0 & 0 & 0.3 & IV IX A & n.r. & - & - & - & 06 & n.r. \\
\hline Oak Lake & Oak Lake & 14 & $6 / 16 / 11$ & 0 & 0 & 0.0 & V A I & UW & $\underline{91}$ & - & 01 & 06 & $\mathrm{~s}(\mathrm{p}), \mathrm{p}$ \\
\hline Salt Lake & Salt Lake & 8 & $6 / 5 / 11$ & 0 & 0 & 0.0 & IV V D & W & 91 & - & - & 06 & $\mathrm{p}$ \\
\hline
\end{tabular}


The 2011 International Piping Plover Breeding Census in Manitoba (Continued)

\begin{tabular}{|c|c|c|c|c|c|c|c|c|c|c|c|c|c|}
\hline \multirow{3}{*}{$\begin{array}{l}\text { REGION } \\
\text { Shoal Lakes } \\
\text { Shoal Lakes }\end{array}$} & \multirow{2}{*}{ 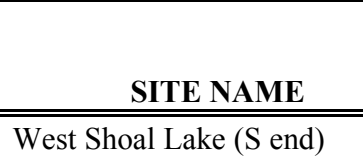 } & \multirow{2}{*}{ MAP\# } & \multirow{2}{*}{$\begin{array}{l}\text { DATE } \\
6 / 4 / 11\end{array}$} & \multirow{2}{*}{ 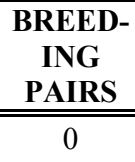 } & \multirow{2}{*}{$\begin{array}{c}\text { TOTAL } \\
\text { PIPL } \\
\text { ADULTS } \\
0\end{array}$} & \multirow{2}{*}{$\frac{\mathbf{K M}}{20.0}$} & \multirow{2}{*}{$\begin{array}{l}\text { SITE } \\
\text { DESCRIPTION } \\
\mathrm{VH}\end{array}$} & \multirow{2}{*}{$\begin{array}{l}\text { DISTURBANCE } \\
\text { CONCERNS } \\
\mathrm{W}\end{array}$} & \multicolumn{4}{|c|}{$\begin{array}{c}\text { PRIOR YEARS } \\
\text { CENSUSED \& YEARS }^{\text {PIPL SEEN }}{ }^{1} \\
\text { PIPL }^{-}\end{array}$} & \multirow{2}{*}{$\frac{\text { OWNER }}{\mathrm{OW}(\mathrm{p})}$} \\
\hline & & & & & & & & & 91 & $\underline{96}$ & 01 & 06 & \\
\hline & West Shoal Lake (W point) & 31 & $6 / 4 / 11$ & 0 & 0 & 0.0 & V H & $\mathrm{W}$ & $\underline{91}$ & $\underline{96}$ & 01 & 06 & $\mathrm{~s}(\mathrm{p})$ \\
\hline Total & & & & 1 & 2 & 14.8 & & & & & & & \\
\hline
\end{tabular}

Bold years indicate that adults were seen. Bold and underlined years indicate that pairs were seen.

${ }^{2}$ Please note that these surveys were conducted outside the Census window. 


\section{The 2011 International Piping Plover Breeding Census in Saskatchewan}

\author{
Melissa Ranalli (current contact) \\ Nature Saskatchewan \\ Room 206,1860 Lorne Street \\ Regina, SK S4P 2L7 \\ 306-780-9270 \\ mranalli@naturesask.ca
}

Jennifer Rumancik (coordinator)

Nature Saskatchewan

Room 206, 1860 Lorne Street

Regina, SK S4P 2L 7

The 2011 International Piping Plover census was undertaken from June 4-17, 2011. It was the fifth census to take place since 1991 and Piping Plover numbers were lower in 2011 than any prior census year. The total Piping Plover count for Saskatchewan in 2011 was 764 birds, including at least 195 pairs. This is a $46 \%$ decrease from the 2006 total, a 5\% decrease from the 2001 total, a $43 \%$ decrease from the 1996 total, and a 35\% decrease from the 1991 total. Volunteers, contractors, and government and non-government biologists (131 individuals) surveyed 278 basins, $2,473 \mathrm{~km}$ (1,537 miles) of habitat, and input 1085 hours of their time.
Piping Plovers were reported at 36 basins, with 32 of these basins supporting nesting pairs. Seventeen of these sites were reported to have high water or were flooded, and seven had an average of less than $2 \mathrm{~m}$ of shoreline width available. Of the basins surveyed, over 200 were reported to have high water and/or flooding, which is the most likely explanation for the low numbers of Piping Plovers detected in Saskatchewan in 2011. Nonetheless, the low 2011 count suggests that conservation efforts are still needed for Piping Plovers in Saskatchewan.

Flooding presumably played a role in the concentration of the Saskatchewan population within the Missouri Coteau, especially at Chaplin Lake, which supported $46 \%$ of the entire Saskatchewan population alone. Other notable sites included Willow Bunch, Shoe Lake-north, and Manitou Lake (with 50, 37, and 35 birds, respectively). No Piping Plovers were observed outside of their typical range. Three new sites provided habitat for 11 birds, including a nesting pair at each. Due to poor weather conditions, inaccessible roads, negligence, or land access denial, 39 sites were not surveyed. Six of these sites were high priority sites (supporting Piping Plovers in the past). The top three have supported a high total of 16 plovers. The other three combined have supported five or fewer Piping Plovers during prior census efforts. 
Comparison of Census Numbers

\begin{tabular}{|l|c|c|c|c|c|}
\hline & 1991 & 1996 & 2001 & 2006 & 2011 \\
\hline $\begin{array}{l}\text { Total } \\
\text { Adults }\end{array}$ & 180 & 276 & 150 & $1420^{1}$ & $764^{1}$ \\
\hline
\end{tabular}

${ }^{\text {I }}$ This is the total from a single survey at each site; if more than one survey was conducted, we count only results from the first survey during the census window.

\section{Detectability Study}

\begin{tabular}{|l|c|c|}
\hline \multicolumn{1}{|c|}{ Sites Included } & $\begin{array}{c}\text { First } \\
\text { Count }\end{array}$ & $\begin{array}{c}\text { Second } \\
\text { Count }\end{array}$ \\
\hline $\begin{array}{l}\text { Big Muddy Lake, Upper (090 } \\
\text { 430) }\end{array}$ & 13 & 24 \\
\hline Unnamed, UTM 560 273 & 1 & 1 \\
\hline Unnamed, UTM 650 075 & 2 & 4 \\
\hline Unnamed, UTM 840 020 & 2 & 3 \\
\hline Unnamed, UTM 842 027 & 11 & 7 \\
\hline Killsquaw Lake (292 100) & 1 & 1 \\
\hline Reflex Lake W (680 350) & 20 & 14 \\
\hline $\begin{array}{l}\text { Zella Lake (215 590; NE } \\
\text { portion) }\end{array}$ & 6 & 4 \\
\hline Lake Diefenbaker - Elbow & 1 & 1 \\
\hline $\begin{array}{l}\text { Lake Diefenbaker - Little } \\
\text { Sage Bay }\end{array}$ & 1 & 0 \\
\hline $\begin{array}{l}\text { Lake Diefenbaker - North } \\
\text { Summit (west) }\end{array}$ & 2 & 0 \\
\hline
\end{tabular}

${ }^{1}$ First and second counts were performed on the same day.

${ }^{2}$ Only the NE portion of Zella Lake was surveyed the second time. Total count for the lake was 10 . 


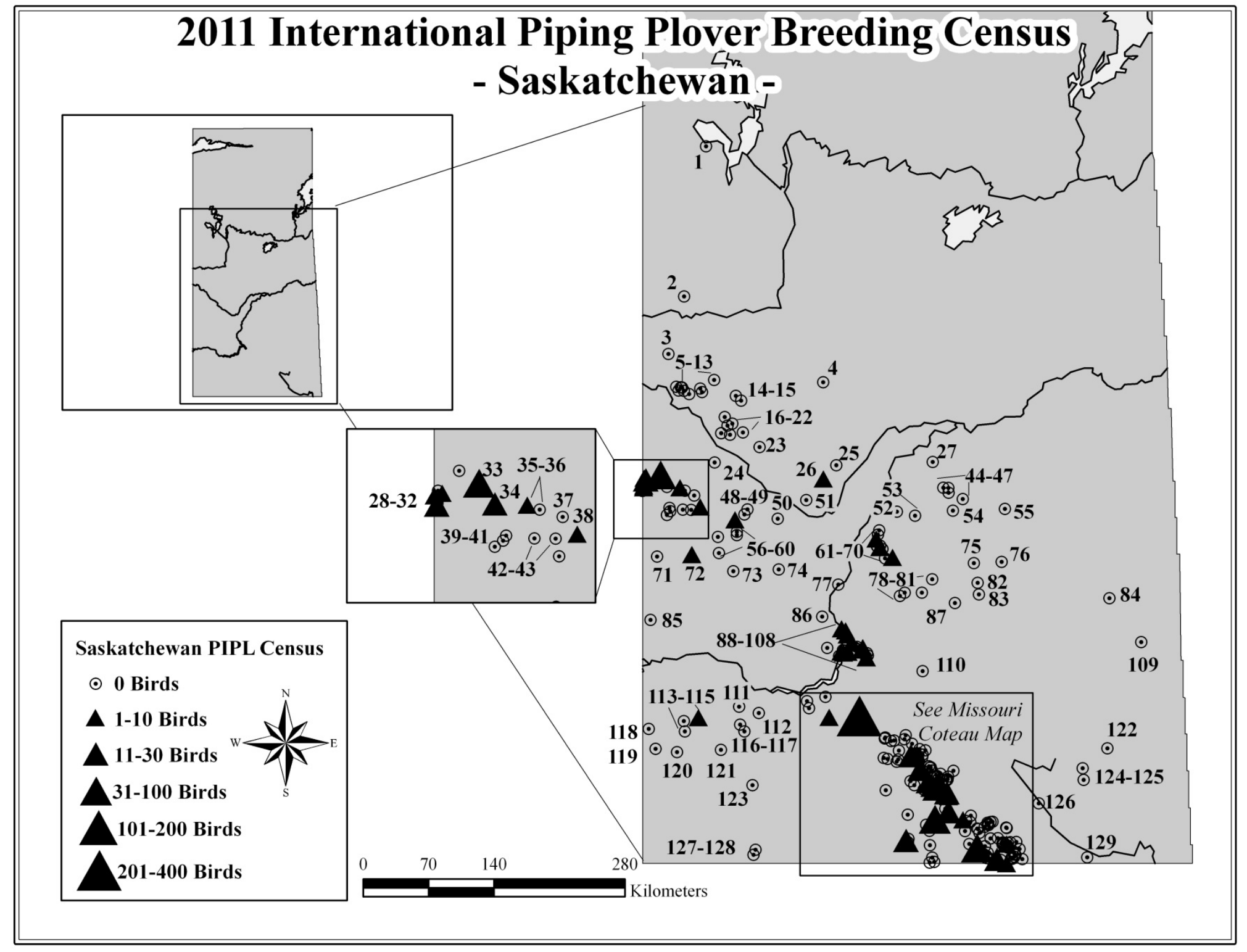




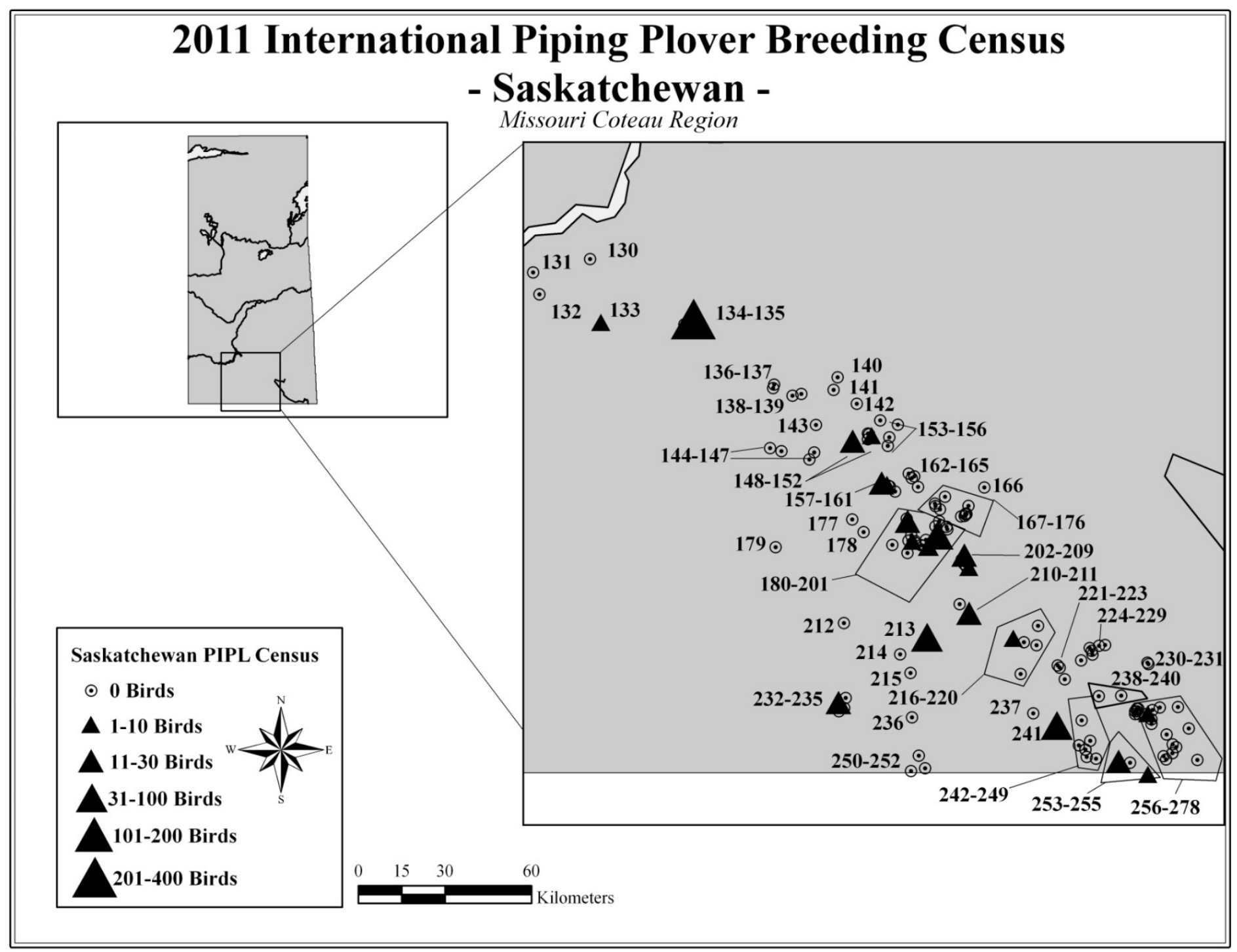


The 2011 International Piping Plover Breeding Census in Saskatchewan

\begin{tabular}{|c|c|c|c|c|c|c|c|c|c|c|c|c|c|c|}
\hline \multirow{2}{*}{$\begin{array}{l}\text { REGION } \\
\text { Big Quill/ } \\
\text { Last Mountain }\end{array}$} & \multirow{2}{*}{$\begin{array}{c}\text { R.M. } \\
\# \\
308\end{array}$} & \multirow{2}{*}{$\begin{array}{c}\text { SITE NAME } \\
\text { Big Quill Lake }\end{array}$} & \multirow{2}{*}{$\frac{\text { MAP\# }}{76}$} & \multirow{2}{*}{$\begin{array}{c}\text { DATE } \\
6 / 5 / 11\end{array}$} & \multirow{2}{*}{ 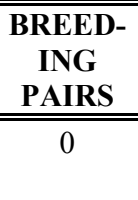 } & \multirow{2}{*}{$\begin{array}{c}\begin{array}{c}\text { TOTAL } \\
\text { PIPL } \\
\text { ADULTS }\end{array} \\
0\end{array}$} & \multirow{2}{*}{$\frac{\mathbf{K M}}{0.0}$} & \multirow{2}{*}{$\begin{array}{l}\text { SITE } \\
\text { DESCRIPTION } \\
\text { IV H I }\end{array}$} & \multirow{2}{*}{$\begin{array}{l}\text { DISTURBANCE } \\
\text { CONCERNS } \\
\mathrm{W}\end{array}$} & \multicolumn{4}{|c|}{$\begin{array}{c}\text { PRIOR YEARS } \\
\text { CENSUSED \& YEARS } \\
\text { PIPL SEEN }^{1} \\
\end{array}$} & \multirow{2}{*}{$\frac{\text { OWNER }}{\mathrm{f}, \mathrm{s}(\mathrm{p}), \mathrm{p}}$} \\
\hline & & & & & & & & & & $\underline{91}$ & $\underline{96}$ & $\underline{01}$ & $\underline{06}$ & \\
\hline $\begin{array}{l}\text { Big Quill/ } \\
\text { Last Mountain }\end{array}$ & 282 & Bultel Lake (385 166) & 80 & $6 / 9 / 11^{*}$ & - & - & 0.0 & V D & $\mathrm{W}$ & 91 & 96 & 01 & 06 & $\mathrm{p}$ \\
\hline $\begin{array}{l}\text { Big Quill/ } \\
\text { Last Mountain }\end{array}$ & 280 & Colt Lake (935 055) & 87 & $6 / 7 / 11^{*}$ & - & - & 0.0 & IV F O & $\mathrm{W}$ & $\underline{91}$ & 96 & 01 & 06 & $\mathrm{p}$ \\
\hline $\begin{array}{l}\text { Big Quill/ } \\
\text { Last Mountain }\end{array}$ & 281 & Devil's Lake (575 165) & 79 & $6 / 9 / 11^{*}$ & - & - & 0.0 & V D & $\mathrm{W}$ & 91 & 96 & 01 & 06 & $\mathrm{~m}, \mathrm{p}$ \\
\hline $\begin{array}{l}\text { Big Quill/ } \\
\text { Last Mountain }\end{array}$ & 282 & Horseshoe Lake (335 133) & 81 & $6 / 9 / 11^{*}$ & - & - & 0.0 & V D & $\mathrm{W}$ & 91 & 96 & 01 & 06 & $s(p), p$ \\
\hline $\begin{array}{l}\text { Big Quill/ } \\
\text { Last Mountain }\end{array}$ & 339 & Jansen Lake (140 480) & 75 & $6 / 4 / 11$ & 0 & 0 & 0.0 & IV A & $\mathrm{W}$ & 91 & 96 & 01 & 06 & $\mathrm{p}$ \\
\hline $\begin{array}{l}\text { Big Quill/ } \\
\text { Last Mountain }\end{array}$ & 279 & $\begin{array}{l}\text { Kutawagan Lake Complex } \\
(185 \text { 155) }\end{array}$ & 83 & $6 / 17 / 11$ & 0 & 0 & 1.0 & IV I & A W & $\underline{91}$ & 96 & 01 & 06 & $f$ \\
\hline $\begin{array}{l}\text { Big Quill/ } \\
\text { Last Mountain }\end{array}$ & 309 & Lac du Chemin (182 272) & 82 & $6 / 9 / 11$ & 0 & 0 & 0.0 & V H O & $\mathrm{W}$ & $\underline{91}$ & 96 & 01 & 06 & n.r. \\
\hline $\begin{array}{l}\text { Big Quill/ } \\
\text { Last Mountain }\end{array}$ & 312 & $\begin{array}{l}\text { Little Manitou Lake } \\
\text { (660 307) }\end{array}$ & 78 & $6 / 9 / 11$ & 0 & 0 & 0.0 & IV VI F H & S W & $\underline{91}$ & 96 & 01 & 06 & unk \\
\hline $\begin{array}{l}\text { Big Quill/ } \\
\text { Last Mountain }\end{array}$ & 222 & $\begin{array}{l}\text { Lovering Lake East } \\
(572326)\end{array}$ & 110 & $6 / 10 / 11$ & 0 & 0 & 0.0 & V H & n.r. & 91 & 96 & 01 & 06 & unk \\
\hline $\begin{array}{l}\text { Missouri } \\
\text { Coteau }\end{array}$ & 101 & Agnellice Lake (660 300) & 164 & $6 / 17 / 11$ & 0 & 0 & 0.0 & V D & $\mathrm{W}$ & 91 & 96 & 01 & 06 & $\mathrm{p}$ \\
\hline $\begin{array}{l}\text { Missouri } \\
\text { Coteau }\end{array}$ & 8 & Alkali Lake (500 280) & 255 & $6 / 14 / 11$ & 0 & $1^{4}$ & 0.0 & IV D & A W & 91 & $\underline{96}$ & $\underline{06}$ & 06 & $\mathrm{p}$ \\
\hline $\begin{array}{l}\text { Missouri } \\
\text { Coteau }\end{array}$ & 8 & Alma Lake (538 494) & 265 & $6 / 4 / 11$ & 0 & 0 & 0.0 & IV H I & $\mathrm{W}$ & 91 & - & 01 & 06 & $\mathrm{p}$ \\
\hline $\begin{array}{l}\text { Missouri } \\
\text { Coteau }\end{array}$ & 40 & Bead Lake (108 714) & 219 & $6 / 10 / 11$ & 0 & 0 & 0.0 & IV A & $\mathrm{W}$ & 91 & 96 & 01 & 06 & $\mathrm{~s}(\mathrm{p})$ \\
\hline $\begin{array}{l}\text { Missouri } \\
\text { Coteau }\end{array}$ & 8 & Beaubier Lake (675 432) & 270 & $6 / 4 / 11$ & 0 & 0 & 0.0 & IV & $\mathrm{W}$ & 91 & - & 01 & 06 & $\mathrm{p}$ \\
\hline $\begin{array}{l}\text { Missouri } \\
\text { Coteau }\end{array}$ & 9 & $\begin{array}{l}\text { Big Muddy Lake, Upper \& } \\
\text { Lower }(090430)^{2}\end{array}$ & 241 & $6 / 13 / 11$ & 16 & 37 & 4.5 & IV I & $\mathrm{W}$ & $\underline{91}$ & $\underline{96}$ & $\underline{01}$ & $\underline{06}$ & $\mathrm{~s}(\mathrm{p}), \mathrm{p}$ \\
\hline $\begin{array}{l}\text { Missouri } \\
\text { Coteau }\end{array}$ & 71 & Bliss Lake (633 135) & 181 & $6 / 9 / 11$ & 2 & 14 & 0.6 & IV A & n.r. & $\underline{91}$ & $\underline{96}$ & $\underline{01}$ & $\underline{06}$ & $s(p), p$ \\
\hline $\begin{array}{l}\text { Missouri } \\
\text { Coteau }\end{array}$ & 42 & Bonneau Lake (603 680) & 214 & $6 / 8 / 11$ & 0 & 0 & 1.0 & IV H & A W & 91 & 96 & 01 & 06 & $\mathrm{p}$ \\
\hline
\end{tabular}


The 2011 International Piping Plover Breeding Census in Saskatchewan (Continued)

\begin{tabular}{|c|c|c|c|c|c|c|c|c|c|c|c|c|c|c|}
\hline \multirow{2}{*}{$\begin{array}{l}\text { REGION } \\
\text { Missouri } \\
\text { Coteau }\end{array}$} & \multirow{2}{*}{$\begin{array}{c}\text { R.M. } \\
\# \\
38\end{array}$} & \multirow{2}{*}{ 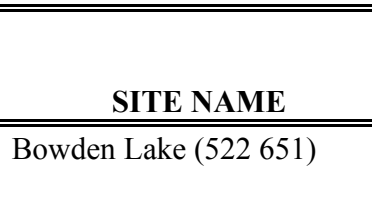 } & \multirow{2}{*}{ MAP\# } & \multirow{2}{*}{$\frac{\text { DATE }}{6 / 8 / 11^{*}}$} & \multirow{2}{*}{$\begin{array}{c}\text { BREED- } \\
\text { ING } \\
\text { PAIRS } \\
-\end{array}$} & \multirow{2}{*}{ 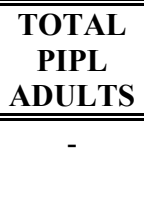 } & \multirow{2}{*}{$\frac{\mathbf{K M}}{20.0}$} & \multirow{2}{*}{$\begin{array}{l}\text { SITE } \\
\text { DESCRIPTION } \\
\text { IV A }\end{array}$} & \multirow{2}{*}{$\begin{array}{l}\text { DISTURBANCE } \\
\text { CONCERNS } \\
\mathrm{W}\end{array}$} & \multicolumn{4}{|c|}{$\begin{array}{c}\text { PRIOR YEARS } \\
\text { CENSUSED \& YEARS } \\
\text { PIPL SEEN }^{1} \\
\end{array}$} & \multirow{2}{*}{$\frac{\text { OWNER }}{\mathrm{O}(\mathrm{p})}$} \\
\hline & & & & & & & & & & 91 & 96 & 01 & 06 & \\
\hline $\begin{array}{l}\text { Missouri } \\
\text { Coteau }\end{array}$ & 71 & Burn Lake (660 070) & 191 & $6 / 10 / 11$ & 0 & 0 & 0.1 & IV & $\mathrm{W}$ & $\underline{91}$ & $\underline{96}$ & $\underline{01}$ & $\underline{06}$ & $\mathrm{f}$ \\
\hline $\begin{array}{l}\text { Missouri } \\
\text { Coteau }\end{array}$ & 70 & Channel Lake (825 855) & 210 & $6 / 8 / 11$ & 0 & 0 & 0.0 & IV D H & $\mathrm{W}$ & $\underline{91}$ & 96 & 01 & $\underline{06}$ & $\mathrm{p}$ \\
\hline $\begin{array}{l}\text { Missouri } \\
\text { Coteau }\end{array}$ & 164 & Chaplin Lake & 135 & $6 / 5 / 11$ & 74 & 359 & 2081.5 & IV A F & A S N V W & $\underline{91}$ & $\underline{96}$ & $\underline{01}$ & $\underline{06}$ & $\mathrm{~s}(\mathrm{p}), \mathrm{p}$ \\
\hline $\begin{array}{l}\text { Missouri } \\
\text { Coteau }\end{array}$ & 11 & $\begin{array}{l}\text { Cookson Reservoir } \\
(670330)\end{array}$ & 250 & $6 / 5 / 11$ & 0 & 0 & 1.3 & VI A E & $\mathrm{A}$ & - & - & - & $\underline{06}$ & unk \\
\hline $\begin{array}{l}\text { Missouri } \\
\text { Coteau }\end{array}$ & 11 & $\begin{array}{l}\text { Coronach Reservoir, East } \\
\text { Poplar River (636 515) }\end{array}$ & 252 & $6 / 4 / 11 *$ & - & - & 0.0 & V A & A W & $\underline{91}$ & 96 & 01 & - & $\mathrm{p}$ \\
\hline $\begin{array}{l}\text { Missouri } \\
\text { Coteau }\end{array}$ & 9 & Coteau Pots (300 342) & 245 & $6 / 8 / 11^{*}$ & - & - & 0.0 & V A & $\mathrm{W}$ & 91 & 96 & 01 & 06 & $\mathrm{p}$ \\
\hline $\begin{array}{l}\text { Missouri } \\
\text { Coteau }\end{array}$ & 9 & Coteau Pots (300 345) & 246 & $6 / 8 / 11^{*}$ & - & - & 0.0 & $\mathrm{~V} \mathrm{~A}$ & $\mathrm{~W}$ & 91 & $\underline{96}$ & $\underline{01}$ & 06 & $\mathrm{p}$ \\
\hline $\begin{array}{l}\text { Missouri } \\
\text { Coteau }\end{array}$ & 9 & Coteau Pots (300 350) & 247 & $6 / 8 / 11^{*}$ & - & - & 0.0 & V A & $\mathrm{W}$ & 91 & 96 & 01 & 06 & $\mathrm{p}$ \\
\hline $\begin{array}{l}\text { Missouri } \\
\text { Coteau }\end{array}$ & 11 & Crookstow River (685 318) & 236 & $6 / 4 / 11$ & 0 & 0 & $<1$ & III A & A W & 91 & - & $\underline{01}$ & - & $\mathrm{p}$ \\
\hline $\begin{array}{l}\text { Missouri } \\
\text { Coteau }\end{array}$ & 71 & Dryboro Lake (640 075) & 188 & $6 / 15 / 11$ & 0 & 0 & 0.0 & IV D H & $\mathrm{W}$ & $\underline{91}$ & $\underline{96}$ & $\underline{01}$ & $\underline{06}$ & $f, p$ \\
\hline $\begin{array}{l}\text { Missouri } \\
\text { Coteau }\end{array}$ & 132 & Dunkirk Lake (490 432) & 152 & $6 / 10 / 11$ & 0 & 0 & 0.0 & IV H & $\mathrm{W}$ & 91 & - & 01 & 06 & unk \\
\hline $\begin{array}{l}\text { Missouri } \\
\text { Coteau }\end{array}$ & 8 & East Coteau Lake (415 315) & 253 & $6 / 14 / 11$ & 11 & 24 & n.r. & IV A & $\mathrm{W}$ & $\underline{91}$ & $\underline{96}$ & $\underline{01}$ & $\underline{06}$ & $\mathrm{~s}(\mathrm{p}), \mathrm{p}$ \\
\hline $\begin{array}{l}\text { Missouri } \\
\text { Coteau }\end{array}$ & 40 & Edna Lake (060 725) & 218 & $6 / 11 / 11$ & 0 & 0 & 0.1 & IV A I & $\mathrm{W}$ & $\underline{91}$ & 96 & $\underline{01}$ & 06 & $\mathrm{p}$ \\
\hline $\begin{array}{l}\text { Missouri } \\
\text { Coteau }\end{array}$ & 39 & Elsie Lake (310 695) & 227 & $6 / 8 / 11$ & 0 & 0 & $<1$ & IV A & $\mathrm{W}$ & $\underline{91}$ & 96 & 01 & 06 & $\mathrm{~s}(\mathrm{p}), \mathrm{p}$ \\
\hline $\begin{array}{l}\text { Missouri } \\
\text { Coteau }\end{array}$ & 12 & Fife Lake $(370520)^{2}$ & 233 & $6 / 6 / 11$ & 9 & 26 & 3.5 & $\mathrm{~V} \mathrm{~A}$ & V W & $\underline{91}$ & $\underline{96}$ & $\underline{01}$ & $\underline{06}$ & $\mathrm{~s}(\mathrm{p})$ \\
\hline $\begin{array}{l}\text { Missouri } \\
\text { Coteau }\end{array}$ & 102 & Frederick Lake (435 425) & 148 & $6 / 8 / 11$ & 4 & 25 & 11.0 & IV G H & A S & $\underline{91}$ & $\underline{96}$ & $\underline{01}$ & $\underline{06}$ & $\mathrm{p}$ \\
\hline $\begin{array}{l}\text { Missouri } \\
\text { Coteau }\end{array}$ & 12 & Grant Lake (370 484) & 235 & $6 / 5 / 11$ & 0 & 0 & 0.0 & IV D & $\mathrm{W}$ & 91 & 96 & 01 & - & $\mathrm{p}$ \\
\hline
\end{tabular}


The 2011 International Piping Plover Breeding Census in Saskatchewan (Continued)

\begin{tabular}{|c|c|c|c|c|c|c|c|c|c|c|c|c|c|c|}
\hline REGION & $\begin{array}{c}\text { R.M. } \\
\#\end{array}$ & SITE NAME & MAP\# & DATE & $\begin{array}{c}\text { BREED- } \\
\text { ING } \\
\text { PAIRS }\end{array}$ & $\begin{array}{c}\text { TOTAL } \\
\text { PIPL } \\
\text { ADULTS }\end{array}$ & $\mathbf{K M}$ & $\begin{array}{l}\text { SITE } \\
\text { DESCRIPTION }\end{array}$ & $\begin{array}{l}\text { DISTURBANCE } \\
\text { CONCERNS }\end{array}$ & & $\begin{array}{r}\text { RIOR } \\
\text { CENS } \\
\text { YE } \\
\text { PIPL }\end{array}$ & $\begin{array}{l}\text { EAl } \\
\text { ED } \\
\text { RS } \\
\text { EEN }\end{array}$ & & OWNER \\
\hline $\begin{array}{l}\text { Missouri } \\
\text { Coteau }\end{array}$ & 40 & Green Lake (114 781) & 216 & $6 / 10 / 11$ & 0 & 0 & 0.0 & IV A & $\mathrm{W}$ & 91 & 96 & 01 & $\underline{06}$ & $\mathrm{~s}(\mathrm{p})$ \\
\hline $\begin{array}{l}\text { Missouri } \\
\text { Coteau }\end{array}$ & 166 & Handsome Lake (310 956) & 132 & $6 / 5 / 11 *$ & - & - & 0.0 & IV A & W & 91 & 96 & 01 & 06 & $\mathrm{p}$ \\
\hline $\begin{array}{l}\text { Missouri } \\
\text { Coteau }\end{array}$ & 40 & Horizon Lake (870 825) & 211 & $6 / 6 / 11$ & 4 & 11 & 1.5 & IV D H & $\mathrm{W}$ & - & $\underline{96}$ & $\underline{01}$ & $\underline{06}$ & $\mathrm{p}$ \\
\hline $\begin{array}{l}\text { Missouri } \\
\text { Coteau }\end{array}$ & 9 & Jim Creek Lake (267 367) & 244 & $6 / 5 / 11$ & 0 & 0 & 0.0 & VI I & $\mathrm{W}$ & - & 96 & 01 & 06 & $s(p), p$ \\
\hline $\begin{array}{l}\text { Missouri } \\
\text { Coteau }\end{array}$ & 38 & $\begin{array}{l}\text { Karl Lake (517 656) and } \\
\text { Unnamed, UTM } 514656\end{array}$ & 231 & $6 / 8 / 11$ & 0 & 0 & 0.0 & IV A & $\mathrm{W}$ & $\underline{91}^{5}$ & 96 & 01 & 06 & $\mathrm{~s}(\mathrm{p})$ \\
\hline $\begin{array}{l}\text { Missouri } \\
\text { Coteau }\end{array}$ & 72 & $\begin{array}{l}\text { Lake of the Rivers } \\
(475 \text { 190) }\end{array}$ & 178 & $6 / 10 / 11$ & 0 & 0 & 1.0 & V H I & $\mathrm{A} \mathrm{W}$ & $\underline{91}$ & 96 & $\underline{01}$ & $\underline{06}$ & $\mathrm{p}$ \\
\hline $\begin{array}{l}\text { Missouri } \\
\text { Coteau }\end{array}$ & 9 & $\begin{array}{l}\text { Little Coteau Lake } \\
\text { (455 310) }\end{array}$ & 254 & $6 / 14 / 11^{*}$ & - & - & 0.0 & IV H & $\mathrm{W}$ & 91 & $\underline{96}$ & 01 & 06 & $\mathrm{p}$ \\
\hline $\begin{array}{l}\text { Missouri } \\
\text { Coteau }\end{array}$ & 9 & Lonetree Lake (355 290) & 249 & $6 / 9 / 11$ & 0 & 0 & 0.0 & $\mathrm{D}$ & W & $\underline{91}$ & 96 & 01 & $\underline{06}$ & $\mathrm{p}$ \\
\hline $\begin{array}{l}\text { Missouri } \\
\text { Coteau }\end{array}$ & 39 & $\begin{array}{l}\text { MacDonaugh Lake } \\
\text { (335 712) }\end{array}$ & 225 & $6 / 9 / 11$ & 0 & 0 & 0.0 & IV A & $\mathrm{W}$ & $\underline{91}$ & 96 & 01 & 06 & $\mathrm{~s}(\mathrm{p})$ \\
\hline $\begin{array}{l}\text { Missouri } \\
\text { Coteau }\end{array}$ & 39 & Marjorie Lake (315 684) & 228 & $6 / 9 / 11$ & 0 & 0 & 0.0 & IV A & W & 91 & - & 01 & $\underline{06}$ & $s(p), p$ \\
\hline $\begin{array}{l}\text { Missouri } \\
\text { Coteau }\end{array}$ & 8 & Mather Lake (630 504) & 267 & $6 / 4 / 11$ & 0 & 0 & 0.0 & IV & $\mathrm{W}$ & 91 & 96 & 01 & 06 & $\mathrm{p}$ \\
\hline $\begin{array}{l}\text { Missouri } \\
\text { Coteau }\end{array}$ & 39 & McGrath Lake (185 646) & 221 & $6 / 9 / 11$ & 0 & 0 & 0.0 & IV D & W & 91 & 96 & 01 & $\underline{06}$ & $\mathrm{p}$ \\
\hline $\begin{array}{l}\text { Missouri } \\
\text { Coteau }\end{array}$ & 39 & $\begin{array}{l}\text { McGrath Lake South } \\
(193 \text { 638) }\end{array}$ & 222 & $6 / 9 / 11$ & 0 & 0 & 0.0 & IV D & W & 91 & - & 01 & 06 & $\mathrm{p}$ \\
\hline $\begin{array}{l}\text { Missouri } \\
\text { Coteau }\end{array}$ & 164 & Midtskogen Lake (830 836) & 134 & $6 / 6 / 11^{*}$ & - & - & 0.0 & IV A H & W & - & - & - & - & $\mathrm{s}(\mathrm{p})$ \\
\hline $\begin{array}{l}\text { Missouri } \\
\text { Coteau }\end{array}$ & 42 & Montague Lake $(400800)^{3}$ & 212 & $6 / 22 / 11$ & 0 & 0 & 27.4 & IV H & $\mathrm{W}$ & $\underline{91}$ & 96 & 01 & 06 & $\mathrm{p}$ \\
\hline $\begin{array}{l}\text { Missouri } \\
\text { Coteau }\end{array}$ & 101 & $\mathrm{~N}$ of Bliss Lake (630 155) & 180 & $6 / 11 / 11$ & 0 & 0 & 0.0 & IV H & A W & 91 & - & 01 & 06 & unk \\
\hline $\begin{array}{l}\text { Missouri } \\
\text { Coteau }\end{array}$ & 12 & North Pond (395 500) & 234 & $6 / 4 / 11$ & 0 & 0 & 0.0 & IV H & A W & 91 & 96 & 01 & 06 & $\mathrm{p}$ \\
\hline $\begin{array}{l}\text { Missouri } \\
\text { Coteau }\end{array}$ & 102 & Old Wives Lake (300 480) & 143 & $6 / 8 / 11$ & 0 & 0 & $<1$ & V A & A S W & $\underline{91}$ & $\underline{96}$ & $\underline{01}$ & $\underline{06}$ & $\mathrm{~s}(\mathrm{p}), \mathrm{p}$ \\
\hline
\end{tabular}


The 2011 International Piping Plover Breeding Census in Saskatchewan (Continued)

\begin{tabular}{|c|c|c|c|c|c|c|c|c|c|c|c|c|c|c|}
\hline REGION & $\begin{array}{c}\text { R.M. } \\
\#\end{array}$ & SITE NAME & MAP\# & DATE & $\begin{array}{c}\text { BREED- } \\
\text { ING } \\
\text { PAIRS }\end{array}$ & $\begin{array}{c}\text { TOTAL } \\
\text { PIPL } \\
\text { ADULTS } \\
\end{array}$ & KM & $\begin{array}{l}\text { SITE } \\
\text { DESCRIPTION } \\
\end{array}$ & $\begin{array}{l}\text { DISTURBANCE } \\
\text { CONCERNS } \\
\end{array}$ & & $\begin{array}{l}\text { RIOR } \\
\text { CENSI } \\
\text { YE } \\
\text { PIPL } \\
\end{array}$ & $\begin{array}{l}\text { EA } \\
\text { ED } \\
\text { RS } \\
\text { EEN }\end{array}$ & & OWNER \\
\hline $\begin{array}{l}\text { Missouri } \\
\text { Coteau }\end{array}$ & $71 / 101$ & Oro Lake (750 145) & 182 & $6 / 15 / 11$ & 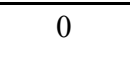 & 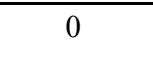 & $<<1$ & $\overline{\mathrm{VA}}$ & $\overline{\mathrm{W}}$ & 91 & 96 & 01 & 06 & $\overline{s(p), m, p}$ \\
\hline $\begin{array}{l}\text { Missouri } \\
\text { Coteau }\end{array}$ & 8 & Overland Lake (590 320) & 277 & $6 / 9 / 11$ & 0 & 0 & 0.0 & IV D & $\mathrm{W}$ & 91 & 96 & 01 & 06 & $\mathrm{p}$ \\
\hline $\begin{array}{l}\text { Missouri } \\
\text { Coteau }\end{array}$ & 8 & Payn Lake (580 333) & 276 & $6 / 9 / 11$ & 0 & 0 & 0.0 & IV D & $\mathrm{W}$ & - & 96 & 01 & 06 & $\mathrm{p}$ \\
\hline $\begin{array}{l}\text { Missouri } \\
\text { Coteau }\end{array}$ & 165 & Reed Lake (530 850) & 133 & $6 / 10 / 11$ & 3 & 6 & 3.5 & IV A & A W & 91 & 96 & $\underline{01}$ & $\underline{06}$ & $\mathrm{~m}$ \\
\hline $\begin{array}{l}\text { Missouri } \\
\text { Coteau }\end{array}$ & 40 & Ritchie Lake (020 739) & 217 & $6 / 8 / 11$ & 1 & 3 & $0.0^{6}$ & IV D H & $\mathrm{W}$ & 91 & 96 & 01 & $\underline{06}$ & $\mathrm{p}$ \\
\hline $\begin{array}{l}\text { Missouri } \\
\text { Coteau }\end{array}$ & 42 & Rivard Lake (633 625) & 215 & $6 / 9 / 11$ & 0 & 0 & 2.5 & IV H & A W & 91 & 96 & 01 & 06 & $\mathrm{p}$ \\
\hline $\begin{array}{l}\text { Missouri } \\
\text { Coteau }\end{array}$ & 39 & Salt Lake (215 590) & 223 & $6 / 11 / 11$ & 0 & 0 & 0.6 & IV A & $\mathrm{W}$ & 91 & 96 & $\underline{01}$ & 06 & $f, p$ \\
\hline $\begin{array}{l}\text { Missouri } \\
\text { Coteau }\end{array}$ & 166 & Salt Lake (288 035) & 131 & $6 / 5 / 11^{*}$ & - & - & 0.0 & V A & $\mathrm{W}$ & 91 & 96 & 01 & 06 & $\mathrm{p}$ \\
\hline $\begin{array}{l}\text { Missouri } \\
\text { Coteau }\end{array}$ & 8 & Sandoff Lake (615 375) & 272 & $6 / 8 / 11$ & 0 & 0 & 0.0 & IV I & $\mathrm{W}$ & $\underline{91}$ & $\underline{96}$ & $\underline{01}$ & $\underline{06}$ & $s(p), p$ \\
\hline $\begin{array}{l}\text { Missouri } \\
\text { Coteau }\end{array}$ & 101 & Skyeta Lake (735 197) & 170 & $6 / 8 / 11$ & 0 & 0 & 0.0 & V E & $\mathrm{W}$ & $\underline{91}$ & - & 01 & 06 & $\mathrm{p}$ \\
\hline $\begin{array}{l}\text { Missouri } \\
\text { Coteau }\end{array}$ & 39 & Stiles Lake (276 667) & 229 & $6 / 11 / 11^{*}$ & - & - & 0.0 & IV A & $\mathrm{W}$ & 91 & - & 01 & 06 & $\mathrm{p}$ \\
\hline $\begin{array}{l}\text { Missouri } \\
\text { Coteau }\end{array}$ & 40 & Unnamed, UTM 050625 & 220 & $6 / 11 / 11$ & 0 & 0 & 0.0 & IV A & $\mathrm{W}$ & 91 & 96 & - & 06 & $\mathrm{p}$ \\
\hline $\begin{array}{l}\text { Missouri } \\
\text { Coteau }\end{array}$ & 10 & Unnamed, UTM 085495 & 237 & $6 / 5 / 11$ & 0 & 0 & 0.0 & IV I & $\mathrm{W}$ & - & 96 & 01 & 06 & $\mathrm{~s}(\mathrm{p})$ \\
\hline $\begin{array}{l}\text { Missouri } \\
\text { Coteau }\end{array}$ & 103 & Unnamed, UTM 135405 & 144 & $6 / 16 / 11$ & 0 & 0 & 0.2 & IV D & $\mathrm{W}$ & 91 & - & 01 & 06 & $\mathrm{p}$ \\
\hline $\begin{array}{l}\text { Missouri } \\
\text { Coteau }\end{array}$ & 133 & Unnamed, UTM 148612 & 137 & $6 / 13 / 11$ & 0 & 0 & 0.1 & IV D & A W & 91 & - & 01 & 06 & $\mathrm{p}$ \\
\hline $\begin{array}{l}\text { Missouri } \\
\text { Coteau }\end{array}$ & 73 & Unnamed, UTM 150065 & 179 & $6 / 14 / 11$ & 0 & 0 & 0.0 & V IX H & $\mathrm{W}$ & 91 & - & 01 & $\underline{06}$ & $\mathrm{p}$ \\
\hline $\begin{array}{l}\text { Missouri } \\
\text { Coteau }\end{array}$ & 133 & Unnamed, UTM 155623 & 136 & $6 / 13 / 11$ & - & - & 0.0 & IV D & A W & 91 & - & 01 & 06 & $\mathrm{p}$ \\
\hline $\begin{array}{l}\text { Missouri } \\
\text { Coteau }\end{array}$ & 103 & Unnamed, UTM 170394 & 145 & $6 / 16 / 11$ & 0 & 0 & 0.1 & IV D & $\mathrm{W}$ & 91 & - & 01 & 06 & $\mathrm{p}$ \\
\hline
\end{tabular}


The 2011 International Piping Plover Breeding Census in Saskatchewan (Continued)

\begin{tabular}{|c|c|c|c|c|c|c|c|c|c|c|c|c|c|c|}
\hline REGION & $\begin{array}{c}\text { R.M. } \\
\# \\
\end{array}$ & SITE NAME & MAP\# & DATE & $\begin{array}{c}\text { BREED- } \\
\text { ING } \\
\text { PAIRS } \\
\end{array}$ & $\begin{array}{c}\text { TOTAL } \\
\text { PIPL } \\
\text { ADULTS } \\
\end{array}$ & $\mathbf{K M}$ & $\begin{array}{l}\text { SITE } \\
\text { DESCRIPTION } \\
\end{array}$ & $\begin{array}{l}\text { DISTURBANCE } \\
\text { CONCERNS } \\
\end{array}$ & & $\begin{array}{r}\text { RIOR } \\
\text { CENSI } \\
\text { YE } \\
\text { PIPL } \\
\end{array}$ & $\begin{array}{l}\text { EAR } \\
\text { ED \& } \\
\text { RS } \\
\text { EEN }{ }^{1} \\
\end{array}$ & & OWNER \\
\hline $\begin{array}{l}\text { Missouri } \\
\text { Coteau }\end{array}$ & 133 & "Unnamed, UTM 220587 & 138 & $6 / 13 / 11$ & 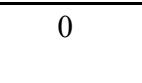 & $\overline{0}$ & 0.0 & $\overline{I V ~ D ~}$ & $\overline{\mathrm{WW}}$ & 91 & 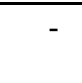 & 01 & $\overline{-}$ & $\bar{p}$ \\
\hline $\begin{array}{l}\text { Missouri } \\
\text { Coteau }\end{array}$ & 133 & Unnamed, UTM 246585 & 139 & $6 / 15 / 11$ & 0 & 0 & 0.0 & IV D & $\mathrm{W}$ & 91 & - & 01 & - & n.r. \\
\hline $\begin{array}{l}\text { Missouri } \\
\text { Coteau }\end{array}$ & 9 & Unnamed, UTM 275456 & 242 & $6 / 4 / 11$ & 0 & 0 & 3.0 & V H & $\mathrm{H}$ & - & 96 & 01 & 06 & $\mathrm{p}$ \\
\hline $\begin{array}{l}\text { Missouri } \\
\text { Coteau }\end{array}$ & 103 & Unnamed, UTM 277363 & 147 & $6 / 14 / 11^{*}$ & - & - & 0.0 & V H I & $\mathrm{W}$ & - & 96 & 01 & - & $\mathrm{p}$ \\
\hline $\begin{array}{l}\text { Missouri } \\
\text { Coteau }\end{array}$ & 9 & Unnamed, UTM 295330 & 248 & $6 / 8 / 11^{*}$ & - & - & 0.0 & V A & $\mathrm{W}$ & - & $\underline{96}$ & 01 & 06 & $\mathrm{p}$ \\
\hline $\begin{array}{l}\text { Missouri } \\
\text { Coteau }\end{array}$ & 102 & Unnamed, UTM 295375 & 146 & $6 / 8 / 11$ & 0 & 0 & $<1$ & IV H & A S W & - & 96 & 01 & 06 & $\mathrm{p}$ \\
\hline $\begin{array}{l}\text { Missouri } \\
\text { Coteau }\end{array}$ & 39 & Unnamed, UTM 304706 & 224 & $6 / 8 / 11$ & 0 & 0 & $<1$ & IV A & $\mathrm{W}$ & 91 & 96 & 01 & $\underline{06}$ & $s(p), p$ \\
\hline $\begin{array}{l}\text { Missouri } \\
\text { Coteau }\end{array}$ & 9 & Unnamed, UTM 310378 & 243 & $6 / 8 / 11^{*}$ & - & - & 0.0 & V A & $\mathrm{W}$ & - & 96 & 01 & 06 & $\mathrm{p}$ \\
\hline $\begin{array}{l}\text { Missouri } \\
\text { Coteau }\end{array}$ & 8 & Unnamed, UTM 337540 & 239 & $6 / 4 / 11$ & 0 & 0 & 1.5 & V H & n.r. & 91 & - & 01 & - & $\mathrm{p}$ \\
\hline $\begin{array}{l}\text { Missouri } \\
\text { Coteau }\end{array}$ & 8 & Unnamed, UTM 340538 & 238 & $6 / 4 / 11$ & 0 & 0 & 1.5 & V H & n.r. & 91 & - & 01 & - & $\mathrm{p}$ \\
\hline $\begin{array}{l}\text { Missouri } \\
\text { Coteau }\end{array}$ & 39 & Unnamed, UTM 360717 & 226 & $6 / 11 / 11$ & 0 & 0 & 0.0 & IV A & $\mathrm{W}$ & 91 & 96 & 01 & 06 & $\mathrm{p}$ \\
\hline $\begin{array}{l}\text { Missouri } \\
\text { Coteau }\end{array}$ & 132 & Unnamed, UTM 375604 & 141 & $6 / 15 / 11$ & 0 & 0 & 0.2 & IV D & A W & 91 & - & 01 & 06 & $\mathrm{p}$ \\
\hline $\begin{array}{l}\text { Missouri } \\
\text { Coteau }\end{array}$ & 132 & Unnamed, UTM 382645 & 140 & $6 / 13 / 11$ & 0 & 0 & 0.0 & IV D & $\mathrm{W}$ & 91 & - & 01 & 06 & $\mathrm{p}$ \\
\hline $\begin{array}{l}\text { Missouri } \\
\text { Coteau }\end{array}$ & 12 & Unnamed, UTM 400535 & 232 & $6 / 4 / 11$ & 0 & 0 & 0.0 & IV H & A W & 91 & 96 & $\underline{01}$ & 06 & $\mathrm{p}$ \\
\hline $\begin{array}{l}\text { Missouri } \\
\text { Coteau }\end{array}$ & 9 & Unnamed, UTM 421542 & 240 & $6 / 4 / 11$ & 0 & 0 & 1.5 & V H & n.r. & 91 & - & - & - & $\mathrm{p}$ \\
\hline $\begin{array}{l}\text { Missouri } \\
\text { Coteau }\end{array}$ & 102 & $\begin{array}{l}\text { Unnamed, UTM } 430164 \\
\text { (Skull Lake) }\end{array}$ & 177 & $6 / 8 / 11$ & 0 & 0 & $<0.1$ & IV V D H & $\mathrm{W}$ & - & 96 & 01 & $\underline{06}$ & $\mathrm{p}$ \\
\hline $\begin{array}{l}\text { Missouri } \\
\text { Coteau }\end{array}$ & 132 & Unnamed, UTM 455552 & 142 & $6 / 15 / 11$ & 0 & 0 & 0.0 & IV D & $\mathrm{W}$ & - & 96 & 01 & 06 & $\mathrm{p}$ \\
\hline $\begin{array}{l}\text { Missouri } \\
\text { Coteau }\end{array}$ & 8 & Unnamed, UTM 475490 & 259 & $6 / 13 / 11$ & 0 & 0 & 0.0 & IV A & A W & - & 96 & - & - & n.r. \\
\hline
\end{tabular}


The 2011 International Piping Plover Breeding Census in Saskatchewan (Continued)

\begin{tabular}{|c|c|c|c|c|c|c|c|c|c|c|c|c|c|c|}
\hline REGION & $\begin{array}{c}\text { R.M. } \\
\#\end{array}$ & SITE NAME & MAP\# & DATE & $\begin{array}{l}\text { BREED- } \\
\text { ING } \\
\text { PAIRS }\end{array}$ & $\begin{array}{c}\text { TOTAL } \\
\text { PIPL } \\
\text { ADULTS }\end{array}$ & KM & $\begin{array}{l}\text { SITE } \\
\text { DESCRIPTION }\end{array}$ & $\begin{array}{l}\text { DISTURBANCE } \\
\text { CONCERNS }\end{array}$ & & $\begin{array}{l}\text { RIOR } \\
\text { CENSt } \\
\text { YE } \\
\text { PIPL } \\
\end{array}$ & $\begin{array}{l}\text { EARS } \\
\text { ED \& } \\
\text { RS } \\
\text { EEN }^{1}\end{array}$ & & OWNER \\
\hline $\begin{array}{l}\text { Missouri } \\
\text { Coteau }\end{array}$ & 8 & Unnamed, UTM 476483 & 261 & $6 / 13 / 11$ & 0 & 0 & 0.0 & IV A & $\mathrm{AW}$ & - & 96 & - & - & n.r. \\
\hline $\begin{array}{l}\text { Missouri } \\
\text { Coteau }\end{array}$ & 8 & Unnamed, UTM 480486 & 260 & $6 / 13 / 11$ & 0 & 0 & 0.0 & IV A & A W & - & 96 & - & - & n.r. \\
\hline $\begin{array}{l}\text { Missouri } \\
\text { Coteau }\end{array}$ & 8 & Unnamed, UTM 483494 & 256 & $6 / 13 / 11$ & 0 & 0 & 0.0 & IV A & A W & - & 96 & - & - & n.r. \\
\hline $\begin{array}{l}\text { Missouri } \\
\text { Coteau }\end{array}$ & 8 & Unnamed, UTM 483498 & 257 & $6 / 13 / 11$ & 0 & 0 & 0.0 & IV A & A W & - & 96 & - & - & n.r. \\
\hline $\begin{array}{l}\text { Missouri } \\
\text { Coteau }\end{array}$ & 132 & Unnamed, UTM 488445 & 149 & $6 / 14 / 11$ & 0 & 0 & 0.0 & IV H & W & 91 & - & 01 & 06 & $\mathrm{p}$ \\
\hline $\begin{array}{l}\text { Missouri } \\
\text { Coteau }\end{array}$ & 165 & Unnamed, UTM 493073 & 130 & $6 / 5 / 11^{*}$ & - & - & 0.0 & V A & W & 91 & 96 & 01 & 06 & $\mathrm{p}$ \\
\hline $\begin{array}{l}\text { Missouri } \\
\text { Coteau }\end{array}$ & 8 & Unnamed, UTM 493480 & 262 & $6 / 13 / 11$ & 0 & 0 & 0.0 & IV A & A W & 91 & 96 & - & - & n.r. \\
\hline $\begin{array}{l}\text { Missouri } \\
\text { Coteau }\end{array}$ & 8 & Unnamed, UTM 495490 & 258 & $6 / 13 / 11$ & 0 & 0 & 0.0 & IV A & $\mathrm{A} \mathrm{W}$ & - & 96 & - & - & n.r. \\
\hline $\begin{array}{l}\text { Missouri } \\
\text { Coteau }\end{array}$ & 132 & Unnamed, UTM 500450 & 150 & $6 / 14 / 11$ & 0 & 0 & 0.0 & IV H I & $\mathrm{W}$ & 91 & $\underline{96}$ & 01 & 06 & $\mathrm{p}$ \\
\hline $\begin{array}{l}\text { Missouri } \\
\text { Coteau }\end{array}$ & 102 & Unnamed, UTM 503440 & 151 & $6 / 14 / 11$ & 2 & 4 & 1.0 & IV H I & W & 91 & $\underline{96}$ & $\underline{01}$ & $\underline{06}$ & $\mathrm{p}$ \\
\hline $\begin{array}{l}\text { Missouri } \\
\text { Coteau }\end{array}$ & 8 & Unnamed, UTM 505486 & 264 & $6 / 6 / 11$ & 1 & 5 & $<0.1$ & IV I & $\mathrm{W}$ & - & 96 & 01 & 06 & $\mathrm{p}$ \\
\hline $\begin{array}{l}\text { Missouri } \\
\text { Coteau }\end{array}$ & 9 & Unnamed, UTM 515475 & 263 & $6 / 13 / 11$ & 0 & 0 & 0.0 & IV A & A W & 91 & 96 & - & - & n.r. \\
\hline $\begin{array}{l}\text { Missouri } \\
\text { Coteau }\end{array}$ & 10 & Unnamed, UTM 533461 & 268 & $6 / 13 / 11$ & 0 & 0 & 0.0 & IV A & A W & - & 96 & - & - & n.r. \\
\hline $\begin{array}{l}\text { Missouri } \\
\text { Coteau }\end{array}$ & 131 & Unnamed, UTM 534490 & 153 & $6 / 13 / 11^{*}$ & - & - & 0.0 & IV H & W & 91 & 96 & 01 & 06 & $\mathrm{p}$ \\
\hline $\begin{array}{l}\text { Missouri } \\
\text { Coteau }\end{array}$ & 8 & Unnamed, UTM 535455 & 269 & $6 / 6 / 11$ & 0 & 0 & 0.0 & V I & W & 91 & 96 & 01 & 06 & $\mathrm{p}$ \\
\hline $\begin{array}{l}\text { Missouri } \\
\text { Coteau }\end{array}$ & 101 & $\begin{array}{l}\text { Unnamed, UTM } 540279 \\
\text { (Butterfly Lake) }\end{array}$ & 157 & $6 / 11 / 11$ & 6 & 26 & 1.5 & IV A & n.r. & $\underline{91}$ & $\underline{96}$ & $\underline{01}$ & $\underline{06}$ & $s(p), p$ \\
\hline $\begin{array}{l}\text { Missouri } \\
\text { Coteau }\end{array}$ & 101 & Unnamed, UTM 560273 & 158 & $6 / 15 / 11$ & 0 & 1 & 2.0 & IV A E & A W & 91 & 96 & 01 & 06 & $\mathrm{~s}(\mathrm{p})$ \\
\hline $\begin{array}{l}\text { Missouri } \\
\text { Coteau }\end{array}$ & 101 & Unnamed, UTM 560404 & 156 & $6 / 13 / 11$ & 0 & 0 & 0.0 & IV I & W & 91 & - & 01 & 06 & $\mathrm{~s}(\mathrm{p})$ \\
\hline
\end{tabular}


The 2011 International Piping Plover Breeding Census in Saskatchewan (Continued)

\begin{tabular}{|c|c|c|c|c|c|c|c|c|c|c|c|c|c|c|}
\hline REGION & $\begin{array}{c}\text { R.M. } \\
\#\end{array}$ & SITE NAME & МАР\# & DATE & $\begin{array}{c}\text { BREED- } \\
\text { ING } \\
\text { PAIRS } \\
\end{array}$ & $\begin{array}{c}\text { TOTAL } \\
\text { PIPL } \\
\text { ADULTS } \\
\end{array}$ & $\mathbf{K M}$ & $\begin{array}{l}\text { SITE } \\
\text { DESCRIPTION }\end{array}$ & $\begin{array}{l}\text { DISTURBANCE } \\
\text { CONCERNS } \\
\end{array}$ & & $\begin{array}{r}\text { RIOR } \\
\text { CENS } \\
\text { YE } \\
\text { PIPL } \\
\end{array}$ & $\begin{array}{l}\text { EA } \\
\text { ED } \\
\text { RS } \\
\text { EEN }\end{array}$ & & OWNER \\
\hline $\begin{array}{l}\text { Missouri } \\
\text { Coteau }\end{array}$ & 101 & Unnamed, UTM 565273 & 159 & $6 / 15 / 11$ & 0 & 0 & 0.1 & IV A E & A W & 91 & 96 & 01 & 06 & $\mathrm{~s}(\mathrm{p})$ \\
\hline $\begin{array}{l}\text { Missouri } \\
\text { Coteau }\end{array}$ & 101 & Unnamed, UTM 567435 & 155 & $6 / 14 / 11^{*}$ & - & - & 0.0 & IV I & n.r. & 91 & - & 01 & 06 & $\mathrm{p}$ \\
\hline $\begin{array}{l}\text { Missouri } \\
\text { Coteau }\end{array}$ & 101 & Unnamed, UTM 571267 & 160 & $6 / 15 / 11^{*}$ & - & - & 0.0 & IV A & none & 91 & - & 01 & 06 & $\mathrm{p}$ \\
\hline $\begin{array}{l}\text { Missouri } \\
\text { Coteau }\end{array}$ & 71 & Unnamed, UTM 578063 & 196 & $6 / 14 / 11$ & 0 & 0 & 1.0 & IV & $\mathrm{W}$ & 91 & 96 & 01 & $\underline{06}$ & $\mathrm{p}$ \\
\hline $\begin{array}{l}\text { Missouri } \\
\text { Coteau }\end{array}$ & 101 & Unnamed, UTM 590248 & 161 & $6 / 11 / 11$ & 0 & 0 & 0.0 & IV H & I W & - & 96 & 01 & 06 & unk \\
\hline $\begin{array}{l}\text { Missouri } \\
\text { Coteau }\end{array}$ & 8 & Unnamed, UTM 591408 & 271 & $6 / 9 / 11^{*}$ & - & - & 0.0 & IV D I & A W & - & 96 & 01 & 06 & $\mathrm{p}$ \\
\hline $\begin{array}{l}\text { Missouri } \\
\text { Coteau }\end{array}$ & 131 & Unnamed, UTM 597478 & 154 & $6 / 13 / 11^{*}$ & - & - & 0.0 & IV H & $\mathrm{W}$ & - & - & - & - & unk \\
\hline $\begin{array}{l}\text { Missouri } \\
\text { Coteau }\end{array}$ & 8 & Unnamed, UTM 613345 & 274 & $6 / 9 / 11$ & 0 & 0 & 0.3 & IV I & W & $\underline{91}$ & $\underline{96}$ & $\underline{01}$ & 06 & $\mathrm{p}$ \\
\hline $\begin{array}{l}\text { Missouri } \\
\text { Coteau }\end{array}$ & 8 & Unnamed, UTM 613353 & 275 & $6 / 4 / 11$ & 0 & 0 & 2.0 & V H & $\mathrm{V}$ & 91 & 96 & $\underline{01}$ & 06 & $\mathrm{p}$ \\
\hline $\begin{array}{l}\text { Missouri } \\
\text { Coteau }\end{array}$ & 8 & Unnamed, UTM 628368 & 273 & $6 / 4 / 11$ & 0 & 0 & 1.0 & V H & none & - & 96 & 01 & 06 & $\mathrm{p}$ \\
\hline $\begin{array}{l}\text { Missouri } \\
\text { Coteau }\end{array}$ & 71 & Unnamed, UTM 632035 & 201 & $6 / 14 / 11$ & 0 & 0 & 0.0 & IV & $\mathrm{W}$ & - & 96 & 01 & - & $\mathrm{p}$ \\
\hline $\begin{array}{l}\text { Missouri } \\
\text { Coteau }\end{array}$ & 101 & Unnamed, UTM $640309^{3}$ & 162 & $6 / 27 / 11$ & 0 & 0 & 0.1 & IV H & A W & 91 & - & 01 & 06 & unk \\
\hline $\begin{array}{l}\text { Missouri } \\
\text { Coteau }\end{array}$ & 71 & Unnamed, UTM 646096 & 186 & $6 / 10 / 11$ & 0 & 0 & 0.0 & IV & W & - & - & 01 & 06 & $\mathrm{p}$ \\
\hline $\begin{array}{l}\text { Missouri } \\
\text { Coteau }\end{array}$ & 71 & Unnamed, UTM $650075^{2}$ & 189 & $6 / 11 / 11$ & 1 & 4 & 0.1 & IV & $\mathrm{W}$ & 91 & 96 & 01 & $\underline{06}$ & $\mathrm{f}$ \\
\hline $\begin{array}{l}\text { Missouri } \\
\text { Coteau }\end{array}$ & 101 & Unnamed, UTM 650295 & 163 & $6 / 15 / 11$ & 0 & 0 & 0.0 & IV E & $\mathrm{W}$ & 91 & 96 & 01 & 06 & $\mathrm{p}$ \\
\hline $\begin{array}{l}\text { Missouri } \\
\text { Coteau }\end{array}$ & 71 & $\begin{array}{l}\text { Unnamed, UTM } 662075 \\
\text { (adj. to Burn Lake) }\end{array}$ & 190 & $6 / 10 / 11$ & 0 & 0 & 0.1 & IV & $\mathrm{W}$ & 91 & 96 & 01 & 06 & $\mathrm{f}$ \\
\hline $\begin{array}{l}\text { Missouri } \\
\text { Coteau }\end{array}$ & 101 & Unnamed, UTM 673266 & 165 & $6 / 15 / 11$ & 0 & 0 & 0.0 & IV E & $\mathrm{W}$ & 91 & - & 01 & 06 & $\mathrm{p}$ \\
\hline $\begin{array}{l}\text { Missouri } \\
\text { Coteau }\end{array}$ & 71 & Unnamed, UTM 684062 & 197 & $6 / 10 / 11$ & 0 & 0 & 0.0 & IV & A W & 91 & - & 01 & $\underline{06}$ & $\mathrm{f}$ \\
\hline
\end{tabular}


The 2011 International Piping Plover Breeding Census in Saskatchewan (Continued)

\begin{tabular}{|c|c|c|c|c|c|c|c|c|c|c|c|c|c|c|}
\hline \multirow{2}{*}{$\begin{array}{l}\text { REGION } \\
\begin{array}{l}\text { Missouri } \\
\text { Coteau }\end{array}\end{array}$} & \multirow{2}{*}{$\begin{array}{c}\text { R.M. } \\
\# \\
71\end{array}$} & \multirow{2}{*}{$\begin{array}{l}\text { SITE NAME } \\
\text { ned, UTM } 691060\end{array}$} & \multirow{2}{*}{$\frac{\text { MAP\# }}{198}$} & \multirow{2}{*}{$\begin{array}{c}\text { DATE } \\
6 / 10 / 11\end{array}$} & \multirow{2}{*}{$\begin{array}{c}\text { BREED- } \\
\text { ING } \\
\text { PAIRS } \\
0\end{array}$} & \multirow{2}{*}{$\begin{array}{c}\text { TOTAL } \\
\text { PIPL } \\
\text { ADULTS } \\
0\end{array}$} & \multirow{2}{*}{$\frac{\mathbf{K M}}{0.1}$} & \multirow{2}{*}{$\begin{array}{l}\text { SITE } \\
\text { DESCRIPTION } \\
\text { IV }\end{array}$} & \multirow{2}{*}{$\begin{array}{l}\text { DISTURBANCE } \\
\text { CONCERNS } \\
\mathrm{AW}\end{array}$} & \multicolumn{4}{|c|}{$\begin{array}{c}\text { PRIOR YEARS } \\
\text { CENSUSED \& } \\
\text { YEARS } \\
\text { PIPL SEEN }^{1} \\
\end{array}$} & \multirow{2}{*}{$\frac{\text { OWNER }}{\mathrm{f}}$} \\
\hline & & & & & & & & & & 91 & 96 & 01 & 06 & \\
\hline $\begin{array}{l}\text { Missouri } \\
\text { Coteau }\end{array}$ & 71 & Unnamed, UTM 700080 & 192 & $6 / 10 / 11$ & 0 & 0 & 0.0 & IV & A W & 91 & 96 & 01 & 06 & $\mathrm{f}$ \\
\hline $\begin{array}{l}\text { Missouri } \\
\text { Coteau }\end{array}$ & 11 & Unnamed, UTM 702290 & 251 & $6 / 4 / 11$ & 0 & 0 & 0.0 & IV H I & A W & - & 96 & $\underline{01}$ & - & $\mathrm{p}$ \\
\hline $\begin{array}{l}\text { Missouri } \\
\text { Coteau }\end{array}$ & 71 & Unnamed, UTM 705056 & 199 & $6 / 10 / 11$ & 0 & 1 & 0.0 & IV A & $\mathrm{W}$ & $\underline{91}$ & $\underline{96}$ & $\underline{01}$ & $\underline{06}$ & $\mathrm{p}$ \\
\hline $\begin{array}{l}\text { Missouri } \\
\text { Coteau }\end{array}$ & 71 & Unnamed, UTM 714054 & 200 & $6 / 10 / 11$ & 4 & 10 & 1.0 & IV A & W & 91 & $\underline{96}$ & 01 & $\underline{06}$ & $\mathrm{p}$ \\
\hline $\begin{array}{l}\text { Missouri } \\
\text { Coteau }\end{array}$ & 71 & Unnamed, UTM 717067 & 195 & $6 / 10 / 11$ & 0 & 0 & 0.1 & IV A & W & 91 & $\underline{96}$ & 01 & $\underline{06}$ & $\mathrm{~F}$ \\
\hline $\begin{array}{l}\text { Missouri } \\
\text { Coteau }\end{array}$ & 71 & Unnamed, UTM 725075 & 193 & $6 / 10 / 11$ & 0 & 0 & 0.1 & IV A & W & 91 & 96 & 01 & 06 & $\mathrm{f}$ \\
\hline $\begin{array}{l}\text { Missouri } \\
\text { Coteau }\end{array}$ & 101 & Unnamed, UTM 733205 & 168 & $6 / 8 / 11$ & 0 & 0 & 0.0 & IV E & W & 91 & - & 01 & 06 & $\mathrm{p}$ \\
\hline $\begin{array}{l}\text { Missouri } \\
\text { Coteau }\end{array}$ & 101 & Unnamed, UTM 735128 & 183 & $6 / 11 / 11^{*}$ & - & - & 0.0 & IV H & $\mathrm{A} \mathrm{W}$ & 91 & - & 01 & 06 & unk \\
\hline $\begin{array}{l}\text { Missouri } \\
\text { Coteau }\end{array}$ & 71 & $\begin{array}{l}\text { Unnamed, UTM } 738085 \\
\text { (Shoe Lake, North) }\end{array}$ & 187 & $6 / 8 / 11$ & 10 & 37 & 2.2 & IV A F & $\mathrm{N}$ & 91 & 96 & 01 & $\underline{06}$ & $f, s(p)$ \\
\hline $\begin{array}{l}\text { Missouri } \\
\text { Coteau }\end{array}$ & 71 & Unnamed, UTM 739075 & 194 & $6 / 10 / 11$ & 0 & 0 & 0.0 & IV & $\mathrm{W}$ & 91 & 96 & 01 & 06 & $\mathrm{p}$ \\
\hline $\begin{array}{l}\text { Missouri } \\
\text { Coteau }\end{array}$ & 101 & Unnamed, UTM 740181 & 171 & $6 / 17 / 11$ & 0 & 0 & 0.0 & V D & W & 91 & - & 01 & 06 & $\mathrm{p}$ \\
\hline $\begin{array}{l}\text { Missouri } \\
\text { Coteau }\end{array}$ & 101 & Unnamed, UTM 770230 & 167 & $6 / 17 / 11$ & 0 & 0 & 0.0 & V D & W & 91 & - & 01 & 06 & $\mathrm{p}$ \\
\hline $\begin{array}{l}\text { Missouri } \\
\text { Coteau }\end{array}$ & 71 & Unnamed, UTM 775125 & 184 & $6 / 15 / 11$ & 0 & 0 & $<0.1$ & IV H & A W & 91 & 96 & 01 & 06 & unk \\
\hline $\begin{array}{l}\text { Missouri } \\
\text { Coteau }\end{array}$ & 71 & Unnamed, UTM $776116^{3}$ & 185 & $6 / 25 / 11^{*}$ & - & - & 0.0 & IV H & A W & 91 & 96 & 01 & 06 & unk \\
\hline $\begin{array}{l}\text { Missouri } \\
\text { Coteau }\end{array}$ & 100 & Unnamed, UTM 831160 & 176 & $6 / 9 / 11$ & 0 & 0 & 0.0 & IV A & A W & 91 & 96 & 01 & 06 & $\mathrm{p}$ \\
\hline $\begin{array}{l}\text { Missouri } \\
\text { Coteau }\end{array}$ & 70 & Unnamed, UTM 832010 & 204 & $6 / 13 / 11 *$ & - & - & 0.0 & IV A & $\mathrm{W}$ & 91 & $\underline{96}$ & 01 & $\underline{06}$ & $\mathrm{f}$ \\
\hline $\begin{array}{l}\text { Missouri } \\
\text { Coteau }\end{array}$ & 70 & Unnamed, UTM $840020^{2}$ & 203 & $6 / 10 / 11$ & 0 & 3 & 0.1 & IV D & n.r. & $\underline{91}$ & $\underline{96}$ & $\underline{01}$ & $\underline{06}$ & $f, s(p)$ \\
\hline
\end{tabular}


The 2011 International Piping Plover Breeding Census in Saskatchewan (Continued)

\begin{tabular}{|c|c|c|c|c|c|c|c|c|c|c|c|c|c|c|}
\hline REGION & $\begin{array}{c}\text { R.M. } \\
\#\end{array}$ & SITE NAME & MAP\# & DATE & $\begin{array}{l}\text { BREED- } \\
\text { ING } \\
\text { PAIRS }\end{array}$ & $\begin{array}{c}\text { TOTAL } \\
\text { PIPL } \\
\text { ADULTS } \\
\end{array}$ & $\mathbf{K M}$ & $\begin{array}{l}\text { SITE } \\
\text { DESCRIPTION }\end{array}$ & $\begin{array}{l}\text { DISTURBANCE } \\
\text { CONCERNS }\end{array}$ & & $\begin{array}{r}\text { RIOR } \\
\text { YENE } \\
\text { PIPL } \\
\end{array}$ & $\begin{array}{l}\text { EAR } \\
\text { SED } \\
\text { RS } \\
\text { EEN }\end{array}$ & & OWNER \\
\hline $\begin{array}{l}\text { Missouri } \\
\text { Coteau }\end{array}$ & 70 & Unnamed, UTM 841995 & 206 & $6 / 13 / 11^{*}$ & - & - & 0.0 & IV A & W & 91 & 96 & 01 & $\underline{06}$ & $\mathrm{f}$ \\
\hline $\begin{array}{l}\text { Missouri } \\
\text { Coteau }\end{array}$ & 70 & Unnamed, UTM 842003 & 205 & $6 / 13 / 11$ & 0 & $0^{7}$ & 0.0 & IV A H & W & 91 & 96 & 01 & 06 & $\mathrm{f}$ \\
\hline $\begin{array}{l}\text { Missouri } \\
\text { Coteau }\end{array}$ & 70 & Unnamed, UTM $842027^{2}$ & 202 & $6 / 10 / 11$ & 5 & 11 & 0.4 & IV A & n.r. & 91 & $\underline{96}$ & $\underline{01}$ & $\underline{06}$ & $f, s(p)$ \\
\hline $\begin{array}{l}\text { Missouri } \\
\text { Coteau }\end{array}$ & 100 & Unnamed, UTM 842162 & 175 & $6 / 9 / 11$ & 0 & 0 & 0.0 & IV A & A W & $\underline{91}$ & $\underline{96}$ & 01 & $\underline{06}$ & $\mathrm{p}$ \\
\hline $\begin{array}{l}\text { Missouri } \\
\text { Coteau }\end{array}$ & 100 & Unnamed, UTM 845167 & 173 & $6 / 9 / 11^{*}$ & - & - & 0.0 & IV A & A & - & 96 & 01 & 06 & $\mathrm{p}$ \\
\hline $\begin{array}{l}\text { Missouri } \\
\text { Coteau }\end{array}$ & 70 & Unnamed, UTM 846992 & 207 & $6 / 13 / 11^{*}$ & - & - & 0.0 & IV A & W & $\underline{91}$ & $\underline{96}$ & $\underline{01}$ & $\underline{06}$ & $\mathrm{f}$ \\
\hline $\begin{array}{l}\text { Missouri } \\
\text { Coteau }\end{array}$ & 100 & Unnamed, UTM 848171 & 172 & $6 / 9 / 11^{*}$ & - & - & 0.0 & IV A & A W & - & 96 & 01 & 06 & $\mathrm{P}$ \\
\hline $\begin{array}{l}\text { Missouri } \\
\text { Coteau }\end{array}$ & 100 & Unnamed, UTM 849167 & 174 & $6 / 9 / 11^{*}$ & - & - & 0.0 & IV A & A & - & 96 & 01 & $\underline{06}$ & $P$ \\
\hline $\begin{array}{l}\text { Missouri } \\
\text { Coteau }\end{array}$ & 70 & Unnamed, UTM 851988 & 208 & $6 / 13 / 11^{*}$ & - & - & 0.0 & IV A & W & - & 96 & 01 & 06 & $\mathrm{~F}$ \\
\hline $\begin{array}{l}\text { Missouri } \\
\text { Coteau }\end{array}$ & 100 & $\begin{array}{l}\text { Unnamed, UTM } 857197 \\
\text { and } 863200\end{array}$ & 169 & $6 / 11 / 11$ & 0 & 0 & 0.0 & IV H & A W & 91 & 96 & 01 & 06 & Unk \\
\hline $\begin{array}{l}\text { Missouri } \\
\text { Coteau }\end{array}$ & 70 & $\begin{array}{l}\text { Unnamed, UTM } 860984 \\
\text { (Plasmodium) }\end{array}$ & 209 & $6 / 13 / 11$ & 1 & 2 & 0.1 & IV A & W & - & $\underline{96}$ & 01 & 06 & $\mathrm{~F}$ \\
\hline $\begin{array}{l}\text { Missouri } \\
\text { Coteau }\end{array}$ & 100 & Unnamed, UTM $915261^{3}$ & 166 & $6 / 25 / 11^{*}$ & - & - & 0.0 & IV H & $\mathrm{W}$ & - & 96 & 01 & 06 & Unk \\
\hline $\begin{array}{l}\text { Missouri } \\
\text { Coteau }\end{array}$ & 8 & Wellington Lake (550 495) & 266 & $6 / 4 / 11$ & 0 & 0 & 0.0 & IV H I & W & 91 & 96 & 01 & 06 & $\mathrm{P}$ \\
\hline $\begin{array}{l}\text { Missouri } \\
\text { Coteau }\end{array}$ & 9 & $\begin{array}{l}\text { West Coteau Lake } \\
(350315)\end{array}$ & 278 & $6 / 9 / 11$ & 0 & 0 & 0.0 & IV A & W & $\underline{91}$ & 96 & 01 & $\underline{06}$ & $s(p), p$ \\
\hline $\begin{array}{l}\text { Missouri } \\
\text { Coteau }\end{array}$ & 42 & $\begin{array}{l}\text { Willow Bunch Lake } \\
(670770)\end{array}$ & 213 & $6 / 9 / 11$ & 15 & 50 & 35.0 & IV A & W & $\underline{91}$ & $\underline{96}$ & $\underline{01}$ & $\underline{06}$ & $\mathrm{~s}(\mathrm{p})$ \\
\hline North Central & 434 & $\begin{array}{l}\text { Blaine Lake North } \\
(680545)\end{array}$ & 25 & $6 / 10 / 11^{*}$ & - & - & 0.0 & IV H & W & 91 & 96 & 01 & 06 & unk \\
\hline North Central & 555 & Pekakumew Lake (600 450) & 4 & $6 / 17 / 11$ & 0 & 0 & 0.0 & IV D I & A W & 91 & - & - & 06 & $\mathrm{~s}(\mathrm{p})$ \\
\hline North Central & 405 & Radisson Lake (365 180) & 51 & $6 / 4 / 11$ & 0 & 0 & 0.0 & IV & $\mathrm{W}$ & 91 & 96 & 01 & 06 & $\mathrm{p}$ \\
\hline
\end{tabular}


The 2011 International Piping Plover Breeding Census in Saskatchewan

(Continued)

\begin{tabular}{|c|c|c|c|c|c|c|c|c|c|c|c|c|c|c|}
\hline \multirow{2}{*}{$\begin{array}{l}\text { REGION } \\
\text { North Central }\end{array}$} & \multirow{2}{*}{$\begin{array}{c}\text { R.M. } \\
\# \\
434\end{array}$} & \multirow{2}{*}{$\frac{\text { SITE NAME }}{\text { Redberry Lake (540 400) }}$} & \multirow{2}{*}{ MAP\# } & \multirow{2}{*}{$\begin{array}{l}\text { DATE } \\
6 / 9 / 11\end{array}$} & \multirow{2}{*}{$\begin{array}{c}\text { BREED- } \\
\text { ING } \\
\text { PAIRS } \\
1\end{array}$} & \multirow{2}{*}{$\begin{array}{c}\text { TOTAL } \\
\text { PIPL } \\
\text { ADULTS } \\
2\end{array}$} & \multirow{2}{*}{$\frac{\mathbf{K M}}{20.0}$} & \multirow{2}{*}{$\begin{array}{l}\text { SITE } \\
\text { DESCRIPTION } \\
\text { IV A }\end{array}$} & \multirow{2}{*}{$\begin{array}{l}\text { DISTURBANCE } \\
\text { CONCERNS } \\
\mathrm{W}\end{array}$} & \multicolumn{4}{|c|}{$\begin{array}{c}\text { PRIOR YEARS } \\
\text { CENSUSED \& } \\
\text { YEARS } \\
\text { PIPL SEEN }{ }^{1} \\
\end{array}$} & \multirow{2}{*}{$\frac{\text { OWNER }}{\mathrm{s}(\mathrm{p}), \mathrm{p}}$} \\
\hline & & & & & & & & & & $\underline{91}$ & $\underline{96}$ & $\underline{01}$ & $\underline{06}$ & \\
\hline North Central & 344 & $\begin{array}{l}\text { S. Saskatchewan River, } \\
\text { Upstream (540 465) }\end{array}$ & 77 & $6 / 4 / 11$ & 0 & 0 & 0.0 & A E & $\mathrm{W}$ & 91 & 96 & 01 & - & $\mathrm{s}(\mathrm{p})$ \\
\hline Northeast & 400 & Basin Lake $(815290)^{3}$ & 44 & $6 / 21 / 11$ & 0 & 0 & 0.0 & IV A & $\mathrm{W}$ & $\underline{91}$ & $\underline{96}$ & 01 & 06 & $\mathrm{p}$ \\
\hline Northeast & 372 & Buffer Lake (310 030) & 52 & $6 / 10 / 11$ & 0 & 0 & 0.0 & IV D H & $\mathrm{W}$ & $\underline{91}$ & $\underline{96}$ & 01 & $\underline{06}$ & $\mathrm{p}$ \\
\hline Northeast & 400 & Elkona Lake (865 282) & 45 & $6 / 5 / 11$ & 0 & 0 & 0.1 & IV D H & V W & $\underline{91}$ & 96 & 01 & 06 & $\mathrm{p}$ \\
\hline Northeast & 370 & Houghton Lake (940 080) & 54 & $6 / 7 / 11$ & 0 & 0 & 0.0 & IV A & W & $\underline{91}$ & 96 & 01 & 06 & $\mathrm{p}$ \\
\hline Northeast & 430 & $\begin{array}{l}\text { Jumping Lake (Big) } \\
\text { (700 560) }\end{array}$ & 27 & $6 / 13 / 11$ & 0 & 0 & 0.0 & IV D H & A W & 91 & 96 & 01 & 06 & $\mathrm{~s}(\mathrm{p})$ \\
\hline Northeast & $398 / 368$ & Lake Charron (470 060) & 55 & $6 / 16 / 11$ & 0 & 0 & 0.0 & V D H & W & 91 & 96 & 01 & 06 & unk \\
\hline Northeast & 399 & Lenore Lake (010 180) & 47 & $6 / 11 / 11$ & 0 & 0 & 0.0 & V A & W & $\underline{91}$ & 96 & 01 & 06 & unk \\
\hline Northeast & 400 & Middle Lake (870 235) & 46 & 6/9/11 & 0 & 0 & 0.0 & IV A & $\mathrm{W}$ & $\underline{91}$ & $\underline{96}$ & 01 & 06 & unk \\
\hline Northeast & 371 & Muskiki Lake (500 000) & 53 & $6 / 11 / 11$ & 0 & 0 & 0.1 & IV D A & W & $\underline{91}$ & 96 & 01 & 06 & $\mathrm{p}$ \\
\hline Northwest & 379 & Aroma Lake (670 960) & 56 & $6 / 10 / 11$ & 2 & 9 & 3.8 & IV A & n.r. & $\underline{91}$ & $\underline{96}$ & $\underline{01}$ & $\underline{06}$ & $s(p), p$ \\
\hline Northwest & 439 & Atton Lake (442 568) & 24 & $6 / 15 / 11$ & 0 & 0 & 2.5 & V A B & U V W & - & 96 & - & 06 & $\mathrm{~s}(\mathrm{p})$ \\
\hline Northwest & 501 & Belliveau Lake (150 300) & 13 & $6 / 19 / 11$ & 0 & 0 & 0.0 & V A & U A W & - & - & 01 & 06 & $\mathrm{~s}(\mathrm{p})$ \\
\hline Northwest & 497 & Birch lake (855 220) & 23 & $6 / 7 / 11$ & 0 & 0 & 0.0 & V A & W & 91 & - & - & 06 & $\mathrm{p}$ \\
\hline Northwest & 499 & Blackfoot Lake (595 880) & 21 & $6 / 13 / 11^{*}$ & - & - & 0.0 & IV A & $\mathrm{W}$ & - & 96 & - & 06 & $\mathrm{p}$ \\
\hline Northwest & 499 & $\begin{array}{l}\text { Brightsand Lake, } \\
\text { McFellar's Beach, S. End } \\
(405 \text { 410) }\end{array}$ & 5 & $6 / 8 / 11$ & 0 & 0 & 5.0 & V A B & U V & - & - & - & 06 & $\mathrm{~s}(\mathrm{p})$ \\
\hline Northwest & 411 & Chisholm Lake (993 080) & 39 & $6 / 12 / 11$ & 0 & 0 & 2.0 & IV A G & n.r. & 91 & 96 & 01 & 06 & $\mathrm{p}$ \\
\hline Northwest & 411 & Dillberry Lake (SK side) & 32 & $6 / 12 / 11$ & 0 & 0 & 1.0 & V A & U V & - & - & - & - & $\mathrm{s}(\mathrm{p})$ \\
\hline Northwest & 468 & Ferron Lake (640 950) & 19 & $6 / 13 / 11$ & 0 & 0 & 3.0 & IV & A V & - & - & - & 06 & $\mathrm{p}$ \\
\hline Northwest & 411 & $\begin{array}{l}\text { Freshwater Lake } N \\
(692 \text { 311) }\end{array}$ & 30 & $6 / 10 / 11$ & 3 & 6 & 4.1 & IV A & A & - & $\underline{96}$ & $\underline{01}$ & 06 & unk \\
\hline Northwest & 411 & $\begin{array}{l}\text { Freshwater Lake S } \\
(690290)\end{array}$ & 31 & $6 / 10 / 11$ & 2 & 4 & 2.2 & IV A & n.r. & - & $\underline{96}$ & $\underline{01}$ & $\underline{06}$ & unk \\
\hline Northwest & 410 & Houchen Lake (228 222) & 37 & $6 / 10 / 11^{*}$ & - & - & 0.0 & $\mathrm{~V}$ & n.r. & - & - & 01 & 06 & $\mathrm{p}$ \\
\hline Northwest & 468 & Jackfish Lake $(850740)^{3}$ & 22 & $6 / 22 / 11$ & 0 & 0 & 1.0 & V A & W & 91 & - & - & 06 & $\mathrm{~s}(\mathrm{p})$ \\
\hline Northwest & 381 & Jay Lake (200 060) & 43 & $6 / 11 / 11$ & 0 & 0 & 1.5 & IV A & A & 91 & 96 & 01 & 06 & $\mathrm{p}$ \\
\hline Northwest & 378 & Jones Lake (775 029) & 49 & $6 / 5 / 11^{*}$ & - & - & 0.0 & V A & W & - & - & 01 & 06 & $\mathrm{~s}(\mathrm{p})$ \\
\hline Northwest & 378 & Keppel Lake (812 090) & 48 & $6 / 5 / 11$ & 0 & 0 & 1.0 & IV A & A & 91 & 96 & 01 & 06 & $\mathrm{~s}(\mathrm{p})$ \\
\hline
\end{tabular}


The 2011 International Piping Plover Breeding Census in Saskatchewan

(Continued)

\begin{tabular}{|c|c|c|c|c|c|c|c|c|c|c|c|c|c|c|}
\hline \multirow{2}{*}{$\begin{array}{l}\text { REGION } \\
\text { Northwest }\end{array}$} & \multirow{2}{*}{$\begin{array}{c}\text { R.M. } \\
\# \\
410\end{array}$} & \multirow{2}{*}{$\frac{\text { SITE NAME }}{\text { Killsquaw Lake (292 100) }}$} & \multirow{2}{*}{ MAP\# } & \multirow{2}{*}{$\begin{array}{c}\text { DATE } \\
6 / 11 / 11\end{array}$} & \multirow{2}{*}{$\begin{array}{c}\text { BREED- } \\
\text { ING } \\
\text { PAIRS } \\
0\end{array}$} & \multirow{2}{*}{$\begin{array}{c}\text { TOTAL } \\
\text { PIPL } \\
\text { ADULTS } \\
1\end{array}$} & \multirow{2}{*}{$\frac{\mathbf{K M}}{8.0}$} & \multirow{2}{*}{$\begin{array}{l}\text { SITE } \\
\text { DESCRIPTION } \\
\text { IV VII A G }\end{array}$} & \multirow{2}{*}{$\begin{array}{l}\text { DISTURBANCE } \\
\text { CONCERNS } \\
\mathrm{N}\end{array}$} & \multicolumn{4}{|c|}{$\begin{array}{c}\text { PRIOR YEARS } \\
\text { CENSUSED \& } \\
\text { YEARS } \\
\text { PIPL SEEN }^{1}\end{array}$} & \multirow{2}{*}{$\frac{\text { OWNER }}{\mathrm{p}}$} \\
\hline & & & & & & & & & & $\underline{91}$ & $\underline{96}$ & $\underline{01}$ & $\underline{06}$ & \\
\hline Northwest & 588 & Lac Des Isles (020 320) & 2 & $6 / 13 / 11$ & 0 & 0 & 5.6 & V A E & $\mathrm{U}$ & $\overline{91}$ & 96 & $\overline{01}$ & $\overrightarrow{06}$ & $\mathrm{~s}(\mathrm{p})$ \\
\hline Northwest & 379 & Landis Lake (701 853) & 57 & $6 / 5 / 11^{*}$ & - & - & 0.0 & IV A H & $\mathrm{W}$ & 91 & 96 & 01 & 06 & $\mathrm{p}$ \\
\hline Northwest & 411 & $\begin{array}{l}\text { Little Manitou Lake } \\
(935308)\end{array}$ & 34 & $6 / 10 / 11$ & 0 & 0 & 0.0 & IV A & $\mathrm{W}$ & - & - & $\underline{01}$ & $\underline{06}$ & $\mathrm{~s}(\mathrm{p})$ \\
\hline Northwest & 377 & Lizard Lake (037 997) & 50 & $6 / 14 / 11 *$ & - & - & 0.0 & IV A & A W & 91 & 96 & 01 & 06 & $\mathrm{p}$ \\
\hline Northwest & 498 & Maiden Lake (695 256) & 15 & $6 / 7 / 11^{*}$ & - & - & 0.0 & V A & n.r. & - & - & - & 06 & $\mathrm{p}$ \\
\hline Northwest & 442 & Manitou Lake (870 470) & 33 & $6 / 11 / 11$ & 2 & 35 & 33.3 & IV A & I & $\underline{91}$ & $\underline{96}$ & $\underline{01}$ & $\underline{06}$ & $\begin{array}{c}\mathrm{f}, \mathrm{s}(\mathrm{p}), \mathrm{m}, \\
\mathrm{p}\end{array}$ \\
\hline Northwest & 349 & N. of Handel (600 784) & 59 & $6 / 5 / 11$ & 0 & 0 & 0.5 & IV G H & W & 91 & 96 & 01 & - & $\mathrm{p}$ \\
\hline Northwest & 501 & Paradise Hill (079 366) & 10 & $6 / 8 / 11$ & 0 & 0 & 1.0 & IV IX H & A W & - & - & - & - & $\mathrm{s}(\mathrm{p})$ \\
\hline Northwest & 561 & Peck Lake (925 725) & 3 & $6 / 8 / 11$ & 0 & 0 & 1.0 & V A & $\mathrm{V} \mathrm{O}$ & 91 & 96 & - & 06 & $\mathrm{~s}(\mathrm{p})$ \\
\hline Northwest & 501 & Perch Lake (015 376) & 6 & $6 / 7 / 11$ & 0 & 0 & $<0.1$ & V A H & UW & - & - & - & - & $\mathrm{s}(\mathrm{p}), \mathrm{p}$ \\
\hline Northwest & 409 & $\begin{array}{l}\text { Peter Pond Lake, Sandy } \\
\text { Point }\end{array}$ & 1 & $6 / 13 / 11$ & 0 & 0 & 9.5 & V A & $\mathrm{V}$ & 91 & 96 & 01 & $\underline{06}$ & $\mathrm{~m}$ \\
\hline Northwest & 469 & Picnic Lake (560 978) & 18 & $6 / 13 / 11$ & 0 & 0 & 0.0 & V A & U W & - & - & 01 & 06 & $\mathrm{~s}(\mathrm{p})$ \\
\hline Northwest & 352 & Plover Lake (845 558) & 71 & $6 / 9 / 11$ & 0 & 0 & 0.0 & IV I & none & 91 & 96 & 01 & 06 & $\mathrm{~s}(\mathrm{p}), \mathrm{p}$ \\
\hline Northwest & 501 & $\begin{array}{l}\text { Potney Lake (079 366) - } \\
\text { formerly Fink Lake }\end{array}$ & 8 & $6 / 19 / 11$ & 0 & 0 & 0.1 & IV A & A W & - & - & - & - & $\mathrm{s}(\mathrm{p})$ \\
\hline Northwest & 501 & Ray's Lake (095 330) & 11 & $6 / 8 / 11$ & 0 & 0 & 0.0 & IX H & A N W & - & - & 01 & 06 & $\mathrm{~s}(\mathrm{p})$ \\
\hline Northwest & 381 & Reed Lake NW (110 061) & 42 & $6 / 11 / 11$ & 0 & 0 & 2.0 & IV A & $\mathrm{W}$ & 91 & 96 & 01 & 06 & $\mathrm{p}$ \\
\hline Northwest & 411 & Reflex Lake W (680 350) ${ }^{2}$ & 29 & $6 / 8 / 11$ & $2^{9}$ & 20 & 6.1 & IV A & $\mathrm{V}$ & $\underline{91}$ & $\underline{96}$ & $\underline{01}$ & $\underline{06}$ & unk \\
\hline Northwest & 498 & Russell Lake (610 590) & 17 & $6 / 13 / 11$ & 0 & 0 & 0.1 & IV A & $\mathrm{W}$ & 91 & $\underline{96}$ & 01 & 06 & $\mathrm{p}$ \\
\hline Northwest & 382 & $\begin{array}{l}\text { Schopfer Slough } \\
(694390)\end{array}$ & 28 & $6 / 7 / 11$ & 1 & 2 & 1.0 & IV D & $\mathrm{W}$ & $\underline{91}$ & 96 & 01 & 06 & $\mathrm{p}$ \\
\hline Northwest & 379 & $\begin{array}{l}\text { SE of Landis Lake } \\
\text { (722 817) }\end{array}$ & 58 & $6 / 4 / 11$ & 0 & 0 & 6.0 & IV G H & A & 91 & 96 & 01 & - & $\mathrm{p}$ \\
\hline Northwest & 498 & $\begin{array}{l}\text { SE of Russel Lake } \\
\text { (639 968) }\end{array}$ & 20 & $6 / 13 / 11^{*}$ & - & - & 0.0 & IV & W & - & - & - & 06 & $\mathrm{p}$ \\
\hline Northwest & 410 & $\begin{array}{l}\text { Seagram Lake E } \\
(128272)\end{array}$ & 36 & $6 / 11 / 11^{*}$ & - & - & 0.0 & IV A & A W & - & 96 & 01 & 06 & $\mathrm{p}$ \\
\hline Northwest & 410 & $\begin{array}{l}\text { Seagram Lake W } \\
(076 \text { 297) }\end{array}$ & 35 & $6 / 10 / 11$ & 1 & 4 & 10.0 & IV A & A & 91 & $\underline{96}$ & 01 & $\underline{06}$ & $\mathrm{p}$ \\
\hline
\end{tabular}


The 2011 International Piping Plover Breeding Census in Saskatchewan

(Continued)

\begin{tabular}{|c|c|c|c|c|c|c|c|c|c|c|c|c|c|c|}
\hline \multirow{2}{*}{$\frac{\text { REGION }}{\text { Northwest }}$} & \multirow{2}{*}{$\begin{array}{c}\text { R.M. } \\
\# \\
501\end{array}$} & \multirow{2}{*}{$\frac{\text { SITE NAME }}{\text { Spelt Lake }(060365)^{3}}$} & \multirow{2}{*}{ MAP\# } & \multirow{2}{*}{$\frac{\text { DATE }}{26 / 19 / 11^{*}}$} & \multirow{2}{*}{$\begin{array}{c}\text { BREED- } \\
\text { ING } \\
\text { PAIRS } \\
-\end{array}$} & \multirow{2}{*}{$\begin{array}{c}\text { TOTAL } \\
\text { PIPL } \\
\text { ADULTS } \\
-\end{array}$} & \multirow{2}{*}{$\frac{\mathbf{K M}}{0.0}$} & \multirow{2}{*}{$\begin{array}{l}\text { SITE } \\
\text { DESCRIPTION } \\
\text { IV A }\end{array}$} & \multirow{2}{*}{$\begin{array}{l}\text { DISTURBANCE } \\
\text { CONCERNS } \\
\text { n.r. }\end{array}$} & \multicolumn{4}{|c|}{$\begin{array}{c}\text { PRIOR YEARS } \\
\text { CENSUSED \& } \\
\text { YEARS } \\
\text { PIPL SEEN }^{1} \\
\end{array}$} & \multirow{2}{*}{$\frac{\text { OWNER }}{\mathrm{s}(\mathrm{p})}$} \\
\hline & & & & & & & & & & - & - & - & - & \\
\hline Northwest & 499 & Spruce Lake $(265360)^{3}$ & 9 & $6 / 19 / 11$ & 0 & 0 & 0.0 & V A H & U A W & - & - & - & 06 & $s(p)$ \\
\hline Northwest & 498 & Stony Lake (635 307) & 14 & $6 / 7 / 11$ & 0 & 0 & 0.0 & V A & $\mathrm{W}$ & 91 & 96 & 01 & 06 & $\mathrm{p}$ \\
\hline Northwest & unk & $\begin{array}{l}\text { Thompson Lakes } \\
(528066)\end{array}$ & 16 & $6 / 13 / 11$ & 0 & 0 & 0.0 & V A & W & - & - & - & 06 & $\mathrm{p}$ \\
\hline Northwest & 350 & Tramping Lake (510 610) & 60 & $6 / 10 / 11$ & 0 & 0 & 3.5 & IV I & A W & $\underline{91}$ & 96 & 01 & 06 & $\mathrm{~s}(\mathrm{p}), \mathrm{p}$ \\
\hline Northwest & 499 & $\begin{array}{l}\text { West of Spruce Lake } \\
(262344)^{3}\end{array}$ & 12 & $6 / 19 / 11$ & 0 & 0 & 0.0 & IX & $\mathrm{W}$ & - & - & 01 & 06 & $\mathrm{~s}(\mathrm{p})$ \\
\hline Northwest & 381 & $\begin{array}{l}\text { Winterhaldt Lake ( } 980 \\
044)\end{array}$ & 40 & $6 / 12 / 11$ & 0 & 0 & 0.0 & IV & W & 91 & 96 & 01 & 06 & $\mathrm{p}$ \\
\hline Northwest & 351 & Zella Lake $(215590)^{2}$ & 72 & $6 / 12 / 11$ & 4 & 10 & 3.1 & IV H I & $\mathrm{A} \mathrm{W}$ & 91 & $\underline{96}$ & 01 & 06 & $f, s(p), p$ \\
\hline Northwest & 382 & Zoller Lake (944 004) & 41 & $6 / 12 / 11$ & 0 & 0 & 7.0 & IV A & n.r. & 91 & 96 & 01 & 06 & $f, s(p), p$ \\
\hline Regina Plains & 5 & $\begin{array}{l}\text { Boundary Dam Reservoir } \\
(454 \text { 351) }\end{array}$ & 129 & $6 / 6 / 11$ & 0 & 0 & $<0.1$ & VI A E & $\mathrm{U}$ & 91 & 96 & - & 06 & unk \\
\hline Regina Plains & 274 & $\begin{array}{l}\text { Good Spirit Lake } \\
(620135)\end{array}$ & 84 & $6 / 9 / 11$ & 0 & 0 & 3.0 & V A & W & 91 & 96 & 01 & 06 & unk \\
\hline Regina Plains & 124 & $\begin{array}{l}\text { Island (Miller) Lake } \\
(345285)\end{array}$ & 122 & $6 / 8 / 11^{*}$ & - & - & 0.0 & V A & $\mathrm{W}$ & - & - & - & - & $\mathrm{p}$ \\
\hline Regina Plains & 95 & Moose Mountain Lake & 124 & $6 / 17 / 11$ & 0 & 0 & 0.0 & V VI D & $\mathrm{W}$ & 91 & 96 & 01 & 06 & $\mathrm{p}$ \\
\hline Regina Plains & 67 & Nickle Lake (885 925) & 126 & $6 / 8 / 11^{*}$ & - & - & 0.0 & n.r. & W & 91 & 96 & 01 & 06 & unk \\
\hline Regina Plains & 95 & Rock Lake (385 180) & 125 & $6 / 17 / 11$ & 0 & 0 & 0.0 & V D & W & 91 & 96 & 01 & 06 & $\mathrm{p}$ \\
\hline Regina Plains & 213 & Soda Lake (975 670) & 109 & $6 / 5 / 11$ & 0 & 0 & 0.0 & V A & n.r. & 91 & 96 & 01 & 06 & $\mathrm{p}$ \\
\hline S. Sask River & 224 & $\begin{array}{l}\text { Lake Diefenbaker - } \\
\text { Aiktow Creek }\end{array}$ & 108 & $6 / 7 / 11$ & 0 & 1 & 6.1 & VI A & V W & $\underline{91}$ & $\underline{96}$ & $\underline{01}$ & $\underline{06}$ & unk \\
\hline S. Sask River & 255 & $\begin{array}{l}\text { Lake Diefenbaker - Camp } \\
\text { Cantakaye }\end{array}$ & 98 & $6 / 8 / 11$ & 0 & 0 & 1.8 & VI A & W & $\underline{91}$ & $\underline{96}$ & $\underline{01}$ & $\underline{06}$ & $\mathrm{p}$ \\
\hline S. Sask River & 255 & $\begin{array}{l}\text { Lake Diefenbaker - } \\
\text { Coteau Beach }\end{array}$ & 91 & $6 / 8 / 11$ & 0 & 0 & 5.0 & VI A & n.r. & $\underline{91}$ & $\underline{96}$ & $\underline{01}$ & $\underline{06}$ & unk \\
\hline S. Sask River & 254 & $\begin{array}{l}\text { Lake Diefenbaker - } \\
\text { Danielson }\end{array}$ & 90 & $6 / 7 / 11$ & 0 & 2 & 4.3 & VI A & W & $\underline{91}$ & $\underline{96}$ & $\underline{01}$ & $\underline{06}$ & unk \\
\hline S. Sask River & 254 & $\begin{array}{l}\text { Lake Diefenbaker - } \\
\text { Danielson Park }\end{array}$ & 89 & $6 / 7 / 11$ & 1 & 2 & 5.3 & VI A & W & $\underline{91}$ & $\underline{96}$ & $\underline{01}$ & $\underline{06}$ & $s(p)$ \\
\hline S. Sask River & 224 & $\begin{array}{l}\text { Lake Diefenbaker - } \\
\text { Douglas }\end{array}$ & 105 & $6 / 6 / 11$ & 0 & 0 & 8.3 & VI A & W & $\underline{91}$ & $\underline{96}$ & $\underline{01}$ & $\underline{06}$ & $s(p)$ \\
\hline S. Sask River & 224 & Lake Diefenbaker - Elbow & 94 & $6 / 7 / 11$ & 0 & 1 & 7.2 & VI A & $\mathrm{W}$ & $\underline{91}$ & $\underline{96}$ & $\underline{01}$ & 06 & unk \\
\hline
\end{tabular}


The 2011 International Piping Plover Breeding Census in Saskatchewan (Continued)

\begin{tabular}{|c|c|c|c|c|c|c|c|c|c|c|c|c|c|c|}
\hline \multirow{2}{*}{$\begin{array}{l}\text { REGION } \\
\text { S. Sask River }\end{array}$} & \multirow{2}{*}{$\begin{array}{c}\text { R.M. } \\
\# \\
255\end{array}$} & \multirow{2}{*}{$\begin{array}{l}\text { SITE NAME } \\
\text { ke Diefenbaker - } \\
\text { rdiner Peninsula }\end{array}$} & \multirow{2}{*}{ MAP\# } & \multirow{2}{*}{$\begin{array}{c}\text { DATE } \\
6 / 6 / 11\end{array}$} & \multirow{2}{*}{$\begin{array}{c}\begin{array}{c}\text { BREED- } \\
\text { ING } \\
\text { PAIRS }\end{array} \\
1\end{array}$} & \multirow{2}{*}{$\begin{array}{c}\text { TOTAL } \\
\text { PIPL } \\
\text { ADULTS } \\
4\end{array}$} & \multirow{2}{*}{$\frac{\mathbf{K M}}{4.0}$} & \multirow{2}{*}{$\begin{array}{l}\text { SITE } \\
\text { DESCRIPTION } \\
\text { VI A }\end{array}$} & \multirow{2}{*}{$\begin{array}{l}\text { DISTURBANCE } \\
\text { CONCERNS } \\
\mathrm{W}\end{array}$} & \multicolumn{4}{|c|}{$\begin{array}{c}\text { PRIOR YEARS } \\
\text { CENSUSED \& } \\
\text { YEARS } \\
\text { PIPL SEEN }^{1} \\
\end{array}$} & \multirow{2}{*}{$\frac{\text { OWNER }}{\mathrm{O}(\mathrm{p})}$} \\
\hline & & & & & & & & & & $\underline{91}$ & $\underline{96}$ & $\underline{01}$ & $\underline{06}$ & \\
\hline S. Sask River & 255 & $\begin{array}{l}\text { Lake Diefenbaker - } \\
\text { Hitchcock Bay }\end{array}$ & 97 & $6 / 8 / 11$ & 0 & 0 & 0.0 & VI A & n.r. & $\underline{91}$ & $\underline{96}$ & $\underline{01}$ & $\underline{06}$ & unk \\
\hline S. Sask River & 224 & $\begin{array}{l}\text { Lake Diefenbaker - Little } \\
\text { Sage Bay }\end{array}$ & 100 & $6 / 6 / 11$ & 0 & 1 & 4.8 & VI A & W & $\underline{91}$ & $\underline{96}$ & $\underline{01}$ & 06 & unk \\
\hline S. Sask River & 224 & $\begin{array}{l}\text { Lake Diefenbaker - } \\
\text { Mackenzie Arm }\end{array}$ & 106 & $6 / 7 / 11$ & 0 & 0 & 3.4 & VI A & W & $\underline{91}$ & $\underline{96}$ & $\underline{01}$ & $\underline{06}$ & unk \\
\hline S. Sask River & 255 & $\begin{array}{l}\text { Lake Diefenbaker - North } \\
\text { Muskapatoon }\end{array}$ & 99 & $6 / 8 / 11$ & 2 & 4 & 1.3 & VI A & n.r. & $\underline{91}$ & $\underline{96}$ & $\underline{01}$ & $\underline{06}$ & unk \\
\hline S. Sask River & 224 & $\begin{array}{l}\text { Lake Diefenbaker - North } \\
\text { Summit (East) }\end{array}$ & 104 & $6 / 7 / 11$ & 0 & 0 & 0.1 & VI A & W & $\underline{91}$ & $\underline{96}$ & $\underline{01}$ & 06 & unk \\
\hline S. Sask River & 224 & $\begin{array}{l}\text { Lake Diefenbaker - North } \\
\text { Summit (west) })^{2}\end{array}$ & 95 & $6 / 7 / 11$ & 1 & 2 & 0.5 & VI A & W & $\underline{91}$ & $\underline{96}$ & $\underline{01}$ & 06 & unk \\
\hline S. Sask River & 255 & $\begin{array}{l}\text { Lake Diefenbaker - PFRA } \\
\text { Coteau Pasture }\end{array}$ & 92 & $6 / 9 / 11$ & 1 & 2 & 2.0 & VI A & n.r. & $\underline{91}$ & $\underline{96}$ & $\underline{01}$ & $\underline{06}$ & $\mathrm{f}$ \\
\hline S. Sask River & 224 & $\begin{array}{l}\text { Lake Diefenbaker - River } \\
\text { South }\end{array}$ & 102 & $6 / 6 / 11$ & 1 & 2 & 1.0 & VI A & W & $\underline{91}$ & $\underline{96}$ & $\underline{01}$ & $\underline{06}$ & $\mathrm{p}$ \\
\hline S. Sask River & 224 & $\begin{array}{l}\text { Lake Diefenbaker - Sage } \\
\text { Bay }\end{array}$ & 101 & $6 / 6 / 11$ & 0 & 0 & 2.4 & VI A & W & $\underline{91}$ & $\underline{96}$ & $\underline{01}$ & $\underline{06}$ & unk \\
\hline S. Sask River & 224 & $\begin{array}{l}\text { Lake Diefenbaker - South } \\
\text { Elbow }\end{array}$ & 93 & $6 / 7 / 11$ & 0 & 0 & 3.0 & VI A & W & $\underline{91}$ & $\underline{96}$ & $\underline{01}$ & $\underline{06}$ & unk \\
\hline S. Sask River & 225 & $\begin{array}{l}\text { Lake Diefenbaker - South } \\
\text { Muskapatoon }\end{array}$ & 103 & $6 / 8 / 11$ & 0 & 0 & 3.5 & VI A & n.r. & $\underline{91}$ & $\underline{96}$ & $\underline{01}$ & $\underline{06}$ & unk \\
\hline S. Sask River & 224 & $\begin{array}{l}\text { Lake Diefenbaker - } \\
\text { Summit Creek }\end{array}$ & 107 & $6 / 7 / 11$ & 0 & 0 & 3.8 & VI A & W & $\underline{91}$ & $\underline{96}$ & $\underline{01}$ & $\underline{06}$ & unk \\
\hline S. Sask River & 255 & Luck Lake (530 593) & 96 & $6 / 11 / 11$ & 0 & 0 & 2.0 & V H & n.r. & 91 & - & 01 & 06 & unk \\
\hline Saskatoon SE & 343 & $\begin{array}{l}\text { Allan Potash Mine } \\
\quad(250560)^{3}\end{array}$ & 70 & $5 / 20 / 11$ & 1 & $2^{10}$ & - & IV & n.r. & - & - & - & - & unk \\
\hline Saskatoon SE & 343 & $\begin{array}{l}\text { Bradwell Reservoir } \\
(182535)\end{array}$ & 69 & $6 / 15 / 11$ & 0 & 0 & 0.5 & V I & W & 91 & 96 & 01 & 06 & $\mathrm{p}$ \\
\hline Saskatoon SE & 373 & Burke Lake (105 795) & 62 & $6 / 16 / 11$ & 0 & 0 & 8.0 & V I & $\mathrm{A} \mathrm{W}$ & 91 & 96 & 01 & 06 & $\mathrm{p}$ \\
\hline Saskatoon SE & 343 & Crawford Lake (130 674) & 64 & $6 / 16 / 11$ & 0 & 0 & 6.0 & V H I & W & 91 & - & - & - & $\mathrm{m}, \mathrm{p}$ \\
\hline Saskatoon SE & 343 & Esker Slough (124 657) & 67 & $6 / 13 / 11$ & 1 & 2 & 2.0 & V I & n.r. & 91 & 96 & 01 & 06 & $\mathrm{p}$ \\
\hline Saskatoon SE & 343 & NW of Blucher (097 670) & 65 & $6 / 9 / 11$ & 0 & 0 & 3.0 & V I & A W & 91 & 96 & - & 06 & $\mathrm{P}$ \\
\hline
\end{tabular}


The 2011 International Piping Plover Breeding Census in Saskatchewan

(Continued)

\begin{tabular}{|c|c|c|c|c|c|c|c|c|c|c|c|c|c|c|}
\hline \multirow{2}{*}{$\begin{array}{l}\text { REGION } \\
\text { Saskatoon SE }\end{array}$} & \multirow{2}{*}{$\begin{array}{c}\text { R.M. } \\
\#\end{array}$} & \multirow{2}{*}{$\frac{\text { SITE NAME }}{\text { NW of Blucher }(103667)}$} & \multirow{2}{*}{$\frac{\text { МАP\# }}{66}$} & \multirow{2}{*}{$\begin{array}{l}\text { DATE } \\
6 / 9 / 11\end{array}$} & \multirow{2}{*}{$\begin{array}{c}\text { BREED- } \\
\text { ING } \\
\text { PAIRS } \\
0\end{array}$} & \multirow{2}{*}{$\begin{array}{c}\text { TOTAL } \\
\text { PIPL } \\
\text { ADULTS } \\
0\end{array}$} & \multirow{2}{*}{$\frac{\mathbf{K M}}{1.0}$} & \multirow{2}{*}{$\begin{array}{l}\text { SITE } \\
\text { DESCRIPTION }\end{array}$} & \multirow{2}{*}{$\begin{array}{l}\text { DISTURBANCE } \\
\text { CONCERNS } \\
\mathrm{A} \mathrm{W}\end{array}$} & \multicolumn{4}{|c|}{$\begin{array}{c}\text { PRIOR YEARS } \\
\text { CENSUSED \& } \\
\text { YEARS } \\
\text { PIPL SEEN }^{1}\end{array}$} & \multirow{2}{*}{$\frac{\text { OWNER }}{\mathrm{p}}$} \\
\hline & & & & & & & & & & 91 & 96 & - & 06 & \\
\hline Saskatoon SE & 343 & NW of Blucher (155 642) & 68 & $6 / 13 / 11$ & 0 & 0 & 3.0 & V I & $\mathrm{W}$ & $\overline{91}$ & $\underline{96}$ & 01 & $\underline{06}$ & $\mathrm{p}$ \\
\hline Saskatoon SE & 343 & Patience Lake (085 750) & 63 & $6 / 16 / 11$ & 0 & 1 & 11.0 & IV H I & $\mathrm{W}$ & $\overline{91}$ & $\overline{96}$ & 01 & $\overrightarrow{06}$ & $\mathrm{p}$ \\
\hline Saskatoon SE & 373 & Porter Lake (120 840) & 61 & $6 / 16 / 11$ & 0 & 0 & 6.0 & V H I & $\mathrm{W}$ & 91 & 96 & 01 & 06 & $\mathrm{p}$ \\
\hline Southwest & 138 & Antelope Lake (860 720) & 117 & $6 / 9 / 11$ & 0 & 0 & 0.0 & IV A & $\mathrm{W}$ & 91 & 96 & - & 06 & unk \\
\hline Southwest & 141 & $\begin{array}{l}\text { Big Stick Lake, N\&W } \\
\text { sides (200 685) }\end{array}$ & 115 & $6 / 13 / 11^{*}$ & - & - & 0.0 & n.r. & $\mathrm{W}$ & 91 & 96 & - & 06 & n.r. \\
\hline Southwest & 111 & Bitter Lake (850 530) & 119 & $6 / 13 / 11$ & 0 & 0 & 17.1 & IV A D I & A S N V W & 91 & - & - & - & $\mathrm{s}(\mathrm{p})$ \\
\hline Southwest & 171 & Freefight Lake (343 845) & 114 & $6 / 6 / 11$ & 0 & 2 & 3.0 & IV & n.r. & 91 & $\underline{96}$ & $\underline{01}$ & $\underline{06}$ & $\mathrm{~s}(\mathrm{p})$ \\
\hline Southwest & 171 & Ingebrigt Lake (195 795) & 113 & $6 / 6 / 11$ & 0 & 0 & 4.0 & VI A & $\mathrm{W}$ & $\underline{91}$ & $\overline{96}$ & $\overline{01}$ & $\overline{06}$ & $\mathrm{p}$ \\
\hline Southwest & 18 & Island Lake (025 455) & 127 & $6 / 15 / 11$ & 0 & 0 & 0.3 & V H I & $\mathrm{W}$ & 91 & - & - & - & $\mathrm{p}$ \\
\hline Southwest & 18 & Lonetree Lake (703 399) & 128 & $6 / 15 / 11$ & 0 & 0 & 0.0 & VI & $\mathrm{W}$ & 91 & 96 & 01 & 06 & $\mathrm{p}$ \\
\hline Southwest & 142 & MacLaren Lake (790 720) & 118 & $6 / 6 / 11$ & 0 & 0 & 6.0 & VI A & $\mathrm{W}$ & 91 & 96 & 01 & 06 & $\mathrm{p}$ \\
\hline Southwest & 168 & $\begin{array}{l}\text { North of Antelope } \\
(818790)\end{array}$ & 116 & $6 / 9 / 11^{*}$ & - & - & 0.0 & IV A & $\mathrm{W}$ & - & 96 & - & 06 & unk \\
\hline Southwest & 108 & Notukeu Lake (966 140) & 123 & $6 / 22 / 11$ & 0 & 0 & 1.0 & $\mathrm{~V}$ & $\mathrm{~W}$ & 91 & 96 & 01 & $\underline{06}$ & $\mathrm{~s}(\mathrm{p})$ \\
\hline Southwest & 141 & S of Tenaille Lake & 120 & $6 / 17 / 11$ & 0 & 0 & 2.5 & IV H & $\mathrm{A}$ & 91 & 96 & - & $\overline{06}$ & $\mathrm{p}$ \\
\hline Southwest & 169 & Snakehole Lake (783 975) & 111 & $6 / 9 / 11$ & 0 & 0 & 0.0 & IV A & $\mathrm{W}$ & 91 & 96 & 01 & 06 & unk \\
\hline Southwest & 168 & Success Lake (005 925) & 112 & $6 / 9 / 11$ & 0 & 0 & 0.0 & IV V A & $\mathrm{W}$ & - & 96 & 01 & 06 & unk \\
\hline Southwest & $\begin{array}{l}141 / \\
110\end{array}$ & Unnamed, UTM 508590 & 121 & $6 / 13 / 11$ & 0 & 0 & 1.3 & IV IX A & $\mathrm{A}$ & - & - & - & - & $\mathrm{p}$ \\
\hline West & 261 & $\begin{array}{l}\text { Alsask Reservoir } \\
(785 \text { 880) }\end{array}$ & 85 & $6 / 9 / 11$ & 0 & 0 & 0.7 & IV I & $\mathrm{N} \mathrm{S}$ & 91 & 96 & 01 & 06 & $\mathrm{~s}(\mathrm{p}), \mathrm{p}$ \\
\hline West & 319 & Opuntia Lake (675 420) & 73 & $6 / 13 / 11$ & 0 & 0 & 1.6 & IV I & none & 91 & 96 & 01 & 06 & $s(p), p$ \\
\hline West & 285 & Stockwell Lake (480 925) & 86 & $6 / 11 / 11$ & 0 & 0 & 0.0 & V I & n.r. & 91 & 96 & 01 & 06 & unk \\
\hline West & 317 & Valley Centre (025 454) & 74 & $6 / 14 / 11^{*}$ & - & - & 0.0 & IV A & $\mathrm{W}$ & 91 & 96 & 01 & $\underline{06}$ & $\mathrm{~m}$ \\
\hline Total & & & & & 195 & 778 & 2473.1 & & & & & & & \\
\hline
\end{tabular}


${ }^{7} 2$ PIPL were seen flying over this site, from the direction of Unnamed, UTM 840020 toward Unnamed, UTM 842003 . The birds did not land in this site.

${ }^{8}$ In 1991, Unnamed UTM 863200 was surveyed, but Unnamed UTM 857197 was not.

${ }_{9}^{6} 6$ pairs were observed in the detectability study.

${ }^{10}$ Although this site was surveyed well outside the census window we chose to include the count because a nest was seen on this initial visit and two juveniles (in addition to two adults) were seen on a subsequent visit on July $28,2011$. 


\section{The 2011 International Piping Plover Breeding Census in Alberta}

Dave Prescott

Alberta Fish and Wildlife

\#404, 4911 51st Street

Red Deer, AB T4N 6V4

403-340-4309

dave.prescott@gov.ab.ca

We survey almost all available and known plover habitat every year, but use the 5-year censuses to survey a few extra lakes. Most of these additional lakes have had plovers in past years, but are not normally occupied by plovers. All known sites likey to hold plovers were surveyed in 2011 . We surveyed 70 basins, but did not survey 3 lakes that we had originally hoped to visit. Nonetheless, these three lakes had a low probability of supporting breeding Piping Plovers.

Water conditions were high, and habitat conditions marginal on many lakes.

Nevertheless, plover numbers were higher than expected, given the relatively poor conditions. Based on our years of survey experience, we believe the survey results to be very close to the actual number of plovers in the province in 2011. The 2011 total was lower than 2006, but higher than a 2010 provincial survey.
Comparison of Census Numbers

\begin{tabular}{|l|c|c|c|c|c|}
\hline & 1991 & 1996 & 2001 & 2006 & 2011 \\
\hline $\begin{array}{l}\text { Total } \\
\text { Adults }\end{array}$ & 180 & 276 & 150 & $274^{1}$ & $244^{1}$ \\
\hline
\end{tabular}

${ }^{1}$ This is the total from a single survey at each site; if more than one survey was conducted, we count only results from the first survey during the census window.

\section{Detectability Study}

\begin{tabular}{|l|c|c|}
\hline \multicolumn{1}{|c|}{ Sites Included } & $\begin{array}{c}\text { First } \\
\text { Count }\end{array}$ & $\begin{array}{c}\text { Second } \\
\text { Count }\end{array}$ \\
\hline Cipher Lake & 0 & 0 \\
\hline Reflex Lake (Alberta side) & 12 & 16 \\
\hline
\end{tabular}




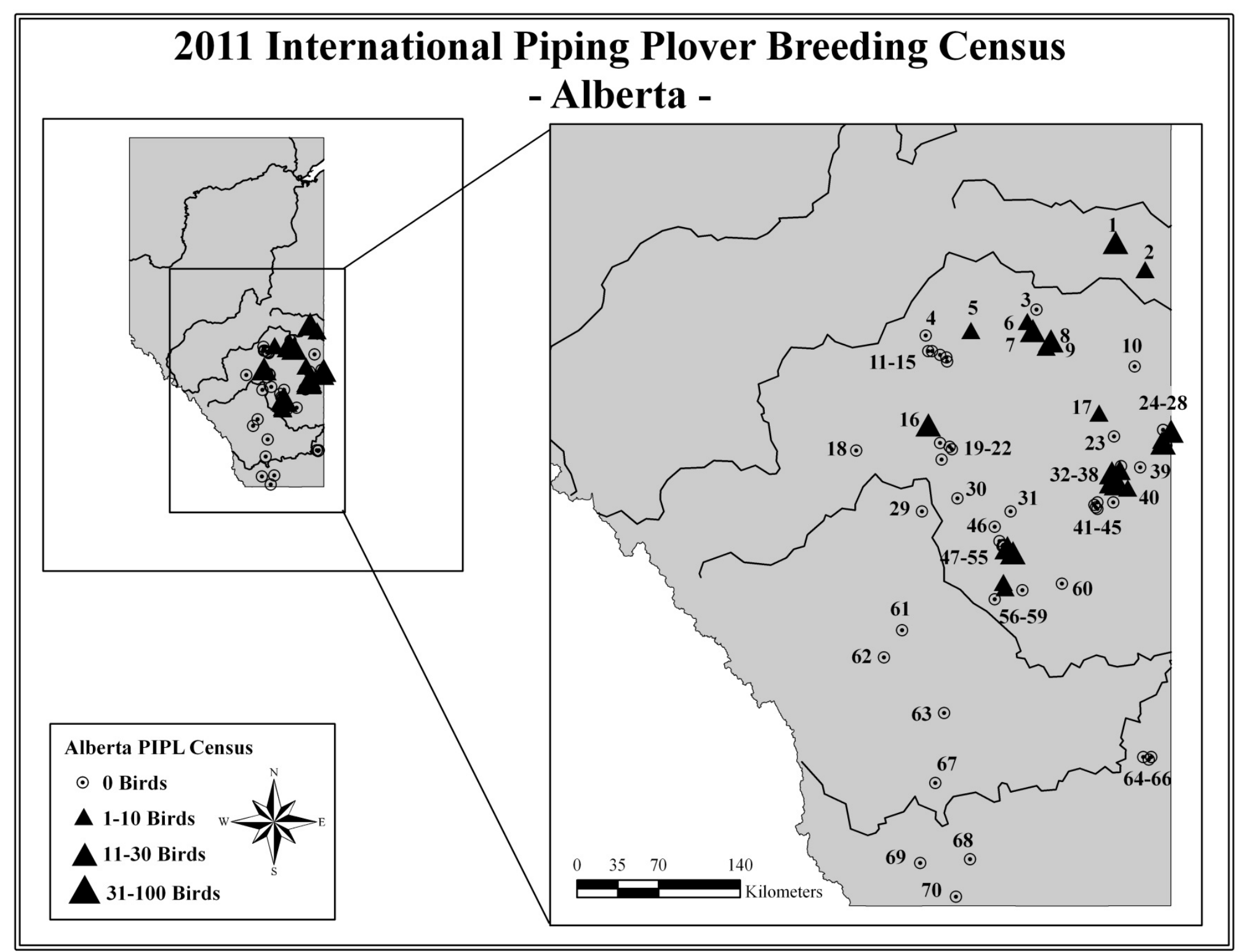


The 2011 International Piping Plover Breeding Census in Alberta

\begin{tabular}{|c|c|c|c|c|c|c|c|c|c|c|c|c|c|}
\hline \multirow{2}{*}{$\begin{array}{l}\text { REGION } \\
\text { Bonnyville (MD) }\end{array}$} & \multirow{2}{*}{$\begin{array}{c}\text { SITE NAME } \\
\end{array}$} & \multirow{2}{*}{ MAP\# } & \multirow{2}{*}{$\begin{array}{c}\text { DATE } \\
5 / 31 / 11\end{array}$} & \multirow{2}{*}{$\begin{array}{c}\text { BREED- } \\
\text { ING } \\
\text { PAIRS } \\
3\end{array}$} & \multirow{2}{*}{$\begin{array}{c}\text { TOTAL } \\
\text { PIPL } \\
\text { ADULTS } \\
6\end{array}$} & \multirow{2}{*}{ 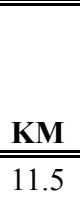 } & \multirow{2}{*}{$\begin{array}{l}\text { SITE } \\
\text { DESCRIPTION } \\
\mathrm{VA}\end{array}$} & \multirow{2}{*}{$\begin{array}{l}\text { DISTURBANCE } \\
\text { CONCERNS } \\
\mathrm{VO}\end{array}$} & \multicolumn{4}{|c|}{$\begin{array}{c}\text { PRIOR YEARS } \\
\text { CENSUSED \& } \\
\text { YEARS } \\
\text { PIPL SEEN }^{1} \\
\end{array}$} & \multirow{2}{*}{$\frac{\text { OWNER }}{=\mathrm{s}(\mathrm{p}), \mathrm{p}}$} \\
\hline & & & & & & & & & 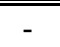 & 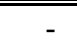 & $\underline{01}$ & $\underline{06}$ & \\
\hline Bonnyville (MD) & Muriel Lake ${ }^{3}$ & 1 & $5 / 31 / 11$ & 9 & 22 & 17.4 & $\mathrm{~V} A$ & $\mathrm{VO}$ & - & $\underline{96}$ & $\overline{01}$ & $\overline{06}$ & $\mathrm{~s}(\mathrm{p}), \mathrm{p}$ \\
\hline Camrose & Miquelon Lake $\# 1^{3}$ & 15 & $6 / 21 / 11$ & 0 & 0 & 0.0 & V A I & A V W O & - & $\overline{96}$ & $\overline{01}$ & $\overline{06}$ & $\mathrm{~s}(\mathrm{p}), \mathrm{p}$ \\
\hline Camrose & Miquelon Lake \#2 & 14 & $6 / 13 / 11$ & 0 & 0 & 1.6 & IV G & U A & 91 & $\overline{96}$ & 01 & 06 & $\mathrm{~s}(\mathrm{p})$ \\
\hline Camrose & $\begin{array}{l}\text { Miquelon Lake \#3 } \\
\text { (Main lake) }\end{array}$ & 13 & $6 / 9 / 11$ & 0 & 0 & 3.5 & IV G & H A V & 91 & 96 & 01 & 06 & $\mathrm{~s}(\mathrm{p}), \mathrm{p}$ \\
\hline Camrose & Rockeling $\mathrm{Bay}^{3}$ & 20 & $5 / 31 / 11$ & 0 & 0 & 0.0 & IV A & $\mathrm{W}$ & $\underline{91}$ & 96 & 01 & 06 & n.r. \\
\hline Camrose & Sittingstone Lake & 19 & $6 / 10 / 11$ & 0 & 0 & 0.0 & IV A & $\mathrm{W}$ & - & - & 01 & 06 & n.r. \\
\hline Camrose/Ponoko & Red Deer Lake ${ }^{3}$ & 16 & $5 / 31 / 11$ & 5 & 12 & 6.0 & IV A & U W & - & $\underline{96}$ & $\underline{01}$ & $\underline{06}$ & n.r. \\
\hline Camrose/Stettler/Lacombe & Buffalo Lake ${ }^{3}$ & 22 & $6 / 1 / 11$ & 0 & 0 & 0.0 & V A & $\mathrm{W} \mathrm{O}$ & 91 & $\overline{96}$ & $\overline{01}$ & $\overrightarrow{06}$ & $\mathrm{~s}(\mathrm{p})$ \\
\hline Cardston & Shanks Lake & 70 & $6 / 14 / 11$ & 0 & 0 & 0.0 & V A & $\mathrm{W}$ & - & 96 & 01 & 06 & $\mathrm{~s}(\mathrm{p}), \mathrm{p}$ \\
\hline Cardston & St. Mary Reservoir & 69 & $6 / 14 / 11$ & 0 & 0 & 0.0 & VI A & n.r. & - & $\underline{96}$ & $\underline{01}$ & 06 & $\mathrm{~s}(\mathrm{p}), \mathrm{p}$ \\
\hline Cypress (MD) & Chappice Lake & 64 & $6 / 7 / 11$ & 0 & 0 & 1.5 & IV A & $\mathrm{W}$ & $\underline{91}$ & 96 & 01 & 06 & $\mathrm{~s}(\mathrm{p})$ \\
\hline Cypress (MD) & $\begin{array}{l}\text { Rutherford Lake } \\
\text { (formerly Unnamed SE } \\
\text { of Sam Lake) }\end{array}$ & 65 & $6 / 7 / 11$ & 0 & 0 & 1.0 & IV A & A W & - & - & - & 06 & n.r. \\
\hline Cypress (MD) & Sam Lake & 66 & $6 / 8 / 11$ & 0 & 0 & 0.5 & IV A & A W & $\underline{91}$ & $\underline{96}$ & 01 & 06 & $\mathrm{~s}(\mathrm{p})$ \\
\hline Lacombe & Gull Lake & 18 & $6 / 16 / 11$ & 0 & 0 & 0.0 & V A & $\mathrm{U}$ & - & - & - & - & $\mathrm{s}(\mathrm{p}), \mathrm{m}, \mathrm{p}$ \\
\hline Leduc & Joseph Lake & 11 & $6 / 9 / 11$ & 0 & 0 & 0.3 & V D & $\mathrm{NO}$ & - & 96 & 01 & 06 & $\mathrm{~s}(\mathrm{p}), \mathrm{p}$ \\
\hline Leduc/Camrose & Oliver Lake & 12 & $6 / 9 / 11$ & 0 & 0 & 0.0 & V A & $\mathrm{O}$ & - & 96 & 01 & 06 & $\mathrm{~s}(\mathrm{p}), \mathrm{p}$ \\
\hline Lethbridge & Keho Lake & 67 & $6 / 14 / 11$ & 0 & 0 & 0.0 & VI A D H & W O & $\underline{91}$ & 96 & 01 & 06 & $\mathrm{~s}(\mathrm{p}), \mathrm{p}$ \\
\hline Minburn & Akasu Lake ${ }^{3}$ & 6 & $6 / 3 / 11$ & 1 & 2 & 15.1 & IV A & $\mathrm{VO}$ & - & $\underline{96}$ & $\underline{01}$ & $\underline{06}$ & $\mathrm{~s}(\mathrm{p}), \mathrm{p}$ \\
\hline Minburn & $\begin{array}{l}\text { Birch Lake, Main } \\
\text { Basin }\end{array}$ & 9 & $6 / 8 / 11$ & 2 & 6 & 5.0 & IV A & $\mathrm{V}$ & - & $\underline{96}$ & $\underline{01}$ & $\underline{06}$ & $\mathrm{~s}(\mathrm{p}), \mathrm{p}$ \\
\hline Minburn & $\begin{array}{l}\text { Birch Lake, North } \\
\text { Basin }\end{array}$ & 8 & $6 / 6 / 11$ & 6 & 12 & 3.0 & IV A & U V & - & $\underline{96}$ & 01 & 06 & $\mathrm{~s}(\mathrm{p}), \mathrm{p}$ \\
\hline Minburn & Junction Lake & 7 & $6 / 1 / 11$ & 5 & 14 & 4.9 & IV A & $\mathrm{V}$ & - & $\underline{96}$ & 01 & $\underline{06}$ & $\mathrm{~s}(\mathrm{p}), \mathrm{p}$ \\
\hline $\begin{array}{l}\text { Pointearth/Stettler/ } \\
\text { Special Area } 2\end{array}$ & Sullivan Lake ${ }^{3}$ & 31 & $5 / 30 / 11$ & 0 & 0 & 0.0 & IV A & $\mathrm{W}$ & - & $\overline{96}$ & 01 & $\overline{06}$ & $f, p$ \\
\hline Provost (MD) & Clark Lake & 37 & $6 / 9 / 11$ & 10 & 22 & 7.5 & IV A & $\mathrm{A}$ & - & - & - & $\underline{06}$ & $s(p), p$ \\
\hline Provost (MD) & Hansman Lake & 39 & $6 / 10 / 11$ & 0 & 0 & 0.0 & IV A & n.r. & - & - & $\underline{01}$ & 06 & $\mathrm{~s}(\mathrm{p}), \mathrm{p}$ \\
\hline Provost (MD) & Horseshoe Lake & 34 & $6 / 9 / 11$ & 5 & 19 & 14.5 & IV A & A N V & 91 & $\underline{96}$ & 01 & $\underline{06}$ & $\mathrm{~s}(\mathrm{p}), \mathrm{p}$ \\
\hline
\end{tabular}


The 2011 International Piping Plover Breeding Census in Alberta (Continued)

\begin{tabular}{|c|c|c|c|c|c|c|c|c|c|c|c|c|c|}
\hline \multirow{2}{*}{$\begin{array}{l}\text { REGION } \\
\text { Provost (MD) }\end{array}$} & \multirow{2}{*}{\begin{tabular}{l}
\multicolumn{1}{c}{ SITE NAME } \\
McLaren Lake (formerly \\
Unnamed SE of Captain Eyre \\
Lake)
\end{tabular}} & \multirow{2}{*}{ MAP\# } & \multirow{2}{*}{$\frac{\text { DATE }}{26 / 9 / 11}$} & \multirow{2}{*}{$\begin{array}{c}\begin{array}{c}\text { BREED- } \\
\text { ING } \\
\text { PAIRS }\end{array} \\
3\end{array}$} & \multirow{2}{*}{$\begin{array}{c}\text { TOTAL } \\
\text { PIPL } \\
\text { ADULTS } \\
6\end{array}$} & \multirow{2}{*}{$\frac{\text { KM }}{25.4}$} & \multirow{2}{*}{$\begin{array}{l}\text { SITE } \\
\text { DESCRIPTION } \\
\text { IV A }\end{array}$} & \multirow{2}{*}{$\begin{array}{l}\text { DISTURBANCE } \\
\text { CONCERNS } \\
\mathrm{A} \mathrm{V}\end{array}$} & \multicolumn{4}{|c|}{$\begin{array}{c}\text { PRIOR YEARS } \\
\text { CENSUSED \& YEARS } \\
\text { PIPL SEEN }^{1} \\
\end{array}$} & \multirow{2}{*}{$\frac{\text { OWNER }}{\mathrm{s}(\mathrm{p}), \mathrm{p}}$} \\
\hline & & & & & & & & & - & - & $\underline{01}$ & $\underline{06}$ & \\
\hline Provost (MD) & Metiskow Lake & 32 & $6 / 9 / 11$ & 0 & 0 & 3.5 & IV A & n.r. & $\underline{91}$ & $\underline{96}$ & 01 & 06 & $\mathrm{~s}(\mathrm{p}), \mathrm{p}$ \\
\hline Provost (MD) & Piper Lake & 35 & $6 / 10 / 11$ & 1 & 3 & 1.2 & IV A & n.r. & - & $\underline{96}$ & $\underline{01}$ & $\underline{06}$ & $s(p), p$ \\
\hline Provost (MD) & Sunken Lake & 33 & $6 / 10 / 11$ & 2 & 7 & 1.9 & IV A & $\mathrm{A} \mathrm{V}$ & 91 & $\underline{96}$ & $\underline{01}$ & $\underline{06}$ & n.r. \\
\hline Provost (MD) & West Lake & 38 & $6 / 9 / 11$ & 3 & 8 & 4.4 & IV A & $\mathrm{A}$ & - & - & - & 06 & $\mathrm{~s}(\mathrm{p}), \mathrm{p}$ \\
\hline Red Deer & Goosequill Lake ${ }^{3}$ & 29 & $6 / 3 / 11$ & 0 & 0 & 0.0 & IV A & $\mathrm{W} \mathrm{O}$ & 91 & 96 & 01 & 06 & $\mathrm{~s}(\mathrm{p}), \mathrm{p}$ \\
\hline $\begin{array}{l}\text { Rockyview } \\
\text { (MD) }\end{array}$ & $\begin{array}{l}\text { Dalemead Lake (Langdon } \\
\text { Reservoir) }\end{array}$ & 62 & $6 / 13 / 11$ & 0 & 0 & 0.0 & VI A I & $\mathrm{W} \mathrm{O}$ & - & - & - & 06 & $\mathrm{~s}(\mathrm{p}), \mathrm{p}$ \\
\hline Special Area 2 & Chain Lake 1 (Pearl Lake) $)^{3}$ & 54 & $6 / 1 / 11$ & 3 & 11 & 5.4 & IV A & n.r. & $\underline{91}$ & 96 & $\underline{01}$ & 06 & $\mathrm{~s}(\mathrm{p}), \mathrm{p}$ \\
\hline Special Area 2 & Chain Lake $2^{3}$ & 52 & $6 / 1 / 11$ & 0 & 0 & 3.6 & IV A & n.r. & - & - & $\overline{01}$ & 06 & $\mathrm{~s}(\mathrm{p}), \mathrm{p}$ \\
\hline Special Area 2 & Chain Lake 3 (Clear Lake) $^{3}$ & 51 & $6 / 1 / 11$ & 0 & 0 & 3.6 & IV A & n.r. & $\underline{91}$ & 96 & 01 & 06 & $\mathrm{~s}(\mathrm{p}), \mathrm{p}$ \\
\hline Special Area 2 & Chain Lake $3 \mathrm{~A}^{3}$ & 48 & $6 / 1 / 11$ & 0 & 0 & 2.0 & IV A & n.r. & $\overline{91}$ & 96 & 01 & 06 & $\mathrm{~s}(\mathrm{p}), \mathrm{p}$ \\
\hline Special Area 2 & Chain Lake $4^{3}$ & 53 & $6 / 1 / 11$ & 4 & 18 & 10.5 & IV A & n.r. & $\underline{91}$ & $\underline{96}$ & $\underline{01}$ & $\underline{06}$ & n.r. \\
\hline Special Area 2 & Chain Lake $5^{3}$ & 47 & $6 / 1 / 11$ & 0 & 0 & 0.0 & IV A & n.r. & - & $\overline{96}$ & 01 & $\overline{06}$ & $\mathrm{~s}(\mathrm{p}), \mathrm{p}$ \\
\hline Special Area 2 & Chain Lake $6^{3}$ & 50 & $6 / 1 / 11$ & 0 & 0 & 6.0 & IV A & n.r. & $\underline{91}$ & 96 & 01 & 06 & $\mathrm{~s}(\mathrm{p}), \mathrm{p}$ \\
\hline Special Area 2 & Chain Lake $7^{3}$ & 49 & $5 / 30 / 11$ & 0 & 0 & 0.0 & IV A & n.r. & 91 & 96 & 01 & 06 & $s(p), p$ \\
\hline Special Area 2 & Coleman Lake & 59 & $6 / 7 / 11$ & 0 & 0 & 0.0 & VI A & $\mathrm{W} \mathrm{O}$ & - & - & - & 06 & $\mathrm{~s}(\mathrm{p})$ \\
\hline Special Area 2 & Dowling Lake ${ }^{3}$ & 55 & $6 / 2 / 11$ & 11 & 28 & 29.2 & IV A & A V & $\underline{91}$ & $\underline{96}$ & $\underline{01}$ & $\underline{06}$ & $\mathrm{~s}(\mathrm{p}), \mathrm{p}$ \\
\hline Special Area 2 & Handhills Lake ${ }^{3}$ & 56 & $5 / 31 / 11$ & 1 & 2 & 15.0 & IV A & $\mathrm{V}$ & $\underline{91}$ & $\underline{96}$ & $\underline{01}$ & $\underline{06}$ & n.r. \\
\hline Special Area 2 & Littlefish Lake ${ }^{3}$ & 58 & $6 / 3 / 11$ & 0 & 0 & 4.6 & IV A & n.r. & $\underline{91}$ & 96 & $\underline{01}$ & $\underline{06}$ & $s(p), p$ \\
\hline Special Area 2 & Plover Lake ${ }^{3}$ & 60 & $6 / 3 / 11$ & 0 & 0 & 0.0 & IV A & n.r. & - & 96 & $\underline{01}$ & $\overline{06}$ & $\mathrm{~s}(\mathrm{p}), \mathrm{p}$ \\
\hline Special Area 2 & $\begin{array}{l}\text { Unnamed }(0.5 \mathrm{~km} \mathrm{~S} \text { of } \\
\text { Handhills })^{3}\end{array}$ & 57 & $5 / 31 / 11$ & 0 & 1 & 1.8 & IV A & n.r. & - & - & 01 & 06 & n.r. \\
\hline Special Area 4 & Foster Lake & 40 & $6 / 8 / 11$ & 2 & 7 & 5.5 & IV A & $\mathrm{A} \mathrm{V}$ & - & 96 & $\underline{01}$ & $\underline{06}$ & $s(p), p$ \\
\hline Special Area 4 & Gooseberry Lake & 45 & $6 / 8 / 11$ & 0 & 0 & 6.8 & IV A & none & $\underline{91}$ & 96 & 01 & $\overline{06}$ & $\mathrm{~s}(\mathrm{p}), \mathrm{p}$ \\
\hline Special Area 4 & Neutral Hills A & 44 & $6 / 7 / 11$ & 0 & 0 & 0.0 & IV A & n.r. & $\underline{91}$ & 96 & 01 & 06 & $s(p), p$ \\
\hline Special Area 4 & Neutral Hills B1 & 43 & $6 / 7 / 11$ & 0 & 0 & 3.0 & IV A & n.r. & 91 & $\underline{96}$ & 01 & 06 & $\mathrm{~s}(\mathrm{p}), \mathrm{p}$ \\
\hline Special Area 4 & Neutral Hills B2 & 42 & $6 / 7 / 11$ & 0 & 0 & 2.0 & IV A & n.r. & 91 & 96 & 01 & 06 & $\mathrm{~s}(\mathrm{p}), \mathrm{p}$ \\
\hline Special Area 4 & Neutral Hills C1 & 41 & $6 / 7 / 11$ & 0 & 0 & 2.5 & IV A & $\mathrm{W}$ & $\underline{91}$ & $\underline{96}$ & 01 & 06 & $\mathrm{~s}(\mathrm{p}), \mathrm{p}$ \\
\hline Stettler & Lowden Lake ${ }^{3}$ & 30 & $5 / 30 / 11$ & 0 & 0 & 0.0 & IV V A & $\mathrm{W} \mathrm{O}$ & 91 & 96 & 01 & 06 & $s(p), p$ \\
\hline Stettler & Rider Lake ${ }^{3}$ & 21 & $5 / 31 / 11$ & 0 & 0 & 0.5 & IV A & $\mathrm{W}$ & $\underline{91}$ & 96 & 01 & 06 & $\mathrm{~s}(\mathrm{p}), \mathrm{p}$ \\
\hline Stettler & Spiers Lake & 46 & $6 / 14 / 11$ & 0 & 0 & 3.2 & IV A & W & 91 & 96 & 01 & 06 & $f, s(p), p$ \\
\hline
\end{tabular}


The 2011 International Piping Plover Breeding Census in Alberta (Continued)

\begin{tabular}{|c|c|c|c|c|c|c|c|c|c|c|c|c|c|}
\hline \multirow{2}{*}{$\begin{array}{l}\text { REGION } \\
\text { Strathcona }\end{array}$} & SITE NAME & \multirow{2}{*}{ MAP\# } & \multirow{2}{*}{$\begin{array}{c}\text { DATE } \\
6 / 9 / 11\end{array}$} & \multirow{2}{*}{ 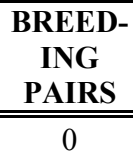 } & \multirow{2}{*}{$\begin{array}{c}\text { TOTAL } \\
\text { PIPL } \\
\text { ADULTS } \\
0\end{array}$} & \multirow{2}{*}{ 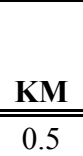 } & \multirow{2}{*}{$\begin{array}{l}\text { SITE } \\
\text { DESCRIPTION } \\
\text { V A D E }\end{array}$} & \multirow{2}{*}{$\begin{array}{l}\text { DISTURBANCE } \\
\text { CONCERNS } \\
\mathrm{W} \mathrm{O}\end{array}$} & \multicolumn{4}{|c|}{$\begin{array}{c}\text { PRIOR YEARS } \\
\text { CENSUSED \& YEARS } \\
\text { PIPL SEEN }^{1} \\
\end{array}$} & \multirow{2}{*}{$\frac{\text { OWNER }}{\mathrm{s}(\mathrm{p}), \mathrm{p}}$} \\
\hline & Cooking Lake & & & & & & & & - & - & - & 06 & \\
\hline Two Hills & Plain Lake ${ }^{3}$ & 3 & $6 / 22 / 11$ & 0 & 0 & 0.0 & V D & $\mathrm{O}$ & - & - & $\underline{01}$ & 06 & $\mathrm{~s}(\mathrm{p}), \mathrm{p}$ \\
\hline $\begin{array}{l}\text { Vermilion } \\
\text { River }\end{array}$ & Albert Lake & 10 & $6 / 7 / 11$ & 0 & 0 & 2.0 & IV A & A & - & - & $\underline{01}$ & - & $\mathrm{s}(\mathrm{p}), \mathrm{p}$ \\
\hline Vulcan & McGregor Lake & 63 & $6 / 8 / 11$ & 0 & 0 & 0.0 & VI A & W O & - & 96 & 01 & 06 & $\mathrm{~s}(\mathrm{p}), \mathrm{m}, \mathrm{p}$ \\
\hline $\begin{array}{l}\text { Wainwright } \\
\text { (MD) }\end{array}$ & Baxter Lakes & 5 & $6 / 8 / 11$ & 2 & 6 & 3.0 & IV A E & V W O & $\underline{91}$ & $\underline{96}$ & $\underline{01}$ & $\underline{06}$ & $\mathrm{~s}(\mathrm{p}), \mathrm{p}$ \\
\hline $\begin{array}{l}\text { Wainwright } \\
\text { (MD) }\end{array}$ & Border Lake & 23 & $6 / 9 / 11$ & 0 & 0 & 0.8 & IV A & A W & - & - & - & 06 & $\mathrm{f}$ \\
\hline $\begin{array}{l}\text { Wainwright } \\
\text { (MD) }\end{array}$ & Cipher Lake ${ }^{2}$ & 24 & $6 / 8 / 11$ & 0 & 0 & 2.3 & IV A & n.r. & $\underline{91}$ & $\underline{96}$ & 01 & $\underline{06}$ & $\mathrm{~s}(\mathrm{p}), \mathrm{p}$ \\
\hline $\begin{array}{l}\text { Wainwright } \\
\text { (MD) }\end{array}$ & Killarney Lake & 27 & $6 / 8 / 11$ & 5 & 16 & 8.2 & IV A & A V & $\underline{91}$ & $\underline{96}$ & $\underline{01}$ & - & $\mathrm{s}(\mathrm{p}), \mathrm{p}$ \\
\hline $\begin{array}{l}\text { Wainwright } \\
\text { (MD) }\end{array}$ & Leane Lake & 28 & $6 / 8 / 11$ & 0 & 0 & 8.0 & IV A & A & $\underline{91}$ & $\underline{96}$ & $\underline{01}$ & - & $\mathrm{s}(\mathrm{p}), \mathrm{p}$ \\
\hline $\begin{array}{l}\text { Wainwright } \\
\text { (MD) }\end{array}$ & Mott Lake & 17 & $6 / 8 / 11$ & 1 & 3 & 0.5 & IV A & W & - & - & - & 06 & $\mathrm{f}$ \\
\hline $\begin{array}{l}\text { Wainwright } \\
\text { (MD) }\end{array}$ & NW Killarney & 26 & $6 / 8 / 11$ & 0 & 1 & 3.7 & IV A & A & - & $\underline{96}$ & 01 & $\underline{06}$ & $\mathrm{~s}(\mathrm{p}), \mathrm{p}$ \\
\hline $\begin{array}{l}\text { Wainwright } \\
\text { (MD) }\end{array}$ & Reflex Lake (Alberta side) ${ }^{2}$ & 25 & $6 / 10 / 11$ & 7 & 16 & 7.7 & IV A & $\mathrm{V}$ & $\underline{91}$ & $\underline{96}$ & 01 & $\underline{06}$ & $\mathrm{~s}(\mathrm{p}), \mathrm{p}$ \\
\hline Warner & Milk River Ridge Reservoir & 68 & $6 / 14 / 11$ & 0 & 0 & 0.0 & VI A & W O & - & - & - & 06 & $\mathrm{~s}(\mathrm{p}), \mathrm{p}$ \\
\hline Wheatland & Dawson Lake & 61 & $6 / 13 / 11$ & 0 & 0 & 0.0 & V A & $\mathrm{W} \mathrm{O}$ & - & - & - & 06 & $\mathrm{~s}(\mathrm{p}), \mathrm{p}$ \\
\hline Total & & & & 91 & 248 & 251.6 & & & & & & & \\
\hline
\end{tabular}

* Site was checked on this date but was found to have no suitable habitat.

${ }^{1}$ Bold years indicate that adults were seen. Bold and underlined years indicate that pairs were seen. Italicized years indicate that the sites were checked but not officially censused due to lack of habitat.

${ }^{2}$ This total is the "high count"; since two surveys were conducted at some sites for the detectability study, this total includes the highest count at each site.

${ }^{3}$ Please note that these surveys were conducted outside the Census window. 


\section{The 2011 International Piping Plover Breeding Census at sites on the Missouri River (MT, ND, SD, NE)}

\author{
Micheal Delvaux (current contact) \\ U.S. Army Corps of Engineers \\ Gavins Point Project \\ PO Box 710 \\ Yankton SD 57078 \\ 402-667-2887 \\ micheal.j.delvaux@usace.army.mil \\ Coral Huber (current contact) \\ U.S. Army Corps of Engineers \\ Gavins Point Project \\ PO Box 710 \\ Yankton SD 57078 \\ 402-667-2883 \\ coral.j.huber@usace.army.mil \\ Greg Pavelka and Gene Bormann \\ (coordinators) \\ U.S. Army Corps of Engineers \\ Gavins Point Project \\ PO Box 710 \\ Yankton SD 57078
}

The area of survey was from Fort Peck Lake in eastern Montana to Lewis \& Clark Lake on the northeastern Nebraska southeastern South Dakota border. Not all of the river and reservoirs between these two boundaries were surveyed due to high water levels or historical lack of habitat. High releases from Fort Peck Dam, Garrison Dam, Fort Randall Dam, and Gavins Point Dam inundated much suitable river and reservoir habitat. The Missouri was completely flooded from Fort Peck Dam to the headwaters of Lake Sakakawea, from Garrison Dam to RM 1300.5 of Lake Oahe, from Fort Randall Dam to RM 842.2 of Lewis \& Clark
Lake (Lake Francis Case behind the dam was also flooded), and from Gavins Point Dam to RM 753.0 Ponca State Park. The western portion of Fort Peck Lake, portions of Lake Sakakawea and its headwaters, and the eastern part of Lewis \& Clark Lake were not surveyed since there is there is not typically any suitable habitat in these areas.

Overall, the Piping Plover adult census for the Missouri River was 186. By state and segment the results are as follows:

\section{Montana}

Fort Peck Lake - 2

Total: 2

North Dakota

Lake Sakakawea - 17

Lake Oahe (ND) - 14

Total: 31

\section{South Dakota}

Lake Oahe (SD) - 7

Lake Sharpe -0

Lewis \& Clark Lake - 144

Total: 151

\section{Nebraska}

Cedar County -2

Total: 2

\section{Missouri River Total - 186}

In comparison to previous International Piping Plover Census results, 2011 showed an $85 \%$ decrease in Piping Plover numbers compared to the 2006 International Census and tied the 1996 International Census for the lowest number ever (see tables below). To add perspective to the census numbers, the Corps of Engineers has annually conducted an adult census on the Missouri River from 1986 to present. For the 25 year period of 1986-2010 the average number of adult Piping Plovers has been 751, with the number varying from a high of 1,764 in 2005 to 
a low of 82 in 1997. Only the 1991 International Census count is somewhat close to the 25 year average while the other four census years are closer to the high and low extremes.

In 2011, the census effort adequately documented Piping Plover numbers on the Missouri River. At the time of the census record runoff had greatly reduced the amount of habitat available to the birds. The little habitat available had, in most cases, been surveyed several times before the census was done. Survey crew quality was generally good with at least one observer having several years of experience in conducting adult censuses and productivity monitoring for the segment censused.

Piping Plover numbers on the Missouri River are a function of annual runoff. In years of high runoff as in 1996 and 2011, shoreline and island habitat in the reservoirs are inundated as water is stored to avert downstream flooding. As the storage capacity of the reservoirs is approached, water releases from the dams are increased, which inundates sandbar habitat below the dams. This leaves very little breeding habitat for plovers. In years of low runoff such as 2001 and 2006, the reservoirs are lowered exposing miles of shoreline and island habitat. Releases from the dams are also decreased, providing sandbar habitat for plovers. Releases from the six mainstem dams on the Missouri River broke all previous record levels in 2011 with releases out of Garrison, Fort Randall and Gavins Point Dams being in excess of 100,000 cubic feet per second (cfs). For perspective, the average June releases for these dams varies from 22,000 to 29,000 cfs. Consequently all sandbar habitat on the Missouri River below the dams was inundated before the 2011 International Census.

Flooding on the reservoirs was almost as severe as the river itself. At the time of the 2011 International Census Fort Peck Lake and Lake Oahe were already at all-time record June elevations and Lake Sakakawea was within two inches of equaling its June record. On Fort Peck Lake the only pair found nesting was in a parking lot. On Lake Sakakawea all but one pair of plovers were observed in recreation area parking lots. On Lake Oahe, plovers were found scattered as singles or pairs at various locations. In 2011, for the first time in an International Census, Lake Sharpe was censused. Lake Sharpe had not been censused previously due to a lack of known habitat. However, the lake is kept at a constant elevation and was not subject to rising lake levels from high runoff. Hence, it was believed that Piping Plovers displaced from Lake Oahe might nest there, but none were found.

Seventy seven percent of the plovers (144) counted on the Missouri River were found on Lewis \& Clark Lake. The reasons for this relative high number come down to two factors. Like Lake Sharpe, Lewis \& Clark Lake is operated at a constant lake level with very little fluctuation and therefore was not subject to the high runoff experienced at the other reservoirs. Secondly, the Corps of Engineers from 20072011 had constructed sandbar habitat at various locations in the middle and upper parts of the lake for Piping Plovers and Least Terns. This habitat was available to the plovers at the time of the census.

The only pair of plovers in Nebraska associated with the Missouri River was found on Corps of Engineers property located adjacent to the river. Their nest was found on the side of a farm road next to a corn field.

\section{Comparison of Census Numbers - Overall}

\begin{tabular}{|l|c|c|c|c|c|}
\hline & 1991 & 1996 & 2001 & 2006 & 2011 \\
\hline $\begin{array}{l}\text { Total } \\
\text { Adults }\end{array}$ & 625 & 187 & 1,048 & $1,266^{1}$ & $186^{1}$ \\
\hline
\end{tabular}

${ }^{1}$ This is the total from a single survey at each site; if more than one survey was conducted, we count only results from the first survey during the census window. 
Comparison of Census Numbers - Montana

\begin{tabular}{|l|c|c|c|c|c|}
\hline & 1991 & 1996 & 2001 & 2006 & 2011 \\
\hline $\begin{array}{l}\text { Total } \\
\text { Adults }\end{array}$ & 26 & 24 & 7 & $23^{1}$ & $2^{1}$ \\
\hline
\end{tabular}

${ }^{\text {I }}$ This is the total from a single survey at each site; if more than one survey was conducted, we count only results from the first survey during the census window.

\section{Detectability Study - Montana}

\begin{tabular}{|l|c|c|}
\hline \multicolumn{1}{|c|}{ Sites Included } & $\begin{array}{c}\text { First } \\
\text { Count }\end{array}$ & $\begin{array}{c}\text { Second } \\
\text { Count }\end{array}$ \\
\hline Big Dry Bay & 0 & 0 \\
\hline $\begin{array}{l}\text { Duck Creek, 3rd Coulee, \& } \\
\text { Skunk Coulee }\end{array}$ & 0 & 0 \\
\hline
\end{tabular}

Comparison of Census Numbers - N Dakota

\begin{tabular}{|l|c|c|c|c|c|}
\hline & 1991 & 1996 & 2001 & 2006 & 2011 \\
\hline $\begin{array}{l}\text { Total } \\
\text { Adults }\end{array}$ & 307 & 125 & 643 & $702^{1}$ & $31^{1}$ \\
\hline
\end{tabular}

${ }^{\text {I }}$ This is the total from a single survey at each site; if more than one survey was conducted, we count only results from the first survey during the census window.

\section{Detectability Study - North Dakota}

\begin{tabular}{|l|c|c|}
\hline \multicolumn{1}{|c|}{ Sites Included } & $\begin{array}{c}\text { First } \\
\text { Count }\end{array}$ & $\begin{array}{c}\text { Second } \\
\text { Count }\end{array}$ \\
\hline $\begin{array}{l}\text { Lake Oahe (Dredge Island) } \\
\text { RM 1270.0 }\end{array}$ & 14 & 12 \\
\hline $\begin{array}{l}\text { Lake Sakakawea - Deepwater } \\
\text { Bay East 1444 }\end{array}$ & 3 & 3 \\
\hline $\begin{array}{l}\text { Lake Sakakawea - Douglas } \\
\text { Creek Bay 1400 }\end{array}$ & 1 & 2 \\
\hline $\begin{array}{l}\text { Lake Sakakawea - Spring } \\
\text { Creek 1400.1 }\end{array}$ & 1 & 2 \\
\hline $\begin{array}{l}\text { Lake Sakakawea - Steinke } \\
\text { Bay 1394 }\end{array}$ & 1 & 2 \\
\hline $\begin{array}{l}\text { Lake Sakakawea - Van Hook } \\
\text { Boat Ramp 1451 }\end{array}$ & 7 & 2 \\
\hline $\begin{array}{l}\text { Lake Sakakawae - Little } \\
\text { Beaver Bay 1499 }\end{array}$ & 1 & \\
\hline
\end{tabular}

Comparison of Census Numbers - S Dakota

\begin{tabular}{|l|c|c|c|c|c|}
\hline & 1991 & 1996 & 2001 & 2006 & 2011 \\
\hline $\begin{array}{l}\text { Total } \\
\text { Adults }\end{array}$ & 290 & 27 & 390 & $25^{1}$ & $151^{1}$ \\
\hline
\end{tabular}

${ }^{1}$ This is the total from a single survey at each site; if more than one survey was conducted, we count only results from the first survey during the census window.

Detectability Study - South Dakota

\begin{tabular}{|c|c|c|}
\hline Sites Included & $\begin{array}{l}\text { First } \\
\text { Count }\end{array}$ & $\begin{array}{l}\text { Second } \\
\text { Count }\end{array}$ \\
\hline $\begin{array}{l}\text { Lewis \& Clark Lake, } \\
\text { Missouri RM } 842 \text { (The } \\
\text { Complex) }\end{array}$ & 24 & 15 \\
\hline $\begin{array}{l}\text { Lake Oahe (Kenel Flats North } \\
\text { \& South) RM } 1231.0\end{array}$ & 0 & 0 \\
\hline $\begin{array}{l}\text { Lake Oahe (Moose Flats) RM } \\
1179\end{array}$ & 0 & 0 \\
\hline $\begin{array}{l}\text { Lake Oahe (S. Railroad } \\
\text { Grande) RM } 1199\end{array}$ & 0 & 0 \\
\hline $\begin{array}{l}\text { Lake Oahe (State Line WPA - } \\
\text { South) RM } 1233\end{array}$ & 0 & 0 \\
\hline $\begin{array}{l}\text { Lake Oahe (Cheyenne River - } \\
\text { NE) RM } 1110\end{array}$ & 0 & 0 \\
\hline $\begin{array}{l}\text { Lake Oahe (Forest City) RM } \\
1150\end{array}$ & 0 & 0 \\
\hline $\begin{array}{l}\text { Lake Oahe (Swift Bird) RM } \\
1159-1161\end{array}$ & 0 & 0 \\
\hline $\begin{array}{l}\text { Sully Flats to Peoria Flats } \\
\text { (RM 1095-1083) }\end{array}$ & 0 & 0 \\
\hline $\begin{array}{l}\text { Lake Oahe (Little Bend - } \\
\text { East) RM } 1111.0\end{array}$ & 2 & 2 \\
\hline $\begin{array}{l}\text { Lake Oahe (Little Bend - } \\
\text { West) RM } 1111.1\end{array}$ & 2 & 1 \\
\hline $\begin{array}{l}\text { Lake Oahe (Little Bend-2) } \\
\text { RM } 1111.2\end{array}$ & 1 & 0 \\
\hline $\begin{array}{l}\text { Lake Oahe (Little Bend-3) } \\
\text { RM } 111.3\end{array}$ & 2 & 0 \\
\hline $\begin{array}{l}\text { Lake Oahe (Blue Blanket) } \\
\text { RM } 1189\end{array}$ & 0 & 0 \\
\hline $\begin{array}{l}\text { Sage Creek to Charlie Creek } \\
\text { (RM 1123-1115) }\end{array}$ & 0 & 0 \\
\hline
\end{tabular}




\section{Comparison of Census Numbers - Nebraska}

\begin{tabular}{|l|c|c|c|c|c|}
\hline & 1991 & 1996 & 2001 & 2006 & 2011 \\
\hline $\begin{array}{l}\text { Total } \\
\text { Adults }\end{array}$ & 0 & 9 & 8 & $191^{1}$ & $2^{1}$ \\
\hline
\end{tabular}

${ }^{1}$ This is the total from a single survey at each site; if more than one survey was conducted, we count only results from the first survey during the census window.

Detectability Study - Nebraska

\begin{tabular}{|l|c|c|}
\hline \multicolumn{1}{|c|}{ Sites Included } & $\begin{array}{c}\text { First } \\
\text { Count }\end{array}$ & $\begin{array}{c}\text { Second } \\
\text { Count }\end{array}$ \\
\hline $\begin{array}{l}\text { Audubon Bend Management } \\
\text { Area }\end{array}$ & 2 & 2 \\
\hline
\end{tabular}




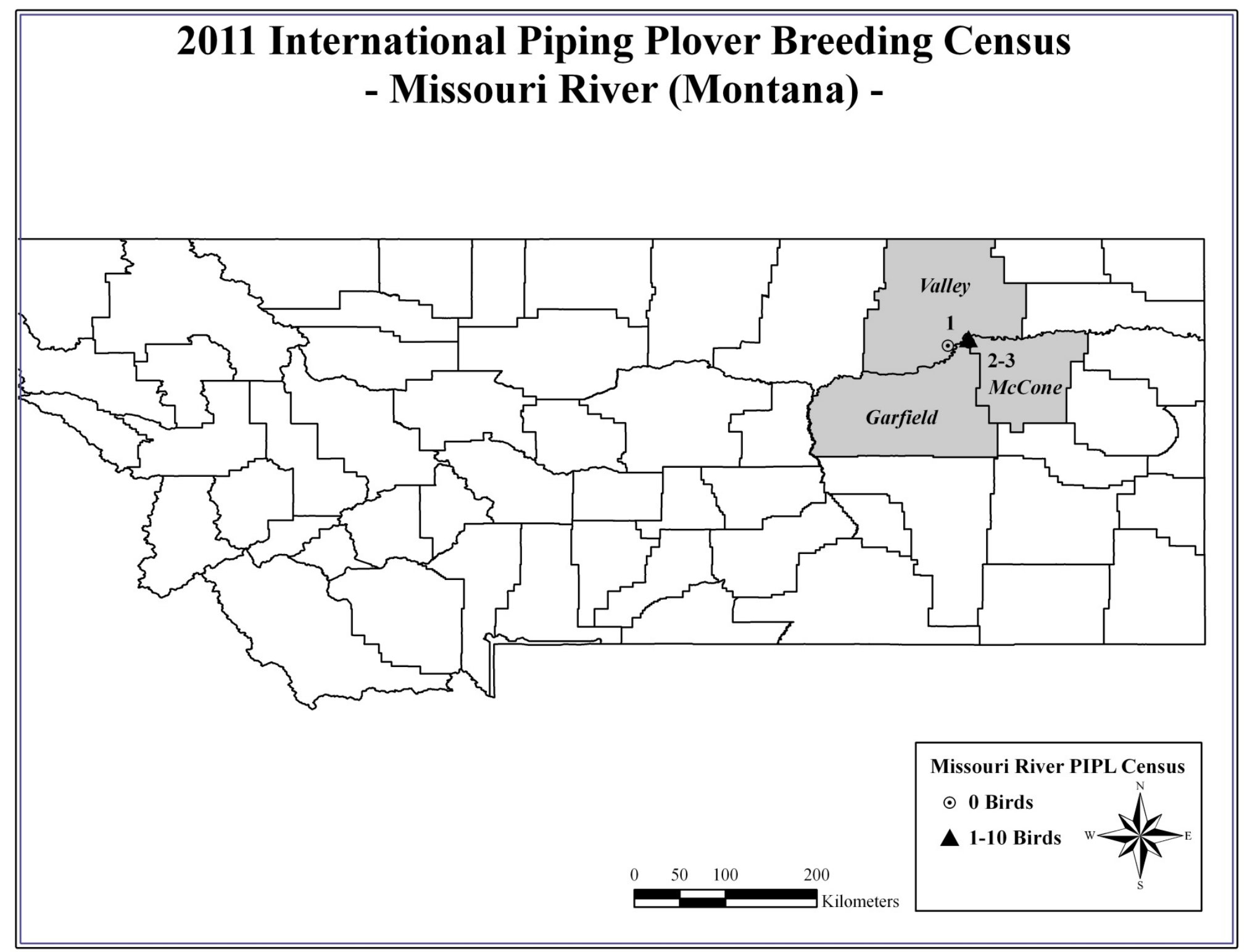


The 2011 International Piping Plover Breeding Census on the Missouri River in Montana

\begin{tabular}{|c|c|c|c|c|c|c|c|c|c|c|c|c|c|}
\hline \multirow{2}{*}{$\begin{array}{l}\text { COUNTY } \\
\text { Garfield/ } \\
\text { McCone }\end{array}$} & SITE NAME & \multirow{2}{*}{ MAP\# } & \multirow{2}{*}{$\begin{array}{c}\text { DATE } \\
6 / 10 / 11\end{array}$} & \multirow{2}{*}{$\begin{array}{c}\begin{array}{c}\text { BREED- } \\
\text { ING } \\
\text { PAIRS }\end{array} \\
0\end{array}$} & \multirow{2}{*}{ 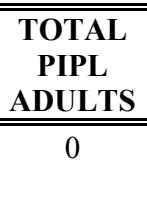 } & \multirow{2}{*}{$\frac{\mathbf{K M}}{20.0}$} & \multirow{2}{*}{$\begin{array}{l}\text { SITE } \\
\text { DESCRIPTION } \\
\text { III A }\end{array}$} & \multirow{2}{*}{$\begin{array}{l}\text { DISTURBANCE } \\
\text { CONCERNS } \\
\mathrm{W}\end{array}$} & \multicolumn{4}{|c|}{$\begin{array}{c}\text { PRIOR YEARS } \\
\text { CENSUSED \& YEARS } \\
\text { PIPL SEEN }^{1} \\
\end{array}$} & \multirow{2}{*}{$\begin{array}{c}\text { OWNER } \\
\mathrm{f}\end{array}$} \\
\hline & Big Dry Bay & & & & & & & & $\overline{-1}$ & 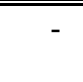 & 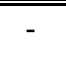 & 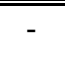 & \\
\hline Valley & $\begin{array}{l}\text { Duck Creek, 3rd Coulee, \& } \\
\text { Skunk Coulee }\end{array}$ & 1 & $6 / 9 / 11$ & 0 & 0 & 0.0 & III A & $\mathrm{W}$ & 91 & 96 & $\underline{01}$ & $\underline{06}$ & $\mathrm{f}$ \\
\hline Valley & Dry Arm (Fort Peck Lake) & 2 & $6 / 16 / 11$ & 1 & 2 & 0.1 & IX O & $\mathrm{W}$ & - & 96 & - & - & $\mathrm{f}$ \\
\hline Total & & & & 1 & 2 & 0.1 & & & & & & & \\
\hline
\end{tabular}

Bold years indicate that adults were seen. Bold and underlined years indicate that pairs were seen. 


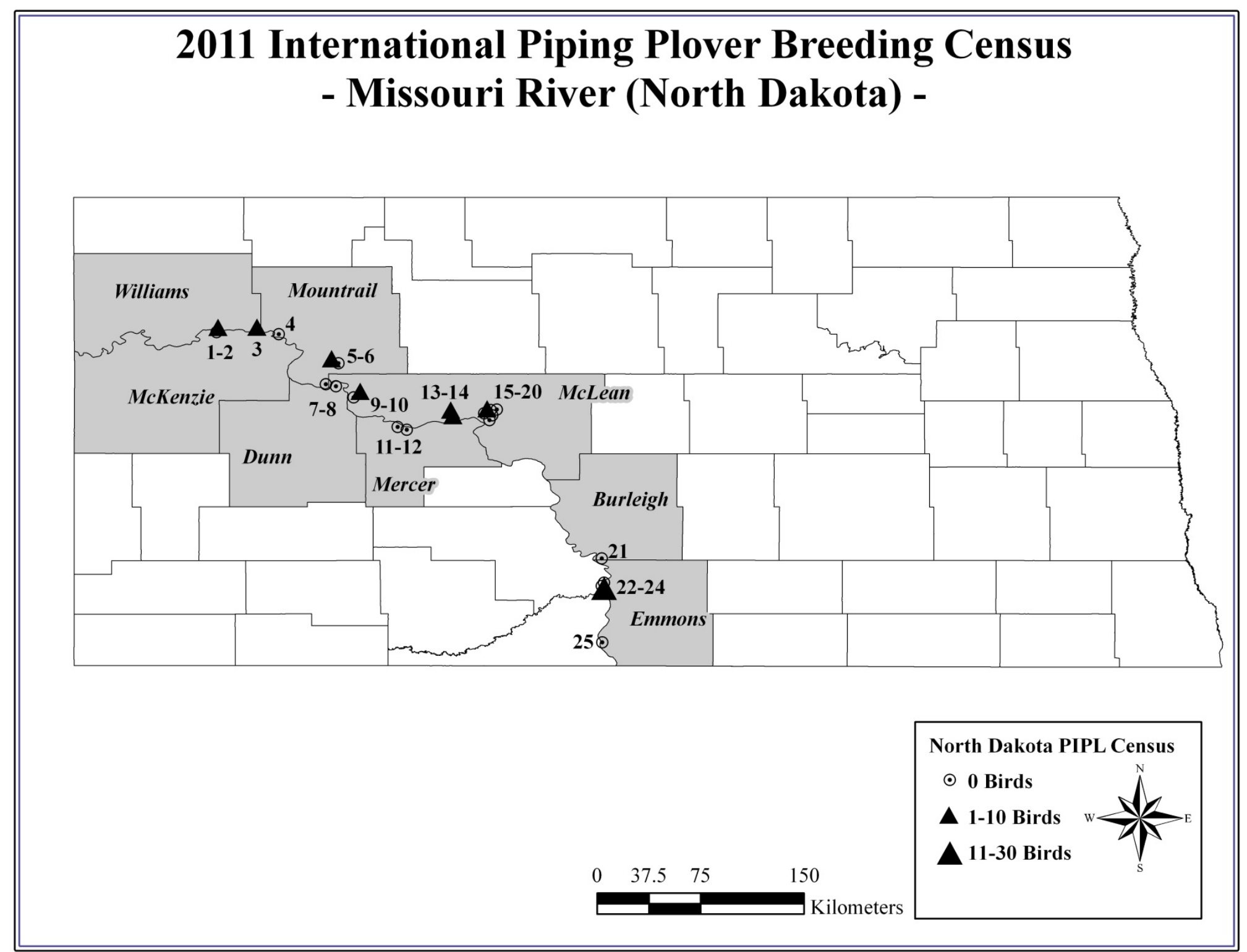


The 2011 International Piping Plover Breeding Census on the Missouri River in North Dakota

\begin{tabular}{|c|c|c|c|c|c|c|c|c|c|c|c|c|c|}
\hline \multirow{2}{*}{$\begin{array}{l}\text { REGION } \\
\text { Burleigh/Emmons }\end{array}$} & \multirow{2}{*}{\begin{tabular}{l}
\multicolumn{1}{c}{ SITE NAME } \\
Lake Oahe (East Shoreline) \\
$1300.7-1277.2$
\end{tabular}} & \multirow{2}{*}{ MAP\# } & \multirow{2}{*}{$\begin{array}{c}\text { DATE } \\
6 / 6 / 11\end{array}$} & \multirow{2}{*}{$\begin{array}{c}\text { BREED- } \\
\text { ING } \\
\text { PAIRS } \\
0\end{array}$} & \multirow{2}{*}{$\begin{array}{c}\text { TOTAL } \\
\text { PIPL } \\
\text { ADULTS } \\
0\end{array}$} & \multirow{2}{*}{$\frac{\mathbf{K M}}{0.0}$} & \multirow{2}{*}{$\begin{array}{l}\text { SITE } \\
\text { DESCRIPTION } \\
\text { III A }\end{array}$} & \multirow{2}{*}{$\begin{array}{l}\text { DISTURBANCE } \\
\text { CONCERNS } \\
\mathrm{W}\end{array}$} & \multicolumn{4}{|c|}{$\begin{array}{c}\text { PRIOR YEARS } \\
\text { CENSUSED \& } \\
\text { YEARS } \\
\text { PIPL SEEN }^{1} \\
\end{array}$} & \multirow{2}{*}{$\frac{\text { OWNER }}{\mathrm{f}}$} \\
\hline & & & & & & & & & - & - & - & - & \\
\hline Dunn & $\begin{array}{l}\text { Lake Sakakawea - } \\
\text { Independence Point } 1445\end{array}$ & 8 & $6 / 9 / 11$ & 0 & 0 & 0.0 & VI A & $\mathrm{W}$ & - & $\underline{96}$ & - & 06 & $\mathrm{f}$ \\
\hline Emmons & $\begin{array}{l}\text { Lake Oahe (East Shoreline) } \\
1256-1232\end{array}$ & 25 & $6 / 7 / 11$ & 0 & 0 & 0.0 & V A & W & - & - & - & - & $\mathrm{f}$ \\
\hline Emmons/Morton & $\begin{array}{l}\text { Lake Oahe (Dredge Island) } \\
\text { RM } 1270.0\end{array}$ & 24 & $6 / 9 / 11$ & 7 & 14 & 0.6 & VI F & $\mathrm{W}$ & 91 & $\underline{96}$ & $\underline{01}$ & - & $\mathrm{f}$ \\
\hline Emmons/Morton & $\begin{array}{l}\text { Lake Oahe (Islands) 1277- } \\
1270.2\end{array}$ & 22 & $6 / 9 / 11$ & 0 & 0 & 0.0 & III E & W & - & - & - & - & $\mathrm{f}$ \\
\hline McKenzie & $\begin{array}{l}\text { Lake Sakakawea - Tobacco } \\
\text { Gardens Bay } 1511\end{array}$ & 2 & $6 / 15 / 11$ & 0 & 0 & 0.0 & VI A & none & - & $\underline{96}$ & $\underline{01}$ & $\underline{06}$ & $\mathrm{f}$ \\
\hline McLean & $\begin{array}{l}\text { Lake Sakakawea - Arikara } \\
1442\end{array}$ & 10 & $6 / 8 / 11$ & 0 & 0 & 0.0 & VI A & none & $\underline{91}$ & - & $\underline{01}$ & $\underline{06}$ & $\mathrm{f}$ \\
\hline McLean & $\begin{array}{l}\text { Lake Sakakawea - } \\
\text { Deepwater Bay East } 1444\end{array}$ & 9 & $6 / 9 / 11$ & 1 & 3 & 0.0 & VI A & $\mathrm{W} \mathrm{O}$ & - & -3 & $\underline{01}$ & $\underline{06}$ & $\mathrm{f}$ \\
\hline McLean & $\begin{array}{l}\text { Lake Sakakawea - } \\
\text { DeTrobriand Bay } 1395\end{array}$ & 15 & $6 / 6 / 11$ & 0 & 0 & 0.0 & VI A & $\mathrm{W}$ & - & -4 & $\underline{01}$ & $\underline{06}$ & $\mathrm{f}$ \\
\hline McLean & $\begin{array}{l}\text { Lake Sakakawea - Douglas } \\
\text { Creek Bay } 1400^{2}\end{array}$ & 14 & $6 / 14 / 11$ & 1 & 2 & 0.0 & VI A & $\mathrm{W}$ & $\underline{91}$ & 96 & $\underline{01}$ & $\underline{06}$ & $\mathrm{f}$ \\
\hline McLean & $\begin{array}{l}\text { Lake Sakakawea - Mallard } \\
\text { Island } 1391\end{array}$ & 19 & $6 / 6 / 11$ & 0 & 0 & 0.0 & VI E & W & $\underline{91}$ & $\underline{96}$ & $\underline{01}$ & $\underline{06}$ & $\mathrm{f}$ \\
\hline McLean & $\begin{array}{l}\text { Lake Sakakawea - Pouch } \\
\text { Point } 1456\end{array}$ & 7 & $6 / 9 / 11$ & 0 & 0 & 0.0 & VI A & W & - & $\underline{96}$ & $\underline{01}$ & - & $\mathrm{f}$ \\
\hline McLean & $\begin{array}{l}\text { Lake Sakakawea - } \\
\text { Sportsman's 1393.3 }\end{array}$ & 17 & $6 / 6 / 11$ & 0 & 0 & 0.0 & VI A & W & - & - & - & - & $\mathrm{f}$ \\
\hline McLean & $\begin{array}{l}\text { Lake Sakakawea - Spring } \\
\text { Creek } 1400.1^{2}\end{array}$ & 13 & $6 / 16 / 11$ & 1 & 2 & 0.1 & VI A & W & - & - & - & - & $\mathrm{f}$ \\
\hline McLean & $\begin{array}{l}\text { Lake Sakakawea - Steinke } \\
\text { Bay } 1394^{2}\end{array}$ & 16 & $6 / 11 / 11$ & 1 & 2 & 0.1 & VI A & $\mathrm{W}$ & - & $\underline{96}$ & $\underline{01}$ & $\underline{06}$ & $\mathrm{f}$ \\
\hline McLean & $\begin{array}{l}\text { Lake Sakakawea - West } \\
\text { Totten } 1393\end{array}$ & 18 & $6 / 6 / 11$ & 0 & 0 & 0.0 & VI A & W & - & - & $\underline{01}$ & $\underline{06}$ & $\mathrm{f}$ \\
\hline McLean & $\begin{array}{l}\text { Lake Sakakawea - Wolf } \\
\text { Creek } 1390\end{array}$ & 20 & $6 / 6 / 11$ & 0 & 0 & 0.0 & VI A & none & - & - & $\underline{01}$ & $\underline{06}$ & $\mathrm{f}$ \\
\hline Mercer & $\begin{array}{l}\text { Lake Sakakawea - Beaver } \\
\text { Creek Bay } 1420\end{array}$ & 11 & $6 / 10 / 11$ & 0 & 0 & 0.0 & VI A & W & - & $\underline{96}$ & $\underline{01}$ & $\underline{06}$ & $\mathrm{f}$ \\
\hline
\end{tabular}


The 2011 International Piping Plover Breeding Census on the Missouri River in North Dakota (Continued)

\begin{tabular}{|c|c|c|c|c|c|c|c|c|c|c|c|c|c|}
\hline \multirow{2}{*}{$\begin{array}{l}\text { COUNTY } \\
\text { Mercer }\end{array}$} & \multirow{2}{*}{$\begin{array}{l}\text { SITE NAME } \\
\text { kakawea - Renner Bay }\end{array}$} & \multirow{2}{*}{$\frac{\text { MAP\# }}{12}$} & \multirow{2}{*}{$\begin{array}{c}\text { DATE } \\
6 / 10 / 11\end{array}$} & \multirow{2}{*}{ 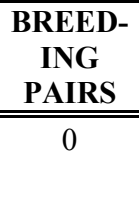 } & \multirow{2}{*}{$\begin{array}{c}\text { TOTAL } \\
\text { PIPL } \\
\text { ADULTS } \\
0\end{array}$} & \multirow{2}{*}{$\frac{\mathbf{K M}}{0.0}$} & \multirow{2}{*}{$\begin{array}{l}\text { SITE } \\
\text { DESCRIPTION } \\
\text { VI A }\end{array}$} & \multirow{2}{*}{$\begin{array}{l}\text { DISTURBANCE } \\
\text { CONCERNS } \\
\mathrm{W}\end{array}$} & \multicolumn{4}{|c|}{$\begin{array}{c}\text { PRIOR YEARS } \\
\text { CENSUSED \& YEARS } \\
\text { PIPL SEEN }^{1} \\
\end{array}$} & \multirow{2}{*}{$\begin{array}{c}\text { OWNER } \\
\mathrm{f}\end{array}$} \\
\hline & & & & & & & & & $\underline{91}$ & - & $\underline{01}$ & $\underline{06}$ & \\
\hline Morton/Sioux & $\begin{array}{l}\text { Lake Oahe (West Shoreline) } \\
1302-1242\end{array}$ & 23 & $6 / 8 / 11$ & 0 & 0 & 0.0 & III A & W & - & - & - & - & $\mathrm{f}$ \\
\hline Mountrail & $\begin{array}{l}\text { Lake Sakakawea - Shell Creek } \\
\text { Bay } 1450\end{array}$ & 6 & $6 / 9 / 11$ & 0 & 0 & 0.0 & VI A & W & - & $\underline{96}$ & $\underline{01}$ & 06 & $\mathrm{f}$ \\
\hline Mountrail & $\begin{array}{l}\text { Lake Sakakawea - Van Hook } \\
\text { Boat Ramp } 1451^{2}\end{array}$ & 5 & $6 / 13 / 11$ & 5 & 10 & 0.8 & VI A & W & - & - & - & - & $\mathrm{f}$ \\
\hline Mountrail & $\begin{array}{l}\text { Lake Sakakawea - White Earth } \\
\text { Bay } 1493\end{array}$ & 4 & $6 / 13 / 11$ & 0 & 0 & 0.0 & VI A & none & - & $\underline{96}$ & $\underline{01}$ & $\underline{06}$ & $\mathrm{f}$ \\
\hline Williams & $\begin{array}{l}\text { Lake Sakakawae - Little Beaver } \\
\text { Bay } 1499\end{array}$ & 3 & $6 / 13 / 11$ & 1 & 2 & 0.0 & VI A & $\mathrm{W} \mathrm{O}$ & - & - & - & - & $\mathrm{f}$ \\
\hline Williams & $\begin{array}{l}\text { Lake Sakakawea - Red Mike } \\
1510\end{array}$ & 1 & $6 / 15 / 11$ & 1 & 2 & 0.0 & VI A & W & - & - & - & $\underline{06}$ & $\mathrm{f}$ \\
\hline Total & & & & 18 & 37 & 1.6 & & & & & & & \\
\hline
\end{tabular}

${ }^{1}$ Bold years indicate that adults were seen. Bold and underlined years indicate that pairs were seen.

2 This total is the "high count"; since two surveys were conducted at some sites for the detectability study, this total includes the highest count at each site.

${ }^{3}$ In 1996, 4 PIPL nests were found in a section of Deepwater Bay $\sim 1 \mathrm{~km}$ east of the area that was surveyed in 2011.

${ }^{4}$ In 1996, 1 PIPL nest was found in a section on DeTrobriand Island $\sim 1 \mathrm{~km}$ southwest of this 2011 survey route. 


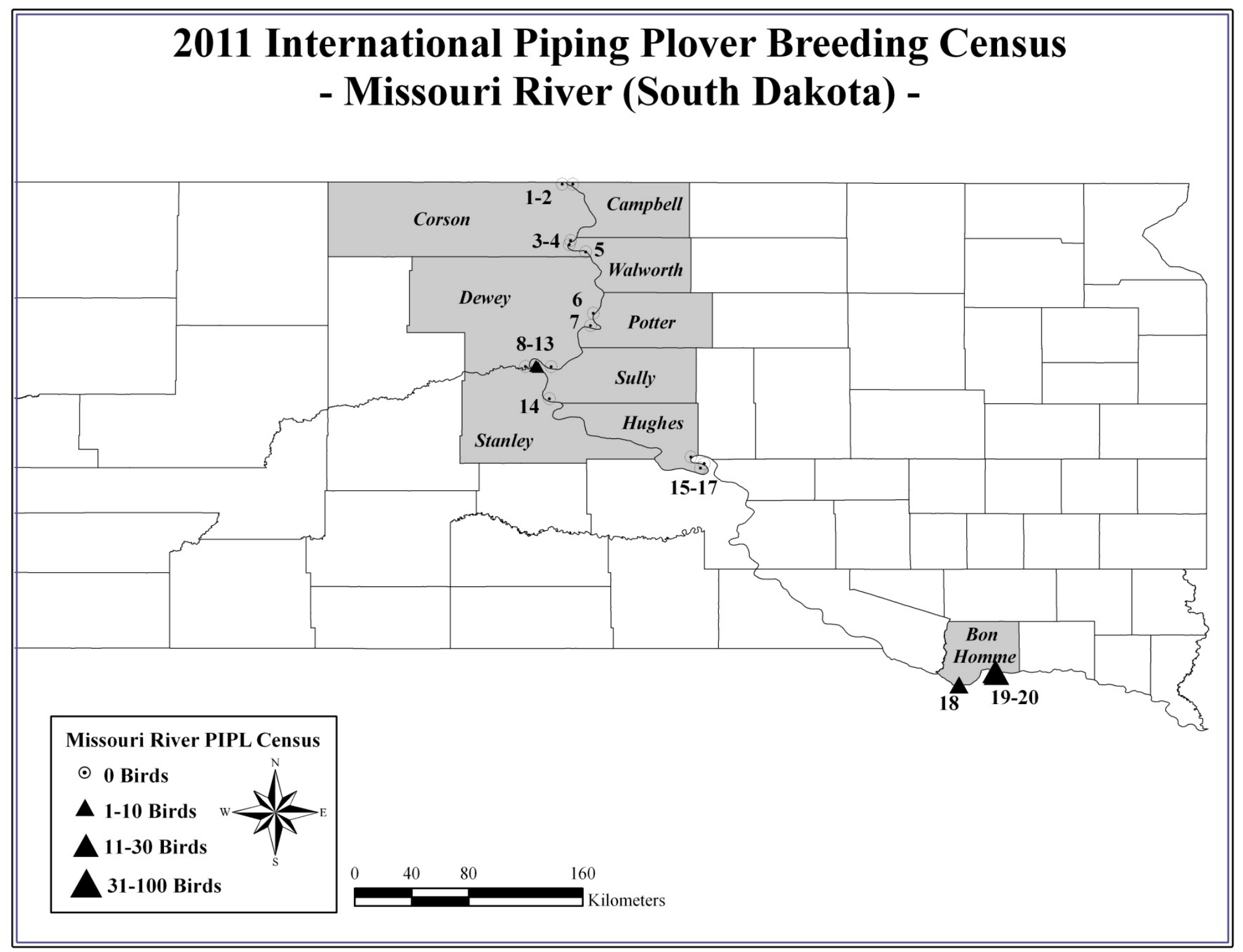


The 2011 International Piping Plover Breeding Census on the Missouri River in South Dakota

\begin{tabular}{|c|c|c|c|c|c|c|c|c|c|c|c|c|c|}
\hline REGION & SITE NAME & MAP\# & DATE & $\begin{array}{l}\text { BREED- } \\
\text { ING } \\
\text { PAIRS } \\
\end{array}$ & $\begin{array}{l}\text { TOTAL } \\
\text { PIPL } \\
\text { ADULTS } \\
\end{array}$ & $\mathbf{K M}$ & $\begin{array}{l}\text { SITE } \\
\text { DESCRIPTION }\end{array}$ & $\begin{array}{l}\text { DISTURBANCE } \\
\text { CONCERNS }\end{array}$ & & $\begin{array}{l}\text { RIOR } \\
\text { YENSI } \\
\text { YE } \\
\text { PIPL }\end{array}$ & $\begin{array}{l}\text { EAR } \\
\text { EDD } \\
\text { RS } \\
\text { EEN }^{1}\end{array}$ & & OWNER \\
\hline Bon Homme & $\begin{array}{l}\text { Lewis \& Clark Lake, } \\
\text { Missouri RM } 842 \text { (The } \\
\text { Complex) }\end{array}$ & 18 & $6 / 13 / 11$ & 5 & 24 & 0.2 & VIF & n.r. & $\underline{91}$ & $\underline{96}$ & $\underline{01}$ & 06 & $\bar{f}$ \\
\hline Bon Homme & $\begin{array}{l}\text { Lewis \& Clark Lake, } \\
\text { Missouri RM } 826.3\end{array}$ & 20 & $6 / 14 / 11$ & 8 & 71 & 1.0 & VI F & n.r. & 91 & - & - & - & $\mathrm{f}$ \\
\hline Bon Homme & $\begin{array}{l}\text { Lewis \& Clark Lake, } \\
\text { Missouri RM } 826.6\end{array}$ & 19 & $6 / 6 / 11$ & 4 & 49 & 1.1 & VI F & n.r. & 91 & - & - & - & $\mathrm{f}$ \\
\hline Corson & $\begin{array}{l}\text { Lake Oahe (Kenel Flats } \\
\text { North \& South) RM 1231.0 }\end{array}$ & 1 & $6 / 6 / 11$ & 0 & 0 & 0.0 & VI A & W & 91 & - & $\underline{01}$ & - & $\mathrm{f}$ \\
\hline Corson & $\begin{array}{l}\text { Lake Oahe (Moose Flats) } \\
\text { RM } 1179\end{array}$ & 4 & $6 / 8 / 11$ & 0 & 0 & 0.0 & VI A & W & 91 & - & - & - & $\mathrm{f}$ \\
\hline Corson & $\begin{array}{l}\text { Lake Oahe (S. Railroad } \\
\text { Grande) RM } 1199\end{array}$ & 3 & $6 / 8 / 11$ & 0 & 0 & 0.0 & VI A & W & $\underline{91}$ & - & $\underline{01}$ & $\underline{06}$ & $\mathrm{f}$ \\
\hline Campbell & $\begin{array}{l}\text { Lake Oahe (State Line WPA } \\
\text { - South) RM } 1233\end{array}$ & 2 & $6 / 6 / 11$ & 0 & 0 & 0.0 & VI A & W & - & - & $\underline{01}$ & $\underline{06}$ & $\mathrm{f}$ \\
\hline Dewey & $\begin{array}{l}\text { Lake Oahe (Cheyenne River } \\
\text { - NE) RM } 1110\end{array}$ & 13 & $6 / 10 / 11$ & 0 & 0 & 1.6 & VI A & W & $\underline{91}$ & 96 & - & $\underline{06}$ & $\mathrm{f}$ \\
\hline Dewey & $\begin{array}{l}\text { Lake Oahe (Forest City) RM } \\
1150\end{array}$ & 7 & $6 / 8 / 11$ & 0 & 0 & 8.0 & VI A & W & 91 & - & $\underline{01}$ & $\underline{06}$ & $\mathrm{f}$ \\
\hline Dewey & $\begin{array}{l}\text { Lake Oahe (Swift Bird) RM } \\
1159-1161\end{array}$ & 6 & $6 / 8 / 11$ & 0 & 0 & 32.2 & VI A & W & 91 & 96 & $\underline{01}$ & $\underline{06}$ & $\mathrm{f}$ \\
\hline Hughes & $\begin{array}{l}\text { Lake Sharpe (North Bend) } \\
\text { RM 1006-1009 }\end{array}$ & 17 & $6 / 9 / 11$ & 0 & 0 & 10.8 & VI A & n.r. & 91 & - & - & - & $\mathrm{f}$ \\
\hline Hughes & $\begin{array}{l}\text { Lake Sharpe (West Bend) } \\
\text { RM 1010-1017 }\end{array}$ & 15 & $6 / 9 / 11$ & 0 & 0 & 10.6 & VI A & n.r. & 91 & - & - & - & $\mathrm{f}$ \\
\hline Hughes/Stanley & $\begin{array}{l}\text { Sully Flats to Peoria Flats } \\
\text { (RM 1095-1083) }\end{array}$ & 14 & $6 / 9 / 11$ & 0 & 0 & 1.6 & VI A & W & $\underline{91}$ & - & $\underline{01}$ & $\underline{06}$ & $\mathrm{f}$ \\
\hline Lyman & $\begin{array}{l}\text { Lake Sharpe (Big Bend) RM } \\
1003.5-1016.5\end{array}$ & 16 & $6 / 9 / 11$ & 0 & 0 & 23.8 & VI A & n.r. & 91 & - & - & - & $\mathrm{f}$ \\
\hline Sully & $\begin{array}{l}\text { Lake Oahe (Little Bend - } \\
\text { East) RM } 1111.0\end{array}$ & 10 & $6 / 7 / 11$ & 1 & 2 & 0.1 & VI A & W & $\underline{91}$ & - & $\underline{01}$ & $\underline{06}$ & $\mathrm{f}$ \\
\hline Sully & $\begin{array}{l}\text { Lake Oahe (Little Bend - } \\
\text { West) RM } 1111.1^{2}\end{array}$ & 11 & $6 / 7 / 11$ & 1 & 2 & 0.1 & VI A & W & 91 & - & $\underline{01}$ & 06 & $\mathrm{f}$ \\
\hline Sully & $\begin{array}{l}\text { Lake Oahe (Little Bend-2) } \\
\text { RM } 1111.2^{2}\end{array}$ & 12 & $6 / 7 / 11$ & 0 & 1 & 0.1 & VI A & W & $\underline{91}$ & - & - & - & $\mathrm{f}$ \\
\hline
\end{tabular}


The 2011 International Piping Plover Breeding Census on the Missouri River in South Dakota (Continued)

\begin{tabular}{|c|c|c|c|c|c|c|c|c|c|c|c|c|c|}
\hline COUNTY & SITE NAME & MAP\# & DATE & $\begin{array}{c}\text { BREED- } \\
\text { ING } \\
\text { PAIRS } \\
\end{array}$ & $\begin{array}{c}\text { TOTAL } \\
\text { PIPL } \\
\text { ADULTS } \\
\end{array}$ & $\mathbf{K M}$ & $\begin{array}{l}\text { SITE } \\
\text { DESCRIPTION } \\
\end{array}$ & $\begin{array}{l}\text { DISTURBANCE } \\
\text { CONCERNS } \\
\end{array}$ & \multicolumn{4}{|c|}{$\begin{array}{c}\text { PRIOR YEARS } \\
\text { CENSUSED \& YEARS } \\
\text { PIPL SEEN }^{1} \\
\end{array}$} & \multirow{2}{*}{$\frac{\text { OWNER }}{\mathrm{f}}$} \\
\hline$\overline{\text { Sully }}$ & $\begin{array}{l}\text { Lake Oahe (Little Bend-3) RM } \\
1111.3^{2}\end{array}$ & 9 & $6 / 7 / 11$ & 1 & 2 & 0.1 & $\overline{\text { VI A }}$ & $\overline{\mathrm{W}}$ & 91 & - & - & - & \\
\hline Walworth & $\begin{array}{l}\text { Lake Oahe (Blue Blanket) RM } \\
1189\end{array}$ & 5 & $6 / 9 / 11$ & 0 & 0 & 8.0 & VI A & W & $\underline{91}$ & $\underline{96}$ & $\underline{01}$ & 06 & $\mathrm{f}$ \\
\hline Zeibach & $\begin{array}{l}\text { Sage Creek to Charlie Creek } \\
\text { (RM 1123-1115) }\end{array}$ & 8 & $6 / 6 / 11$ & 0 & 0 & 12.9 & VI A & W & $\underline{91}$ & - & - & $\underline{06}$ & $\mathrm{f}$ \\
\hline Total & & & & 20 & 151 & 112.2 & & & & & & & \\
\hline
\end{tabular}

${ }^{1}$ Bold years indicate that adults were seen. Bold and underlined years indicate that pairs were seen.

${ }^{2}$ This total is the "high count"; since two surveys were conducted at some sites for the detectability study, this total includes the highest count at each site.

${ }^{3}$ This site was a part of "Ft Randall/Gavin" in 1991. 11 PIPL were seen 1 river-mile upstream and 10 PIPL were seen 11 river-mile downstream fom the center of this site. 


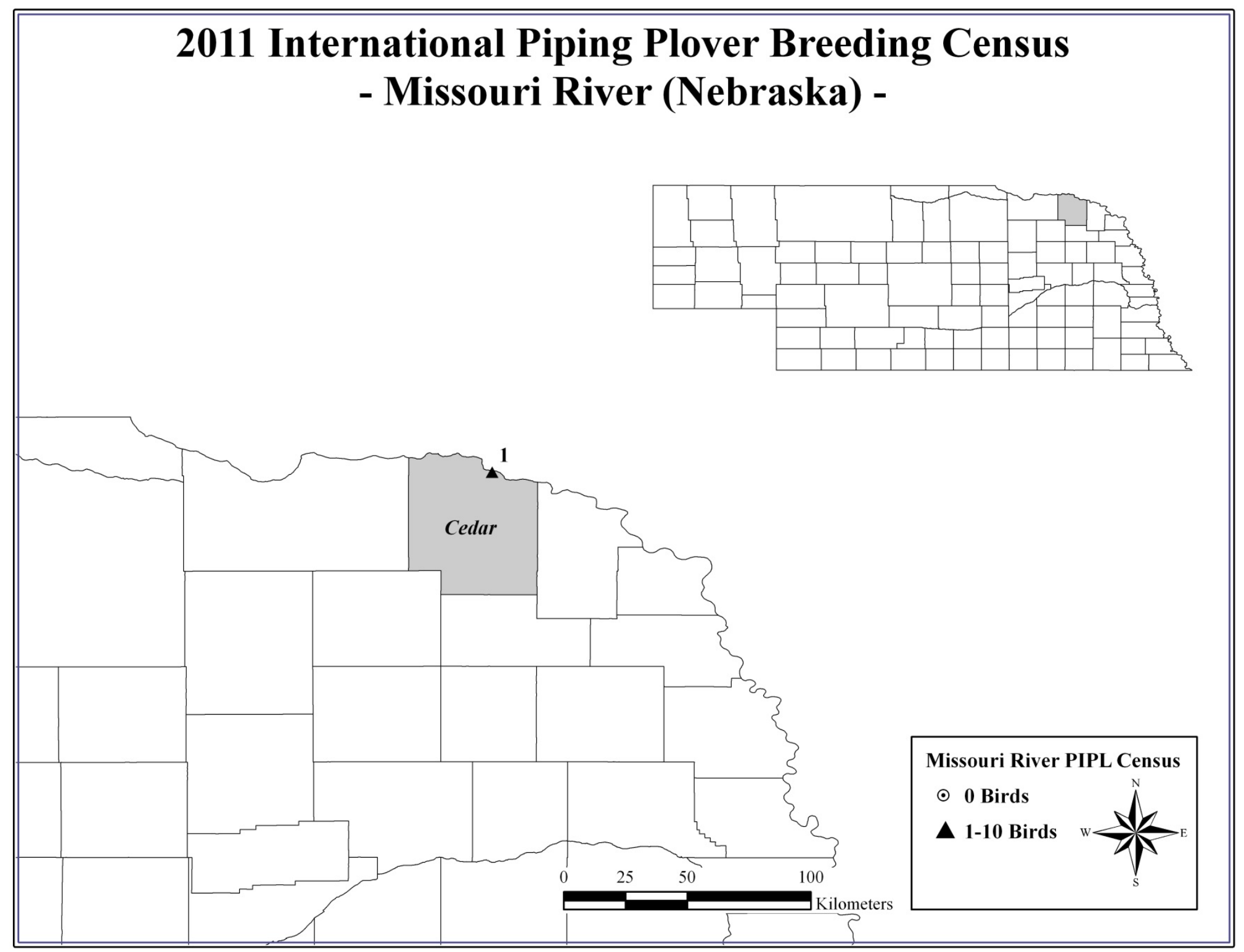

Missouri River PIPL Census

$\odot 0$ Birds 
The 2011 International Piping Plover Breeding Census on the Missouri River in Nebraska

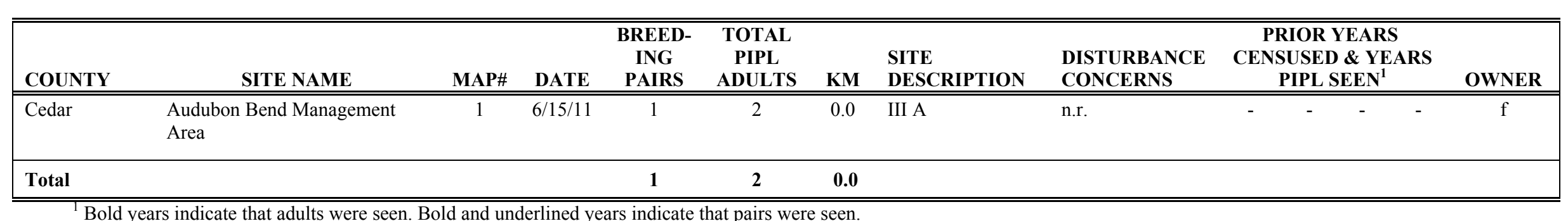

${ }^{1}$ Bold years indicate that adults were seen. Bold and underlined years indicate that pairs were seen. 


\section{The 2011 International Piping Plover Breeding Census in Montana (off-Missouri River)}

Kirsten Brennan

U.S. Fish and Wildlife Service

8315 Highway 8

Kenmare, ND 58746

701-848-2722 (ext 24)

kirsten_brennan@fws.gov

Fritz Prellwitz

BLM - Malta Field Office

501 S. 2nd Street E.

Malta, MT 59538

406-654-5118

fritz_prellwitz@blm.gov

The 2011 International Piping Plover Census in Montana (off-Missouri River) was conducted by 17 observers who surveyed 56 sites and detected 89 Piping Plovers (high count off-river was 92; 2 additional plovers sighted on the Missouri River). This count was lower than all prior Census counts. However, this count is likely conservative since plovers were found nesting in unusual habitats (e.g., gravel roads, agricultural fields) due to flooding of traditional spots.

Water levels were high thoughout the region in 2011. Given pervasive flooding, the 2011 Census was comprehensive. Some sites were completely flooded and others could not be surveyed until July when water levels finally receded. We were not able to access a small number of sites due to flooded roadways (e.g., VR2 Reservoir and Hamm's Reservoir).
Similar to 2006, Piping Plovers were confined to the alkali lakes in Sheridan County. One additional pair was counted outside the county on the Missouri River. Also, a pair was counted at Alkali Lake in Pondera County, a site that supported plovers in 1991 and 1996 but was not surveyed in 2006.

Comparison of Census Numbers ${ }^{1}$

\begin{tabular}{|l|c|c|c|c|c|}
\hline & 1991 & 1996 & 2001 & 2006 & 2011 \\
\hline $\begin{array}{l}\text { Total } \\
\text { Adults }\end{array}$ & 308 & 153 & 137 & $130^{2}$ & $91^{2}$ \\
\hline
\end{tabular}

${ }^{1}$ Missouri River data are included in all totals.

${ }^{2}$ This is the total from a single survey at each site; if more than one survey was conducted, we count only results from the first survey during the census window.

\section{Detectability Study}

\begin{tabular}{|l|c|c|}
\hline \multicolumn{1}{|c|}{ Sites Included } & $\begin{array}{c}\text { First } \\
\text { Count }\end{array}$ & $\begin{array}{c}\text { Second } \\
\text { Count }\end{array}$ \\
\hline Erickson WPA & 0 & 0 \\
\hline Goose Lake & 1 & 0 \\
\hline $\begin{array}{l}\text { Katy's Lake, Medicine Lake } \\
\text { NWR }\end{array}$ & 0 & 0 \\
\hline Lake North of Espen WPA & 0 & 0 \\
\hline Lake North of Stateline WPA & 2 & 2 \\
\hline $\begin{array}{l}\text { Murphy Wetland (Upper } \\
\text { Goose) }\end{array}$ & 0 & 0 \\
\hline North Lake & 2 & 3 \\
\hline Parry WPA & 5 & 2 \\
\hline Upper Goose Lake & 0 & 2 \\
\hline West Goose Lake & 2 & 2 \\
\hline
\end{tabular}

Summarized by E. Elliott-Smith 


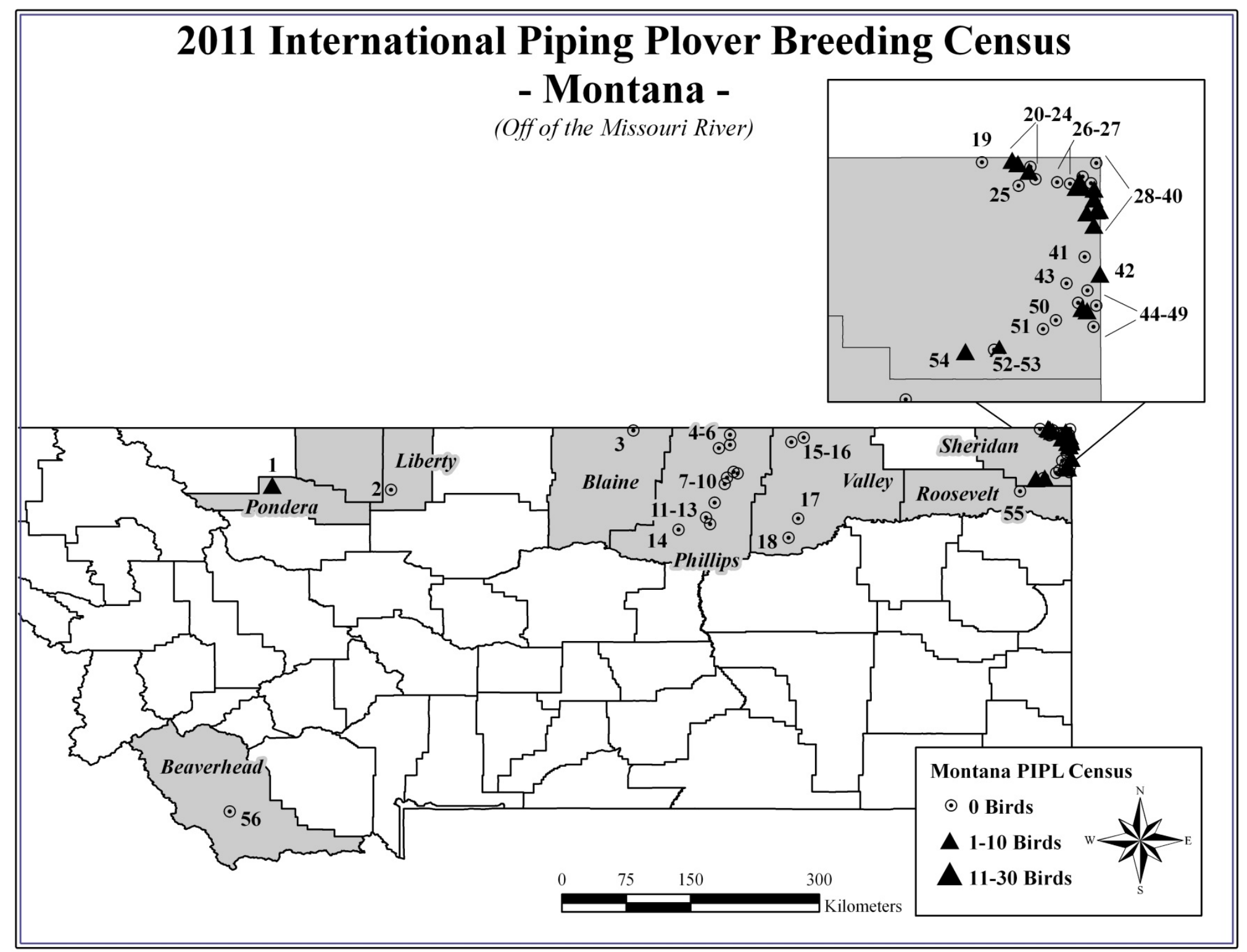


The 2011 International Piping Plover Breeding Census in Montana

\begin{tabular}{|c|c|c|c|c|c|c|c|c|c|c|c|c|c|}
\hline \multirow{2}{*}{$\begin{array}{l}\text { REGION } \\
\text { Beaverhead }\end{array}$} & \multirow{2}{*}{$\frac{\text { SITE NAME }}{\text { Canyon Reservoir }}$} & \multirow{2}{*}{ MAP\# } & \multirow{2}{*}{$\begin{array}{c}\text { DATE } \\
6 / 9 / 11\end{array}$} & \multirow{2}{*}{$\begin{array}{c}\text { BREED- } \\
\text { ING } \\
\text { PAIRS } \\
0\end{array}$} & \multirow{2}{*}{$\begin{array}{c}\text { TOTAL } \\
\text { PIPL } \\
\text { ADULTS } \\
0\end{array}$} & \multirow{2}{*}{$\frac{\mathbf{K M}}{1.6}$} & \multirow{2}{*}{$\begin{array}{l}\text { SITE } \\
\text { DESCRIPTION } \\
\text { VI A }\end{array}$} & \multirow{2}{*}{$\begin{array}{l}\text { DISTURBANCE } \\
\text { CONCERNS } \\
\mathrm{VW}\end{array}$} & \multicolumn{4}{|c|}{$\begin{array}{c}\text { PRIOR YEARS } \\
\text { CENSUSED \& } \\
\text { YEARS } \\
\text { PIPL SEEN }^{1} \\
\end{array}$} & \multirow{2}{*}{$\frac{\text { OWNER }}{\mathrm{f}}$} \\
\hline & & & & & & & & & 91 & - & 01 & 06 & \\
\hline Blaine & Alkali Lake & 3 & $6 / 13 / 11$ & 0 & 0 & n.r. & IV D & n.r. & 91 & 96 & 01 & 06 & $\mathrm{f}$ \\
\hline Liberty/Tooele & Tiber Reservoir & 2 & $6 / 12 / 11$ & 0 & 0 & 0.0 & VI A & W & 91 & 96 & 01 & 06 & $\mathrm{f}$ \\
\hline Phillips & Bennett Lake & 11 & $6 / 14 / 11$ & 0 & 0 & 0.4 & V A & $\mathrm{N}$ & 91 & 96 & 01 & 06 & $f, p$ \\
\hline Phillips & Bowdoin NWR ${ }^{3}$ & 10 & $6 / 21 / 11$ & 0 & 0 & 2.5 & IV D E I & $\mathrm{W}$ & 91 & $\underline{96}$ & 01 & 06 & $\mathrm{f}$ \\
\hline Phillips & Dibbler Reservoir $^{3}$ & 6 & $7 / 5 / 11$ & 0 & 0 & 0.4 & VI A F & $\mathrm{W}$ & 91 & $\overrightarrow{96}$ & 01 & 06 & $\mathrm{f}$ \\
\hline Phillips & Erphit Lake & 9 & $6 / 16 / 11$ & 0 & 0 & 0.4 & V A & $\mathrm{W}$ & - & - & - & 06 & $\mathrm{p}$ \\
\hline Phillips & Hewitt Lake NWR ${ }^{3}$ & 7 & $6 / 21 / 11$ & 0 & 0 & 0.0 & IV I & $\mathrm{W}$ & 91 & $96^{4}$ & 01 & 06 & $\mathrm{f}$ \\
\hline Phillips & Nelson Reservoir & 8 & $6 / 9 / 11$ & 0 & 0 & 1.6 & VI A & W N I & $\underline{91}$ & $96^{4}$ & $\underline{01}$ & 06 & $\mathrm{f}$ \\
\hline Phillips & Pea Lake & 4 & $6 / 17 / 11$ & 0 & 0 & 0.0 & n.r. & $\mathrm{W}$ & $\overline{91}$ & 96 & $\overline{01}$ & 06 & $\mathrm{f}, \mathrm{s}(\mathrm{p}), \mathrm{p}$ \\
\hline Phillips & Spencer Reservoir ${ }^{3}$ & 12 & $6 / 21 / 11$ & 0 & 0 & 0.0 & VI A I & A W & 91 & 96 & 01 & 06 & $\mathrm{f}, \mathrm{p}$ \\
\hline Phillips & Veseth Reservoir ${ }^{3}$ & 14 & $7 / 14 / 11$ & 0 & 0 & 0.0 & n.r. & $\mathrm{W}$ & - & - & - & 06 & $\mathrm{f}, \mathrm{p}$ \\
\hline Phillips & Whitcomb Lake ${ }^{3}$ & 13 & $7 / 14 / 11$ & 0 & 0 & 0.8 & IV A & A W & 91 & 96 & 01 & 06 & $\mathrm{f}$ \\
\hline Phillips & Whitewater Lake ${ }^{3}$ & 5 & $6 / 3 / 11$ & 0 & 0 & 0.8 & VI A F & W & 91 & 96 & 01 & 06 & $\mathrm{f}, \mathrm{s}(\mathrm{p}), \mathrm{p}$ \\
\hline Pondera & $\begin{array}{l}\text { Alkali Lake Wetland } \\
\text { Mitigation Site }\end{array}$ & 1 & $7 / 11 / 11$ & 1 & 2 & 0.0 & IV G H I & n.r. & $91^{5}$ & 96 & 01 & - & $\mathrm{f}$ \\
\hline Roosevelt & Johnson Lake WPA & 55 & $6 / 10 / 11$ & 0 & 0 & 0.0 & IV A & $\mathrm{W}$ & 91 & 96 & 01 & 06 & n.r. \\
\hline Sheridan & Berger Pond WPA ${ }^{3}$ & 50 & $6 / 3 / 11$ & 0 & 0 & 0.0 & IV A E & $\mathrm{W}$ & 91 & 96 & 01 & 06 & $f, p$ \\
\hline Sheridan & Big Slough WPA & 41 & $6 / 4 / 11$ & 0 & 0 & 0.0 & IV A & $\mathrm{W}$ & 91 & $\underline{96}$ & $\underline{01}$ & 06 & $\mathrm{f}, \mathrm{p}$ \\
\hline Sheridan & Border Lake & 42 & $6 / 13 / 11$ & 0 & 1 & 0.1 & IV A & none & - & - & - & - & $\mathrm{p}$ \\
\hline Sheridan & Brush Lake ${ }^{3}$ & 45 & $6 / 3 / 11$ & 0 & 0 & 0.0 & IV A & UW & 91 & 96 & 01 & 06 & $\mathrm{~s}(\mathrm{p}), \mathrm{p}$ \\
\hline Sheridan & Chandler and Valpone WPA & 19 & $6 / 7 / 11$ & 0 & 0 & 0.0 & IV A & n.r. & 91 & 96 & 01 & 06 & $\mathrm{f}$ \\
\hline Sheridan & Clear Lake ${ }^{3}$ & 43 & $6 / 3 / 11$ & 0 & 0 & 0.3 & IV A & n.r. & 91 & $\underline{96}$ & 01 & 06 & $\mathrm{p}$ \\
\hline Sheridan & Deep Lake ${ }^{3}$ & 53 & $6 / 2 / 11$ & 0 & 0 & 0.0 & IV A E & V W & $\underline{91}$ & $\overline{96}$ & 01 & $\underline{06}$ & $\mathrm{f}$ \\
\hline Sheridan & Dog Leg WPA & 29 & $6 / 8 / 11$ & 0 & 0 & 0.0 & IV A & $\mathrm{W}$ & $\underline{91}$ & 96 & 01 & 06 & $\mathrm{f}, \mathrm{p}$ \\
\hline Sheridan & Erickson $\mathrm{WPA}^{3}$ & 46 & $6 / 3 / 11$ & 0 & 0 & 0.0 & IV A D & $\mathrm{W}$ & $\overline{91}$ & $\underline{96}$ & $\underline{01}$ & 06 & $\mathrm{f}$ \\
\hline Sheridan & Ferguson WPA & 27 & $6 / 13 / 11$ & 0 & 0 & 0.0 & IV A & n.r. & $\overline{91}$ & $\overline{96}$ & $\overline{01}$ & 06 & $\mathrm{f}, \mathrm{p}$ \\
\hline Sheridan & Flat Lake & 32 & $6 / 9 / 11$ & 14 & 36 & 4.8 & IV A & n.r. & $\underline{91}$ & $\underline{96}$ & $\underline{01}$ & $\underline{06}$ & $\mathrm{~s}(\mathrm{p}), \mathrm{p}$ \\
\hline Sheridan & Gaffney Lake ${ }^{3}$ & 52 & $6 / 2 / 11$ & 0 & 1 & $<0.1$ & IV A D E & n.r. & $\overline{91}$ & $\overline{96}$ & $\overline{01}$ & $\overline{06}$ & $\mathrm{f}$ \\
\hline Sheridan & Galloway's Lake & 23 & $6 / 6 / 11$ & 2 & 4 & 0.5 & IV A & n.r. & $\underline{91}$ & $\underline{96}$ & $\underline{01}$ & $\underline{06}$ & $\mathrm{p}$ \\
\hline Sheridan & Gjesdal East WPA & 31 & $6 / 9 / 11$ & 0 & 0 & 0.0 & IV A & n.r. & - & $\underline{96}$ & 01 & $\underline{06}$ & $\mathrm{f}$ \\
\hline Sheridan & Goose Lake ${ }^{2}$ & 40 & $6 / 4 / 11$ & 0 & 2 & 1.6 & IV A & W & 91 & $\overline{96}$ & $\underline{01}$ & $\overline{\mathbf{0 6}}$ & $\mathrm{f}, \mathrm{s}(\mathrm{p}), \mathrm{p}$ \\
\hline Sheridan & Justice Slough $^{3}$ & 49 & $6 / 3 / 11$ & 0 & 0 & 0.2 & IV A D E & $\mathrm{W}$ & $\overline{91}$ & $\overline{96}$ & $\overline{01}$ & $\overline{06}$ & $\mathrm{p}$ \\
\hline
\end{tabular}


The 2011 International Piping Plover Breeding Census in Montana

(Continued)

\begin{tabular}{|c|c|c|c|c|c|c|c|c|c|c|c|c|c|}
\hline \multirow{2}{*}{$\begin{array}{l}\text { COUNTY } \\
\text { Sheridan }\end{array}$} & \multirow{2}{*}{$\begin{array}{l}\text { SITE NAME } \\
\text { ake, Medicine Lake }\end{array}$} & \multirow{2}{*}{$\begin{array}{c}\text { MAP\# } \\
51\end{array}$} & \multirow{2}{*}{$\begin{array}{c}\text { DATE } \\
6 / 10 / 11\end{array}$} & \multirow{2}{*}{$\begin{array}{c}\text { BREED- } \\
\text { ING } \\
\text { PAIRS } \\
0\end{array}$} & \multirow{2}{*}{$\begin{array}{c}\text { TOTAL } \\
\text { PIPL } \\
\text { ADULTS } \\
0\end{array}$} & \multirow{2}{*}{$\frac{\mathbf{K M}}{0.4}$} & \multirow{2}{*}{$\begin{array}{l}\text { SITE } \\
\text { DESCRIPTION } \\
\text { IV A D E }\end{array}$} & \multirow{2}{*}{$\begin{array}{l}\text { DISTURBANCE } \\
\text { CONCERNS } \\
\mathrm{W}\end{array}$} & \multicolumn{4}{|c|}{$\begin{array}{c}\text { PRIOR YEARS } \\
\text { CENSUSED \& YEARS } \\
\text { PIPL SEEN }^{1} \\
\end{array}$} & \multirow{2}{*}{$\frac{\text { OWNER }}{\mathrm{f}, \mathrm{s}(\mathrm{p})}$} \\
\hline & & & & & & & & & $\underline{\underline{91}}$ & 96 & 01 & $\underline{06}$ & \\
\hline Sheridan & Lake North of Espen WPA & 26 & $6 / 15 / 11$ & 0 & 0 & 0.8 & IV A & $\mathrm{W}$ & -6 & 96 & 01 & $\underline{06}$ & $s(p), p$ \\
\hline Sheridan & Lake North of Gaffney Lake ${ }^{3}$ & & $6 / 2 / 11$ & 0 & 1 & 1.1 & IV A & n.r. & - & $\overline{-}$ & - & $\overline{-}$ & $\mathrm{f}$ \\
\hline Sheridan & Lake North of Stateline WPA & 33 & $6 / 9 / 11$ & 1 & 2 & 0.4 & IV A & n.r. & $\underline{91}$ & $\underline{96}$ & $\underline{01}$ & 06 & $\mathrm{f}, \mathrm{p}$ \\
\hline Sheridan & Lake SE of Parry WPA & 48 & $6 / 5 / 11$ & 3 & 8 & 0.6 & IV A & n.r. & $\overline{91}$ & $\overline{96}$ & $\underline{01}$ & $\underline{06}$ & $\mathrm{p}$ \\
\hline Sheridan & Lake SE of Salt & 21 & $6 / 6 / 11$ & 0 & 2 & 0.3 & IV A & A & - & 96 & 01 & 06 & $\mathrm{p}$ \\
\hline Sheridan & Lone Tree Lake & 24 & $6 / 15 / 11$ & 0 & 0 & 0.0 & IV A & W & 91 & 96 & 01 & 06 & n.r. \\
\hline Sheridan & Marsh Wetland & 25 & $6 / 6 / 11$ & 0 & 0 & 0.0 & IV A & $\mathrm{A}$ & - & - & - & 06 & $\mathrm{p}$ \\
\hline Sheridan & Medicine Lake & 54 & $6 / 10 / 11$ & 2 & 5 & 3.2 & IV A & A & $\underline{91}$ & 96 & 01 & $\underline{06}$ & $\mathrm{f}$ \\
\hline Sheridan & Melby WPA & 44 & $6 / 8 / 11$ & 0 & 0 & 0.0 & IV A & A & 91 & 96 & 01 & 06 & $f, p$ \\
\hline Sheridan & Murphy Wetland (Upper Goose) & 39 & $6 / 4 / 11$ & 0 & 0 & 0.2 & IV A & $\mathrm{W}$ & $\underline{91}$ & - & $\underline{01}$ & $\underline{06}$ & $\mathrm{p}$ \\
\hline Sheridan & North Lake ${ }^{2,3}$ & 35 & $6 / 19 / 11$ & 1 & 3 & 1.6 & IV A & n.r. & $\underline{91}$ & 96 & $\underline{01}$ & $\underline{06}$ & $\mathrm{p}$ \\
\hline Sheridan & Northeast WPA & 28 & $6 / 7 / 11$ & 0 & 0 & 0.0 & IV A & n.r. & - & 96 & 01 & 06 & n.r. \\
\hline Sheridan & Parry WPA ${ }^{2}$ & 47 & $6 / 5 / 11$ & 2 & 5 & 1.3 & IV A & A W & $\underline{91}$ & 96 & $\underline{01}$ & $\underline{06}$ & $f, p$ \\
\hline Sheridan & $\begin{array}{l}\text { Rabenberg Wetland (Upper } \\
\text { Goose) }\end{array}$ & 37 & $6 / 4 / 11$ & 2 & 4 & 0.2 & IV A & n.r. & - & - & - & $\overline{06}$ & $\mathrm{p}$ \\
\hline Sheridan & Salt Lake & 20 & $6 / 6 / 11$ & 0 & 1 & 0.3 & IV A & W & $\underline{91}$ & $\underline{96}$ & $\underline{01}$ & $\underline{06}$ & $\mathrm{~s}(\mathrm{p}), \mathrm{p}$ \\
\hline Sheridan & Stateline WPA & 34 & $6 / 9 / 11$ & 0 & 0 & 0.0 & IV A & $\mathrm{W}$ & - & $\overline{96}$ & $\overline{01}$ & $\overline{06}$ & $\mathrm{f}$ \\
\hline Sheridan & Throntviet Lake & 30 & $6 / 13 / 11$ & 4 & 11 & 1.6 & IV A & $\mathrm{A}$ & - & $\underline{96}$ & $\underline{01}$ & $\underline{06}$ & $\mathrm{p}$ \\
\hline Sheridan & Upper Goose Lake ${ }^{2,3}$ & 36 & $6 / 19 / 11$ & 1 & 2 & 1.6 & IV A & A N & $\underline{91}$ & $\underline{96}$ & $\underline{01}$ & $\overline{06}$ & $\mathrm{~m}, \mathrm{p}$ \\
\hline Sheridan & West Goose Lake & 38 & $6 / 12 / 11$ & 1 & 2 & $<0.1$ & IV A & $\mathrm{W}$ & $\overline{91}$ & $\overline{96}$ & $\overline{01}$ & $\underline{06}$ & $s(p), p$ \\
\hline Sheridan & Wigeon Slough WPA & 22 & $6 / 6 / 11$ & 0 & 0 & 0.2 & IV A & $\mathrm{W}$ & 91 & 96 & 01 & 06 & $\mathrm{f}, \mathrm{p}$ \\
\hline Valley & Chambers Coulee Reservoir ${ }^{3}$ & 16 & $7 / 7 / 11$ & 0 & 0 & 0.0 & VI A & W I & - & 96 & 01 & 06 & $\mathrm{f}, \mathrm{p}$ \\
\hline Valley & Grub Reservoir $^{3}$ & 17 & $6 / 22 / 11$ & 0 & 0 & 0.8 & IV VI I & $\mathrm{W}$ & 91 & 96 & 01 & 06 & $\mathrm{f}$ \\
\hline Valley & Itchpair Slough (Lake Grable) $^{3}$ & 15 & $7 / 7 / 11$ & 0 & 0 & 0.6 & V A & $\mathrm{W}$ & 91 & 96 & 01 & 06 & $\mathrm{f}$ \\
\hline Valley & Valley Reservoir ${ }^{3}$ & 18 & $6 / 22 / 11$ & 0 & 0 & 0.2 & IV VI I & $\mathrm{W}$ & 91 & 96 & 01 & 06 & $\mathrm{f}, \mathrm{p}$ \\
\hline & Off-Missouri River Subtotal & & & 34 & $92^{2}$ & 31.4 & & & & & & & \\
\hline & Missouri River Subtotal & & & 1 & $2^{2}$ & 0.1 & & & & & & & \\
\hline Total & & & & 35 & $94^{2}$ & 31.5 & & & & & & & \\
\hline
\end{tabular}


${ }^{1}$ Bold years indicate that adults were seen. Bold and underlined years indicate that pairs were seen.

2 This total is the "high count"; since two surveys were conducted at some sites for the detectability study, this total includes the highest count at each site.

${ }^{3}$ Please note that these surveys were done outside the Census window.

${ }^{4}$ Nelson Reservoir, Bowdoin NWR, and Hewitt Lake NWR were combined as a single site in 1996. A pair of nesting PIPL were observed on Lake Bowdoin, but a single unpaired

PIPL was also observed though its specific location was not provided. It may have occurred at either Nelson Reservoir, Bowdoin NWR, and Hewitt Lake NWR.

${ }^{5}$ In 1991, 2 pairs were observed on this site on July 11, 1991, outside the census window.

${ }^{6}$ A 1991 map for the census shows that this site was likely to have plovers but access to the site was denied so an official census never occurred. 


\section{The 2011 International Piping Plover Breeding Census in North Dakota (off-Missouri River)}

Kirsten Brennan

U.S. Fish and Wildlife Service

8315 Highway 8

Kenmare, ND 58746

701-848-2722 (ext 24)

kirsten_brennan@fws.gov

In North Dakota most known (off the Missouri River) breeding sites were censused. Thirteen new sites were added to the 2011 census. Most new sites were within the Long Lake Wetland Management District (4 in Burleigh County, 1 in Emmons County, and 6 in Kidder County). Plovers were documented at these sites for the first time in 2008. Several sites were not surveyed because no suitable nesting haitat was available due to high water conditions. Some sites were totally flooded and therefore not surveyed (Upper Souris National Wildlife Refuge (NWR), Chase Lake and Arrowwood NWRs. Numerous other areas were surveyed even though high water covered much or all suitable nesting habitat.

In the alkali lakes region of North Dakota, 591 Piping Plovers were counted this year which was down from 806 in 2006, but higher than the 2001 count of 469. Fluctuation in water levels, both in the lakes and the Missouri River was the largest factor influencing local population numbers. Snow melt and spring rains caused high river and lake levels in 2011, which in many cases flooded all suitable habitat at traditional nesting sites. In response to the reduction of available nesting shoreline plovers were observed nesting on roads and in flooded agricultural fields more frequently than in prior years. Because some plovers distribution were observed nesting in non-traditional habitats which were not comprehensively surveyed, it is likely that the 2011 count was an underestimate of the actual number of birds in the region.

Comparison of Census Numbers ${ }^{1}$

\begin{tabular}{l|c|c|c|c|c|}
\hline & 1991 & 1996 & 2001 & 2006 & 2011 \\
\hline $\begin{array}{l}\text { Total } \\
\text { Adults }\end{array}$ & 992 & 1004 & 1112 & $1508^{2}$ & $623^{2}$ \\
\hline
\end{tabular}
$\begin{aligned} & { }^{1} \text { Missouri River data are included in all totals. } \\
& \text { 2This is the total from a single survey at each site; if more than } \\
& \text { one survey was conducted, we count only results from the first } \\
& \text { survey during the census window. }\end{aligned}$

\section{Detectability Study}

\begin{tabular}{|l|c|c|}
\hline \multicolumn{1}{|c|}{ Sites Included } & $\begin{array}{c}\text { First } \\
\text { Count }\end{array}$ & $\begin{array}{c}\text { Second } \\
\text { Count }\end{array}$ \\
\hline Shively WPA & 6 & 6 \\
\hline $\begin{array}{l}\text { Lostwood NWR - Phalarope } \\
\text { Wetland }\end{array}$ & 6 & 5 \\
\hline Long Lake Pool - Unit I & 2 & 0 \\
\hline $\begin{array}{l}\text { Long Lake Pool - Unit II } \\
\text { Marsh Dike }\end{array}$ & 32 & 32 \\
\hline Long Lake NWR - Unit III & 2 & 2 \\
\hline Kreil Wetland & 1 & 1 \\
\hline North Lake & 1 & 2 \\
\hline Mud Lake South (Bitz Lake) & 6 & 5 \\
\hline Bluehill WPA & 0 & 0 \\
\hline Crystal Lake & 0 & 0 \\
\hline Engel Lake & 0 & 0 \\
\hline McGinnis WPA & 0 & 0 \\
\hline Pelican Lake & 66 & 77 \\
\hline $\begin{array}{l}\text { Lostwood WMD - Palermo } \\
\text { Lake }\end{array}$ & 6 & 1 \\
\hline $\begin{array}{l}\text { Lostwood NWR - Piping } \\
\text { Plover Wetland }\end{array}$ & 12 & 9 \\
\hline $\begin{array}{l}\text { Lostwood WMD - Redmond } \\
\text { Lake }\end{array}$ & 7 & 7 \\
\hline Strasburg WPA & 0 & 0 \\
\hline LGFR & 11 & 22 \\
\hline Orlien WPA & 6 & 12 \\
\hline Schaefer Lake & 6 \\
\hline Appam Lake & 6 & \\
\hline & 0 & 0 \\
\hline
\end{tabular}




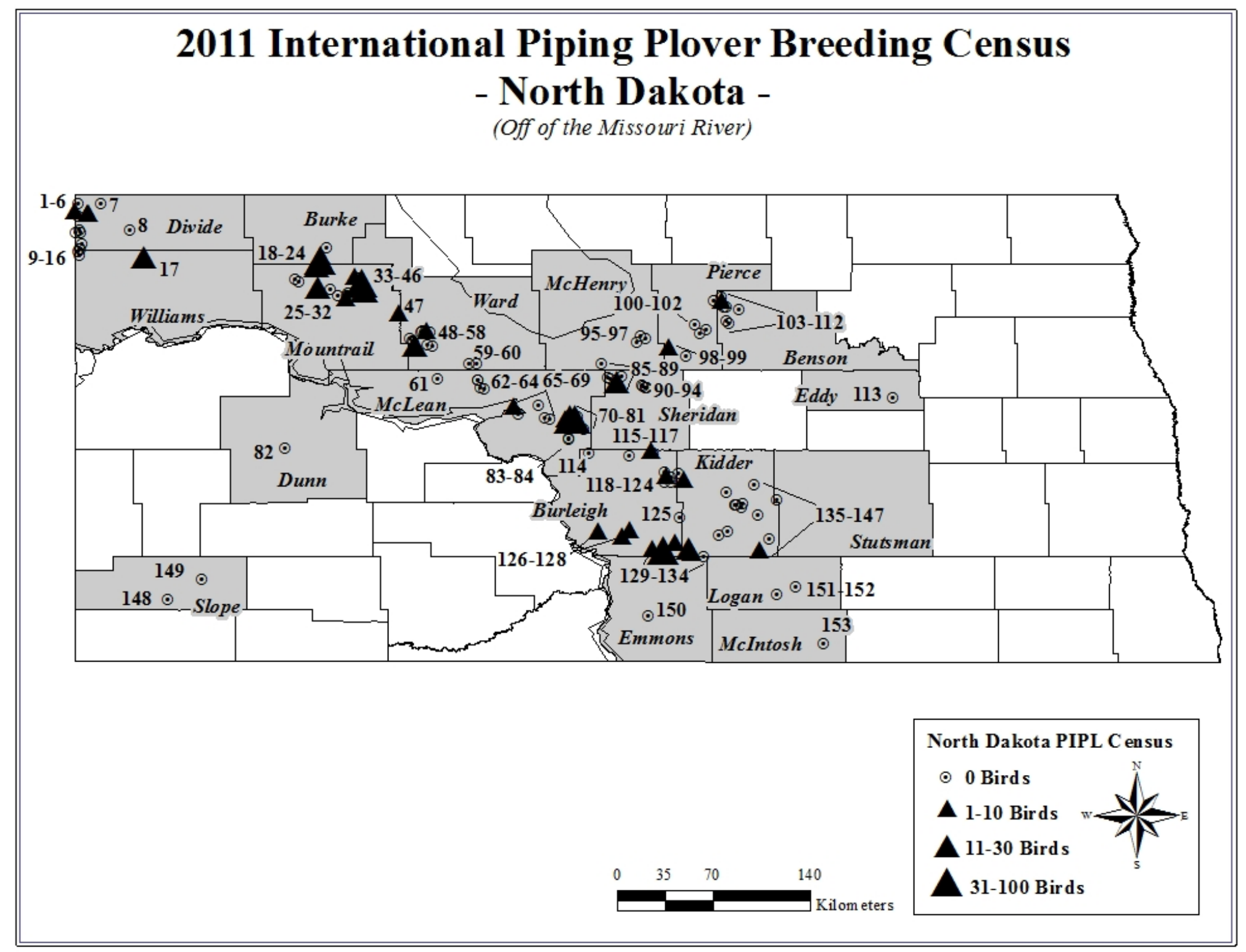


The 2011 International Piping Plover Breeding Census in North Dakota

\begin{tabular}{|c|c|c|c|c|c|c|c|c|c|c|c|c|c|}
\hline \multirow{2}{*}{$\begin{array}{l}\text { REGION } \\
\text { Benson }\end{array}$} & \multirow{2}{*}{$\begin{array}{r}\text { SITE NAME } \\
\text { Cranberry Lake }\end{array}$} & \multirow{2}{*}{ MAP\# } & \multirow{2}{*}{$\begin{array}{c}\text { DATE } \\
6 / 6 / 11\end{array}$} & \multirow{2}{*}{$\begin{array}{c}\text { BREED- } \\
\text { ING } \\
\text { PAIRS } \\
0\end{array}$} & \multirow{2}{*}{$\begin{array}{c}\text { TOTAL } \\
\text { PIPL } \\
\text { ADULTS } \\
0\end{array}$} & \multirow{2}{*}{$\frac{\mathbf{K M}}{0.0}$} & \multirow{2}{*}{$\begin{array}{l}\text { SITE } \\
\text { DESCRIPTION } \\
\text { IV A }\end{array}$} & \multirow{2}{*}{$\begin{array}{l}\text { DISTURBANCE } \\
\text { CONCERNS } \\
\mathrm{W}\end{array}$} & \multicolumn{3}{|c|}{$\begin{array}{c}\text { PRIOR YEARS } \\
\text { CENSUSED \& } \\
\text { YEARS } \\
\text { PIPL SEEN }^{1} \\
\end{array}$} & \multirow{2}{*}{\multicolumn{2}{|c|}{$\frac{\text { OWNER }}{\mathrm{p}}$}} \\
\hline & & & & & & & & & - & 96 & - & & \\
\hline Benson & Duchscher Lake & 108 & $6 / 8 / 11$ & 0 & 0 & 0.0 & V A & none & - & 96 & 01 & 06 & $\mathrm{p}$ \\
\hline Benson & Horseshoe Lake & 104 & $6 / 8 / 11$ & 0 & 0 & 0.0 & IV A & $\mathrm{W}$ & - & 96 & 01 & 06 & $\mathrm{f}, \mathrm{s}(\mathrm{p}), \mathrm{p}$ \\
\hline Benson & Long Lake WPA & 109 & $6 / 6 / 11$ & 0 & 0 & 0.0 & IV A & $\mathrm{W}$ & - & $\underline{96}$ & 01 & 06 & $f, p$ \\
\hline Benson & Pfeifer Lake & 106 & $6 / 8 / 11$ & 0 & 0 & 0.0 & IV A & $\mathrm{W}$ & 91 & $\underline{96}$ & 01 & 06 & $\mathrm{f}$ \\
\hline Benson & Ripplinger Slough & 107 & $6 / 8 / 11$ & 0 & 0 & 0.0 & IV A & $\mathrm{W}$ & - & - & - & - & $\mathrm{p}$ \\
\hline Benson & Shively WPA & 105 & $6 / 8 / 11$ & 2 & 6 & 0.4 & IV A & $\mathrm{W}$ & 91 & $\underline{96}$ & 01 & $\underline{06}$ & $f, p$ \\
\hline Benson & Simon WPA & 111 & $6 / 6 / 11$ & 0 & 0 & 0.0 & IV A & $\mathrm{W}$ & - & $\underline{96}$ & - & 06 & $\mathrm{f}, \mathrm{p}$ \\
\hline Benson & Volk WPA & 110 & $6 / 6 / 11$ & 0 & 0 & 0.0 & IV A & $\mathrm{W}$ & - & $\underline{96}$ & 01 & 06 & $\mathrm{f}$ \\
\hline Burke & $\begin{array}{l}\text { Lostwood NWR - Salt } \\
\text { Wetland }\end{array}$ & 21 & $6 / 6 / 11$ & 0 & 0 & 1.9 & IV D & n.r. & $\underline{91}^{4}$ & $\overline{96}$ & 01 & 06 & $\mathrm{f}$ \\
\hline Burke & $\begin{array}{l}\text { Lostwood NWR - School } \\
\text { Section Lake }\end{array}$ & 19 & $5 / 26 / 11$ & 1 & 2 & 4.2 & IV D & n.r. & - & $\underline{96}$ & 01 & 06 & $\mathrm{f}$ \\
\hline Burke & $\begin{array}{l}\text { Lostwood NWR - Thompson } \\
\text { Lake }^{3}\end{array}$ & 18 & $5 / 26 / 11$ & 0 & 0 & 4.8 & IV D & n.r. & - & 96 & - & 06 & $\mathrm{f}$ \\
\hline Burke & $\begin{array}{l}\text { Lostwood NWR - Upper } \\
\text { Lostwood Lake }\end{array}$ & 20 & $6 / 13 / 11$ & 20 & 49 & 10.6 & IV D & n.r. & $\underline{91}^{4}$ & $\underline{96}$ & $\underline{01}$ & $\underline{06}$ & $\mathrm{f}$ \\
\hline Burke/Mountrail & $\begin{array}{l}\text { Lostwood NWR - Phalarope } \\
\text { Wetland }^{2,3}\end{array}$ & 23 & $6 / 1 / 11$ & 3 & 6 & 3.0 & IV D & n.r. & $\underline{91}^{4}$ & $\underline{96}$ & 01 & $\underline{06}$ & $\mathrm{f}$ \\
\hline Burleigh & BLM \#1 WPA & 115 & $6 / 8 / 11$ & 0 & 0 & 0.0 & IV V A I & W & - & $\underline{96}$ & - & - & $\mathrm{f}, \mathrm{p}$ \\
\hline Burleigh & $\begin{array}{l}\text { Bryan/Mohler WPA (Gravel } \\
\text { Road) }\end{array}$ & 126 & $6 / 13 / 11$ & 1 & 2 & 0.0 & IV V I & V & - & - & - & - & $\mathrm{s}(\mathrm{p}), \mathrm{p}$ \\
\hline Burleigh & Harriet Lake & 123 & $6 / 9 / 11$ & 0 & 0 & 0.0 & IV V A I & $\mathrm{W}$ & - & - & - & - & $\mathrm{p}$ \\
\hline Burleigh & Hertz Lake ${ }^{3}$ & 117 & $6 / 20 / 11$ & 0 & 0 & 0.0 & IV V A I & $\mathrm{W}$ & - & 96 & 01 & - & $\mathrm{p}$ \\
\hline Burleigh & Hysterical 02 & 114 & $6 / 10 / 11$ & 0 & 0 & 0.2 & VI A & A W & - & - & 01 & 06 & $\mathrm{p}$ \\
\hline Burleigh & Krueger Slough & 127 & $6 / 17 / 11$ & 1 & 3 & 0.0 & IX I & none & - & - & - & - & $\mathrm{p}$ \\
\hline Burleigh & Lake Arena & 124 & $6 / 9 / 11$ & 0 & 0 & 0.0 & IV V A I & $\mathrm{W}$ & 91 & 96 & 01 & $\underline{06}$ & $f, p$ \\
\hline Burleigh & Long Lake Pool - Unit I ${ }^{2}$ & 129 & $6 / 6 / 11$ & 1 & 2 & 1.6 & IV V E F & V W P & $\underline{91}^{5}$ & - & 01 & $\overline{06}$ & $\mathrm{f}$ \\
\hline Burleigh & $\begin{array}{l}\text { Long Lake Pool - Unit II } \\
\text { Marsh Dike }^{2}\end{array}$ & 130 & $6 / 16 / 11$ & 16 & 32 & n.r. & IV V F I & $\mathrm{W}$ & $\overline{\mathbf{9 1}}^{5}$ & 96 & $\underline{01}$ & 06 & $\mathrm{f}$ \\
\hline Burleigh & McKenzie Slough & 128 & $6 / 17 / 11$ & 1 & 2 & 2.4 & V A H I & W & - & - & - & 06 & $\mathrm{f}, \mathrm{p}$ \\
\hline Burleigh & Rachel Hoff & 120 & $6 / 7 / 11$ & 2 & 5 & 0.8 & IV V H I & $\mathrm{W}$ & $\underline{91}$ & $\underline{96}$ & $\underline{01}$ & 06 & $\mathrm{f}, \mathrm{p}$ \\
\hline Burleigh & Rath WPA ${ }^{3}$ & 118 & $6 / 23 / 11$ & 0 & 0 & 0.0 & IV V A I & $\mathrm{W}$ & $\overline{91}$ & $\overline{96}$ & $\overline{01}$ & $\underline{06}$ & $f, p$ \\
\hline Burleigh & Trusty WPA & 121 & $6 / 7 / 11$ & 0 & 0 & 0.0 & IV V H I & $\mathrm{W}$ & 91 & 96 & 01 & 06 & $\mathrm{f}, \mathrm{p}$ \\
\hline
\end{tabular}


The 2011 International Piping Plover Breeding Census in North Dakota (Continued)

\begin{tabular}{|c|c|c|c|c|c|c|c|c|c|c|c|c|c|}
\hline \multirow{2}{*}{$\begin{array}{l}\text { REGION } \\
\text { Burleigh/Kidder }\end{array}$} & \multirow{2}{*}{$\begin{array}{c}\text { SITE NAME } \\
\text { Long Lake NWR }\end{array}$} & \multirow{2}{*}{$\begin{array}{c}\text { MAP\# } \\
131\end{array}$} & \multirow{2}{*}{$\frac{\text { DATE }}{6 / 6 / 11}$} & \multirow{2}{*}{$\begin{array}{c}\text { BREED- } \\
\text { ING } \\
\text { PAIRS } \\
1\end{array}$} & \multirow{2}{*}{$\begin{array}{c}\text { TOTAL } \\
\text { PIPL } \\
\text { ADULTS } \\
2\end{array}$} & \multirow{2}{*}{ 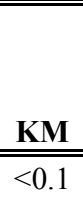 } & \multirow{2}{*}{$\begin{array}{l}\text { SITE } \\
\text { DESCRIPTION } \\
\text { IV V H I }\end{array}$} & \multirow{2}{*}{$\begin{array}{l}\text { DISTURBANCE } \\
\text { CONCERNS } \\
\mathrm{W}\end{array}$} & \multicolumn{4}{|c|}{$\begin{array}{c}\text { PRIOR YEARS } \\
\text { CENSUSED \& } \\
\text { YEARS } \\
\text { PIPL SEEN }^{1}\end{array}$} & \multirow{2}{*}{$\frac{\text { OWNER }}{\mathrm{f}, \mathrm{p}}$} \\
\hline & & & & & & & & & 91 & 96 & 01 & $\underline{06}$ & \\
\hline Burleigh/Kidder & Stoney Slough ${ }^{3}$ & 125 & $6 / 23 / 11$ & 0 & 0 & 0.0 & IV V A I & $\mathrm{W}$ & - & - & 01 & - & $\mathrm{p}$ \\
\hline Burleigh/Sheridan & Salt Lake & 116 & $6 / 8 / 11$ & 1 & 2 & 0.8 & IV V A I & $\mathrm{W}$ & - & 96 & 01 & $\underline{06}$ & $\mathrm{p}$ \\
\hline Divide & Camp Lake & 13 & $6 / 9 / 11$ & 0 & 0 & 0.0 & IV A & $\mathrm{W} \mathrm{O}$ & - & $\underline{96}$ & $\underline{01}$ & $\underline{06}$ & $s(p), p$ \\
\hline Divide & Daneville Lake ${ }^{3}$ & 9 & $6 / 1 / 11$ & 0 & 0 & 0.0 & IV A E & $\mathrm{W} \mathrm{O}$ & - & $\underline{96}$ & 01 & 06 & $\mathrm{p}$ \\
\hline Divide & Daneville Lake SE & 11 & $6 / 5 / 11$ & 0 & 0 & 0.0 & IV A E & I W & - & 96 & $\underline{01}$ & $\underline{06}$ & $\mathrm{p}$ \\
\hline Divide & Hapet Lake & 8 & $6 / 5 / 11$ & 0 & 0 & 0.0 & IV A & A W P O & - & - & $\underline{01}$ & - & $s(p), p$ \\
\hline Divide & Johnson WPA & 10 & $6 / 5 / 11$ & 0 & 0 & 0.0 & IV A E & $\mathrm{W}$ & - & $\underline{96}$ & $\underline{01}$ & $\underline{06}$ & $\mathrm{f}, \mathrm{p}$ \\
\hline Divide & Kreil Wetland & 5 & $6 / 8 / 11$ & 0 & 1 & 0.2 & IV A & A & - & 96 & $\underline{01}$ & 06 & $\mathrm{p}$ \\
\hline Divide & McCone Lake ${ }^{3}$ & 1 & $6 / 2 / 11$ & 0 & 0 & 0.3 & IV A D & A W & - & $\underline{96}$ & $\underline{01}$ & $\underline{06}$ & $\mathrm{p}$ \\
\hline Divide & Miller Lake & 6 & $6 / 10 / 11$ & 22 & 101 & 8.0 & IV A E & n.r. & $\underline{91}$ & $\underline{96}$ & $\underline{01}$ & $\underline{06}$ & $\mathrm{f}, \mathrm{p}$ \\
\hline Divide & Mine Pond & 12 & & & & & & & & & & & \\
\hline Divide & No Name 01 & 3 & $6 / 13 / 11$ & 0 & 0 & 0.0 & IV A & n.r. & - & 96 & $\underline{01}$ & $\underline{06}$ & $\mathrm{p}$ \\
\hline Divide & North Lake** & 4 & $6 / 16 / 11$ & 1 & 2 & 0.4 & IV A & n.r. & $\underline{91}$ & $\underline{96}$ & $\underline{01}$ & $\underline{06}$ & $\mathrm{p}$ \\
\hline Divide & Radar WPA & 7 & $6 / 8 / 11$ & 0 & 0 & 0.0 & IV A & $\mathrm{O}$ & - & - & 01 & 06 & $\mathrm{f}, \mathrm{p}$ \\
\hline Divide/Sheridan & Round/Westby Lake & 2 & $6 / 16 / 11$ & 2 & 4 & 11.8 & IV A E & W & 91 & 96 & $\underline{01}$ & $\underline{06}$ & $\mathrm{f}, \mathrm{s}(\mathrm{p}), \mathrm{p}$ \\
\hline Divide/Williams & Africa Lake & 14 & $6 / 6 / 11$ & 0 & 0 & 0.2 & IV A E I & W P & - & $\underline{96}$ & $\underline{01}$ & $\underline{06}$ & $\mathrm{p}$ \\
\hline Dunn & Lake Ilo NWR & 82 & $6 / 14 / 11$ & 0 & 0 & n.r. & IV A & $\mathrm{W}$ & $\underline{91}$ & 96 & 01 & 06 & $\mathrm{f}$ \\
\hline Eddy & Lake Coe & 113 & $6 / 15 / 11$ & 0 & 0 & 0.0 & IV A E & $\mathrm{W}$ & $\underline{91}$ & 96 & 01 & 06 & $\mathrm{f}$ \\
\hline Emmons & Maier Lake ${ }^{3}$ & 150 & $6 / 1 / 11$ & 0 & 0 & 0.0 & IV I & $\mathrm{W}$ & - & - & - & - & $\mathrm{p}$ \\
\hline Emmons & Sisco-Fallgater $\mathrm{WPA}^{3}$ & 134 & $6 / 1 / 11$ & 0 & 0 & 0.0 & V A H I & none & - & 96 & 01 & $\underline{06}$ & $f, p$ \\
\hline Kidder & Alkaline Lake ${ }^{3}$ & 146 & $6 / 21 / 11$ & 0 & 5 & 2.4 & V I & $\mathrm{W}$ & - & - & - & - & $\mathrm{p}$ \\
\hline Kidder & Bayer Lake & 122 & $6 / 15 / 11$ & 4 & 8 & 0.8 & IV V A I & W & - & - & - & - & $\mathrm{P}$ \\
\hline Kidder & Big Muddy East ${ }^{3}$ & 139 & $6 / 3 / 11$ & 0 & 0 & 0.0 & V A H I & $\mathrm{W}$ & - & 96 & - & - & $\mathrm{p}$ \\
\hline Kidder & Big Muddy West ${ }^{3}$ & 137 & $6 / 3 / 11$ & 0 & 0 & 0.0 & V A E I & $\mathrm{W}$ & $\underline{91}$ & 96 & 01 & $\underline{06}$ & $\mathrm{f}, \mathrm{p}$ \\
\hline Kidder & Dewald Slough & 143 & $6 / 8 / 11$ & 0 & 0 & 0.0 & VA I & n.r. & - & - & - & 06 & $\mathrm{f}, \mathrm{p}$ \\
\hline Kidder & Horsehead Lake & 135 & $6 / 16 / 11$ & 0 & 0 & 0.0 & IV V A I & $\mathrm{W}$ & $\underline{91}$ & 96 & $\underline{01}$ & $\underline{06}$ & $\mathrm{p}$ \\
\hline Kidder & Hutchinson NWR & 119 & $6 / 6 / 11$ & 0 & 0 & 0.0 & V H I & $\mathrm{W}$ & - & - & - & - & $f, p$ \\
\hline Kidder & Lake $\mathrm{Etta}^{3}$ & 144 & $6 / 1 / 11$ & 0 & 0 & 0.8 & V H I & $\mathrm{W}$ & - & - & 01 & $\underline{06}$ & $\mathrm{f}, \mathrm{s}(\mathrm{p}), \mathrm{p}$ \\
\hline Kidder & Lake George $^{3}$ & 145 & $6 / 1 / 11$ & 0 & 0 & 0.0 & V A I & W & - & 96 & 01 & 06 & $\mathrm{f}, \mathrm{p}$ \\
\hline Kidder & McPhail WMA & 142 & $6 / 17 / 11$ & 0 & 0 & 0.0 & V A & $\mathrm{O}$ & - & - & 01 & 06 & $\mathrm{p}$ \\
\hline Kidder & Mud Lake & 132 & $6 / 7 / 11$ & 5 & 11 & 1.2 & IV V A H & A & - & - & - & - & $\mathrm{p}$ \\
\hline
\end{tabular}


The 2011 International Piping Plover Breeding Census in North Dakota (Continued)

\begin{tabular}{|c|c|c|c|c|c|c|c|c|c|c|c|c|c|}
\hline \multirow{2}{*}{$\begin{array}{l}\text { REGION } \\
\text { Kidder }\end{array}$} & \multirow{2}{*}{ 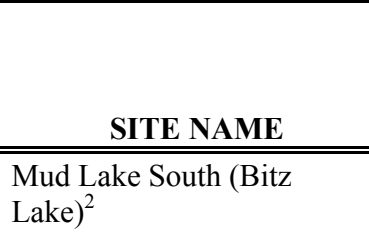 } & \multirow{2}{*}{$\frac{\text { MAP\# }}{133}$} & \multirow{2}{*}{$\begin{array}{c}\text { DATE } \\
6 / 7 / 11\end{array}$} & \multirow{2}{*}{$\begin{array}{c}\begin{array}{c}\text { BREED- } \\
\text { ING } \\
\text { PAIRS }\end{array} \\
3\end{array}$} & \multirow{2}{*}{$\begin{array}{c}\text { TOTAL } \\
\text { PIPL } \\
\text { ADULTS } \\
6\end{array}$} & \multirow{2}{*}{$\frac{\mathbf{K M}}{0.8}$} & \multirow{2}{*}{$\begin{array}{l}\text { SITE } \\
\text { DESCRIPTION } \\
\text { IV V H I }\end{array}$} & \multirow{2}{*}{$\begin{array}{l}\text { DISTURBANCE } \\
\text { CONCERNS } \\
\mathrm{W}\end{array}$} & \multicolumn{4}{|c|}{$\begin{array}{c}\text { PRIOR YEARS } \\
\text { CENSUSED \& } \\
\text { YEARS } \\
\text { PIPL SEEN }^{1}\end{array}$} & \multirow{2}{*}{$\frac{\text { OWNER }}{\mathrm{p}}$} \\
\hline & & & & & & & & & - & - & 01 & 06 & \\
\hline Kidder & Sibley Lake & 138 & $6 / 6 / 11$ & 0 & 0 & 0.0 & IV V H I & W & $\underline{91}$ & 96 & 01 & 06 & $\mathrm{p}$ \\
\hline Kidder & South Lake & 136 & $6 / 15 / 11$ & 0 & 0 & 0.0 & IV V A I & W & - & - & - & - & $\mathrm{p}$ \\
\hline Kidder & Spring Lake & 140 & $6 / 6 / 11$ & 0 & 0 & 0.0 & V H I & W & 91 & 96 & 01 & 06 & $\mathrm{p}$ \\
\hline Kidder & Stony Lake & 141 & $6 / 3 / 11$ & 0 & 0 & 0.0 & V A H I & none & - & - & - & - & $\mathrm{p}$ \\
\hline Logan & Logan County WMA & 151 & $6 / 8 / 11$ & 0 & 0 & 0.0 & V A & $\mathrm{W}$ & - & $\underline{96}$ & 01 & 06 & $f, s(p), p$ \\
\hline Logan & Schweigert WPA & 152 & $6 / 8 / 11$ & 0 & 0 & 0.8 & V A & W & 91 & 96 & 01 & 06 & $\mathrm{f}, \mathrm{p}$ \\
\hline McHenry & Bromley Lake & 96 & $6 / 14 / 11$ & 0 & 0 & 0.8 & V A & n.r. & 91 & $\underline{96}$ & 01 & 06 & $\mathrm{f}, \mathrm{p}$ \\
\hline McHenry & Crooked Lake & 97 & $6 / 9 / 11$ & 0 & 0 & n.r. & IV A & W & $\underline{91}$ & $\underline{96}$ & $\underline{01}$ & 06 & n.r. \\
\hline McHenry & Lake Lemer & 95 & $6 / 9 / 11$ & 0 & 0 & n.r. & IV A & W & 91 & $\underline{96}$ & 01 & 06 & $\mathrm{f}, \mathrm{p}$ \\
\hline McHenry & Spichke WPA & 85 & $6 / 9 / 11$ & 0 & 0 & 0.0 & IV A & W & - & 96 & 01 & 06 & $\mathrm{f}, \mathrm{p}$ \\
\hline McIntosh & McIntosh 02 & 153 & $6 / 8 / 11$ & 0 & 0 & 0.0 & V A & W & - & 96 & 01 & 06 & $f, p$ \\
\hline McLean & Amoeba Lake & 72 & $6 / 9 / 11$ & 0 & 0 & 0.9 & IV A & none & - & $\underline{96}$ & $\underline{01}$ & $\underline{06}$ & $\mathrm{p}$ \\
\hline McLean & $\begin{array}{l}\text { Audubon Refuge (Lake } \\
\text { Audubon) }\end{array}$ & 65 & $6 / 4 / 11$ & 1 & 2 & 1.6 & VI A & W & - & 96 & 01 & $\underline{06}$ & $\mathrm{f}$ \\
\hline McLean & Blue Lake & 78 & $6 / 9 / 11$ & 0 & 0 & 6.4 & IV A & W & 91 & 96 & 01 & 06 & $\mathrm{~s}(\mathrm{p})$ \\
\hline McLean & Bluehill WPA & 61 & $6 / 6 / 11$ & 0 & 0 & 0.0 & IV A E & W & - & $\underline{96}$ & 01 & 06 & $\mathrm{f}, \mathrm{p}$ \\
\hline McLean & Cherry Lake & 69 & $6 / 6 / 11$ & 0 & 0 & 0.4 & IV A & n.r. & - & $\underline{96}$ & 01 & 06 & $\mathrm{f}, \mathrm{p}$ \\
\hline McLean & Crystal Lake & 62 & $6 / 9 / 11$ & 0 & 0 & 0.4 & IV A E I & n.r. & 91 & $\underline{96}$ & $\underline{01}$ & $\underline{06}$ & $\mathrm{p}$ \\
\hline McLean & Day Lake & 76 & $6 / 8 / 11$ & 0 & 0 & 1.5 & V A & none & - & - & - & 06 & $\mathrm{p}$ \\
\hline McLean & Elbow Lake & 75 & $6 / 8 / 11$ & 5 & 10 & 2.5 & IV A & none & $\underline{91}$ & $\underline{96}$ & $\underline{01}$ & $\underline{06}$ & $\mathrm{p}$ \\
\hline McLean & Engel Lake & 64 & $6 / 16 / 11$ & 0 & 0 & 0.0 & IV A & n.r. & 91 & $\underline{96}$ & $\underline{01}$ & $\underline{06}$ & $\mathrm{p}$ \\
\hline McLean & Fischer Lake (Koenig Lake) & 84 & $6 / 6 / 11$ & 0 & 0 & 0.0 & IV A & n.r. & $\underline{91}$ & 96 & 01 & 06 & $\mathrm{f}, \mathrm{p}$ \\
\hline McLean & Fisher Lake (Laib's Marsh) & 83 & $6 / 6 / 11$ & 0 & 0 & 0.0 & IV A & n.r. & - & 96 & 01 & 06 & $\mathrm{f}, \mathrm{p}$ \\
\hline McLean & Gaub WPA & 81 & $6 / 6 / 11$ & 0 & 0 & 0.0 & IV A & n.r. & 91 & 96 & 01 & 06 & $f, p$ \\
\hline McLean & Lake Nettie & 67 & $6 / 9 / 11$ & 0 & 0 & 8.0 & IV A & $\mathrm{W}$ & 91 & 96 & 01 & 06 & $\mathrm{f}, \mathrm{s}(\mathrm{p})$ \\
\hline McLean & Lake Williams & 70 & $6 / 9 / 11$ & 2 & 6 & 1.3 & IV A & none & $\underline{91}$ & $\underline{96}$ & $\underline{01}$ & $\underline{06}$ & $\mathrm{f}, \mathrm{s}(\mathrm{p}), \mathrm{p}$ \\
\hline McLean & McGinnis WPA & 63 & $6 / 10 / 11$ & 0 & 0 & 0.0 & IV A & n.r. & - & - & 01 & $\underline{06}$ & $\mathrm{f}, \mathrm{p}$ \\
\hline McLean & Mud Lake & 73 & $6 / 8 / 11$ & 0 & 0 & 0.5 & VA & none & - & - & - & 06 & $\mathrm{p}$ \\
\hline McLean & Paramecium Lake & 71 & $6 / 9 / 11$ & 1 & 2 & 0.7 & IV A & none & - & 96 & $\underline{01}$ & $\underline{06}$ & $\mathrm{p}$ \\
\hline McLean & Pelican Lake ${ }^{2}$ & 77 & $6 / 9 / 11$ & 37 & 77 & 11.8 & IV A & none & - & $\underline{96}$ & $\underline{01}$ & $\underline{06}$ & $\mathrm{p}$ \\
\hline McLean & Peterson Lake & 74 & $6 / 8 / 11$ & 16 & 36 & 13.0 & IV A & none & - & $\underline{96}$ & $\underline{01}$ & $\underline{06}$ & $\mathrm{f}, \mathrm{p}$ \\
\hline
\end{tabular}


The 2011 International Piping Plover Breeding Census in North Dakota (Continued)

\begin{tabular}{|c|c|c|c|c|c|c|c|c|c|c|c|c|c|}
\hline \multirow{2}{*}{$\begin{array}{l}\text { REGION } \\
\text { McLean }\end{array}$} & \multirow{2}{*}{$\begin{aligned} \text { SITE NAME } \\
\text { Spot Lake }\end{aligned}$} & \multirow{2}{*}{ MAP\# } & \multirow{2}{*}{$\begin{array}{l}\text { DATE } \\
6 / 9 / 11\end{array}$} & \multirow{2}{*}{$\begin{array}{c}\begin{array}{c}\text { BREED- } \\
\text { ING } \\
\text { PAIRS }\end{array} \\
4\end{array}$} & \multirow{2}{*}{$\begin{array}{c}\text { TOTAL } \\
\text { PIPL } \\
\text { ADULTS } \\
8\end{array}$} & \multirow{2}{*}{$\frac{\mathbf{K M}}{3.5}$} & \multirow{2}{*}{$\begin{array}{l}\text { SITE } \\
\text { DESCRIPTION } \\
\text { IV A }\end{array}$} & \multirow{2}{*}{$\begin{array}{l}\text { DISTURBANCE } \\
\text { CONCERNS } \\
\text { none }\end{array}$} & \multicolumn{3}{|c|}{$\begin{array}{c}\text { PRIOR YEARS } \\
\text { CENSUSED \& } \\
\text { YEARS } \\
\text { PIPL SEEN }^{1} \\
\end{array}$} & \multirow{2}{*}{\multicolumn{2}{|c|}{$\frac{\text { OWNER }}{\mathrm{p}}$}} \\
\hline & & & & & & & & & - & $\underline{96}$ & $\underline{01}$ & & \\
\hline McLean & Stessman Marsh & 66 & $6 / 6 / 11$ & 0 & 0 & 0.0 & IX I & W & - & - & $\underline{01}$ & $\overline{06}$ & $\mathrm{f}$ \\
\hline McLean & Tractor Lake & 80 & $6 / 9 / 11$ & 0 & 0 & 0.0 & IV A & none & - & 96 & $\underline{01}$ & $\underline{06}$ & $s(p), p$ \\
\hline McLean & Turtle Lake & 68 & $6 / 6 / 11$ & 0 & 0 & 0.0 & IV A D & $\mathrm{W}$ & 91 & 96 & $\overline{01}$ & $\overline{06}$ & $f, p$ \\
\hline Mountrail & $\begin{array}{l}\text { Lostwood NWR - Lower } \\
\text { Lostwood Lake }\end{array}$ & 24 & $6 / 6 / 11$ & 3 & 16 & 9.9 & IV D & $\mathrm{W}$ & $\underline{91}^{4}$ & $\underline{96}$ & $\underline{01}$ & $\underline{06}$ & $\mathrm{f}$ \\
\hline Mountrail & $\begin{array}{l}\text { Lostwood NWR - Piping } \\
\text { Plover Wetland }\end{array}$ & 22 & $6 / 6 / 11$ & 6 & 12 & 1.0 & IV D & W & $\underline{91}^{4}$ & $\underline{96}$ & $\underline{01}$ & $\underline{06}$ & $\mathrm{f}$ \\
\hline Mountrail & $\begin{array}{l}\text { Lostwood WMD - Bieri } \\
\text { Wetland }\end{array}$ & 46 & $6 / 6 / 11$ & 0 & 1 & 1.4 & IV D & W & $\underline{91}^{4}$ & - & 01 & 06 & $\mathrm{p}$ \\
\hline Mountrail & Lostwood WMD - BLM 01 & 29 & $6 / 8 / 11$ & 0 & 0 & 3.3 & IV D & n.r. & $\underline{91}^{4}$ & $\underline{96}$ & $\underline{01}$ & 06 & $\mathrm{f}, \mathrm{p}$ \\
\hline Mountrail & $\begin{array}{l}\text { Lostwood WMD - } \\
\text { Cottonwood Lake East }\end{array}$ & 25 & $6 / 15 / 11$ & 0 & 0 & 8.8 & IV D & n.r. & $\underline{91}$ & $\underline{96}$ & $\underline{01}$ & $\underline{06}$ & $f, s(p), p$ \\
\hline Mountrail & $\begin{array}{l}\text { Lostwood WMD - } \\
\text { Cottonwood Lake West }\end{array}$ & 26 & $6 / 15 / 11$ & 0 & 0 & 15.9 & IV D & n.r. & $\underline{91}$ & $\underline{96}$ & 01 & $\underline{06}$ & $\mathrm{f}, \mathrm{p}$ \\
\hline Mountrail & $\begin{array}{l}\text { Lostwood WMD - Goettle } \\
\text { Wetland }\end{array}$ & 36 & $6 / 9 / 11$ & 0 & 0 & 1.2 & IV D & $\mathrm{W}$ & - & - & 01 & $\underline{06}$ & $\mathrm{p}$ \\
\hline Mountrail & $\begin{array}{l}\text { Lostwood WMD - Halvorson } \\
\text { WPA North }\end{array}$ & 32 & $6 / 8 / 11$ & 0 & 0 & 9.2 & IV D & n.r. & 91 & 96 & 01 & 06 & $\mathrm{f}, \mathrm{p}$ \\
\hline Mountrail & $\begin{array}{l}\text { Lostwood WMD - Halvorson } \\
\text { WPA South }\end{array}$ & 31 & $6 / 8 / 11$ & 0 & 0 & 3.1 & IV D & n.r. & 91 & 96 & - & 06 & $\mathrm{p}$ \\
\hline Mountrail & Lostwood WMD - ND 02 & 28 & $6 / 8 / 11$ & 0 & 0 & 9.6 & IV D & n.r. & 91 & - & 01 & 06 & $f, s(p), p$ \\
\hline Mountrail & $\begin{array}{l}\text { Lostwood WMD - Palermo } \\
\text { Lake }^{2}\end{array}$ & 43 & $6 / 5 / 11$ & 1 & 6 & 6.2 & IV D & $\mathrm{W}$ & 91 & $\underline{96}$ & $\underline{01}$ & 06 & $\mathrm{p}$ \\
\hline Mountrail & $\begin{array}{l}\text { Lostwood WMD - Palermo } \\
\text { Lake SW }\end{array}$ & 30 & $6 / 8 / 11$ & 0 & 1 & 7.9 & IV D & n.r. & $\underline{91}$ & $\underline{96}$ & $\underline{01}$ & 06 & $\mathrm{f}, \mathrm{p}$ \\
\hline Mountrail & $\begin{array}{l}\text { Lostwood WMD - Piping } \\
\text { Plover WPA }\end{array}$ & 42 & $6 / 5 / 11$ & 3 & 6 & 3.2 & IV D & $\mathrm{W}$ & 91 & $\underline{96}$ & $\underline{01}$ & $\underline{06}$ & $\mathrm{f}, \mathrm{p}$ \\
\hline Mountrail & $\begin{array}{l}\text { Lostwood WMD - Redmond } \\
\text { Lake }\end{array}$ & 37 & $6 / 9 / 11$ & 2 & 7 & 14.0 & IV D & $\mathrm{W}$ & 91 & $\underline{96}$ & $\underline{01}$ & $\underline{06}$ & $s(p), p$ \\
\hline Mountrail & $\begin{array}{l}\text { Lostwood WMD - Redmond } \\
\text { Lake East }\end{array}$ & 38 & $6 / 9 / 11$ & 18 & 48 & 2.6 & IV D & n.r. & $\underline{91}$ & $\underline{96}$ & $\underline{01}$ & $\underline{06}$ & $\mathrm{~s}(\mathrm{p}), \mathrm{p}$ \\
\hline Mountrail & $\begin{array}{l}\text { Lostwood WMD - Redmond } \\
\text { Lake North }\end{array}$ & 34 & $6 / 6 / 11$ & 0 & 0 & 5.6 & IV D & W & 91 & 96 & $\underline{01}$ & $\underline{06}$ & $\mathrm{p}$ \\
\hline
\end{tabular}


The 2011 International Piping Plover Breeding Census in North Dakota (Continued)

\begin{tabular}{|c|c|c|c|c|c|c|c|c|c|c|c|c|c|}
\hline \multirow{2}{*}{$\begin{array}{l}\text { REGION } \\
\text { Mountrail }\end{array}$} & \multirow{2}{*}{$\begin{array}{l}\text { SITE NAME } \\
\text { Lostwood WMD - Redmond } \\
\text { Lake SE }\end{array}$} & \multirow{2}{*}{ MAP\# } & \multirow{2}{*}{$\begin{array}{c}\text { DATE } \\
6 / 9 / 11\end{array}$} & \multirow{2}{*}{$\begin{array}{c}\text { BREED- } \\
\text { ING } \\
\text { PAIRS } \\
3\end{array}$} & \multirow{2}{*}{$\begin{array}{c}\begin{array}{c}\text { TOTAL } \\
\text { PIPL } \\
\text { ADULTS }\end{array} \\
12\end{array}$} & \multirow{2}{*}{$\frac{\mathbf{K M}}{8.4}$} & \multirow{2}{*}{$\begin{array}{l}\text { SITE } \\
\text { DESCRIPTION }\end{array}$} & \multirow{2}{*}{$\begin{array}{l}\text { DISTURBANCE } \\
\text { CONCERNS } \\
\text { n.r. }\end{array}$} & \multicolumn{4}{|c|}{$\begin{array}{c}\text { PRIOR YEARS } \\
\text { CENSUSED \& } \\
\text { YEARS } \\
\text { PIPL SEEN } \\
\end{array}$} & \multirow{2}{*}{$\frac{\text { OWNER }}{\mathrm{f}, \mathrm{p}}$} \\
\hline & & & & & & & & & $\underline{91}$ & $\underline{96}$ & $\underline{01}$ & $\underline{06}$ & \\
\hline Mountrail & $\begin{array}{l}\text { Lostwood WMD - Redmond } \\
\text { Lake South }\end{array}$ & 40 & $6 / 5 / 11$ & 9 & 21 & 9.5 & IV D & $\mathrm{W}$ & 91 & 96 & 01 & $\underline{06}$ & $\mathrm{f}, \mathrm{p}$ \\
\hline Mountrail & $\begin{array}{l}\text { Lostwood WMD - Rued } \\
\text { Wetland }\end{array}$ & 35 & $6 / 6 / 11$ & 0 & 0 & 0.5 & IV D & $\mathrm{W}$ & 91 & 96 & - & 06 & $\mathrm{p}$ \\
\hline Mountrail & Lostwood WMD - US1 F\&G & 47 & $6 / 5 / 11$ & 0 & 4 & 9.6 & IV D & $\mathrm{W}$ & $\underline{91}^{4}$ & $\underline{96}$ & $\underline{01}$ & $\underline{06}$ & $f, p$ \\
\hline Mountrail & Lostwood WMD - USA 01 & 44 & $6 / 6 / 11$ & 5 & 10 & 4.9 & IV D H & $\mathrm{W}$ & $\underline{91}^{4}$ & $\underline{96}$ & $\underline{\mathbf{0 1}}$ & $\overline{06}$ & $f, p$ \\
\hline Mountrail & $\begin{array}{l}\text { Lostwood WMD - USA } 01 \\
\text { SE }\end{array}$ & 45 & $6 / 6 / 11$ & 0 & 0 & 0.6 & IV D & $\mathrm{W}$ & $\underline{91}^{4}$ & $\overline{96}$ & $\overline{01}$ & 06 & $\mathrm{f}$ \\
\hline Mountrail & $\begin{array}{l}\text { Lostwood WMD - Wetland } \\
\text { South of Redmond South }\end{array}$ & 41 & $6 / 5 / 11$ & 0 & 0 & 1.1 & IV D & $\mathrm{W}$ & - & - & - & - & $\mathrm{p}$ \\
\hline Mountrail & $\begin{array}{l}\text { Lostwood WMD - White } \\
\text { Lake }^{3}\end{array}$ & 27 & $6 / 19 / 11$ & 4 & 12 & 25.5 & IV D & n.r. & $\underline{91}$ & $\underline{96}$ & 01 & $\underline{06}$ & $\mathrm{p}$ \\
\hline Mountrail & Silo Lake (Crowfoot Plat) ${ }^{6}$ & 33 & $6 / 16 / 11$ & 0 & 1 & 0.4 & V A H I & V I & - & - & - & - & $\mathrm{p}$ \\
\hline Pierce & Balta WPA & 100 & $6 / 13 / 11$ & 0 & 0 & 0.0 & IV A & $\mathrm{W}$ & 91 & - & - & - & $\mathrm{f}, \mathrm{p}$ \\
\hline Pierce & Little Antelope Lake & 99 & $6 / 13 / 11$ & 0 & 0 & 0.0 & IV A & $\mathrm{W}$ & 91 & $\underline{96}$ & 01 & 06 & $\mathrm{f}, \mathrm{p}$ \\
\hline Pierce & Meyer WPA & 103 & $6 / 14 / 11$ & 0 & 0 & 3.2 & V A & n.r. & - & 96 & 01 & 06 & $f, p$ \\
\hline Pierce & Orrin Lake & 98 & $6 / 16 / 11$ & 1 & 2 & 0.2 & IV A & $\mathrm{W}$ & 91 & $\underline{96}$ & 01 & 06 & $\mathrm{f}, \mathrm{p}$ \\
\hline Pierce & Petrified Lake ${ }^{3}$ & 102 & $6 / 3 / 11$ & 0 & 0 & 0.2 & IV A & n.r. & 91 & $\overline{96}$ & 01 & 06 & $\mathrm{p}$ \\
\hline Pierce & Sandhill Crane WPA & 101 & $6 / 13 / 11$ & 0 & 0 & 0.0 & IV A & n.r. & 91 & 96 & 01 & 06 & $f, s(p), p$ \\
\hline Sheridan & Kandt Lake & 88 & $6 / 6 / 11$ & 0 & 0 & 0.4 & IV A & $\mathrm{A}$ & 91 & 96 & 01 & 06 & $\mathrm{p}$ \\
\hline Sheridan & Krueger Lake & 89 & $6 / 8 / 11$ & 8 & 17 & 0.4 & IV A & $\mathrm{W}$ & 91 & $\underline{96}$ & $\underline{01}$ & $\underline{06}$ & $\mathrm{f}, \mathrm{p}$ \\
\hline Sheridan & $\begin{array}{l}\text { Lonetree WMA - Avocet } \\
\text { Lake }\end{array}$ & 91 & $6 / 13 / 11$ & 0 & 0 & 0.0 & IV A & $\mathrm{W}$ & 91 & 96 & 01 & 06 & $\mathrm{~s}(\mathrm{p})$ \\
\hline Sheridan & $\begin{array}{l}\text { Lonetree WMA - Gadwall } \\
\text { Lake }\end{array}$ & 92 & $6 / 6 / 11$ & 0 & 0 & 0.0 & IV A & $\mathrm{W}$ & 91 & 96 & 01 & 06 & $\mathrm{~s}(\mathrm{p})$ \\
\hline Sheridan & Lonetree WMA - New Lake & 90 & $6 / 13 / 11$ & 0 & 0 & 0.0 & IV A & $\mathrm{W}$ & $\underline{91}$ & 96 & 01 & 06 & $\mathrm{~s}(\mathrm{p})$ \\
\hline Sheridan & Lonetree WMA - Other Lake & 94 & $6 / 6 / 11$ & 0 & 0 & 0.1 & IV A & $\mathrm{W}$ & $\overline{91}$ & 96 & 01 & 06 & $\mathrm{~s}(\mathrm{p})$ \\
\hline Sheridan & $\begin{array}{l}\text { Lonetree WMA - Plover } \\
\text { Pond }\end{array}$ & 93 & $6 / 6 / 11$ & 0 & 0 & 0.0 & IV A & $\mathrm{W}$ & 91 & 96 & 01 & 06 & $\mathrm{~s}(\mathrm{p})$ \\
\hline Sheridan & Moesner Lake & 87 & $6 / 9 / 11$ & 0 & 0 & 0.0 & IV A I & n.r. & $\underline{91}$ & 96 & 01 & 06 & $\mathrm{p}$ \\
\hline Sheridan & Strasburg WPA & 86 & $6 / 6 / 11$ & 0 & 0 & 0.0 & IV A & n.r. & $\overline{91}$ & $\underline{96}$ & 01 & $\underline{06}$ & $\mathrm{f}, \mathrm{p}$ \\
\hline Slope & Stewart Lake & 148 & $6 / 9 / 11$ & 0 & 0 & 0.0 & IV A & $\mathrm{W}$ & $\overline{91}$ & $\overline{96}$ & 01 & $\overline{06}$ & n.r. \\
\hline
\end{tabular}


The 2011 International Piping Plover Breeding Census in North Dakota (Continued)

\begin{tabular}{|c|c|c|c|c|c|c|c|c|c|c|c|c|c|}
\hline \multirow{2}{*}{$\begin{array}{l}\text { REGION } \\
\text { Slope }\end{array}$} & \multirow{2}{*}{$\begin{array}{c}\text { SITE NAME } \\
\text { White Lake NWR }\end{array}$} & \multirow{2}{*}{$\frac{\text { MAP\# }}{149}$} & \multirow{2}{*}{$\frac{\text { DATE }}{6 / 14 / 11}$} & \multirow{2}{*}{$\begin{array}{c}\begin{array}{c}\text { BREED- } \\
\text { ING } \\
\text { PAIRS }\end{array} \\
0\end{array}$} & \multirow{2}{*}{$\begin{array}{c}\text { TOTAL } \\
\text { PIPL } \\
\text { ADULTS } \\
0\end{array}$} & \multirow{2}{*}{$\frac{\mathbf{K M}}{20.0}$} & \multirow{2}{*}{$\begin{array}{l}\text { SITE } \\
\text { DESCRIPTION } \\
\text { IV A }\end{array}$} & \multirow{2}{*}{$\begin{array}{l}\text { DISTURBANCE } \\
\text { CONCERNS } \\
\mathrm{W}\end{array}$} & \multicolumn{4}{|c|}{$\begin{array}{c}\text { PRIOR YEARS } \\
\text { CENSUSED \& } \\
\text { YEARS } \\
\text { PIPL SEEN }^{1}\end{array}$} & \multirow{2}{*}{$\frac{\text { OWNER }}{\mathrm{f}}$} \\
\hline & & & & & & & & & 91 & $\overline{996}$ & 01 & 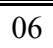 & \\
\hline Stutsman & Chase Lake NWR & 147 & $6 / 16 / 11$ & 0 & 0 & 0.0 & IV A E & $\mathrm{W}$ & $\underline{91}$ & 96 & 01 & 06 & $\mathrm{f}$ \\
\hline Ward & Danielson WPA & 60 & $6 / 9 / 11$ & 0 & 0 & 4.0 & IV A & W & - & $\underline{96}$ & 01 & 06 & $\mathrm{f}$ \\
\hline Ward & Foss Lake & 59 & $6 / 6 / 11$ & 0 & 0 & 0.0 & IV A & W & - & 96 & 01 & 06 & $\mathrm{p}$ \\
\hline Ward & Galusha WPA & 54 & $6 / 6 / 11$ & 0 & 0 & 0.0 & IV A E & n.r. & - & $\underline{96}$ & $\underline{01}$ & 06 & $f, p$ \\
\hline Ward & LGFR Pond & 57 & $6 / 13 / 11$ & 0 & 0 & 0.0 & IV A & n.r. & 91 & - & 01 & 06 & $\mathrm{p}$ \\
\hline Ward & Middle Lake & 50 & $6 / 6 / 11$ & 0 & 0 & 0.0 & IV A & W & - & - & 01 & 06 & $\mathrm{p}$ \\
\hline Ward & One-legged lake & 51 & $6 / 11 / 11$ & 0 & 0 & 1.5 & IV E & n.r. & - & - & $\underline{01}$ & 06 & $\mathrm{p}$ \\
\hline Ward & Orlien WPA & 56 & $6 / 6 / 11$ & 8 & 18 & 6.4 & IV A E & $\mathrm{A} \mathrm{W}$ & - & $\underline{96}$ & $\underline{01}$ & $\underline{06}$ & $f, p$ \\
\hline Ward & Roberts Lake & 58 & $6 / 9 / 11$ & 0 & 0 & 0.0 & IV A I & n.r. & 91 & $\underline{96}$ & $\underline{01}$ & 06 & $\mathrm{p}$ \\
\hline Ward & Schaefer Lake & 49 & $6 / 6 / 11$ & 3 & 6 & 0.8 & IV E & $\mathrm{W}$ & 91 & $\underline{96}$ & $\underline{01}$ & $\underline{06}$ & $\mathrm{p}$ \\
\hline Ward & Simonson Lake & 52 & $6 / 6 / 11$ & 0 & 0 & 0.0 & IV A E I & n.r. & 91 & $\underline{96}$ & $\underline{01}$ & $\underline{06}$ & $\mathrm{p}$ \\
\hline Ward & Ward 01 & 55 & $6 / 6 / 11$ & 0 & 0 & 0.0 & IV A I & $\mathrm{V}$ & 91 & $\underline{96}$ & 01 & 06 & $\mathrm{p}$ \\
\hline Ward & Weltikol WPA & 53 & $6 / 6 / 11$ & 0 & 0 & 0.0 & IV V A E I & n.r. & - & $\underline{96}$ & 01 & 06 & $f, p$ \\
\hline Ward & Wheeler Wetland & 48 & $6 / 6 / 11$ & 0 & 0 & 0.0 & IV A I & A & - & 96 & $\underline{01}$ & $\underline{06}$ & $\mathrm{p}$ \\
\hline Williams & Appam Lake & 17 & $6 / 15 / 11$ & 10 & 22 & 0.8 & IV A E & $\mathrm{W}$ & $\underline{91}$ & $\underline{96}$ & $\underline{01}$ & $\underline{06}$ & $f, p$ \\
\hline Williams & Stink Lake $02^{3}$ & 15 & $6 / 2 / 11$ & 0 & 0 & 0.0 & IV A & $\mathrm{W}$ & - & $\overline{96}$ & $\overline{01}$ & $\overline{06}$ & $\mathrm{p}$ \\
\hline Williams & Twin Lake & 16 & $6 / 13 / 11$ & 0 & 0 & 0.0 & IV A & A W O & - & 96 & $\underline{01}$ & 06 & $\mathrm{~s}(\mathrm{p}), \mathrm{p}$ \\
\hline \multicolumn{2}{|c|}{ Off-Missouri River Subtotal } & & & 237 & $615^{2}$ & 293.1 & & & & & & & \\
\hline \multicolumn{2}{|c|}{ Missouri River Subtotal } & & & 18 & $37^{2}$ & 1.6 & & & & & & & \\
\hline Total & & & & 255 & $652^{2}$ & 294.7 & & & & & & & \\
\hline
\end{tabular}

Bold and underlined years indicate that pairs were seen. Bold (only) years indicate that adults were seen.

2 This total is the "high count"; since two surveys were conducted at some sites for the detectability study, this total includes the highest count at each site.

${ }^{3}$ Please note that these surveys were done outside the Census window.

${ }^{4}$ The entire Lostwood WMD was surveyed in 1991, but no maps were provided. PIPL may or may not have occurred within the range of this 2011 site.

${ }^{5}$ Long Lake NWR was surveyed in 1991, but no maps were provided. The survey route and locations of the PIPL pairs is unclear. The pairs may have occurred within the range of this 2011 survey route.

${ }^{6}$ This plover was seen on a road. 


\section{The 2011 International Piping Plover Breeding Census in South Dakota (off-Missouri River)}

Natalie A. Gates

U.S. Fish and Wildlife Service

420 South Garfield Avenue, Suite 400

Pierre, South Dakota 57501

605-224-8693 x 227

Natalie_Gates@fws.gov

High water levels in South Dakota precluded the presence of Piping Plovers on the majority of wetlands censused off of the Missouri River this year. Only two Piping Plovers were observed at one alkali wetland on private land in McPherson County, South Dakota, during the census. This site was one of several new wetlands added to the list of areas to be checked in 2011 that had records of Piping Plovers in recent years. All of the sites checked during the 2006 were censused again in 2011. The majority of both old and new sites had no exposed shoreline. During the 2006 census, drought was present on the plains and plovers were observed at four sites off the Missouri River. Those sites did not harbor nesting plovers this year, as wetter conditions prevailed in 2011.
The relatively low number of lakes and wetlands checked ( 25 sites) during the 2011 census represents a small portion of wetlands in the state. Other wetlands may provide Piping Plover breeding habitat. We are only aware of a few alkali wetlands, all of which were included in our census effort. If additional alkali sites are identified in the future, they may provide potential habitat and should be surveyed. Historically, breeding Piping Plovers in South Dakota have been documented primarily on the sandbars and shorelines of the Missouri River and its man-made reservoirs.

Comparison of Census Numbers ${ }^{1}$

\begin{tabular}{|l|c|c|c|c|c|}
\hline & 1991 & 1996 & 2001 & 2006 & 2011 \\
\hline $\begin{array}{l}\text { Total } \\
\text { Adults }\end{array}$ & 295 & 29 & 390 & $375^{2}$ & $151^{2}$ \\
\hline
\end{tabular}

${ }^{1}$ Missouri River data are included in all totals.

${ }^{2}$ This is the total from a single survey at each site; if more than one survey was conducted, we count only results from the first survey during the census window.

Detectability Study

\begin{tabular}{|l|c|c|}
\hline \multicolumn{1}{|c|}{ Sites Included } & $\begin{array}{c}\text { First } \\
\text { Count }\end{array}$ & $\begin{array}{c}\text { Second } \\
\text { Count }\end{array}$ \\
\hline Mound City & 0 & 0 \\
\hline Ipswich & 0 & 0 \\
\hline Eureka & 0 & 2 \\
\hline $\begin{array}{l}\text { Odessa GPA No. 1 (formerly } \\
\text { Igle Walk-in) }\end{array}$ & 0 & 0 \\
\hline Ordway Prairie Pond & 0 & 0 \\
\hline
\end{tabular}




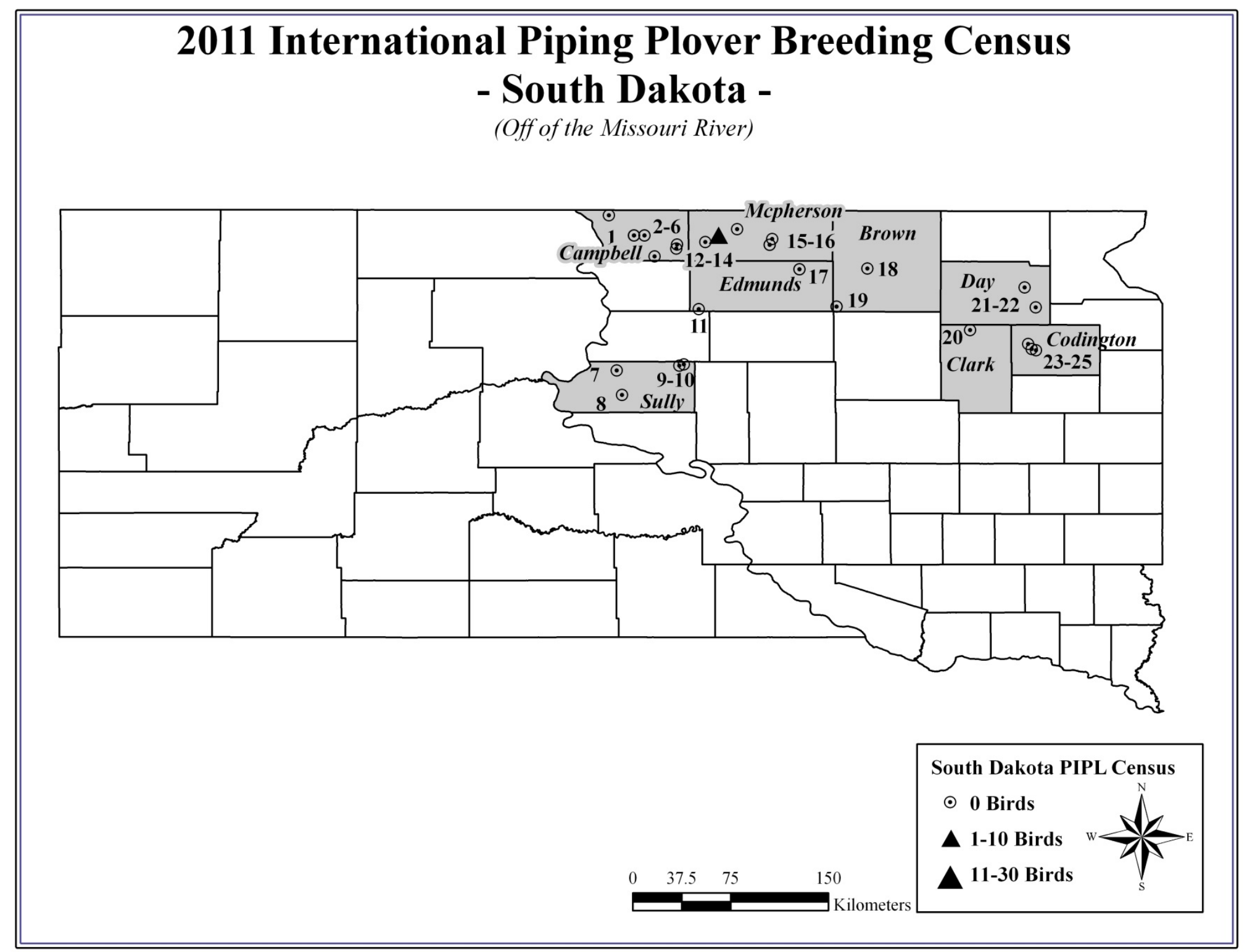


The 2011 International Piping Plover Breeding Census in South Dakota

\begin{tabular}{|c|c|c|c|c|c|c|c|c|c|c|c|c|c|}
\hline \multirow{2}{*}{$\begin{array}{l}\text { REGION } \\
\text { Brown }\end{array}$} & $\begin{array}{c}\text { SITE NAME } \\
\end{array}$ & \multirow{2}{*}{$\begin{array}{c}\text { МAP\# } \\
18\end{array}$} & \multirow{2}{*}{$\frac{\text { DATE }}{6 / 15 / 11}$} & \multirow{2}{*}{$\begin{array}{c}\text { BREED- } \\
\text { ING } \\
\text { PAIRS } \\
0\end{array}$} & \multirow{2}{*}{$\begin{array}{c}\text { TOTAL } \\
\text { PIPL } \\
\text { ADULTS } \\
0\end{array}$} & \multirow{2}{*}{$\frac{\mathbf{K M}}{0.0}$} & \multirow{2}{*}{$\begin{array}{l}\text { SITE } \\
\text { DESCRIPTION } \\
\mathrm{VI}\end{array}$} & \multirow{2}{*}{$\begin{array}{l}\text { DISTURBANCE } \\
\text { CONCERNS } \\
\mathrm{W}\end{array}$} & \multicolumn{4}{|c|}{$\begin{array}{c}\text { PRIOR YEARS } \\
\text { CENSUSED \& } \\
\text { YEARS } \\
\text { PIPL SEEN }^{1} \\
\end{array}$} & \multirow{2}{*}{$\begin{array}{c}\text { OWNER } \\
\mathrm{f}\end{array}$} \\
\hline & Proud Waterfowl Production Area & & & & & & & & 91 & 96 & 01 & 06 & \\
\hline Brown & Salt Lake Brown Co & 19 & $6 / 15 / 11$ & 0 & 0 & 0.0 & V I & A W & 91 & 96 & 01 & 06 & $\mathrm{p}$ \\
\hline Campbell & Goetz Waterfowl Production Area & 5 & $6 / 7 / 11$ & 0 & 0 & 0.0 & V I & $\mathrm{W}$ & 91 & 96 & 01 & 06 & $\mathrm{f}$ \\
\hline Campbell & Hwy. 10 & 3 & $6 / 7 / 11$ & 0 & 0 & 0.0 & V I & $\mathrm{W}$ & - & 96 & 01 & 06 & $\mathrm{f}$ \\
\hline Campbell & Mound City & 2 & $6 / 7 / 11$ & 0 & 0 & 0.0 & V H & n.r. & - & - & - & - & $\mathrm{p}$ \\
\hline Campbell & Pocasse NWR & 1 & $6 / 6 / 11$ & 0 & 0 & 0.0 & VI A & W & 91 & 96 & 01 & $\underline{06}$ & $\mathrm{~s}(\mathrm{p})$ \\
\hline Campbell & Salt Lake Campbell Co. & 4 & $6 / 7 / 11$ & 0 & 0 & 0.0 & V I & $\mathrm{W}$ & - & 96 & 01 & $\overline{06}$ & $\mathrm{~s}(\mathrm{p})$ \\
\hline Campbell & West Flat Lake & 6 & $6 / 7 / 11$ & 0 & 0 & 0.8 & V A & n.r. & 91 & 96 & 01 & 06 & $f, p$ \\
\hline Clark & Crocker & 20 & $6 / 8 / 11$ & 0 & 0 & 0.0 & V H I & W & - & - & - & - & $\mathrm{p}$ \\
\hline Codington & Horseshoe Lake & 25 & $6 / 8 / 11$ & 0 & 0 & 0.0 & IV A & $\mathrm{W}$ & 91 & 96 & 01 & 06 & $\mathrm{f}, \mathrm{s}(\mathrm{p}), \mathrm{p}$ \\
\hline Codington & Lake Nicholson & 23 & $6 / 8 / 11$ & 0 & 0 & 0.0 & IV A & $\mathrm{W}$ & 91 & 96 & 01 & 06 & $\mathrm{~s}(\mathrm{p}), \mathrm{p}$ \\
\hline Codington & Medicine Lake & 24 & $6 / 8 / 11$ & 0 & 0 & 0.0 & IV A & W & 91 & 96 & 01 & 06 & $\mathrm{p}$ \\
\hline Day & Bitter Lake & 22 & $6 / 13 / 11$ & 0 & 0 & 0.0 & IV H I & A V W U I & 91 & 96 & 01 & 06 & $\mathrm{~s}(\mathrm{p}), \mathrm{p}$ \\
\hline Day & Waubay Lake & 21 & $6 / 8 / 11$ & 0 & 0 & 0.0 & IV A & W & 91 & 96 & 01 & 06 & $\mathrm{f}, \mathrm{s}(\mathrm{p})$ \\
\hline Edmunds & Alkali Lake & 11 & $6 / 6 / 11$ & 0 & 0 & 0.0 & IV H I & n.r. & - & 96 & 01 & 06 & $\mathrm{f}$ \\
\hline Edmunds & Ipswich & 17 & $6 / 13 / 11$ & 0 & 0 & 0.0 & V H & A & - & - & - & - & $\mathrm{p}$ \\
\hline McPherson & Eureka $^{2}$ & 13 & $6 / 9 / 11$ & 1 & 2 & 0.3 & IV H I & n.r. & - & - & - & - & $\mathrm{p}$ \\
\hline McPherson & Kempf Waterfowl Production Area & 16 & $6 / 16 / 11$ & 0 & 0 & 0.0 & V I & n.r. & 91 & 96 & 01 & 06 & $\mathrm{f}$ \\
\hline McPherson & $\begin{array}{l}\text { Melhoff Island Waterfowl } \\
\text { Production Area }\end{array}$ & 12 & $6 / 6 / 11$ & 0 & 0 & 0.0 & IV I & W & 91 & 96 & 01 & 06 & $\mathrm{f}$ \\
\hline McPherson & $\begin{array}{l}\text { Odessa GPA No. } 1 \text { (formerly Igle } \\
\text { Walk-in) }\end{array}$ & 14 & $6 / 12 / 11$ & 0 & 0 & 0.0 & IV A E & W & - & - & - & - & $\mathrm{s}(\mathrm{p}), \mathrm{p}$ \\
\hline McPherson & Ordway Prairie Pond & 15 & $6 / 14 / 11$ & 0 & 0 & 0.0 & V I & n.r. & - & - & - & - & $\mathrm{p}$ \\
\hline Sully & Agar & 7 & $6 / 13 / 11$ & 0 & 0 & 0.0 & V H & W & - & - & - & - & $\mathrm{p}$ \\
\hline Sully & $\begin{array}{l}\text { NE Sully Waterfowl Production } \\
\text { Area }\end{array}$ & 9 & $6 / 11 / 11$ & 0 & 0 & 0.0 & IV H I & W & - & 96 & 01 & 06 & $\mathrm{f}$ \\
\hline Sully & Onida & 8 & $6 / 13 / 11$ & 0 & 0 & 0.0 & V H & A & - & - & - & - & $\mathrm{p}$ \\
\hline Sully & Stone Lake GPA & 10 & $6 / 11 / 11$ & 0 & 0 & 0.0 & IV H I & W & - & - & - & 06 & $\mathrm{~s}(\mathrm{p})$ \\
\hline \multicolumn{3}{|c|}{ Off-Missouri River Subtotal } & & 1 & $2^{2}$ & 1.1 & & & & & & & \\
\hline \multicolumn{3}{|c|}{ Missouri River Subtotal } & & 20 & $151^{2}$ & 112.2 & & & & & & & \\
\hline Total & & & & 21 & $153^{2}$ & 113.3 & & & & & & & \\
\hline
\end{tabular}


${ }^{1}$ Bold and underlined years indicate that pairs were seen. Bold (only) years indicate that adults were seen. Italicized years indicate that the sites were checked but not officially censused due to lack of habitat.

${ }^{2}$ This total is the "high count"; since two surveys were conducted at some sites for the detectability study, this total includes the highest count at each site. 


\section{The 2011 International Piping Plover Breeding Census in Iowa}

Daryl Howell

Iowa Department of Natural Resources

Wallace Building

502 E. $9^{\text {th }}$ St.

Des Moines, IA 50319

515-281-8524

daryl.howell@dnr.iowa.gov

Historically, Piping Plovers have only been found breeding in Iowa along the fly-ash ponds of MidAmerican's power plants. Due to the expected Missouri River floods, all of MidAmerican's resources were directed towards flood preparedness and asset protection.

Thererfore, they were unable to complete the census and no official surveys were conducted. At the time of the census window water levels were so high that all Piping Plover habitat was flooded. Water receded slowly and remained high through the summer. Overall, less than a handful of Piping Plover were seen over the entire summer (at MidAmerican sites) and one nest was seen but its fate is unknown.

\section{Comparison of Census Numbers}

\begin{tabular}{|l|c|c|c|c|c|}
\hline & 1991 & 1996 & 2001 & 2006 & 2011 \\
\hline $\begin{array}{l}\text { Total } \\
\text { Adults }\end{array}$ & 13 & 14 & 11 & $9^{1}$ & n.a. \\
\hline
\end{tabular}

${ }^{1}$ This is the total from a single survey at each site; if more than one survey was conducted, we count only results from the first survey during the census window.

Summarized by E. Elliott-Smith 


\section{The 2011 International Piping Plover Breeding Census in Nebraska (off-Missouri River)}

Joel Jorgensen

Nebraska Game and Parks Commission

P.O. Box 30370

Lincoln, NE 68503

402-471-5440

joel.jorgensen@nebraska.gov

The wet conditions experienced across Nebraska during the 2011 International Piping Plover Census period contrasted sharply with the drought conditions of the 2006 Census. Sandbar and shoreline habitats were reduced statewide by high water in rivers, lakes and reservoirs. As a result, the number of Piping Plovers recorded during the 2011 International Census was much lower than 2006.

Over $600 \mathrm{~km}$ (373 miles) of river were surveyed by airboat or kayak and canoe. Forty four sand and gravel mines and one large reservoir, Lake McConaughy, were also surveyed. For the first time, a natural lake, Goose Lake, at Crescent Lake National Wildlife Refuge (Garden County) was included in the census. Piping Plovers were first attracted to this site a few years ago after the creation of an island in Goose Lake, but have subsequently used a sandy roadside near the lake.

In 2011, 348 adult Piping Plovers were counted in Nebraska (not counting the 2 birds seen on the Missouri River). This total is a $52 \%$ decrease from the 2006 total when 718 adults were recorded, but is similar to earlier census results in 2001, 1996, and 1991 when 300,366, and 398 adults were recorded, respectively (off the Missouri River). The greatest decrease occurred at Lake McConaughy where totals went from 358 adults in 2006 to only 38 adults in 2011. In 2006, Lake McConaughy was holding water at less than $50 \%$ of capacity and in 2011 it was at $100 \%$ capacity with record or near-record releases into the North Platte River and Sutherland Canal. These releases contributed to high water levels on the Platte River downstream areas, resulting in virtually no sandbar habitat available to birds along the Central Platte River. In 2006, most of the Central Platte River was not surveyed because of a lack of water.

The 104 Piping Plovers recorded on the Niobrara River were more than any other river system. The Lower Platte River was second with 73 adults, followed by the Central Platte River where 58 adults were recorded. The majority $(65 \%, n=48)$ of plovers on the Lower Platte River were found at off-river sites, sand and gravel mines and lakeshore housing developments. All but one Piping Plover were recorded at off-river sites on the Central Platte River.

The majority of suitable Piping Plover habitat was surveyed in Nebraska. A few areas were not included in the survey, such as small sand and gravel mines that possessed very limited or marginal habitat or where access was not granted by property owners. These sites have generally been surveyed in the past and it has been determined that there is a low likelihood of plover occupancy. We believe that inclusion of these areas would have had minimal impact on the total recorded during the 2011 Census.

The International Piping Plover Census serves as a useful index of Piping Plover numbers in Nebraska. As noted in 2006, survey efforts in Nebraska are challenging due to the varied habitat types surveyed and various methods (e.g. airboat, foot, canoe) used to survey areas. Standardization of some aspects of the survey would be useful, particularly when there are personnel changes. 
Fifty-one individuals, from twelve entities, contributed to the 2011 Census in Nebraska. The entities involved include the Missouri River Institute, Nebraska Game and Parks Commission, Nebraska Public Power District, Central Nebraska Public Power and Irrigation District, Central Platte Natural Resources District, Tern and Plover Conservation Partnership, National Park Service, U.S. Fish and Wildlife Service, U.S. Geological Survey, Virginia Tech University, and Wayne State College. We are grateful for their assistance.

\section{Comparison of Census Numbers ${ }^{1}$}

\begin{tabular}{|l|c|c|c|c|c|}
\hline & 1991 & 1996 & 2001 & 2006 & 2011 \\
\hline $\begin{array}{l}\text { Total } \\
\text { Adults }\end{array}$ & 398 & 375 & 308 & $909^{2}$ & $350^{2}$ \\
\hline
\end{tabular}

${ }^{\mathrm{I}}$ Missouri River data are included in all totals.

${ }^{2}$ This is the total from a single survey at each site; if more than one survey was conducted, we count only results from the first survey during the census window.

Detectability Study - Nebraska

\begin{tabular}{|l|c|c|}
\hline \multicolumn{1}{|c|}{ Sites Included } & $\begin{array}{c}\text { First } \\
\text { Count }\end{array}$ & $\begin{array}{c}\text { Second } \\
\text { Count }\end{array}$ \\
\hline $\begin{array}{l}\text { Niobrara River, Spencer Dam } \\
\text { to Redbird Bridge }\end{array}$ & 8 & 10 \\
\hline $\begin{array}{l}\text { Central Platte River, } \\
\text { Broadfoot's North of Minden } \\
\text { - (Newark) }\end{array}$ & 3 & 3 \\
\hline Lower Platte River, Arps Pit & 1 & 2 \\
\hline $\begin{array}{l}\text { Elkhorn River, Lyman- } \\
\text { Richey Fremont Pit (\#47) }\end{array}$ & 5 & 6 \\
\hline Lower Platte River, Lux S\&G & 27 & 17 \\
\hline $\begin{array}{l}\text { Lower Platte River, Western } \\
\text { Fremont Pit }\end{array}$ & 3 & 8 \\
\hline $\begin{array}{l}\text { Lower Platte River, Mallard } \\
\text { Pit at Valley }\end{array}$ & 2 & 1 \\
\hline $\begin{array}{l}\text { Niobrara River, Meadville to } \\
\text { Highway 183 }\end{array}$ & 0 & 0 \\
\hline $\begin{array}{l}\text { Niobrara River, Norden to } \\
\text { Meadville }\end{array}$ & 0 & 0 \\
\hline $\begin{array}{l}\text { Niobrara River, Highway 183 } \\
\text { to Highway 7 }\end{array}$ & 12 & 1 \\
\hline $\begin{array}{l}\text { Niobrara River, Carns Bridge } \\
\text { to Highway 137 }\end{array}$ & 0 & 6 \\
\hline $\begin{array}{l}\text { Niobrara River, Highway 7 to } \\
\text { Carns Bridge }\end{array}$ & 0 & 4 \\
\hline Loup River, Loup Diversion & 6 & 8 \\
\hline $\begin{array}{l}\text { Lower Platte River, Western } \\
\text { North Pit (Big Sandy) }\end{array}$ & 0 & 0 \\
\hline $\begin{array}{l}\text { Replicate survey was conducted first (outside of Census } \\
\text { tondow) so second survey was used to calculate official state }\end{array}$ \\
total.
\end{tabular}




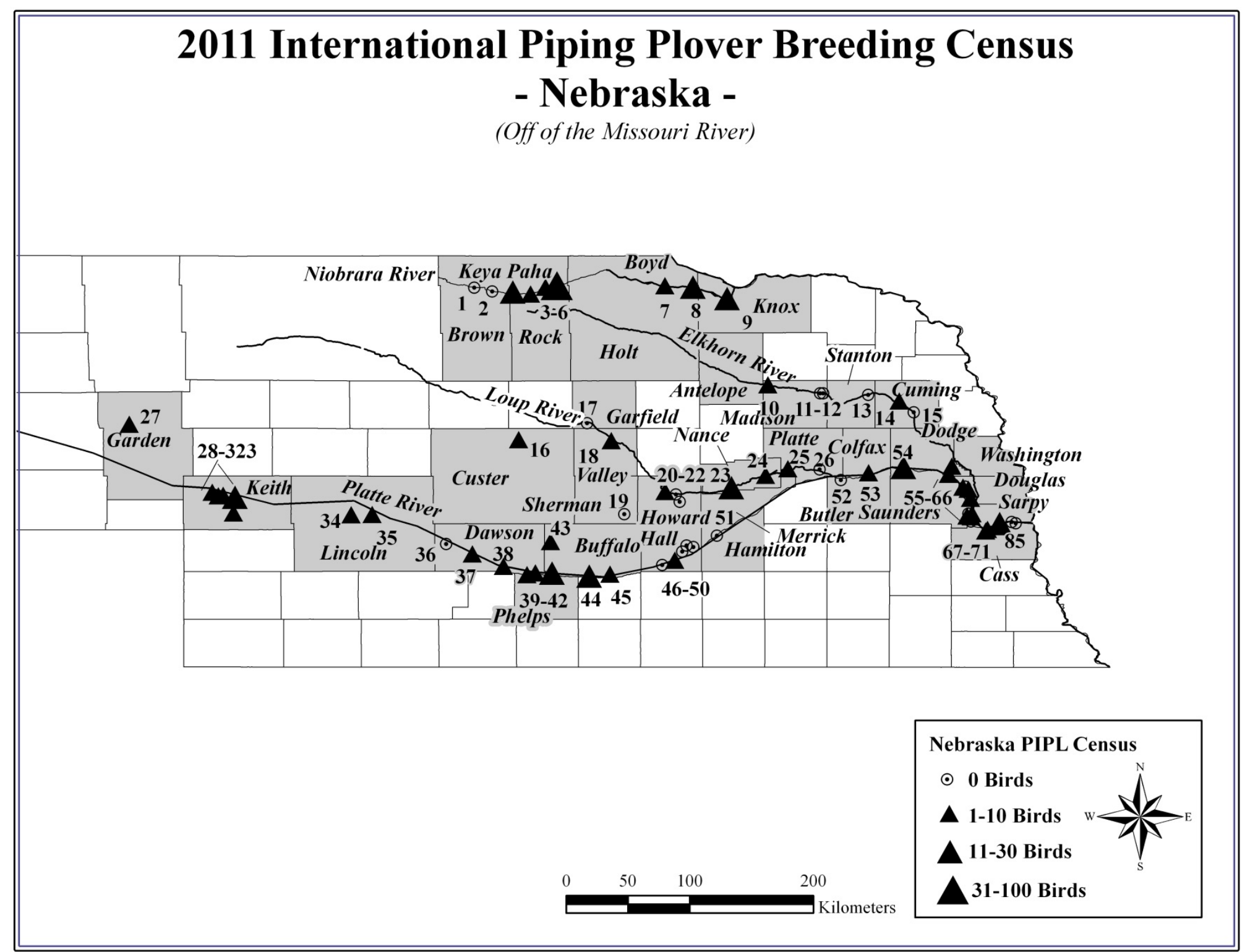


The 2011 International Piping Plover Breeding Census in Nebraska

\begin{tabular}{|c|c|c|c|c|c|c|c|c|c|c|c|c|c|}
\hline \multirow[b]{2}{*}{$\begin{array}{l}\text { REGION } \\
\text { Antelope/ } \\
\text { Cuming/ Dodge/ } \\
\text { Douglas/ } \\
\text { Madison/ Sarpy/ } \\
\text { Stanton }\end{array}$} & \multirow{2}{*}{\begin{tabular}{l}
\multicolumn{1}{c}{ SITE NAME } \\
Elkhorn River, N. Fork \\
Mouth to S. Fork Mouth
\end{tabular}} & \multirow{2}{*}{ MAP\# } & \multirow{2}{*}{$\begin{array}{c}\text { DATE } \\
6 / 14 / 11\end{array}$} & \multirow{2}{*}{$\begin{array}{c}\text { BREED- } \\
\text { ING } \\
\text { PAIRS } \\
0\end{array}$} & \multirow{2}{*}{$\begin{array}{c}\begin{array}{c}\text { TOTAL } \\
\text { PIPL } \\
\text { ADULTS }\end{array} \\
6\end{array}$} & \multirow{2}{*}{$\frac{\mathbf{K M}}{4.8}$} & \multirow{2}{*}{$\begin{array}{l}\text { SITE } \\
\text { DESCRIPTION } \\
\text { III E }\end{array}$} & \multirow{2}{*}{$\begin{array}{l}\text { DISTURBANCE } \\
\text { CONCERNS } \\
\text { n.r. }\end{array}$} & \multicolumn{3}{|c|}{$\begin{array}{c}\text { PRIOR YEARS } \\
\text { CENSUSED \& } \\
\text { YEARS } \\
\text { PIPL SEEN }^{1} \\
\end{array}$} & \multirow[b]{2}{*}{ - } & \multirow{2}{*}{ OWNER } \\
\hline & & & & & & & & & - & 96 & 01 & & \\
\hline Boyd/ Holt & $\begin{array}{l}\text { Niobrara River, Spencer } \\
\text { Dam to Redbird Bridge }\end{array}$ & 7 & $6 / 16 / 11$ & 0 & 10 & 18.5 & III E & n.r. & $\underline{91}$ & $\underline{96}$ & $\underline{01}$ & $\underline{06}$ & $\mathrm{p}$ \\
\hline $\begin{array}{l}\text { Boyd/ Holt/ Keya } \\
\text { Paha/ Rock }\end{array}$ & $\begin{array}{l}\text { Niobrara River, Spencer } \\
\text { Dam to Hwy } 137\end{array}$ & 6 & $6 / 8 / 11$ & 11 & 61 & 64.4 & III E & n.r. & $\underline{91}$ & $\underline{96}$ & $\underline{01}$ & $\underline{06}$ & n.r. \\
\hline Boyd/ Holt/ Knox & $\begin{array}{l}\text { Niobrara River, Redbird } \\
\text { Bridge to Pischelville Bridge }\end{array}$ & 8 & $6 / 15 / 11$ & 0 & 11 & 19.5 & III E & n.r. & $\underline{91}$ & $\underline{96}$ & $\underline{01}$ & $\underline{06}$ & $\mathrm{p}$ \\
\hline Brown/ Keya Paha & $\begin{array}{l}\text { Niobrara River, Meadville to } \\
\text { Highway } 183\end{array}$ & 2 & $6 / 16 / 11$ & 0 & 0 & 9.7 & III E & n.r. & $\underline{91}$ & 96 & 01 & 06 & $\mathrm{p}$ \\
\hline Brown/ Keya Paha & $\begin{array}{l}\text { Niobrara River, Norden to } \\
\text { Meadville }^{3}\end{array}$ & 1 & $6 / 22 / 11$ & 0 & 0 & 17.7 & III E & n.r. & - & 96 & 01 & 06 & $\mathrm{p}$ \\
\hline $\begin{array}{l}\text { Brown/ Keya } \\
\text { Paha/ Rock }\end{array}$ & $\begin{array}{l}\text { Niobrara River, Highway } \\
183 \text { to Highway } 7\end{array}$ & 3 & $6 / 14 / 11$ & 0 & 12 & 14.5 & III E & n.r. & 91 & 96 & 01 & $\underline{06}$ & $\mathrm{p}$ \\
\hline Buffalo & $\begin{array}{l}\text { Central Platte River, } \\
\text { Broadfoot's North of Minden } \\
\text { - (Newark) }\end{array}$ & 45 & $6 / 14 / 11$ & 1 & 3 & 1.8 & VIII F & $\mathrm{S}$ & - & 96 & 01 & $\underline{06}$ & $\mathrm{p}$ \\
\hline Buffalo & $\begin{array}{l}\text { Central Platte River, } \\
\text { Broadfoot's West (Kearney } \\
\text { South) }\end{array}$ & 44 & $6 / 15 / 11$ & 6 & 13 & 3.3 & VIII F & $\mathrm{S}$ & $\underline{91}$ & $\underline{96}$ & $\underline{01}$ & $\underline{06}$ & $\mathrm{p}$ \\
\hline Buffalo & $\begin{array}{l}\text { Central Platte River, Elm } \\
\text { Creek- Paulsen/Bluehole } \\
\text { Sandpit }\end{array}$ & 41 & $6 / 17 / 11$ & 7 & 16 & 0.7 & VIII F & none & 91 & $\underline{96}$ & $\underline{01}$ & $\underline{06}$ & $\mathrm{p}$ \\
\hline Buffalo & $\begin{array}{l}\text { Central Platte River, Sandy } \\
\text { Channels/ Johnson Pit }\end{array}$ & 42 & $6 / 9 / 11$ & 2 & 4 & 0.3 & VIII F & none & $\underline{91}$ & $\underline{96}$ & $\underline{01}$ & $\underline{06}$ & $\mathrm{p}$ \\
\hline Buffalo/Dawson & $\begin{array}{l}\text { Central Platte River (RM } \\
\text { 215-247) }\end{array}$ & 43 & $6 / 13 / 11$ & 0 & 1 & 0.4 & III E F & none & $\underline{91}$ & $\underline{96}$ & 01 & 06 & $\begin{array}{c}\mathrm{f}, \mathrm{s}(\mathrm{p}), \mathrm{m}, \\
\mathrm{p}\end{array}$ \\
\hline $\begin{array}{l}\text { Buffalo/ Hall/ } \\
\text { Hamilton/ } \\
\text { Merrick/ Platte/ } \\
\text { Polk }\end{array}$ & $\begin{array}{l}\text { Central Platte River (RM } \\
\text { 103-215) }\end{array}$ & 51 & $6 / 13 / 11$ & 0 & 0 & 0.4 & III E F & none & $\underline{91}$ & $\underline{96}$ & 01 & - & $\begin{array}{c}\mathrm{f}, \mathrm{s}(\mathrm{p}), \mathrm{m}, \\
\mathrm{p}\end{array}$ \\
\hline Butler & $\begin{array}{l}\text { Lower Platte River, } \\
\text { Bellwood Central S\&G }\end{array}$ & 52 & $6 / 8 / 11$ & 0 & 0 & n.r. & VIII F & n.r. & - & - & - & 06 & $\mathrm{p}$ \\
\hline
\end{tabular}


The 2011 International Piping Plover Breeding Census in Nebraska (Continued)

\begin{tabular}{|c|c|c|c|c|c|c|c|c|c|c|c|c|c|}
\hline REGION & SITE NAME & MAP\# & DATE & $\begin{array}{l}\text { BREED- } \\
\text { ING } \\
\text { PAIRS } \\
\end{array}$ & $\begin{array}{l}\text { TOTAL } \\
\text { PIPL } \\
\text { ADULTS } \\
\end{array}$ & $\mathbf{K M}$ & $\begin{array}{l}\text { SITE } \\
\text { DESCRIPTION }\end{array}$ & $\begin{array}{l}\text { DISTURBANCE } \\
\text { CONCERNS } \\
\end{array}$ & & $\begin{array}{l}\text { RIOR } \\
\text { CENSI } \\
\text { YE } \\
\text { PIPL }\end{array}$ & $\begin{array}{l}\text { EAR } \\
\text { ED } \\
\text { RS } \\
\text { EEN }\end{array}$ & & OWNER \\
\hline $\begin{array}{l}\text { Butler/ Colfax/ } \\
\text { Dodge/ Douglas/ } \\
\text { Platte/ Sarpy/ } \\
\text { Saunders }\end{array}$ & $\begin{array}{l}\text { Lower Platte River, Elkhorn } \\
\text { River Mouth to Loup River } \\
\text { Mouth }\end{array}$ & 63 & $6 / 10 / 11$ & 0 & 5 & 111.0 & III E & n.r. & $\underline{91}$ & $\underline{96}$ & $\underline{01}$ & 06 & $\mathrm{~s}(\mathrm{p}), \mathrm{m}, \mathrm{p}$ \\
\hline Cass & $\begin{array}{l}\text { Lower Platte River, Cullom } \\
\text { (Lyman-Richey) }\end{array}$ & 71 & $6 / 13 / 11$ & 0 & 0 & n.r. & VIII F & N S & - & - & - & - & $\mathrm{p}$ \\
\hline Cass & $\begin{array}{l}\text { Lower Platte River, Cullom } \\
\text { (New Pit) }\end{array}$ & 70 & $6 / 13 / 11$ & 0 & 0 & n.r. & VIII F & $\mathrm{N} \mathrm{S}$ & - & 96 & 01 & 06 & $\mathrm{p}$ \\
\hline Cass/ Sarpy & $\begin{array}{l}\text { Lower Platte River, Salt } \\
\text { Creek Mouth to Missouri } \\
\text { River Confluence } \\
\text { (Plattsmouth) }\end{array}$ & 69 & $6 / 13 / 11$ & 0 & 16 & 43.4 & III E & n.r. & $\underline{91}$ & $\underline{96}$ & $\underline{01}$ & 06 & $\begin{array}{c}\mathrm{f}, \mathrm{s}(\mathrm{p}), \mathrm{m} \\
\mathrm{p}\end{array}$ \\
\hline $\begin{array}{l}\text { Cass/ Sarpy/ } \\
\text { Saunders }\end{array}$ & $\begin{array}{l}\text { Lower Platte River River, } \\
\text { Salt Creek Mouth to Elkhorn } \\
\text { River Mouth }\end{array}$ & 67 & $6 / 14 / 11$ & 0 & 4 & 11.0 & III E & n.r. & $\underline{91}$ & 96 & $\underline{01}$ & $\underline{06}$ & $\begin{array}{c}\mathrm{f}, \mathrm{s}(\mathrm{p}), \mathrm{m} \\
\mathrm{p}\end{array}$ \\
\hline Colfax & Lower Platte River, Arps Pit ${ }^{2}$ & 53 & $6 / 17 / 11$ & 1 & 2 & n.r. & VIII F & n.r. & $\underline{91}$ & 96 & 01 & $\underline{06}$ & $\mathrm{p}$ \\
\hline Cuming & $\begin{array}{l}\text { Elkhorn River, West Point } \\
\text { (Stalp) }\end{array}$ & 15 & $6 / 7 / 11$ & 0 & 0 & 4.8 & VIII F & N S I & 91 & $\underline{96}$ & $\underline{01}$ & 06 & $\mathrm{p}$ \\
\hline $\begin{array}{l}\text { Cumming/ } \\
\text { Madison/ Stanton }\end{array}$ & $\begin{array}{l}\text { Elkhorn River, Mouth to N. } \\
\text { Fork Elkhorn River Mouth }\end{array}$ & 14 & $6 / 13 / 11$ & 2 & 7 & 5.0 & III E & $\mathrm{V}$ & - & 96 & 01 & 06 & $\mathrm{p}$ \\
\hline Custer & $\begin{array}{l}\text { North Loup River, Paulsen's } \\
\text { Sand and Gravel }\end{array}$ & 16 & $6 / 14 / 11$ & 3 & 6 & n.r. & VIII F & n.r. & - & - & - & - & $\mathrm{p}$ \\
\hline Dawson & $\begin{array}{l}\text { Central Platte River, } \\
\text { Cottonwood Ranch Sandpit }\end{array}$ & 40 & $6 / 15 / 11$ & 0 & 1 & 2.7 & VIII F & none & - & - & - & - & $\mathrm{p}$ \\
\hline Dawson & $\begin{array}{l}\text { Central Platte River, } \\
\text { Lexington Sandpit }\end{array}$ & 38 & $6 / 17 / 11$ & 3 & 8 & 0.6 & VIII F & none & $\underline{91}$ & $\underline{96}$ & $\underline{01}$ & $\underline{06}$ & $\mathrm{p}$ \\
\hline Dawson & $\begin{array}{l}\text { Upper Platte River, } \\
\text { Kirkpatrick's Sand Pit }\end{array}$ & 36 & $6 / 9 / 11$ & 0 & 0 & 1.6 & VIII A & n.r. & $\underline{91}$ & 96 & 01 & 06 & $\mathrm{p}$ \\
\hline Dawson & $\begin{array}{l}\text { Upper Platte River, Koch's } \\
\text { South- Cozad Pit }\end{array}$ & 37 & 6/9/11 & 3 & 6 & 1.6 & VIII A & n.r. & $\underline{91}$ & $\underline{96}$ & $\underline{01}$ & $\underline{06}$ & $\mathrm{p}$ \\
\hline Dodge & $\begin{array}{l}\text { Elkhorn River, Lyman- } \\
\text { Richey Fremont Pit (\#47) }{ }^{2}\end{array}$ & 55 & $6 / 14 / 11$ & 2 & 6 & n.r. & VIII A F & n.r. & - & - & 01 & 06 & $\mathrm{P}$ \\
\hline Dodge & $\begin{array}{l}\text { Lower Platte River, Lux } \\
\text { S\&G }^{2}\end{array}$ & 54 & $6 / 9 / 11$ & 7 & 27 & n.r. & VIII F & n.r. & 91 & 96 & 01 & $\underline{06}$ & $\mathrm{p}$ \\
\hline
\end{tabular}


The 2011 International Piping Plover Breeding Census in Nebraska

(Continued)

\begin{tabular}{|c|c|c|c|c|c|c|c|c|c|c|c|c|c|}
\hline \multirow{2}{*}{$\begin{array}{l}\text { REGION } \\
\text { Dodge }\end{array}$} & \multirow{2}{*}{$\begin{array}{l}\text { SITE NAME } \\
\text { Lower Platte River, Western } \\
\text { Fremont Pit }{ }^{2}\end{array}$} & \multirow{2}{*}{ MAP\# } & \multirow{2}{*}{$\begin{array}{c}\text { DATE } \\
6 / 15 / 11\end{array}$} & \multirow{2}{*}{$\begin{array}{c}\text { BREED- } \\
\text { ING } \\
\text { PAIRS } \\
2\end{array}$} & \multirow{2}{*}{$\begin{array}{c}\text { TOTAL } \\
\text { PIPL } \\
\text { ADULTS } \\
8\end{array}$} & \multirow{2}{*}{ 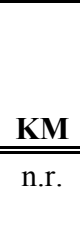 } & \multirow{2}{*}{$\begin{array}{l}\text { SITE } \\
\text { DESCRIPTION } \\
\text { VIII F }\end{array}$} & \multirow{2}{*}{$\begin{array}{l}\text { DISTURBANCE } \\
\text { CONCERNS } \\
\text { n.r. }\end{array}$} & \multicolumn{4}{|c|}{$\begin{array}{c}\text { PRIOR YEARS } \\
\text { CENSUSED \& } \\
\text { YEARS } \\
\text { PIPL SEEN }{ }^{1} \\
\end{array}$} & \multirow{2}{*}{$\frac{\text { OWNER }}{\mathrm{p}}$} \\
\hline & & & & & & & & & 91 & $\underline{96}$ & 01 & $\underline{06}$ & \\
\hline Douglas & $\begin{array}{l}\text { Lower Platte River, Ginger } \\
\text { Cove Pit (Valley \#11) }\end{array}$ & 57 & $6 / 7 / 11$ & 1 & 3 & n.r. & VIII F & n.r. & 91 & $\underline{96}$ & $\underline{01}$ & $\underline{06}$ & $\mathrm{p}$ \\
\hline Douglas & $\begin{array}{l}\text { Lower Platte River, Lyman } \\
\text { Richie S\&G (Waterloo \#40 } \\
\text { Pit) }\end{array}$ & 60 & $6 / 7 / 11$ & 0 & 0 & n.r. & VIII F & n.r. & $\underline{91}$ & 96 & - & 06 & $\mathrm{p}$ \\
\hline Douglas & $\begin{array}{l}\text { Lower Platte River, Mallard } \\
\text { Pit at Valley }\end{array}$ & 59 & $6 / 7 / 11$ & 1 & 2 & n.r. & VIII F & n.r. & - & - & $\underline{01}$ & $\underline{06}$ & $\mathrm{p}$ \\
\hline Douglas & $\begin{array}{l}\text { Lower Platte River, OMG- } \\
\text { Venice }\end{array}$ & 61 & $6 / 7 / 11$ & 0 & 1 & n.r. & VIII A & n.r. & - & - & - & - & $\mathrm{p}$ \\
\hline Douglas & $\begin{array}{l}\text { Lower Platte River, Valley } \\
\text { (Lyman-Richey) }\end{array}$ & 58 & $6 / 7 / 11$ & 0 & 0 & n.r. & VIII F & n.r. & - & - & - & - & $\mathrm{p}$ \\
\hline Garden & Crescent Lake, NWR & 27 & $6 / 4 / 11$ & 1 & 3 & n.r. & V A & A & - & 96 & - & - & $\mathrm{f}, \mathrm{s}(\mathrm{p})$ \\
\hline Garfield & $\begin{array}{l}\text { North Loup River, Jeffres } \\
\text { S\&G }\end{array}$ & 17 & $6 / 16 / 11$ & 0 & 0 & n.r. & VIII F & n.r. & - & - & - & - & $\mathrm{p}$ \\
\hline Hall & $\begin{array}{l}\text { Central Platte River, Hooker } \\
\text { Bros. S\&G, Grand Island } \\
\text { (South) }\end{array}$ & 50 & $6 / 9 / 11$ & 0 & 0 & 0.8 & VIII F & n.r. & - & - & 01 & 06 & n.r. \\
\hline Hall & $\begin{array}{l}\text { Central Platte River, Hooker } \\
\text { Bros. S\&G, Grand Island } \\
\text { (West) }\end{array}$ & 49 & $6 / 9 / 11$ & 0 & 0 & 1.6 & VIII F & $\mathrm{V}$ & - & - & 01 & 06 & $\mathrm{p}$ \\
\hline Hall & $\begin{array}{l}\text { Central Platte River, Lilley's } \\
\text { in Prosser }\end{array}$ & 46 & $6 / 6 / 11$ & 0 & 0 & 0.4 & VIII F & $\mathrm{N}$ & - & - & 01 & 06 & $\mathrm{p}$ \\
\hline Hall & $\begin{array}{l}\text { Central Platte River, Trust } \\
\text { Wildrose (East) }\end{array}$ & 47 & $6 / 6 / 11$ & 4 & 8 & 0.1 & VIII F & n.r. & 01 & 96 & - & - & $\mathrm{p}$ \\
\hline Hall & Deweese - Alda & 48 & $6 / 6 / 11$ & 0 & 0 & 1.6 & VIII F & $\mathrm{U}$ & - & - & - & 06 & $\mathrm{p}$ \\
\hline Howard & $\begin{array}{l}\text { North Loup River, St. Paul } \\
\text { Pit }\end{array}$ & 21 & $6 / 15 / 11$ & 0 & 0 & n.r. & VIII F & n.r. & - & 96 & $\underline{01}$ & 06 & $\mathrm{p}$ \\
\hline Howard & $\begin{array}{l}\text { North Loup River, Tri- } \\
\text { County S\&G }\end{array}$ & 20 & $6 / 17 / 11$ & 2 & 4 & n.r. & VIII F & n.r. & 91 & 96 & 01 & 06 & $\mathrm{p}$ \\
\hline Howard/ Nance & $\begin{array}{l}\text { Loup River, Loup Diversion } \\
\text { to North Loup Mouth }\end{array}$ & 23 & $6 / 6 / 11$ & 5 & 11 & 61.1 & III E & n.r. & $\underline{91}$ & 96 & $\underline{01}$ & $\underline{06}$ & $\mathrm{P}$ \\
\hline Howard/ Sherman & $\begin{array}{l}\text { Middle Loup River, } \\
\text { Rockville to Loup City }\end{array}$ & 19 & $6 / 17 / 11$ & 0 & 0 & 61.1 & III E & n.r. & - & - & - & - & n.r. \\
\hline
\end{tabular}


The 2011 International Piping Plover Breeding Census in Nebraska

(Continued)

\begin{tabular}{|c|c|c|c|c|c|c|c|c|c|c|c|c|c|}
\hline REGION & SITE NAME & MAP\# & DATE & $\begin{array}{c}\text { BREED- } \\
\text { ING } \\
\text { PAIRS }\end{array}$ & $\begin{array}{c}\text { TOTAL } \\
\text { PIPL } \\
\text { ADULTS }\end{array}$ & $\mathbf{K M}$ & $\begin{array}{l}\text { SITE } \\
\text { DESCRIPTION }\end{array}$ & $\begin{array}{l}\text { DISTURBANCE } \\
\text { CONCERNS }\end{array}$ & & $\begin{array}{l}\text { RIOR } \\
\text { CENS } \\
\text { YE } \\
\text { PIPL }\end{array}$ & $\begin{array}{l}\text { ZEAR } \\
\text { SED } \\
\text { RS } \\
\text { EEN }\end{array}$ & & OWNER \\
\hline Howard/ Sherman & $\begin{array}{l}\text { Middle Loup River, St. Paul } \\
\text { to Boelus }\end{array}$ & 22 & $6 / 13 / 11$ & 0 & 0 & 61.1 & III E & n.r. & - & - & - & - & n.r. \\
\hline Keith & $\begin{array}{l}\text { North Platte River, Lake } \\
\text { McConaughy, Arthur Bay to } \\
\text { Sandy Beach }\end{array}$ & 30 & $6 / 11 / 11$ & 0 & 1 & $<1$ & VI I & $\mathrm{U}$ & $\underline{91}$ & $\underline{96}$ & $\underline{\mathbf{0 1}}^{4}$ & $\underline{06}$ & $\mathrm{p}$ \\
\hline Keith & $\begin{array}{l}\text { North Platte River, Lake } \\
\text { McConaughy, Dam to Arthur } \\
\text { Bay }\end{array}$ & 31 & $6 / 11 / 11$ & 9 & 28 & $<1$ & VI VIII I & U S V & $\underline{91}$ & $\underline{96}$ & $\underline{\mathbf{0 1}}^{4}$ & $\underline{06}$ & $\mathrm{p}$ \\
\hline Keith & $\begin{array}{l}\text { North Platte River, Lake } \\
\text { McConaughy, Lemoyne to } \\
\text { Spring Park }\end{array}$ & 28 & $6 / 7 / 11$ & 0 & 1 & $<1$ & VI A I & $\mathrm{U}$ & $\underline{91}$ & 96 & $\underline{\mathbf{0 1}}^{4}$ & $\underline{06}$ & $\mathrm{p}$ \\
\hline Keith & $\begin{array}{l}\text { North Platte River, Lake } \\
\text { McConaughy, Sandy Beach } \\
\text { to Lemoyne }\end{array}$ & 29 & $6 / 7 / 11$ & 0 & 1 & $<1$ & VI A D & $\mathrm{U}$ & 91 & $\underline{96}$ & $\underline{\mathbf{0 1}}^{4}$ & $\underline{06}$ & $\mathrm{p}$ \\
\hline Keith & $\begin{array}{l}\text { North Platte River, Lake } \\
\text { McConaughy,ORM Water } \\
\text { Treatment Area (Ready Mix } \\
\text { Plant) }\end{array}$ & 33 & $6 / 9 / 11$ & 0 & 1 & $<1$ & VI VIII F & U S I & - & - & - & - & $\mathrm{m}$ \\
\hline Keith & $\begin{array}{l}\text { North Platte River, Lake } \\
\text { Ogallala, Mitigation Ground- } \\
\text { N. Dike }\end{array}$ & 32 & $6 / 8 / 11$ & 3 & 6 & $<1$ & VI VIII F & S I & - & - & - & - & $\mathrm{p}$ \\
\hline Keya Paha/ Rock & $\begin{array}{l}\text { Niobrara River, Carns Bridge } \\
\text { to Highway } 137^{2,3}\end{array}$ & 5 & $6 / 29 / 11$ & 0 & 6 & 12.9 & III E & n.r. & $\underline{91}$ & $\underline{96}$ & 01 & 06 & $\mathrm{p}$ \\
\hline Keya Paha/ Rock & $\begin{array}{l}\text { Niobrara River, Highway } 7 \\
\text { to Carns Bridge }{ }^{2,3}\end{array}$ & 4 & $6 / 27 / 11$ & 1 & 4 & 9.7 & III E & n.r. & $\underline{91}$ & $\underline{96}$ & $\underline{01}$ & 06 & $\mathrm{p}$ \\
\hline Knox & $\begin{array}{l}\text { Niobrara River, Pischelville } \\
\text { Bridge to Highway } 12\end{array}$ & 9 & $6 / 14 / 11$ & 0 & 13 & 22.2 & III A & n.r. & $\underline{91}$ & $\underline{96}$ & $\underline{01}$ & $\underline{06}$ & $\mathrm{p}$ \\
\hline Lincoln & $\begin{array}{l}\text { Upper Platte River, North } \\
\text { Platte Diversion Spoil Pile }\end{array}$ & 35 & $6 / 13 / 11$ & 3 & 6 & 0.8 & VIII A & n.r. & - & - & - & - & $\mathrm{p}$ \\
\hline Lincoln & $\begin{array}{l}\text { Upper Platte River, North } \\
\text { Platte West Sandpit }\end{array}$ & 34 & $6 / 13 / 11$ & 2 & 4 & 0.8 & VIII A & n.r. & - & - & - & - & $\mathrm{s}(\mathrm{p})$ \\
\hline Madison & $\begin{array}{l}\text { Elkhorn River, Central S\&G } \\
\text { Norfolk } \# 92\end{array}$ & 11 & $6 / 8 / 11$ & 0 & 0 & 5.6 & VIII F & U S I & $\underline{91}$ & 96 & $\underline{01}$ & $\underline{06}$ & $\mathrm{p}$ \\
\hline
\end{tabular}


The 2011 International Piping Plover Breeding Census in Nebraska (Continued)

\begin{tabular}{|c|c|c|c|c|c|c|c|c|c|c|c|c|c|}
\hline \multirow{2}{*}{$\begin{array}{l}\text { REGION } \\
\text { Madison }\end{array}$} & \multirow{2}{*}{$\begin{array}{l}\text { SITE NAME } \\
\text { lorn River, Pilger S\&G, } \\
\text { folk Pit }\end{array}$} & \multirow{2}{*}{ MAP\# } & \multirow{2}{*}{$\begin{array}{c}\text { DATE } \\
6 / 9 / 11\end{array}$} & \multirow{2}{*}{$\begin{array}{c}\text { BREED- } \\
\text { ING } \\
\text { PAIRS } \\
0\end{array}$} & \multirow{2}{*}{$\begin{array}{c}\text { TOTAL } \\
\text { PIPL } \\
\text { ADULTS } \\
0\end{array}$} & \multirow{2}{*}{$\frac{\mathbf{K M}}{1.6}$} & \multirow{2}{*}{$\begin{array}{l}\text { SITE } \\
\text { DESCRIPTION } \\
\text { VIII F }\end{array}$} & \multirow{2}{*}{$\begin{array}{l}\text { DISTURBANCE } \\
\text { CONCERNS } \\
\mathrm{U}\end{array}$} & \multicolumn{4}{|c|}{$\begin{array}{c}\text { PRIOR YEARS } \\
\text { CENSUSED \& } \\
\text { YEARS } \\
\text { PIPL SEEN }^{1} \\
\end{array}$} & \multirow{2}{*}{$\frac{\text { OWNER }}{\text { OW.r. }}$} \\
\hline & & & & & & & & & - & $\underline{96}$ & 01 & 06 & \\
\hline Nance & Loup River, Loup Diversion ${ }^{2}$ & 24 & $6 / 17 / 11$ & 3 & 8 & n.r. & VIII A & n.r. & $\underline{91}$ & $\underline{96}$ & $\underline{01}$ & 06 & $\mathrm{p}$ \\
\hline Phelps & $\begin{array}{l}\text { Central Platte River, Dyer } \\
\text { Sandpit }\end{array}$ & 39 & $6 / 14 / 11$ & 2 & 4 & 1.7 & VIII F & none & - & - & - & - & $\mathrm{p}$ \\
\hline Platte & Loup River, Columbus \#71 & 26 & $6 / 8 / 11$ & 0 & 0 & n.r. & VIII IX F I & n.r. & - & - & 01 & - & $\mathrm{p}$ \\
\hline Platte & $\begin{array}{l}\text { Loup River, Columbus to } \\
\text { Loup Diversion }\end{array}$ & 25 & $6 / 16 / 11$ & 3 & 6 & 46.7 & III VIII F & n.r. & $\underline{91}$ & 96 & - & - & n.r. \\
\hline Sarpy & $\begin{array}{l}\text { Lower Platte River, Gretna } \\
\text { Pit }\end{array}$ & 65 & $6 / 10 / 11$ & 1 & 3 & n.r. & VIII F & n.r. & 91 & 96 & $\underline{01}$ & - & $\mathrm{p}$ \\
\hline Sarpy & $\begin{array}{l}\text { Lower Platte River, Linoma } \\
\text { Beach Pit }\end{array}$ & 66 & $6 / 10 / 11$ & 0 & 0 & n.r. & VIII F & n.r. & - & - & - & 06 & $\mathrm{p}$ \\
\hline Sarpy & $\begin{array}{l}\text { Lower Platte River, Western } \\
\text { S\&G at Louisville Pit }\end{array}$ & 68 & $6 / 13 / 11$ & 1 & 2 & n.r. & VIII F & $\mathrm{S}$ & 91 & 96 & $\underline{01}$ & $\underline{06}$ & $\mathrm{p}$ \\
\hline Saunders & $\begin{array}{l}\text { Lower Platte River, Sand } \\
\text { Creek - W. Ashland }\end{array}$ & 64 & $6 / 10 / 11$ & 2 & 6 & n.r. & VIII F & n.r. & - & - & - & - & $\mathrm{p}$ \\
\hline Saunders & $\begin{array}{l}\text { Lower Platte River, Western } \\
\text { North Pit (Big Sandy) }\end{array}$ & 62 & $6 / 10 / 11$ & 0 & 0 & n.r. & VIII F & n.r. & - & $\underline{96}$ & $\underline{01}$ & $\underline{06}$ & $\mathrm{p}$ \\
\hline Stanton & Elkhorn River, Willers Cove & 13 & $6 / 8 / 11$ & 0 & 0 & 4.8 & VIII F & U I & 91 & - & - & - & $\mathrm{p}$ \\
\hline Valley & $\begin{array}{l}\text { North Loup River, Ulrich } \\
\text { S\&G (East) }\end{array}$ & 18 & $6 / 16 / 11$ & 2 & 4 & n.r. & VIII F & n.r. & 91 & 96 & 01 & 06 & $\mathrm{p}$ \\
\hline \multicolumn{2}{|c|}{ Off-Missouri River Subtotal } & & & 96 & $369^{2}$ & 632.3 & & & & & & & \\
\hline \multicolumn{2}{|c|}{ Missouri River Subtotal } & & & 1 & $2^{2}$ & 0.0 & & & & & & & \\
\hline Total & & & & 97 & $371^{2}$ & 632.3 & & & & & & & \\
\hline
\end{tabular}

${ }^{1}$ Please note that these surveys were conducted outside the Census Window.

${ }^{2}$ This total is the "high count"; since two surveys were conducted at some sites for the detectability study, this total includes the highest count at each site.

${ }^{3}$ Please note that these surveys were conducted outside the Census window.

${ }^{4}$ PIPL pairs were seen along Lake McConaughy in 2001, but the specific locations were not given. The 2001 PIPL may have occurred within the range of this 2011 site but we cannot say for certain. 


\section{The 2011 International Piping Plover Breeding Census in Colorado}

\author{
Duane Nelson \\ 342 E $6^{\text {th }}$ St. \\ Las Animas, CO 81054 \\ 719-456-6098 \\ dnelson@centurytel.net \\ Peter Plage \\ Colorado Field Office, USFWS \\ P.O. Box 25486, DFC (MS 65412) \\ Denver, CO 80225-0486 \\ 303-236-4750 \\ peter_plage@fws.gov
}

No official census was conducted in Colorado in 2011. However, all reservoirs in the Lower Arkansas River drainage were visited in late May and early June, including many historic sites that did not have habitat. A total of 20 Piping Plovers were observed. This included one photo-documented observation of a single Piping Plover by birders at a reservoir in the northeastern portion of the state. The remaining birds were seen in the southeastern part of the state nesting on reservoirs where they have historically been observed.

Southeast Colorado experienced the tenth consecutive year of low water levels in 2011. The limited amount of suitable habitat in Colorado is heavily used by the recreating public, and it is essential for us to identify every nesting location so we can adequately protect the birds. All habitat is on reservoir shorelines or islands in reservoirs, as the Arkansas River is either heavily drawn down for irrigation (resulting in little more than a trickle of flow), or flowing fast through a narrow channel lined with saltcedar trees to the edge of the river.

Sixteen Piping Plovers were counted on John Martin Reservoir on June $2^{\text {nd }} 2011$, the largest detection of the season. All birds were paired and seven of the pairs were incubating nests. A nest for the eighth pair was found a few days after the survey. Four pairs nested on reclaimed habitat at Dinosaur Island in the northwest part of the reservoir. Three pairs nested on Point 5 on the south side of the reservoir. One pair nested on Point 6.

A kayak survey of Adobe Creek Reservoir in calm conditions on June $4^{\text {th }}$ resulted in the detection of 3 adult Piping Plovers on Tern Island. Tern Island is the site of major habitat reclamation. Two of these birds paired and nested on a smaller adjacent island (Long Island) later in the season.

Other large bodies of water were surveyed in SE Colorado in late May and early June but had very poor habitat or none at all. Sites checked but completely lacking habitat included Verhoeff Lake (Bent County), Lake Henry (Crowley County), Lake Meredith (Crowley County), Thurston Reservoir (Prowers County), Neesopah Reservoir (Kiowa County), Neeskah Reservoir (Kiowa County), King Reservoir (Prowers County), and Lake Cheraw (Otero County). Limited habitat was present at Lake Holbrook (Otero County), Nee Noshe Reservoir (Kiowa County), Carlton Gravel Pit (Prowers County), and Nee Grande (Neegronda) Reservoir (Kiowa County). Single Piping Plovers were observed at Nee Grande Reservoir, Lake Holbrook, and Lake Henry (on the dam road) in early-mid May but there was no evidence of nesting and no additional sightings were made during subsequent visits. 
We have had good success in maintaining our population through vegetation removal and mechanical control at nesting sites, despite loss of habitat due to shrinking lakes, vegetation encroachment and increased predator presence. The nine nesting pairs equals our historic high count in Colorado.

\section{Comparison of Census Numbers}

\begin{tabular}{|l|c|c|c|c|c|}
\hline & 1991 & 1996 & 2001 & 2006 & 2011 \\
\hline $\begin{array}{l}\text { Total } \\
\text { Adults }\end{array}$ & 13 & 14 & 13 & $20^{1}$ & $20^{1}$ \\
\hline
\end{tabular}

${ }^{\mathrm{I}}$ This is the total from a single survey at each site; if more than one survey was conducted, we count only results from the first survey during the census window. 


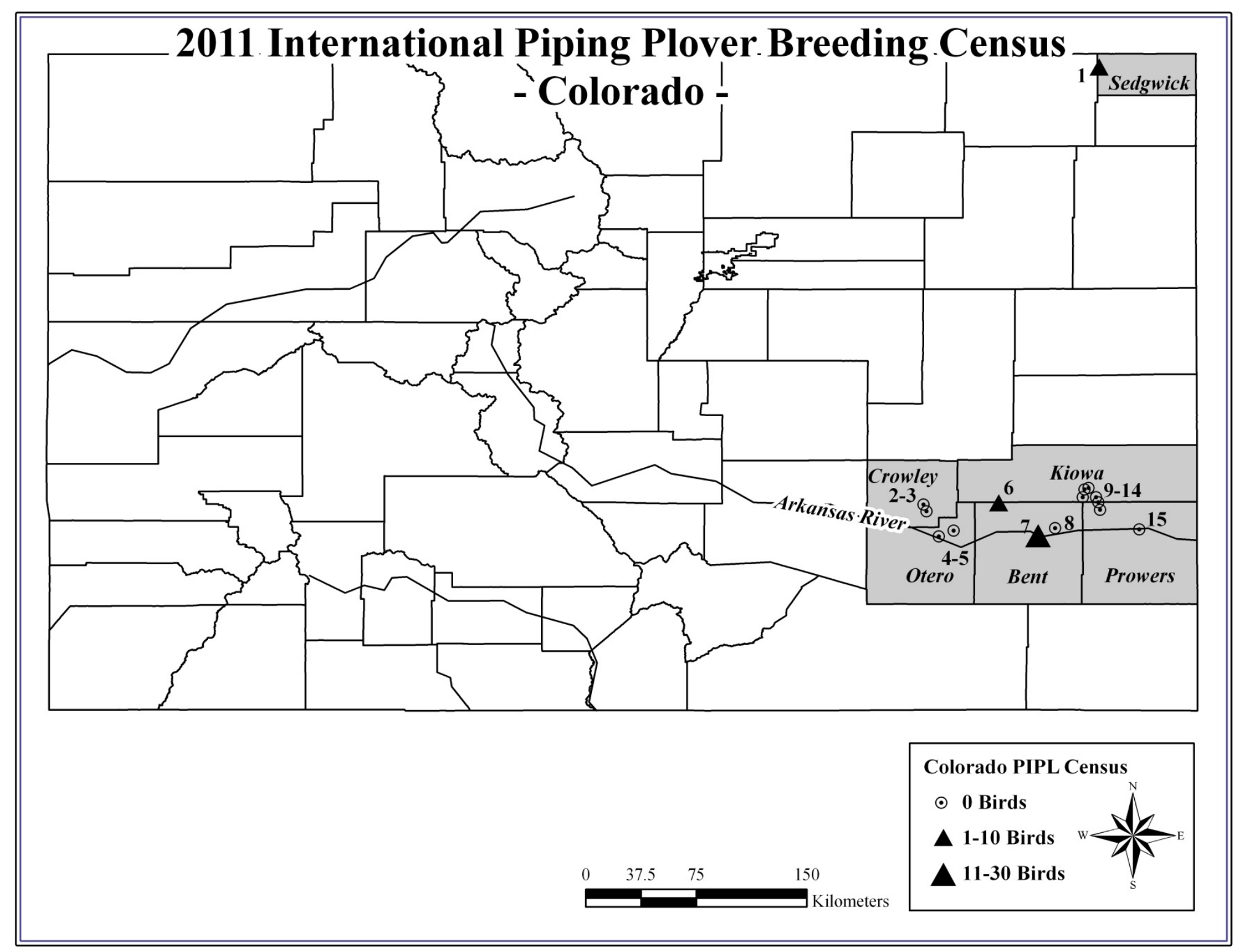


The 2011 International Piping Plover Breeding Census in Colorado

\begin{tabular}{|c|c|c|c|c|c|c|c|c|c|c|c|c|c|}
\hline \multirow{2}{*}{ COUNTY } & \multirow{2}{*}{$\begin{array}{c}\text { SITE NAME } \\
{\text { John } \text { Martin Reservoir }^{2}}^{2}\end{array}$} & \multirow{2}{*}{ MAP\# } & \multirow{2}{*}{$\frac{\text { DATE }}{6 / 2 / 11}$} & \multirow{2}{*}{$\begin{array}{c}\begin{array}{c}\text { BREED- } \\
\text { ING } \\
\text { PAIRS }\end{array} \\
8\end{array}$} & \multirow{2}{*}{$\begin{array}{c}\begin{array}{c}\text { TOTAL } \\
\text { PIPL } \\
\text { ADULTS }\end{array} \\
16\end{array}$} & \multirow{2}{*}{$\frac{\mathbf{K M}}{99.7}$} & \multirow{2}{*}{$\begin{array}{l}\text { SITE } \\
\text { DESCRIPTION } \\
\text { VI A }\end{array}$} & \multirow{2}{*}{$\begin{array}{l}\text { DISTURBANCE } \\
\text { CONCERNS } \\
\text { n.r. }\end{array}$} & \multicolumn{4}{|c|}{$\begin{array}{c}\text { PRIOR YEARS } \\
\text { CENSUSED \& YEARS } \\
\text { PIPL SEEN }^{1} \\
\end{array}$} & \multirow{2}{*}{$\frac{\text { OWNER }}{\mathrm{f}, \mathrm{p}}$} \\
\hline & & & & & & & & & 91 & $\overline{966}$ & $\overline{\underline{01}}$ & (06 & \\
\hline Bent & Verhoeff Reservoir $^{2}$ & 8 & $5 / 21 / 11^{*}$ & - & - & & & & - & - & $\overline{01}$ & - & \\
\hline Bent/Kiowa & Adobe Creek Reservoir & 6 & $6 / 4 / 11$ & 1 & 3 & 0.8 & VI A & n.r. & 91 & 96 & 01 & $\underline{06}$ & $\mathrm{~s}(\mathrm{p})$ \\
\hline Crowley & Lake Henry ${ }^{23}$ & 2 & $5 / 25 / 11^{*}$ & - & - & & & & - & - & 01 & - & \\
\hline Crowley & Lake Meredith $^{2}$ & 3 & $5 / 25 / 11^{*}$ & - & - & & & & - & - & 01 & - & \\
\hline Kiowa & Nee Grande Reservoir ${ }^{24}$ & 9 & $6 / 3 / 11$ & 0 & 0 & 9.7 & & & $\underline{91}$ & 96 & 01 & $\underline{06}$ & \\
\hline Kiowa & Nee Noshe Reservoir ${ }^{2}$ & 11 & $6 / 2 / 11$ & 0 & 0 & 4.8 & & & $\overline{91}$ & 96 & $\underline{01}$ & - & \\
\hline Kiowa & Neesopah Reservoir & 10 & $6 / 4 / 11^{*}$ & - & - & & & & - & - & 01 & - & \\
\hline Kiowa & Queens (Neeskah) Reservoir & 12 & $6 / 4 / 11^{*}$ & - & - & & & & $\underline{91}$ & 96 & 01 & - & \\
\hline Otero & Holbrook Reservoir ${ }^{25}$ & 4 & $5 / 25 / 11$ & 0 & 0 & n.r. & VI A & n.r. & - & - & 01 & - & $\mathrm{s}(\mathrm{p}) / \mathrm{p}$ \\
\hline Otero & Lake Cheraw & 5 & $6 / 7 / 11^{*}$ & - & - & & & & 91 & 96 & 01 & - & \\
\hline Prowers & Carlton Gravel $\mathrm{Pit}^{2}$ & 15 & $6 / 3 / 11$ & 0 & 0 & n.r. & VIII IX A & n.r. & - & - & - & - & $\mathrm{p}$ \\
\hline Prowers & King Reservoir & 13 & $6 / 4 / 11^{*}$ & - & - & & & & - & - & 01 & - & \\
\hline Prowers & Thurston Reservoir & 14 & $6 / 4 / 11^{*}$ & - & - & & & & - & - & 01 & - & \\
\hline Sedgwick & Jumbo (Julesberg) Reservoir & 1 & $6 / 9 / 11$ & 0 & 1 & n.r. & VI A & $\mathrm{H}$ & 91 & 96 & - & - & $\mathrm{s}(\mathrm{p})$ \\
\hline Total & & & & 9 & 20 & 25.0 & & & & & & & \\
\hline
\end{tabular}

* Site was checked on this date but was found to have no suitable habitat.

${ }^{1}$ Bold years indicate that adults were seen. Bold and underlined years indicate that pairs were seen.

${ }^{2}$ Please note that these surveys were done outside the Census window.

${ }^{3}$ One Piping Plover was observed at this site on 5/15/11.

${ }^{4}$ One Piping Plover was observed at this site on 5/20/11.

${ }^{5}$ One Piping Plover was seen at this site on 5/8/11. 


\section{The 2011 International Piping Plover Breeding Census in Kansas}

Dan Mulhern

U.S. Fish and Wildlife Service

Kansas Field Office

315 Houston St., Suite E

Manhattan, KS 66502

785-539-3474

dan_mulhern@fws.gov

There was no suitable habitat in Kansas in 2011

due to high water levels. Therefore no surveys were conducted.

\section{Comparison of Census Numbers}

\begin{tabular}{|l|c|c|c|c|c|}
\hline & 1991 & 1996 & 2001 & 2006 & 2011 \\
\hline $\begin{array}{l}\text { Total } \\
\text { Adults }\end{array}$ & n.a. & 1 & 3 & $4^{1}$ & n.a. \\
\hline
\end{tabular}

${ }^{\mathrm{I}}$ This is the total from a single survey at each site; if more than one survey was conducted, we count only results from the first survey during the census window.

Summarized by E. Elliott-Smith 
Publishing support provided by the U.S. Geological Survey

Science Publishing Network, Tacoma Publishing Service Center

For more information concerning the research in this report, contact the Director, Forest and Rangeland Ecosystem Science Center,

U.S. Geological Survey, 777 NW 9th Street

Corvallis, Oregon 97330

http://fresc.usgs.gov 
